\author{
UNIVERSIDADE DE SÃO PAULO \\ FACULDADE DE ECONOMIA, ADMINISTRAÇÃO E CONTABILIDADE \\ DEPARTAMENTO DE ADMINISTRAÇÃO \\ PROGRAMA DE PÓS-GRADUAÇÃO EM ADMINISTRAÇÃO
}

\title{
O DESAFIO DO VAREJO MULTICANAL: COMPORTAMENTO FREE-RIDING DO CONSUMIDOR
}

SUZANA WAYAND DIAS

Orientador: Professor Dr José Augusto Giesbrecht da Silveira

SÃO PAULO

2014 
Prof. Dr. Marco Antonio Zago

Reitor da Universidade de São Paulo

Prof. Dr. Reinaldo Guerreiro

Diretor da Faculdade de Economia, Administração e Contabilidade

Prof. Dr. Roberto Sbragia

Chefe do Departamento de Administração

Prof. Dr. Lindolfo Galvão de Albuquerque

Coordenador do Programa de Pós-Graduação em Administração 


\section{O DESAFIO DO VAREJO MULTICANAL: COMPORTAMENTO FREE-RIDING DO CONSUMIDOR}

Tese apresentada ao departamento de Administração da Faculdade de Economia, Administração e Contabilidade da Universidade de São Paulo como requisito para a obtenção do título de Doutor em Ciências.

Orientador: Professor $\mathrm{Dr}$ José Augusto Giesbrecht da Silveira

Versão Corrigida

(versão original disponível na Faculdade de Economia, Administração e Contabilidade)

\section{SÃo PAULO}


FICHA CATALOGRÁFICA

Elaborada pela Seção de Processamento Técnico do SBD/FEA/USP

Dias, Suzana Wayand

O desafio do varejo multicanal: comportamento free-riding do consumidor / Suzana Wayand Dias. -- São Paulo, 2014.

$335 \mathrm{p}$.

Tese (Doutorado) - Universidade de São Paulo, 2014.

Orientador: José Augusto Giesbrecht da Silveira.

1. Comportamento do consumidor 2. Canais múltiplos de marketing 3. Free-riding 4. Alternância de compras em loja física e virtual I. Univer sidade de São Paulo. Faculdade de Economia, Administração e Contabilidade. II. Título.

CDD - 658.8342 


\section{AGRADECIMENTOS}

A realização do doutorado apresentou-se para mim como um caminho tortuoso de descobertas, sofrimentos sobre a decisão do que fazer e a busca por um projeto apaixonante até o seu final. Levei dois anos para me engajar com o tema. Quando estava praticamente terminando a disciplina de Comportamento do consumidor ministrada pelo Prof. Dr. José Afonso Mazzon, eis que surgiu uma possibilidade ao se passar quase dois anos de doutorado. Minha amiga Patrícia Salles Vance, estudava naquela época na UMASS e me disse sobre o tema varejo multicanal, algo que seu Prof. Thomas Brashear estava investigando. Fiz um levantamento de artigos mais recentes e, incentivada pela disciplina, encontrei um artigo que, na avaliação do Prof. Mazzon, poderia ser um caminho de inspiração. Prof. Silveira se encantou com o modelo PPM da geografia humana. Conheci em sala de aula, na época, o doutorando Leandro Prearo. Perguntei a ele se toparia me ajudar no desenvolvimento da estatística a que me propunha realizar. Gentilmente Leandro aceitou também o desafio de me orientar após a sua defesa. Pudemos concretizar o longo caminho de análises de resultados nas visitas a São Caetano - USCS. Prof. Dr. Nuno Fouto me facilitou o contato com a equipe do E-bit, o presidente Pedro Guasti e a gerente de inteligência de mercado lone Mendes. E assim fui caminhando com uma equipe colaborativa: Prof. Mazzon, Prof. Leandro, Prof. Silveira, Prof. Nuno, Prof. ${ }^{a}$ Heloisa Bernardo até o fim. Foi um árduo caminho, começando do zero em modelagem de equações estruturais como um desafio para minha aprendizagem, o que não seria diferente.

Meu marido, Sergio Luiz Lepsch, sempre um grande incentivador e investidor perseverante para este longo caminho. Prof. ${ }^{a}$ Patrícia Vance e Prof. ${ }^{\text {a }}$ Heloisa Bernardo como as boas amigas incentivadoras desta jornada. E agradeço a todos os amigos pessoais que caminharam lado a lado. Por último, à terapeuta Heloisa Garbuglio, um especial agradecimento, pois sem a presença dela não conseguiria resignificar os medos que se originaram ao trilhar caminhos tão desconhecidos. 
What we observe is not nature itself, but nature exposed to our method of questioning.

\section{Werner Heisenberg}

In pursuit of knowledge, every day something is acquired; in pursuit of wisdom, every day something is dropped.

Lao Tzu, $6^{\text {th }}$ century BC 


\section{RESUMO}

Canais de marketing proliferaram nos últimos anos. Por meio da integração de canais virtuais, as vendas de varejistas tradicionais se expandiram. Num ambiente multicanal, os consumidores podem se movimentar facilmente entre diferentes canais. O free-riding acontece quando os consumidores realizam pesquisa on-line ou em sites de comparação de preços e acabam realizando a compra em outro varejista não pesquisado. $O$ cruzamento entre canais pode levar a perdas para 0 varejista e se torna questão-chave do varejo multicanal na retenção do consumidor. Lançando luz sobre esta questão foi utilizado um modelo teórico originário da geografia humana, o paradigma Push-Pull-Mooring para explicar o comportamento de alternância do consumidor. Este estudo propõe um modelo teórico para explicar o comportamento de alternância do consumidor e o impacto na intenção de free-riding. O modelo final apresentou antecedentes para autoeficácia (push): a experiência prévia com internet e a satisfação em free-riding; para retenção na firma (mooring): o alto custo de mudança e a busca de variedade e, para atratividade do varejo tradicional (pull): qualidade percebida, risco percebido e satisfação com loja física. Foi realizada uma pesquisa qualitativa e quantitativa do tipo survey, aplicada em consumidores com experiência de compra na internet, e modelagem pela análise de equações estruturais. Os resultados empíricos revelam efeito mediador para a variável atratividade do varejo por meio do alto risco percebido na interação com lojas virtuais. Há efeitos moderadores dados pela idade, gênero, renda, busca de informação e hábito de compra. Há fortes evidências de motivação para retenção na firma.

Palavras-chave: comportamento do consumidor, canais múltiplos de marketing, freeriding, alternância de compra em loja física e virtual. 


\begin{abstract}
Marketing channels have proliferated in recent years. Through integration of on-line channel, sales of traditional retailers have expanded. In a multichannel environment, consumers can move easily between different channels. Free-riding occur when consumers perform on-line search or consult price comparison sites and end up performing purchase at a retailer not searched before. The crossover between channels can lead to losses for the retailer and becomes one the main issues of multichannel retailing in the area of consumer retention. To shed some light on this issue, a theoretical model from the literature on human geography was used, the Push-Pull-Mooring paradigm to explain the switching behavior of consumers. This study proposes a theoretical model to explain the switching behavior and its impact on free-riding. The final model presents antecedents to self-efficacy (push): previous experience with internet and satisfaction in free-riding; with-in firm lock-in (mooring): the switching costs and the variety seeking; and attractiveness to the competitor's offline retail store (pull): perceived quality, perceived risk and satisfaction with offline stores. A qualitative and quantitative survey research was applied to consumer regarding their shopping experience with the internet. The technique of structural equation modeling was performed. The empirical results reveal mediating effect of with-in firm lock-in when the consumer realizes that he/she is serviced on his/her need for variety of products and brands. The mediating effect of attractiveness of competitor's offline store is given by perception of satisfaction with retail stores and perceived high risk in interacting with on-line stores. Moderating effects were also found: age, gender, income, information search and buying habit. There is strong evidence of motivation for with-in firm lock-in.
\end{abstract}

Keywords: consumer behavior, multichannel, free-riding, switching behavior. 


\section{SUMÁRIO}

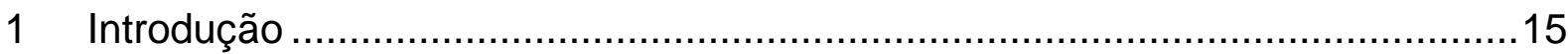

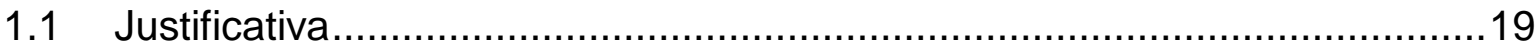

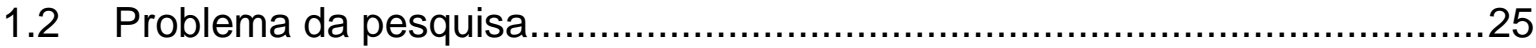

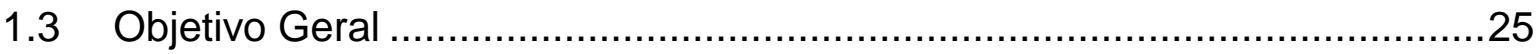

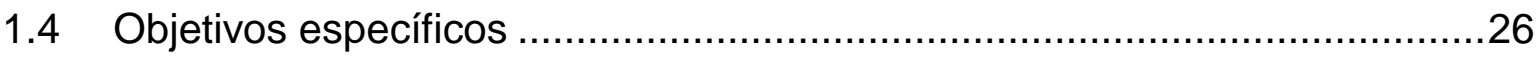

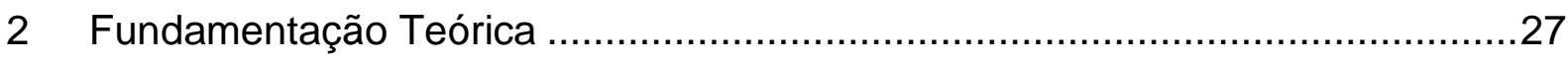

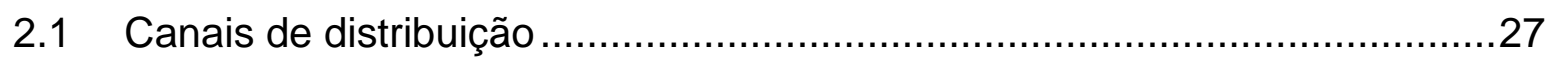

2.1.1 Evolução do Varejo Multicanal................................................. 30

2.1.2 Integração do Varejo Multicanal ................................................. 37

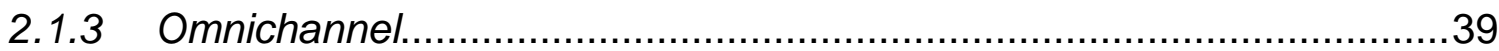

2.2 Comportamento Free-riding no varejo multicanal ....................................43

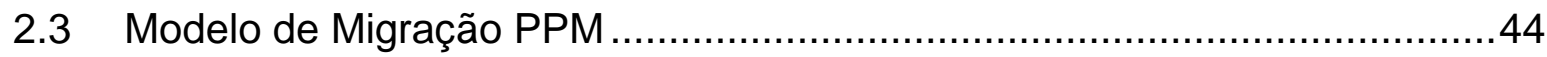

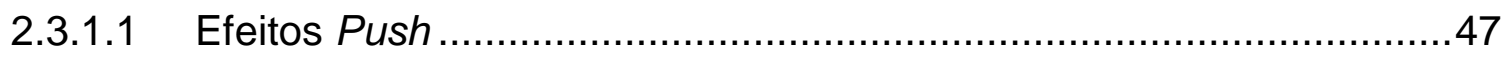

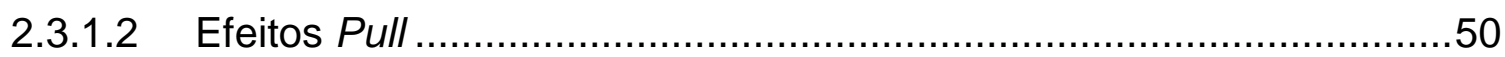

2.3.1.3 Efeitos Mooring ................................................................... 50

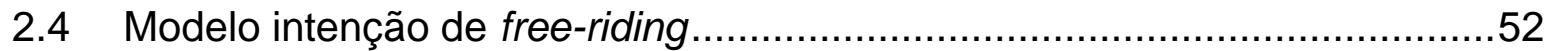

3 Modelo Teórico e hipóteses de pesquisa .................................................. 58

3.1 Intenção de free-riding no cruzamento multicanal.................................59

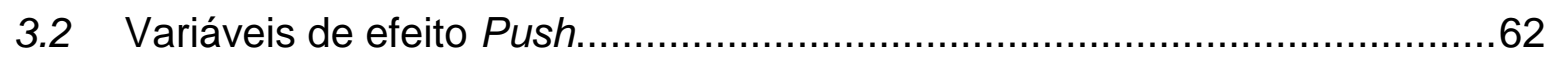

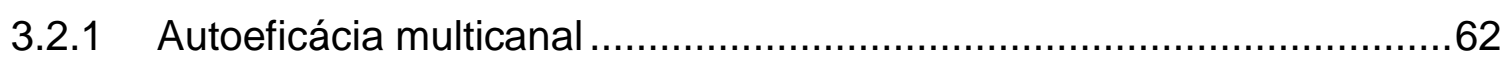

3.2.2 Experiência prévia com internet...................................................66

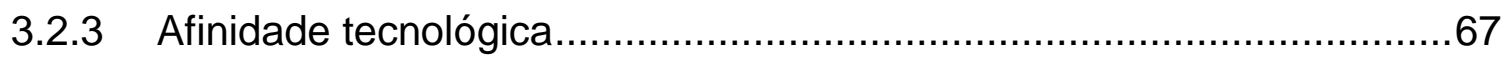

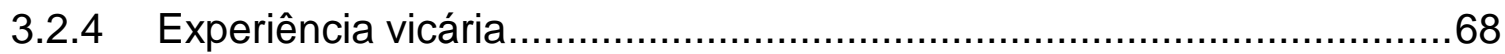

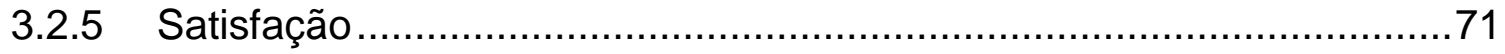

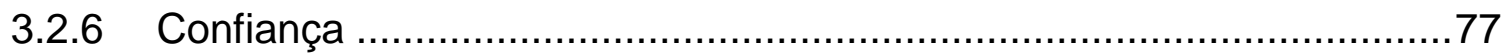

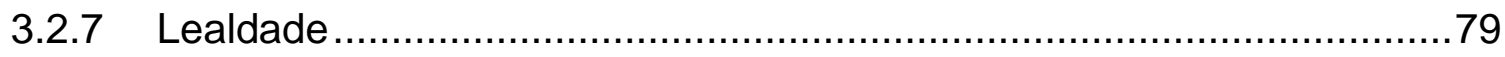

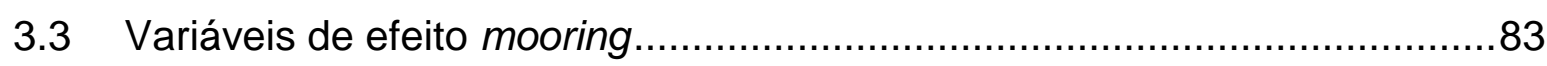

3.3.1 Retenção na firma (within-firm lock-in) .......................................... 84

3.3.2 Busca de variedade .................................................................... 92

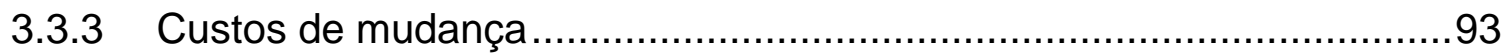

3.3.4 Integração percebida pelo consumidor do multicanal .........................97

3.3.5 Conveniência de compra ........................................................99

3.3.6 Design do Site .................................................................. 104

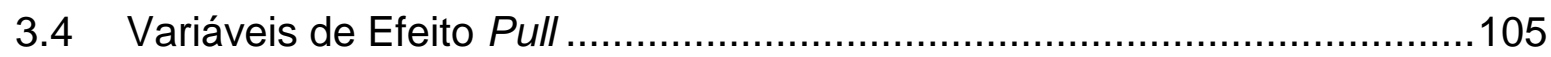

3.4.1 Grau de atratividade dos concorrentes varejistas off-line ................... 105 
3.4.2 Qualidade de serviço percebida nos concorrentes off-line .................107

3.4.3 Risco percebido pelas compras on-line ........................................... 109

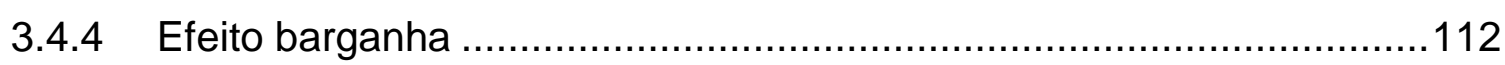

3.5 Contribuições do modelo proposto ....................................................114

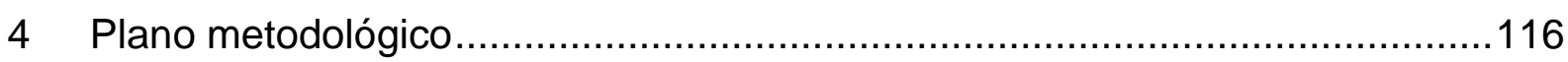

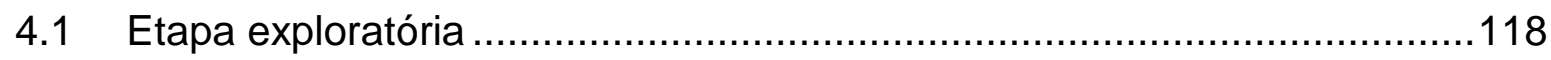

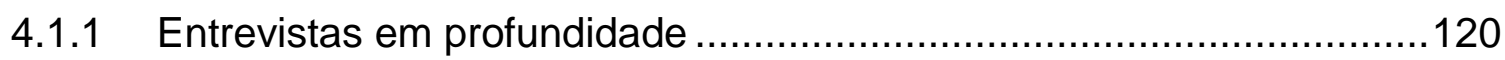

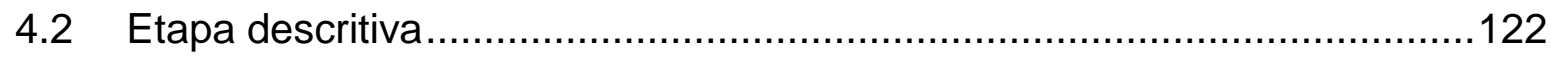

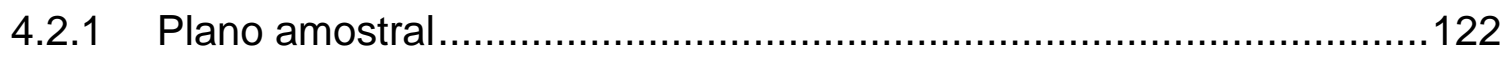

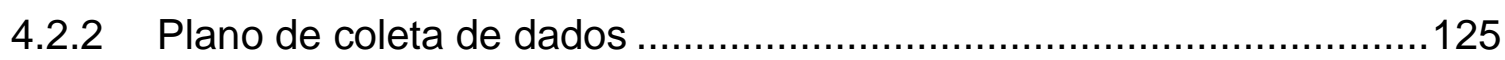

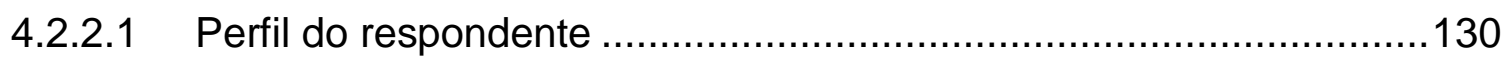

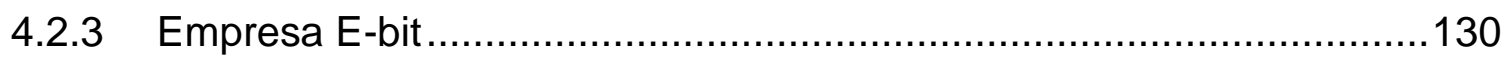

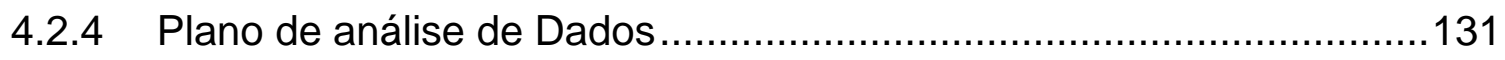

4.2.5 Análise fatorial exploratória e confirmatória.....................................132

4.2.6 Modelagem de Equações Estruturais .............................................133

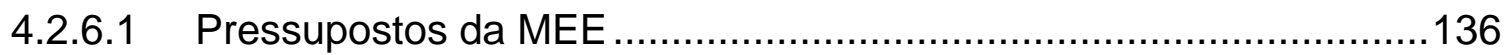

4.2.6.2 Índices de qualidade de ajustamento .........................................138

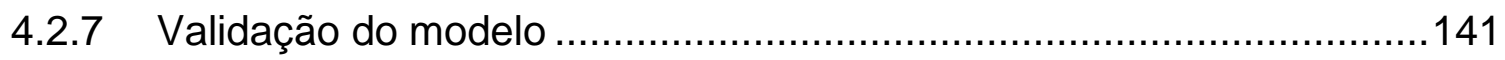

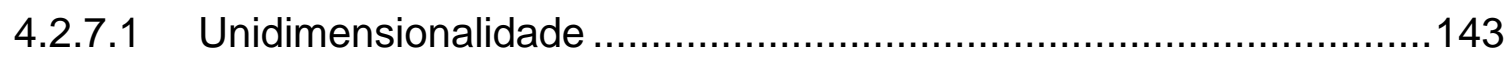

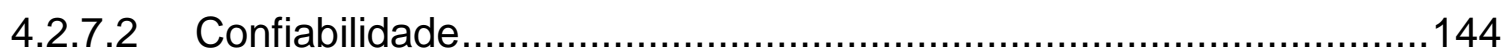

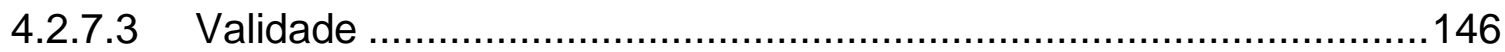

4.2.8 Reespecificação e Validação do Modelo .........................................149

4.2.9 Análise de mediação e moderação..................................................151

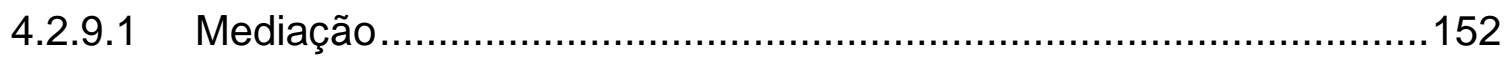

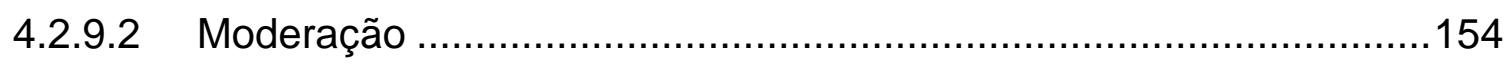

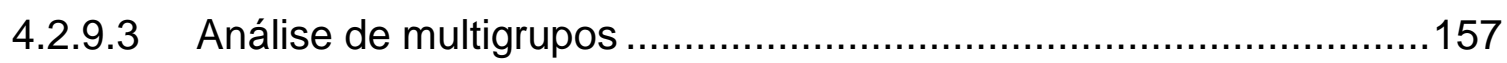

4.2.9.4 Comparação de médias entre grupos com variáveis latentes ...........158

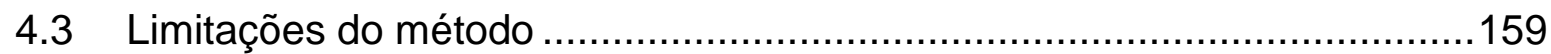

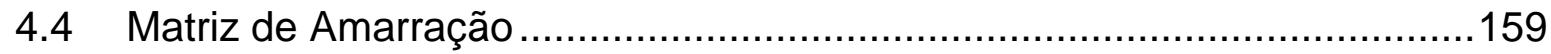

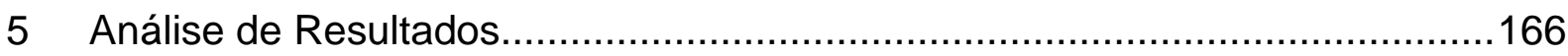

5.1 Resultados das entrevistas em profundidade .......................................166

5.1.1 Experiência de compra pela internet: .............................................166

5.1.2 Experiência multicanal para busca e compra ..................................171

5.1.3 Contribuições da pesquisa exploratória para o modelo teórico …........173

5.2 Resultados das Análises de dados quantitativos .....................................174

5.2.1 Preparação do banco de dados para análise ...................................174

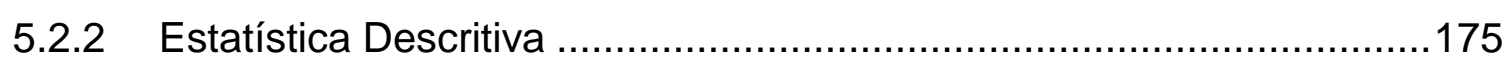




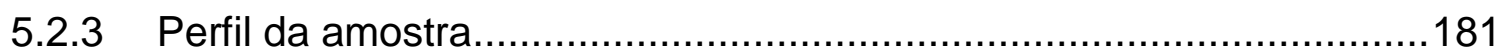

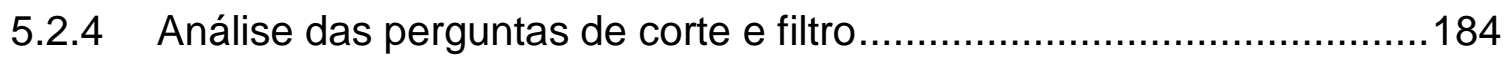

5.2.5 Análise fatorial Exploratória e Confirmatória......................................190

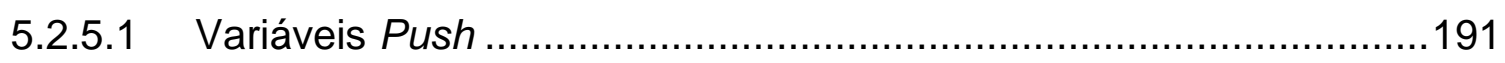

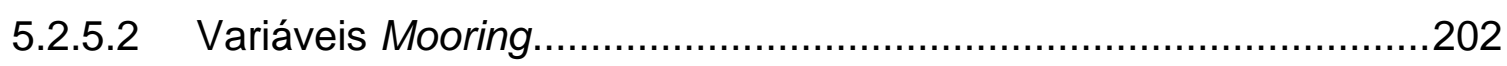

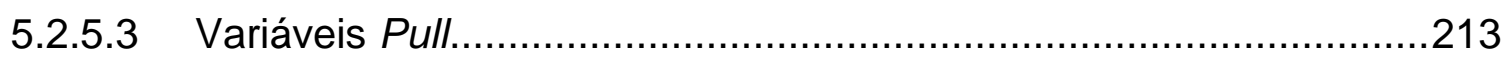

5.2.5.4 Fator 18 - Intenção de Free-riding (FA_FR) .................................220

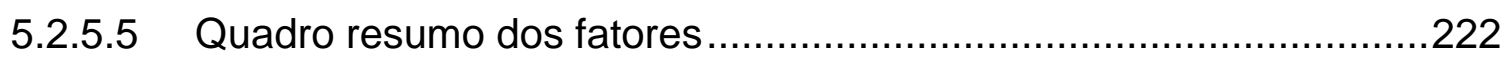

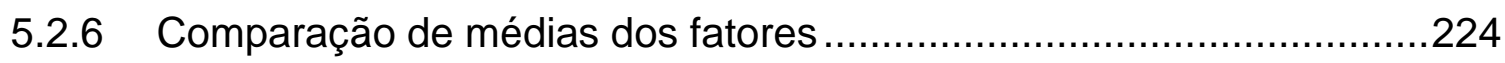

5.2.6.1 Comparação de médias para Fatores Push .....................................225

5.2.6.2 Comparação de médias para fatores Mooring …..............................229

5.2.6.3 Comparação de médias para fatores Pull ......................................232

5.2.6.4 Comparação de médias do fator intenção de free-riding ...................236

5.2.6.5 Variáveis de perfil da amostra em relação aos fatores .....................237

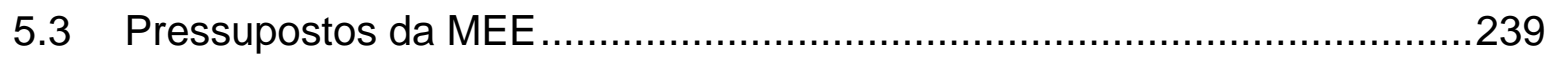

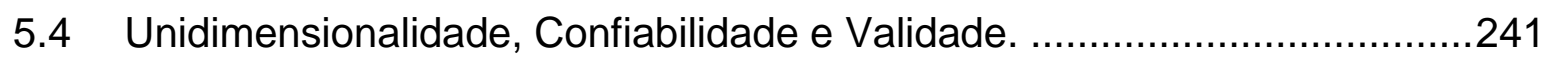

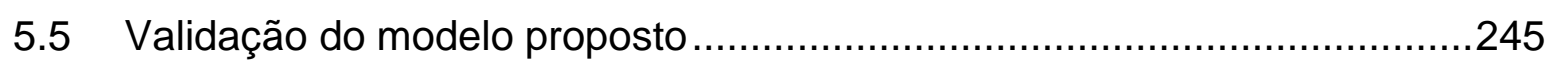

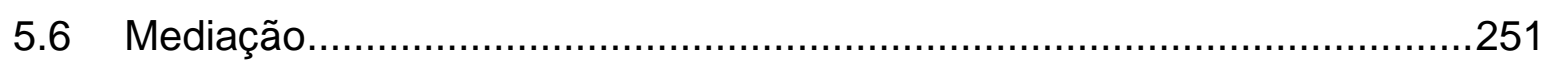

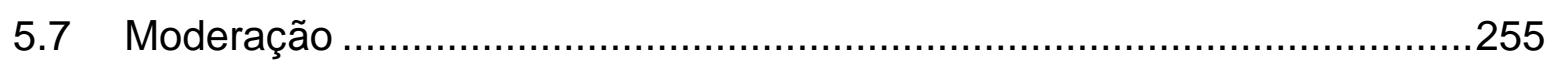

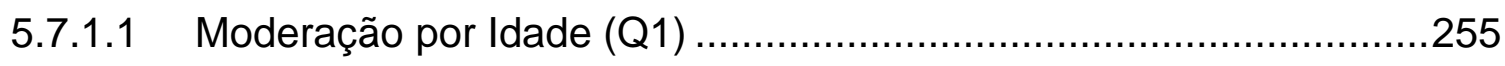

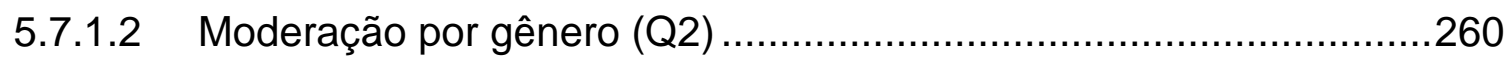

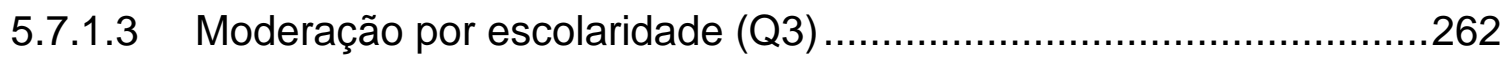

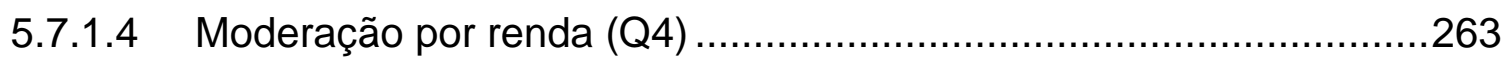

5.7.1.5 Moderação por busca de informação (P4) ......................................266

5.7.1.6 Moderação por local de compra efetiva (P6) .................................270

5.7.1.7 Moderação por hábito de compra (P7) ..........................................270

5.7.1.8 Moderação por opções de pesquisa e compra P8 …......................275

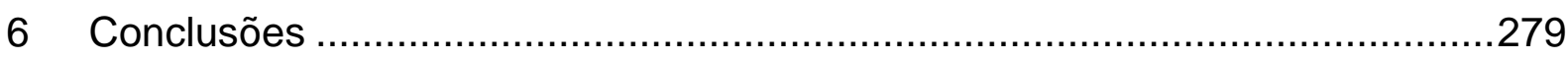

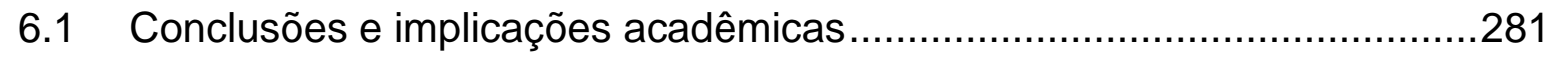

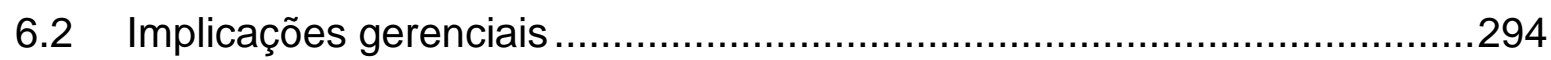

6.3 Limitações do estudo e direcionamentos futuros .......................................296

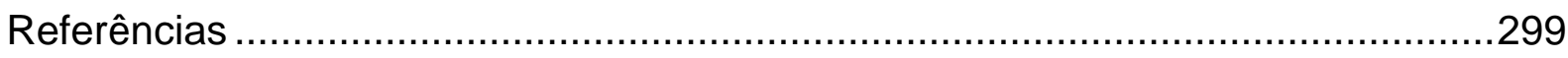

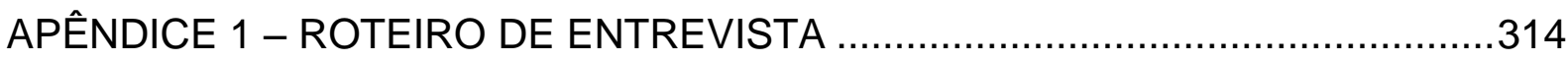

APÊNDICE 2 - QUESTIONÁRIO DA PESQUISA ….............................................. 314

ANEXO 1 - QUESTIONÁRIO ORIGINAL COM FONTES BIBLIOGRÁFICAS........314 
Tabela 1: Ocorrência de outliers

\section{Índice de Tabelas}

Tabela 2 - Produtos que comprou nos últimos seis meses ..................................185

Tabela 3 - Buscou informação sobre o produto com quem? ................................185

Tabela 4 - Local de busca de informação para o produto. ...................................186

Tabela 5 - Local de compra efetivo. ............................................................186

Tabela 6 - Cruzamento entre local de busca (P3-múltipla resposta) e local de

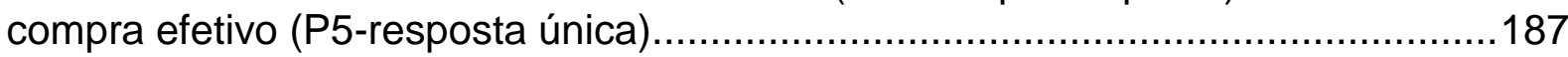

Tabela 7 - Quantas lojas buscou para informação? ..........................................187

Tabela 8 - Quantas Lojas buscou para compra efetiva? ...................................187

Tabela 9 - Hábito de busca e compra...........................................................188

Tabela 10 - Cruzamento do hábito com o local de compra efetiva........................188

Tabela 11 - P.8.1 - Intenção de free-riding - busca on-line e compra loja física .....189

Tabela 12- P.8.2 - Intenção de free-riding - busca loja física e compra on-line .....189

Tabela 13 - Cruzamento entre questões 8.1 e 8.2 ..........................................189

Tabela 14 - Qualidade de ajustamento Autoeficácia ...........................................192

Tabela 15: Qualidade de ajustamento Experiência com Internet ...........................193

Tabela 16 - Qualidade de ajustamento Afinidade Tecnológica .............................195

Tabela 17 Qualidade de Ajustamento Experiência Vicária....................................196

Tabela 18 - Qualidade do ajustamento - Satisfação em Free-riding .......................198

Tabela 19 - Qualidade do ajustamento - Satisfação em Loja Física.......................198

Tabela 20 - Qualidade de ajustamento Confiança On-line ...................................20

Tabela 21 - Qualidade de ajustamento Confiança Loja Física .............................200

Tabela 22 - Qualidade de ajustamento - Lealdade .............................................202

Tabela 23: Fator 5 - Retenção na Firma........................................................203

Tabela 24 - Qualidade de ajustamento Retenção na Firma ................................203

Tabela 25 - Qualidade de ajustamento Busca de Variedade ...............................205

Tabela 26 - Qualidade de ajustamento Custo de Mudança (alto)- CMR ...............207

Tabela 27 - Qualidade de ajustamento Custo de Mudança (baixo) - CMM .............208

Tabela 28 - Qualidade de ajustamento - Integração Percebida.............................209

Tabela 29 - Qualidade de ajustamento - Conveniência On-line............................211

Tabela 30 - Qualidade de ajustamento - Conveniência Loja Física.......................212

Tabela 31 - Qualidade de ajustamento Design do Site .......................................213

Tabela 32 - Qualidade de Ajustamento - Atratividade do Varejo .........................214

Tabela 33 - Qualidade de ajustamento Risco Percebido .....................................216

Tabela 34 - Qualidade de ajustamento para Qualidade Percebida ......................218

Tabela 35 - Qualidade de ajustamento - Barganha ...........................................219

Tabela 36 - Qualidade de ajustamento Intenção de Free-riding............................221

Tabela 40 - Avaliação de normalidade e normalidade multivariada ......................240

Tabela 41 - Diferenças de Qui-quadrado entre modelo estrutural P10 saturado e

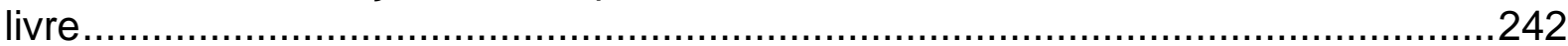

Tabela 42 - Validade discriminante Modelo estrutural final ................................244

Tabela 43 - Correlações entre variáveis exógenas do modelo P10 …..................245

Tabela 37 - Resultados do procedimento de ajustamento do modelo ....................247

Tabela 38 - Qualidade de ajustamento do modelo estrutural P10 .........................249

Tabela 39 - Teste de hipóteses para o modelo estrutural final P10.....................251

Tabela 44 - Qualidade de ajustamento para efeitos de mediação..........................252

Tabela 45 - Análise de mediação para o modelo estrutural P10 …......................253

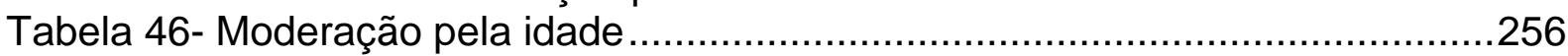

Tabela 47 - Estatísticas da análise de multigrupo idade ....................................257 
Tabela 48 - Teste de diferenças de médias para idade....................................258

Tabela 49 - Teste de diferenças de médias para idade ......................................259

Tabela 50 - Teste de diferenças de médias para idade .....................................259

Tabela 51 - Teste de diferenças de médias para idade ......................................260

Tabela 52 - Teste de diferenças de médias para idade .....................................260

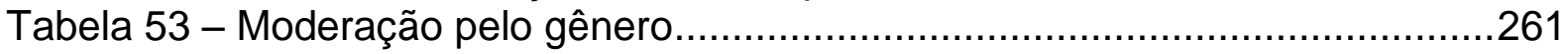

Tabela 54- Estatísticas da análise de multigrupo para gênero..............................262

Tabela 55 - Moderação pela escolaridade ……………....................................263

Tabela 56 - Moderação pela renda...............................................................26

Tabela 57 - Estatística da análise de multigrupo para renda...............................264

Tabela 58 - Teste de diferenças de médias - renda .........................................265

Tabela 59 - Teste de diferenças de média para renda ......................................265

Tabela 60 - Moderação pela busca de informação............................................266

Tabela 61 - Estatística da análise de multigrupo sobre a busca de informação .....267

Tabela 62 - Diferença de médias para busca de informação ................................268

Tabela 63 - Diferença de médias para busca de informação .................................269

Tabela 64 - Diferença de médias para busca de informação .................................269

Tabela 65- P6: Sobre a compra efetiva: quantas lojas visitou? .............................270

Tabela 66 - Moderação para P7: hábito de compra ..........................................271

Tabela 67 - Estatística da análise de multigrupo sobre o hábito ..........................2272

Tabela 68 - Teste de diferenças de médias para hábito......................................272

Tabela 69 - Teste de diferenças de médias para hábito ........................................273

Tabela 70 - Teste de diferenças de médias para hábito ....................................273

Tabela 71 - Teste de diferenças de médias para hábito ......................................2274

Tabela 72 - Teste de diferenças de médias para hábito .....................................2274

Tabela 73 - Teste de diferenças de médias para hábito .....................................274

Tabela 74 - Moderação por busca em loja on-line e compra efetiva em loja física 275

Tabela 75 - Estatísticas da análise de multigrupo para local de busca e compra

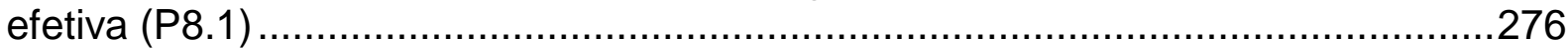

Tabela 76 - Teste de diferenças de médias para busca on-line e compra loja física

Tabela 77 - Moderação pela busca loja física e compra efetiva on-line 


\section{ÍNDICE DE QUADROS}

Quadro 1 - Arcabouço teórico e conceitual .......................................................27

Quadro 2: Varejo Omnichanne/ para satisfazer omni-shoppers.............................41

Quadro 3- variáveis principais para o modelo PPM de Chiu et al. (2011) ...............54

Quadro 4 - Resumo de hipóteses do modelo .....................................................55

Quadro 5 - Relação de construtos ..............................................................58

Quadro 6 - Resumo de valores de referencia para índices de ajustamento ............141

Quadro 7 - Matriz de Amarração ..............................................................160

Quadro 8 - Estatística descritiva das variáveis Push......................................176

Quadro 9 - estatística descritiva das variáveis push.........................................177

Quadro 10- Estatística descritiva das variáveis Mooring ...................................178

Quadro 11- Estatística Descritiva das variáveis Pull ........................................179

Quadro 12- Estatística descritiva - variáveis dependente ...................................180

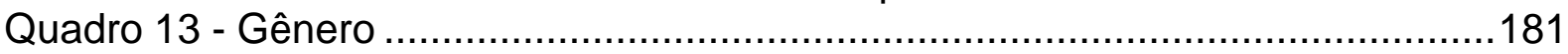

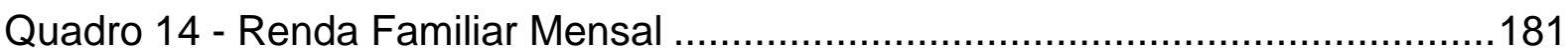

Quadro 15 - Gênero x Faixa de renda mensal ..............................................182

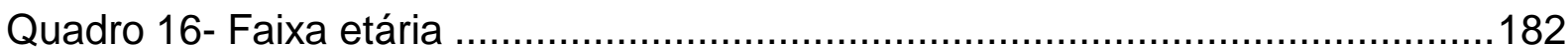

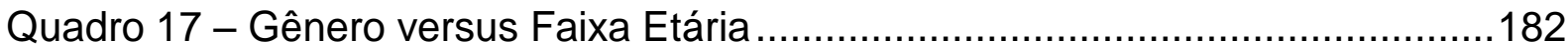

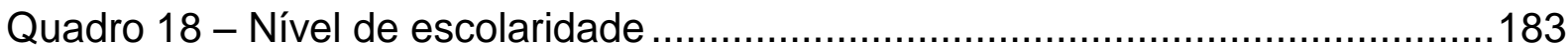

Quadro 19 - Gênero versus Escolaridade ...................................................183

Quadro 20 - Distribuição da amostra em relação à população brasileira ................184

Quadro 21: Fator 1 - Autoeficácia multicanal.....................................................191

Quadro 22: Fator 2- Experiência prévia com internet........................................193

Quadro 23: Fator 3 - Afinidade Tecnológica ..................................................194

Quadro 24: Fator 4 - Experiência Vicária ……………..................................196

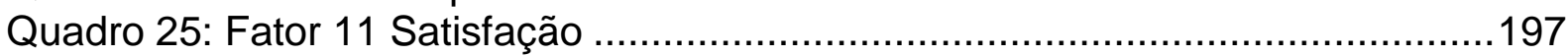

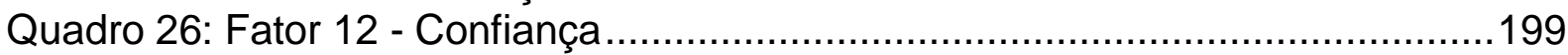

Quadro 27: Fator 13 Lealdade ...................................................................201

Quadro 28: Fator 6 - Busca de variedade com dois componentes.......................204

Quadro 29: Fator 6 - Busca de Variedade ........................................................205

Quadro 30: Fator 7 - Custo de Mudança .......................................................207

Quadro 31: Fator 8 - Integração Percebida .....................................................209

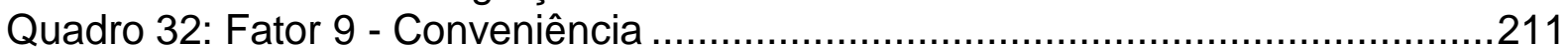

Quadro 33: Fator 10 - Design do Site..........................................................212

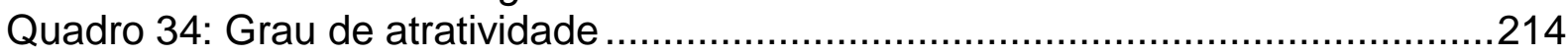

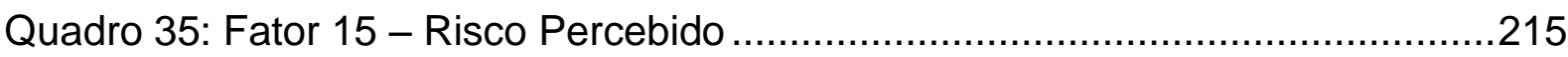

Quadro 36: Fator 17 - Qualidade Percebida...............................................217

Quadro 37: Fator 17 - Barganha ……......................................................219

Quadro 38: Fator 18 - Intenção Free-riding ...................................................220

Quadro 39 - Resumo dos fatores após análise fatorial exploratória e confirmatória

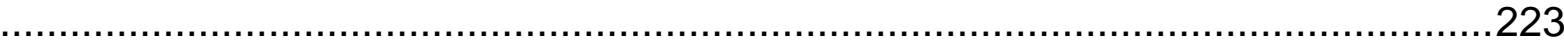

Quadro 40: Comparação de médias dos fatores Push por grupo ...........................225

Quadro 41 - Comparação de médias para os fatores SA_FR, CF_OL, LE ............228

Quadro 42 - Comparação de médias dos fatores CMR, CMM, IN e BV ..................229

Quadro 43 - Comparação de médias dos fatores RF, CO_OL e DS .....................231

Quadro 44 - Comparação de médias dos fatores QP, RP, BA, AV ......................233

Quadro 45 - Comparação de médias dos fatores SA_LF, CF_LF e CO_LF...........234

Quadro 46 - Comparação de médias do fator Intenção de free-riding .....................236 
Quadro 47 - comparação de médias significativas das variáveis de perfis e fatores Quadro 48 - Confiabilidade composta, Variância Extraída, análise de resíduos padronizados. 238

Quadro 49- Resumo das médias maiores e significativas para busca (P4) .243 Quadro 50 - Resumo sobre médias maiores e significativas para hábito 269 275 


\section{ÍNDICE DE ILUSTRAÇÕES}

Figura 1: Busca para Multichannel Marketing, Mutichannel sales, Mutichannel

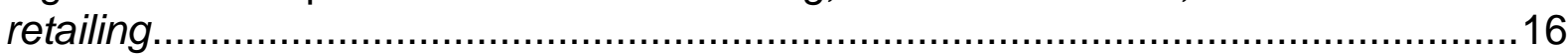

Figura 2 - Previsão de impacto do cross-channe/ no varejo 2006 - 2010 nos EUA...37

Figura 3 - Modelo PPM - push-pull-mooring de troca de serviço ............................47

Figura 4 - Seleção prévia das pesquisas empíricas para variáveis de alternância de

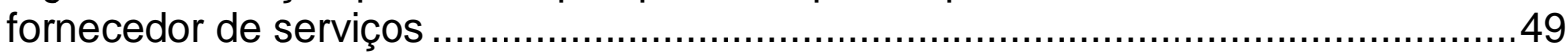

Figura 5 - Matriz de comportamento do consumidor multicanal .............................53

Figura 6- Modelo desenvolvido por Chiu et al. (2010) ..........................................57

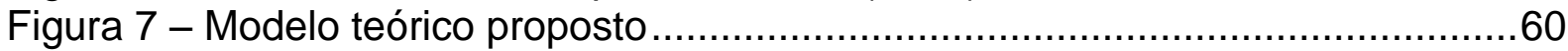

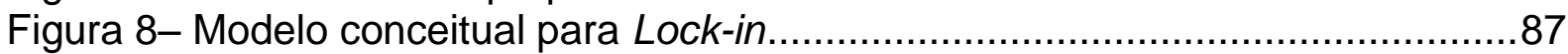

Figura 9 - Variáveis Mediadoras .................................................................153

Figura 10- Tipologia para as variáveis de especificação ou teste ..........................154

Figura 11 - Modelo moderador ....................................................................155

Figura 12 - Diagrama de caminho: Construto Autoeficácia .................................192

Figura 13 - Diagrama de caminho: Construto Experiência Prévia com Internet .....194

Figura 14 - Diagrama de caminho: Construto Afinidade Tecnológica.....................195

Figura 15 - Diagrama de caminho: Construto Experiência Vicária ..........................196

Figura 16 - Diagrama de caminho: Construto Satisfação em Free-riding ................198

Figura 17 - Diagrama de caminho: Construto Satisfação Loja Física ......................199

Figura 18 - Diagrama de caminho: Construto Confiança On-line ..........................200

Figura 19 - Diagrama de caminho: Construto Confiança Loja Física ......................201

Figura 20 - Diagrama de caminho: Construto Lealdade .....................................202

Figura 21 - Diagrama de caminho: Construto Retenção na Firma ........................204

Figura 22 - Diagrama de caminho: Construto Busca de Variedade.......................206

Figura 23 - Diagrama de caminho: Construto Alto Custo de Mudança (CMR) .......208

Figura 24 - Diagrama de caminho: Construto Baixo Custo de Mudança (CMM) ....208

Figura 25 - Diagrama de caminho: Construto Integração Percebida .......................210

Figura 26 - Diagrama de caminho: Construto Conveniência On-line......................211

Figura 27 - Diagrama de caminho: Construto Conveniência Loja Física ................212

Figura 28 - Diagrama de caminho: Construto Design do Site...............................213

Figura 29 - Diagrama de caminho Construto Atratividade do Varejo.....................215

Figura 30 - Diagrama de caminho: Construto Risco Percebido.............................216

Figura 31 - Diagrama de caminho: Construto Qualidade Percebida .....................218

Figura 32 - Diagrama de caminho: Construto Barganha ....................................220

Figura 33 - Diagrama de caminho: Construto Intenção de Free-riding ....................221

Figura 34 - Modelo Estrutural final (P10) .....................................................249

Figura 35 - Desenho do modelo final P10 após mediação ....................................254 


\section{Introdução}

O varejo vem assumindo uma importância cada vez maior no cenário brasileiro, acompanhando a tendência mundial. O ritmo de consolidação caracterizado pelas atividades varejistas brasileiras tem evidenciado um número crescente de maiores empresas do Brasil que atendem ao consumo das famílias, equivalente a $62,3 \%$ do PIB brasileiro, 52\% representa o varejo de bens, da ordem de $R \$ 1.152 .670$ milhões. As 120 maiores empresas do varejo de bens ${ }^{1}$ somaram $\mathrm{R} \$ 325.988$ milhões (dados de 2012 , faturamento bruto $^{2}$ ), retratando $28 \%$ no total do consumo de bens. As dez maiores correspondem a 55\% deste valor e estão representadas em ordem decrescente pelo grupo Pão de Açúcar, Grupo Carrefour, Grupo Walmart Brasil, Lojas Americanas LASA, Cencosud, Magazine Luiza, Máquina de vendas, Makro, O Boticário e Raia Drogasil (RANKING IBVAR, 2013). À medida que as empresas varejistas ganham escala e se expandem, passam a adotar sofisticadas tecnologias de informação e gestão, também contribuindo para o desenvolvimento do sistema logístico e de distribuição no Brasil. A mudança nos padrões de consumo do brasileiro continuará na mesma intensidade e causará impacto na relação com produtos, marcas e lojas. (MATTAR, 2011; PARENTE, 2010).

À proporção que a tecnologia da internet evoluiu, alguns setores de serviços como bancos, seguros, viagens etc. passaram a operar através de novos canais. $O$ serviço caminhou na frente da distribuição física com a tecnologia. Os benefícios de um canal de marketing adicional não estão limitados a apenas vendas. Ao contrário, quando a administração dos canais não é feita na forma de silos isolados, os varejistas poderiam esperar que um canal complementasse ou desse suporte ao outro, aumentando em vendas totais. (VAN BAAL; DACH, 2005). Além disso, alguns estudos identificam que os consumidores do multicanal são mais valiosos, pois gastam mais do que o consumidor uni-canal (DELOITTE, 2011; MCKINSEY, 2000).

\footnotetext{
${ }^{1}$ Exceto veículos e combustíveis

${ }^{2}$ Levantamento realizado pelo PROVAR e PWC considerando: bases secundárias; análises de balanços publicados; consulta a especialistas; identificação, separação e junção de operações; construção do ranking e de indicadores. Faturamento Líquido para o Makro.
} 
O termo multicanal foi pesquisado no Google N Gram Viewer (acesso em 22/03/13) para três grupos de palavras chaves: multichannel marketing, multichannel sales multichannel retailing (Figura 1). O Google N Gram Viewer apresenta recurso que cataloga livros lançados com as três palavras-chave no período de 1800 a 2008 (último ano até a data da pesquisa). O termo multicanal surgiu na década de 50 e foi utilizado pelas áreas de engenharia e computação. A expressão marketing multicanal começou a ser empregado a partir de 1969, associado à logística de distribuição multicanal. Em 1985 o termo foi abordado por Graham (1985) referindose aos acordos de franquias relacionados com estágios de produção e distribuição. Kotler e Armstrong (1989) reconheceram o crescimento do marketing multicanal, seja horizontal, seja vertical, conceituando como arranjos simbólicos para venda em múltiplos mercados a partir da proliferação da segmentação do consumidor e possibilidades de canais. Assinala que essa tendência afetou: a cooperação de canal, conflito e concorrência. Em 1992, o termo ganhou nova conotação. Os pequenos negócios deveriam incorporar a mentalidade multicanal e desenhar um programa de marketing multicanal. A expressão vendas multicanal surgiu na década de 70-80 em revistas acadêmicas de economia. A força do significado multicanal teve seu apogeu em 1989 com inúmeras publicações. E por último, o termo multicanal varejo surgiu em 1981 no livro da companhia de leilão Sotheby's ao descrever a adesão do grupo japonês Seibu, que se autodescreve como uma organização de multicanal varejo. Depois foi adotado o termo por Kotler (1989). Em aproximadamente 2006, o termo vendas multicanal ganhou máxima notoriedade.

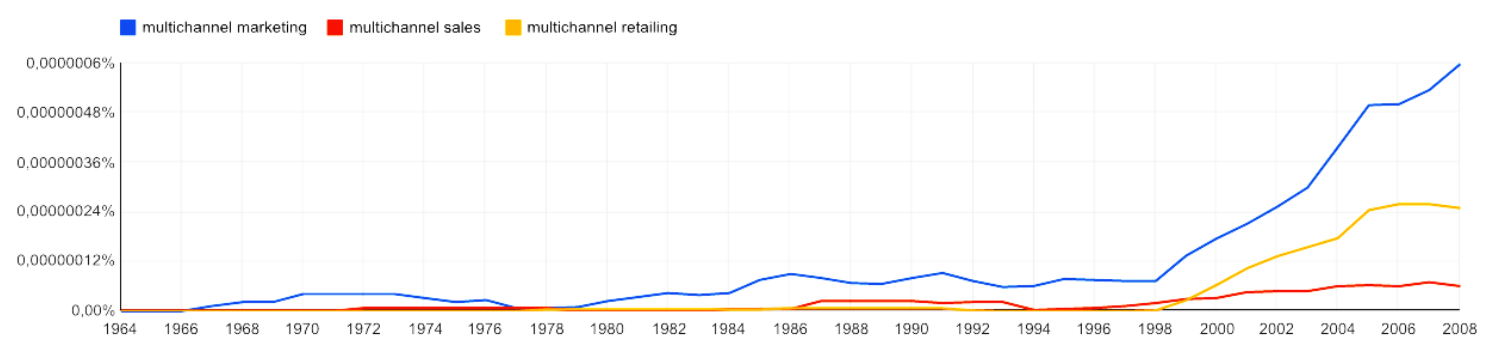

Figura 1: Busca para Multichannel Marketing (linha mais alta), Mutichannel sales (linha intermediaria), Mutichannel retailing (linha mais baixa).

Fonte: Google books N Gram Viewer

Mattar (2011) ressalta que o varejo brasileiro vem ressurgindo na nova economia passando a ser chamado de multivarejo, tendo o multicanal como estratégia com 
foco no consumidor, para atendê-lo com o quê, onde, quando e como ele quiser comprar. O tema multicanal está em pauta há mais de uma década, reafirmando que comercio eletrônico e vendas on-line não representa mais uma opção de canal, tornou-se uma obrigação para o varejista. Os avanços prosseguem para a integração de canais, com geração de vendas cruzadas e ampliação do relacionamento com consumidores. A ampliação do relacionamento se dá pela maior flexibilidade da operação em resposta ao consumidor. Isso significa poder comprar on-line e retirar na loja, pesquisa e comprar na loja pelo canal on-line ou por catálogo, oferecer troca e condições de devolução em canais distintos e flexibilizar formas de compra que reduzam a taxa de entrega e perda de vendas por ruptura.

Um maior número de varejistas, outrora lojas tradicionais, se transformou em varejistas multicanais ao estabelecer presença on-line. Não obstante, as lojas on-line de varejistas multicanais continuam com desempenho abaixo da intenção de compra comparada com as lojas on-line puras na internet (NIELSEN/NETRATINGS, 2005). Os pesquisadores enfatizaram que os varejistas multicanais precisavam entender melhor o comportamento do consumidor on-line para concorrer de forma mais eficaz com as lojas virtuais varejistas (KONUS; VOERHEUF; NESLIN, 2008).

Brashear; Kashyap; Musante e Donthu (2009) comentam que na última década a internet moveu-se de uma nova tecnologia para um canal rotineiro de informação, comunicação e compras do varejo. Porém ainda o canal internet não é o método mais comum de compra. $O$ varejo on-line não tem obtido sucesso como plataforma independente, como negócio exclusivo da web. Pesquisadores e o comercio varejista estão interessados nas formas como o consumidor irá utilizar a internet. $O$ crescimento das compras on-line e o contínuo movimento dos varejistas para um formato multicanal demonstram que esse meio irá ainda crescer em importância. No relatório Internet Retailer (America's Top Ten Retail Business, 2008), Brashear et al. (2009) informam que sete dos maiores varejistas nos EUA são negócios tradicionais com presença on-line. São eles em ordem decrescente de faturamento: Staples, Office Depot, Dell, Hewlett-Packard, OfficeMax, Sears e Sony. Além disso, as 25 maiores cadeias varejistas que contam com cerca de $20 \%$ de todas as vendas online em 2006 enfatizam o potencial para crescimento na área de multicanais. 
Compradores on-line europeus e asiáticos apresentam média de compra (ticket médio) de quase o dobro em relação a compradores on-line americanos.

O crescimento de compras on-line é mais rápido nos mercados em desenvolvimento do que em economias desenvolvidas, segundo Acnielsen (2005 apud BRASHEAR et al., 2009). Espera-se maior crescimento do uso da internet e do comércio eletrônico em regiões fora dos Estados Unidos, provenientes de países populosos tais como Brasil e China.

Em função dessa tendência, as empresas buscam a globalização para agregar valor aos negócios, justificado na seguinte ordem: primeiro, pelo crescimento do comércio eletrônico no mundo; em segundo, espera-se que a população on-line seja dominada por compradores on-line fora dos EUA, que hoje representam mais de $75 \%$ do poder de compra; em terceiro, uma presença virtual global é mais viável e mais barata do que a presença física. Porém a empresa deve atentar antes de migrar para um comércio eletrônico global às características culturais dos paísesalvo (MAHMOOD; BAGCHI; FORD, 2004).

Consumidores cada vez mais compram por meio de canais (seja para promoção, venda e distribuição de produtos, seja para serviços), tais como loja física, internet, venda por catálogos, quiosques e call centers. A tendência a empregar um canal para busca de informação e outro para compra continua a crescer, segundo revisão de artigos de Yu, Niehm e Russel (2011). O canal on-line é a forma mais popular para busca de informação, descoberta de produto e comparação de preços, enquanto a loja física é utilizada para a compra real (VERHOEF; NESLIN; VROOMEN, 2007).

Compra multicanal, definida como compra em diferentes canais de varejo, capacita o consumidor a ter mais opções de compras flexíveis, obter acesso fácil à informação de produto e experimentar uma qualidade maior de serviços (VERHOEF; NESLIN; VROOMEN, 2007). Do ponto de vista da área comercial, as vendas por meio de canais podem criar oportunidades para vendas e lucros, atingir mais clientes, alavancar os ativos da marca pela presença entre canais e desenvolver estratégias 
competitivas para alcançar públicos diferentes de mercado. Entretanto, a mudança de canais pelo consumidor e a canibalização do canal são considerados um dos maiores desafios que impedem varejistas de se movimentar na direção de uma estratégia multicanal (YU; NIEHM; RUSSEL, 2011).

Yu, Niehm e Russel (2011) ressaltam que a pesquisa sobre multicanal varejo tem investigado principalmente os benefícios utilitários e hedônicos, tais como os valores de compra experiencial, obtenção de informações, sortimento, conveniência de compra, economizar tempo e custos de busca, comparação de preços, redução de riscos, como determinantes do comportamento de compra multicanal (VERHOEF; NESLIN; VROOMEN, 2007).

Por outro lado, as organizações varejistas estão se movendo cada vez mais para a integração multicanal, fenômeno recorrente, abrangendo segmentos como indústria, varejo, viagem, banco, computadores, softwares e manufatura (SAWHNEY, 2001). Consumidores podem lidar com uma simples organização para busca de informação, comprar produtos e retornar produtos por meio de um ou mais canais: loja física, vendedor, catálogo, venda por telefone e on-line. Tanto o lado de suprimento quanto o do consumidor explicam a tendência de integração multicanal (KUMAR; VENKATESAN, 2005).

\subsection{Justificativa}

Foi realizado um levantamento sobre dissertações e teses com o tema "compras online", "comportamento do consumidor on-line" e "varejo multicanal" no banco de teses e dissertações da Capes. Encontraram-se no máximo 40 publicações sobre compras on-line, em que foram realizadas pesquisas exploratórias: de perfil e hábitos do consumidor on-line, de satisfação, de risco e suas dimensões, de comunicação das empresas, de intenção de compra. Na busca com as palavraschave "varejo multicanal" foi encontrado três publicações no período 2006-2011, sendo duas da PUC-RJ e uma da FGV-SP. 
Dentre a pesquisa acadêmica de varejo multicanal realizada no site da Capes, destaca-se o estudo de Oliveira (2009) sobre a percepção de risco e orientação de compra em canais distintos (on-line e loja física), um estudo de caso por meio de survey realizado em um grande varejista multicanal. Houve outro estudo semelhante para o contexto de alimentos perecíveis com o mesmo orientador. $E$, finalmente, a tese de Porto (2006), que realiza um estudo de caso com livrarias em São Paulo, tendo como unidade de análise o grau de integração de canais on-line e loja física em relação a gestão, operação e mensuração.

O tema em torno do varejo multicanal é ainda muito novo na pesquisa acadêmica brasileira. O varejo multicanal surgiu a partir da evolução do mercado de internet no Brasil e no mundo. Oliveira (2009) destaca que a internet iniciou o crescimento no Brasil a partir dos anos 1990 e, em meados daquela década, o comércio on-line já abria as portas.

Em 2013, segundo o 29ำ relatório Webshopper da E-bit, registrou-se 51,3 milhões de e-consumidores que fizeram, ao menos, uma compra on-line, sendo 88,3 milhões de pedidos em todo o território nacional. Faturou-se $\mathrm{R} \$ 28,8$ bilhões em vendas de bens de consumo no e-commerce brasileiro, crescimento nominal de $28 \%$ em relação a 2012, superando a curva de desenvolvimento anual de $25 \%$ nos últimos quatro anos. As vendas por dispositivos móveis indicam franco crescimento no Brasil. Em janeiro de 2013, as transações concluídas por dispositivos móveis correspondiam a $2,5 \%$ de todas as vendas on-line. Em dezembro, esse número praticamente dobrou: $4,8 \%$. As categorias de produtos mais vendidos em ordem decrescente destacam: moda \& acessórios que manteve a liderança durante o ano; cosméticos e perfumaria / cuidados pessoais e saúde; eletrodomésticos; livros e assinaturas de revistas; informática; telefonia e celulares; casa e decoração; eletrônicos; esporte e lazer; brinquedos e games.

Seguindo este relatório, o tíquete médio das compras em 2013 foi de $R \$ 327,00$, (4,4\%) abaixo de 2012 que foi $R \$ 342,00$ (WEBSHOPPER, 2014). As mulheres com idade superior a 50 anos passaram de $14 \%$ para $21 \%$ do total de compradoras entre 2005 e 2010, evidenciando aumento da senioridade das compradoras virtuais. O 
tíquete médio das compras femininas subiu de $R \$ 240,00$ em 2005 para $R \$ 314,00$ em 2010 ( $31 \%$ em cinco anos), porém continua inferior ao ticket médio dos gastos efetuados pelos homens, que foi de $R \$ 425,00$. Os integrantes da classe $C^{3}$ são mais jovens do que o restante do mercado. A média de idade dos consumidores online é de 41 anos, enquanto a média dos consumidores de baixa renda ficou em 37 anos (WEBSHOPPER, 2010).

O incremento em vendas de 2010 pode ser explicado pelo evento "Copa do Mundo", que contribuiu para o aumento na venda de televisores de telas finas, especialmente o tipo LCD, elevando o valor do tíquete médio (WEBSHOPPER, 2010).

Outro dado importante do relatório WEBSHOPPER (2010) é que o desempenho do comércio on-line em 2010 pode ter sido atribuído à satisfação dos consumidores pelos serviços oferecidos nas lojas virtuais. $\mathrm{O}$ índice E-bit relativo à internet segura $\mathrm{e}$ confiança dos consumidores, teve aprovação de $87 \%$ durante o ano, sendo que o patamar de excelência definido para o índice é de $85 \%$.

Por sua vez, notícia publicada sobre a pesquisa divulgada pelo Instituto de Pesquisa Econômica Aplicada (IPEA, 2011) e com dados até 2008 (não houve atualização deste relatório ainda), o Brasil tinha 11,97 milhões de consumidores compradores on-line, o equivalente a $19 \%$ dos usuários da internet no país, que adquirem produtos pela rede. Apesar disso, apenas $0,4 \%$ das empresas brasileiras têm presença on-line, o que faz com que apenas $1 \%$ do volume total das vendas do varejo seja efetuada pela Internet. Nos Estados Unidos, por exemplo, com dados de 2008, mesmo ano base do estudo do IPEA, mostravam que 3,6\% das negociações no varejo eram feitas via e-commerce. A pesquisa também revelou que o status empregatício dos indivíduos não é relevante para diferenciar compradores on-line e off-line.

Esses dados sinalizam que 0 varejo multicanal tem longo caminho ainda para percorrer no Brasil como estratégia das empresas varejistas com alguns desafios de

${ }^{3}$ Critério Brasil 
integração de sistema de informação, gestão e processos. Trata-se de um novo conceito de negócio, segundo Deloitte (2011), para satisfazer a demanda do consumidor. Acredita-se, por outro lado, constituir uma nova maneira de trabalhar que irá afetar a operação do varejo como um todo, no sentido de trazer a excelência para o consumidor, também denominado de "neoconsumidor", visto que é conectado, digital, multicanal, multimídia e altamente informado.

A facilitação do processo de compra tem sido a máxima como diferencial no atendimento num ambiente concorrencial. Mais do que disponibilizar produtos e serviços ao consumidor, o momento da compra se tornou o ponto alto, quando ocorre a percepção de troca de valor e as duas partes negociam a satisfação de expectativas. O momento da compra se torna o momento mais importante do relacionamento entre fornecedor e consumidor. O grau de envolvimento, de diferenciação de marca, de informação necessária, de lealdade à marca, de hábito construído e outras variáveis pode ser explicado pelos modelos de compra da literatura de marketing. No processo de compra, o uso da informação, poder e tempo é fator importante na negociação, segundo o modelo de Cohen (GIGLIO, 2008).

O comportamento de compra varia entre diferentes consumidores e diferentes tipos de produto, havendo alguma relação entre características do produto e tipo de comportamento de compra. Existem decisões em que a busca de informações e todo o processo de compra ocorrem de forma mais simples, o que se torna bem diferente quando o produto é mais complexo. O processo de busca de informação depende do custo do produto, importância, conhecimento e experiência do consumidor em relação ao produto. O tempo de busca para uma decisão de compra depende e pode ser colocada numa perspectiva de custo, importância do produto, conhecimento e experiência do consumidor em relação ao produto (PARENTE, 2010).

Na revisão de Dabholkar (1994), pesquisadores concordam que as decisões do consumidor refletem processos de cognição, motivação e afeto, porém poucos esforços incorporam todos esses processos num modelo de escolha. A maioria dos modelos de escolha de tomada de decisão do tipo informação-processamento é 
baseada no paradigma da Psicologia Cognitiva. Porém, tais modelos ignoram os aspectos motivacionais e emocionais das decisões do consumidor. Por sua vez, as pesquisas atitudinais pela abordagem da Psicologia Social, baseadas em modelos de atitude em multiatributos, têm focado no vínculo entre componentes da cognição, afetividade e intenção (conativo) para incorporar a escolha nos modelos de predição de comportamento de consumidor.

Nas últimas décadas, a internet deixou de ser uma nova tecnologia para tornar-se, do ponto de vista do comércio, um canal rotineiro de informação, comunicação e varejo de compra on-line. Esperava-se que haveria uma revolução, porque os consumidores optariam pela desintermediação em certas indústrias, colocando várias lojas tradicionais fora do negócio. Isso não aconteceu na extensão esperada; apesar de a internet ser o canal de varejo com maior crescimento, não se tornou ainda o método de compra preferido do consumidor. Com algumas exceções, varejistas on-line não são um sucesso como plataforma independente e virtual (BRASHEAR et al., 2009).

Focar em consumidores heavy users de internet (usuários intensos) não representa frequência de compras on-line necessariamente, o que se torna verdadeiro para os mercados emergentes repletos de usuários jovens. Atitudes e dimensões motivacionais são componentes importantes para a estratégia de marketing efetiva quando se coloca o foco no público de compradores pela internet (BRASHEAR et al., 2009).

Conforme aumenta a variedade de canais, o comportamento de compras do consumidor tem se tornado mais complexo. Coughlan; Anderson; Stern e El-Ansari (2002) revelam que consumidores podem usar os serviços de um canal e comprar em outra loja, seja no mesmo canal, seja em outro. Mudam de canal e de varejista quando comparam preços. Se o consumidor permanece fiel a uma marca de varejo no cruzamento de canais, o varejo multicanal mostra vantagem em relação ao varejo unicanal. Mas, se o consumidor muda de varejista (seja alterando o tipo de canal ou não), após ganhar informação da pesquisa, engaja-se em comportamento do tipo free-riding, no sentido de "acesso grátis" ou de "pegar carona" na informação disponibilizada (VAN BAAL; DACH, 2005). 
Van Baal e Dach (2005) alegam que, com a ampliação do uso da internet, espera-se que as compras por multicanais também aumentem. Bakos (2001) revela que, no contexto de comércio eletrônico, a questão mais saliente é o free-riding do consumidor nas lojas e depois compra on-line. O free-riding no sentido contrário parece não ser o problema, pois os custos das lojas on-line são amplamente fixos, e a oferta de informação on-line torna-se pública, enquanto os custos das lojas físicas dependem amplamente do número de visitantes. Do ponto de vista do fabricante, a revisão de literatura dos autores assinala que devem ser consideradas ambas as direções de compras em canais cruzados no sentido de gerenciar o conflito entre canais e alocação de compensação, tal como campanhas com pagamentos cooperados. De fato, o consumidor é que decide a escolha do canal de compra, e eles se caracterizam como free-riders.

A forma como os consumidores executam as tarefas diárias, tais como compras e relacionamento com banco, tem mudado dramaticamente na última década. Tais mudanças vêm ocorrendo por meio do desenvolvimento da tecnologia baseada em autosserviço, o que permite que o consumidor possa realizar serviços de forma rápida e convenientemente (BOBBITT; DABHOLKAR, 2001).

Num ambiente tradicional unicanal, consumidores reúnem informações e compram em diferentes varejistas ou completam ambos os estágios da decisão de compra na mesma loja, processo este também denominado de retenção. No ambiente multicanal, a discussão deve considerar retenção cross-channel e cross-channel com free-riding. (CHIU et al., 2011; VAN BAAL; DACH, 2005).

Carlton e Chevalier (2001) destacaram a necessidade de os fabricantes colocarem restrições nos varejistas on-line para controlar o free-riding. Será que a informação pode ser controlada no âmbito do varejo on-line? À época, os autores sinalizavam que o conflito de canal seria um sério problema para os fabricantes. Em contraponto, a tecnologia baseada em autosserviço está crescendo em percentuais altos a cada ano e em todo o mundo, porém existe falta de uma teoria unificada para entender essa forma de serviço. Coughlan et al. (2002) destacam a natureza dos conflitos de 
canais. Podem surgir conflitos por objetivo, de domínio e de percepção da realidade, cabendo aos produtores a avaliação do nível de conflito e o encaminhamento do mesmo.

Todos esses fatos apontam para novos comportamentos de compra do consumidor que cada vez mais desenvolve autoeficácia na compra on-line; e, portanto, estudar o comportamento free-rider do comprador on-line apresenta impacto gerencial para o varejo multicanal.

O tema é inovador e acompanha as pesquisas internacionais mais recentes para entender o comportamento do comprador on-line e o impacto que causa no varejo multicanal.

\subsection{Problema da pesquisa}

Quando o consumidor navega num ambiente multicanal para a busca e a compra de produtos, ele pode obter serviços de um varejista e colocar o pedido em outro varejista, se engajando em free-riding entre canais on-line e off-line (ou vice-versa) e entre varejistas. A lacuna que se buscou endereçar nesta pesquisa empírica foi verificar se, no comportamento de alternância durante o cruzamento entre canais (cross-channel), ocorreu motivação para free-riding entre varejistas e/ou houve motivação para retenção na firma (lock-in).

O comprador ao se engajar na busca e compra teve intenção de free-riding entre varejistas? Ao realizar ou não o free-riding ele está retido nos varejistas de sua preferência?

\subsection{Objetivo Geral}

A pesquisa empírica propôs explorar os antecedentes que influenciaram o consumidor para o comportamento de alternância entre canais, investigando se a 
capacidade e habilidade em utilizar o ambiente multicanal afetou sua intenção em free-riding e/ou influenciou a sua retenção pela firma.

\subsection{Objetivos específicos}

- Explorar as crenças salientes sobre comportamento do consumidor para o varejo multicanal;

- Verificar por análise confirmatória os construtos latentes;

- Verificar o impacto dos antecedentes e avaliar o desempenho geral do modelo proposto;

- Validar o modelo estrutural final;

- Verificar o papel mediador das variáveis latentes: autoeficácia, retenção na firma e atratividade do varejo;

- Verificar o papel do efeito moderador pelas variáveis categóricas: gênero, faixa etária, renda, escolaridade, busca de informação, local de compra efetiva, hábito de compra, por opções de pesquisa e compra. 


\section{Fundamentação Teórica}

A revisão de literatura deste estudo cumpriu descrever os conceitos dos principais autores em canais de distribuição e varejo multicanal sob o ponto de vista da economia e do marketing. Os conceitos aqui relacionados embasaram o modelo teórico proposto neste estudo. Na perspectiva do comportamento do consumidor, a teoria da aprendizagem social foi o foco com os conceitos de autoeficácia e experiência vicária. Estudou-se em seguida sobre o comportamento multicanal e o comportamento free-riding.

O arcabouço teórico foi construído em três perspectivas conforme o quadro 1 a seguir.

Quadro 1 - Arcabouço teórico e conceitual

\begin{tabular}{|c|c|}
\hline Perspectiva econômica & $\begin{array}{l}\text { 1. Canais de distribuição } \\
\text { 1.1. Evolução do Varejo multicanal } \\
\text { 1.2. Integração de canais } \\
\text { 1.3. Omnichannel } \\
\text { 1.4. Lock-in } \\
\text { 1.5. Free-riding }\end{array}$ \\
\hline $\begin{array}{l}\text { Perspectiva do } \\
\text { Comportamento do } \\
\text { Consumidor e } \\
\text { comportamento de } \\
\text { alternância entre canais }\end{array}$ & $\begin{array}{l}\text { 2. Intenção de Free-riding no varejo multicanal } \\
\text { 3. Antecedentes para autoeficácia } \\
\text { 4. Antecedentes para retenção na firma } \\
\text { 5. Antecedentes para atratividade do varejo tradicional }\end{array}$ \\
\hline Modelos Push-Pull-Mooring & $\begin{array}{l}\text { 6. Modelo PPM de Bansal, Taylor e James (2005) } \\
\text { 7. Modelo de Chiu et al. (2011) }\end{array}$ \\
\hline
\end{tabular}

Fonte: o próprio autor

\subsection{Canais de distribuição}

O varejo tem migrado cada vez mais para uma oferta multicanal, atendendo a questões de conveniência e empreendendo formas de acesso ao consumidor. O Brasil é um país de dimensões territoriais continentais que combinadas com os avanços da tecnologia permitem novas possibilidades de acesso ao consumidor.

$\mathrm{Na}$ visão de marketing, Kotler e Keller (2006) ressaltam que a maioria dos fabricantes não vende diretamente para os consumidores finais. Assim, a decisão 
sobre os canais de marketing está entre uma das mais críticas de uma organização, afetando as demais decisões como preço, força de vendas, comunicação, produto ou serviço, público-alvo. As decisões de canais envolvem relacionamentos e ou compromissos de longo prazo com empresas na cadeia de suprimentos. A criatividade no sistema de distribuição pode viabilizar e tornar-se uma vantagem competitiva (KOTLER; ARMSTRONG, 2003; KOTLER, 2000). Kotler e Armstrong (2003) ao definirem canais, descrevem como um conjunto de organizações interdependentes envolvidas no processo de oferecimento de produto ou serviço para uso do consumidor final.

A abordagem do ponto de vista de redes de valor, considerada mais ampla do que canais de vendas e colocada na perspectiva da cadeia de suprimentos, põe a empresa no centro de uma rede de valor, como um sistema de parcerias e alianças criado para produzir, aumentar e entregar as ofertas. A rede de valor enxerga as relações valiosas com terceiros, incluindo tanto os pesquisadores acadêmicos como as agências reguladoras governamentais. O gerenciamento da rede de valor requer que as empresas invistam continuamente em tecnologia de informação (TI) e em software (KOTLER; KELLER, 2006). O desenho das relações interfirmas se torna uma variável de decisão estratégica, sendo que a natureza dessas relações contribui na diferenciação de produtos, uma diferenciação que possa ser preservada (PORTER, 1996).

A estrutura de canal é apresentada por muitos autores pelos diagramas que mostram os níveis intermediários de canal, do fabricante até chegar ao consumidor final. A estrutura de canal apresentada na forma de diagramas não define a estrutura em si, pois não sugere as relações entre estrutura e gestão. Rosenbloom (2004) define o conceito de estrutura de canal como "o grupo de membros do canal para o qual um conjunto de tarefas de distribuição foi alocado", contemplando uma perspectiva de gestão.

Do ponto de vista da economia e a partir da abordagem de Coase para os limites da firma, a ênfase na principal corrente da microeconomia está no trade-off entre mercados e hierarquia; porém, a partir da década de 1990, a atenção foi direcionada 
para o que Williamson identificou como formas híbridas, tendo como principal olhar e foco as transações entre firmas, proposta que sai da teoria de preço tradicional e se movimenta para uma análise mais qualitativa institucional (MENARD, 2004; WILLIAMSON, 1991). Um conceito desenvolvido um pouco mais à frente foi o de networks, ${ }^{4}$ que cobre todos os arranjos que envolvem um conjunto de amarrações contratuais entre entidades autônomas. Canais de distribuição têm como ênfase a forma como os parceiros se coordenam no sentido de redução do custo e geração de valor, capturando ou desenvolvendo mercados por meio de sinalização, serviços etc. (MENARD, 2004).

O mecanismo de controle para governança de canais pode ser construído explicita e verticalmente entre as relações das instituições de canais adjacentes. Coughlan et al. (2002) sugerem que acordos entre firmas podem ser estruturados de tal forma que tornam indistinguíveis os canais integrados e não integrados.

A questão-chave será a maneira como uma relação privada é organizada, e não necessariamente a propriedade, segundo o modelo de mercado de hierarquia versus integração. A teoria da dependência de recurso enxerga a governança entre firmas como uma resposta estratégica a condições ambientais de incerteza e de dependência. A teoria de custo de transação de Williamson (1991) percebe a governança em termos de desenho de mecanismos particulares para suportar os custos de transação. A teoria do contrato relacional de McNeil apresenta a tipologia para um mecanismo de clã, um processo normativo no qual os membros de um sistema adotam as normas do grande sistema com esforços de socialização (HEIDE, 1994).

Kotler e Keller (2012) empregam o conceito de canais híbridos ou multicanais para quando uma empresa emprega dois ou mais canais de marketing para atingir segmentos de consumidores. Num mercado multicanal, cada canal tem como alvo um diferente segmento de comprador, ou diferentes necessidades para um comprador, de forma a entregar o produto certo, no lugar certo, na forma certa com

\footnotetext{
${ }^{4}$ Redes de relacionamento
} 
menor custo. Quando isso não acontece, pode haver conflito de canal, custo excessivo ou insuficiência de demanda. Consumidores que gostam de gastar o tempo em visitas utilizam compra por catálogo ou vão à loja física; tais canais são intercambiáveis. Consumidores que usam a internet, por sua vez, são mais focados em transação e interessados em eficiência e, portanto, menos afetados pela introdução de novas lojas físicas. Retornos e trocas na loja aumentaram devido à facilidade de acesso. Compras extras feitas pelos clientes de retorno ou troca na loja compensam qualquer déficit de receita. $O$ desafio do multicanal para as empresas é garantir que os multicanais trabalhem de forma integrada e combinem formas preferidas de fazer negócio de cada cliente-alvo. Os consumidores esperam da integração de canais: 1 - pedir um produto on-line e retirá-lo num varejo de conveniente localização; 2- devolver um produto comprado on-line na loja física do varejista mais próxima; 3- receber descontos e ofertas promocionais baseadas nas compras totais: on-line e off-line.

Kotler e Keller (2012) introduzem os conflitos multicanais que surgem quando dois canais vendem para o mesmo segmento de mercado, principalmente quando os membros de um canal obtém preço menor (baseado em volume de compra) ou trabalham com margem menor. $O$ desafio no varejo permanece num bom desenho integrado e efetivo. Catálogos estão sendo ofertados cada vez mais pela internet. Victoria's Secret integrou os multicanais de loja física, catálogo e internet. A internet da empresa tem desempenhado papel central para o desenvolvimento da marca.

\subsubsection{Evolução do Varejo Multicanal}

O varejo consiste de um conjunto de atividades envolvidas na venda de bens e serviços a consumidores finais para utilização no consumo pessoal, familiar ou residencial (COUGHLAN et al., 2002; MATTAR, 2011; PARENTE, 2010). A maneira como o varejista escolhe posicionar-se no mercado, afeta significativamente a competitividade e desempenho; são escolhas baseadas nas características da empresa que determinam custos e demanda dos consumidores. Pelo lado da demanda, os varejistas escolhem níveis de serviços a ser oferecidos ao consumidor 
final. Por parte dos custos, a empresa determina a filosofia operacional para margem e rotatividade que certos segmentos de consumidores estão dispostos a assumir em dadas classes de comportamento de compras e trazendo resultado financeiro pelas muitas combinações das variáveis envolvidas (COUGHLAN et al., 2002).

Souza e Serrentino (2002) antecipam ao varejo brasileiro as transformações do cenário de negócios em quase todo mercado, trazendo profundas mudanças no comportamento do consumidor global, novas relações de poder entre produção e distribuição, concentração de negócios e velocidade na mudança de cenários. Como pano de fundo no ano de 2000, as mudanças tiveram origem direta ou indiretamente nos avanços proporcionados pela tecnologia. Também contribuíram as mudanças desencadeadas pelo processo evolutivo natural dos mercados e dos consumidores. A economia do novo milênio será, segundo os autores, um produto híbrido da velha economia, impactada pela tecnologia e pelas telecomunicações, produzindo transformações numa velocidade exponencial. Na próxima economia, os autores conceituam a inclusão do canal internet para todos os varejistas sem diferença entre lojas tradicionais e virtuais.

Souza e Serrentino (2002) comentam os cenários econômicos em transição que afetavam o Brasil. No aspecto demográfico, há participação maior da população consumidora idosa, envelhecimento da população brasileira e amadurecimento da demanda. Novas necessidades de lazer, consumo e expectativas. A dificuldade em criar e educar filhos na sociedade moderna, casamentos tardios, maior número de separações e, principalmente o fato de as pessoas passarem a maior parte da vida sozinha. $O$ envelhecimento da população afeta a distribuição e as características dos produtos ofertados. Novos conceitos foram desenvolvidos para essa parcela da população: lojas, produtos, ambientes, serviços, entretenimento e comunicação, um consumidor que aloca de forma diferente os recursos. Gera adaptação do mix de produtos, formato de lojas, serviços e comunicação. O consumidor idoso tem mais tempo livre, mas também busca conveniência, facilidade e conforto. Torna-se menos sensível ao apelo de moda. 
A crescente participação no mercado de trabalho das mulheres na população economicamente ativa tem alterado o perfil das lojas e marcas por conta das características pessoais bem como pelo crescente poder de compra e influência na decisão de compra. Houve também evolução no rendimento da mulher em relação ao homem, porém permanecendo abaixo da remuneração masculina. A mulher estuda mais, segundo dados do IBGE (estimativa 2013), tem reconhecida tendência a estabelecer relacionamentos mais duradouros com marcas e lojas, aliada a uma profunda curiosidade sobre produtos, informações e seus usos. Isso gera maior investimento em instalações e equipamentos, além de despesas operacionais crescentes, sem que isso represente melhores margens ante os custos adicionais (SOUZA; SERRENTINO, 2002).

Coughlan et al. (2002) ressaltam que todas as inovações do varejo no século $X X$ dependeram da manipulação da variável de serviços ao cliente. Os serviços relacionados como ajuda às vendas dentro da loja, também ditos como assistência às vendas, que eram ancorados por mão-de-obra intensiva, tendem a ser cada vez menor, seja pela diminuição gradual da necessidade de assistência, seja pelo aperfeiçoamento da produtividade de uma força de trabalho redimensionada.

A partir de um projeto e gerenciamento de canal de marketing, um fabricante ou fornecedor deve entender as principais questões estratégicas enfrentadas pelos varejistas. Como primeira delas, Coughlan et al. (2002) destacam a crescente tendência entre os consumidores da busca por conveniência. Em segundo, as questões relativas aos níveis expandidos do poder do varejo, incluindo a capitalização de varejistas em marcas privadas. Também se inclui aqui a discussão dos pontos varejistas que sugerem refinar ainda mais o atingimento do público-alvo do varejista, como os varejistas poderosos, chamados de "matadores" da categoria, que no Brasil, como exemplo, poderiam ser exemplificados como as Casas Bahia. Em terceiro, a crescente internacionalização do varejo e os impactos causados no país ou no mercado.

Souza e Serrentino (2002) convidam a um exercício de antevisão por meio de um modelo teórico ancorado em sete vetores, sintetizando os desafios das empresas 
varejistas. O exercício aponta caminhos a ser percorridos e desenvolvimento de capacidades e competências para responder e antecipar o cenário. Atribuem o termo "multivarejo" como o núcleo central em que gravitam satélites do multicanal, multimobilidade, multivarejo-nação, multiparcerias, multiunicidade e multitalento.

O multicanal se fortaleceu com a reação a partir de 1999 dos varejistas tradicionais nos EUA, que passaram a destinar recursos, esforços e prioridades estratégicas para a internet. A entrada dos varejistas tradicionais mostrou vantagem sobre os varejistas exclusivamente virtuais. O e-commerce surge como um canal complementar e cada vez mais integrado a outros canais de vendas. A internet força o varejo a se reinventar para enfrentar o desafio da conveniência e das crescentes alternativas de customização e interatividade proporcionadas pelo canal virtual, seja pelo valor e diferenciação, seja pela geração de experiências de compra memoráveis. Além disso, a internet será indispensável como ferramenta de comunicação e relacionamento com o cliente, mesmo que ele não venha a adquirir produtos pelos sites.

Canais de marketing em que o consumidor interage com empresas proliferaram. Nos Estados Unidos, sete dos dez maiores varejistas da internet - Staples, Office Depot, Dell, Hewlett-Packard, OfficeMax, Sears e Sony - oferecem canais on-line. Na última década, a internet deixou de ser uma nova tecnologia para ser um canal rotineiro para busca de informação, comunicação e compras no varejo. Apesar de a internet ter trazido oportunidades de negócio e se tratar de um canal em ascensão, ainda não é o método mais comum de compra; como plataforma independente frequentemente não sobrevive, salvo algumas exceções. Como o uso da internet se ampliou no mundo, espera-se que haja crescimento do uso dessa ferramenta interativa nas decisões de compra do consumidor (BRASHEAR et al., 2009).

Multicanais também representaram uma resposta estratégica dos fornecedores para o poder crescente do setor varejista. Coughlan et al., (2002) relatam que os produtores assumiram mais fluxos de canais ou desenvolveram novas tecnologias de canal que ajudam a reequilibrar o poder de canal e o melhor gerenciamento do mesmo. A distribuição dupla (direta do fabricante e via intermediário) ocorre pela 
expansão do número de canais para distribuição dos produtos a fim de reduzir a dependência do varejo. O princípio operativo passa a ser o gerenciamento do consumidor e não o gerenciamento de categoria no contexto de mercearia. A Starbucks montou o negócio por meio de lojas e aumentou o consumo de café em cerca de $25 \%$. De rede de lojas independentes, a marca foi enxergada como um negócio que se estendeu para venda em supermercado, restaurantes e companhias aéreas, por exemplo. Com isso, o negócio saiu e evolui a partir da visão restrita do modelo de distribuição de café como o comercializado pela General Foods (Kraft).

Segundo Coughlan et al. (2002), a introdução do comércio eletrônico proporcionou prestações de serviços adicionais aos usuários finais, assim como uma divisão diferente de desempenho de fluxo entre os membros do canal. Os autores ressaltam que houve vários tipos de conflito de canal e que foram encaminhados de maneiras diversas. Os parceiros de canal participavam do processo de aprendizagem com esse canal alternativo, ainda novo em 2002, como mais uma forma de atingir o público-alvo. O varejo de catálogo, muito usado nos EUA, e o varejo de venda direta compartilham espaço com o varejo tradicional de loja. O varejo de vendas diretas, para Coughlan et al. (2002, p. 348), se define como venda ao consumidor distante de uma localização fixa do varejista. Estão representados pela Natura, Avon, Mary Kay, Amway etc. $O$ varejo eletrônico está limitado ao número de consumidores que podem comprar on-line.

Rosembloom (2004) ressalta que, com o desenvolvimento da tecnologia de comércio eletrônico e vendas on-line, várias firmas criaram estruturas multicanais incluindo canais on-line; e, cada vez mais, firmas que vendem produtos por apenas uma única estrutura de canal se tornam exceções à regra. A maioria das firmas usa estratégia multicanal, tirando vantagens do comércio eletrônico.

Varejistas também percebem que os clientes mais valiosos são os que se relacionam com a empresa por meio de múltiplos canais e estão expostos a vários relacionamentos com marcas, produtos e serviços. O artigo da Deloitte (2011) sobre uma pesquisa com executivos do varejo durante seis meses revela a visão de cada um sobre o multicanal no varejo, o efeito nos negócios e impacto no local do varejo. 
Também na pesquisa se ressalta o crescimento na compra cruzada de canais. Os consumidores estão utilizando dois ou mais canais do varejo para descobrir, pesquisar, avaliar, comprar, buscar serviço e talvez devolver produtos. As vendas cruzadas para busca on-line $\rightarrow$ compra em loja física, fornecidos pelo relatório Forrester Research (2012) revelam que as vendas das lojas físicas, resultantes da busca on-line em 2011, foram US\$ 1.103 trilhões e a estimativa para 2016 é de $\mathrm{R} \$ 1.660$ trilhões e representarão $44 \%$ das vendas totais do varejo americano. No Brasil, segundo dados da pesquisa Top of mind Internet 2010, a penetração da internet subiu 47\% no período de 2006 a 2010, para maiores de 16 anos, chegando a $50 \%$ dessa população. São $44 \%$ que responderam ter feito pelo menos uma compra pela internet (32\% livros, $23 \%$ artigos de informática, 18\% CDs, $18 \%$ turismo e passagens aéreas).

O multivarejo que surge na nova economia brasileira sinaliza para forte crescimento das vendas no varejo eletrônico. Em 2010, as vendas chegaram a $R$ \$13,6 bilhões e poderão alcançar $R \$ 25$ bilhões em 2014 (MATTAR, 2011).

A definição de varejo multicanal da Deloitte (2011) expressa um conceito de negócio baseado na integração de canais e não simplesmente na coexistência de multicanais. Um varejo multicanal integrado satisfaz a demanda do consumidor independente do canal. Cross-channe $F^{5}$ representa um comportamento, de tal forma que o comprador pesquisa, seleciona, compra e retoma atividades por meio dos canais. Acredita-se que o multicanal represente uma nova maneira de trabalhar que irá afetar cada etapa da operação do varejo. Não se trata da loja, mas de servir o consumidor, quando e como ele quer. Uma compra na loja não será mais importante do que uma compra via notebook, call center ou smartphone. Novas tarefas são adotadas pelo comprador, tais como: 1- pesquisar na loja antes de comprar on-line; 2- pesquisar on-line antes de ligar para o call center e solicitar serviço; e 3- buscar informação na web, fazer o pedido na loja e, em contrapartida, ter o produto enviado para o endereço informado ou instalado em casa.

${ }^{5}$ Cross-channel: multicanais, cruzamento entre canais. 
Parente (2010) relata que os clientes têm acesso a produtos iguais vindos de várias fontes diferentes, tendo a satisfação e a rentabilidade aumentadas. O autor ressalta que a interação multicanal pode incrementar a lealdade e o tempo de permanência do cliente. Os vários canais de varejo permitem a customização. Parente (2010) afirma que os clientes podem encomendar e devolver produtos pelo canal mais apropriado, fornecendo uma verdadeira experiência de compras válida para os vários canais. As vendas passam pela integração. É preciso saber integrar smartphone, mídia social, e-mail, e-commerce, loja física, publicidade e atendimento no ponto-de-venda. Parente (2010) adicionou ao conceito de varejo multicanal os elementos dos conceitos consagrados, como estratégia de crescimento, unidade estratégica de negócios e sinergia.

Algumas pesquisas organizadas por consultorias (Harris Interactive, DOM Strategy Partners, Deloitte, McKinsey, IBM) verificam que, na construção de percepções e atendimento às expectativas e necessidades do consumidor, os diversos canais (mídias, ambientes e veículos) da empresa devem atuar de forma integrada na entrega do branding, relacionamento, produtos e serviços dos canais. A partir desse estágio, os consumidores passam a estar no centro de uma estratégia multicanal, em que cada ponto de contato da empresa com o cliente é trabalhado de forma específica, de forma coordenada com os demais canais. O mix de canais é determinado a partir de mídias, ambiente e veículo com atuações delimitadas em relação aos aspectos comerciais, de relacionamento e branding.

O "neoconsumidor", que espera encontrar o "neovarejo", é digital, conectado, multicanal, multimídia e altamente informado. Deloitte (2011) ressalta que a intimidade na conexão com o consumidor é característica de um varejo multicanal bem-sucedido que quer criar interações relevantes com os clientes.

E pensando num ambiente multicanal, a ação de aumento de tráfego na internet, influencia as vendas na loja pela correlação de padrões quantificáveis de "browsing" e o comportamento de compra para compradores individuais. Os denominados cross-channel shoppers muito bem informados possuem expectativas que mudam rápido. Os executivos de loja não sabem ao certo se entendem como os 
compradores estão mudando ou como eles deveriam estar respondendo a essas mudanças. A experiência do consumidor dentro da loja também está aumentando de importância. A Figura 2 apresenta o cenário dos segmentos de varejo e sua aderência e proximidade com o multicanal nos EUA entre 2006 e 2010. A figura indica o quanto os diversos segmentos de varejo migraram para o contexto multicanal, aumentando a possibilidade de cruzamento entre canais. Dessa forma, tornou-se importante pesquisar os critérios de compra dos consumidores em ambiente multicanal e como os varejistas estão conduzindo suas estratégias em ambiente multicanal.

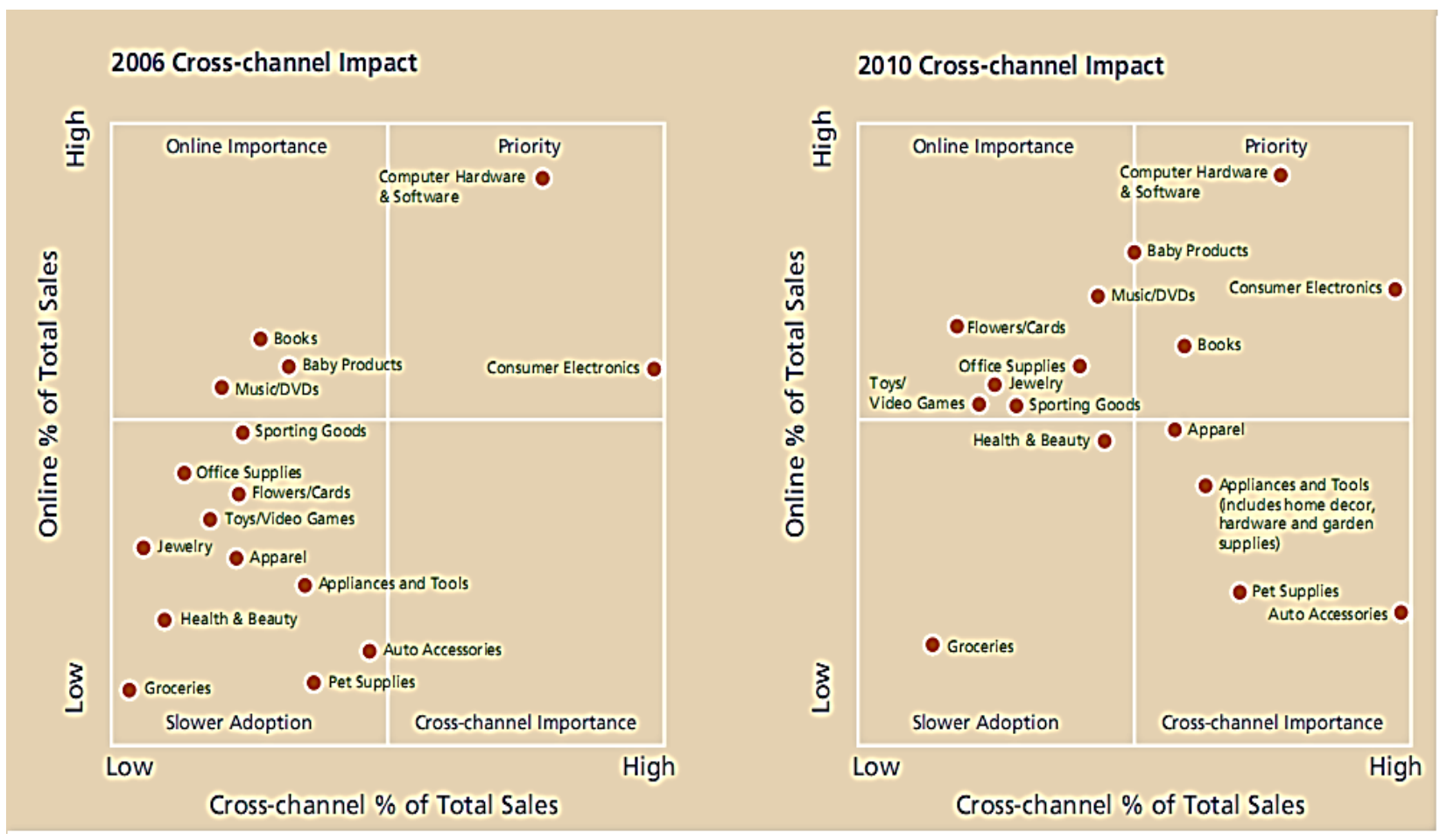

Figura 2 - Impacto do cross-channel no varejo 2006 - 2010 nos EUA

Fonte: Deloitte, 2011

\subsubsection{Integração do Varejo Multicanal}

Souza e Serrentino (2002) ressaltam que as empresas varejistas tradicionais ao incorporar a cultura, o processo e a estratégia do e-commerce descobrem os benefícios da integração desse canal à sua atividade principal. Mais ainda, os autores afirmam que o varejo do futuro não é o varejo da loja, ou do catálogo ou 
muito menos virtual, mas sim o varejo multicanal. $\mathrm{O}$ varejo multicanal estabelece relacionamento com os clientes e os atende onde, quando e como eles quiserem. Expectativas, motivações, padrões de compra são diferentes nos diversos canais de vendas, de forma complementar e não concorrencial entre si. O varejo dá um passo mais próximo do cliente, entendendo seus hábitos, atitudes, expectativas e oferecendo opções. Cada canal tem atributos únicos que o distinguem e motivam o consumidor em diferentes momentos.

Mattar (2011) ressalta que não existe mais a dualidade operacional virtual ou tradicional. As empresas operam com todos os canais que o consumidor deseja e de forma sinérgica. Porém, questões desafiantes ainda precisam ser minimizadas: a cultura predominante de loja presencial, o uso de cartão débito/crédito, nível de segurança para a transação, número de computadores na residência, acesso à internet, proteção das informações e logística de entrega. A personificação do atendimento on-line possibilita customização maior para o consumidor.

Souza e Serrentino (2002) dão ênfase aos atributos de cada canal. O canal virtual apresenta conveniência, informação, atualização, interatividade. O canal tradicional apresenta gratificação imediata, toque e contato humano. O canal catálogo apresenta a venda de conceito e estilo de vida, portabilidade, imagens de alta qualidade. Por sua vez, o cliente pode se relacionar com a mesma empresa em diversos canais, sentindo-se atendido nas diversas motivações de compra que possa ter. As inúmeras opções de serviço e conveniência que só uma operação multicanal integrada pode oferecer geram clientes mais fiéis, que compram mais e são mais rentáveis.

O grande desafio da operação multicanal passa a ser a integração entre os canais, de forma a explorar sinergias, atender melhor os clientes e alavancar o negócio. Para Souza e Serrentino (2002), a integração passa por diversos níveis da operação. A infraestrutura inclui a implantação do banco de dados, consolidação e armazenagem, integração dos sistemas (PDV, retaguarda, site) e controle de estoques. E mais, preço com homogeneização, transparência e coerência na política de preços; comunicação, tanto nas mensagens quanto no posicionamento da marca; 
relacionamento: $24 \mathrm{~h} \times 7 \times 365$, a empresa não fecha jamais para o cliente; logística e sistema de distribuição; toda a política de trocas e devoluções com quadro de alternativas e flexibilidade. E, por último, o cross-channel, traduzido como um "freeriding" incentivado entre canais para geração de tráfego recíproco.

Para Souza e Serrentino (2002), não existe uma receita única para multicanais. Cada empresa varejista, a partir do mercado em que atua, vai precisar identificar seu modelo, do cliente e suas competências e recursos. Deverá desenhar a melhor alternativa e estratégia de operação em múltiplos canais. Os autores ressaltam que a diversidade será a tônica para chegar mais próximo do cliente. As fronteiras entre mercados e concorrência tornam-se mais nebulosas e complexas.

\subsubsection{Omnichannel}

Estudos mais recentes referem-se a uma evolução do varejo multicanal e do marketing integrado: o consumidor omnichannel ${ }^{6}$ e o varejo omnichannel. Termo criado por "marqueteiros" para expressar todas as formas de consumo que o consumidor se engaja ou compra produtos.

Leggatt (2009) cita o relatório IDC Retail Insights sobre: "Satisfying the Omnichannel Consumers Whenever and Wherever They Shop" que faz uma comparação reveladora entre segmentos de consumidores americanos: consumidores multicanal gastam cerca de $15 \%$ a $30 \%$ mais com um varejista do que o consumidor uni canal. Os consumidores omnichannel irão gastar $15 \%$ a $30 \%$ mais do que os consumidores multicanais. Além disso, os consumidores omnichannel irão influenciar outros por meio da rede social e atividade on-line, exibindo forte lealdade. Esse segmento apresenta três tipos de consumidores:

- omni-Integrado - afluente, orientado à casa, mas bem ligado no movimento e no escritório, de 30 a 50 anos de idade.

${ }^{6}$ Omnichannel shopper 
- jovem com mobiles ${ }^{7}$ - clientes mais jovens do que 30 anos que estão em constante movimento, mas que principalmente encaminham mensagens SMS (whatsapp etc.) e raramente utilizam o e-mail.

- engajados em comunidades sociais ${ }^{8}$ - principalmente jovens, mas incluem todas as faixas etárias. Conectados por interesse, em vez de idade ou localização.

Thoma (2010) define essa emergente segmentação de consumidores como: informados, "empoderados" e sempre conectados. São consumidores que demandam por verdadeiras escolhas quando se trata de seleção e aquisição de bens. Diferente dos consumidores multicanais tradicionais, este consumidor utiliza todos os canais simultaneamente: loja, catálogo, call center, web e dispositivos móveis. Para este autor, as implicações para os varejistas são claras: se não entrega o pacote completo em termos de uma experiência de compra multicanal unificado, o varejista coloca suas vendas globais e a fidelidade do cliente em risco. Uma abordagem de canais unificados e convergentes que suportam os processos "sem costura" para entregar informação e comunicação de marketing consistente em todos os canais de vendas. Com os consumidores agora podendo fazer comparações de preços e tendo acesso à revisão de produtos em tempo real enquanto em movimento, o "comércio móvel" está provando ser um fator-chave na experiência unificada do consumidor do varejo.

Rigbi (2011) define o varejo omnichannel como um novo termo para o varejo digital que reflete a forma como os varejistas vão interagir com o consumidor por meio de incontáveis canais: websites, lojas físicas, quiosques, mala direta e catálogos, call centers, mídia social, aplicativos em smarthphones, consoles de jogos, TVs, aplicativos de redes, serviços residenciais etc. Elencando-se as razões para o crescimento rápido do varejo digital, citam-se: a seleção é vasta e fácil de pesquisar; os preços são bons e facilmente comparados; é conveniente, pois pode ser feito em casa ou no trabalho, sem precisar estacionar carro; metade das compras on-line é entregue gratuitamente; muitas devoluções são gratuitas; a revisão de produtos e as

\footnotetext{
${ }^{7}$ Mobiles - dispositivos móveis como celular smarthphone, Ipad etc.

${ }^{8}$ Social Networker
} 
recomendações são extensivas. A média do índice American Customer Satisfaction para varejistas on-line, tal como Amazon (87 pontos), está 11 pontos mais alta do que para lojas físicas de desconto e lojas de departamento. As inovações do varejo digital com as inovações tecnológicas, como por exemplo, a Amazon incorporou a compra "1-click", bem como o Submarino no Brasil. Além disso, a Amazon realiza um sistema de troca de presentes indesejáveis antes de recebê-los. Os varejistas estão conduzindo a inovação, recrutando talento técnico, salários e bônus para retenção de colaboradores. Os varejistas são um dos primeiros a utilizarem a tecnologia nas nuvens (que reduz dramaticamente os custos de operação e reduz entradas) e a enriquecerem a eficiência de marketing por meio de mídias sociais e campanhas on-line.

Rigby (2011) comenta que o varejo omnichannel será o caminho futuro para os varejistas que buscam satisfazer o consumidor que cada vez mais quer "tudo". Eles querem as vantagens digitais: seleção quase ilimitada, transparência de preços ao click, recomendações personalizadas dos amigos e de especialistas. Também querem a vantagem das lojas físicas: a interação face-a-face com o vendedor, disponibilidade de produtos para experimentação e a experiência social no shopping como um evento. Diferentes consumidores irão avaliar com pesos diferentes, mas todos são candidatos a querer integração perfeita entre o digital e o físico. O Quadro 2 abaixo resume e expressa o desejo dos consumidores conectados:

Quadro 2: Varejo Omnichannel para satisfazer omni-shoppers

\begin{tabular}{|l|l|}
\hline \multicolumn{1}{|c|}{ Vantagens do canal digital } & \multicolumn{1}{c|}{ Vantagens do canal físico } \\
\hline Riqueza de informação de produto & Sortimento editado \\
\hline Ampla seleção & A compra como um vento e uma experiência. \\
\hline $\begin{array}{l}\text { Revisão de produtos por consumidores e e } \\
\text { dicas }\end{array}$ & $\begin{array}{l}\text { Possibilidade de vestir ou experimentar } \\
\text { produtos. }\end{array}$ \\
\hline Conteúdo editorial e recomendações & $\begin{array}{l}\text { Atenção pela equipe de vendas } \\
\text { Ajuda para iniciar o produto ou conduzir } \\
\text { reparos. }\end{array}$ \\
\hline Engajamento social e diálogo de mão dupla & Acesso instantâneo a produtos \\
\hline $\begin{array}{l}\text { Conveniência de acesso a qualquer coisa, em } \\
\text { qualquer tempo, em qualquer lugar. }\end{array}$ & $\begin{array}{l}\text { Retorno conveniente } \\
\text { Gratificação instantânea em todos os } \\
\text { sentidos. }\end{array}$ \\
\hline
\end{tabular}

Fonte: Adaptado de Rigby (2011), HBR 66, p. 72.

Winter (2012), presidente do POPAI, acredita na convergência de canais entre "clicks" e "bricks", transpondo cada vez mais as barreiras entre eles, se tornando uma oportunidade para reimaginar a experiência de compra, juntando os benefícios 
de cada experiência de canal (físico e digital) sem costuras no processo, de forma divertida e rápida. A ideia é agregar valor para o consumidor pela integração dos canais on-line, móveis e de mídia social com os existentes canais físicos. Hardgrave (2012) acrescenta que para criar a experiência de compra, o varejo omnichannel necessita ter uma operação que entregue em tempo real, com inventário eficiente e custo efetivo. Se o varejista não sabe o que tem, onde tem e quando terá, a criação de canais móveis de nada adiantará para o consumidor final.

Wilding (2013) comenta que a diferença entre multicanal e omnichannel está na integração do último, um serviço dito "sem costuras", refletindo a qualidade da marca tanto na compra quanto na entrega. Isso é atingível quando se garante que todos os aspectos da cadeia de suprimentos estão integrados, corroborando para o valor da marca independente do local de compra. O autor reforça que a proposta de integração deve ser entre os canais on-line e off-line.

Brynjolfsson; Hu e Rahman (2013) colocam a tecnologia como a responsável pela superposição ${ }^{9}$ entre os canais on-line e off-line o que requer que o varejo e seus parceiros de cadeia de suprimento repensem suas estratégias competitivas. A tecnologia remove as barreiras geográficas e o desconhecimento do consumidor. Sugere que os varejistas venham adaptar as melhores práticas do canal off-line e on-line quanto à precificação, desenho da experiência de compra e construção do relacionamento com o cliente. A explosão de informação de novos dados dos canais móveis, sociais e locais permite uma oportunidade sem precedentes para entender não somente a transação bem como a interação do consumidor. A limitação estará na habilidade de analisar os dados. Como assuntos críticos a serem endereçados, estes autores ressaltam: evitar a comparação direta de preços, aprender a vender nicho de produtos, enfatizar o conhecimento do produto, estabelecer os custos de mudança, encarar a concorrência, compreender os impactos.

Stelzer (2013) considerou que a abordagem omnichannel requer que o varejo coordene as suas interações com o cliente, de forma que coletivamente se crie um

\footnotetext{
${ }^{9}$ Channel blurring
} 
diálogo contínuo que não seja segmentado por canal e por tipo de comunicação. 0 autor apresentou o estudo feito em 2012 pela IBM Smarter Commerce Consumer Advocacy com 1200 americanos. Os achados indicaram que 64\% dos compradores multicanal consideraram que o pós-compra é mais importante para a formação da última impressão sobre o varejista, contra $36 \%$ para a fase de pré-compra.

\subsection{Comportamento Free-riding no varejo multicanal}

Buscando uma definição para o termo econômico de free-riding, Mankiw (2006) conceitua como "alguém que recebe o benefício de um bem, mas evita pagar por ele". Considera como uma falha de mercado (privado) e surge a partir de uma externalidade, tornando-se um bem público. Os bens públicos não são excludentes; a questão do free-riding impede que o mercado privado os oferte. O governo pode potencialmente resolver o problema, pagando com a receita de impostos, se concluir que os benefícios totais (sociais) excedem os custos. Quando o mercado deixa de ser cooperativo como possibilidade e as companhias individuais estão pensando exclusivamente no seu lucro, acaba incentivando o comportamento de free-riding que tem significado mais amplo para Gremaud (2003). Além de "pegar carona" é conotado como também "oportunista".

O conceito de free-riding aplicado ao varejo, a partir da microeconomia neoclássica, aborda a questão da não captura do uso de um recurso entre os participantes do mercado e, portanto, o mercado de tal recurso não produzirá um resultado ótimo. Um recurso com tal característica pode tomar a forma de um bem público ou um pool de recursos comuns, dependendo de haver ou não rivalidade no consumo. Em varejo, os consumidores podem "pegar carona" quando uma empresa não consegue cobrar separadamente pelo serviço a partir da disponibilização de informação sobre os produtos. Também o uso do termo inclui a questão da empresa que não consegue distinguir free-riders de outros clientes. Os inputs necessários para realizar o fechamento de uma venda, tais como: manter o esforço de venda informado, espaço para showroom, investimento em propaganda pelo varejista, não pode ser vendido separado do produto físico. Se uma loja pratica vendas abaixo dos preços ofertados por outra loja, ocorre a possibilidade de free-riding em cima do 
investimento feito pela última, erodindo o incentivo à promoção de qualquer loja que o faça primeiramente (CARLTON; CHEVALIER, 2001; VAN BAAL; DACH, 2005).

\subsection{Modelo de Migração PPM}

Bansal, Taylor e James (2005), exploraram o modelo de migração, originário da literatura sobre a geografia humana, como proposição de um modelo teórico unificado para entender o comportamento de alternância entre prestadores de serviço. Dessa forma, buscaram entender porque o consumidor muda de fornecedor de serviço, aplicando o modelo numa pesquisa de campo com oficinas mecânicas e cabeleireiros.

A literatura sobre a geografia humana contem vários estudos que investigam 0 comportamento de alternância, especificamente a pesquisa de migração (o movimento do indivíduo entre duas localidades por certo período de tempo), examinando a comutação entre localidades. Enquanto a migração envolveu o fluxo de pessoas de uma área geográfica para outra, a alternância de fornecedores de serviço envolveu o fluxo de consumidores de um provedor de serviço para outro.

A literatura de migração destaca o modelo "push-pull" como um paradigma dominante. Posteriormente, foram incluídos os efeitos mooring ${ }^{10}$ relatados por Lee (1966) e Moon (1995 apud BANSAL; TAYLOR; JAMES, 2005, p.96). Os autores exploraram a aplicabilidade do paradigma push-pull-mooring (PPM) para a alternância de fornecedor de serviço. Sugeriram uma nova contribuição para a literatura do marketing de serviço, pois havia falta de modelos compreensivos sobre o comportamento de alternância entre fornecedores de serviço.

Os autores consideraram que a analogia entre os construtos de migração e o fenômeno de comutação entre fornecedores de serviço poderia ser razoavelmente direta. Migrantes (consumidores) movem-se (comutam) de um país (provedor de

\footnotetext{
${ }^{10}$ Efeito mooring - não tem tradução única: local de atracação, ancoragem, elementos que promovem estabilidade e segurança emocional.
} 
serviço) para outro. Eles podem livremente escolher migrar (comutar) entre fornecedores de serviço e assim serem migrantes voluntários. Alternadamente, eles podem sentir que não possuem escolha e precisam migrar (trocar) quando, o serviço corrente fecha a loja; esses consumidores são considerados os refugiados. $O$ movimento de migração pode ser conceituado de acordo com sua significância ou grau de mudança envolvido, portanto pode ser modesto: comutação entre vários provedores de serviços dentro de uma mesma organização ou entre diferentes mecanismos de entrega de um provedor de serviço (por exemplo, trocando entre os vários canais de atendimento de um banco). Esses movimentos de comutação são tratados como migração intraurbana ou mobilidade residencial. Por outro lado, consumidores podem trocar de um tipo de fornecedor de serviço para outro tipo, preenchendo suas novas necessidades, por exemplo, trocar de um clube de saúde para uma clínica de cirurgia plástica no sentido de melhorar a aparência, um movimento semelhante a uma migração internacional. Entre esses dois extremos, os consumidores frequentemente trocam de marcas de provedores de serviços, movimento similar aos movimentos dentro da fronteira nacional, porém cruzando localidades urbanas (migração nacional).

Na revisão da literatura de migração, Bansal, Taylor e James (2005) ressaltam que os movimentos migratórios eram descritos por fatores externos ambientais de origem e destino: push com variáveis de conotação negativa e pull cujas variáveis possuíam conotação positiva. Num segundo momento, o movimento migratório passou a ser visto pela ótica da percepção do sujeito migrante e do seu comportamento em si, que focou as diferenças de percepção do individuo migrante e não mais os fatores ambientais externos da origem e do destino. Em seguida, as variáveis normativas e psicológicas destacaram-se como importantes nas decisões de migração, denominadas de obstáculos intervenientes ao modelo push-pull por Lee (1966). A decisão de migração poderia ser afetada e modificada pelos fatores tais como laços familiares, ansiedade pessoal ou custo de mudança. Na evolução dos estudos, as variáveis intervenientes passaram a ser vistas não mais como obstáculos, mas como variáveis facilitadoras ou inibidoras da migração. E posteriormente, foi introduzido o conceito de mooring tais como, curso de vida, cultura, questões espaciais, que facilitam ou dificultam a decisão de migração. 
Em suma, os autores comentam que as pesquisas recentes reconhecem que as decisões de migração são baseadas em percepção do nível macro das variáveis push e pull, mais as variáveis no nível micro, variáveis mooring, percepções das variáveis com especificidade pessoal que facilitam ou dificultam a decisão de migração tais como os fatores pessoal e social, os elementos que promovem estabilidade e segurança emocional.

Como variáveis antecedentes aos construtos do paradigma push-pull-mooring, os autores citam o impacto dos eventos de encontros na prestação de serviço, tais como falha e recuperação do serviço na alternância entre fornecedores. Os impactos dos encontros em serviços são moderados pelas respostas avaliativas que eles suscitam nos clientes. Essa abordagem é consistente com a pesquisa recente que examina consequências das falhas ou recuperações de serviços na satisfação, compromisso e confiança. O modelo PPM de migração ofereceu uma estrutura útil para unificar as variáveis preditoras.

O modelo PPM desenhado por Bansal, Taylor e James (2005) para prestação de serviços, teve como variável dependente a intenção de alternância, e como variáveis latentes e refletidas para os fatores push, pull e mooring que explicam a intenção de alternância entre fornecedores.

A Figura 3 mostra o modelo sugerido Bansal, Taylor e James (2005) para substituição de serviço de fornecedor, o modelo PPM, com 12 variáveis manifestas. 


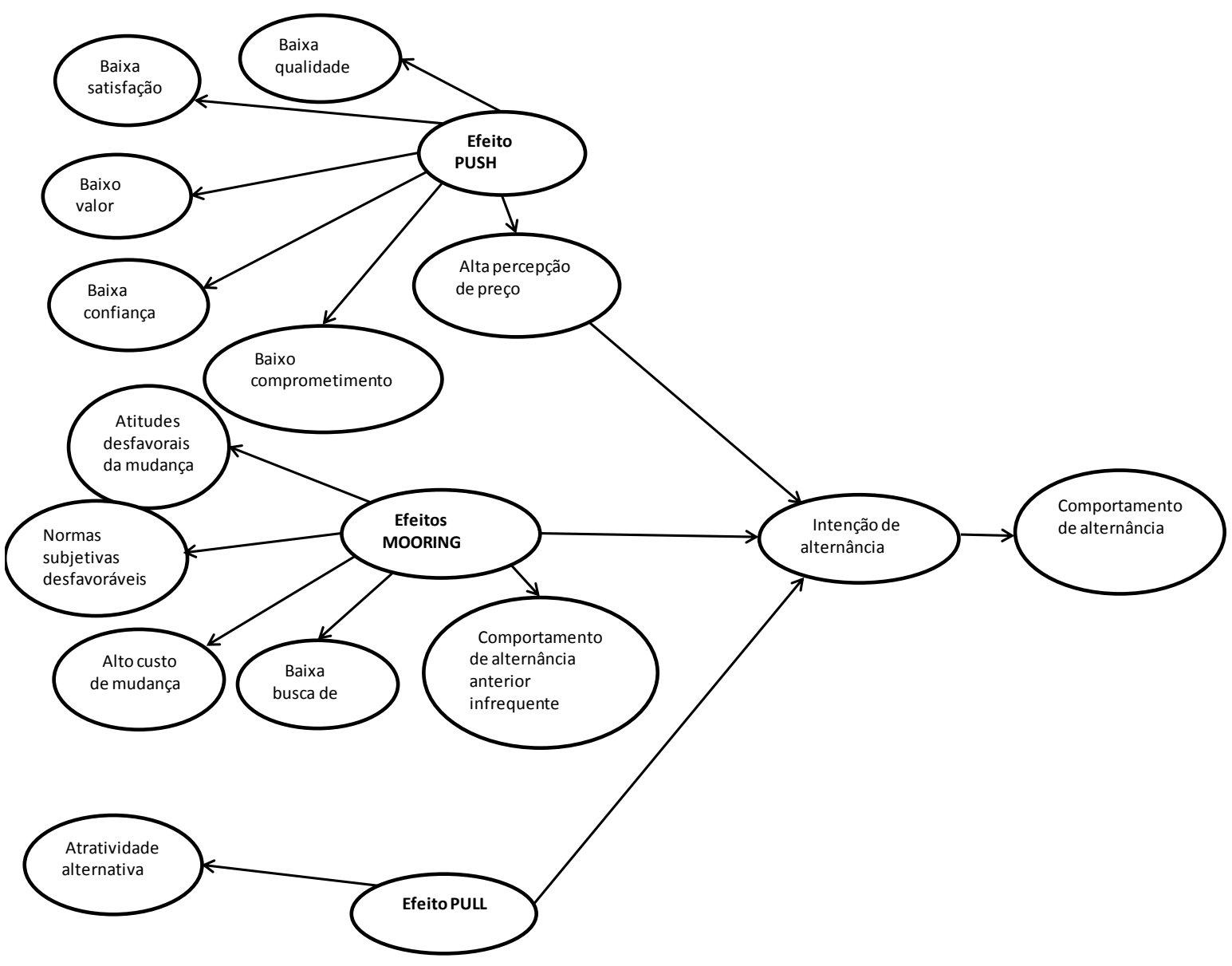

Figura 3 - Modelo PPM - push-pull-mooring de troca de serviço Fonte: adaptado de Bansal, Taylor e James (2005, p. 101)

\subsubsection{Efeitos Push}

No desenho deste modelo, Bansal, Taylor e James (2005) explicam que os antecedentes push têm força de "expulsão" ("deixar a origem") em relação à intenção de alternância. Consistem dos fatores que motivam as pessoas a deixar a origem, como fatores que possuem uma influencia negativa na qualidade de indicadores de vida na origem. $O$ autor relata que existe uma correspondência conceitual entre o construto dos fatores push da literatura de migração e vários motivadores das intenções de mudança em serviço, tais como: satisfação, qualidade, valor, confiança, comprometimento e percepção do preço. A revisão feita pelos autores em pesquisas empíricas sobre as variáveis preditoras para variáveis 
dependentes, como comportamento de alternância, intenção, intenção de recompra, repatrocinar (novamente indicar o serviço/produto), intenção de alternância, atitude em relação à alternância, comprometimento, satisfação e valor está apresentada na Figura 4.

Bansal, Taylor e James (2005) lembram que satisfação ou insatisfação são usadas extensivamente na literatura de migração. Na pesquisa de serviço, a relação negativa entre satisfação com um fornecedor de serviço e intenções de substituição está documentada. O termo qualidade no contexto de serviço, como qualidade percebida, exerce influência direta e indireta na recompra do serviço. Valor, uma escolha entre qualidade e sacrifício, é proposto como um terceiro fator em decisões de substituição de fornecedor. Confiança, como o sentimento do consumidor de que o vendedor irá cumprir sua promessa, é um antecedente da intenção de comportamento futuro do consumidor. Confiança é um preditor para comprometimento, o qual deriva, por sua vez, para a intenção de recompra. 0 comprometimento é definido como uma crença do consumidor de que vale a pena investir na relação em curso. Comprometimento e confiança são, portanto variáveis push.

Bansal, Taylor e James (2005) também consideram que as variáveis econômicas são criticas nos modelos de migração. Pesquisas extensas sugerem que preço, na percepção do cliente, torna o consumidor mais propenso de substituição se percebem que o seu atual fornecedor de serviços pratica preços altos.

Em resumo, Bansal, Taylor e James (2005) evidenciam que várias variáveis estudadas como preditores da alternância de fornecedor de serviços correspondem aos efeitos push, forças expulsórias da origem que motivam a substituição de fornecedor. Cada uma dessas variáveis terá uma relação negativa com a intenção e o comportamento de troca do fornecedor, exceto para preço. Quanto menor a percepção da qualidade, satisfação, confiança e comprometimento do fornecedor de serviço e maior a percepção do preço, mais propenso se torna o cliente à intenção de trocar de fornecedor de serviço (Figura 4). 


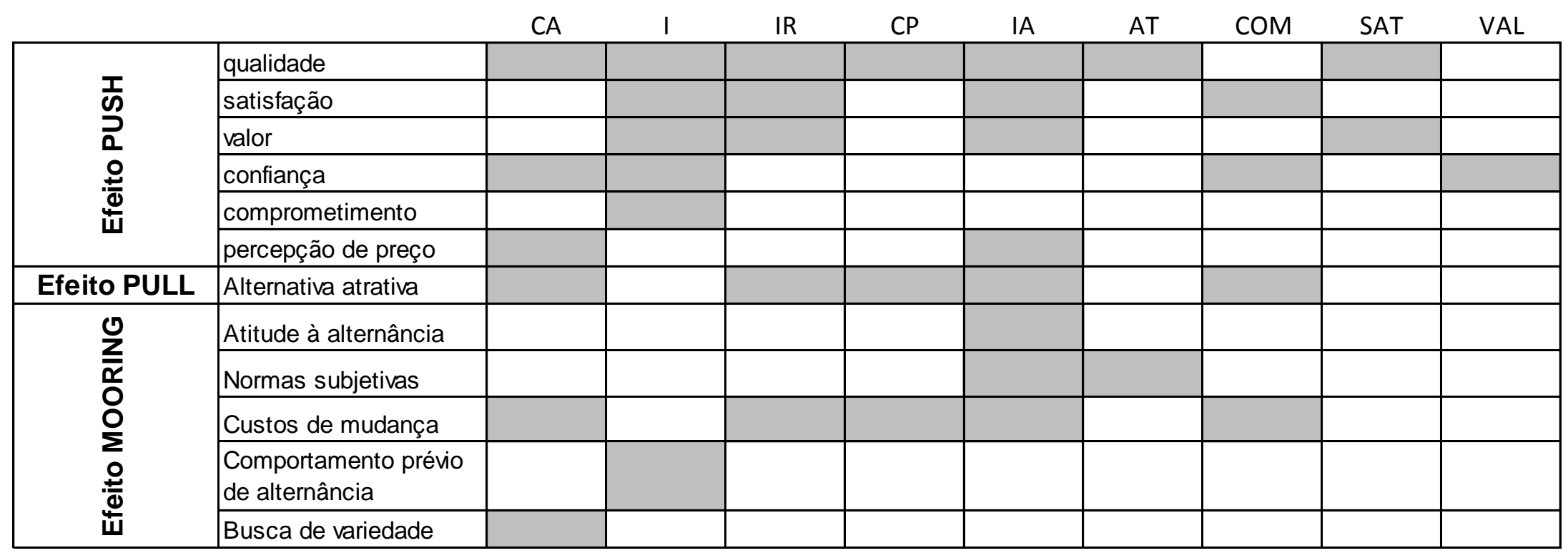

Figura 4 - Variáveis dependentes listadas acima encontradas em pesquisas empíricas: CA - comportamento de alternância; I - intenção; IR- intenção de recompra; intenção de "repatrocinar" (indicar o serviço); IA - intenção de alternância; AT - atitudes em relação à alternância; COM - comprometimento; SAT - satisfação; VAL - valor.

Fonte: adaptado de Bansal, Taylor e James (2005, p. 99). 


\subsubsection{Efeitos Pull}

São fatores positivos, atributos de lugar, que atraem para o destino. Na literatura para substituição de serviço Bansal, Taylor e James (2005) encontraram apenas a variável atratividade alternativa, que influência positivamente a intenção do consumidor de substituir o fornecedor. Quanto maior a atratividade alternativa de fornecedores de serviços concorrentes, maior a propensão dos consumidores em trocar de fornecedor de serviço.

\subsubsection{Efeitos Mooring}

Bansal, Taylor e James (2005) selecionaram as principais variáveis que apresentavam a característica de estabilidade e segurança, seja facilitando ou inibindo a substituição de fornecedor. Mesmo que fatores push ou pull sejam fortes, um indivíduo pode não migrar, devido a fatores situacionais ou restrições contextuais que são específicas à pessoa (LEE, 1966), não se tratando de traços psicológicos. Essas variáveis operam similarmente para um grande número de pessoas. Como variáveis mooring, Bansal, Taylor e James (2005) ressaltaram que a literatura relata as restrições de migração em relação a tempo, custos de mudança, seja na forma de custos financeiros, quer como o custo emocional de deixar pessoas, tempo, esforço e habilidade.

Jones, Mothersbaugh, Beatty (2000) investigaram as barreiras de mudança: qualquer fator que torne mais difícil ou custoso para os consumidores mudarem de provedor. Os achados indicaram que, apesar de a satisfação ser um fator crítico e determinante do processo de retenção, as barreiras de mudança na forma de relacionamento interpessoal, custos de mudança e atratividade de alternativas foram consideradas igualmente importantes em se tratando de serviços. Elas se tornam principalmente importantes quando, apesar da baixa satisfação com o serviço prestado, ela se torna atenuada em alguma extensão por esses fatores. 
Bolton, Kannan e Bramlett (2000) estudaram a implicação dos programas de fidelidade e experiência do serviço para retenção do consumidor e valor. Os achados indicaram que os membros em geral possuem grandes ganhos de qualidade e grandes perdas na dimensão preço em se tratando de concorrentes. Uma das razões possíveis pode ser que o cliente esteja obtendo melhor qualidade e serviço pelo preço pago, ou seja, bom custo-benefício. ${ }^{11}$ Porém não houve resposta para o fato de se poder afirmar que ser membro de um programa de fidelidade conduz à percepção do valor do custo-benefício entre os clientes ou, especificamente, se é a percepção do valor do custo-benefício que motiva o cliente a ser um membro do programa de fidelidade.

Segundo Fishbein e Ajzen (1975), as normas subjetivas traduzem a pressão social para engajar ou não a um comportamento específico, que se traduz numa equação matemática para os autores. Pesquisa mais recente sugeriu que normas subjetivas influenciam a atitude do consumidor em relação à mudança e sua intenção de mudança. Normas culturais mais amplas têm sido encontradas como moderadores da relação entre qualidade e troca de serviço.

Fatores pessoais, como o comportamento prévio e a propensão à busca de variedade foram apontados como variáveis de ancoragem, segundo Bansal, Taylor e James (2005). O consumo histórico influência as preferencias individuais bem como a busca por variedade. Mudanças múltiplas e a composição da escolha tem recebido atenção de pesquisadores. Portanto, a intenção de troca de fornecedor de serviço estará positivamente relacionada ao comportamento prévio e também à propensão de busca de variedade na experiência de serviço. A intenção de mudar de serviço é baixa quando o custo de mudança é alto, a busca de variedade é baixa, a atitude do consumidor e as normas subjetivas em relação à troca são menos favoráveis e se o consumidor não trocou frequentemente no passado.

Bansal, Taylor e James (2005) trazem o conceito de lealdade poligâmica como comportamento de compra de alguns consumidores que buscam variedade,

${ }^{11}$ Good value 
segundo Dowling e Uncles (1997), em contraposição à ideia de comportamento de mudança de marca ou de promiscuidade - tendência de borboleta que voa de marca em marca sem qualquer fidelidade, num ambiente em que não existe 0 relacionamento de longo prazo e somente a próxima compra.

Finalmente, o modelo PPM ofereceu um instrumento útil para mapear as forças concorrentes que influenciam o movimento da base de consumidores, os fatores que afastam consumidores e os empurram para a concorrência, fatores que facilitam ou inibem a troca de fornecedor.

\subsection{Modelo intenção de free-riding}

Chiu; Hsieh; Roan; Tseng e Hsieh (2011) desenvolveram um modelo que considera a intenção do consumidor em free-riding entre canais, conceito específico para quando o consumidor muda de canal e de varejista, explorado anteriormente por Van Ball e Dach (2005) e baseado no modelo de alternância de fornecedor de Bansal, Taylor e James (2005).

Diante de um contexto multicanal Chiu et al. (2011), perguntaram: Será que o consumidor usa o mesmo canal para as fases de busca e compra? Será que o consumidor contata o mesmo varejista tanto para busca quanto para compra?

A matriz da Figura 5 mostra como foram formuladas as duas dimensões do comportamento de alternância do consumidor para investigar os comportamentos de compra num ambiente multicanal. Os autores consideraram as dimensões em quatro quadrantes: 1- alternância de firmas dentro do canal on-line; 2- Retenção na firma dentro do canal on-line; 3- free-riding entre canais e firmas; 4- Retenção da firma entre os canais on-line e off-line. 


\begin{tabular}{|c|c|c|}
\hline \multicolumn{3}{|c|}{$\begin{array}{l}\text { Será que o consumidor contata } \\
\text { a mesma empresa na fase de } \\
\text { busca a compra? }\end{array}$} \\
\hline \multirow[b]{2}{*}{ NÃO } & $\begin{array}{l}\text { 1-Alternância de firmas no } \\
\text { canal on-line }\end{array}$ & $\begin{array}{l}\text { 3-Free-riding entre canais e } \\
\text { firmas }\end{array}$ \\
\hline & $\begin{array}{l}\text { O consumidor } \\
\text { informação onsca } \\
\text { empresa A e compra pelo } \\
\text { canal on-line da empresa } \mathrm{B} \text {. }\end{array}$ & $\begin{array}{l}\text { Consumidores fazem a busca } \\
\text { pelo canal on-line da empresa A e } \\
\text { compram pelo canal off-line na } \\
\text { empresa B. }\end{array}$ \\
\hline \multirow{3}{*}{ SIM } & $\begin{array}{l}\text { 2-Retenção na firma pelo } \\
\text { canal on-line }\end{array}$ & $\begin{array}{l}\text { 4-Retenção na firma entre } \\
\text { canais on-line e off-line }\end{array}$ \\
\hline & $\begin{array}{l}\text { O consumidor busca } \\
\text { informação e compra pelo } \\
\text { mesmo canal on-line da } \\
\text { mesma empresa A. }\end{array}$ & $\begin{array}{l}\text { O consumidor busca informação } \\
\text { pelo canal on-line da empresa A e } \\
\text { compra pelo canal off-line da } \\
\text { mesma empresa } A \text {. }\end{array}$ \\
\hline & SIM & NÃO \\
\hline
\end{tabular}

Será que o consumidor usa o mesmo canal para busca e compra?

Figura 5 - Matriz de comportamento do consumidor multicanal

Fonte - Adaptado de Chiu et al. (2011, p. 269)

Por sua vez, se o consumidor navega na internet para busca de informação ou visita a loja física para mesma atividade e ao mudar de canal para realizar a transação, se mantiver o mesmo varejista, as empresas multicanais levam vantagem. Para os autores, o comportamento free-riding entre canais representa um caso misto de alternância entre canais on-line/off-line e alternância entre empresas varejistas. Para entender tal comportamento Chiu et al. (2011) buscaram fundamento no modelo de Bansal, Taylor e James (2005).

Baseado no modelo conceitual PPM, os autores Chiu et al. (2011) construíram as variáveis antecedentes para cada fator, pensando no contexto multicanal, conforme Quadro 3. Mesmo que os efeitos push e pull sejam fortes os consumidores podem não migrar devido aos efeitos de ancoragem (mooring). Porém, diferente de Bansal, Taylor e James (2005), os autores Chiu et al. (2011) nomearam os efeitos PPM como construtos latentes expressos: a autoeficácia multicanal representou o efeito push o que motiva o consumidor a deixar a sua origem. Quanto maior autoeficácia maior habilidade multicanal. O efeito pull foi nomeado de atratividade do varejo tradicional, porque ela motiva a mudança de canal encaminhando o consumidor online para compra off-line. Nomeou os efeitos mooring de retenção na firma (lock-in), 
aquilo que gera relutância do consumidor para sair do canal on-line e mudar para o canal off-line, alternando de canais e/ou de firma (ver resumo no Quadro 3).

Quadro 3- variáveis principais para o modelo PPM de Chiu et al. (2011)

\begin{tabular}{|l|l|}
\hline Efeito push & \multicolumn{1}{|c|}{ Construto das variáveis latentes manifestas } \\
\hline $\begin{array}{ll}\text { Autoeficácia multicanal (no sentido de desempenho e resultado) - } \\
\text { representa a habilidade e confiança para empregar múltiplos canais, } \\
\text { iniciando com a fase de informação e finalizando com a transação. Uma } \\
\text { autopercepção de habilidade para selecionar escolhas entre melhores } \\
\text { varejistas. O consumidor com alta percepção de autoeficácia multicanal } \\
\text { pensa de si mesmo ser um experts ao selecionar os melhores fornecedores } \\
\text { de serviços em diferentes estágios de consumo. Quanto mais ele acredita } \\
\text { saber lidar com vários problemas em diferentes canais, maior a possibilidade } \\
\text { de free-riding. Se o consumidor acredita que não é capaz de desempenhar } \\
\text { uma tarefa no ambiente de internet não se engajará em comportamento on- } \\
\text { line, mesmo sabendo da vantagem da compra on-line. Isso empurra esse } \\
\text { consumidor para loja física. Os autores postulam que a autoeficácia } \\
\text { multicanal tem efeito push, expulsa e empurra os consumidores a serem } \\
\text { free-riders entre canais on-line de varejistas e entre on-line e off-line do } \\
\text { mesmo varejista ou diferentes varejistas. Chiu et al. (2011). }\end{array}$ \\
\hline Efeito pull & $\begin{array}{l}\text { Atratividade de lojas tradicionais - Aqui, num contexto multicanal, refere-se } \\
\text { à atratividade dos concorrentes off-line. Causam a alternância porque retiram } \\
\text { o consumidor da busca on-line para uma compra off-line que pode ser na } \\
\text { concorrência entre varejistas. }\end{array}$ \\
\hline Efeito mooring & $\begin{array}{l}\text { Retenção da firma (lock-in) refere-se à extensão em que uma empresa } \\
\text { retém o comprador por meio da fase de busca e compra, dificultando-o de } \\
\text { migrar para a concorrência. }\end{array}$ \\
\hline
\end{tabular}

$$
\text { Fonte - adaptado de Chiu et al. (2011) }
$$

O conceito de free-riding entre canais para um contexto multicanal pode erodir a motivação de qualquer varejista, quando seus gastos com promoção não trazem a contrapartida em aumento de vendas. Segundo Wind, Mahajan e Gunther (2002) os consumidores buscam utilidade híbrida por meio de vários canais, requerendo que os varejistas ofereçam pelo canal on-line: informação de produto, preço, mensagem de comunicação e formatos de distribuição que servem suas necessidades individuais. Cada canal de distribuição envolve estrutura específica de custos e capacidades, restritos ao volume de vendas que pode gerar. Portanto, para o consumidor maximizar sua utilidade, os consumidores podem fazer free-riding pelos canais eletrônicos. Os autores focaram especificamente no free-riding entre canais que ocorre com busca on-line e compra off-line.

Chiu et al. (2011) desenharam o modelo teórico (Figura 6), focando especificamente o cruzamento da fase (1) busca on-line e depois fase (2) compra em outro varejista 
off-line. O modelo contribuiu para explicar por que os consumidores podem estar alternando entre os canais. Porém o efeito mooring de retenção dentro da firma tem efeito negativo na intenção de free-riding entre canais, o que é consistente com estudos anteriores que indicam que a retenção de clientes se dá quando o varejo constrói uma boa integração de canais, quando retém o consumidor dentro da firma.

O modelo dos autores formulou nove hipóteses conforme o Quadro 4.

Quadro 4 - Resumo de hipóteses do modelo

H1 - Autoeficácia multicanal tem efeito positivo no free-riding entre canais.

H2 - a experiência previa na internet tem efeito positivo na autoeficácia multicanal.

H3 - a experiência vicária tem efeito positivo na autoeficácia multicanal

H4 - Retenção dentro do canal (lock-in) tem efeito negativo no free-riding entre canais.

H5 Custos de mudança tem efeito positivo na retenção dentro dos canais do varejista

H6 - Percepção de integração do multicanal tem efeito positivo na retenção.

H7 - A atratividade do concorrente varejista off-line tem efeito positivo no free-riding entre canais.

H8 - A qualidade percebida do serviço do concorrente varejista off-line tem efeito positivo na atratividade pelo mesmo.

H9 - Risco percebido de compra on-line tem efeito positivo na atratividade pelo varejista offline.

Fonte: elaborado pelo autor, baseado em Chiu et al. (2011).

Chiu et al. (2011) conduziram uma pesquisa de campo em Taiwan e aplicaram questionários para pessoas que tivessem experiência com internet. Inicialmente houve um filtro de respondentes para selecionar àqueles que tivessem experiência de free-riding, além do cruzamento multicanal (cross-channel) para compra de produtos eletrônicos, equipamento de computadores/hardware ou software nos últimos três meses. Os respondentes eram empregados iniciantes em serviços da indústria de alta tecnologia.

No artigo de Chiu et al. (2011) houve uma pesquisa de campo em Taiwan. Estudantes de graduação foram treinados e instruídos a aplicarem questionários em pessoas que tivessem experiência com internet.

Os achados de Chiu et al. (2011) indicaram que não foi encontrada nenhuma influência significativa do antecedente percepção de integração multicanal, tendo como mediador a retenção dentro da firma, revelando que os multicanais de um varejista ainda funcionam de forma relativamente independente e que o conceito de integração multicanal permanece na sua fase da infância. Chiu et al. (2011) sugerem 
que a integração multicanal evoluiu mais no nível operacional do que no de comunicação de marketing para os varejistas, no sentido de valor agregado de serviços como 1- integração da informação - para localização de lojas, checagem de inventário, pedido e pagamento, registro e controle de contas on-line, ou 2Integração logística - o que capacita o consumidor pedir on-line e buscar na loja mais próxima ou devolver produtos comprados na Web para a loja física. O levantamento na literatura feita pelos autores indicou que para o gerenciamento efetivo de um sistema multicanal, o varejista deve ter um sistema de informação que compartilhe cliente, preço e informação baseada em inventário entre canais. Quanto maior a percepção de risco e de qualidade na compra on-line, maior a intenção para free-riding entre canais. Chiu et al. (2011) observaram também a questão do comportamento de free-riding entre canais e compra na loja física pois o consumidor pode checar fisicamente a mercadoria, levar consigo imediatamente, ter assistência dos funcionários e o mesmo evita dessa forma o risco de uma compra insatisfatória.

O modelo de Chiu et al. (2011) para intenção de free-riding, embasado no paradigma PPM para alternância entre serviços de varejistas estabelece uma dinâmica entre os conceitos econômicos de free-riding e de retenção na firma (lockin), enxergando o consumidor no cruzamento entre canais no sentido da busca online e compra loja física (Figura 6). A proposta das variáveis mediadoras no lugar dos efeitos push-pull-mooring abriu a possibilidade para um modelo integrativo em ambiente multicanal, porém o modelo não contemplou o fenômeno completo de cruzamentos entre canais em todas as direções de busca e compra. Além disso, os antecedentes para as variáveis mediadoras não incluíram importantes variáveis do comportamento do consumidor, tais como: satisfação, confiança, lealdade, conveniência. A realização de uma pesquisa exploratória no Brasil pôde incluir mais construtos antecedentes. 


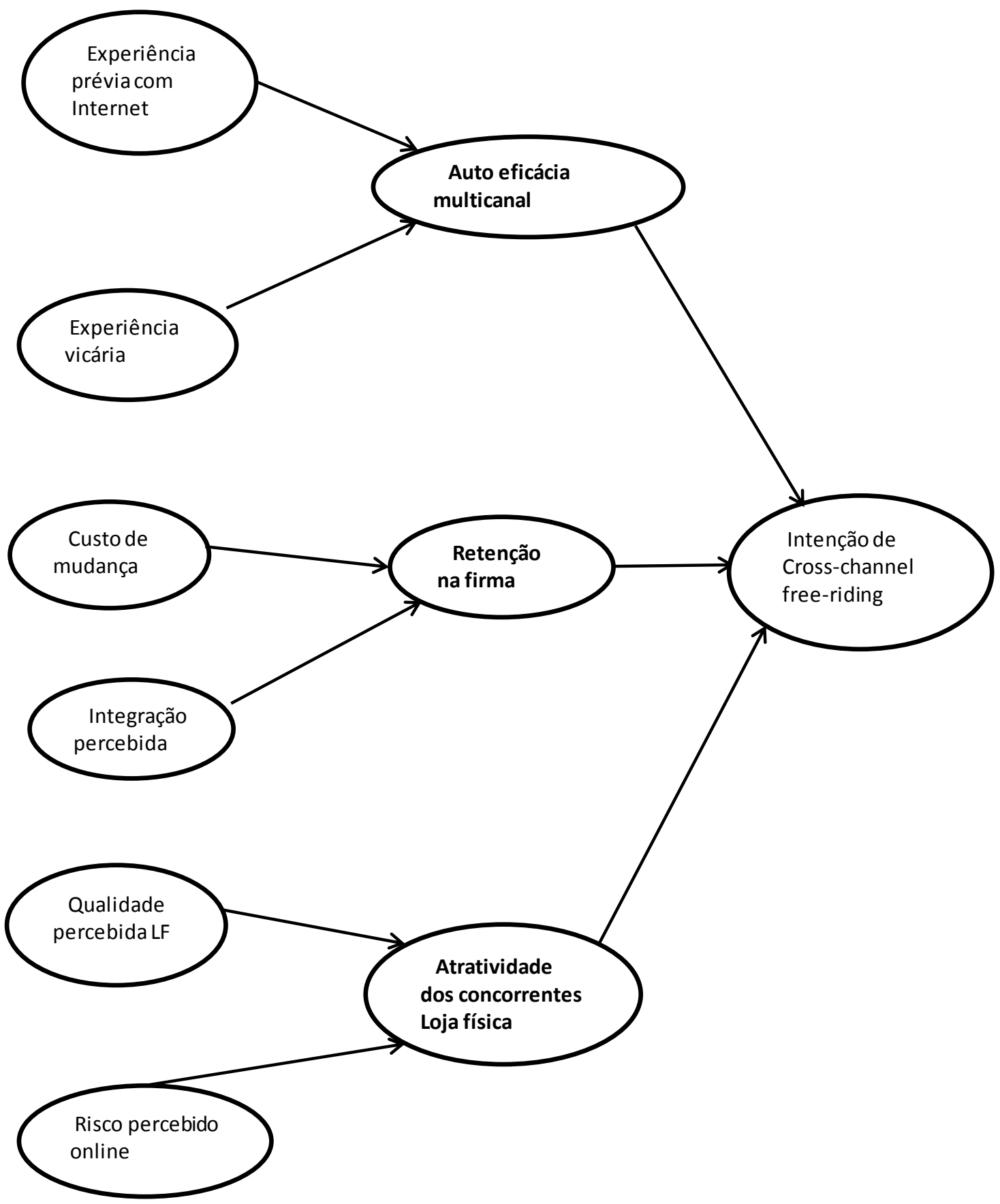

Figura 6- Modelo desenvolvido por Chiu et al. (2010)

Fonte - Adaptado de Chiu et al. (2010, p.274). 


\section{Modelo Teórico e hipóteses de pesquisa}

O modelo teórico para esse estudo foi construído sobre o paradigma PPM de Bansal, Taylor e James (2005) com três construtos centrais de segunda ordem, conforme o modelo de Chiu et al. (2011): autoeficácia multicanal, retenção da firma e grau de atratividade dos varejistas tradicionais. A variável dependente e consequente foi a intenção de free-riding no multicanal. Esses construtos centrais apresentaram efeito mediador no modelo de Chiu et al. (2011). Além dos construtos latentes o modelo teórico apresentou construtos antecedentes de primeira ordem, conforme o Quadro 5.

Quadro 5 - Relação de construtos

\begin{tabular}{|c|c|}
\hline Construtos das variáveis PPM & Antecedentes \\
\hline Autoeficácia multicanal & $\begin{array}{l}\text { Afinidade tecnológica } \\
\text { Experiência Vicária } \\
\text { Experiência prévia com internet } \\
\text { Lealdade } \\
\text { Confiança } \\
\text { Satisfação }\end{array}$ \\
\hline Retenção da firma & $\begin{array}{l}\text { Busca de variedade } \\
\text { Integração percebida no multicanal } \\
\text { Custos de mudança } \\
\text { Conveniência } \\
\text { Design do site }\end{array}$ \\
\hline Atratividade do varejo tradicional & $\begin{array}{l}\text { Risco percebido na compra on-line } \\
\text { Qualidade percebida do varejo off-line } \\
\text { Barganha } \\
\text { Lealdade } \\
\text { Confiança } \\
\text { Satisfação }\end{array}$ \\
\hline
\end{tabular}

Fonte: o próprio autor

Os construtos antecedentes de primeira ordem surgiram parte, como contribuição da pesquisa exploratória qualitativa e parte de sugestões antes e depois da banca de qualificação deste estudo ${ }^{12}$.

No modelo de Chiu et al. (2011), a opção de busca de informação foi dada apenas para o canal on-line. Para o modelo proposto foram consideradas ambas as possibilidades de busca off-line e on-line, nos dois sentidos, porém os respondentes

${ }^{12}$ Contribuições do Prof. Dr. José Afonso Mazzon. 
obrigatoriamente estavam relacionados com o canal on-line, pois a pesquisa foi realizada pela empresa E-bit.

\subsection{Intenção de free-riding no cruzamento multicanal}

Van Baal e Dach (2005) comentam que a maioria do varejo não consegue cobrar uma taxa pelos serviços padronizados de pré-vendas. A intenção de compras do consumidor é desconhecida ex ante para o varejista. Os serviços do varejo tornamse, portanto, um bem público se não houver nenhuma rivalidade de consumo. Entretanto, em muitos casos, os serviços do varejo funcionam como um pool de recursos comuns, especialmente nas lojas tradicionais que apresentam uma quantidade de vendedores reduzida para 0 número de consumidores. A probabilidade para o free-riding aumenta quando diferentes lojas oferecem serviços e preços diferenciados (lojas de descontos, lojas especializadas, lojas de varejo tradicionais, lojas on-line). Se um fabricante distribui seus produtos por canal direto ou se for por canal indireto exclusivo, não se torna factível o free-riding (CARLTON; CHEVALIER, 2001). Se o fabricante está integrado verticalmente com o consumidor não há free-riding. Se a empresa varejista não controla os canais de distribuição, seus serviços não conseguem ser internalizados e integrados, segundo Coughlan et al. (2002).

Para fins de pesquisa, Van Baal e Dach (2005), consideram apenas free-riders os consumidores que mudam de varejista quando mudam de canal. $O$ efeito adverso do free-riding tem diferentes formas. Na visão do varejista, significa perda de receita, pois a intenção de compra não se realiza. Há estudos que mostram perda da moral da equipe de vendas, devido à redução na eficiência da venda e serviço ao consumidor, bem como uma redução no nível de serviço do varejo. Na visão dos fabricantes, que dependem dos serviços do varejo para aumentar demanda, são afetados negativamente (VAN BAAL; DACH, 2005).

O modelo proposto para este estudo (Figura 7) tem como variável dependente a intenção de free-riding dos consumidores entre canais e entre varejistas. 


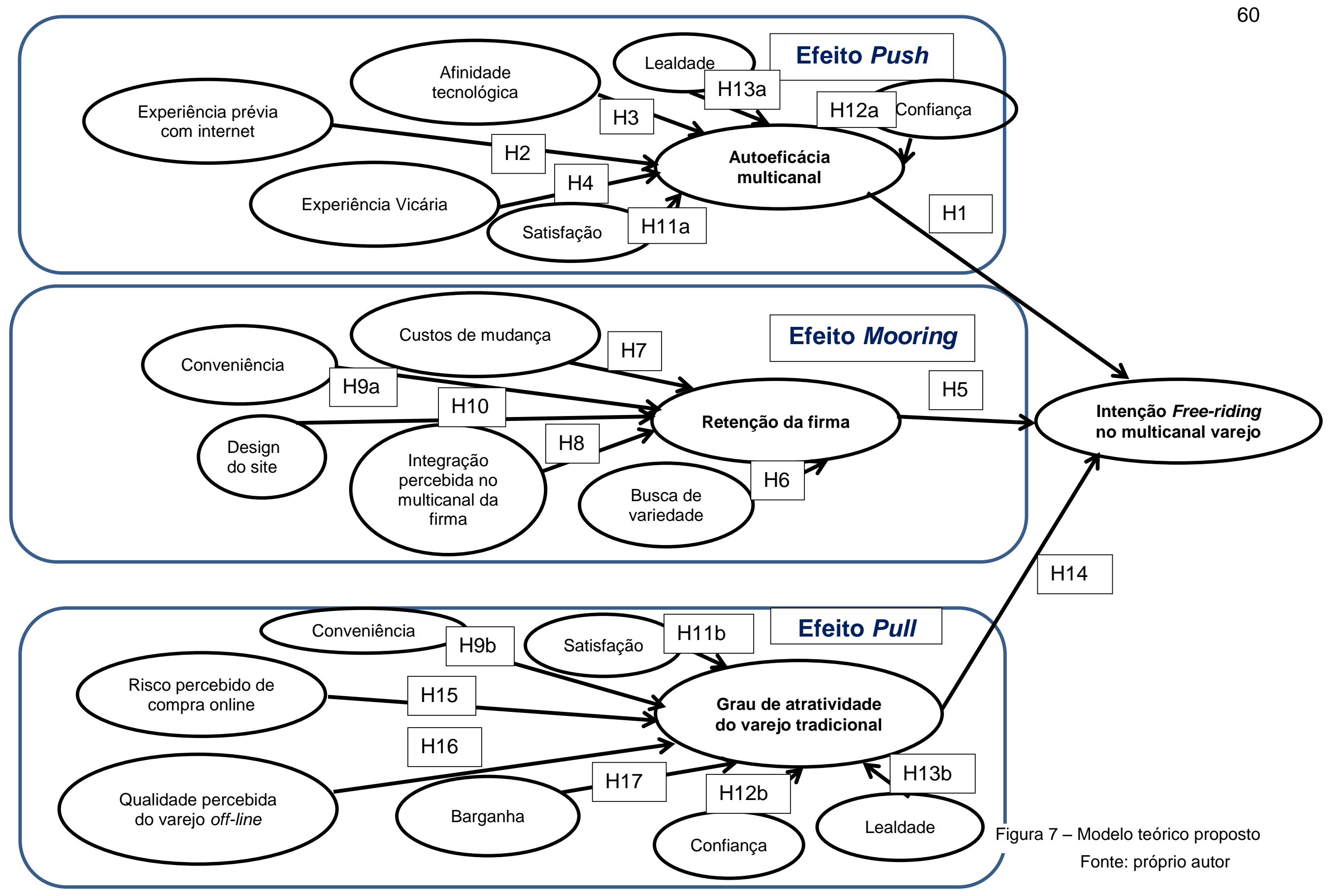


Wind; Mahajan e Gunther (2002) encorajam executivos a pensar seriamente sobre as implicações da internet e outras inovações. Comentam que as novas tecnologias criam oportunidades para consumidores fazerem coisas que nunca fizeram antes. Relatam que muitos negócios on-line estão baseados na ideia de que o consumidor está apenas interessado na eficiência transacional e informacional. Num ambiente multicanal, o problema do free-riding se tornou mais complexo porque os consumidores perseguem utilidades híbridas por meio de vários canais. Os consumidores requerem que o varejista ofereça produtos, preços, mensagens de comunicação e que entregue formatos que sirvam para atender a sua necessidade.

O marketing de convergência abordado por Wind; Mahajan; Gunther (2002) mostra esse consumidor híbrido que está virtual e fisicamente na loja. Eles querem interagir por meio do multicanal, fazendo seus investimentos on-line e no dia seguinte consultando um especialista por telefone. Tomam vantagem dos leilões e outros modelos de precificação, porém continuam comprando produtos com preços fixos. Em adição ao produto e serviços atrelados, também esperam informação, educação e entretenimento como parte da equação de valor. A chave está na convergência dos canais de vendas, tido como o início da terceira era da internet. $\mathrm{E}$, porque cada canal envolve custos de estrutura e capacidade, só podem oferecer uma gama limitada, em função da intensidade de bens e serviços determinados pelas necessidades preenchidas e pelo volume de vendas gerado. Consistente com a economia da pesquisa de informação, os indivíduos devem pesquisar informação por algumas horas ou pesquisar de forma mais abrangente.

Segundo os achados de Klein e Ford (2003), a internet é conveniente para busca de informação porque ela oferece uma gama ampla de informação a custo baixo. Baseado em Stigler (1961), o paradigma dominante para busca de informação se dá pela análise de custo-benefício implícita na escolha de uma estratégia de busca - o que, quando, onde e quanto pesquisar. De acordo com tal paradigma, consumidores pesquisam informação até quando percebem que o beneficio marginal da busca é igual ao custo marginal percebido. Porém a internet afetou ambos os lados da equação. O custo da informação deixou de ser o tempo de busca e passou a ser mais uma questão cognitiva de assimilar e integrar grande quantidade de informação 
e ponderar o valor de cada alternativa de informação. Entretanto, para maximizar a utilidade, consumidores podem fazer o free-riding pelo varejo on-line.

A intenção de free-riding é a variável dependente para o modelo teórico testado por Chiu et al. (2011). O termo free-riding será empregado para as situações em que ocorre a troca de canal e a troca de varejista.

\subsection{Variáveis de efeito Push}

Os efeitos push referem-se, então, a característica do lugar de origem que influencia a decisão de migração (BANSAL; TAYLOR; JAMES, 2005). Chiu et al. (2011) alertam que, se o consumidor acredita que não é capaz de desempenhar uma tarefa no ambiente da internet ele não se engajará no canal on-line, mesmo sabendo das vantagens da compra on-line. Isso "empurra" ${ }^{13}$ esses consumidores para os canais físicos.

\subsubsection{Autoeficácia multicanal}

Bandura (1977) relata que a teoria de aprendizagem social enfatiza o papel proeminente do funcionamento psicológico desempenhado pela experiência vicária, pelo simbólico e pelo processo de autorregulação. A teoria reconhece que o pensamento humano, afeto e comportamento podem ser marcadamente influenciados pela observação e pela experiência direta. $O$ autor ressalta que a extraordinária capacidade humana de usar símbolos permite representar eventos, analisar a experiência consciente, comunicar-se com outros a qualquer distância em tempo e espaço para planejar, criar, imaginar, e engajar em ações previdentes. A ênfase nas funções simbólicas expandiu a gama de técnicas para análise de pensamento e do mecanismo pelo qual o pensamento regula a ação. 
Bandura (1977) ressalta que a terceira característica distinta da teoria social de aprendizagem é o papel central que ela atribui aos processos autorregulatórios. Shinyashiki (2006) acrescenta em sua tese que essa teoria dá um passo a frente da teoria de aprendizagem behaviorista e de suas limitações. A teoria comportamental se caracterizava principalmente pelo objetivismo e positivismo dos behavioristas, desprezando aspectos cognitivos e afetivos e colocava as pessoas, segundo Bandura (1977) como apenas "reatores a influencias externas", como no modelo estímulo-resposta. $\mathrm{O}$ campo de ação humana ficaria assim reduzido às respostas a estímulos condicionados. O autor acrescenta que o comportamento humano seleciona, organiza e transforma o estimulo que impinge sobre ele. Por meio de incentivos autogerados e consequências, as pessoas podem exercitar alguma influência sobre o próprio comportamento. O reconhecimento da capacidade da pessoa de se autodirecionar fornece o impulso necessário para o paradigma autorregulatório, onde os próprios indivíduos servem como principal agente de sua mudança.

Como bem descreve a tese de Shinyashiki (2006) sobre o autor Bandura, o indivíduo influencia a própria motivação, a qual determina suas escolhas para ações e que influencia no meio ambiente. Por sua vez, o meio ambiente vai influenciar o individuo dentro de um sistema de tríade de influências recíprocas: fatores pessoais, comportamentos e estímulos do meio ambiente que se interagem e se influenciam bidirecionalmente. $\mathrm{O}$ que as pessoas pensam, sentem e acreditam afeta a forma de se comportar. Por sua vez, os efeitos naturais e externos interferem nos modelos de pensamentos e em suas relações afetivas.

Wood e Bandura (1989, p.364) relatam sobre o mecanismo autorregulador da eficácia, o conceito de autoeficácia percebida, como "o julgamento da pessoa sobre a sua capacidade de mobilizar a motivação, recursos cognitivos e executar um curso de ação necessário para exercitar controle sobre eventos em sua vida"14 (tradução nossa). Não diz respeito à habilidade das pessoas, mas ao julgamento da pessoa

\footnotetext{
14 "Perceived self-efficacy concerns people beliefs in their capabilities to mobilize the motivation, cognitive resources, and courses of action needed to exercise control over events in their lives."
} 
sobre o que ela pode fazer com a sua habilidade. Relaciona-se com a percepção do consumidor do seu grau de eficiência capaz de realizar o processo de busca de informação.

Bandura (1999) recorda que devido à necessidade de centralidade de controle nos seres humanos, muitas teorias foram propostas ao longo dos anos. O nível de motivação, estados afetivos e ações são baseados mais no que as pessoas acreditam do que aquilo que é objetivamente o caso em questão. Portanto, é a opinião das pessoas em suas capacidades causais que é o foco principal de investigação. A teoria da autoeficácia endereça todos os subprocessos em nível individual e coletivo. Incorporando a teoria do sistema de crença da eficácia numa teoria social-cognitiva mais ampla, pode integrar diversos corpos de descobertas em variadas esferas de funcionamento. $O$ valor de uma teoria é julgado pelo poder dos métodos que resulta para a produção das mudanças desejadas. A teoria de autoeficácia oferece diretrizes explícitas em como desenvolver e aprimorar a eficácia humana.

Na revisão feita por Maity, Hsu e Pelton (2012) a baixa autoeficácia tem a ver com alta resistência à mudança. Em contraste, um relativo alto nível de autoeficácia tem efeito positivo sobre o processamento cognitivo, incrementa a automotivação, reduz ansiedade e permite ao indivíduo a resiliência para inovar ou perseverar em comportamentos de longo prazo com resultados ambíguos.

Autoeficácia é um preditor forte de comportamento e influencia o comportamento de escolha, que frequentemente depende o quanto eficaz se sente um consumidor em relação a uma opção. Quando uma pessoa se sente incapaz a desempenhar uma tarefa, ela não se engajara no comportamento, mesmo que reconheça que seria a melhor alternativa. Maddux; Norton e Stoltenberg (1986) complementa a teoria da autoeficácia, alegando todos os processos de mudança psicológica operam por meio de sentido do indivíduo da própria maestria pessoal ou eficácia, o que permite transformar isso numa variável preditora. 
Utilizando tal conceito, os autores Chiu et al. (2011) definem autoeficácia no multicanal como a habilidade e a confiança do consumidor para empregar o multicanal, incluindo o canal on-line e loja tradicional, para a busca de informação e depois finalizar uma transação.

Seltzer (1983) em achados para autoeficácia, identificou que debaixo de situações de decisão mais difíceis, quando acredita que é incapaz de desempenhar uma tarefa, o indivíduo não se engajará nesse comportamento, mesmo reconhecendo que tal comportamento é a melhor alternativa, o que reforça que o individuo adere à alternativa que inspire menor desconforto.

Balasubramanian; Raghunatan e Mahajan (2005) ressaltam que uma ocasião de compra pode oferecer um traço positivo ou desejado pelo indivíduo como autoafirmação de si. Entre os traços mais comuns, os consumidores podem ser motivados pela busca de autoafirmação em "saber poupar" ou "mostrar competência", também nomeado como "expertise". O traço de "economia" representa a busca para adquirir produtos ou serviços de forma barata. Os canais on-line geralmente oferecem grande potencial para comparação de preços e para encontrar barganhas. Pergunta-se então: quanto 0 compromisso de autoaprimoramento por meio do engajamento em comportamento de economizar influencia a escolha do canal? Entretanto, os achados indicam que o objetivo de economizar pode ser maior on-line, porém a percepção de ter economizado pode ser geralmente maior na loja tradicional.

Balasubramanian; Raghunatan e Mahajan (2005) relatam que o expediente de compra pode ser afirmado por "economia" na compra. O expediente de compra pode também ser afirmado pelo senso de expertise como consumidor. O termo expertise é utilizado para pessoas que possuem a percepção de ser habilidosas na seleção dos melhores varejistas de um conjunto. A expertise pode ser subjetiva ou objetiva. A expertise subjetiva é uma percepção própria de domínio em conhecimento. A expertise objetiva corresponde ao domínio de uma categoria de produto em questão e resulta geralmente em melhor decisão de compra, porém a subjetiva dá mais confiança na decisão de compra ou satisfação com a mesma. E a partir dessa 
subjetividade para expertise, Chiu et al. (2011) relacionaram a autoeficácia, quando o indivíduo com alta percepção para autoeficácia multicanal pensa a partir de si mesmo como um "expert" na seleção do melhor prestador de serviço em diferentes estágios do processo de compra. Quanto mais o consumidor acredita que consegue lidar com os diferentes problemas de diferentes canais, maior a chance de acontecer o free-riding.

Baseado em Chiu et al. (2011), num contexto de varejo multicanal, a autoeficácia multicanal significa a habilidade e a confiança do consumidor em empregar multicanais no varejo, então propõe-se a seguinte hipótese $\mathrm{H}_{1}$ :

$\mathrm{H}_{1}-\mathrm{o}$ alto nível de autoeficácia no varejo multicanal tem efeito positivo no free-riding entre canais.

\subsubsection{Experiência prévia com internet}

Bandura e Jourden (1991) relatam que uma experiência de sucesso oferece validação de comportamento de eficácia pessoal e controle ambiental. A afirmação repetitiva da eficácia pessoal em situações difíceis produz pessoas persistentes inabaláveis. A crença das pessoas na própria eficácia influencia as escolhas que fazem.

Lazonder, Biemans e Wopereis (2000) comentam que os níveis de experiência com a web no desempenho de busca revelam que as pessoas com mais experiência de busca requerem menos tempo pesquisando, produzem respostas mais corretas e se envolvem com poucas ações durante a tarefa de busca.

Meuter et al. (2005) citam estudos que concluem que com o aumento da experiência com tecnologias relacionadas, a chance de adotar uma nova tecnologia também aumenta. Os achados em seu artigo indicam que a experiência ampliada com as ferramentas baseadas na internet conduz a uma maior probabilidade de tentativa, mas também essa experiência ampliada conduz a um maior nível de clareza do papel, motivação e habilidade relativa ao sistema de pedido por meio do 
autosserviço baseado em tecnologias na internet. Chiu et al. (2011) observam, portanto, que pessoas com maior experiência de internet tem menor barreira para aprender como usar multicanais de forma eficiente.

E para completar, Kumar e Venkatesan (2005) revelam que clientes que compram por meio de múltiplas categorias de produtos também são propensos a comprarem por meio de multicanais. Os achados dos autores com B2B (transação entre empresas) evidenciaram que o retorno de mercadoria é um importante fenômeno e estão relacionados de forma não linear a compras por multicanais. Os clientes que iniciaram contatos com o fornecedor estão mais inclinados a comprar por multicanais. Os usuários on-line são inclinados a comprar por meio de multicanais. Clientes antigos são mais propensos a comprarem por multicanais do que clientes novos. E finalmente, alta frequência de compras está associada a compras por multicanais. A confiança no fornecedor está mais associada a compras multicanais do que a familiaridade com o processo de transação em novos canais, o que leva a concluir que clientes que possuem profundo relacionamento com uma firma são melhores alvos para migração a novos canais. Os compradores multicanais são mais confiáveis e rentáveis do que os que consomem por um único canal.

Calcado em Chiu et al. (2011) a experiência prévia com a internet $\left(\mathrm{H}_{2}\right)$ afeta a autoeficácia e propõe-se a seguinte hipótese:

$\mathrm{H}_{2}$ - A experiência prévia com internet tem efeito positivo para a autoeficácia no varejo multicanal.

\subsubsection{Afinidade tecnológica}

Afinidade tecnológica é considerada uma atitude e é definida como um afeto positivo ou negativo em relação à tecnologia em geral (EDISON; GEISSLER, 2003; MAITY; HSU; PELTON, 2012). Captura o grau de conforto que os consumidores possuem ao utilizar tecnologia. Afeto positivo em direção à tecnologia significa disposição positiva em relação à adoção de nova tecnologia. Estudo revela que afinidade pela internet está relacionada positivamente a percepções favoráveis de relações 
românticas on-line (ANDERSON, 2005). Portanto, consumidores que demonstram uma atitude positiva em relação à internet são mais propensos a se engajar em busca de informação on-line para esse contexto multicanal, o que origina outra hipótese $\left(\mathrm{H}_{3}\right)$.

$\mathrm{H}_{3}$ - A afinidade com internet tem efeito positivo para a autoeficácia no varejo multicanal.

\subsubsection{Experiência vicária}

A crença na autoeficácia é construída por quatro recursos: 1- por meio da maestria de experiências; 2-experiência vicária; 3- persuasão social; 4-estados fisiológicos e emocionais (BANDURA, 1999), descritos a seguir.

- A busca pela maestria de experiências resume-se à reunião do que for possível para se obter sucesso. O sucesso constrói a mais robusta crença na autoeficácia do indivíduo. Os fracassos minam a autoeficácia, principalmente quando ocorrem antes de ter sido estabelecido um senso pessoal de autoeficácia.

- Uma segunda maneira de construir crenças de autoeficácia é pela experiência vicária, que descreve o processo de aprendizagem por observação e não somente pelo esforço como proposto por Skinner, na teoria comportamental. A modelagem de experiências sociais constrói crença pessoal sobre a capacidade do próprio individuo. Modelos proficientes dessas experiências transmitem aos observadores, estratégias eficazes para 0 gerenciamento de diferentes situações. A modelagem afeta a crença na autoeficácia por um processo de comparação social. As pessoas julgam parcialmente a própria capacidade em comparação com outros indivíduos. Presenciar o sucesso de outros por esforços sustentáveis aumenta a crença de observadores sobre suas próprias capacidades. (BANDURA, 1999; WOOD e BANDURA, 1989).

- Uma terceira fonte para fortalecer a crença na autoeficácia é a persuasão social, Pessoas que são persuadidas de forma verbalmente, de que possuem 
a capacidade de dominar dada atividade são capazes de mobilizar grande esforço e sustentá-lo se abrigarem a dúvida ou se debruçarem sobre as deficiências pessoais quando o problema surge. Porém o indivíduo que foi persuadido de que the faltam capacidade tende a evitar o desafio que poderia cultivar sua potencialidade e desiste facilmente ante a dificuldade. Os facilitadores eficazes de autoeficácia em indivíduos fazem mais do que transmitir avaliações positivas. Além de aumentar a crença na própria capacidade, eles estruturam situações de maneira que tragam sucesso e evitam colocar pessoas em situações prematuras em que possam falhar.

- Estados emocionais e fisiológicos - o modo como são percebidos e interpretados (julgados) os próprios estados emocionais e fisiológicos e, o impacto que os mesmos promovem em sua capacidade, importa. Melhorar o estado físico, reduzir o stress e as tendências emocionais negativas, e, finalmente, fazer interpretações corretas dos estados corporais alteram as crenças na autoeficácia.

Bandura (1999) relata que o fortalecimento das crenças de autoeficácia também pode vir por meio de experiências vicárias oferecidas pelo modelo social. Ao observar pessoas similares a obter sucesso por perseverança, aumenta a crença do observador de que ele também possui a capacidade de dominar atividades comparadas. Pela mesma razão, observando outros falhar, apesar do esforço elevado, reduz o julgamento positivo do observador da própria eficácia e compromete o seu nível de motivação. O impacto da modelagem de crenças sobre a sua própria eficácia é fortemente influenciado pela percepção de similaridade aos modelos. Quanto maior a similaridade, maior o poder de persuasão. Chiu et al. (2011) colocam em outras palavras. Se as pessoas carecem de realização prévia significativa, a eficácia delas aumenta pelo resultado do desempenho de outros, o que é nomeado como experiência vicária. Se pessoas de características muito diferentes podem obter sucesso, os observadores possuem uma base razoável para aumentar o próprio sentido de autoeficácia.

Os achados de Hagen et al. (1998) demonstram que por meio da exposição por filmagem em vídeo de bons professores que sabem lidar com crianças difíceis, os 
participantes (professores novatos) que estão sendo treinados aumentam a própria eficácia pela experiência vicária e persuasão verbal. Os efeitos da experiência vicária afetam a aprendizagem e o desempenho. Ao atender aos padrões de sucesso e falhas dos outros, os observadores aprender mais rápido do que os que estão de fato desempenhando, principalmente para tarefas conceituais. A aprendizagem por observação permite ao individuo modelar modelos cognitivos sem participar fisicamente em um dado comportamento. As pessoas são propensas a exibirem o comportamento modelado se os resultados validam, mais do que se houvesse o efeito recompensa ou punição (BANDURA, 1977; EASTIN, 2005).

O artigo de Compeau e Higgins (1995) descreve a habilidade de usar computadores de forma competente, a autoeficácia em computador, determinando o uso de computador. O encorajamento por colegas do grupo de referência foi utilizado como variável que influencia a autoeficácia e as expectativas de resultado. $O$ encorajamento representa uma persuasão verbal, uma das quatro fontes de crença de autoeficácia. Indivíduos confiam, em parte, na opinião de outros ao formar o julgamento da própria habilidade. Por sua vez, o encorajamento ao uso de computadores também pode ser influenciado pelas expectativas de resultados. Se os colegas de trabalho encorajam o uso da tecnologia de computador, o julgamento do indivíduo das consequências do comportamento sobre o uso de computador será afetado. Pelo menos, o indivíduo espera que o colega de trabalho ficará satisfeito por seu comportamento. A aprendizagem pela observação ou pela modelagem de comportamento tem sido considerada um poderoso meio de aquisição de novos comportamentos. Os achados indicam que 0 encorajamento influencia 0 comportamento indiretamente, pela influência na autoeficácia e na expectativa de resultado. Os achados representam importante passo no desenvolvimento de teorias sobre autoeficácia e o uso de computador, indicando que a autoeficácia do indivíduo e a expectativa de resultado são positivamente influenciadas pelo encorajamento dos pares no trabalho, bem como de outros usuários de computador.

Eastin (2005) buscou incorporar a influência de modelos sociais à teoria da ação racional (TRA) de Fishbein e Ajzen (1975). O modelo da teoria da ação racional envolve as crenças de um indivíduo sobre dado comportamento e as ações tomadas 
a partir das crenças. Ligando crenças a emoções e incluindo consequências futuras, os pesquisadores aumentaram o poder preditivo e o entendimento do uso do sistema de informação. Além disso, a pesquisa de Compeau e Higgins (1995) e a de Fishbein e Ajzen (1975) sugerem que a percepção do indivíduo sobre a própria habilidade para desempenhar um comportamento pode ter participação importante no processo de adoção de novos comportamentos: ambas ressaltam que o nível de complexidade de cada comportamento pode influenciar o papel da percepção interna no processo de adoção. A influência da aprendizagem vicária ou entendimento socialmente construído ocorre quando as observações são realizadas dentro de um grupo de referência: colegas de trabalho, familiares, amigos e atividades sociais na internet.

Chiu et al. (2011) fazem uma transposição para o ambiente do varejo multicanal. Se os consumidores reconhecem que os grupos de referência empregam multicanal para completar uma transação e ganham a máxima utilidade, eles se se sentem mais confiantes para adotar comportamento similar.

Para um contexto multicanal a experiência vicária influencia a autoeficácia, o que permite formular outra hipótese $(\mathrm{H} 4)$ :

$\mathrm{H}_{4}$ - Experiência vicária tem efeito positivo para a autoeficácia no varejo multicanal.

\subsubsection{Satisfação}

$\mathrm{Na}$ literatura acadêmica, a satisfação tem sido interpretada por vários ramos da ciência. Satisfação significa a efetividade do sistema de marketing, segundo a economia; bem-estar social para a sociologia; e um sentimento emocional do indivíduo em psicologia (NIRMALYA; JAYASHREE; HARSH, 2012).

Segundo os autores, entender sobre satisfação se tornou uma área de interesse enorme nas últimas três décadas ao analisar o comportamento do consumidor. É importante buscar a motivação do como o consumidor se satisfaz e/ou se insatisfaz, 
assim como ela influencia a lealdade do consumidor, gera o boca a boca, reduzindo a deserção de clientes e aumentando a aquisição de novos clientes.

O artigo de Nirmalya, Jayashree e Harsh (2012) comenta os paradigmas da satisfação na pesquisa de marketing e a formulação de estratégia para assegurar a satisfação do consumidor. Dois paradigmas de satisfação são importantes: 1confirmação/desconfirmação de padrões de expectativa anteriormente préconcebidos; 2- pós-interação de compra.

Neste paradigma, o determinante é visto como um estado mental; e a expectativa tem sido definida como a percepção do consumidor para a probabilidade de ocorrência de efeito positivo ou negativo e se ele se engaja em algum comportamento. Desconfirmação tem sido definida como comparação mental de um estado real da natureza com as probabilidades antecipadas. O construto expectativa atua como um "modelo de referência" ou "nível de adaptação". ${ }^{15}$ Os indivíduos comparam o nível de resultados da experiência de serviços e produtos com 0 modelo de referência. Se o resultado for classificado abaixo da expectativa, ocorre desconfirmação negativa, o que conduz a insatisfação no consumidor. Se o resultado percebido é compatível com as expectativas ou as excede, ocorre satisfação (OLIVER, 1981).

Oliver (1981) define satisfação como a avaliação da surpresa inerente na aquisição de um produto e/ou experiência de consumo. Representa um resumo do estado psicológico quando a emoção que desconfirma a expectativa está associada a sentimentos anteriores sobre a experiência de consumo. A surpresa ou excitação causada pela avaliação é pensada como de curta duração, de tal forma que a satisfação decai. $O$ autor apresentou um modelo cognitivo de confirmação/desconfirmação com antecedentes e consequentes, considerando a satisfação como resultado de um processo.

\footnotetext{
15 "Frame of reference" or an "adaptation level"
} 
Buscar a satisfação dos clientes é uma das principais ocupações do profissional de marketing para manutenção e retenção de clientes. A satisfação de uma necessidade é um resultado do consumo, seja a satisfação percebida ou satisfação real da necessidade (HAWKINS; MOTHERSBAUGH; BEST, 2007).

Para Schiffman e Kanuk (2009), a satisfação do cliente está relacionada à percepção individual do desempenho do produto ou serviço em relação à expectativa. Relaciona satisfação com expectativas. Os níveis de satisfação do cliente quando interligados com o comportamento permitem fazer predições por meio de técnicas de mensuração. Solomon (2011) ressalta que a satisfação ou insatisfação do consumidor exerce papel importante no comportamento futuro, pois se avaliam as compras à medida que são utilizadas e integradas nas atividades de consumo diárias.

Marchetti e Prado (2001) realizaram análise comparativa sobre os métodos de avaliação da satisfação do consumidor e ressaltam que na literatura existem dois tipos de definição de satisfação: 1 - ênfase no resultado; 2- ênfase no processo. Os autores em seu artigo examinam as definições e os formatos de mensuração para entender as diferenças entre eles, pontos fortes e limitações.

A orientação para o resultado da experiência de consumo tem sido definida por vários autores. Tse e Wilton (1988) definem a satisfação como a resposta do consumidor à avaliação da discrepância percebida entre a expectativa anterior e o atual desempenho do produto, percebido após o consumo.

Oliver (1981) apresentou uma base conceitual para entender o processo de satisfação do consumidor e buscou atualização da teoria de satisfação do consumidor baseada na teoria integrada ou em achados empíricos. A abordagem do autor está centrada na orientação para o processo e define satisfação como:

Satisfação pode ser mais bem entendida como uma avaliação da surpresa inerente num dado produto adquirido e/ou experiência de consumo. Em sua essência, é o resumo do estado psicológico resultante quando a emoção circundante das expectativas refutadas está acoplada aos sentimentos prévios do consumidor sobre a experiência de consumo. Além disso, a surpresa ou excitamento dessa avaliação são pensados com duração finita, de tal forma que a satisfação rapidamente decaia; sem que no entanto deixe 
de afetar grandemente, nas atitudes gerais em relação à compra do produto, particularmente em consideração ao ambiente específico do varejo (OLIVER, 1981, p. 27, tradução nossa).

Oliver (1981) ressalta que as escalas de multipontos de satisfação não irão refletir a verdadeira satisfação a não ser que o elemento-surpresa tenha ocorrido e a menos que a reação do consumidor não tenha tido tempo de diminuir. $O$ autor resume que há quatro conceitos mensuráveis a ser discutidos: expectativa, desconfirmação, satisfação e atitude.

O paradigma da interação pós-compra sustenta que satisfação se trata mais de um processo pós-compra do que de um estado mental. No artigo de Tse, Nicosia e Wilton (1990), observa-se que nas diferentes disciplinas (Marketing, Sociologia, Psicologia, Economia, Comportamento do Consumidor), satisfação tem assumido diferente conceitos e conteúdos operacionais: tanto em estado objetivo como subjetivo. Os autores propõem que a satisfação do consumidor deva ser conceituada como um processo dinâmico, multidimensional, subjetivo, seguindo o ato da compra. A discrepância entre a expectativa e a percepção de um produto conduz a um desequilíbrio psicológico (stress), e que o consumidor se engaja em um processo de pós-compra para reduzi-lo.

Nirmalya, Jayashree e Harsh (2012) afirmam que o processo de satisfação se paralisa quando o stress é reduzido. A redução do stress pode ser atribuída a fatores internos ou externos. Um exemplo de stress externo é o boca a boca. $O$ stress interno pode incluir: dissonância, atribuição de falha do produto e mudança na intenção futura de compra.

Estes autores ressaltam as implicações da medida da satisfação para o marketing. A satisfação influencia outros construtos. Satisfação tem influência na lealdade do consumidor; satisfação desempenha papel crucial nas duas formas de lealdade; satisfação influencia o comportamento de recompra e a atitude de lealdade, como instrumento de boca a boca. Gerenciar a satisfação do consumidor é extremamente importante. A satisfação é vista como confirmação ou desconfirmação da percepção do consumidor contra sua expectativa, e é importante ao marketing gerenciar a expectativa do consumidor. Três fatores são importantes: entender a formação da 
expectativa do consumidor, desenvolver capacidade para preencher a expectativa do consumidor e assegurar consistência na entrega de satisfação.

Giese e Cote (2000) organizam a literatura de satisfação do consumidor por três óticas: 1- satisfação do consumidor como resposta emocional ou cognitiva; 2- a resposta pertence a um foco específico (expectativa, produto, experiência de consumo etc.); 3- a resposta ocorre em dado momento (após consumo, após escolha, baseada em experiência acumulada etc.). Resumindo, satisfação compreende uma resposta referente a um foco específico em determinado momento. Há concordância geral de que o fenômeno da satisfação é um fenômeno pós-compra. A operacionalização do construto insatisfação não está claramente definido na literatura. Tem sido abordado como polaridade oposta à satisfação ou é visto como duas dimensões diferentes.

Szymanski e Hise (2000) referem-se a "e-satisfação" para a experiência on-line de satisfação do consumidor em "e-varejistas'. Evanschitzky et al. (2004) examinaram o construto e-satisfação no contexto da Alemanha, em que o varejo é composto por lojas pequenas e especializadas, o que contrasta com os EUA, há décadas oferecendo uma experiência de parada única em compras para os americanos, ${ }^{16}$ experiência que oferece grande sortimento de produtos. Para os autores, a qualidade e quantidade de informação sobre ofertas de produtos podem ser mais importante nos EUA do que na Alemanha.

Christodoulides e Michaelidou (2011) estudaram a motivação de compra como antecedentes da e-satisfação e da e-lealdade no contexto de moda e acessórios no domínio de produtos hedônicos. Os achados indicaram que a e-satisfação do consumidor está relacionada positivamente a e-lealdade, sendo a e-satisfação um preditor primário para e-lealdade. Os achados evidenciam que três dos quatro motivos de compra on-line contribuíram para a predição da e-satisfação: conveniência, busca por variedade, interação social e indiretamente à e-lealdade. Porém, a interação social é a única motivação como antecedente direto da e-

${ }^{16}$ One-stop shopping 
lealdade. Estudos ressaltam que a conveniência de compra é o motivo de maior impacto nos níveis de e-satisfação. Na revisão de literatura destes autores, a interação social representa um motivo primário para compra em loja tradicional, porém os achados relacionam o construto diretamente com e-lealdade.

O autor Ha (2012), num estudo longitudinal com 219 consumidores na indústria de viagens da Coreia sobre atributos da satisfação on-line com efeito temporal, evidenciou que os níveis de avaliação dos atributos e satisfação são dinâmicos e mudam ao longo do tempo. Os atributos alterados ao longo do tempo foram conveniência e design do site. Os achados indicam que existem efeitos de longo prazo significantes na satisfação e intenção de compra. Foram mensurados cinco atributos: conveniência, oferta de serviços, informação de serviços, design do site e segurança. Dois atributos permaneceram no mesmo nível: oferta de serviços e informação de serviços. As implicações do estudo sinalizam que nem todos os atributos influenciam na satisfação geral no mercado de viagens nem permanecem consistentes ao longo do tempo.

Bansal, Taylor e James (2005) selecionaram literatura prévia para comportamento de alternância entre provedores de serviços e classificaram os preditores de acordo com os feitos push-pull-mooring (Figura 4).

Ao pensar a satisfação do consumidor no contexto multicanal, buscou-se a influencia positiva da satisfação sobre a autoeficácia multicanal e a satisfação relacionada com a atratividade ao varejo tradicional. Isso originou as hipóteses $\left(\mathrm{H}_{11 \mathrm{a}}\right.$ e $\left.\mathrm{H}_{11 \mathrm{~b}}\right)$ :

$\mathrm{H}_{11 \mathrm{a}}$ - A maior satisfação free-riding de compras tem efeito positivo sobre a autoeficácia no varejo multicanal.

$\mathrm{H}_{11 \mathrm{~b}}$ - A maior satisfação de compras pelo canal tradicional tem efeito positivo sobre a atratividade do varejo. 


\subsubsection{Confiança}

Solomon (2011) destaca que as crenças dos consumidores sobre o que o futuro thes reserva são indicadoras do nível de confiança do consumidor. Tais crenças influenciam a quantidade de dinheiro que as pessoas injetam na economia quando fazem compras.

Dash e Saji (2007) descrevem que confiança pode ser uma crença na confiabilidade de um parceiro ou uma intenção de comportamento de depender de um parceiro numa situação de vulnerabilidade. Confiança impacta no comportamento e na intenção. Os autores ressaltam que existe um número de estudos que focaram em diferentes impactos da confiança on-line que podem ser agrupados em três categorias amplas. Um estudo é de Shankar e Ratchford (2002 apud DASH; SAJI, 2007, p. 36), que assim caracteriza os impactos da confiança: 1- intenção de agir; 2satisfação e lealdade das partes; 3- desempenho da firma.

Mayer, Davis e Schoorman (1995) estudaram um modelo integrativo para confiança, tentando elucidar problemas de definição do construto, falta de clareza na relação entre risco e confiança, confusão da variável confiança em relação aos antecedentes e resultados. Os autores definiram confiança como:

(...) o desejo de uma parte estar vulnerável para as ações da outra parte, baseada na expectativa de que a outra irá desempenhar uma ação particular importante ao outorgante, independente da habilidade de monitorar ou controlar essa outra parte ${ }^{17}$ (MAYER; DAVIS; SCHOORMAN, 1995, p. 712, nossa tradução).

O significado de se tornar vulnerável é para os autores assumir riscos. Confiança não significa tomar risco per se, mas, sobretudo o desejo de tomar risco.

A definição dos autores foi adaptada para essa pesquisa como: o desejo de o consumidor estar vulnerável para ações dos multicanais de vendas de varejistas,

\footnotetext{
17 "The willingness of a party to be vulnerable to the actions of another party based on the expectation that the other will perform a particular action important to the trustor, irrespective of the ability to monitor or control that other party."
} 
baseado na expectativa de que os multicanais de um mesmo varejista irão desempenhar uma ação particular importante para o consumidor, independente da habilidade de monitorar ou controlar os multicanais varejistas.

No contexto multicanal, o consumidor que tradicionalmente compra da loja física de dado varejista, pode transferir a confiança ao comprar produtos pela loja on-line da mesma empresa. Especialmente quando há incerteza na compra on-line, o consumidor deve transferir a confiança para as lojas on-line de lojas físicas de varejistas tradicionais (HAHN; KIM, 2009).

Os estudos de Chaudhuri e Holbrook (2001) evidenciaram que a lealdade à marca deve ser vista como um elo na cadeia de efeitos que indiretamente conecta confiança na marca e afetividade pela marca, aspectos relacionados com o valor da marca $^{18}$ e dos aspectos de desempenho no mercado. Lealdade da marca, confiança na marca e afetividade pela marca possuem diferentes antecedentes. A categoria de produto importa, pois influencia de forma diferente na confiança e na afetividade pela marca. Por exemplo, o valor hedônico pela categoria de produto mostrou-se relacionado de forma significativa e positiva com afetividade pela marca. $\mathrm{O}$ valor utilitário da categoria de produto mostrou-se significativa, mas negativamente relacionado com afetividade pela marca.

Hahn e Kim (2009) estudaram o ambiente multicanal on-line e loja física, com uma amostra de estudantes, no setor de vestuário. Os achados evidenciaram que a confiança do consumidor na loja física foi um preditor significativo para a confiança percebida na internet e na intenção de busca de informação de produtos on-line oferecida pelo varejista tradicional. A confiança em varejista com loja física tem relação positiva com a confiança percebida na internet do mesmo varejista. Entretanto, o efeito direto entre a confiança do consumidor no varejista de loja física para a variável dependente (intenção em direção à loja on-line) não foi suportado no estudo de Hahn e Kim (2009). Isso sugere que a confiança do consumidor não tem impacto direto no comportamento de intenção de compra, mas indiretamente o

${ }^{18}$ Brand equity 
influencia por meio da confiança percebida na internet do varejista e pela intenção de busca de informação on-line no mesmo varejista.

Numa situação vulnerável de compra pela internet, a confiança de um consumidor em dado varejista pode ter papel importante na redução da incerteza sobre compras on-line. Uma das questões dos negócios on-line é converter buscadores em compradores on-line. Os consumidores se sentem mais confiantes nas compras online quando realizam compras por meio de varejistas em que confiam (HAHN; KIM, 2009). No Brasil, os sites de comparação de preços oferecem o menor preço on-line, porém a compra do produto na loja on-line vai depender da confiança que o consumidor deposita no varejista. Os sites de comparação de preços oferecem avaliação do varejista pelas compras anteriores por consumidores, minimizando a incerteza.

Na revisão de Bansal, Taylor e James (2005), a confiança pode estar relacionada com o efeito push. Porém a literatura acima demonstra que a confiança pode estar relacionada à retenção de clientes pelo canal tradicional. Isso leva a duas hipóteses $\left(\mathrm{H}_{12 \mathrm{a}} ; \mathrm{H}_{12 \mathrm{a})}\right.$ :

$\mathrm{H}_{12 \mathrm{a}}$ - A maior confiança no canal on-line tem efeito positivo sobre a autoeficácia no varejo multicanal.

$\mathrm{H}_{12 b}$ - A maior confiança no canal tradicional tem efeito positivo sobre a atratividade do varejo tradicional.

\subsubsection{Lealdade}

Segundo Schiffman e Kanuk (2009), a lealdade pode ser expressa como uma estrutura conceitual integrada por três influências: 1- direcionadores de consumidores, como o grau de aversão ao risco ou de busca de variedade; 2direcionadores de marca, como reputação da marca e disponibilidade de marcas substitutivas; 3- direcionadores sociais, a influência do grupo social e dos pares. Estas influências produzem quatro tipos de lealdade: a- nenhuma lealdade com 
nenhuma compra e vínculo cognitivo à marca; b- lealdade cobiçosa, ou seja, nenhuma compra, porém forte vínculo e predisposição em relação à marca desenvolvida no ambiente social da pessoa; c- lealdade inercial, compra da marca devido ao hábito e à conveniência, porém sem vínculo emocional; d- lealdade premium, com alto vínculo à marca e alto nível de repetição de compras. Neste último, o consumidor está comprometido com a marca, com menor propensão à mudança.

Oliver (1999) comenta que tanto para acadêmicos quanto praticantes, a lealdade do consumidor e sua satisfação estão intimamente ligadas. A mudança da ênfase na satisfação para lealdade deveu-se ao fato de que lealdade impacta diretamente no lucro do negócio ao ter uma base de clientes leais. Além disso, verificou-se que os custos relativos de retenção de cliente são substancialmente menores do que na aquisição de consumidores.

Shankar, Smith e Rangswamy (2003) compararam a lealdade do consumidor da internet com o consumidor da loja na indústria de serviços de viagem. Para este contexto, a internet reforça a lealdade e fortalece a relação positiva entre satisfação e lealdade. Os autores estudaram o significado do conceito de lealdade.

O artigo de Verhoef e Donkers (2005) assume que, na perspectiva de gerenciar o relacionamento com consumidor, a aquisição de novos consumidores por meio de novos canais de vendas (incluindo mídias) afeta o comportamento do consumidor. Os resultados sinalizam que a lealdade do consumidor é diferente nos distintos canais. Segundo revisão de literatura, os autores suspeitam que a compra cruzada seja afetada por uma segunda etapa na relação, fruto de intervenções de marketing da empresa.

Dick e Basu (1994) apresentaram um modelo integrativo conceitual sobre lealdade. Em seu artigo, lealdade do consumidor é vista como a força da relação entre a relativa atitude de um indivíduo e seu padrão de repetição. Nesse modelo, a relação parece ser mediada pelos padrões sociais e fatores situacionais. Antecedentes cognitivos, afetivos e conativos (intenção) da atitude relativa são identificados como 
contributivos para a lealdade, juntamente a consequências motivacionais, perceptivas e comportamentais.

Baptista (2005), em achados sobre lealdade e seus antecedentes aplicados ao setor varejista na internet, identifica que a satisfação demonstrou ser o antecedente com maior influência sobre a lealdade. A maior importância nos efeitos totais sobre a lealdade foi dada a satisfação e qualidade. Isso contrasta com a estrutura de relações em achados de outros autores, cujas pesquisas foram realizadas em outros contextos (banco, lojas de vestuário, empresas aéreas). Aqui a relação de maior influência sobre a lealdade é com confiança, comprometimento ou ambos. O autor comenta que talvez se expliquem as diferenças entre compras virtuais e em lojas tradicionais em virtude das interações face a face costumar ser mais frequentes e o contato com a empresa no momento da compra ou consumo ser mais extenso do que pela internet.

Molina (2008) estudou valor percebido e atitude do consumidor, considerando essas variáveis importantes determinantes da lealdade do consumidor no contexto do varejo espanhol. No setor de serviço, a autora ressalta que a lealdade fica mais difícil de conceituar devido às características do serviço. A intangibilidade e a falta de padronização pode implicar que fiabilidade e confiança possuam papéis mais importantes em construir e manter a lealdade. A inseparabilidade da produção e do consumo e a participação do cliente no processo refletem o componente interpessoal do serviço e adicionam uma dimensão emocional à lealdade. A lealdade do consumidor depende, em grande extensão, da customização do serviço e da gestão da comunicação pessoal, além de trazer sentimentos de prazer ao comprar na loja.

Molina (2008) também considera que a avaliação do consumidor dos valores percebidos relativos deve apresentar diferenças significantes nos diferentes tipos de serviço. Nesse sentido, o valor percebido na atitude do consumidor e lealdade por meio das atividades no varejo foi analisado para o setor de hortifrúti, vestuário/calçados, eletroeletrônicos, móveis/madeira e decoração. Os achados 
indicam alto envolvimento emocional e valores sociais para o setor de vestuário, calçados, móveis, madeiras e decoração.

Molina (2008) considera isso consistente com a característica hedônica desses processos de compra. Quanto maior o valor emocional e a qualidade do produto ofertado na loja, mais positiva a atitude do consumidor em relação ao varejo. Ao contrário de atitude, há clara evidência da influência do componente emocional nos setores varejistas analisados. Considerando os demais componentes do valor percebido, a qualidade do produto é também determinante da lealdade do consumidor, exceto no setor de vestuário e calçados. Os setores eletroeletrônicos mostraram-se sensíveis ao componente emocional e à qualidade. No setor de vestuário destaca-se também o preço, explicado talvez pela experiência e motivação hedônica. O artigo evidencia e confirma que existem diferenças de avaliação pelo consumidor dos componentes de valor por meio das atividades varejistas.

Em artigo mais recente, Swaid e Wigand (2012) ressaltam que os padrões de compra evoluíram para multicanais, e varejistas inovadores desenvolveram configurações de programas de serviços do site para as lojas. ${ }^{19} \mathrm{O}$ artigo examina a relação entre qualidade (tendo os autores desenvolvido uma escala específica), variáveis de valor percebido e intenção de lealdade. Os autores encontraram poucos artigos sobre qualidade em serviço no sistema multicanal. Buscaram identificar quais atributos on-line são focados pelos compradores quando julgam a qualidade do serviço. Os autores buscaram desenvolver uma escala de qualidade de serviço quando compradores usam o site e depois a loja. Os resultados evidenciam que a qualidade de serviço é função da eficiência do site, segurança do site, qualidade da informação, capacidade de resposta, garantia, personalização e coleta integrada.

Swaid e Wigand (2012) verificaram que a percepção da qualidade de serviço melhora o valor percebido, que por sua vez influência a lealdade. Coleta integrada é uma das dimensões-chave que influenciam significativamente a qualidade global de serviço, valor percebido e intenção de lealdade. Os autores ressaltam o serviço de

${ }^{19}$ Site-to-store settings. 
coleta no multicanal varejista com maior sucesso: a venda on-line, a coleta na loja e a devolução de produto para a loja, fatores importantes que influenciam nas intenções de lealdade, além da garantia e segurança do site.

A partir das informações levantas a lealdade foi abordada como lealdade ao canal on-line, com efeito positivo para autoeficácia multicanal e lealdade ao canal físico com efeito positivo para atratividade ao varejo tradicional.

$\mathrm{H}_{13 a}$ - A maior lealdade ao canal on-line tem efeito positivo sobre a autoeficácia no varejo multicanal.

$\mathrm{H}_{13 b}$ - A maior lealdade ao canal loja física tem efeito positivo sobre a atratividade ao varejo tradicional.

\subsection{Variáveis de efeito mooring}

Não existe uma única palavra em português apropriada para a tradução de mooring, portanto o termo foi considerado como "ancoragem", "atracação", "aprisionamento", "retenção". Variáveis de efeito mooring podem ser facilitadoras ou limitadoras. Bansal, Taylor e James (2005) explicam as variáveis mooring dentro do modelo PPM e na teoria de migração. Ao longo da pesquisa de marketing as variáveis mooring foram adquirindo conotação de variáveis intervenientes, pois elas podem facilitar ou inibir a migração. Além disso, a conotação para variáveis mooring foi se ampliando para temas de trajetória de vida, de cultura e questões espaciais que agem para facilitar ou dificultar a decisão de migração. Bansal, Taylor e James (2005) acrescentam que na pesquisa de migração ela reconhece recentemente que as decisões de migração são baseadas em percepções no nível macro e micro. As variáveis mooring ocupam o nível micro tal como fatores pessoais e sociais que dificultam ou facilitam a decisão de migração.

Chiu et al. (2011) no artigo sobre os serviços multicanal, resgatam o modelo PPM para explicar o comportamento de free-riding do consumidor no multicanal, como um 
caso misto de: troca de canal e troca de empresas. Em se tratando de um ambiente multicanal as variáveis mooring para os autores foram descritas pelo construto retenção intrafirma (within-firm lock-in), representando a capacidade de o consumidor ficar retido dentro dos multicanais de uma dada empresa de varejo ou em lojas on-line.

\subsubsection{Retenção na firma (within-firm lock-in)}

Encontra-se ampla literatura sobre retenção de clientes, uma meta desejada pelo marketing. A retenção de clientes é mais vantajosa por ser mais barata do que investir em novos clientes. A lealdade do cliente baseada em genuína satisfação do consumidor se torna um dos maiores ativos da empresa, principalmente em mercados mais saturados, em que a base de novos clientes é reduzida. Ao mesmo tempo, muitos consumidores se tornam mais abertos à experimentação de novos produtos que surgem em situação de promoção ou de um novo varejista. Os consumidores possuem mais possibilidades de escolhas, com a diminuição entre as diferenças entre marcas. E com isso parece não se sentir recompensados por ser simplesmente leais, passando a perceber a similaridade das marcas em termos de qualidade e valor. $O$ desafio de marketing das empresas se torna mais complexo (BLACKWELL; MINIARD; ENGEL, 2011).

Retenção na firma ${ }^{20}$ é um termo utilizado em economia e refere-se a alguma forma de aprisionamento que torna o cliente ou consumidor dependente de uma venda de produtos ou serviços, quando se torna incapaz de se movimentar para outro fornecedor sem haver custos de mudanças substanciais. Existem várias definições que podem ser encontradas na literatura econômica. Liebowitz (2002) tenta organizar o conceito, que se apresenta de forma simplificada em seu livro para apenas dois tipos. Os consumidores podem, em princípio, se aprisionar a um produto (ou serviço), aparentemente incapazes de mudar para algo melhor. Há inúmeros artigos em economia que esclarecem como isso funciona na teoria. Como

${ }^{20}$ Lock-in 
isso funciona na vida é assunto de poucos artigos e notavelmente escasso na literatura.

Liebowitz (2002) agrega que custos de retenção na firma podem ser classificados em dois tipos. Primeiro, existe o custo envolvido pela mudança de marca ou versão do produto, tal como: reaprender velhos hábitos, familiarizar-se com o novo produto; ser capaz de usar o novo produto com os antigos produtos, por exemplo, saber usar um novo processador de palavras para ler um documento antigo. Esses são os custos para ser compatíveis consigo mesmo. Em segundo lugar, existem custos envolvidos na possível perda de compatibilidade com outros, tal como mudar do sistema VHS para o Beta e descobrir que existem problemas para leitura das fitas de vídeo antigas. Esses dois fatores são essenciais para delinear a distinção crucial entre lock-in fraco e forte. A forma forte de retenção na firma suporta o conceito de que os pioneiros inovadores ganham sempre, o que conduz a problemas de coordenação potenciais no futuro.

Retenção na firma refere-se à habilidade de um canal, separado de seus atributos, de aprisionar os consumidores tanto para busca quanto para compra. Deveria ser considerado como um efeito inercial ou um efeito de compra com apenas uma escala (NESLIN et al., 2006). Porém, o artigo de Verhoef, Neslin e Vroomen (2007) revela que o canal de vendas internet possui um baixo lock-in, enquanto a loja física possui alto lock-in. A sinergia no cruzamento entre canais ${ }^{21}$ permite que 0 consumidor tenha maior utilidade ao buscar no canal A e comprar no canal B, além dos atributos óbvios dos canais. Por exemplo, pesquisar na internet antes de ir à loja pode habilitar o consumidor a aprender sobre escolhas ${ }^{22}$ entre os atributos do produto, permitindo que faça melhor seleção de produto quando estiver na loja física. Os autores encontraram sinergia entre web e loja física, mas os resultados ainda não foram significativos.

\footnotetext{
21 Cross-channel

22 Trade-off
} 
A teoria econômica supõe geralmente que, quanto menor a busca de informação e menores os custos de avaliação, mais pesquisas serão feitas pelos consumidores para encontrar a melhor opção. No entanto, achados na pesquisa inicial não suportam essa visão. Em vez disso, elas sugerem aderência (ou seja, busca e substituição minimizadas) ainda maior do consumidor no canal internet em comparação ao ambiente da loja física. O autor ressalta que o fenômeno da internet em relação à busca e alternância de fornecedores ${ }^{23}$ proporciona oportuno e importante exemplo dos efeitos gerais sobre a estrutura de custo de informação e sobre o comportamento dos consumidores no tempo (ZAUBERMANN, 2003).

Lock-in pode ser definido como a propensão minimizada para realizar a busca e alternar de fornecedor após um investimento inicial. O lock-in seria impulsionado pela preferência do consumidor em minimizar custos imediatos, exercendo ponderação sobre o futuro impacto dos custos de mudança. Os consumidores tendem a focar nas considerações de curto prazo para selecionar a opção com mais fácil acesso no momento da transação, mesmo ao custo de renunciar benefícios futuros. Os consumidores não conseguem antecipar os custos de mudança futuros nas decisões. E, quando o futuro chega, os custos de mudança exercem um efeito poderoso (ZAUBERMANN, 2003).

Zauberman (2003) propôs um modelo para lock-in (Figura 8), que se baseia na combinação entre o impacto da estrutura do custo de informação e a preferência do consumidor no tempo para os comportamentos de busca e mudança. A estrutura do custo de informação refere-se a qualquer custo associado à aquisição ou ao processamento de informação sobre o ambiente, incluindo custos de busca e custos de transação. Mais especificamente, os custos de informação referem-se ao esforço que se faz para iniciar, processar, avaliar e finalizar a tarefa de busca. A preferência do consumidor no tempo refere-se à preferência para o momento de ocorrência do custo-benefício. No caso específico de Zauberman (2003), o artigo refere-se mais estritamente à preferência pela utilidade imediata sobre a utilidade postergada (e custo diferido sobre custo imediato).

${ }^{23}$ Switching behavior 
Zauberman (2003) realizou três experimentos: 1- o efeito das compras prévias em compras on-line; 2- o efeito da estrutura de custo no lock-in; 3- busca previsível e comportamento de mudança. Os achados indicam que o lock-in é induzido pela preferência de minimizar custos imediatos e por não conseguir antecipar o impacto de custos de mudança futuros. Também se verificou que, quando seleciona entre alternativas de custo-benefício no tempo, o consumidor foca na utilidade do momento e é insensível aos efeitos das próprias escolhas à utilidade relativa das opções num conjunto. Esse efeito geral está bem documentado na psicologia, mas não tem recebido atenção na pesquisa de comportamento do consumidor.

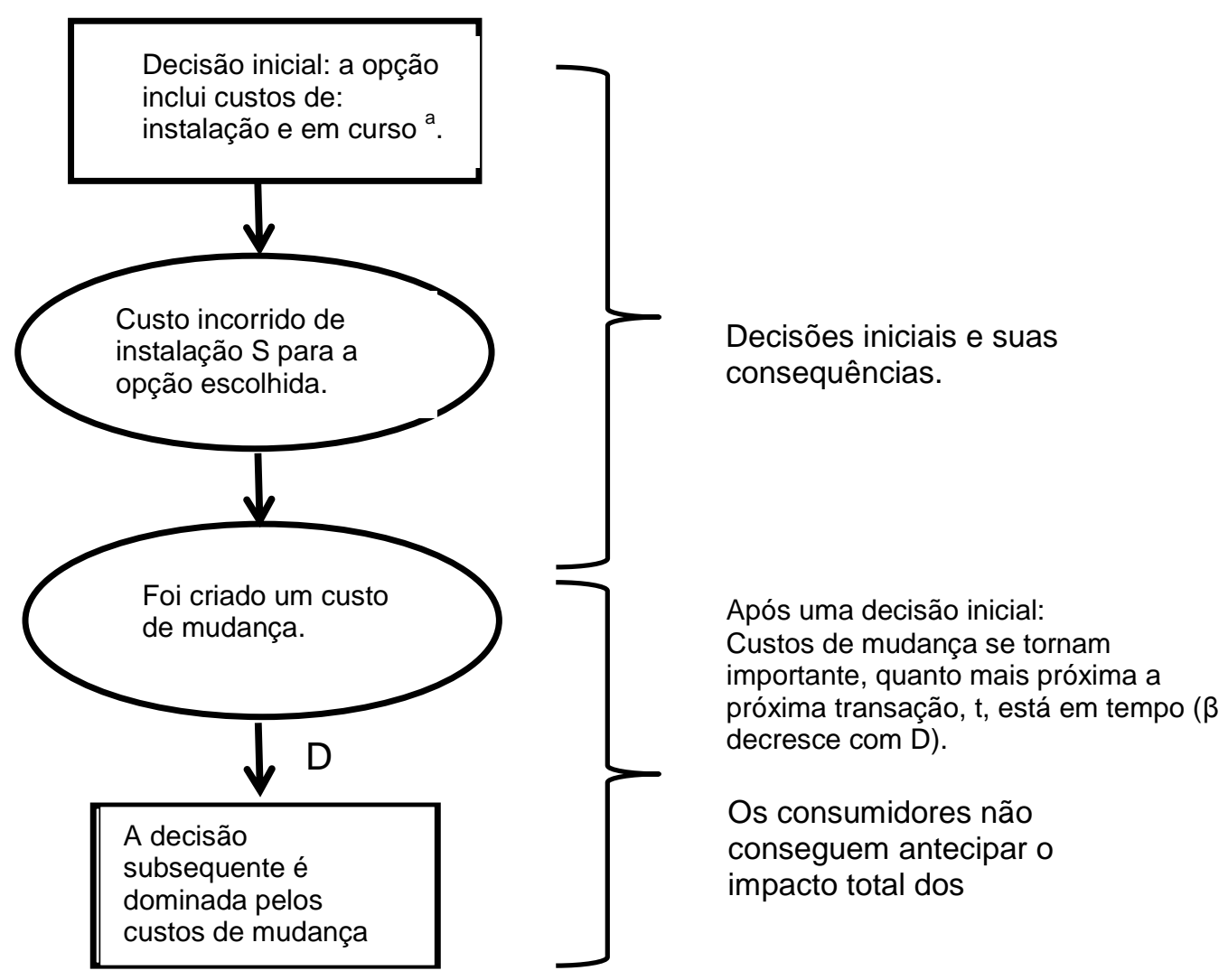

Figura 8- Modelo conceitual para Lock-in

Legenda: $\left({ }^{a}\right)=$ preferencia de tempo (minimizar custos totais imediatos) afeta a decisão.

Fonte: Adaptado de Zauberman (2003, p. 407).

A pesquisa sobre lealdade do consumidor mostra um comportamento complexo, estudado em múltiplas perspectivas, variando desde a satisfação do consumidor ao comprometimento emocional até a um simples hábito. A literatura sobre lealdade do consumidor também distingue entre lealdade verdadeira e um comportamento de 
simples repetição de compra. Dentro do guarda-chuva complexo da lealdade do consumidor, cabe considerar o lock-in e os fatores que afetam a propensão ao comportamento de alternância entre fornecedores ${ }^{24}$ (OLIVER, 1999; ZAUBERMAN, 2003).

A literatura sobre retenção de clientes abrange perspectivas múltiplas. Oliver (1999) aborda a transferência da ênfase em satisfação para a ênfase em lealdade, devido ao impacto no lucro quando há uma base de clientes leais. $O$ autor apresenta um modelo de quatro fases atitudinais em relação à lealdade relacionadas a diferentes elementos da estrutura atitudinal. Os consumidores se tornam leais num sentido cognitivo primeiramente; depois no sentido afetivo; mais para a frente no sentido conativo (intenção); e finalmente no sentido comportamental, descrito como inérciaação. Os achados em pesquisa sugerem que o crescimento de $5 \%$ na retenção de clientes aumenta os lucros em 25\% a 95\%. Porém, retenção de clientes pode ocorrer sem haver lealdade atitudinal, se, por exemplo, os consumidores estão indiferentes ou porque não existem outras escolhas viáveis no mercado (OLIVER, 1999; REICHHELD; SCHEFTER, 2000; SHANKAR; SMITH; RANGASWAMY, 2003).

A pesquisa sobre ambiente multicanal avança de forma ainda não consolidada no sentido da lealdade do consumidor. A literatura por um lado se inclina para a associação do multicanal com o aumento da lealdade, pelo aumento de percepção das ofertas nos canais da firma, o que por sua vez está relacionado com a alta satisfação do consumidor e alta lealdade. Porém, no caso de instituições bancárias, a proliferação da tecnologia de canais causou perda da relação banco-cliente, com associação negativa entre lealdade e uso de internet em bancos (NESLIN; GREWAL; LEGHORN; SHANKAR; TEERLING; THOMAS; VERHOEF, 2006).

Johnson, Bellman e Lohse (2003) ressaltam em artigo de revisão o foco dado ao custo cognitivo para utilização de um site e como esse custo diminui à medida que se aprofunda a experiência prática de navegação. Os custos cognitivos são dinâmicos e mudam com a experiência. Isso implica que o custo de mudança 
percebido aumenta à medida que o site favorito é mais visitado, criando-se um lockin cognitivo ao site ao longo do tempo; bem como o fato de as empresas poder aprisionar consumidores com altos custos de mudanças em lojas físicas. A lei da prática trata-se de uma generalização empírica dos achados onipresentes de que a habilidade em qualquer tarefa aumenta rapidamente a princípio; porém, posteriormente até mesmo pequenas melhorias requerem esforços consideráveis. A lei é explicada pela seleção do método. Quando uma tarefa é repetida, métodos menos eficientes para cumprir a tarefa são abandonados em favor de métodos mais eficientes quanto mais eficiência é obtida.

O motivo pelo qual se generaliza que o consumidor multicanal compra ou gasta mais do que o consumidor de canal único ainda não está claro, apesar de evidências. Dentre os motivos estão: alta lealdade, autosseleção do consumidor ou exposição ao marketing aumentada (NESLIN et al., 2006; WEINBERG; PARISE; GUINAN, 2007).

Os achados de Kumar e Venkatesan (2005) mostram que naturalmente os consumidores multicanais possuem mais alto nível de vendas, são mais propensos a participar em compra cruzada entre canais, ${ }^{25}$ recebem mais contatos de marketing, são consumidores de longo prazo e compram mais frequentemente. Os resultados realçam a importância da comunicação interpessoal na influência da compra multicanal. Além disso, os achados indicam que os consumidores multicanais são mais leais e rentáveis do que consumidores de canais únicos. A confiança no fornecedor está mais fortemente associada a compras multicanais do que fatores como familiaridade com o processo de transação em novos canais e outros. Clientes com profundos relacionamentos com um fornecedor são melhores alvos para migração a novos canais do mesmo fornecedor.

Várias características de comportamento de consumidores (compra cruzada, tratamento para retornos de mercadoria, contato inicial do consumidor, frequência de

${ }^{25}$ Cross-buying 
contatos pela Web, período de estabilidade da relação, ${ }^{26}$ frequência de compra) e fatores de posicionamento de fornecedores (número de canais para contato, tipos de canal para contato, mix de interação dos contatos) estão associados com os compradores multicanais. Consumidores que compram múltiplas categorias de produtos são propensos a comprar em multicanais (KUMAR; VENKATESAN, 2005)

As pesquisas do comportamento de compra on-line muito pouco abordam e focam especificamente nas lojas on-line dos varejistas multicanal. Como essas lojas provavelmente estão inclinadas a ser influenciadas pelas atitudes de compradores e pela confiança que transposta dos canais do varejo tradicional, bem como também sofrem a comparação entre imagens da loja física e virtual, o artigo focou os efeitos de transferência e congruência na confiança, atitude e intenção de compra. Os achados evidenciam que existe transferência de confiança, porém não confirmam a transferência de atitude. A congruência de imagem entre loja física e virtual exerce influência positiva em atitude e confiança do consumidor no varejo multicanal para loja on-line. O varejista multicanal deve intensificar a confiança e as atitudes, melhorando a intenção de compra nas lojas on-line (BADRINARAYANAN; BECERRA; KIM; MADHAVARAM, 2012).

As razões para o consumidor pesquisar e usar o sistema de busca para compras foram estudadas por Verhoef, Neslin e Vroomen (2007), sugerindo e confirmando achados para três hipóteses: 1- decisão baseada em atributo; 2- ausência de retenção no canal; e 3- busca de sinergia pelo multicanal. Chiu et al. (2011) utilizam a hipótese da ausência/presença de retenção no canal, sugerindo que o varejista multicanal deve determinar como manter os consumidores aprisionados dentro dos canais, mesmo quando trocam de canal.

Os consumidores avaliam o desempenho multicanal da firma de forma holística. Uma estratégia de multicanal bem-sucedida requer oferecer ao consumidor uma experiência holística, identificando como os diversos canais podem trabalhar juntos e de forma sinérgica. Uma estratégia multicanal forte e integrada satisfaz as

${ }^{26}$ Customer tenure, p. 47 
necessidades do consumidor toda vez que há mudança de canal, pelo processo de consumo e compra. A organização que pensa holisticamente a experiência do consumidor se dá conta que precisa entender como os diferentes canais podem interagir para oferecer sinergia. As firmas de maior sucesso no marketing multicanal estabelecem e mantêm conexões ou interfaces entre os canais e as categorias de produtos (WEINBERG; PARISE; GUINAN, 2007).

Para um consumidor free-rider num ambiente multicanal, a satisfação bem como o compromisso emocional em relação ao website parece pouco desenvolvida para atividades de curto prazo, embora o tempo e o esforço investido possa criar algum lock-in percebido. Se o consumidor entende que pode realizar a busca on-line e completar a transação de forma fácil, ele pode não mudar para outro varejo para realizar a compra. A forma como a firma realiza o lock-in minimiza a intenção do consumidor em mudar de varejista (CHIU et al., 2011; ZAUBERMAN, 2003).

Chiu et al. (2011) consideram que o lock-in dentro dos canais da firma constituem uma barreira à mudança ${ }^{27}$ e podem minimizar a intenção do consumidor para mudança de varejista, mesmo mudando de canal; em outras palavras, deverá diminuir a intenção de free-riding no cruzamento entre canais, conforme hipótese formulada mais abaixo $\left(\mathrm{H}_{5}\right)$.

Schramm-Klein et al. (2011) investigaram a percepção de valor do consumidor pela integração do varejo multicanal e seus efeitos e também a percepção da integração multicanal sobre a lealdade do consumidor. No estudo, propuseram uma abordagem centrada no consumidor segundo trabalho de Reinartz, Krafft e Hoyer (2004), para mostrar que a integração percebida no sistema multicanal da firma para marketing e distribuição influencia a confiança do consumidor, a imagem do varejista, assim como o portfólio de canais, o que resulta em lealdade e conduz a usos diferenciados dos canais individuais de um sistema multicanal de varejista. No estudo, a imagem do consumidor sobre o varejista e a confiança são variáveis que mediam avaliação individual de canal, integração percebida e lealdade. A pesquisa cobriu várias 
opções de canais: loja física, loja virtual, venda por catálogos tradicionais, em setores variados de livrarias, hortifrútis, cosméticos, vestuário, compreendendo uma amostra de 981 respondentes, familiarizados com os três canais.

Os estudos de Schramm-Klein et al. (2011) confirmam que tanto a avaliação individual como a integração percebida dos canais são fatores importantes de influencia no comportamento do consumidor. A integração dos canais tem efeito positivo na lealdade do consumidor, moderados pelo efeito positivo da imagem e confiança do varejista. Os resultados indicam que uma estratégia de integração multicanal pode habilitar a migração de consumidores em canais mais eficientes, 0 que poderá aumentar a lucratividade sobre o consumidor no longo prazo. Desta forma, propõe-se a hipótese $\mathrm{H}_{5}$.

$\mathrm{H}_{5}$ - a retenção dentro dos canais da firma de um varejista tem efeito negativo no free-riding de canais para outros varejistas.

\subsubsection{Busca de variedade}

Girard, Korgaonkar e Silverblatt (2003) explicaram o fenômeno no qual os consumidores estão dispostos a negociar o prazer pela variedade. O fenômeno foi estudado como estratégia de escolha por vários autores, incluindo o autor Kahneman. A busca de variedade é mais propensa de ocorrer quando as pessoas estão de bom humor ou quando existe pequeno estimulo no ambiente. Quando as pessoas estão motivadas em encontrar uma variedade de produtos no sentido de tentar coisas diferentes, irão preferir realizar compras na internet porque a opção online oferece um ambiente com variedade de bens de consumo de fácil acesso. Portanto, pessoas que buscam variedade estão mais propensas a comprar pela internet. Os resultados encontrados pelos autores mostraram que essa variável não foi um preditor significativo para preferências de compra na internet para qualquer das categorias estudadas. 
Para a presente pesquisa, a oferta de variedade de alternativas de tipo e marca de produtos e de variedade em canais de vendas do varejista, influencia a retenção na firma. Do que se elaborou outra hipótese $\left(\mathrm{H}_{6}\right)$

$\mathrm{H}_{6}$ - a alta variedade encontrada de produto e marca no varejista tem efeito positivo na retenção pela firma entre os multicanais do mesmo varejista.

\subsubsection{Custos de mudança}

O trabalho seminal de Stigler publicado em 1961 argumenta que o comportamento para busca de informação pelo comprador tem impacto importante na estrutura de preços competitivos dos mercados. O autor reconhece que nem todos os compradores estarão perfeitamente informados sobre as alternativas do mercado porque os compradores individuais colocam diferentes pesos nos custos e nos retornos da busca de informação. Stigler se tornou uma pedra angular para a pesquisa econômica e de marketing sobre a pesquisa do comprador. Os achados indicam que compradores com baixa incerteza se comportam de forma consistente com o modelo de custo-benefício, realizando menos pesquisa ou busca de informação do que os compradores com alta incerteza. Os resultados indicam que o comportamento de "pesquisa" é um processo complexo e não pode ser preditivo ou interpretado sem considerar as interações entre custo-benefício da pesquisa. $O$ conhecimento prévio dos preços reduz o comportamento de busca. Porém, a dispersão de preço e a percepção do custo da pesquisa não afetam o comportamento de busca pelo consumidor com baixa incerteza sobre a decisão de compra (URBANY, 1986). Chiu et al. (2011) ressaltam que, quando o custo da informação aumenta, a extensão da pesquisa declina.

Custos de mudança são custos de ocasião, ${ }^{28}$ que os consumidores associam ao processo de mudança de um provedor a outro (BURNHAM; FRELS; MAHAJAN, 2003). Como o custo de mudança precisa estar associado ao processo de mudança,

${ }^{28}$ One-time costs 
ele não acontece imediatamente após a mudança. Por sua vez, os custos de mudança não necessariamente são custos econômicos. Quando percebe que não vale a pena mudar, o consumidor percebe impedimentos que variam desde o custo da busca, custo de transação, custo de aprendizagem, desconto obtido pela lealdade, hábitos próprios, custo emocional e esforço cognitivo, associados a risco financeiro, social, psicológico da parte do comprador. Outros custos incluem reciclagem de pessoal, requerimento de capital e de aquisição de novo equipamento auxiliar. Essas barreiras podem ser maiores em mercados B2B (FORNELL, 1992).

Os custos de mudança consideram o tempo dispendido que o consumidor associa ao processo de mudança de canal entre provedores. Representa a busca, a transação, os custos de aprendizagem, os sistemas de descontos pela lealdade, os hábitos do consumidor, o apego emocional, o esforço cognitivo; tudo isso associado ao risco financeiro, social e psicológico. Os riscos são confrontados quando os consumidores mudam de canal (BURNHAM; FRELS; MAHAJAN, 2003; FORNELL, 1992).

Burnham, Frels e Mahajan (2003) desenvolveram uma tipologia para antecedentes e consequentes de custos sobre a mudança de consumo. A literatura sobre comportamento de alternância indica três abordagens para medir os custos de mudança: 1- facetas de custos de mudanças específicas a um dado contexto; 2como construto global e unidimensional; 3- assumido que os consumidores percebem os custos de mudança, que têm sido atribuídos a todas as evidências de diferenças em resposta à satisfação de tais custos. Na revisão da literatura sobre custos de mudança, bem como em entrevistas realizadas na indústria e focus group com consumidores, encontraram-se evidencias para oito facetas de custos de mudança que posteriormente foram organizadas em três tipos, como segue (BURNHAM; FRELS; MAHAJAN, 2003).

1- Custos de mudanças processuais: risco econômico, avaliação, aprendizagem, custos de instalação. Este tipo de custo de mudança envolve dispêndio de tempo e esforço. 
2- Custos de mudança financeiros: perda de benefícios e custos de perda financeira, correspondendo a perdas de recursos financeiros quantificáveis.

3- Custos de mudança relacionais: custos da perda de relacionamento e de relacionamento com a marca, o que envolve custos psicológicos e de desconforto emocional devido à perda da identidade e a quebra de ligações.

Os antecedentes testados por Burnham, Frels e Mahajan (2003) para custos de mudança são abaixo listados.

\section{- Percepções sobre características de produto e mercado}

1- Complexidade de produto: o aumento da complexidade do produto requer esforço para estabelecer um novo relacionamento. Quando detecta o produto como mais complexo, o consumidor percebe como alto custo de mudança processual.

2- Heterogeneidade do provedor: definido como a extensão em que um provedor é visto no mercado como diferente ou insubstituível. A falta de padronização em produtos e serviços, devido à heterogeneidade, sugere que as habilidades para empregar um provedor podem não ser aplicáveis a outro.

\section{- Investimentos no fornecedor}

1. Amplitude de uso de um fornecedor: os investimentos em relacionamentos vinculam os membros (MORGAN; HUNT, 1994). Além de gerar custos processuais, o uso de mais produtos ou serviços vinculados pode aumentar o custo financeiro da mudança. Quanto maior amplitude de produtos empregados, mais provavelmente o cliente acumulou benefícios que serão perdidos na troca de fornecedor. Estabelecer múltiplas ligações com um fornecedor requer grande interação, o que leva a identificação pessoal e com a marca. (BURNHAM; FRELS; MAHAJAN, 2003). 
2. Modificação de produto: definido como adaptação do produto para o consumidor, de forma que o mesmo possa atender a necessidades individuais.

\section{- Expertise de domínio}

1. A expertise de um consumidor no domínio de um dado produto permite-lhe avaliar mais rápido e precisamente opções e aprender com as informações sobre os novos produtos. A experiência de alternância entre provedores representa a amplitude da experiência que o consumidor tem com vários produtos, recursos e funções oferecidos por fornecedor do serviço concorrente. Ampla experiência com fornecedores alternativos reduz a propensão de exclusividade.

2. A experiência de alternância entre fornecedores é definida pela extensão com que a alternância foi praticada no passado. O aumento da alternância reduz os custos de mudança, pelo aumento da familiaridade com o processo de aprendizagem e mudança para novos fornecedores. Experiência de alternância implica tempo reduzido com o fornecedor estabelecido, que gerou menos tempo para acumular benefícios e que seriam perdidos ao trocar de fornecedor.

- Características individuais - Duas características individuais associadas ao custo de mudança se destacam: pressão do tempo e o nível de aversão ao risco.

Em resumo sobre os antecedentes, Burnham, Frels e Mahajan (2003) sugerem que, quanto maior a percepção de complexidade e heterogeneidade, maior a amplitude para o fornecedor estabelecido. Quanto maior a modificação de produto, ela estará geralmente associada a altos custos de mudança. Enquanto o aumento de experiência com fornecedores alternativos e a experiência crescente com mudança serão geralmente associados com baixos custos de mudança. 
Chiu et al. (2011) relatam que para alto custo de mudança, o consumidor experimenta alto lock-in (aprisionamento) dentro dos canais de uma firma e estará mais inclinado a permanecer com o atual fornecedor.

Assim se elaboram mais duas hipóteses $\left(\mathrm{H}_{7 \mathrm{a} ;} \mathrm{H}_{7 \mathrm{~b}}\right)$ :

$\mathrm{H}_{7 \mathrm{a}}$ - $\mathrm{O}$ alto custo de mudança possui um efeito positivo sobre a retenção da firma através do multicanal do varejista.

$\mathrm{H}_{7 b}$ - o baixo custo de mudança tem efeito negativo sobre a retenção da firma através do multicanal do varejista.

\subsubsection{Integração percebida pelo consumidor do multicanal}

Neslin et al. (2006) abordam em artigo um modelo para gerenciamento do cliente multicanal que é definido como o desenho, implantação, coordenação e avaliação dos canais para reforçar o valor ao cliente pela aquisição efetiva de consumidores, retenção e desenvolvimento. O gerenciamento do cliente multicanal é uma função centrada no consumidor, diferente das pesquisas de canais de venda que focam na firma e nos distribuidores. Os autores buscam entender o comportamento do consumidor num ambiente multicanal. Os gestores precisam buscar entender como os consumidores escolhem canais e como essa escolha impacta nos padrões gerais de compra. A seguir, algumas perguntas-chaves pertinentes à escolha do consumidor são listadas:

- Escolha do canal: o que determina a escolha de canal pelo cliente? Que atributos de canal são importantes? Será que a comunicação de marketing influencia a escolha do canal?

- Multicanal: a abordagem multicanal seria um meio para segmentar cliente?

Existem segmentos distintos de consumidores que utilizam vários canais e combinações de canais?

- Decisão de canal: o consumidor decide o canal de acordo com o canal ou com a firma? o consumidor primeiro dirá: "Vou verificar nos websites dos 
varejistas que vendem uma TV HD", ou: "Vou verificar no site da Fast Shop e depois visitar a loja para dar uma melhor olhada". Similarmente, durante a fase de busca, os consumidores levam em conta o varejista?

- Ambiente multicanal da firma: qual o impacto do ambiente multicanal na lealdade do cliente?

- Estratégia multicanal: será que uma estratégia multicanal aumenta as vendas da firma?

A pesquisa mais robusta na área de gerenciamento de cliente multicanal está na determinação da escolha de canal pelo cliente, que foi listado em seis determinantes básicos: esforços da firma em marketing, atributos dos canais, integração dos canais, influência social, variáveis situacionais e diferenças entre os indivíduos (NESLIN et al., 2006).

A percepção de canais bem integrados encoraja comportamentos desejados do consumidor. Se o consumidor faz o pedido pela internet para ser retirado na loja, encoraja os usuários de internet a utilizar também a loja (BENDOLY et al., 2005; MONTOYA-WEISS; VOSS; GREWAL, 2003).

Segundo Burke (2002), há preferência do consumidor para uso de multicanal, por estar cercado de tecnologia, porém as empresas lutam para encontrar uma forma lucrativa de servir ao público por meio do multicanal. Ainda se estão adquirindo meios para compreender a experiência holística do consumidor, com ênfase na satisfação do consumidor pela combinação dos canais, antes de desenvolver uma estratégia multicanal (WEINBERG; PARISE; GUINAN, 2007). A pesquisa sugere que os gerentes devem aumentar a sinergia entre canais (NESLIN et al., 2006). A definição de integração multicanal perpassa pelo suporte mútuo e intercambiável entre canais on-line e off-line (BENDOLY et al., 2005).

Os consumidores querem maximizar a utilidade pelo multicanal (BALASUBRAMANIAN; RAGHUNATHAN; MAHAJAN, 2005). Pelo aspecto de aprendizagem, as lojas on-line podem fazer extensão efetiva em novos canais ou 
novas categorias de produtos pelo uso familiar de navegação que encoraja a compra (JOHNSON; BELLMAN; LOHSE, 2003).

Quando o consumidor visita mais canais, ele desenvolve uma carteira de multicanais, o que reduz o custo de aprendizagem e aumenta a percepção de aprisionamento dentro da firma. A percepção do consumidor na compra integrada multicanal on-line e off-line deve promover adesão à empresa (BENDOLY; BLOCHER; BRETTHAUER, 2005).

O varejista multicanal também pode aumentar a adesão do consumidor ao oferecer mais oportunidades de opções e serviços, de tal forma que a familiaridade com o varejista reduza a troca entre varejistas (DHOLAKIA; ZHAO; DHOLAKIA, 2005).

Verhoef e Donkers (2005) ressaltam que a aquisição de novos canais pelo cliente é um bom preditor de lealdade nos primeiros estágios de uma relação de compras e que o web site da firma parece desempenhar-se bem na retenção. Dado que a pesquisa anterior suporta a ideia de que uma estratégia multicanal integrada fortalece a retenção do consumidor, Chiu et al. (2011) propõem em modelo uma relação positiva entre a percepção da integração multicanal e o lock-in.

O varejo brasileiro das maiores redes como Casas Bahia, Extra e Ponto Frio, por exemplo, ainda não possuem integração de operação e logística entre os canais online e lojas físicas. As operações são separadas, exceto o serviço de atendimento ao consumidor e o pós-venda. Nasce aqui nova hipótese $\left(\mathrm{H}_{8}\right)$ :

$\mathrm{H}_{8}$ - A percepção do consumidor sobre a integração multicanal tem efeito positivo na retenção da firma do varejista.

\subsubsection{Conveniência de compra}

O comportamento do consumidor vem mudando com a introdução das compras online. $\mathrm{Na}$ ampla revisão de literatura feita pelos autores Berry, Seiders, Grewal (2002) sobre o entendimento de conveniência em serviços, o termo surgiu na literatura de 
marketing em relação à categoria de produtos. Copeland (1923), em artigo sobre hábitos de compra, realizou uma classificação de produtos para consumidor e apresentou os produtos de conveniência, aqueles com distribuição maciça que requerem mínimo tempo e mínimo esforço físico e mental para ser adquiridos, geralmente produtos de custo baixo.

A expressão conveniência de compra do consumidor, abordada por Kelley (1958), veio carregada do custo de conveniência e do custo da mercadoria ${ }^{29}$ no comportamento de compra. O custo de conveniência envolve dispêndio de tempo, energia física, nervosismo e dinheiro requerido para superar os atritos de espaço e tempo para obter os produtos e serviços. Além do aspecto temporal e espacial, o autor considera que conveniência tem ainda a dimensão social e estética e reportouse ao advento dos shoppings centers na comunidade social.

Anderson (1972), analisando a orientação à conveniência e comportamento de consumo, apresentou uma tipologia com os padrões observados que enriqueceram o planejamento mercadológico das empresas de bens de consumo. Para o autor, a orientação para o consumo de conveniência representa um ponto de convergência entre a coincidência da crescente riqueza e a consciência do tempo no consumidor contemporâneo, por dupla motivação: 1- satisfazer um desejo ou necessidade imediata; 2- liberar tempo e energia para uso alternativo.

Yale e Venkatesh (1986) desenvolveram uma teoria preliminar sobre conveniência como um construto para o comportamento do consumidor. Na revisão de literatura dos autores, a conveniência é atributo principal do produto. O conceito de conveniência equivalente à economia de tempo ou tempo de compra era sustentado pelo conceito econômico do domicílio como unidade de produção. Portanto, renda e tempo restringem a capacidade de produção da família.

Yale e Venkatesh (1986) ressaltam que a unidimensionalidade da conveniência como economia de tempo foi muito ambígua para os estudos empíricos. No 
marketing, o tema conveniência se tornou importante em dois níveis: 1- a determinação do segmento de consumidores orientados para conveniência; 2- a determinação e a inclusão dos atributos de conveniência em produtos e serviços. Portanto, conveniência representa um construto importante em dois níveis: 1- no comportamento de consumo; b- como atributo de produto. Os autores organizaram em seis categorias ou classes as conveniências: 1- utilização do tempo, 2acessibilidade (máquinas ATMs para sacar dinheiro); 3- portabilidade (notebook); 4adequação referente ao ajuste de necessidades específicas (margarina líquida, pratos congelados); 5- praticidade, referente ao esforço de economizar capacidade (sucos congelados, locação de filmes); 6- evitar dissabores (fraldas descartáveis, máquina de lavar pratos). Os autores sugerem que a escolha de conveniência atribuída a produtos seja uma estratégia de consumo, uma função das variáveis acima.

Berry, Seiders e Grewal (2002) entendem que a questão central da conveniência está no custo não monetário. A literatura de marketing do estudo destes autores apresentou duas correntes: 1- espera do consumidor (como o consumidor responde à espera e como as firmas gerenciam o processo de espera); 2- orientação à conveniência do consumidor (por que alguns consumidores são mais orientados a comprar produtos e serviços de conveniência do que outros). Segundos os autores, a literatura sobre o tempo atrelado à conveniência é de natureza multidisciplinar e a literatura sobre o esforço atrelado a conveniência é pequena e limitada ao esforço cognitivo. A dimensão esforço físico recebeu pouca atenção na pesquisa de consumo, e esforço emocional tem sido explorado no sentido do custo psicológico da espera.

O construto de conveniência em serviços tem como fator intrínseco o tempo e o esforço requerido para comprar ou usar o produto. Ambos são custos não monetários que o consumidor irá despender. A literatura de marketing ressalta 0 valor do tempo: quanto maior o custo do tempo associado ao serviço, menor a percepção do consumidor da conveniência do serviço. Os autores também comentam que o esforço cognitivo associado à decisão de compra, o esforço físico e emocional, será maior quanto maior participação no processo do serviço. 
Por fim, Berry, Seiders e Grewal, (2002) dividem a conveniência nos serviços em categorias de percepção: 1- conveniência de decisão (percepção de tempo e esforço do consumidor para realizar a compra ou tomar a decisão); b- conveniência de acesso (tempo e esforço para iniciar o serviço); c- conveniência de transação (esforço e tempo para efetuar a transação); d- conveniência de benefício (esforço e tempo para experimentar os benefícios do serviço); e- conveniência de pós-benefício (esforço e tempo do consumidor para reiniciar contato com a empresa que efetuou o serviço).

Berry, Seiders, Grewal (2002) também estudaram os fatores de conveniência relacionados à operação e vendas da empresa, como: ambiente do serviço prestado, informação dada ao consumidor durante o consumo de tempo para o serviço, importância da marca, desenho do processo do serviço. Finalmente, os pesquisadores consistentemente encontraram que, no que tange ao tempo de espera e a avaliação geral do serviço, ambos afetam a satisfação do consumidor para com o serviço prestado. Também foi encontrada na literatura pesquisada pelos autores a relação entre a conveniência e a inconveniência na prestação de serviços relacionada à satisfação com o serviço prestado, avaliação da qualidade e percepção de justiça.

Aagja, Mammen, Saraswat (2011) buscaram validação da escala de conveniência em serviços ServCon desenvolvida por Berry, Seiders, Grewal (2002) no contexto indiano. No modelo desenvolvido, os autores ressaltam que conveniência influencia uma variedade de consequentes como intenção de comportamento.

O varejo eletrônico no Brasil é promovido amplamente como forma conveniente de compras desde 2000 pela empresa E-bit, uma referência brasileira de fornecimento de informações sobre o e-commerce nacional, tanto para o consumidor quanto para a empresa. Além disso, a E-bit está representada por outras empresas, como sites de comparação de preços (Buscapé e Bondfaro). Szimanski e Hise (2000) comentam que a compra on-line pode economizar tempo e esforço pela facilidade de localização de lojas virtuais para encontrar produtos e ofertas. É provável que tanto o tempo quanto os benefícios de busca se manifestem em uma percepção mais positiva de conveniência e satisfação on-line. Evanschizky et al. (2004) 
replicaram na Alemanha o artigo de Szimanski e Hise (2000), obtendo resultados similares para o contexto alemão. O modelo relacionou a e-satisfação e seus antecedentes, tendo a conveniência se confirmado como bom antecedente para esatisfação.

Kaufman-Scarborough e Lindquist (2002) comentam a importância de enxergar a compra on-line pelo contexto de alternativas do multicanal disponível para os consumidores. A inter-relação entre os vários tipos de canal de compra não físicos não estão bem entendidos, nem o impacto que causam nas lojas físicas. Estudos sugerem que a conveniência como motivação de compras está relacionada a gênero, educação e renda. Há consumidores motivados primariamente pela conveniência on-line, bem como há os que se interessam pela interação social e pelas características das lojas físicas. Mais motivados pelas características de contato social e de poder possuir o produto imediatamente (ROHM; SWAMINATHAN, 2004; SWAMINATHAN; LEPKOWSKA-WHITE; RAO, 1999;). Christodoulides e Michaelidou (2011) também confirmaram a conveniência como um dos motivos de compra para a e-satisfação e e-lealdade em produtos hedônicos.

Os estudos relacionam conveniência com satisfação, porém não foi encontrada na literatura prévia uma base teórica e empírica que relacionasse a retenção na firma (lock-in) com conveniência de compra, mas já há relação entre a conveniência e o canal on-line, conforme abordado anteriormente. Ao pensar a conveniência de compra num contexto multicanal, buscou-se a influência da conveniência na retenção da firma pelo canal on-line, assim como a conveniência de compra do consumidor pelos canais tradicionais do varejo, levando em consideração as categorias de produtos selecionadas para a pesquisa de campo. Pensou-se o construto conveniência dentro dos fatores de mooring e pull, avaliando o contexto do ambiente multicanal quanto à conveniência de acesso e de benefício descrito por Berry, Seiders e Grewal (2002).

A partir do que se viu acima, constroem-se novas hipóteses $\left(\mathrm{H}_{9 \mathrm{a}} ; \mathrm{H}_{9 b}\right)$, relacionando a conveniência com a retenção na firma e com a variável atratividade do varejo tradicional. 
$\mathrm{H}_{9 \mathrm{a}}$ - A maior conveniência de compra pelo canal on-line tem efeito positivo sobre a retenção na firma do varejista.

$\mathrm{H}_{9 b}$ - A maior conveniência de compra pelo canal tradicional (loja física) tem efeito positivo na atratividade do varejo tradicional.

\subsubsection{Design do Site}

Szimanski e Hise (2000) ressaltam o aumento exponencial das compras on-line e o crescente número de varejistas tradicionais com vendas on-line, originando um mercado muito competitivo. A pesquisa acadêmica enveredou pelo campo da computação cognitiva para obter percepções sobre o comportamento de compra do consumidor. Computação cognitiva foi resumida por estes autores como uma abordagem de orientação do consumidor para a concepção e gestão do website. Baseiam-se sobre os estilos de processamento de informação do consumidor, padrões de compra, preferências de frente de loja e áreas relacionadas. O objetivo foi desenvolver sites mais atrativos, amigáveis e bem-sucedidos. Os autores buscaram os determinantes para a satisfação on-line e incluíram o construto desenho do site.

Ao pensar a retenção do consumidor no contexto multicanal, o desenho do site tem efeito positivo sobre a retenção na firma por meio do canal on-line.

Szimanski e Hise (2000) discutem o campo de pesquisa da computação cognitiva, uma abordagem orientada ao consumidor para gestão e design do site. Baseia-se em processamento de informação ao consumidor em relação a estilo, padrões de compra, preferências de fachada ${ }^{30}$ e áreas correlatas para inspirar lojas on-line mais atraentes, amigáveis e bem-sucedidas. Os autores estudaram possíveis antecedentes para o e-satisfaction, cujos resultados indicaram que a variável conveniência foi mais significante do que design do site nos níveis de e-satisfação. 
Percepções positivas do design do site estão vinculadas à percepção de segurança na transação.

A percepção sobre design do site está no contexto ambiental específico do varejista e contida na definição de variáveis mooring, segundo Bansal, Taylor e James (2005). Do que se formula outra hipótese $\left(H_{10}\right)$ :

$\mathrm{H}_{10}-\mathrm{O}$ desenho do site e sua funcionalidade tem efeito positivo na retenção da firma.

\subsection{Variáveis de Efeito Pull}

Variáveis pull, segundo Bansal, Taylor e James (2005), representam os fatores que atraem os migrantes potenciais para o destino. Fatores atraentes no destino puxam o migrante para esse novo destino.

\subsubsection{Grau de atratividade dos concorrentes varejistas off-line}

A atratividade das lojas varejistas reflete a atitude positiva do consumidor para os provedores de serviços e produtos off-line, o que influencia positivamente na intenção de mudar de canal quando se realiza busca on-line.

Pela teoria de razão-ação ${ }^{31}$ de Fishbein e Ajzen (1975), a percepção dos consumidores sobre os atributos de lojas alternativas se traduz em atratividade de compra, o que influencia na escolha da loja. As dez razões para não comprar on-line incluem a qualidade de serviço pobre e o risco de privacidade em comparação ao varejo tradicional. Concorrentes mais atrativos aumentam a intenção do consumidor para compra nesses provedores (BANSAL; TAYLOR; JAMES, 2005). Para um comprador multicanal em diferentes estágios do processo de compra, uma loja mais

\footnotetext{
${ }^{31}$ Theory of reasoned action as posited by Fishbein e Ajzen.
} 
atrativa de varejo tradicional aumenta a possibilidade de free-riding (VERHOEF; NESLIN; VROOMEN, 2007).

Jones, Mothersbaugh e Beatty (2000) examinam as barreiras para mudança de fornecedor e destacam, dentre elas, o fator atratividade das alternativas. Esse fator se refere à percepção do consumidor em relação à amplitude das alternativas de concorrentes viáveis disponíveis no mercado. Quando o consumidor percebe poucas alternativas viáveis, o benefício percebido da deserção deve ser relativamente baixo, resultando em alto nível de retenção. Há evidências empíricas da literatura que incluem relacionamento interpessoal e rotatividade de empregado, bem como relacionamento entre canais, suportando o argumento e demonstrando que, quando faltam as alternativas viáveis, a probabilidade de encerrar um relacionamento existente decresce. A escassez de opções na busca de satisfação para obter benefícios na mudança mitiga esse efeito e aumenta a confiança do consumidor no fornecedor concorrente, mesmo quando os serviços desempenhados fiquem abaixo da média. Bansal, Taylor e James (2005) citam que o maior grau de atratividade das alternativas, uma característica positiva da concorrência de serviços, influencia positivamente a mudança de fornecedor.

O artigo de Verhoef, Neslin e Vroomen (2007) mostra um modelo que sugere medir o impacto de estratégias especificas para gerenciar a pesquisa de compras, que pode ser feita por meio de três estratégias: 1- mudar os atributos de pesquisa/compra de um dos canais ou ambos; 2- criar ou reduzir o lock-in entre canais; 3- criar ou reduzir as sinergias de pesquisas em cruzamento de canais. $O$ cruzamento entre canais on-line para a loja de varejo é o mais comum reportado nas pesquisas da literatura. Os achados sugerem que as principais razões para o cruzamento on-line $\rightarrow$ loja física ocorre porque a loja on-line foi considerada pouco atrativa para realizar a transação. Dois atributos que particularmente ferem a internet como canal de compra são: baixo nível de serviço e privacidade quando comparada à loja física. Esses atributos mostram ser determinantes importantes para tornar atrativa a compra pela internet. Os achados também evidenciam que a melhoria do serviço e da privacidade no canal da internet, ao modificar-se o atendimento para uma assistente de compras em tempo real e adotar uma política transparente de 
privacidade, aumentou em $10 \%$ as compras pela internet em detrimento de compras na loja física. E a percentagem de consumidores pesquisando na internet e comprando nas lojas diminuiu em cerca de $7 \%$.

Chiu et al. (2011) utilizam a terminologia PPM do modelo de Bansal, Taylor e James (2005) e descrevem que uma atratividade relativa de um varejista puxa ${ }^{32}$ o consumidor para essa destinação num ambiente multicanal.

$\mathrm{H}_{14}$ - a atratividade do varejo tradicional tem efeito positivo no cruzamento entre canais e entre varejistas com a intenção de free-riding.

\subsubsection{Qualidade de serviço percebida nos concorrentes off-line}

A qualidade por muitos anos teve a perspectiva da indústria, porém a aproximação da distância entre qualidade objetiva e percebida requereu que a empresa enxergasse a qualidade segundo a percepção do consumidor. A percepção de qualidade do consumidor modifica-se com o aumento de informação, aumento de competição numa dada categoria e mudança de expectativa. A natureza dinâmica da qualidade sugere que as percepções sobre o julgamento de qualidade sejam monitoradas para alinhar produto e estratégia de promoção. $O$ consumidor também precisa ser educado sobre a avaliação de qualidade. A qualidade percebida representa o julgamento do consumidor sobre a excelência ou superioridade de um produto. Qualidade percebida exige alto grau de abstração do que simplesmente conscientizar-se de um atributo específico do produto (ZEITHAML, 1988).

Investigar a qualidade percebida pelo consumidor por meio do canal on-line representa uma estratégia essencial para o sucesso. Para entregar qualidade on-line superior, os gerentes de empresas com serviço on-line precisam primeiro entender como os consumidores percebem e avaliam os serviços ao consumidor on-line da empresa (ZEITHAML; PARASURAMAN; MALHOTRA, 2002). Na revisão dos 
autores, há vários critérios para os consumidores avaliarem os Websites e a qualidade dos serviços. Os critérios incluem: disponibilidade de informação e conteúdo; facilidade de uso; privacidade e segurança; estilo gráfico; e cumprimento de promessas. Os autores fazem um paralelo entre avaliação do consumidor de lojas tradicionais versus lojas on-line, destacando que a forma como os consumidores avaliam on-line e off-line revela diferenças no papel das expectativas, no número e natureza das dimensões e no conteúdo cognitivo-emocional. Além disso, parece haver elevado grau de trade-offs para os consumidores. Na pesquisa dos autores SERVQUAL com focus group, o atendimento pessoal não parece ser crítico para os aspectos de transação no serviço on-line. Os consumidores requerem cortesia e outros aspectos de atenção pessoal no contexto off-line, porém o requerimento desses serviços não é crítico para o contexto on-line. Isso ocorre apenas na recuperação de serviço ou em decisões altamente complexas, quando os consumidores requerem atendimento pessoal e assistencial. A empatia não é requerida, somente o é quando o consumidor experimenta problemas no contexto on-line. A compra on-line parece ser um comportamento dirigido por meta. Emoções como medo e frustração são expressas no caso de problemas com as transações on-line, mas parecem ser menos intensas do que as associadas com o contexto de lojas tradicionais.

Chiu et al. (2011) realizam uma transposição para o contexto multicanal, em que os consumidores apresentam maior experiência com o varejo tradicional. Eles acessam os serviços on-line, realizando um benchmark de qualidade com o varejo tradicional. Dessa forma, os consumidores formam percepções de qualidade de serviços em bases comparativas on-line e off-line (ZEITHAML; PARASURAMAN; MALHOTRA, 2002). O nível do desempenho em serviços tem efeito direto na atratividade de concorrentes do varejo tradicional. Na percepção do consumidor, o varejo tradicional oferece melhor qualidade e terá maior atratividade do que o on-line, o que favorece o free-riding do varejo on-line para o off-line em se tratando de produtos tecnológicos e mais complexos (MICK; FOURNIER, 1998). Fundamenta-se dessa forma a hipótese a seguir $\left(\mathrm{H}_{16}\right)$ : 
$\mathrm{H}_{16}$ - a qualidade percebida do serviço no canal tradicional tem efeito positivo na atratividade do varejo tradicional.

\subsubsection{Risco percebido pelas compras on-line}

Bobbitt e Dabholkar (2001) consideram as influências externas como variáveis diretas e moderadoras que influenciam atitudes ou comportamentos relacionados a serviços baseados em tecnologia. Uma das influências diretas são os riscos percebidos associados com o autosserviço baseado em tecnologia. Consumidores associam diferentes tipos e níveis de risco com métodos de compras tradicionais e não tradicionais. Gillett (1976) demonstra que os níveis de risco social, desempenho, físico, financeiro e psicológico variam com o canal da compra e com o produto ou serviço. A pesquisa demonstra que comprar por telefone ou correio é considerado mais arriscado do que comprar nas lojas físicas. De modo similar, consumidores devem perceber que a tecnologia baseada em autosserviço é mais arriscada do que de formas tradicionais devido ao risco atribuído à internet.

Bobbitt e Dabholkar (2001) propõem que o risco financeiro, psicológico e de desempenho é mais aplicado às compras pela internet do que em outros canais não tradicionais ou tradicionais. Dentre os riscos financeiros, os consumidores podem considerar que comprar de empresas conhecidas pela internet pode trazer o risco de fazerem mau uso do cartão de crédito. O vendedor recebe o dinheiro sem ter entregado a mercadoria. As informações de cartão de crédito podem cair nas mãos erradas e ser usadas por terceiros. Também os consumidores se sentem sob o risco financeiro quando desconhecem as políticas de reembolso dos vendedores. Em alguns sites, essa informação não está disponível para fácil acesso. E, finalmente, os consumidores podem ser cobrados indevidamente nas compras devido a erro. Se o site não oferece um pedido de confirmação que inclua a quantidade de dinheiro, o consumidor fica sem saber se foi cobrado ou não incorretamente até chegar a fatura do cartão.

Riscos psicológicos, segundo as autoras, decorrem do mau uso de informações pessoal pelos Websites associado à internet. Outro tipo de risco psicológico é 
quando o consumidor não tem informação sobre qual site é confiável e qual não é. Risco de desempenho ocorre em saber como o site irá comportar-se ao oferecer informação necessária para a decisão de compra. Em algumas situações, os consumidores podem perceber que a internet não oferece informação suficiente para tomar decisões, por exemplo, ao comparar alternativas de preços entre opções de um mesmo produto e se estão conseguindo o melhor preço. Alguns consumidores não acreditam que o ambiente virtual ofereça o tipo de informação que uma loja física oferece com os vendedores. Outros preferem interagir presencialmente com funcionários da loja para tomar uma decisão de compra, com que se podem aconselhar e receber recomendações, reduzindo a percepção de risco. Alguns sites vêm oferecendo suporte on-line para dar assistência aos consumidores para tomar decisões de compra.

Gillett (1976) também ressalta que o produto não responde por si só como o determinante mais importante do sucesso ou falha na compra dentro de casa. ${ }^{33} \mathrm{~A}$ experiência anterior de compra, a qualidade do produto, preço, entrega, políticas de garantia também interagem para influenciar o grau do risco percebido. Esses fatores devem variar tremendamente entre as situações de vendas para dentro de casa. Os compradores em casa são considerados mais cosmopolitas, conscientes do estilo e do valor, orientados à conveniência e geralmente mais demandadores do que outros consumidores. Os compradores de casa são considerados conhecedores, mais flexíveis no estilo de compra, visitam as lojas com maior frequência e enxergam a compra bem como o risco da compra de forma mais positiva. A compra em casa é mais discricionária, geralmente impulsiva ou motivada por conveniência. Usam uma variedade de métodos de compra em casa e de fontes e compram em casa por várias razões: conveniência, sortimento e exclusividade do produto e preço como sendo as razões mais óbvias.

Nos achados da tese de Oliveira (2009), o risco de desempenho e a orientação por conveniência são predominantes para a escolha de canal utilizado para a fase de busca, enquanto os riscos de tempo, psicológico e financeiro são relevantes para a

\footnotetext{
${ }^{33}$ In-home sale
} 
escolha do canal onde será efetuada a transação. Os consumidores que pesquisam on-line e depois efetuam a transação na loja física parecem perceber risco de tempo (ou de conveniência) e risco financeiro mais elevado do que os consumidores que privilegiam a loja on-line para essas duas etapas do processo de compra. Os consumidores que buscam informações na loja física, mas preferem efetuar a transação na loja on-line, parecem perceber maior risco de desempenho, sendo orientados mais por recreação do que os consumidores que tanto buscam informações quando efetuam transação no canal on-line.

Os achados de Chang e Wu (2012) indicam que o risco percebido no site influencia a intenção de compra por meio de atitudes baseadas na cognição e afeto. Além disso, os autores ressaltam que o efeito moderador do estilo de tomada de decisão na relação entre risco percebido e seus consequentes é condicional, o que torna o risco percebido crucial nas compra on-line.

A percepção de risco na revisão de Oliveira (2009) inclui a associação do risco à categoria de produto além da marca.

Bettman (1973) sugere a divisão do risco percebido em dois construtos ligeiramente diferentes. A distinção deve ser feita entre risco inerente e risco manipulado. $\mathrm{O}$ risco inerente representa o risco latente referente a uma categoria de produto. $\mathrm{O}$ risco manipulado representa os resultados das ações de informação e processo de redução de risco inerente. No caso de um consumidor não ter nenhuma informação, o risco inerente e o risco manipulado devem ser o mesmo. O risco manipulado inclui o efeito de dada informação particular de uma marca, enquanto o risco inerente lida com o grau de risco sentido por um consumidor quando não há informação.

Por fim, Dowling e Staelin (1994) referem-se aos construtos apresentados por Bettman (1973) e os nomeiam como risco específico do produto e risco de categoria de produto. Uma percepção de grande risco inerente implica necessariamente um rico total maior na compra de um produto. 
Chiu et al. (2011) ressaltam da literatura que o risco percebido na compra on-line consiste de dois componentes: incerteza (probabilidade de resultados desfavoráveis) e consequências (importância da perda). Usuários de internet escolhem não comprar on-line devido às considerações de risco, incluindo a segurança da transação e a impossibilidade de checar a mercadoria antes da compra (VERHOEF; NESLIN; VROOMEN, 2007). A percepção de risco do consumidor torna-se chave para a avaliação e o comportamento de compra, o que fez Chiu et al. (2011) proporem a inclusão dessa variável numa forma direta, que constitui a nova hipótese $\left(\mathrm{H}_{15}\right)$ :

$\mathrm{H}_{15}$ - o risco percebido pela compra on-line tem um efeito positivo na atratividade pelo varejo tradicional.

\subsubsection{Efeito barganha}

O estimulo do consumidor pela barganha e pela promoção de preço pode ser medido pelo aspecto utilitário econômico ou pelo aspecto da expressão do ego, que gera sentimentos de "consumidor inteligente". Schindler (1989) esclarece o conceito do consumidor inteligente e esperto. A propriedade de um produto pode ter diferentes tipos de consequência em relação ao preço que o consumidor paga. Uma das consequências sobre o preço é denominada de utilitária. A utilidade pode ser medida pela disponibilidade de alternativas para o dinheiro empregado. Se o preço de compra teve desconto, outra consequência utilitária surge ao pensar nos itens que poderiam ser comprados com a economia. Uma terceira consequência utilitária resultante do preço seria que referência uma indicação da qualidade. Pagar um preço particular por um produto pode suscitar o desejo de consequência do consumidor pelo aumento da confiança no produto, seja pelo bom desempenho, seja pela alta qualidade.

Schindler (1989), por sua vez, ressalta em artigo de revisão, um segundo tipo de consequência sobre o preço que pode resultar na "expressão do ego". Esta categoria de consequências inclui as implicações que o preço pode trazer ao autoconceito do consumidor. Pagar um preço baixo por dado produto pode despertar 
sentimentos de orgulho, esperteza ou competência. Pode haver um sentimento de realização ou uma sensação de vitória sobre grandes corporações. Também pode haver a satisfação em antecipar a terceiros o fato de ter encontrado um preço baixo, a partir do sentido de ajuda ao próximo. Também descreve o sentimento de arrependimento se um item comprado foi encontrado com preço inferior.

A habilidade do preço para provocar fortes sentimentos como orgulho ou medo foi ressaltada pela teoria da aprendizagem social quando se considera a importância dos sentimentos na eficácia da motivação humana (BANDURA, 1977).

Schindler (1989) revela que na cultura americana a representação do uso do dinheiro é sinal de status e de sucesso pessoal. No Brasil, Moreira (2002) testou a escala do significado de dinheiro (ESD) e observou que o significado do perfil nacional coloca a estabilidade em primeiro lugar. O progresso está em terceiro, a cultura em quarto e o prazer em oitavo. O significado de dinheiro que representa a coletividade ficou entre o segundo e quarto lugar (desigualdade, progresso e cultura). Dessa forma, o dinheiro assume dimensão de preocupação eminentemente social, o que contrasta com outros contextos em outros países, como os Estados Unidos, que tratam o significado do dinheiro em nível individual.

Jones, Trocchia e Mothersbaugh (1997) formulam a hipótese de que, ao buscar pechinchar, o ganho financeiro não seria suficiente para motivar o comportamento de barganha devido aos vários custos envolvidos: econômicos e psicológicos. Os achados indicam motivação não econômica. A necessidade de realização: seja por uma necessidade de alto desempenho, seja por fazer melhor que outros. A necessidade de dominância ou de poder foi outro aspecto, no sentido de um indivíduo controlar o ambiente, uma maneira de experimentar autoestima. A vitória no barganhar para alguns se assemelha a virilidade. Outra característica foi a necessidade de afiliação com vendedores, amigos e família ou outros indivíduos que não estejam presentes na negociação.

Otnes e McGrath (2001) estudaram o comportamento de compra masculino, por meio de um estudo exploratório sobre as diferenças no comportamento de compra 
de gênero. Uma das percepções que contradiz o comportamento masculino de "pegar e sair da loja" remeteu à necessidade de o consumidor caçar ou barganhar um desconto - o desejo de barganhar como um sentimento masculino. Além disso, o estudo revelou desejos masculinos de perambular na loja e a necessidade de socialização. As implicações gerenciais recomendadas pelas autoras para o varejo foram que os varejistas deveriam reforçar o sentimento masculino de vitoriosos na compra.

Ganesh, Reynolds e Luckett (2007) compararam várias tipologias de consumidor por meio de um método múltiplo e de abordagem de formato múltiplo. Os achados indicaram um grupo de "pechinchadores" motivados primariamente pela necessidade de barganhar do que por uma escolha otimizada. Isso permitiu propor a nova hipótese $\left(\mathrm{H}_{17}\right)$ :

$\mathrm{H}_{17}$ - a necessidade de barganhar tem efeito positivo na atratividade pelo varejo tradicional.

\subsection{Contribuições do modelo proposto}

O modelo teórico dessa pesquisa incluiu novos construtos latentes que surgiram da pesquisa exploratória e sugestões após passar pela banca de qualificação. Bansal, Taylor e James (2005) propuseram um modelo de intenção de alternância entre prestadores de serviço. No levantamento realizado pelos autores, para os efeito push (fatores que motivam sair da origem) outros construtos estão presentes na literatura, tais como: satisfação, confiança, compromisso etc. O modelo proposto incluiu hipóteses relacionadas ao desejo de sair da origem e relacionadas com autoeficácia: a satisfação free-riding, confiança on-line, lealdade, afinidade tecnológica. Entre as variáveis com efeitos mooring, que segundo a proposta de Chiu et al. (2011) foram relacionados à retenção na firma, incluíram-se os construtos design do site, conveniência on-line e busca de variedade. E, finalmente, para variáveis com efeito pull (efeitos positivos que levam a um novo destino), representado pelo construto atratividade do varejo tradicional foram incluídos os 
construtos: barganha, confiança loja física, satisfação loja física, conveniência loja física.

O modelo proposto não seguiu a orientação de Chiu et al. (2011) ao fixar apenas o cruzamento entre busca on-line $\rightarrow$ compra loja física, oferecendo outras alternativas de busca e compra como: busca on-line e loja física $\rightarrow$ compra on-line e, busca online $\rightarrow$ compra on-line. 


\section{Plano metodológico}

Quantos aos fins a presente pesquisa foi realizada em duas fases: exploratória e descritiva. Quanto aos meios de investigação foi realizada uma pesquisa de campo tanto exploratória quando descritiva (VERGARA, 2007).

A autora Vergara (2007), acrescenta que a pesquisa exploratória "é realizada em área na qual há pouco conhecimento acumulado e sistematizado. Por sua natureza de sondagem, não comporta hipóteses". As hipóteses poderão surgir durante ou ao final da pesquisa. Aaker, Kumar e Day (2004) acrescentam que a pesquisa exploratória é também útil para o estabelecimento de prioridades entre questões de pesquisa e para o aprendizado sobre os problemas práticos na execução do trabalho.

Segundo Vergara (2007) a pesquisa descritiva expõe características de uma dada população, podendo estabelecer correlações entre variáveis e definir natureza.

Quanto aos meios de investigação, foi realizada uma pesquisa de campo, local onde ocorreu o fenômeno tanto para a finalidade exploratória quanto para a finalidade descritiva (VERGARA, 2007).

Gil (2007) diferencia o estudo de coorte, de levantamento e de estudo de campo. O estudo de coorte refere-se a um grupo de pessoas com alguma característica comum, construindo uma amostra que será acompanhada por certo período de tempo, para ser observada e analisada. Muito utilizada em ciências da saúde. A pesquisa de levantamento refere-se à indagação direta a pessoas, cujo comportamento se deseja conhecer. E em seguida, utiliza-se de análise quantitativa para obter conclusões relativas aos dados pesquisados. Se o levantamento recolhe informações da população, será chamado de censo.

O autor Gil (2007) comenta que se a amostra for estatística e significativa de todo o universo, as conclusões obtidas com base na amostra são projetadas para o total da população, levando em consideração a margem de erro. 
E por último, o autor comenta que a pesquisa de campo mostra semelhanças com o levantamento, porém apresenta algumas distinções. A primeira distinção refere-se ao levantamento como tendo maior alcance e a pesquisa de campo como tendo característica de maior profundidade. O levantamento busca ser representativo do universo definido e oferece resultados precisados pela estatística. Já o estudo de campo busca maior aprofundamento nas questões propostas do que a distribuição das características da população segundo variáveis selecionadas. Gil (2007) acrescenta que o planejamento do estudo de campo se torna mais flexível, mesmo que seus objetivos sejam reformulados ao longo da pesquisa.

Outra diferença apresentada por Gil (2007) é que o levantamento procura identificar características dos componentes do universo pesquisado, porém a pesquisa de campo tem como finalidade estudar um único grupo ou comunidade em termos de estrutura social, dando ênfase à interação entre seus componentes.

Marconi e Lakatos (2007) ressaltam que a pesquisa de campo é utilizada para obter informações e/ou conhecimentos acerca de um problema ou de uma hipótese que se queira comprovar. Em seguida, comentam sobre as fases da pesquisa de campo, iniciando-se pela pesquisa bibliográfica sobre o tema em questão, o que já foi descrito anteriormente pelos pesquisadores. Como segundo passo, a pesquisa de campo deve estabelecer um modelo teórico inicial de referencia, com determinação das variáveis e a elaboração do plano geral da pesquisa. Em terceiro deve-se determinar as técnicas que serão empregadas na coleta de dados e na determinação da amostra a qual deverá ser representativa e suficiente para apoiar as conclusões.

De acordo com Tripoli et al. (1975, p. 42-71 apud MARCONI; LAKATOS, 2007, p. 189), as pesquisas de campo podem ser classificadas em três grandes grupos: quantitativo-descritivo, exploratório e experimental. A pesquisa de campo quantitativo-descritivo, em que se baseou esta tese, consiste em investigações de pesquisa empírica com a principal finalidade de delinear e analisar variáveis principais. O método adotado foi formal e se aproximou das pesquisas 
experimentais, caracterizado pela precisão e o rigor estatístico com intenção de verificar hipóteses. Os autores ainda acrescentam que os estudos de verificação de hipóteses apresentam hipóteses explícitas que devem ser validadas. São hipóteses sustentadas por teorias e, por esse motivo, são declarações de associações entre duas ou mais variáveis, sem referencia a uma relação causal entre elas.

Não se trata de uma pesquisa experimental empírica onde o pesquisador manipula e controla variáveis independentes e observa as variações que tal manipulação e controle produzem em variáveis dependentes (VERGARA, 2007).

Por último, Marconi e Lakatos (2007) ressaltam as desvantagens da pesquisa de campo. O pequeno grau de controle sobre a situação de coleta de dados e a possibilidade de fatores desconhecidos para o pesquisador poderem interferir no resultado da mesma, além de que o comportamento do respondente ao preencher 0 questionário pode resultar em baixa confiança.

\subsection{Etapa exploratória}

De acordo com Tripoli et al. (1975, p. 42-71 apud MARCONI; LAKATOS, 2007, p. 190), os estudos exploratórios são investigações de pesquisa empírica cujo objetivo é obter a formulação de questões para desenvolver hipóteses, aumentar a familiaridade do pesquisador com o contexto pesquisado, modificar ou clarificar conceitos. As descrições podem ser quantitativas ou qualitativas do objeto do estudo e o pesquisador deve conceituar as inter-relações entre as propriedades do fenômeno observado. Os autores ainda complementam que os estudos exploratórios dividem-se: 1- estudos exploratório-descritivos combinados; 2- estudos com procedimentos específicos para coleta de dados; 3- estudos de manipulação experimental. Para fins da pesquisa exploratória dessa tese foi utilizada a descrição qualitativa das informações obtidas e detalhadas pela pesquisa participante e a técnica de entrevista profunda. As informações obtidas foram organizadas de forma sistemática. Os autores acrescentam que o procedimento específico para coleta de dados exploratórios é realizado pela análise de conteúdo, com o objetivo de extrair 
generalizações e com o propósito de produzir categorias conceituais que possam ser posteriormente operacionalizadas em estudo subsequente.

Vergara (2007) define que a pesquisa participante apresenta uma fronteira tênue entre pesquisador e pesquisado, ao contrário do que ocorre na pesquisa tradicional. Marconi e Lakatos (2007) comentam que o observador participante enfrenta grande dificuldade para manter objetividade pelo fato de exercer influencia no grupo, ser influenciado por antipatias ou simpatias pessoais e pelo choque de referencias entre observador e observado.

Marconi e Lakatos (2007) acrescentam que a observação direta e intensiva é uma técnica de coleta de dados para conseguir informações e utiliza os sentidos na obtenção de determinados aspectos da realidade, muito utilizada pela Antropologia. A observação ajuda ao pesquisador a identificar e a obter provas a respeito de objetos sobre os quais os indivíduos não têm consciência, mas que orientam seu comportamento. Destaca-se como principal limitação na utilização desta técnica de entrevista profunda, o risco pela ausência de neutralidade do pesquisador. $O$ objeto observado tende a criar impressões favoráveis e desfavoráveis no observador. Além disso, vários aspectos da vida cotidiana, particular do observado podem não ser acessíveis ao pesquisador.

A pesquisa exploratória para essa tese teve a intenção de investigar o tema "freeriding no varejo multicanal" para obter maior compreensão do comportamento do consumidor brasileiro e, identificar novos construtos para o modelo teórico proposto.

A pesquisa sobre o comportamento de compra pode ser enxergada de forma negativa ou positiva, segundo o contexto da empresa. Geralmente para consumidores multicanais que realizam o cruzamento on-line $\rightarrow$ loja física, há uma percepção negativa do ponto de vista do varejista, devido ao receio de perda do cliente. Um varejo exclusivamente on-line irá enxergar esse caminho de compra online $\rightarrow$ loja física como negativo. Porém quando o varejista integra mais canais de compra, o cruzamento on-line $\rightarrow$ loja física pode ser visto como positivo, se a empresa consegue integrar muito bem seus canais de vendas, de forma que o canal 
on-line capta novos clientes e os encaminha para a loja (VORHEF; NESLIN; VROOMEN, 2007).

A decisão de escolha de canais pode estar atrelada a uma decisão baseada em atributos do varejista, por sinergia de cruzamento entre canais ou por falta de aprisionamento entre os canais (lock-in), como abordado pela teoria da ação racional (TRA) de Fishbein e Ajzen adaptada por Verhoef, Neslin e Vroomen, (2007). O consumidor multicanal que troca de canais para finalizar a sua compra pode ser free-rider e realizar a melhor compra para si. Ainda não se tem um bom entendimento sobre o fenômeno do free-riding do consumidor e como esse cruzamento acontece. (CHIU et al., 2011; VAN BAAL; DACH, 2005; VERHOEF; NESLIN; VROOMEN, 2007;)

A etapa da pesquisa exploratória investigou os antecedentes que poderiam influenciar o comportamento de alternância de canais, observando a habilidade do consumidor para empregar múltiplos canais, e se essa habilidade influenciou a intenção de free-riding.

\subsubsection{Entrevistas em profundidade}

A técnica de entrevista para Marconi e Lakatos (2007) é um procedimento utilizado na investigação social para a coleta de dados. Trata-se de uma conversação face-aface, de maneira metódica, proporcionando ao entrevistado, de forma verbal, a informação necessária.

Best (1972, p. 120 apud MARCONI; LAKATOS, 2007, p. 198) afirma que a entrevista, quando realizada por um investigador experiente, "é muitas vezes superior a outros sistemas de obtenção de dados". Requer habilidades e perspicácias por parte do entrevistador.

Foi adotado o método de entrevistas em profundidade para obtenção de dados qualitativos, entrevista não estruturada e direta para obter informações realizadas de forma individual e para revelar motivações, crenças, atitudes e sentimentos sobre as 
compras por meio de múltiplos canais. A colocação sequencial de perguntas ao entrevistado foi orientada e influenciada pelas respostas do mesmo. No questionamento de problemas ocultos o foco não esteve em valores compartilhados socialmente, mas em pontos específicos e individuais, realizando uma análise simbólica (MALHOTRA, 2006).

As entrevistas em profundidade realizadas com consumidores se orientaram por Marconi e Lakatos (2007). Tiveram um roteiro estruturado, focalizado com tópicos relativos ao problema, resguardando a devida liberdade do pesquisador para fazer sondagem, solicitar esclarecimentos. (Apêndice 1).

A investigação foi conduzida por cinco entrevistas em profundidade com consumidores para se compreender o problema e os fatores subjacentes. A escolha de consumidores levou em consideração pessoas que possuíam uma ampla experiência com compras on-line e multicanal, nacional e internacional para levantar possíveis antecedentes e crenças salientes entre os consumidores brasileiros. 0 autor deste estudo tem formação em mediação de conflitos e desenvolveu a habilidade para levantar questões sobre motivações, emoções, crenças, valores e interesses. As entrevistas duraram cerca de 30 a 40 minutos. Houve uma pergunta de corte feita para compra de produtos complexos nos últimos seis meses, tais como linha branca, eletroeletrônicos, computadores, tablets, smartphones etc.

Quanto ao registro da entrevista, foi utilizada a gravação da voz, com autorização previa do entrevistado. Ainda seguindo a orientação de Marconi e Lakatos (2007) o registro foi realizado com as mesmas palavras do entrevistado, uma transcrição literal. Gestos, atitudes não foram considerados, porém inflexão de voz influenciou na transcrição. Foi relevante a intensidade da resposta quanto aos sentimentos colocados, pensamentos e lembranças do entrevistado.

A amplitude da resposta ficou registrada na transcrição. Após as entrevistas de profundidades houve transcrição das mesmas para formato de texto e depois foi realizada uma análise de conteúdo. Nesta análise algumas variáveis foram 
categorizadas e utilizadas para construção do modelo teórico, das hipóteses de pesquisa e do instrumento de coleta de dados.

\subsection{Etapa descritiva}

Segundo Malhotra (2006) a pesquisa descritiva se utiliza dos métodos de levantamento e de observação. Como pesquisa descritiva irá descrever as características do comportamento do consumidor ao realizar compras por multicanais. Mais especificamente, busca-se entender se a capacidade/habilidade do consumidor em utilizar o varejo multicanal influencia sua intenção de free-riding.

Foi feito um estudo transversal com coleta de informação por meio de questionário estruturado disponibilizado on-line pela empresa E-bit. O questionário foi disponibilizado por um período menor do que um mês pela empresa E-bit e serviu como unidade básica de análise. Portanto, não se trata de um estudo longitudinal, dado que a amostra de consumidores foi única, o que limita a pesquisa para a percepção de mudanças no comportamento no longo prazo, como nos estudos longitudinais. (MALHOTRA, 2006)

\subsubsection{Plano amostral}

A etapa descritiva foi realizada com a base de consumidores da empresa E-bit (relatório Webshoppers 25a edição), que se utiliza de um sofisticado sistema de coleta de dados, gerando informações detalhadas sobre o comércio eletrônico a partir de dados do próprio consumidor on-line após a efetivação de compras em mais de 5000 lojas virtuais brasileiras.

A base de consumidores da empresa E-bit atende à composição dos elementos da população-alvo. A pesquisa de Chiu et al. (2011) colocou como corte a experiência em compras virtuais, portanto para a pesquisa brasileira, a base de dados da empresa E-bit atende à necessidade do consumidor ter experiência prévia de compras on-line e tem cobertura nacional. Os entrevistados foram examinados em 
relação às características demográficas, familiaridade, experiência em compra multicanal a fim de que eles possam satisfazer os critérios da população-alvo (MALHOTRA, 2006).

Quanto à seleção técnica de amostragem, tratou-se de uma amostra sem reposição, ou seja, "um elemento não pode figurar na amostra mais de uma vez". Trata-se também de uma amostra não probabilística, não sendo possível generalizar os dados dentro da população de compradores on-line da empresa E-bit (MALHOTRA, 2006).

Quanto ao tamanho da amostra, o critério de decisão levou em conta o número de variáveis operacionalizadas na análise quantitativa. Uma análise sofisticada com técnicas multivariadas e com dados analisados em subgrupos requereria um tamanho de amostra grande. (MALHOTRA, 2006)

A realização da modelagem de equações estruturais (MEE) representa um conjunto de técnicas que necessita de grandes amostras de acordo com o número de parâmetros. Algumas estimativas estatísticas na MEE, tal como o erro padrão, não conseguem obter precisão quando a amostra não é grande. A possibilidade de acontecerem problemas técnicos também é grande. Como a amostra representa uma questão essencial para a análise, qual deveria ser esse tamanho? Modelos complexos requerem desdobramentos, devido ao numero de parâmetros. $\mathrm{O}$ tipo de algoritmo de estimação usado na análise afeta o requerimento do tamanho da amostra. Tem mais de um tipo de método de estimação na MEE. Outro fato importante representa a característica de distribuição da normalidade multivariada. Em geral, tamanhos de amostra menores são necessários quando a distribuição das variáveis é normal na forma e quando as correlações entre elas são lineares.

Aaker, Kumar e Day (2004) apresentam a determinação do tamanho da amostra pelos métodos $A d H o c$. Sugere que a amostra deva ser grande o suficiente para que, quando dividida em grupos, cada um deles tenha um tamanho mínimo de 100 ou mais unidades. O importante é considerar o menor grupo para assegurar que seu tamanho seja suficiente para proporcionar a confiabilidade necessária. Se a análise 
considerar subgrupos, por exemplo, por faixa etária, sugere tamanho mínimo de 20 a 50 sujeitos para cada grupo.

Kline (2011) ressalta que uma regra de ouro útil para tamanho da amostra e complexidade do modelo foi referido por Jackson (2003 apud KLINE, 2011, p.12), a regra $\mathbf{N}: \mathbf{q}$. Essa regra é utilizada quando o método de estimação é de máxima verossimilhança, o método mais utilizado pela MEE. Um método padrão de alguns softwares. O autor enfatiza que não se deve confiar demais nesse método e lembra que o "motorista" sempre é o pesquisador. Para a estimação pelo método da máxima verossimilhança, o pesquisador deve pensar sobre o menor tamanho de amostra em termos da proporção de casos $(\mathrm{N})$ para o número de parâmetros do modelo que requer estimativa estatística (q). Um tamanho de amostra ideal seria 20:1. Por exemplo, se o modelo requer 10 parâmetros para estimativa estatística, então um tamanho ideal de amostra seria $20 \times 10$, ou $\mathrm{N}=200$. Menos ideal seria uma proporção n:q de 10:1. O autor comenta que abaixo dessa proporção a confiança dos resultados obtidos diminui.

Kline (2011) acrescenta que pensar em termos absolutos também ajuda. Um tamanho típico de amostra em estudos que utilizaram MEE fica em torno de 200 casos. Esse número representa a média de amostras de pesquisas publicadas. Incluiu uma revisão realizada por Breckler (1990 apud KLINE, 2011) em 72 artigos nos jornais de personalidade e psicologia social. No entanto, um tamanho de amostra de 200 casos, pode ser muito pequeno quando se analisa um modelo complexo, usando um método de estimativa que não a máxima verossimilhança, ou quando as distribuições são severamente não normal. Com menos de 100 casos, qualquer tipo de MEE pode se tornar insustentável, exceto em avaliação de modelos simples. A recomendação do autor não se trata de prática padrão, mas ela enfatiza o fato de que analisar amostras pequenas em MEE se torna um problema.

Considerando o número de parâmetros do modelo que foram 86 e N=20, a amostra deve ter em torno de 1000 questionários válidos em que consumidores se utilizam do free-riding entre canais e varejistas (KLINE, 2011). 


\subsubsection{Plano de coleta de dados}

A fase quantitativa teve o instrumento de coleta de dados realizado a partir de vários construtos de atitudes, crenças, atributos e julgamentos já estudados e demonstrados em estudos empíricos anteriores. O Anexo 1 apresenta o questionário original com 104 itens e as fontes bibliográficas. Ao entregar o questionário para Ebit a mesma solicitou que fosse colocada no formato da plataforma (LimeSurvey) da empresa. Foi sugerida a redução do tamanho do questionário, tanto na extensão de itens e quanto nas redundâncias. O Apêndice 2 apresenta os itens do questionário final submetido à pesquisa on-line. Além disso, a empresa E-bit sugeriu incluir smartphones, celular, console de videogame e que retirasse gravador. Foi sugerido incluir o site de comparação de preços e site do fabricante. A pesquisa foi disponibilizada pela E-bit que divulgou o questionário on-line no período de 3 a 23 de abril de 2013. Os consumidores que responderam o questionário completamente entraram para um sorteio de um tablet oferecido em todas as suas pesquisas online, além de pontuações.

Marôco (2010) esclarece a terminologia para as variáveis manifestas ou observadas diretamente no modelo e as variáveis latentes, como fatores ou construtos que são as variáveis não observáveis diretamente. O modelo teórico foi formado com 22 construtos, 21 hipóteses e 78 itens. A variável dependente foi a "intenção de freeriding multicanal".

$\mathrm{Na}$ definição de atitudes por Aaker, Kumar e Day (2004), descrevem os três componentes que formam uma atitude: um componente cognitivo ou de conhecimento; um componente sentimental ou afetividade e, um componente de intenção ou ação. O componente cognitivo representa as informações de um indivíduo sobre um objeto. $\mathrm{O}$ componente afetivo representa os sentimentos que uma pessoa tem em relação a um objeto, uma situação ou um indivíduo. Expresso em termos de preferencias. E, finalmente os componentes de intenção ou ação, referem-se à expectativa de um indivíduo quanto ao seu futuro comportamento em relação a um objeto. 
O questionário foi organizado a partir do modelo de Chiu et al. (2011), sendo que as perguntas e frases foram traduzidas para o português por diferentes pessoas ${ }^{34} \mathrm{e}$ depois a tradução reversa para o inglês, garantindo a integridade das perguntas originais. A tradução foi realizada por professores da área de varejo, assegurando a utilização de termos da área. Não foi possível o pré-teste do questionário para correção de possíveis mal entendidos no texto e a prioridade dada foi de manter a integridade das perguntas originais dos artigos internacionais, garantindo-se uma boa tradução.

Segundo Aaker, Kumar e Day (2004), a escolha de números remete à necessidade de análises estatísticas. Outra ferramenta no método científico básica são as escalas aplicadas em praticamente todas as situações da pesquisa de marketing. A escala adotada na pesquisa foi a escala de Likert que expressa o grau de concordância ou discordância em relação a uma série de afirmações relacionadas à atitude e à intenção. A escala de Likert consiste em duas partes: uma declaração ou afirmação e uma parte avaliativa. A escala utilizada foi com sete pontos e expressada em graus de concordância e números, sendo uma escala unidimensional.

\begin{tabular}{|c|c|c|c|c|c|c|}
\hline \multicolumn{3}{|c|}{ DISCORDO } & & \multicolumn{3}{c|}{ CONCORDO } \\
\hline totalmente & muito & pouco & neutro & pouco & muito & totalmente \\
\hline 1 & 2 & 3 & 4 & 5 & 6 & 7 \\
\hline
\end{tabular}

Chiu et al. (2011) descreveram duas perguntas de corte para detectar o comportamento de free-riding entre canais. Se ambos os critérios não fossem atingidos, o respondente foi desconsiderado da pesquisa. As perguntas de corte selecionaram os respondentes que tinham experiência de free-riding em ambiente multicanal com as categorias selecionadas.

\footnotetext{
${ }^{34}$ Realizada pelo orientador prof. Dr. José Augusto G. da Silveira, prof. Dr. Nuno Dias Fouto e seu estagiário Lucas, Prof. ${ }^{a}$ e tradutora Diana Goulart.
} 
1- Você buscou informação numa loja on-line antes de realizar a compra em loja física? Se afirmativo, o respondente entrou para a pesquisa.

2- Você buscou informação numa loja on-line da mesma empresa varejista que você realizou a compra na loja física? Se negativo, o respondente entrou para a pesquisa.

As duas perguntas filtro dos autores Chiu et al. (2011) assumiram como premissa a busca on-line e a compra na loja física, porém para essa pesquisa no Brasil foram abertas outras possibilidades para busca e transação que caracterizem o free-riding no cruzamento multicanal ${ }^{35}$.

1- Você buscou informação em uma loja on-line antes de comprar numa loja física de varejo?

2- Você buscou informação numa loja física de varejo antes de comprar on-line?

3- Você buscou informação numa loja on-line da empresa $A$ e comprou na loja on-line da empresa $B$ ?

4- Você buscou informação numa loja on-line da mesma loja física que você decidiu comprar?

5- Você buscou informação numa loja física da mesma loja on-line que você decidiu comprar?

Os que responderem "sim" para questão 1 ou 2 ou 3 e "não" para 4 e 5 caracterizaram-se para a amostra da pesquisa sobre comportamento free-riding entre canais. Foi incluída a consulta a sites de comparação de preços, como ocorre no contexto brasileiro. Houve uma pergunta filtro para respondentes que realizaram compra apenas nos últimos seis meses. Para tornar a amostra mais homogênea foram escolhidas apenas as categorias de experiência (NELSON, 1970). Os produtos de experiência requerem mais do que o levantamento de preço. $O$ consumidor necessita investigar sobre a marca, a qualidade e entender os atributos do produto para estimar a utilidade da compra.

${ }^{35}$ Cross-channel free-riding 
São 10 categorias adotadas pelo E-bit, a saber: 1- linha branca; 2- eletroeletrônicos; 3- informática; 4- telefonia e celulares; 5- títulos de CDs/ DVDs, livros e revistas; 6brinquedos; 7- utilidades domésticas de pequeno porte; 8-cosméticos, perfumaria e saúde; 9- serviços; 10- viagem e turismo. Para esta pesquisa foi dado o foco nos produtos: aparelho de som, aparelho de ar condicionado, aparelho DVD/Blue Ray player, câmara digital, computador/notebook, console de videogame, eletrodomésticos (opção com janela para especificar o produto), filmadora, impressora, smartphone/celular, tablete, TV digital.

De acordo com Van Baal e Dach (2005) as categorias de produtos eletrônicos como computador, possuem característica de busca dominante, mudam rapidamente de tecnologia e provocam compras não frequentes o que aumenta as chances de freeriding nas compras entre canais.

O Anexo 1 apresenta o questionário da pesquisa com as perguntas em inglês utilizadas por Chiu et al. (2011) e de outros autores. Alguns ajustes foram realizados pela autora e houve a inclusão dos temas revelados pela pesquisa exploratória. Além disso, realizaram-se adaptações conforme a seguir, a partir do questionário de Chiu et al. (2011).

O construto para experiência vicária (EV) teve originalmente duas perguntas e foi acrescido de mais uma pergunta que inclui a experiência vicária com aprendizado dentro da família, algo mais pertencente à cultura brasileira. Por exemplo, quando pais aprendem com filhos o manuseio da internet ou pedem para o filho realizar a compra em nome deles.

Sobre o construto retenção na firma (RF) apenas duas variáveis foram descritas no artigo de Chiu et al. (2011). Portanto, foram introduzidas mais duas frases adaptadas de Ranaweera e Prabbhu (2003).

Sobre o construto custo de mudança $(\mathrm{CM})$, havia apenas duas variáveis no modelo de Chiu at al (2011). Foi acrescentado mais duas variáveis de Burnham, Freis e Mahajan (2003), adaptado para o varejo. 
Sobre o construto qualidade percebida (QP) para as lojas físicas de varejistas concorrentes, foram considerados itens da escala SERVQUAL de Parasuraman, Zeithhaml e Berry (1988), Zeitlhaml, Parasuraman e Malhotra (2002). Os itens utilizados pelos autores Chiu et al. (2011) foram:

- Tangibilidade: instalação física, layout, equipamento e aparência do pessoal;

- Confiabilidade: habilidade de desempenhar o serviço prometido de forma confiável e com precisão;

- Capacidade de resposta: desejo de ajudar os consumidores e oferecer pronto atendimento.

- Interatividade: não foi encontrado o construto para interatividade no conceito do SERVQUAL. Porém para serviços on-line os autores Parasuraman, Zeithaml e Malhotra (2005, p.8) desenvolveram uma escala específica E_S_QUAL que inclui a dimensão "contato", como disponibilidade de assistência pelo telefone ou ter representante on-line (chat on-line). Na escala SERVQUAL existe a dimensão empatia no atendimento.

- Empatia: foi escolhida a dimensão empatia com duas perguntas em relação ao atendimento na loja.

O construto qualidade percebida (QP) foi formado com questões que envolvem as dimensões tangibilidade, confiabilidade, capacidade de prontidão de resposta que envolve a interatividade.

O construto percepção de risco (RP) dos autores Chiu et al. (2011) levou em consideração cinco questões de Verhoef , Neslin e Vroomen (2007) que envolvem as dimensões risco de desempenho, risco financeiro, risco de tempo (ou de conveniência) e risco total. Os autores não incluíram a percepção para risco psicológico e social e também não foi incluído neste estudo.

$E$, finalmente, o questionário foi dividido em blocos para facilitar a compreensão com enunciados e respostas para cada bloco, partindo-se de uma distância temporal de compra para os últimos seis meses. Foram oito blocos de questões com filtros e informações gerais sobre o processo de compra, 18 blocos de questões com 86 itens sobre os construtos latentes; e, finalmente, um bloco sobre perfil do 
respondente. Os dados obtidos com o questionário foram capturados num banco de dados Excel e entregues ao autor desta pesquisa.

\subsubsection{Perfil do respondente}

Foram feitas perguntas de perfil do consumidor on-line com as seguintes questões, conforme indicação na dissertação de Oliveira (2009).

1. Faixa etária: até 20 anos, $21-30 ; 31-40 ; 41-50$, acima de 50 .

2. Gênero: você é do sexo feminino ( ) masculino ( )

3. Qual o seu nível de escolaridade mais alto que você concluiu?

$1^{\circ}$ completo, $2^{\circ}$ completo, graduação completa, pós-graduação completa.

4. Qual a faixa de renda líquida familiar mensal?

Até $R \$ 1.500, R \$ 1501-R \$ 3.000, R \$ 3.001-R \$ 6.000, R \$ 6001-R \$ 10.000$, acima de $\mathrm{R} \$ 10.000$.

5. Em que cidade você reside? Estado:

Como referência para renda, o salário mínimo vigente em 2013 foi de $\mathrm{R} \$ 678,00$.

\subsubsection{Empresa E-bit}

A E-bit é uma empresa de pesquisa de referência no fornecimento de informações sobre e-commerce nacional, presente no mercado desde 2000. Para os consumidores a E-bit atua como um consultor de compras on-line, publicando no site www.ebit.com.br a certificação das lojas virtuais por excelência de serviços obtida a partir das avaliações de pessoas que efetivamente realizaram compras na internet. Para as empresas, a E-bit disponibiliza diversos produtos e serviços que auxiliam na orientação e elaboração das estratégias de marketing de seus clientes. Os principais produtos para empresas são listados abaixo:

- Retail Monitor: conjunto de análises que permite entender o posicionamento de uma dada loja no mercado de e-commerce em relação a preço na concorrência. 
- Painel de pesquisa: a empresa possui um painel de respondentes formado por 600.000 consumidores que fazem compras pela internet e pode ser segmentado por mais de 80 critérios diferentes para renda, CPF, sexo, idade, região e área de atuação profissional. Os questionários podem ser hospedados pelo E-bit que mantém controle do ambiente pesquisado. $O$ sistema garante que somente compradores efetivos preencham as pesquisas.

- E-mail marketing: uma forma de comunicação do varejo com seu público consumidor altamente qualificado e obter ótimas taxas de retorno em suas ações de comunicação, como incremento da base de clientes, promoções, vendas e campanhas específicas.

- Informações do comércio eletrônico: são relatórios de informação produzidos pelo E-bit para perfil do consumidor virtual, evolução da categoria mais vendida, intenção de compra, tíquete médio das compras on-line, panorama do comércio eletrônico no Brasil, monitores de preços, monitor de frete.

- Publicidade no site E-bit: divulgação em formatos gráficos (banners, floaters etc.) e editoriais no portal de compras da empresa E-bit.

- E-dashboard: uma ferramenta on-line que disponibiliza informações atualizadas diariamente para acompanhar o crescimento do e-commerce, para monitoramento e desempenho de loja.

O Webshoppers é um relatório semestral, gratuito, da empresa E-bit que analisa a evolução do comércio eletrônico, as mudanças de comportamento e preferências dos consumidores. Seus principais objetivos são: difundir informações essenciais para o entendimento do comportamento do internauta brasileiro e sua relação com o e-commerce, bem como, procurar encontrar pontos a serem melhorados no desenvolvimento do comércio eletrônico nacional. (E-BIT, 2012)

\subsubsection{Plano de análise de Dados}

As análises de dados desta pesquisa serão efetuadas por meio de estatística descritiva, análise fatorial exploratória, modelagem de equações estruturais e outras 
análises estatísticas multivariadas aplicadas à ciência comportamental e social, disponíveis nos softwares IBM SPSS ${ }^{\circledR}$ versão 19 e IBM AMOS ${ }^{\circledR}$ versão 21.

\subsubsection{Análise fatorial exploratória e confirmatória}

Segundo Marôco (2010), a análise fatorial pode ser classificada em dois tipos, de acordo com a inexistência ou existência, a priori, de hipóteses sobre a estrutura correlacional: 1- Análise fatorial Exploratória (AFE), 2- Análise Fatorial Confirmatória (AFC). A AFE não impõe restrições sobre os fatores e as variáveis manifestas. Os fatores comuns e os fatores específicos (erros) são independentes. A AFC é um método confirmatório que se usa quando há informação prévia sobre a estrutura fatorial que é preciso confirmar. A AFC impõe restrições sobre os fatores e as variáveis manifestas. Os fatores específicos (erros ou resíduos) podem aparecer correlacionados sugerindo existência de problemas ou outros fatores comuns não apresentados no modelo.

Marôco (2010, p.172) comenta que no âmbito da análise de equações estruturais, a análise fatorial confirmatória é "geralmente utilizada para avaliar a qualidade de ajustamento de um modelo de medida teórico à estrutura correlacional observada entre as variáveis manifestas (itens)". E nesse sentido, a análise fatorial confirmatória corresponde ao primeiro passo na avaliação de um modelo de equações estruturais ou pode por si, validar o fator de um instrumento. O importante que o número de fatores seja estabelecido a priori pelo pesquisador de acordo com a teoria ou com estudos anteriores. Foram utilizados fatores padronizados, fixando a sua variância em 1.

Para além da qualidade global do ajustamento, é usual avaliar a confiabilidade e a validade dos instrumentos de medida. Marôco (2010) refere-se à confiabilidade de um instrumento como a propriedade de consistência e reprodutibilidade da medida: "Um instrumento diz-se confiável, se mede, de forma consistente e reprodutível uma determinada característica ou fator de interesse." (MARÔCO, 2010, p. 174). Uma das medidas mais utilizadas para avaliar a confiabilidade ou consistência interna é o Alpha de Cronbach, contudo a validade dessa medida tem sido questionada e vários 
autores têm sugerido medidas alternativas, apesar da tradição de utilização nos artigos de psicometria.

Após as análises fatoriais, os fatores da AFE foram submetidos a análises de comparação de média pela ANOVA com variáveis categóricas, porém, Sauer e Dick (1993) reenquadram os modelos lineares da ANOVA, MANOVA e regressão como casos especiais da modelagem de equações estruturais (MEE). A MEE oferece ferramenta superior para testar a teoria de marketing.

\subsubsection{Modelagem de Equações Estruturais}

Fornell e Larcker (1981) comentam que o avanço de Jöreskog e sua formulação de um modelo geral para a análise de covariâncias fez com que pesquisadores pudessem utilizar as vantagens dos modelos de equação estrutural com construtos não observáveis (latentes) para estimação de parâmetros e testes de hipóteses em modelos causais. A importância do método está na habilidade de compor análises psicométricas e econométricas de tal forma que os melhores recursos de ambos possam ser explorados. É possível formar modelos de equações estruturais econométricos que explicitamente incorporam a noção psicométrica de variáveis latentes. Os pesquisadores de marketing foram introduzidos à técnica de análise pelos trabalhos de Bagozzi (1977). Na aplicação em marketing, os construtos teóricos são tipicamente difíceis de operacionalizar em termos de uma simples medida e erros de medida são frequentemente inevitáveis.

O termo análise de equações estruturais (MEE) designa uma família de procedimentos estatísticos (KLINE, 2011). Essa família é conhecida por diversos nomes: análise de equações estruturais, análise estrutural de covariância, modelo estrutural de covariância ou análise de estruturas de covariância. Jöreskog e Sörbom (1982) comentam que a MEE é empregado para especificar o fenômeno de causa e efeito entre variáveis. Cada equação no modelo presenta uma relação causal, mais do que uma simples associação empírica. Goldberg (1973 apud JÖRESKOG; SÖRBOM, 1982, p.404) considera três situações nas quais o modelo de equações estruturais é importante e os parâmetros de regressão falham ao 
oferecer informação relevante sobre: (1) - quando as medidas observadas possuem erros de medida e quando a relação importante está entre variáveis verdadeiras ou não atenuadas; (2) - quando existe interdependência ou relação causal simultânea entre as variáveis observáveis; e (3) - quando importantes variáveis explicativas não foram observadas (variáveis omitidas).

Kline (2011) ressalta que há dois tipos de variáveis: observáveis (manifestas) e latentes (endógenas). Para a MEE as variáveis observáveis, podem ser categóricas, ordinais ou contínuas, porém as variáveis latentes são contínuas. As variáveis latentes são os construtos hipotéticos ou fatores, também denominadas de variáveis explicativas. Uma variável observável usada como uma medida indireta de um construto é referida como um indicador. Outra classe de variáveis são as denominadas de resíduos ou termos de erro, que podem estar associados a variáveis observáveis ou fatores. Os erros representam a variância não explicada pelo fator, cujo indicador correspondente é suposto de mensurar. Kline (2011) ressalva que os resultados de uma MEE geralmente não podem ser tomados como evidencia de relação causal sem haver o desenho de um experimento.

A fase de estimação do modelo requer obtenção de estimativas dos parâmetros do modelo de forma a reproduzir o melhor possível os dados observados na amostra. $O$ objetivo da estimação é encontrar um conjunto de estimativas para os parâmetros do modelo (pesos fatoriais, coeficientes de regressão, covariâncias, médias etc.). A avaliação da qualidade do ajustamento do modelo pode ser feita por meio de: 1testes de ajustamento; 2- índices empíricos que se baseiam nas funções de verossimilhança ou na matriz de resíduos obtidos durante o ajustamento do modelo; ou ainda 3- testes com a análise de resíduos e da significância dos parâmetros. (MARÔCO, 2010)

Marôco (2010) comenta que os métodos de ajustamento utilizados em MEE variam conforme o software utilizado e respectivas funções de discrepância (f), bem como variam com o tipo de pressuposto sobre a natureza da medida e das distribuições de variáveis. O software adotado AMOs (IBM, SPSS) utiliza o método mais tradicional, Máxima Verossimilhança (ML), assim como: o de Mínimos Quadrados Não 
Ponderados (ULS), Mínimos Quadrados Generalizados (GLS), Distribuição Assimptótica (ADF) ou também chamado de Mínimos Quadrados Ponderados (WLS).

Outra recomendação de Kline (2011) refere-se à ênfase em testes estatísticos para MEE. Vários efeitos podem ser testados para significância estatística em MEE, desde variância de uma simples variável até o modelo inteiro, avaliado por múltiplas amostras. A MEE permite avaliação do modelo inteiro o que traz uma perspectiva maior à análise: o modelo deve ser rejeitado? Modificado? Em caso afirmativo, como? Existe um senso para que a visão de todo o modelo tenha precedência sobre as de efeitos individuais. A segunda razão refere-se ao menor papel dos testes estatísticos em relação aos requerimentos gerais. Se a amostra é grande, um resultado estatisticamente significante, simplesmente confirma uma grande amostra. A terceira razão é que a significância estatística (valores de p) para efeito de variáveis latentes é calculada pelo computador, porém essa estimativa pode mudar, digamos para diferentes algoritmos de estimação ou por diferentes ferramentas de softwares utilizadas para um mesmo conjunto de dados. E, finalmente, a quarta razão não é específica à $M E E$, porém considera os vários tipos de análises estatísticas na ciência do comportamento: deve-se em geral estar mais preocupado em estimar os tamanhos ou magnitudes dos efeitos do que os resultados dos testes estatísticos.

A avaliação da qualidade do modelo de regressão linear no âmbito da MEE pode ser feita à semelhança da análise de regressão tradicional, pelo coeficiente de determinação $\left(R^{2}\right)$. Segundo Hair et al. (2005), o coeficiente de determinação explica a variância da variável dependente em torno de sua média que é explicada pelas variáveis independentes ou preditoras. $O$ coeficiente de determinação estima a fração da variabilidade de $Y$ que é explicada pelo modelo, sendo $0 \leq R^{2} \leq 1$. De uma forma geral considera-se que $R^{2} \geq 0,5$ é indicador de modelos com capacidade explicativa adequada. Quanto mais próximo de 1, melhor o poder explicativo. A significância também é testada e para resultados diferentes de zero, o modelo explica significativamente a variabilidade da variável dependente. $O$ coeficiente de determinação é estimado somente para as variáveis latentes endógenas. 


\subsubsection{Pressupostos da MEE}

Marôco (2010) descreve que o método de estimação do modelo: máxima verossimilhança $(\mathrm{ML})$ ou o método dos mínimos quadrados generalizados (GLS) requer que as variáveis manifestas apresentem distribuição normal multivariada para que os mesmos apresentem propriedades de consistência. A estimativa do parâmetro tende ao seu verdadeiro valor quando o tamanho da amostra aumenta. Além disso, o autor relata que é frequente utilizar as medidas de forma de distribuição (assimetria e curtose) para verificar a normalidade. Kline (2011) cita que existe menos consenso em torno da curtose. Curtoses univariada e multivariada com valores absolutos entre 8 a 20 são consideradas extremas. A regra de bolso sugere que valores absolutos $>10$ representam problema $\mathrm{e}>20$ são indicadores de violações severas à distribuição da normalidade. No caso de assimetrias, variáveis com valores absolutos $>3$ são consideradas extremamente assimétricas e tornam-se inadequadas para o emprego dos métodos ML e GLS.

Marôco (2010) ainda comenta que apesar de existirem testes de normalidade multivariada e se poder assumir, com algumas exceções, que se um conjunto de variáveis apresentarem distribuição normal univariada então a distribuição condicionada das variáveis é normal multivariada, estes mesmos testes de ajustamento à distribuição normal não estão inseridos nos principais softwares de MEE. São testes muito sensíveis a pequenos desvios de normalidade tendo probabilidade de erros tipo I muito elevada. A alternativa frequente é utilizar as medidas da forma da distribuição (curtose e assimetria) acima descritas. A não rejeição de Ho no teste de curtose ou assimetria indica que estas medidas de forma não são significativamente diferentes de zero, o que corresponde à situação ideal. $\mathrm{A}$ análise é feita em valores absolutos.

Marôco (2010) considera uma questão relevante em aplicações da MEE, na frequência de utilização de variáveis com diferentes graus de afastamento à normalidade, até que ponto a violação do pressuposto de normalidade afeta a qualidade dos resultados. $O$ teste $X^{2}$ é afetado e não central. A estimativa da significância do teste obtida com a distribuição central é inadequada. Se as variáveis 
exógenas não são normais, elas tendem a inflacionar o valor da estatística do $\mathrm{X}^{2}$, quanto maior for o desvio à normalidade, levando à rejeição de Ho mais vezes do que o correto (inflação do erro tipo I). $O$ teste pode ser corrigido por uma medida de enviesamento multivariado, transformando-se as variáveis para forçar a normalidade. Ou se usar um método de estimação que não exija a normalidade. De forma semelhante, os índices de ajustamento calculados a partir da estatística do $\mathrm{X}^{2}$ serão também inflacionados (CFI e RMSEA). Sob as condições de não normalidade os erros padrão serão subestimados, o que os torna significativos mais vezes do que o correto. A recomendação é utilizar métodos de estimação que não exigem normalidade multivariada (distribuição assimptótica livre - ADF ou mínimos quadrados ponderados - WLS). Este método exige amostras de dimensão muito elevadas com $n>1.000$ de forma a evitar problemas de convergência numérica e de singularidade. Em último caso, se a dimensão da amostra não for suficiente, alguns softwares permitem a utilização de métodos bootstrap. Bollen (1989) sugere primeiro, a transformação das variáveis para se aproximarem da normalidade; em segundo, o ajustamento dos testes estatísticos e erros padrões de forma a modificar os testes de significância; em terceiro, o bootstrap, porém o método requer várias horas de análise e até tempo demais consumido para ser empregado na prática. A quarta abordagem seria o emprego de um estimador alternativo que permita não normalidade e seja eficiente assimptoticamente, como o WLS (weighted least squares). Prearo $^{36}$ sugeriu ampliar a amostra para mínimo de 2.000 casos ou utilizar outro método de estimação, como o PLS, por exemplo.

Segundo Prearo (2008) o teste de Mardia é o mais disponível teste de normalidade multivariada e o mesmo está inserido no pacote do software LISREL e EQS, baseando-se nos valores de assimetria e curtose. Entretanto, Johnson e Wichern (1998) alertaram que para dados reais, a presença de variáveis com distribuição normal multivariada dificilmente ocorre. Prearo (2008) reitera que a densidade normal é frequentemente uma aproximação útil à verdadeira distribuição da população.

\footnotetext{
${ }^{36}$ Em reunião com o prof. Dr Leandro Campi Prearo do INPES - USCS, durante a discussão dos resultados das análises do modelo estrutural.
} 
Por último, Marôco (2010) comenta que além da normalidade multivariada, a ausência de multicolinearidade (abordada no item 4.2.7.3 - validade) e a inexistência de outliers devem ser verificadas. $O$ autor comenta que a medida mais frequente é a distância $\left(D^{2}\right)$ de Mahalanobis para outliers multivariados.

\subsubsection{2 Índices de qualidade de ajustamento}

A estimação da qualidade do ajustamento do modelo estrutural tem o objetivo de avaliar o quão bem o modelo teórico é capaz de reproduzir a estrutura correlacional das variáveis manifestas observadas na amostra. Marôco (2010) constata que a avaliação da qualidade é uma das áreas menos consensuais entre os diversos autores com diferentes estratégias e recomendações. Por sua vez, existem dezenas de estatísticas que podem ser utilizadas para a avaliação da qualidade, calculadas pela maioria dos softwares de MEE. O autor classifica os índices em cinco grandes famílias: 1- índices absolutos; 2- índices relativos; 3- índices de parcimônia; 4índices de discrepância populacional e 5- índices baseados na teoria da informação.

As principais estatísticas escolhidas para avaliar fatores latentes e o modelo estrutural final foram (MARÔCO, 2010):

a. Limite inferior e superior das cargas padronizadas ( );

b. Teste de Qui Quadrado $\left(X^{2}\right)$ : medida de "competência" do ajuste. Jöreskog e Sörbom (1982) ressaltam que o teste $X^{2}$ não é válido como parâmetro na maioria dos casos. Primeiro, porque o modelo é uma aproximação da realidade. O problema estatístico é de ajuste do modelo e não de um teste de hipóteses. Segundo, o teste $X^{2}$ somente é válido se: (1) todas as variáveis observadas possuem uma distribuição normal multivariada; (2) a análise é baseada na amostra da matriz de covariância $S$ (não é permitida a padronização); e (3) o tamanho da amostra precisa ser bastante grande.

c. Verificação dos graus de liberdade.

d. O $p$-value - para significância de $p<0,05$. 


\section{1- Índices absolutos}

e. O índice absoluto $\mathrm{X}^{2} / g$ l: o valor esperado dos graus de liberdade é igual ao valor esperado da estatística do teste. No ajustamento perfeito esse valor é 1 . De uma forma geral, o ajustamento considerado bom deve ser $<2$, aceitável se $<5$ e inaceitável para valores $>5$, segundo Arbuckle (2008 apud MARÔCO, 2010, p. 43)

f. GFI - Goodness of fit index - índice criado por Jöreskog e Sörbom (1982). GFI é uma medida da quantidade relativa de variância e covariância contabilizadas conjuntamente para o modelo. Como o modelo é uma tentativa e ele é considerado apenas uma aproximação da realidade, deveria obedecer a três quesitos: 1- distribuição normal das variáveis observáveis, 2- a análise ser baseada na matriz de covariância da amostra e, 3- o tamanho da amostra deve ser grande. Todos esses pressupostos são raramente obtidos na prática, portanto o GFI explica a proporção da covariância observada entre as variáveis manifestas, explicada pelo modelo ajustado. Valores de $\mathrm{GFI}<0,9$ indicam modelos com mau ajustamento aos dados; GFI com intervalo de $[0,90 ; 0,95]$ indica um bom ajustamento; valores de GFI > 0,95 indicam ajustamento muito bom. Um GFI = 1 indica um ajustamento perfeito. O GFI tem a tendência de aumentar com o tamanho da amostra. (MARÔCO, 2010, p.44)

\section{2- Índices relativos}

g. CFI - Comparative fit index - compara o ajustamento do modelo em estudo $\left(X^{2}\right)$ em graus de liberdade $(g l)$ com o ajustamento do modelo basal em graus de liberdade $g l_{b}$ (MARÔCO, 2010, p.45). Valores de CFI $<0,9$ indicam um mau ajustamento; valores no intervalo $[0,90 ; 0,95]$ indicam bom ajustamento $e$ valores 0,95 indicam ajus0tamento muito bom.

h. TLI - Tucker-Lewis index ou também conhecido como Bentler-Bonett nonnormed fit index (NNFI). Os valores variam entre 0 e 1, mas não estão limitados a este intervalo. Valores próximos de 1 indicam um ajustamento muito bom. 


\section{3- Índice de parcimônia}

i. AGFI (PGFI) - Goodness of fit index ajustado para graus de liberdade do modelo, para valores entre 0 e 1 . Diferente do $X^{2}$, tanto o GFI quanto o AGFI são independentes para o tamanho da amostra e relativamente robustos quanto a desvios de normalidade (JÖRESKOG E SÖRBOM, 1982). Os valores de referência são menores aos do índice relativo (sem penalização). Em geral, valores < 0,6 indicam mau ajustamento; valores no intervalo ]0,6;0,8] indicam um ajustamento razoável; valores $>0,8$ são indicadores de um bom ajustamento.

\section{4- Índice de discrepância populacional}

j. RMSEA - Root Mean Square Error of Approximation - a maioria dos softwares calcula um intervalos de confiança de $90 \%$ para a RMSEA populacional. Segundo Marôco (2010) os estudos empíricos sugerem ajustamento inapropriado para valores $>0,1$; o ajustamento é considerado médio para RMSEA no intervalo de [0.08; 0,10$]$, bom para $[0,05 ; 0,08]$ e muito bom quando for $<0,05$ Arbuckle (2008, apud MARÔCO, 2010, p.48). Porém, Marôco (2010) comenta que o valor do RMSEA tende aumentar com a adição de mais variáveis ao modelo. Chen et al. (2008 apud MARÔCO, 2010 p. 48) demonstraram que $o$ ajustamento para valores inferiores a 0,05 pode não ser adequado. Para os autores, a utilização de indicadores de um bom ajustamento vai depender da especificação do modelo, dos graus de liberdade e da dimensão da amostra e não de uma regra ou valor universal do RMSEA. Bagozzi e Yi (2012) comentam que este é um índice reconhecido e mais recomendado, o qual oferece a quantidade média de desajuste de um modelo por grau de liberdade. Em sua revisão sugere os valores recomendados por Hu e Bentler (1998) e Hu e Bentler (1999, apud BAGOZZI; $\mathrm{YI}, 2012$, p. 28) RMSEA $\leq 0,06, \mathrm{TLI} \geq 0,95, \mathrm{CFI} \geq 0,95$.

\section{5- Índices baseados na teoria da informação}

Marôco (2010) comenta que esses índices são baseados na estatística $X^{2} e$ penalizam o modelo de acordo com sua complexidade. São apropriados quando houver comparação de modelos alternativos que se ajustem igualmente aos dados. 
Abaixo se encontra o quadro 6 - resumo dos valores de referência dos índices adotados para este estudo.

Quadro 6 - Resumo de valores de referencia para índices de ajustamento

\begin{tabular}{|l|l|}
\hline \multicolumn{1}{|c|}{ Estatística } & \multicolumn{1}{c|}{ Valores de referência } \\
\hline $\mathrm{X}^{2}$ e $p$-value & Quanto menor, melhor; $p>0,05$ \\
\hline $\mathrm{X}^{2} / g l$ & $>5-$ mau ajustamento \\
& {$[2 ; 5]-$ ajustamento aceitável } \\
& ] $1 ; 2]-$ ajustamento bom \\
& $\sim 1-$ ajustamento muito bom \\
\hline CFI & $<0.8-$ mau ajustamento \\
GFI & {$[0.8 ; 0.9[-$ ajustamento aceitável } \\
TLI & {$[0.9 ; 0.95[$ ajustamento bom } \\
& $\geq 0.95-$ ajustamento muito bom \\
\hline AGFI & $<0.6-$ mau ajustamento \\
& {$[0.6 ; 0.8[-$ ajustamento bom } \\
\hline RMSEA com intervalo de confiança $90 \%$ & $\geq 0.8-$ ajustamento muito bom \\
& $>0.10-$ ajustamento inaceitável \\
& ] $0.05 ; 0.10]-$ ajustamento bom \\
& $\leq 0.06-$ ajustamento muito bom (BAGOZZI E \\
& YI,2012) \\
& $p$-value $\geq 0.05$ \\
\hline
\end{tabular}

Fonte: adaptado de Marôco (2010, p. 51) e Bagozzi e Yi (2012, p. 28).

\subsubsection{Validação do modelo}

Marôco (2010) ressalta que além da qualidade global do ajustamento a confiabilidade e a validade dos instrumentos de medidas estão no âmbito da AFC. O conceito de confiabilidade refere-se à capacidade de uma medida ser consistente, como propriedade de consistência e reprodutibilidade da medida. Porém toda medida é sujeita a erro e a confiabilidade se torna uma estimativa e não é um dado.

Para Marôco e Garcia-Marques (2006) o erro é a variabilidade observada no processo de mensuração de um mesmo objeto. Ausência de erro é consistência. $O$ erro associado à variabilidade observada é um erro aleatório (que seja de magnitude reduzida), porém o erro pode ser sistemático, o que traduz uma questão de validade e não mais de confiabilidade. A presença de erro sistemático reduz a validade do instrumento que mede algo que não é suposto de medir, mesmo que o faça de forma confiável. A confiabilidade é condição necessária, porém não suficiente para validade. Se os dados não são confiáveis, não são igualmente válidos, visto que não 
traduzem o conceito que pretendiam traduzir. A confiabilidade de uma medida é o primeiro passo para saber da sua validade, porém não é suficiente.

Para Marôco e Garcia-Marques (2006) a consistência de uma medida nada traduz sobre sua dimensionalidade. Se uma medida é unidimensional, ela apresenta certamente maior consistência. Cortina (1993) descreve que um conjunto de itens pode apresentar elevada consistência interna (grau de inter-relação interna), porém, ainda assim, definir uma escala multidimensional. Marôco e Garcia-Marques (2006) comentam que a elevada consistência na presença de multidimensionalidade indica que os itens que compõem cada construto estão fortemente correlacionados, apesar da existência das dimensões estabelecerem uma relação inferior àquela que é observada entre os itens que as compõem. E por fim, uma escala pode ser unidimensional e por falta de confiabilidade da sua medida (ou elevado erro de medida), apresentar fraca consistência.

Para Marôco e Garcia-Marques (2006) os fatores que afetam a magnitude do índice de confiabilidade são: variabilidade e simetria da distribuição. A mesma medida aplicada a uma amostra com sujeitos mais homogêneos ou mais heterogêneos produzirá resultados diferentes de confiabilidades. Todas as características dos contextos de coleta dos dados que estejam relacionadas com uma maior variabilidade observada nos dados (intra ou inter) afetam o índice de alfa de Cronbach. O tamanho da amostra influencia a variabilidade observada, portanto maior número de itens terão valores de alfa superiores e de erros-padrão inferiores em relação aos instrumentos com menor número de itens. O alfa de Cronbach apresenta várias limitações. É afetado pela não normalidade multivariada, pela simetria composta, pelo pressuposto de homogeneidade, pelas covariâncias heterogêneas e pela heteroscedasticidade de variâncias. A recomendação dos autores é para interpretar os índices alpha de Crombach à luz das características da medida a que se associa e da população onde essa medida foi feita.

Bagozzi e Yi (2012) comentam que se tornou lugar comum medidas de confiabilidade em qualquer estudo, mesmo com MEE. Os autores afirmam que em MEE esta prática é desnecessária ou redundante, pois a informação oferecida pelas 
cargas e variâncias de erros dos fatores incorpora confiabilidade. Porém há uma tradição na psicometria e muitas revistas acadêmicas a requerem.

\subsubsection{Unidimensionalidade}

Garver e Mentzer (1999) comentam o conceito de unidimensionalidade, definida como a existência de um construto subjacente para um conjunto de itens (ou indicadores). A unidimensionalidade representa o grau em que os itens representam somente uma variável latente ou fator ou construto. A pergunta da unidimensionalidade seria: os indicadores formam um único construto subjacente?

Para Garver e Mentzer (1999) comentam que os pesquisadores ao examinarem unidimensionalidade em estudos contemporâneos sugerem fortemente que a análise fatorial confirmatória (AFC) é um método mais rigoroso e preciso para testar a unidimensionalidade, quando comparado às técnicas multivariadas tradicionais, tais como a análise fatorial exploratória (AFE). A AFC oferece uma interpretação mais restrita da unidimensionalidade em comparação com métodos tradicionais, tais como: coeficiente alpha de Cronbach, correlação total entre itens e a AFE. Anderson e Gerbin (1988), por sua vez, ressaltam que os critérios para atingimento da unidimensionalidade são obtidos por meio das análises de consistência interna e externa.

O critério de unidimensionalidade para este estudo foi atendido, realizando-se primeiramente uma análise fatorial exploratória. A partir da AFE, foi feita a eliminação dos indicadores que apresentaram problemas com o construto latente ou apresentaram correlação com outros construtos. Em seguida efetuou-se a análise fatorial confirmatória individual. Além disso, Garver e Mentzer (1999) recomendam que a AFC deva ser feita individualmente com os construtos latentes e, em seguida, deve ser feita com todos os construtos. E, por fim, a avaliação da qualidade de ajustamento do modelo geral evidenciará a unidimensionalidade na presença de outros construtos, o que assegurará se os construtos possuem consistência interna e externa. 
Marôco (2010) e Garver e Mentzer (1999) informam que os critérios para avaliar unidimensionalidade na AFC são: 1- índices de qualidade de ajuste do modelo geral; 2- componentes de medida do modelo ajustado. No segundo critério os componentes da medida do modelo devem ser avaliados para testar a unidimensionalidade. Indicadores de diagnóstico tais como: resíduos padronizados e índices de modificação, as relações entre indicadores e variáveis latentes devem ser investigadas. Ao examinar os resíduos padronizados, o modelo não pode apresentar valores > 2,00 ou 2,58 em módulo, dependendo do intervalo de confiança escolhido. Se resíduos padronizados estão relacionados com subconjunto de itens que mediram o mesmo construto, portanto este subconjunto representa em si um fator unidimensional. Se um item está indicando um fator "incorreto", este item apresentará altos resíduos padronizados negativos com seus itens a priori e possuirá altos resíduos padronizados positivos com seu fator "correto". Se o item pertence a mais de um fator, o mesmo terá grandes resíduos com itens diferentes e diferentes fatores, devendo ser descartado. E, finalmente, grandes resíduos padronizados sem um padrão aparente podem representar um item ruim. O modelo deve ser reespecificado.

Garver e Mentzer (1999) e Marôco (2010) recomendam que para avaliação dos componentes de medidas do modelo é importante examinar as direções, magnitudes e significância dos parâmetros estimados entre indicadores e variáveis latentes. Os sinais dos parâmetros estimados devem ser consistentes com a teoria. A magnitude das estimativas padronizadas dos parâmetros para o modelo devem ser $\geq 0,70$ para assegurar a unidimensionalidade. Cada parâmetro deve ser estatisticamente significativo $(\alpha \leq 0,50)$ o que corresponde a um valor $t \geq 1,96$.

\subsubsection{Confiabilidade}

Garver e Mentzer (1999) comentam que confiabilidade de escala ou instrumento se refere à consistência interna da escala para medir uma variável latente. Escalas confiáveis possuem itens que medem os mesmos construtos unidimensionais e eles variam em conjunto, estatisticamente. Confiabilidade avalia a consistência, não a precisão, da escala de medida. A questão envolvida é se a escala for administrada 
ao longo do tempo, ela produziria resultados consistentes? Os testes de confiança assumem a unidimensionalidade, portanto a unidimensionalidade deve ser alcançada primeiramente.

Marôco e Garcia-Marques (2006) consideram que o alfa de Cronbach é uma das medidas mais utilizadas para avaliar a confiança ou a consistência interna, porém tem sido questionado o seu emprego e oferecem alternativas. A partir da década de 90, vários autores argumentam ser o alpha de Cronbach errado para inferências de confiabilidade. Entre psicometristas o critério de seleção de instrumento de escala psicométrica ainda tem adotado a comparação da confiabilidade de alpha de Cronbach. Para o presente estudo, a escala utilizada não foi construída para fins de escala psicométrica, portanto se desconsiderou esta análise. Bagozzi e Yi (2012) também comentam que o Alfa de Cronbach e outras formas de confiabilidade não devem ser aplicadas rigidamente na MEE e o foco deve estar nas hipóteses a serem testadas e nos índices de qualidade de ajustamento.

Marôco (2010) elenca as medidas alternativas sugeridas por vários autores. A medida de confiabilidade facilmente calculável a partir dos resultados da AFC e particularmente apropriada para análise de todos os itens de um fator é a confiabilidade composta definida por Fornell e Larcker (1981) com cargas fatoriais padronizadas e seus erros (1 - carga padronizada):

Os resultados devem estar acima de 0,70 ou um pouco abaixo se a pesquisa for exploratória ou se o modelo geral tiver um ajuste satisfatório (BAGOZZI; YI, 2012). Bagozzi e Yi (2012) comentam que não existem padrões aceitáveis universais para confiabilidade composta, pois apesar de um parâmetro apresentar carga individual baixa, o fator a que ele corresponde pode ter desempenho satisfatório em modelos mais complexos. Os padrões de confiabilidade individual clássica são $\geq 0,70$ para se obter uma confiabilidade composta satisfatória, ideal para 50\% da variância explicada pelo fator. Porém em modelos complexos podem ser encontradas cargas tão baixas quanto 0,50 desde que ainda ocorra dentro de um ajustamento satisfatório para o modelo geral. 


\subsubsection{Validade}

E, finalmente, validade é conceituada, segundo Marôco (2010) como uma propriedade do instrumento que avalia se o mesmo mede o que de fato se quer medir e se ele é a operacionalização dos construtos latentes. Bagozzi e Yi (2012) acrescentam que a validade do construto endereça tanto o grau de concordância dos indicadores hipotetizados a medir um dado construto bem como a distinção entre tais indicadores e os indicadores de outro construto.

Anastasi e Urbina, 1997 (apud MARÔCO, 2010, p. 175) descrevem os componentes da validade: a validade para a descrição de conteúdo, a validade para o critério de predição e a validade para a identificação do construto. No âmbito da MEE, a validade relacionada com o construto é obtida pela validade fatorial, validade convergente e validade discriminante. A validade fatorial confere se os indicadores de um determinado construto medem o fator latente que se pretende medir. A validade convergente é a extensão pela qual as variáveis latentes se correlacionam positiva e significativamente a indicadores desenhados a medir o mesmo construto latente e quando os indicadores apresentam correlações positivas e elevadas entre si. Ao contrário, a validade discriminante representa a extensão pela qual os indicadores que representam um dado construto discrimina tal construto de outros indicadores pertencentes a outros construtos. Ocorre quando o construto em estudo não se encontra correlacionado com construtos que operacionalizam fatores diferentes (por exemplo: construtos relacionados à autoeficácia não podem se correlacionar com construtos relacionados à atratividade do varejo). A validade de critério pode ser determinada com análises de multigrupos. (MARÔCO, 2010; GARVER e MENTZER, 1999)

Marôco (2010) ressalta que a validade fatorial é avaliada pelos pesos das cargas padronizadas ( ij). É usual assumir que se todos os itens são $\geq 0,5$, o fator apresenta validade fatorial. A confiabilidade individual do item ( $\left.\mathrm{ij}^{2}\right)$, correspondendo à fração da variabilidade total do item explicado pelo fator de cujo item se manifesta. A confiabilidade do item é uma condição necessária, porém não suficiente para 
demonstrar a validade fatorial. De uma forma geral se considera $i^{2} \geq 0,25$ como indicador de confiabilidade apropriado.

Marôco (2010) comenta que a validade convergente ocorre quando o comportamento dos itens é explicado essencialmente por esse fator. Fornell e Larcker (1981) propuseram avaliar a validade convergente por meio da medida de variância extraída média (VEM) que reflete a quantia geral da variância nos itens do construto latente. Calcula-se a variância extraída média para cada um dos fatores em estudo, refletindo a quantia geral de variância nos itens explicada pelo construto latente. Valores de $\mathrm{VEM}_{\mathrm{j}} \geq 0,50$ para um construto. (MARÔCO, 2010; HAIR et al., 1995) $)^{37}$

Bollen (1989) flexibiliza para um limite inferior de 0,4 para variância média extraída (VEM).

Garver e Mentzer (1999) definem a validade convergente como a extensão na qual a variável latente se correlaciona com itens desenhados a medir a mesma variável latente. Traduzindo, será que os indicadores intencionados a medir uma dada variável latente estatisticamente convergem conjuntamente?

A validade discriminante explica a extensão em que os itens representados por uma dada variável latente discriminam tal construto de outros itens que representam outros construtos. (GARVER e MENTZER, 1999)

A validade discriminante no contexto da MEE, segundo Marôco (2010) avalia se os itens que refletem um fator não estão correlacionados com outros fatores, ou seja, os fatores definidos por cada conjunto de variáveis manifestas (indicadores) são distintos. A literatura utiliza a avaliação de medida do modelo apresentada por

\footnotetext{
${ }^{37}$ Confiabilidade e variância extraída foram orientadas pelo prof. Dr. Leandro Prearo em reunião 26/03/14 e de seu material de aula.
} 
Fornell e Larcker (1981), porém Marôco (2010) descreve que a validade discriminante deve ser demonstrada ao ser atendida uma, ou mais, condições abaixo:

- A variância extraída média para cada construto deve ser: VEM $\geq$ (correlação entre construtos) ${ }^{2}$, o que é denominado de variância compartilhada. Os dados são apresentados na forma de uma matriz com todos os fatores, sendo na diagonal a VEM. (MARÔCO, 2010; FORNELL e LARCKER, 1981).

- O teste da diferença dos $X^{2}$ é realizado entre o modelo inicial constrito que força em $100 \%$ a correlação entre todos os construtos latentes (exógenas) do modelo (a correlação entre fatores é perfeita e igual a 1) contra o modelo final livre. As hipóteses do teste são: $H \square: X_{r}{ }_{r}=X^{2}{ }_{u}$ ou $H_{1}: X^{2}{ }_{r} \neq X^{2}{ }_{u}$. A ideia é rejeitar $\mathrm{H} \square$.

- Se no intervalo de confiança a 95\% para o modelo estimado com correlação livre não contiver o valor 1 .

Marôco (2010) comenta que na parte estrutural do modelo as variáveis exógenas (independentes) não se encontram fortemente associadas. Grewal, Cote e Baumgartner (2004) destacam o problema de a multicolinearidade estar intimamente relacionada com a validade discriminante. A multicolinearidade em excesso pode criar problemas de inferência e estimação, principalmente quando há alta multicolinearidade em combinação com baixa confiabilidade composta, amostra com tamanho pequeno e baixa variância explicada nos construtos endógenos. Os autores relatam que se o critério de Fornell e Larcker (1981) for atendido, dificilmente ocorrerá um erro de inferência. Grewal; Cote; Baumgartner (2004) levantaram os vários métodos gerais citados na literatura para detectar multicolinearidade: 1- matriz de correlação das variáveis preditivas; 2- matriz de correlação dos coeficientes dos caminhos; 3- determinantes da matriz de correlação das variáveis preditivas; 4- o sinal dos coeficientes dos caminhos; e finalmente, 5fatores de inflação da variância.

Além disso, Grewal, Cote e Baumgartner (2004) ressaltaram que a multicolinearidade entre $0,4-0,5$, o erro tipo II tende a ser pequeno, exceto para: 
valor de confiabilidade $\leq 0,7, R^{2}<0,25$ (baixo) e o tamanho da amostra é pequeno (proporção de $3: 1$ ). Neste caso, os erros tipo II podem ter valores $\geq 50 \%$. Quando a multicolinearidade está entre $0,6-0,8$, o percentual do erro tipo II pode ser substancioso ( $\geq 50 \%$ e frequentemente $>80 \%$ ). Quando a correlação é extremada, em torno de 0,95 , o percentual do erro tipo II, é geralmente inaceitável, com valores $>80 \%$.

\subsubsection{Reespecificação e Validação do Modelo}

O critério de ajustamentos seguiu a orientação de Marôco (2010) para quando o modelo não apresentar bom ajuste. Bagozzi e Yi (2012) comentam que a discriminação é mais difícil de demonstrar quando dois ou mais construtos estão altamente correlacionados, embora eles sejam considerados distintos pela teoria, o que significa que o modelo proposto não é apropriado para explicar a estrutura correlacional das variáveis observadas em uma dada amostra. É possível reespecificar o modelo com algumas alterações reduzidas e melhora significativa do ajustamento.

A reespecificação do modelo pode ser feita por meio de eliminação de vias não significativas, pela libertação de parâmetros anteriormente fixos, pela fixação de parâmetros anteriormente livres ou correlacionando erros de medidas. O software IBM: AMOS calcula os índices de modificação (IM) pelo método dos Multiplicadores de Lagrange. O autor do AMOS, Arbuckle (2009, apud MARÔCO, 2010, p.54) recomenda que a significância dos IM seja avaliada para $\alpha=0,05$. Além disso, a adição de uma nova trajetória ou correlação entre erros pode melhorar consideravelmente o mau ajustamento.

A avaliação da qualidade do ajustamento permite analisar o quão bem o modelo teórico é capaz de reproduzir a estrutura correlacional das variáveis manifestas observadas na amostra em estudo. Segundo Marôco (2010) a avaliação é feita: apelos testes de ajustamento; b- índices empíricos que se baseiam nas funções de verossimilhança ou na matriz de resíduos obtidos durante o ajustamento do modelo; c- ou ainda com a análise de resíduos e da significância de parâmetros. 


\section{a- Teste de $X^{2}$ de ajustamento}

O teste do $X^{2}$ de ajustamento é um teste à significância da função de discrepância minimizada durante o ajustamento do modelo. Se o ajustamento for perfeito o O teste está correto para os métodos ML, ULS, GLS e DWLS ${ }^{38}$ sob a normalidade multivariada das variáveis observadas. A aceitação do $\mathrm{H}_{0}$ tem alto impacto pelo tamanho da amostra e pela não normalidade do modelo. Os softwares MEE reportam o p-value do teste. Para um determinado nível e significância ( $\alpha$ ), rejeita-se $\mathrm{H}_{0}$ se $\mathrm{p}$-value $\leq \alpha$. Barrett (2007) ressalta que o objetivo é aceitar a hipótese nula da não diferença entre a matriz de covariância populacional e a matriz de covariância estimada pelo modelo. Porém o teste apresenta questões de validade na maior parte das aplicações (BENTLER, 2007; JÖRESKOG E SÖRBOM, 1996, MARÔCO, 2010). Em muitos trabalhos empíricos, o modelo se trata de uma tentativa e é considerado como uma aproximação da realidade. Em outras palavras, Marôco (2010) considera "uma simplificação do fenômeno real, com algum significado e utilidade substantiva". O autor comenta sobre a imperfeição dos modelos por não apresentarem-se com o conteúdo de toda a informação. O problema não é considerado estatístico e sim, encerra a capacidade de avaliar se o modelo ajustado é razoável, uma representação simples, mas adequada do fenômeno sob o estudo, um ajuste aos dados coletados.

Ainda sobre índice de modificação (IM), o autor comenta que os mesmos são estimados pela redução conservadora do $\mathrm{X}^{2}$ do modelo, seja pela libertação de parâmetros fixos, pela correlação e erros de medida, pela adição de novas trajetórias estruturais etc. A análise de índices de modificação é feita sequencialmente, iniciando-se pelo maior até chegar ao parâmetro menor, ainda estatisticamente significativo para uma dada probabilidade de erro de tipo I. São introduzidas covariâncias entre construtos nos maiores IM até que $O$ índice de qualidade de ajustamento não apresenta mais um ajuste significativo. A regra recomendada é modificar os parâmetros com IM superior a 11. A adição de uma

\footnotetext{
${ }^{38}$ Métodos de ajustamento utilizados em MEE.
} 
nova correlação entre erros pode melhorar consideravelmente o ajustamento, porém deve ser realizada sempre se avaliando a implicação destas correlações no modelo teórico sustentado em literatura. Sem uma explicação sensata ou teoricamente defensável o resultado fica, no mínimo, dúbio. Quando o reajuste não é mais possível, partiu-se para a retirada do construto, verificando-se beta $(\beta)$ mais frágil entre as estimativas dos parâmetros do modelo.

Por fim, Marôco (2010) ressalta que o processo de ajustamento de um modelo está baseado a uma amostra particular o que aumenta a probabilidade dos erros de super ajustamento do modelo e reduz a validade do modelo para a população.

Após ajustamento do modelo, Marôco (2010) comenta que o mesmo precisa ser validado para uma amostra independente daquela em que o modelo foi ajustado. Uma solução frequente é recorrer a uma estratégia de validação cruzada quando as amostras são de grande dimensão, como por exemplo, 3/4 da amostra, selecionada aleatoriamente pode ser usada para ajustar o modelo e 0 1/4 restante é utilizado para avaliar a invariância do modelo (manutenção da estrutura). Se o modelo ajustado na primeira amostra apresentar um bom ajustamento na segunda amostra, pode-se assumir que o modelo é invariante, o que também representa uma abordagem e análise em multigrupos.

\subsubsection{Análise de mediação e moderação}

Baron e Kenny (1986) esclarecem a função mediadora e moderadora da terceira variável. A função mediadora de uma terceira variável representa o mecanismo gerador que por meio dela a variável independente é capaz de influenciar a variável dependente em estudo. A função moderadora da terceira variável divide uma variavel independente em subgrupos que estabelecem seus domínios de eficácia máxima no que diz respeito a uma determinada variável dependente.

Marôco (2010) comenta que as diferenças entre os modelos de moderação e mediação às vezes são inexistentes. $O$ recurso a um modelo de mediação ou 
moderação é defensável apenas por critérios teóricos, de natureza conceptual e não estatísticos.

Marôco (2010) relata que a interação entre variáveis independentes e dependentes é muito comum na análise estatística clássica de variáveis manifestas. Porém, a inclusão de variáveis latentes na MEE, torna a análise mais complexa, pois: i) os termos de interação podem ser de natureza linear e/ou não linear; ii- a interação pode ocorrer entre variáveis manifestas e latentes; iii- a validação dos pressupostos do modelo, tais como a normalidade multivariada e a ausência de multicolinearidade é difícil de realizar com os fatores de moderação (variável independente $\mathrm{x}$ a variável moderadora). Uma estratégia é estimar scores para variáveis latentes e utilizar estes scores como variáveis manifestas num modelo de path analysis. Outra questão é o termo do produto com variáveis latentes, ou seja, um termo do seu produto explicitamente.

\subsubsection{Mediação}

No modelo de mediação, Baron e Kenny (1986) descrevem que as variáveis mediadoras explicam como as variáveis independentes possuem um efeito mediado por uma variável mediadora que resultam numa variável de desfecho ou dependente. A variável possui efeito mediador quando: (1) variações da variável independente representam significativamente variações na variável mediadora (a); (2) quando variações da variável mediadora representam significativamente variações na variável dependente (b); (3) quando as relações anteriores estiverem controladas, uma relação significante prévia entre as variáveis independente e dependente (direto) já não é significativa (c), o que torna o efeito mediador forte quando o passo (c) é reduzido à zero. Se o passo (c) não é zero, isto indica a operação de efeitos múltiplos de mediação. Se o passo (c) apresenta efeito menor do que o do mediador, em termos de teoria é desejável, pois indica que um dado mediador é potente, embora nem tanto seja uma necessidade e uma condição suficiente para um efeito de ocorrer. 


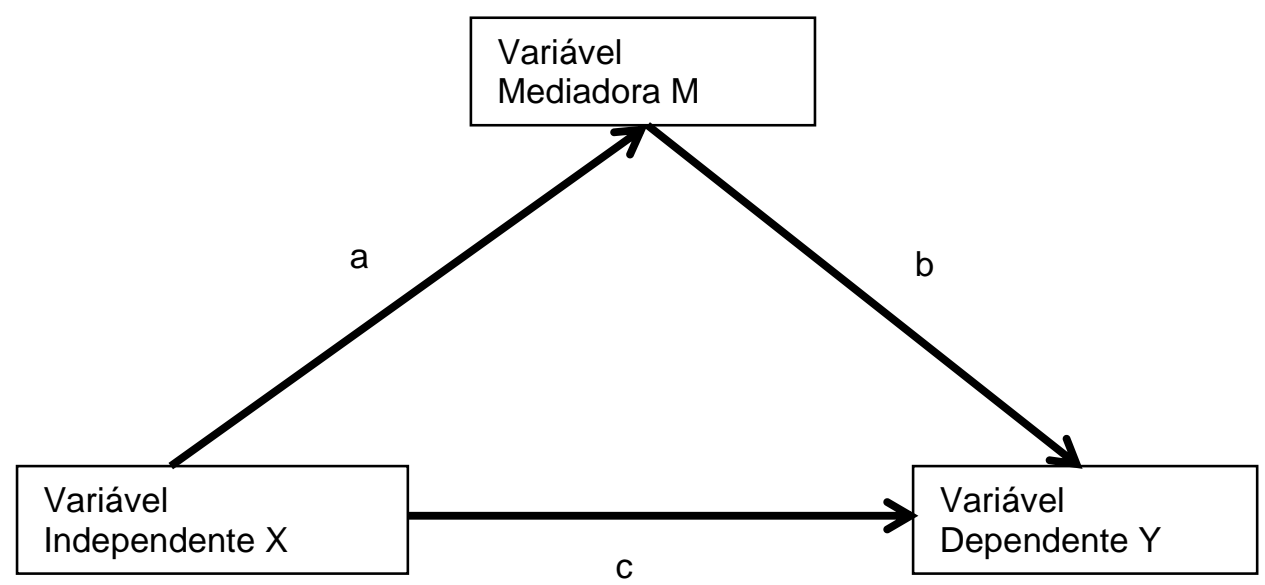

Figura 9 - Variáveis Mediadoras

Fonte - adaptado de Baron e Kenny (1986, p.1176).

Para estabelecer um efeito de mediação, segundo Baron e Kenny (1986), as seguintes condições precisam existir (Figura 9): 1- a variável independente deve afetar o mediador na primeira equação (a); 2- a variável independente precisa afetar a variável dependente na terceira equação (c); 3- a variável mediadora precisa afetar a variável dependente na segunda equação (b). E, finalmente, 4- o efeito direto da variável independente na variável dependente (c) deve ser menor do que na segunda equação (b). E por que a variável independente causa a variável mediadora elas devem estar correlacionadas.

Baron e Kenny (1986) afirmam que a evidencia de mediação é maior quando existe um efeito indireto e não direto denominado de mediação plena (full mediation). Quando ambos os efeitos ocorrem é denominado de mediação parcial. Porém o conceito de efeito direto é claro estatisticamente e não claro teoricamente. Às vezes existem razões teóricas para se esperar efeito direto (ZHAO, LYNCH JR. E CHEN, 2010).

Hair et al. (2009) define mediação completa (full) quando a relação entre uma variável preditora (independente) e uma variável dependente se torna insignificante depois que um mediador é incluído no modelo completo. Mediação parcial se define quando a relação entre preditor e a dependente é reduzida e significante, na presença do mediador (modelo full). 


\subsubsection{Moderação}

Sharma, Durand e Gur-Arie (1981) propuseram-se a estudar mais profundamente as variáveis moderadoras. Para ciências sociais, eles consideram que representam um subconjunto das variáveis ditas "teste" ou de especificação. Em seus estudos, ela especifica a forma e/ou a magnitude da relação entre o preditor e a variável de critério. Dois métodos foram usados para identificar a presença de variáveis moderadoras: análise de subgrupos (multigrupos), análise de moderação por análise de regressão. Porém ambos não são procedimentos intercambiáveis ou equivalentes. Desenvolveram uma tipologia para variáveis testes ou de especificação, com duas características: i- avalia a relação com a variável critério; iiavalia a interação entre a variável teste (especificação) e as variáveis preditoras (Figura 10). Os quadrantes 2,3 e 4 demonstram variáveis moderadoras que ora influenciam a força (quadrante 2) e ora influenciam a forma de relacionamento (quadrante 3 e 4). $O$ conceito da variável moderadora dita análoga (Q. 2) está atrelado à variância parcial, e será determinada pelo tamanho do termo do erro. Quanto maior o erro, menor o grau de relacionamento e vice-versa. Nos quadrantes 3 e 4, há a função de uma terceira variável "z" que modera a forma da relação entre yex (

\begin{tabular}{|c|c|c|}
\hline & $\begin{array}{l}\text { Relacionada com a variável } \\
\text { critério e/ou preditora }\end{array}$ & $\begin{array}{l}\text { Não relacionada com a } \\
\text { variável critério e/ou preditora }\end{array}$ \\
\hline $\begin{array}{l}\text { Sem interação com a variável } \\
\text { preditora }\end{array}$ & $\begin{array}{ll}\text { 1- Variável } & \text { preditora } \\
\text { interveniente, exógena, } \\
\text { antecedente, supressora. } \\
\text { Ou variável preditora } \\
\text { adicional. }\end{array}$ & $\begin{array}{ll}\text { 2- } & \text { Moderador (análogo ou } \\
\text { similar) }\end{array}$ \\
\hline $\begin{array}{l}\text { Interação com a variável } \\
\text { preditora }\end{array}$ & $\begin{array}{ll}\text { 3- } & \text { Moderador } \\
& \text { moderador) }\end{array}$ & $\begin{array}{ll}\text { 4- } & \text { Moderador } \\
& \text { moderador) }\end{array}$ \\
\hline
\end{tabular}

Figura 10- Tipologia para as variáveis de especificação ou teste Fonte: adaptado de Sharma, Durand e Gur-Arie (1981, p.292)

Sharma, Durand e Gur-Arie (1981) descrevem o tipo quase moderador como um caso de não moderação na literatura de psicometria, porque é um preditor. Ele interage com a variável preditora, mas é também uma variável preditora por si. 
Baron e Kenny (1986) comentam que uma forma de capturar o efeito de moderação é explicada pelo diagrama de caminho abaixo (Figura 11). A atividade moderadora é suportada se o diagrama de caminho "c" é significante.

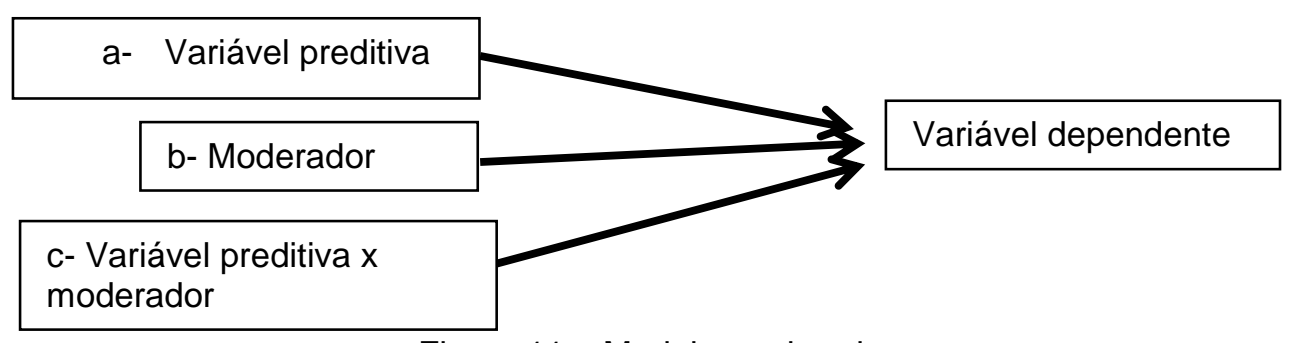

Figura 11 - Modelo moderador

Fonte: adaptado de Baron e Kenny (1986, p.1174).

Baron e Kenny (1986) comentam que é desejável que a variável moderadora não esteja correlacionada com a variável preditiva e/ou com a variável dependente e que ambas estejam no mesmo nível em relação ao seu papel, como variáveis causais antecedentes ou exógenas, ou seja, as variáveis moderadoras sempre funcionam como variáveis independentes. A variável moderadora afeta a direção e/ou a força da relação entre a variável independente e a variável dependente. Os autores consideram que no tipo quase moderador, em contrapartida ao que descreveu Sharma, Durand e Gur-Arie (1981), pode haver efeitos principais para a variável preditora e moderadora, mas não são diretamente relevantes para testar a hipótese de moderação.

Sauer e Dick (1993) assumem que as variáveis moderadoras (sustentadas em teorias a priori) podem afetar relações entre variáveis observadas e/ou latentes de várias maneiras, conforme já discutido acima. Porém, não consideram o tipo quase moderador, que é equivalente ao tipo híbrido de variáveis com efeitos moderadormediador ou mediador-moderador, focando somente nas variáveis do tipo "moderador puro" anunciado por Sharma, Durand e Gur-Arie (1981).

Kenny e Judd (1984) propuseram que os efeitos de moderação entre variáveis latentes poderiam ser obtidos com uma variável latente moderadora nas seguintes formas: i- refletindo-a no cruzamento de todos os itens de dois outros fatores; iicruzando os itens de cada fator em pares; iii- cruzando os itens com pesos mais elevados em cada fator; e/ou ainda iv- cruzando pelo menos três itens para o fator 
de moderação. Marôco (2010) ressalta que dentre estas estratégias, estudos de simulação revelaram que a estratégia de cruzamento de pares de itens teve melhor atuação.

Marôco (2010) lista a seguinte estratégia de análise para um modelo de moderação: a- verificar a normalidade das variáveis manifestas (normalidade multivariada); bassumir que as variáveis latentes são independentes dos resíduos e os resíduos são independentes; c- centrar as variáveis manifestas e ajustar um modelo de medida para cada fator individualmente, $\mathrm{d}$ - usar as estimativas dos parâmetros dos modelos em (c) para calcular e fixar os parâmetros dos termos de interação; e- ajustar o modelo estrutural de moderação e avaliar a significância dos diagramas de caminho.

Marôco (2010) ainda comenta que se o pressuposto de normalidade não é válido (mais frequente do que o contrário), as variáveis latentes também não são normais. A estimação pelo método $M L$ é problemática (sobre-estimação do $X^{2}$ e subestimação dos erros dos parâmetros). O produto das variáveis latentes também não será normal. E, finalmente, a existência de multicolinearidade pode ser outro problema, principalmente quando se usa o produto de todos os indicadores (itens) manifestos.

Bansal, Taylor e James (2005) ao desenvolverem o modelo PPM pensaram em também capturar a complexidade do modelo por meio do papel moderador do efeito mooring. Na pesquisa de migração as variáveis mooring moderam a relação entre os fatores push e pull (LEE, 1966). Mesmo que os fatores push e pull sejam fortes, o consumidor pode permanecer no canal on-line, afetando a intenção de free-riding. As variáveis mooring podem moderar a relação entre fator push e intenção de freeriding e moderar a relação entre fator pull e intenção de free-riding. Os autores trabalharam a moderação de duas formas: 1- variáveis mooring moderam a relação entre variáveis push e intenção de substituição de fornecedor de serviço. Quanto mais forte as variáveis mooring, mais fraca é a relação entre variáveis push e intenção de substituição de fornecedor; 2- variáveis mooring moderam a relação entre variáveis pull e intenção de substituição de fornecedor de serviço. Quanto mais forte as variáveis mooring, mais fraca a relação entre variáveis pull e intenção de substituição de fornecedor. 


\subsubsection{Análise de multigrupos}

A análise de multigrupos, segundo Sharma, Durand e Gur-Arie (1981) se enquadra como moderação com variáveis categóricas (gênero, idade, escolaridade, renda, hábito de compra, comportamentos de busca e compra etc.), também denominadas de discretas segundo Sauer e Dick (1993). A amostra é dividida em subgrupos tomando como referencia uma variável terceira, o moderador hipotético (na forma qualitativa como, por exemplo, gênero, faixa etária e renda; como variável contínua ou quantitativa ou por importância). Após a separação em grupos, procede-se uma análise da regressão para investigar a relação entre a variável preditiva e variável de critério em cada subgrupo.

A comparação entre os parâmetros de regressão (cargas fatoriais padronizadas) para homens e mulheres pode apoiar uma interação de gênero e a variável independente, se houver significância na diferença. Requer amostra grande para não dar distorções no teste $\mathrm{X}^{2}$ e erros padronizados (BAGOZZI; YI, 2012).

Tem como objetivo avaliar a equivalência ou invariância, seja do fator, seja do modelo estrutural para diferentes grupos ou populações (variáveis categóricas) com características diferentes entre si, segundo Marôco (2010). Este tipo de análise requer grupos mutuamente exclusivos. A análise é realizada por meio de comparação do ajustamento do modelo aos diferentes grupos, simultaneamente. Também pode ser feito a análise de médias de variáveis latentes em diferentes populações, análogo a ANOVA para variáveis manifestas.

Marôco (2010) relata que a análise simultânea impõe restrições ordenadas e de complexidade crescentes: i- aos pesos fatoriais e covariâncias dos fatores de um modelo de medida (invariância entre grupos); ii- aos coeficientes estruturais (se as relações causais são invariantes entre os grupos); iii- às variâncias/covariâncias (se os resíduos do modelo se mantêm invariantes nos diferentes grupos).

Sauer e Dick (1993) recomendam que a estimação dos parâmetros seja feita no modo de "restrição" quando se compara a amostra da matriz covariâncias 
observadas dos indicadores medidos com a matriz de covariância dos parâmetros estimados pelo modelo inteiro. Na aplicação pelo software Amos (IBM SPSS) a variável discreta moderadora, as matrizes de covariâncias ou qualquer conjunto de parâmetros será constrito para ser igual entre grupos, conforme a especificação para multigrupos. Isso acontece em duas rodadas. $\mathrm{Na}$ primeira rodada se utiliza a restrição e se compara os $\mathrm{X}^{2}$ e os $\mathrm{gl}$. Na segunda rodada se remove a restrição e se especifica a relação que vai ser estudada. $O$ efeito moderador é testado estatisticamente pela diferença observada entre os novos valores de $X^{2}$ e os $g /$ são lançados na tabela de distribuição de $X^{2}$ (utilizado o software econométrico GRETL).

$\mathrm{Na}$ análise de multigrupos buscou-se identificar comparativamente a dinâmica de intensidade de forças entre cargas padronizadas para um dado parâmetro de cada grupo da variável categórica, o que possibilitou muita riqueza de informação.

\subsubsection{Comparação de médias entre grupos com variáveis latentes}

Marôco (2010) comenta que para estimar diferenças entre médias de grupos nas variáveis latentes, o modelo necessita ser expandido nos grupos para incluir um vetor (intercepto) de ordenadas na origem, um vetor adicional de médias. A análise procede com a comparação das médias das variáveis latentes (exógenas) do modelo estrutural em relação às médias de um grupo de controle fixado em "0". O procedimento foi realizado pelo software Amos, conforme passo a passo orientado pelo autor. Os valores das diferenças de médias, bem como as estatísticas das relações foram capturados da análise.

Cabe ressaltar, que o cálculo da média das variáveis latentes somente é possível para as variáveis latentes exógenas, de primeira ordem (segundo descreve o software Amos: IBM SPSS versão 21). Para os modelos que não possuem médias estruturais a partir de variáveis exógenas, a função "structural means" fica desabilitada. Portanto, não foi possível calcular diferenças de médias para as variáveis latentes de segunda ordem: autoeficácia, retenção na firma e atratividade do varejo tradicional. 


\subsection{Limitações do método}

Szymanski e Hise (2000) comentam que a pesquisa on-line não pode ser longa. Os consumidores mostram ser refratários ao tempo estimado para responder o questionário on-line. Cita como princípios das pesquisas NFO (National Family Opinion - EUA) o questionário não ter mais do que 40 itens. Desta forma, construtos e conceitos precisariam ser capturados de forma parcimoniosa em pesquisas interativas. Uma pesquisa on-line apresenta limitações a serem consideradas nos achados. A presente pesquisa foi considerada longa, pois foram oito blocos de questões com filtros e informações gerais sobre o processo de compra; 18 blocos de questões com 86 itens sobre os construtos; e, finalmente, um bloco sobre perfil do respondente.

Além disso, Szymanski e Hise (2000) endereçam a questão da representatividade da população. Os participantes desta pesquisa on-line E-bit são frequentemente participantes de outras pesquisas E-bit e membros do painel de respondentes da empresa, identificados e cadastrados pela mesma.

\subsection{Matriz de Amarração}

Telles (2001) explicou sobre a importância da arquitetura da metodologia, um paradigma unificador que balize ou referencie uma estrutura de validação de consistência da configuração metodológica, a partir da efetividade da matriz de amarração de Mazzon (1981) nas pesquisas em Administração. Telles (2001) considera uma etapa necessária para identificação clara de sua configuração, da transparência de suas limitações e ressalvas e da avaliação de sua efetividade e eficácia, na busca de uma síntese do planejamento da intervenção, revisão e/ou modificação. Além disso, a matriz de amarração apresenta uma estrutura matricial, comparando os contornos das decisões e definições da pesquisa. 
A matriz de amarração representa uma forma de visualização concreta do trabalho realizado, facilitando a compreensão concatenada dos objetivos de pesquisa com o modelo teórico adotado, das questões e hipóteses de pesquisa e as técnicas utilizadas no tratamento dos dados (Quadro 7).

Quadro 7 - Matriz de Amarração

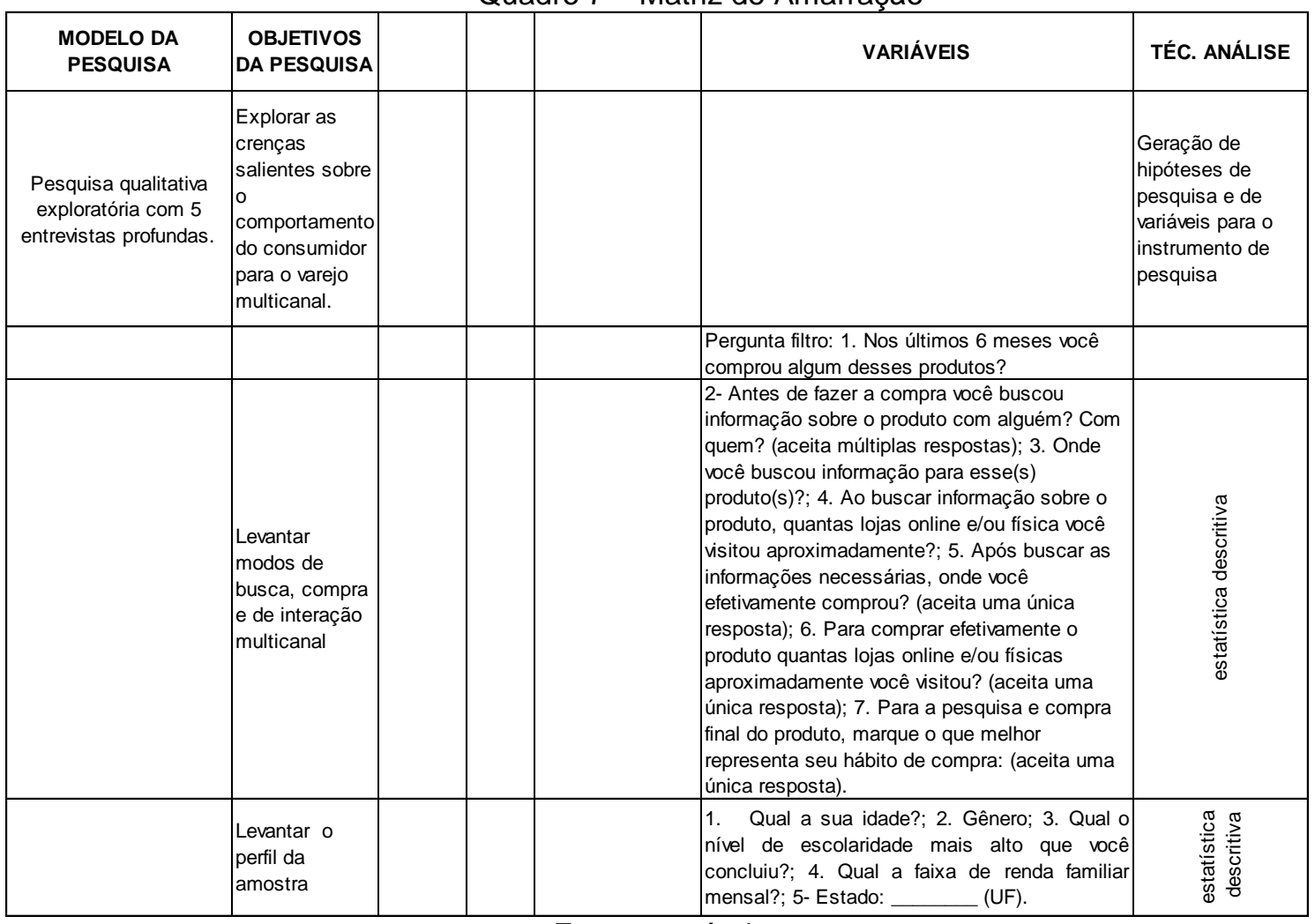

Fonte: o próprio autor 
Quadro 7 - Matriz de amarração - continuação

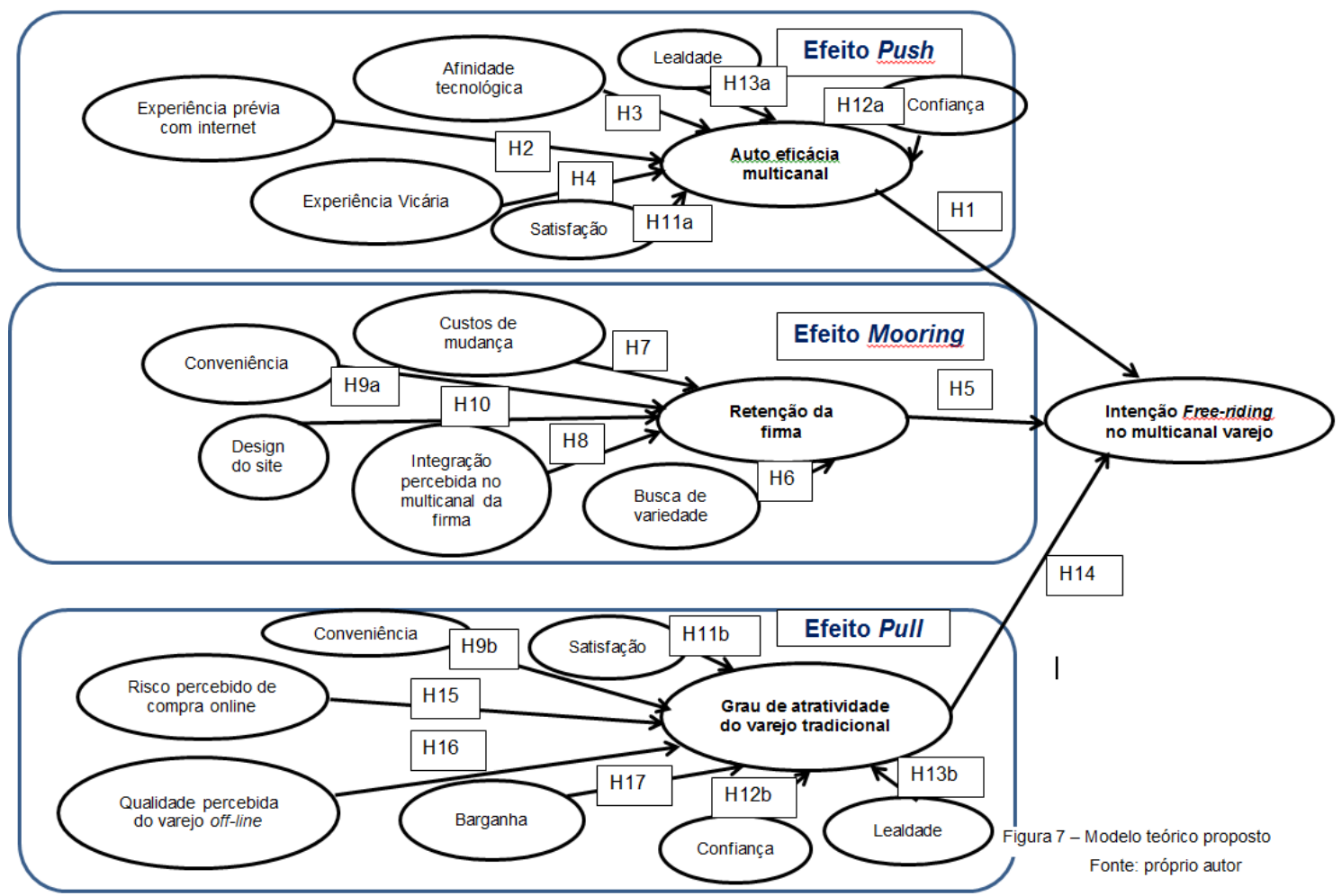

Fonte: o próprio autor 
Quadro 7 - Matriz de amarração - continuação

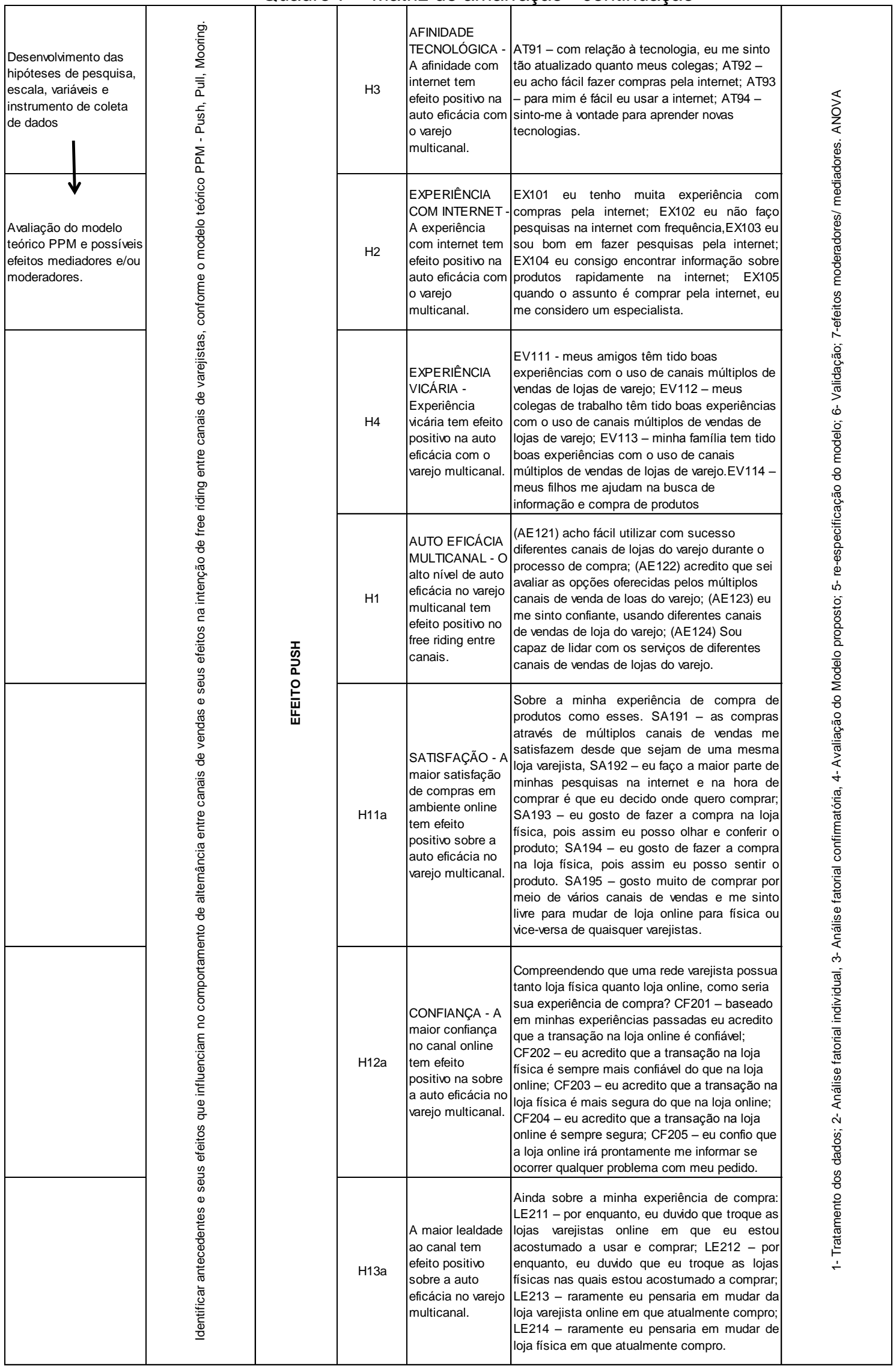

Fonte: o próprio autor 
Quadro 7 - Matriz de amarração - continuação

\begin{tabular}{|c|c|c|c|c|c|c|}
\hline $\begin{array}{c}\text { MODELO DA } \\
\text { PESQUISA }\end{array}$ & $\begin{array}{c}\text { OBJETIVOS DA } \\
\text { PESQUISA }\end{array}$ & $\begin{array}{l}\text { MODELO } \\
\text { PPM }\end{array}$ & HIPÓTESE & CONSTRUTO & VARIÁVEIS & \\
\hline $\begin{array}{l}\text { Desenvolvimento das } \\
\text { hipóteses de pesquisa, } \\
\text { escala, variáveis e } \\
\text { instrumento de coleta } \\
\text { de dados }\end{array}$ & \multirow{6}{*}{ 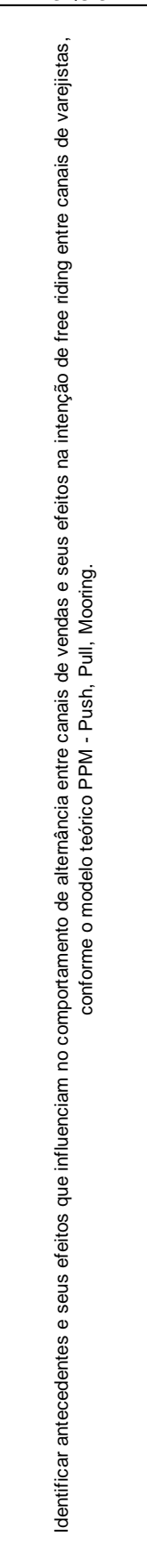 } & \multirow{6}{*}{ 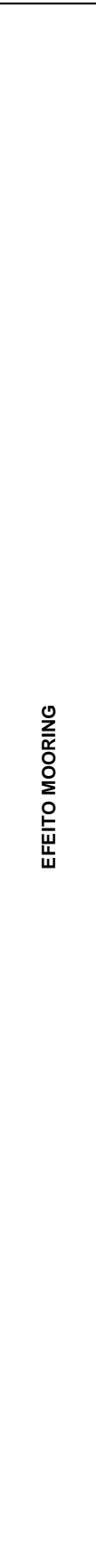 } & $\mathrm{H} 7$ & \begin{tabular}{|l|} 
CUSTO DE \\
MUDANÇA - O \\
custo do esforço, \\
tempo e volume \\
de mudança não \\
importa e há free \\
ride.
\end{tabular} & $\begin{array}{l}\text { CM131 - às vezes eu experimento outras lojas } \\
\text { e redes varejistas; CM132 - custa esforço para } \\
\text { eu mudar de loja ou rede varejista; CM133 - eu } \\
\text { tenho mudado muito de loja ou rede varejista; } \\
\text { CM134 - leva tempo para eu mudar de loja ou } \\
\text { rede varejista }\end{array}$ & 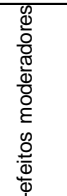 \\
\hline \multirow[t]{5}{*}{$\begin{array}{l}\text { Avaliação do modelo } \\
\text { teórico PPM e possíveis } \\
\text { efeitos mediadores e/ou } \\
\text { moderadores. }\end{array}$} & & & $\mathrm{H} 8$ & \begin{tabular}{l|} 
INTEGRAÇÃO \\
PERCEBIDA - A \\
percepção da \\
integração \\
multicanal pelo \\
consumidor tem \\
efeito positivo no \\
aprisionamento \\
dentro da firma.
\end{tabular} & $\begin{array}{l}\text { Quando eu compro um produto na loja online } \\
\text { da internet: In141 - eu posso comprar o } \\
\text { produto pela internet dentro da loja física; } \\
\text { IN142 - eu posso retirar o produto na loja física } \\
\text { da rede varejista; In143 - eu posso devolver o } \\
\text { produto pela loja física, caso ele esteja com } \\
\text { defeito; IN144 - eu posso trocar o produto na } \\
\text { loja física. }\end{array}$ & 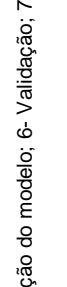 \\
\hline & & & $\mathrm{H} 6$ & $\begin{array}{l}\text { BUSCA DE } \\
\text { VARIEDADE - A } \\
\text { baixa busca de } \\
\text { variedade tem } \\
\text { efeito positivo na } \\
\text { retenção do } \\
\text { consumidor entre } \\
\text { os canais do } \\
\text { varejista }\end{array}$ & $\begin{array}{l}\text { BV151 - eu compro coisas que eu não tinha } \\
\text { planejado adquirir; BV152- eu gosto um bocado } \\
\text { de variedade de alternativas de tipo e marca de } \\
\text { produtos do varejo; BV153- eu gosto de } \\
\text { experimentar diferentes canais de vendas } \\
\text { dentro das alternativas do varejo; BV154- eu } \\
\text { gosto de explorar e alternar entre lojas físicas e } \\
\text { loja online (internet); BV155- eu gosto de novos } \\
\text { estilos e diferentes tipos de produto e } \\
\text { marca;BV156 - pesquisar uma nova loja em } \\
\text { um novo site é geralmente uma perda de } \\
\text { tempo. }\end{array}$ & 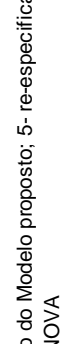 \\
\hline & & & $\mathrm{H} 5$ & $\begin{array}{l}\text { RETENÇÃO NA } \\
\text { FIRMA - A } \\
\text { retenção dentro } \\
\text { dos canais da } \\
\text { firma tem efeito } \\
\text { negativo no free- } \\
\text { riding para canais } \\
\text { de outros } \\
\text { varejistas. }\end{array}$ & $\begin{array}{l}\text { RF161 - eu não tenho problema em mudar } \\
\text { entre os canais de vendas varejistas; RF162 - } \\
\text { eu não gosto de mudar para o canal de venda } \\
\text { de outro varejista depois de eu ter gasto algum } \\
\text { tempo com pesquisa online no site de um } \\
\text { varejista; RF163 - eu teria feito troca entre } \\
\text { lojas e canais de vendas varejistas se eu } \\
\text { pudesse fazer isso sem aborrecimento; RF } 164 \\
\text { - Não há dificuldades técnicas associadas } \\
\text { com a troca entre canais de vendas de } \\
\text { varejistas. }\end{array}$ & 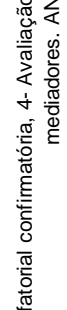 \\
\hline & & & $\mathrm{H} 9$ & $\begin{array}{l}\text { CONVENIÊNCIA } \\
\text { A maior } \\
\text { conveniência de } \\
\text { compra pelo } \\
\text { canal online tem } \\
\text { efeito positivo } \\
\text { sobre a retenção } \\
\text { na firma. }\end{array}$ & $\begin{array}{l}\text { Na compra de produtos como esses: CO171 - } \\
\text { Comprar na internet é muito prático; CO172 - } \\
\text { eu economizo muito tempo comprando } \\
\text { produtos como esse na internet; CO173 - é } \\
\text { maravilhoso comprar esses produtos em loja } \\
\text { online; CO174 - passear em lojas físicas e } \\
\text { comprar online é muito conveniente para mim; } \\
\text { cO175 - pesquisar em lojas físicas é muito } \\
\text { prático; CO176 - pesquisar na internet e } \\
\text { comprar em loja física é muito conveniente } \\
\text { para esse produto. }\end{array}$ & 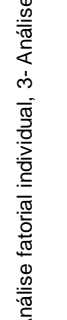 \\
\hline & & & $\mathrm{H} 10$ & $\begin{array}{l}\text { DESIGN DO } \\
\text { SITE - O } \\
\text { ambiente } \\
\text { associado ao site } \\
\text { e sua } \\
\text { funcionalidade } \\
\text { aumenta a } \\
\text { satisfação nas } \\
\text { compras em } \\
\text { ambiente online. }\end{array}$ & $\begin{array}{l}\text { DS181 - eu prefiro comprar em sites que não } \\
\text { demoram em carregar e onde a navegação é } \\
\text { rápida; DS182 - eu não gosto do formato de } \\
\text { apresentação diferente de alguns websites de } \\
\text { lojas varejistas; DS183 - em muitos sites } \\
\text { tenho que navegar muito até achar o que } \\
\text { procuro; DS184 - é realmente irritante quando } \\
\text { os sites demoram a carregar, DS185 - para } \\
\text { falar a verdade não aguento mais as } \\
\text { propagandas no site de lojas varejistas }\end{array}$ & 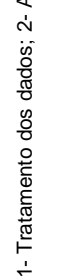 \\
\hline
\end{tabular}

Fonte: o próprio autor 
Quadro 7 - Matriz de amarração - continuação

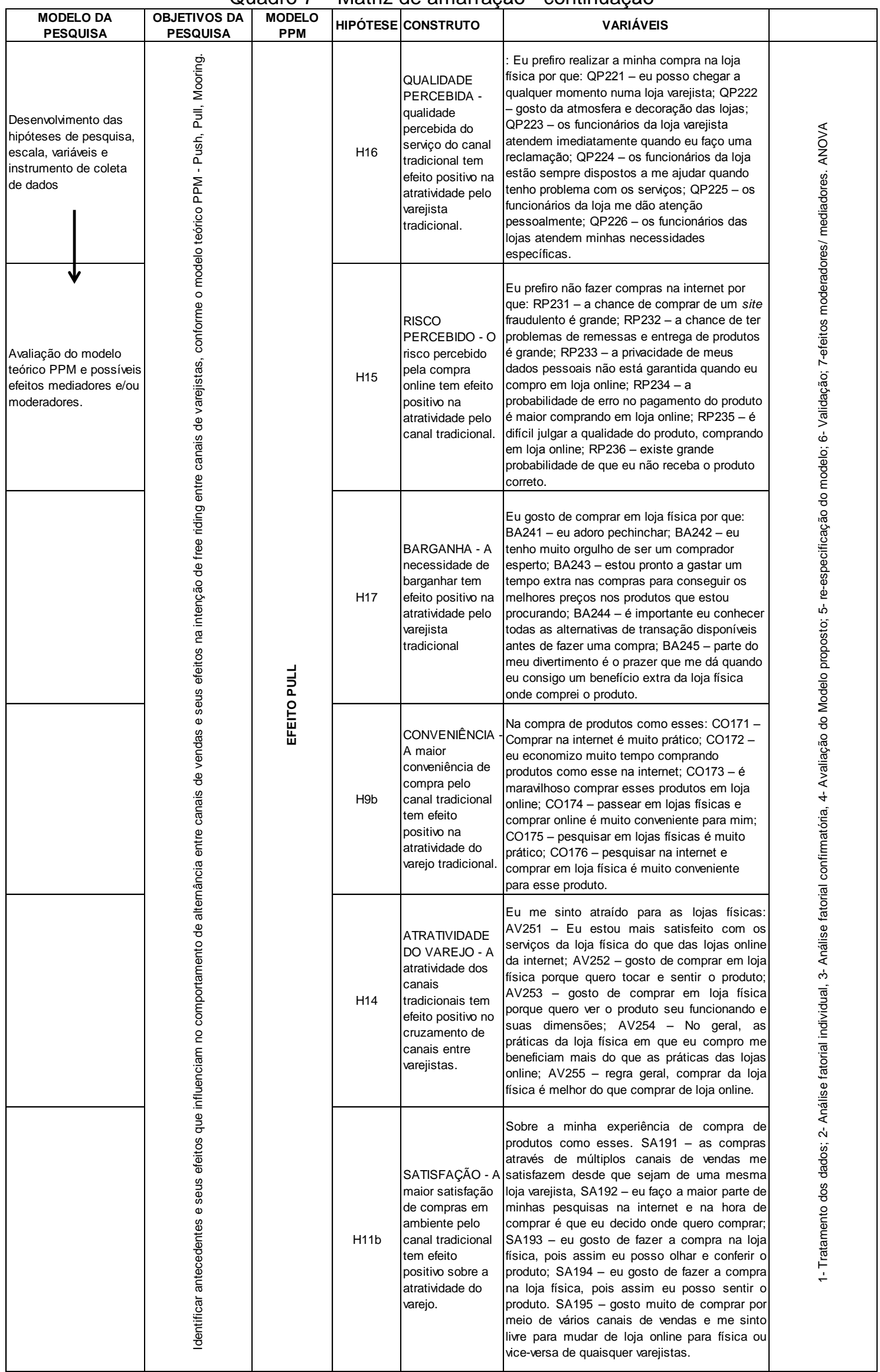


Quadro 7 - Matriz de amarração - continuação

\begin{tabular}{|c|c|c|c|c|c|c|}
\hline $\begin{array}{c}\text { MODELO DA } \\
\text { PESQUISA }\end{array}$ & $\begin{array}{c}\text { OBJETIVOS DA } \\
\text { PESQUISA }\end{array}$ & $\begin{array}{l}\text { MODELO } \\
\text { PPM }\end{array}$ & HIPÓTESE & CONSTRUTO & VARIÁVEIS & \\
\hline & \multirow{2}{*}{ 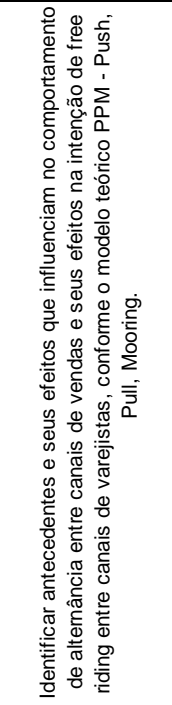 } & \multirow{2}{*}{ 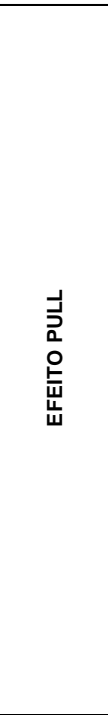 } & $\mathrm{H} 12 \mathrm{~b}$ & $\begin{array}{l}\text { CONFIANÇA - A } \\
\text { maior confiança } \\
\text { no canal } \\
\text { tradicional tem } \\
\text { efeito positivo } \\
\text { sobre a } \\
\text { atratividade do } \\
\text { varejo tradicional. }\end{array}$ & $\begin{array}{l}\text { Compreendendo que uma rede varejista possua } \\
\text { tanto loja física quanto loja online, como seria } \\
\text { sua experiência de compra? CF201 - baseado } \\
\text { em minhas experiências passadas eu acredito } \\
\text { que a transação na loja online é confiável; } \\
\text { CF202 - eu acredito que a transação na loja } \\
\text { física é sempre mais confiável do que na loja } \\
\text { online; CF203 - eu acredito que a transação na } \\
\text { loja física é mais segura do que na loja online; } \\
\text { CF204 - eu acredito que a transação na loja } \\
\text { online é sempre segura; CF205 - eu confio que } \\
\text { a loja online irá prontamente me informar se } \\
\text { ocorrer qualquer problema com meu pedido. }\end{array}$ & \multirow{2}{*}{ 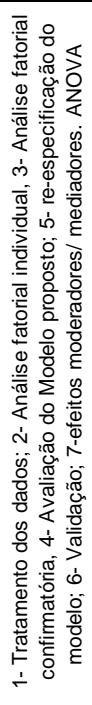 } \\
\hline & & & $\mathrm{H} 13 \mathrm{~b}$ & $\begin{array}{l}\text { A maior lealdade } \\
\text { ao canal } \\
\text { tradicional tem } \\
\text { efeito positivo } \\
\text { sobre a } \\
\text { atratividade do } \\
\text { varejo tradicional. }\end{array}$ & $\begin{array}{l}\text { Ainda sobre a minha experiência de compra: } \\
\text { LE211 - por enquanto, eu duvido que troque as } \\
\text { lojas varejistas online em que eu estou } \\
\text { acostumado a usar e comprar; LE212 - por } \\
\text { enquanto, eu duvido que eu troque as lojas } \\
\text { físicas nas quais estou acostumado a comprar; } \\
\text { LE213 - raramente eu pensaria em mudar da } \\
\text { loja varejista online em que atualmente compro; } \\
\text { LE214 - raramente eu pensaria em mudar de } \\
\text { loja física em que atualmente compro. }\end{array}$ & \\
\hline 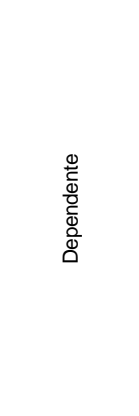 & 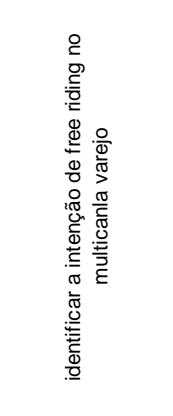 & & & $\begin{array}{l}\text { FREE RIDING - A } \\
\text { intenção de free } \\
\text { riding entre } \\
\text { canais online e } \\
\text { tradicional tem } \\
\text { efeito positivo } \\
\text { sobre a } \\
\text { alternância entre } \\
\text { varejistas. }\end{array}$ & $\begin{array}{l}\text { Eu iria pesquisar numa loja online, mas } \\
\text { comprar em uma loja física ou vice-versa. } \\
\text { FR261 - quando eu compro produtos } \\
\text { semelhantes aos desta pesquisa; FR262 - } \\
\text { quando eu compro produtos diferentes ao desta } \\
\text { pesquisa; FR263 - Sinto-me confortável em } \\
\text { navegar nos múltiplos canais de vendas de } \\
\text { uma mesma rede varejista, para pesquisa pela } \\
\text { internet e compra na loja física ou vice-versa, } \\
\text { quando se trata de produtos como o desta } \\
\text { pesquisa; FR264 - sinto-me confortável em } \\
\text { navegar nos múltiplos canais de vendas de } \\
\text { diferentes lojas varejistas para pesquisa pela } \\
\text { internet e compra na loja física ou vice-versa, } \\
\text { no caso de produtos como desta pesquisa. }\end{array}$ & \\
\hline
\end{tabular}

Fonte: o próprio autor 


\section{Análise de Resultados}

A análise de resultados apresenta-se estruturada em: 1- apresentação dos resultados do estudo exploratório qualitativo; 2- apresentação dos resultados do estudo quantitativo, descritivo. As tabelas seguiram a orientação do IBGE que consta na ABNT para Normas Tabulares do IBGE, 1993, conforme diretrizes para apresentação de dissertações e teses da USP, $2^{2}$ edição. A inserção das tabelas de análise de resultados neste capítulo seguiu as diretrizes do SIBi/USP (2009).

\subsection{Resultados das entrevistas em profundidade}

A análise de conteúdo das entrevistas em profundidade gerou a inserção de novos construtos ao modelo teórico Push-Pull-Mooring (PPM), bem como itens para a escala. O conteúdo da pesquisa exploratória foi organizado em dois blocos: 1experiência de compra pela internet; 2- experiência multicanal. Dos cinco entrevistados, um deles é profissional de e-commerce da Nextel com ampla experiência em compras on-line e viagens internacionais para compras locais. Os demais foram homens e mulheres com ampla experiência de compra nos produtos pesquisados em ambiente on-line nacional, internacional e em loja física brasileira e estrangeira. O roteiro seguiu a orientação conceitual de Bandura (1977) para experiência vicária, portanto algumas perguntas foram realizadas intencionalmente para que o respondente pudesse responder o interesse subjacente da pesquisa.

\subsubsection{Experiência de compra pela internet:}

Foi explorado todo processo de consulta a produtos durante a busca pela informação, atributos do produto, preço, prazos de entrega, experiência com o varejista etc. Também foram exploradas as necessidades para tomar a decisão de compra e a experiência vicária. Abaixo se encontram os resumos organizados por construtos, conforme indica a revisão teórica. 
Sobre a afinidade tecnológica e inovação de produtos tecnológicos percebeu-se o quanto impacta a tecnologia na vida dessas pessoas e como elas gostam de descobrir, investigar produtos inovadores na área de eletrônicos, degustar produtos tecnológicos inovadores e como isso também diz da sua identidade social, conforme os depoimentos transcritos abaixo:

\begin{abstract}
Quando comprou o Ipod, como buscou informação? Meu 1aparelho foi um Iphone mesmo. Como chegou à informação do produto? [tempo para pensar]. Com amigos? [foi investigado a experiência vicária] Não. Eu na verdade desejei o aparelho antes mesmo de ter sido lançado. Sou um pouco earlier adopter. Eu vi a novidade e comecei a pesquisar o produto e se ele valia o preço que valia. O que Ihe ajudou a dizer que o produto vale o preço? Pesquisas longas, vídeo, fórum, especialistas (blogs de aparelhos), a mídia, imprensa. Especialistas digo blogs especialistas de aparelhos. Comprou quando? Comprei quando lançou o primeiro, comprei em 2009. Foi longe! Você foi atrás de toda essa informação para ver se valia a pena. Buscou como? Pela internet sempre. Por contato e área de trabalho. A compra foi pela internet? Não, fui lá comprar. Comprei na Apple. Na época nem a parte de ecommerce da Apple estava tão forte. Eu queria pegar na mão, degustar. Foi na loja e foi comprar. Pode dizer que para um produto inovador, além de ter feito uma super busca, de quantas horas acumuladas? Mais de 1 a 2 dias acumulados, cerca de 48 horas. É uma aquisição de um grande valor e foi o primeiro. Estava investindo muito mais. Entre a decisão e a sua compra, quanto tempo? Uma semana, um mês. Namorou um mês... Acho que assim, deu quase dois meses, mas a decisão "eu quero comprar" demorou um mês de pesquisa. Mais um tempinho para realizar a viagem mesmo, não era só para comprar. Casei tudo e acabou atrasando um pouquinho mais.

Eu nunca compraria nada que eu não conhecesse. Muito do meu perfil. Eu gosto de conhecer. Não compraria nada só pelo papo do vendedor. Eu não posso depender disso porque às vezes sou o primeiro dos meus colegas, muitas vezes sou a tendência de inovação.

Já que eu sou multi task na internet eu vou lá e compro. Eu sair de casa para ir à loja física seria mais difícil. Sou heavy user total. Muito conectado. As pessoas não me entendem. Fazem brincadeira, pois trabalho $15 \mathrm{~h}$ por dia, chego em casa e ligo o computador. Eu não assisto TV. Há oito anos. Filme vê? Se me convida na sua casa eu assisto. Mas eu em nenhum momento eu paro meu dia para ligar a TV para assistir... Tudo eu consigo fazer pela internet, inclusive os programas, novelas. Netflix? Eu consigo outros meios...
\end{abstract}

Sobre a experiência de busca e compra on-line, os depoimentos destacaram abaixo a ampliação para novas categorias de produtos (como sapatos, por exemplo), busca em: sites de fabricantes, sites de reclamação, de revisão de consumidores, de blogueiros que testam e realizam a experiência de novos produtos, vídeos, fóruns, opinião de consumidores nos sites de compra. Os depoimentos abaixo evidenciaram isso:

Como consultor independe do produto. Uso o mesmo sistema para sapato. Eu compro pela internet. 
Foi tudo pela internet. Eu passei em loja assim, para dar uma olhada, mas não me agradou. E geladeira via internet? Sim já comprei varias coisas: TV maquina de lavar roupa, já comprei pelo computador, notebook, leitor ótico, impressora. Você é um usuário da internet? Tudo eu praticamente compro na internet. $\mathrm{O}$ monitor e a impressora eu comprei no Valão da Informática.

Foi pelo menor preço, porém eu considero muito a opinião dos que compraram o produto. Eu entro nesses comentários. Pode ser Electrolux, GE, Consul, mas se os consumidores que compraram estão reclamando do produto não vou comprar.

Outra coisa que uso muito, por exemplo, eu uso a revisão dos consumidores.

Para produtos inovadores e que requerem mais conhecimento você precisa tocar no produto? Não necessariamente, e porque assim, por exemplo, se lança um aparelho novo hoje, já tem muita gente que recebe o aparelho antes: o blogueiro para ele fazer a degustação e grava o vídeo. Porém na época do Iphone não tinha um blogueiro que tivesse recebido antes. Hoje já e normal. Ai ele vira uma referencia? É. Tudo depende.

E no smartphone? Ainda tem o Iphone? Não porque fui roubado. Eu tive todas as gerações do Iphone. Agora estou no momento de decisão do próximo e talvez haja uma ruptura. Android, Galaxy. Tem uma chance de ruptura para mim também, estou pesquisando. Em blogs? Em vídeos, porque depende da disponibilidade do tempo. Se tiver tempo eu gosto de ler artigos. Vídeo e mais rápido. O cara já fala a diferença entre Galaxy e Iphone. Tem vídeos de todos os tipos.

Você foi direto às lojas de varejo? Vou a fóruns e sites de especialistas que ficam analisando coisas. Varejo, nem todos os varejos tem essa parte de análise. No Brasil acho que a palavra nem é análise. Magazine Luiza faz muito um vídeo sobre o produto. É legal para quem não conhece o produto, ela fala das características do produto. Mas lá fora, a própria Amazon ou BestBy tem bastante espaço para compradores falarem do produto. Eu leio muito isso. Você lê os comentários das pessoas? Gostei não gostei. Se é ruim, se é bom. Tem sites de especialistas: para que você compraria uma TV para assistir um DVD. Perguntaria se seria bom para essa necessidade. Fórum é mais específico ainda. Então no meu caso eu queria uma TV que fosse monitor e que serve para ver vídeos, filmes e jogos. Tem uma especificidade muito grande, eu fui afunilando. Demorou um mês? Não tanto, uns 20 dias.

No começo eu tive a coragem de testar. Hoje a China já está super consolidada no mercado. Já compro lá há sete anos... A China já tem a pretensão de ser um ecommerce no mundo. Globalizada. No começo eram os chineses falando inglês com muito sotaque. Hoje já estão mais profissionalizados. Menos sotaque. Muito legal.

A geladeira foi interessante. Que tivesse entrada de água e o processo de gelo side by side. Diante da falta, escolhemos uma geladeira duplex com melhor tecnologia: Electrolux. Busca na internet para entrada de agua. E depois outras funções interessantes. Atributos diferentes: resfriar cerveja etc. Depois tamanho. Depois pesquisei o ponto de venda on-line para ver onde tinha as geladeiras.

\section{Sobre a retenção da firma ou free-riding destacaram-se parcerias dos fornecedores, marketing promocional (milhagem, como o Múltiplus), como nos depoimentos} transcritos abaixo:

Vi na Fast Shop e até possibilidade de trocar por milhas (ponto Frio) com múltiplos. Essas milhas são com qualquer varejo? Não Casas Bahia e Ponto Frio. Ai cheguei a ver e o que tinha lá disponível não era o que ele queria. Acabei comprando separado. Comprei na Dell. Fui para vários varejos... Eu uso Buscapé, os sites que conheço: LASA, Fast Shop... Até usei filtro de busca utilizei aquelas marcas e configurações. Porque a Dell era a melhor opção de produto versus custo. Por exemplo, a Dell tem parceria com Mackenzie e dá desconto. 
A partir do momento que defino o produto que eu quero, eu escolho qual loja quero comprar. Na escolha: preço. Você usa site de busca? Eu uso Buscapé. Se por acaso tem alguma loja que eu quero ter referencia eu buscaria como referencia. Fui buscar menor preço e prazo de entrega. Comprei um no Magazine Luiza; outro no Ricardo Eletro; outro nas Lojas Americanas, pensando em preço e prazo. Fiz 4 a 5 compras diferentes pensando em preço e prazo. Se compro na Best Buy, se deu algum problema eu devolvo na loja.

Compra em vários canais? Sente-se confortável para usar os multicanais. O que preza como valor? O que olha? $\mathrm{Na}$ internet procuro preço. Compra em qualquer loja da internet? Não. Não compro em loja absolutamente reconhecida e que não tenha reputação. Gosto de pesquisar no reclame aqui sobre a empresa.

Sobre a experiência vicária com colegas os depoimentos ressaltaram a indicação da marca, a indicação das características do produto e a degustação do produto com amigos que compraram.

Tinha desconto, tinham falado bem da Dell. Pela indicação das pessoas que a marca era legal. Por mais que fosse próximo de outros produtos eu achei que a proposta era mais interessante.

A TV está ligada na loja e de acordo com a marca tem tonalidades diferentes. Meu tio me orientou para isso.

Você iria à loja para fazer uma degustação? Não necessariamente, não para concretizar a decisão porque, de novo, no vídeo e meus amigos já tem. Vira e mexe com meus amigos, "me deixa dar uma olhada"...

Sobre a lealdade e a qualidade percebida à marca, em primeiro lugar, do produto e/ou do varejo, em segundo, para depois escolher as características do produto de acordo com a utilidade da compra (para si ou para outros). Os depoimentos transcritos abaixo assinalaram:

Eu tinha algumas preocupações com marca. Marcas que fossem uma referência de qualidade. Com base nisso os sites lhe permitem que se façam seleções. Eu queria que fosse uma geladeira frostfree, duas portas, defini o espaço de $\mathrm{x}$ litros e ai vi as opções que deram selecionando as marcas que me interessaram.

Eu posso dizer que nessa sua experiência de compras, você praticamente foi atrás de uma marca, modelo, design... É no começo foi mais marca e lá na loja virtual ele consegui reverter um pouco para similares e depois o preço acabou ganhando no caso da tostadeira por ser um produto simples. E legal, por esse site ser seguro eu vou comprar? Acho que lealdade não. Acontece de acabar comprando numa loja que é mais referencia quando é para outras pessoas. Já que eu vou te dar um presente eu vou comprar numa loja que você conhece (Fast Shop). Comigo não. Uma TV digital você já passou pela experiência de comprar uma TV digital? Como você fez a compra? Decisão de marca, modelo, tamanho. Como foi isso? Lembro, normalmente para produtos grandes, mas ao mesmo tempo super competitivo eu seleciono duas a três marcas ou dois a três modelos. Eu gosto de afunilar um pouco e a partir dai o fator que decide mesmo pode varia em inúmeras variáveis mesmo assim. 
Sobre a confiança no varejo, surgiram as questões em relação ao prazo de entrega. A experiência positiva de relacionamento acumulada com o varejo confirma a confiança naquele varejista. A qualidade também é percebida atrelada à confiança em relação ao varejo, conforme os depoimentos abaixo:

Eu fui pensando em confiabilidade, em alguém que eu possa... Na verdade hoje eu tenho viés americano por que estou acostumada num mercado que se não gostou do produto eu posso devolver. Aqui no Brasil não acontece. O que eu prezo muito se está me falando 25 dias eu espero que seja até isso. Se eu tiver experiência de compra que estourou o prazo eu não compro mais na loja. Prazo é fundamental! Eu quero que me entregue o produto e no prazo. Não quero que chegue 5 dias após compra e me diga que não tinha em estoque. Tem que ser antes. Estes percalços estas surpresas me incomodam.

Só trabalho com algumas lojas que eu conheço. Ai é um pouco de experiências anteriores e conhecimento técnico. Se aparece lá nem perco meu tempo nisso. Se apresenta o Extra, Submarino, Fastshop, Magazine Luiza. Tem confiança? Sim confiança muito grande on-line.

Você acha que no Brasil a gente vai evoluir? Acho que vai ter muita empresa se arriscando, mas no Brasil tem um fator de cultura. Demora às pessoas confiarem. Mas acredito que sim. Não vou falar que vai virar uma tendência, mas vai ter gente que vai... A confiar que o sistema funcione? Não só o sistema: a qualidade, não vai ter fraude etc. (O Brasil teve problema de fraude). Confiar na marca ou não.

Sobre a satisfação relacionada à necessidade dos sentidos de "ver", "pegar", "sentir" o produto e um envolvimento maior com o mesmo, os depoimentos sinalizaram:

Interessante e porque não compra na internet? Por que na verdade eu compro coisas na internet. Já comprei computador também. Nesses últimos casos foi uma mistura de oportunidade com intenção. Do carro, precisava da experiência. E da geladeira? Eu também queria mesmo mexer, vê (botar a mão). Para mim é um composto da experiência que você tem: pesquisa na internet. Ir até a loja permite vivenciar aquilo que você viu na internet. Lê, vê imagens e na hora que você compra não é bem aquilo que imaginava. Para mim essa experiência de você poder vivenciar na maioria dos produtos... Não e o caso do livro. O restante, todos os outros tipos de produtos tem certo tipo de envolvimento. Sentir o produto. Pegar o produto, botar na mão ou visualmente? Mais do que visualmente na foto. Deixa-me ver se isso aqui é isso (botar a mão). Esse é o meu jeito.

Para produto de alto valor agregado eu gosto de ver o produto (visual) antes de comprar. É engraçado. Tem alguns produtos que eu tenho mais cuidado e outros menos. Laptop eu não fiz. A geladeira eu fiz questão de olhar. Maquina de lavar roupa fiz por internet. Nem fui ver no PDV e descobri que não pode usar sabão liquido, mas tinha excelente preço. 


\title{
5.1.2 Experiência multicanal para busca e compra
}

\author{
A decisão de compra foi explorada sob a perspectiva multicanal. Os depoimentos
} abaixo ressaltaram as experiências com multicanais, a compra racional e emocional, a compra pela conveniência do consumidor, apesar do preço ser um pouco maior.

Fui à Best Buy. Depois comprei numa loja que não tenho a menor ideia. Loja conceituada pela segurança, não pesou? Nesse caso, não. Hoje em dia não compro em loja que não conheça muito bem. Já tive problema com compra de celular desbloqueado sem garantia na Amazon. Não compraria de novo um produto caro na Amazon. Eu preciso ter garantia.

Você buscou informação numa loja física antes de comprar on-line?

A TV sim, nos EUA, antes de conhecer a marca. Eu escolhi qual a imagem que mais me agradava na TV e depois escolhi as marcas. Não, o resto tudo pela internet. Nem cheguei à loja física para geladeira, fogão, micro-ondas e a segunda TV comprada no Brasil. Pela Amazon eu tenho restrição por ser somente virtual. Muitos produtos são vendidos e não são vendidos por ela diretamente. Ela virou um shopping. São diversos fornecedores que você não conhece.

Mas se precisar buscar informação na loja física eu vou buscar e pode ser que chegando à loja física, pode ser que faça a compra. Mas eu tenho a tendência a comprar on-line.

Comprou algum eletrodoméstico? Ah sim uma geladeira. Como foi? Quase emocional. Estava no litoral. Queria uma geladeira que tivesse saída de água gelada. A busca foi exatamente essa. E ai também, da mesma maneira, apesar das limitações que estavam lá, nós fizemos uma consulta no Ponto frio, Casa Bahia. Como conheceu a geladeira? Nos sites tem um bom descritivo. Como encaixou a geladeira no espaço? Você tem as dimensões. Mas antes, eu cheguei a ter uma ideia no site, busca conjunta com esposa de como ela se apresentava (design: cor, inox), uma geral para depois nos dirigirmos na loja. A compra foi também efetuada na loja. Você faz uma busca para que? Para avaliar o que tem de variedade, oferta. Uma combinação, não compra por apenas um atributo.

No caso da geladeira foi no centro com varias marcas e concorrentes: Casas Bahia, Ponto Frio, Pernambucanas. Tinha umas três lojas na mesma avenida. Paguei o carro na primeira, Casas Bahia. É o melhor preço, mas depois você volta aqui. A mesma historia do outro lado. Melhor preço é esse? Quanto me faz para não ter que voltar lá? Comprei no Ponto frio.

Buscou informação na loja ou no blog? Para geladeira busquei no Buscapé ou Bom de Faro. E depois nas Casas Bahia para comprar. Fiz a busca pelo celular. Busquei com filtro direto, o melhor preço. Tivemos desconto e fechamos lá mesmo, embora não fosse o melhor preço em relação à internet. $\mathrm{O}$ critério foi logística.

Sobre a integração percebida entre canais, destacou-se a percepção pela não integração dos vários canais de varejistas. Há uma percepção de que o varejista multicanal tem preferência para loja física em detrimento de lojas virtuais quando se trata de reclamações e devolução de mercadoria e dinheiro. Foi comentado sobre o SAC 2.0, para reclamações em chat ou telefone na página do site da loja, conforme depoimentos abaixo:

Comprei um livro na livraria cultura e no mesmo dia meu marido também comprou. Entrei na livraria cultura e pedi para cancelar o produto. Eu queria na verdade que não me cobrassem. Fui à loja com o livro embalado. E nesse tempo conversando 
pela loja virtual por e-mail. A loja virtual não tinha a menor ideia do que fiz. Eles me creditaram no meu cadastro como cliente: como credito. A loja virtual conversando comigo como se nada tivesse acontecido...

Eu prefiro comprar em operações que tenham lojas físicas porque é dificílimo reclamar com loja on-line. Na loja física você consegue ir lá e reclamar. Eu tenho essa preferencia para ser ouvida. Mesmo nos EUA. É um dos diferenciais que muitos varejos se diferenciam da Amazon. A Amazon tem uma caixa postal. Eu não gosto da Amazon. Eu tenho duas experiências negativas: o sapato e o celular. $O$ prazo de devolução da Amazon é um mês. Não vou receber o full refund [devolução de dinheiro] e somente o partial refund. O produto demorou a chegar a mim. A politica de troca da Amazon é muito ruim. Paguei $\$ 40$ e vou receber $\$ 10$. A Amazon tem uma politica muito esquisita, não há recolhimento de imposto on-line. A Amazon é desleal ao varejo físico. Não paga imposto. Eu acho isso esquisito. É injusto com o varejo. Esta sendo revista a lei nos EUA.

Então já com uma visão de especialista (trabalha com E-commerce) e do lado da empresa, pensando em meu consumidor é muito importante ter um alinhamento de informação entre todos os canais. Um eco sistema entre eles. O que você chama de ecossistema? Uma empresa que tinha uma cultura de varejo off-line, como Pernambucanas. Não trabalhou lá. A própria TAM é assim, quase $100 \%$ on-line. No passado o off-line via o on-line como ameaça, vai roubar a minha fatia da venda. A nossa visão é que existe o mercado para todo mundo. A empresa que quer ser consolidada como multicanal ela precisa acreditar que existem pessoas que vão preferir ir à loja, pessoas que vão preferir comprar na internet e pessoas que vão preferir comprar por telefone. Isso é que eu falo de um ecossistema. A loja não é coisa mais simples. Têm trabalhos mais complexos e coisas mais simples. $O$ site pode fazer a coisa mais simples. Acho que a Best Buy é um bom exemplo disso. A Best Buy tem a loja e o site. Você pode comprar no site muitas coisas, mas se tem alguma duvida sobre uma TV que é um valor alto, muita gente vai lá e o cara que está lá é como se fosse um consultor (manual ambulante) da TV. Então focaram bem. Se não quiser comprar agora, comprar pelo site é mesma coisa. Da loja ou on-line. A diferença é que ele está lá fisicamente e pode the atender. Coisa que na internet já estão querendo superar essa barreira: SAC 2.0. Mas quando falei de ecossistema o valor como consumidor multicanal é um alinhamento tanto de preço, de informação como de canais, uma politica de canais que se agregam. O que é o SAC 2.0? É online, pode fazer reclamações... Por telefone ou chat? Sim. Para o multicanal é uma tendência muito forte. De novo, tem mercado para tudo. Tem gente que prefere loja, telefone, chat, passear. Olhando todos os canais precisa entender que cada um tem um custo. Se preferir telefone, porque eu vou esconder o número do telefone? Por que não colocar "retorne a ligação e você dá seu número". Essa parte de superar expectativas e checar as barreiras de cada canal. Nesse ecossistema estaria o clic and collect? Compra on-line do supermercado e coleta na loja. Isso! Essa integração de canais é superimportante!

\section{Seleção de depoimentos que ressaltam a necessidade de barganhar no ponto de} venda:

No caso de geladeira... Nesses casos tanto faz. Os preços bateram com preços online. Então nesse caso especifico foi legal, mais baixo do que on-line. O que não é comum! Em que sentido? O inverso é comum. Não foi esse o caso da geladeira. Mais caro na internet e ficou mais barato no ponto de venda. No caso do Sansung nem teve negociação. No caso do notebook acabou tendo negociação: eu ganhei um ano de antivírus na Best Buy. Na Amazon estava $\$ 120$ mais caro sem taxas. A loja the ofereceu algo mais por quê? Eu pedi um desconto, me dá um desconto maior. Ele me deu. Muito bom, mas deu algo a mais.

Tinha já o preço. E ai, fomos ao ponto de venda para investigar os modelos. Fomos à Fast Shop para ver os modelos com os preços obtidos da internet. Descobrimos que 
era possível negociar no próprio ponto venda. E acabamos fechando no próprio ponto de venda. No varejo tradicional busco o atendimento e abertura para negociação. Para você é importante barganhar no ponto de venda? Ah sim!

\subsubsection{Contribuições da pesquisa exploratória para o modelo teórico}

A pesquisa qualitativa exploratória permitiu ampliar a revisão teórica para novas hipóteses (e construtos) que foram incluídas no modelo de Bansal, Taylor e James (2005) e Chiu et al. (2011). O construto afinidade tecnológica surgiu da pesquisa exploratória e da revisão de literatura. O construto barganha surgiu da entrevista e foi incluído na variável latente atratividade do varejo. Confiança, lealdade, satisfação foram construtos sugeridos em orientação na FEA - USP ${ }^{39}$. Os construtos experiência vicária, retenção na firma, integração percebida e qualidade percebida surgiram nas entrevistas, porém já estavam inclusos no modelo teórico.

Além disso, houve contribuições para os itens da escala de alguns construtos a partir da pesquisa exploratória e das experiências com varejistas no Brasil:

Experiência Vicária: "tanto meus amigos como colegas de trabalho tiveram experiências de sucesso em múltiplos canais de venda". "Meus filhos me ajudam, facilitam a busca de informação e compra de produtos."

Integração percebida: "eu posso comprar o produto pela internet dentro da loja física".

Satisfação: "as compras por meio de múltiplos canais de vendas me satisfazem desde que sejam de uma mesma loja varejista"; "eu gosto de fazer a compra na loja física, pois assim eu posso olhar e conferir o produto"; "eu gosto de fazer a compra na loja física, pois assim eu posso sentir o produto"; "gosto muito de comprar por meio de vários canais de vendas e me sinto livre para mudar de loja on-line para física ou vice-versa de quaisquer varejistas".

\footnotetext{
${ }^{39}$ Em reunião de discussão sobre o modelo teórico com prof. José Afonso Mazzon, antes e após a qualificação em setembro de 2012 (informação verbal).
} 
Atratividade do varejo: "gosto de comprar em loja física porque quero tocar e sentir o produto"; "gosto de comprar em loja física porque quero ver o produto, seu funcionamento e suas dimensões".

Intenção de free-riding multicanal: "sinto-me confortável em navegar em vários canais de vendas de uma mesma rede varejista, tanto pela internet quanto em sua loja física" e "sinto-me confortável em navegar entre vários canais de vendas de vários varejistas do mercado, tanto pela internet quanto pela loja física".

\subsection{Resultados das Análises de dados quantitativos}

As análises quantitativas realizadas na base de dados foram: 1- preparação do banco de dados; 2- perfil da amostra; 3- comparação de médias (ANOVA) e pelo método não paramétrico; 4- análise fatorial exploratória para identificar dimensões; 5- Análise fatorial confirmatória; 6- Validação e ajustamento do modelo estrutural; 7Mediação; 8- Moderação por multigrupos.

\subsubsection{Preparação do banco de dados para análise}

O banco de dados teve 888 respondentes sem falhas no preenchimento do instrumento por terem sido respostas on-line em plataforma adequada para a empresa de pesquisa E-bit. Portanto não existem dados faltantes.

No entanto, foram retirados cinco respondentes devido a terem respostas iguais para todas as perguntas de 8 a 26, não atendendo ao critério de confiabilidade, que segundo Hair et al. (2005, p.29), "confiabilidade é o grau em que a variável observada mede o valor verdadeiro e está livre de erro". Não faz sentido para essa pesquisa que um indivíduo atribua exatamente a mesma nota para todas as questões. Foram retirados do banco de dados os códigos de identidade que responderam "1" para todas as questões (ID: 15174174, 75219189) e os que responderam "7" para todas as questões (ID: 15619867, 15192227, 15539495). 
O novo total da amostra utilizado nas análises foi de 883 respondentes. Ainda buscando preparar o banco de dados, foi realizada uma análise de escores z para identificação de outliers. O critério de exclusão de possíveis respondentes outliers foi ter um escore $z$ superior a três. Como pode ser observado abaixo (Tabela 1), a maioria dos respondentes apresentou comportamento outlier em apenas uma das 86 variáveis, identificando-se poucos casos em que houve uma ocorrência com 9, 10, 11 e 12 outliers. Considerou-se que esses respondentes tenham opinião discrepante o que não necessariamente represente erro de medida, segundo Hair et al. (2005).

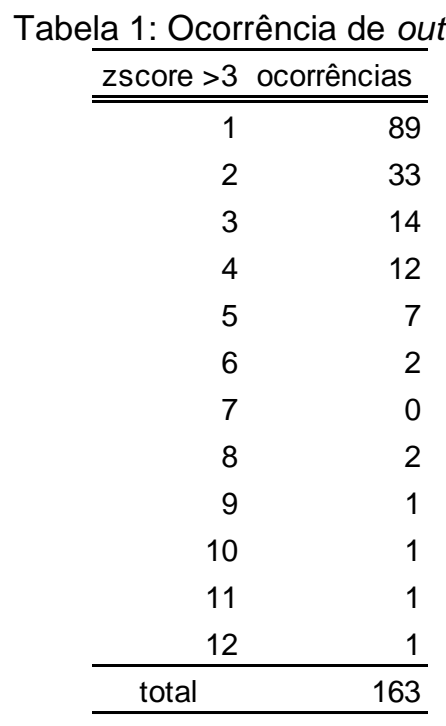

\subsubsection{Estatística Descritiva}

A estatística descritiva foi organizada por grupo de variáveis Push-Pull-Mooring (PPM) e apresentou as distribuições de média, desvio padrão, coeficiente de variação de Pearson e mediana, conforme quadros a seguir.

Sobre as variáveis push, a tabela abaixo (Quadro 8) mostra que se obteve mediana com pontuação máxima $(7,0)$ para alguns itens do construto afinidade tecnológica, porém quanto à avaliação de si mesmo na experiência de internet a mediana pontua em 5,0. A variável EX102 apresentou baixa mediana, baixa média, desvio padrão e coeficiente de variação elevados $(2,127 ; 77 \%)$, evidenciando-se baixa adesão à afirmação. A experiência vicária apresentou maior mediana $(5,0)$ para a experiência da família e maior coeficiente de dispersão para experiência com filhos (48\%). A 
autoeficácia multicanal teve medianas iguais e elevadas $(6,0)$ para todos os itens, confirmando a autoavaliação na eficácia multicanal.

Quadro 8 - Estatística descritiva das variáveis Push

\begin{tabular}{|c|c|c|c|c|c|c|c|}
\hline $\begin{array}{l}\text { Variáveis } \\
\text { Push }\end{array}$ & & & $\mathrm{N}$ & Média & $\begin{array}{l}\text { Desvio } \\
\text { Padrão }\end{array}$ & $\begin{array}{c}\text { Coef. } \\
\text { Variação }\end{array}$ & Mediana \\
\hline \multirow{4}{*}{ 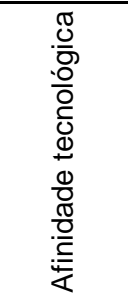 } & AT91 & $\begin{array}{l}\text { Com relação à tecnologia, eu me sinto tão atualizado } \\
\text { quanto meus colegas. }\end{array}$ & 883 & 5,47 & 1,478 & $27 \%$ & 6,00 \\
\hline & AT92 & Eu acho fácil fazer compras pela internet. & 883 & 6,16 & 1,191 & $19 \%$ & 6,00 \\
\hline & AT93 & Para mim, é fácil eu usar a internet. & 883 & 6,28 & 1,083 & $17 \%$ & 7,00 \\
\hline & AT94 & Sinto-me à vontade para aprender novas tecnologias. & 883 & 6,22 & 1,151 & $19 \%$ & 7,00 \\
\hline \multirow{5}{*}{ 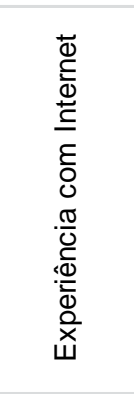 } & EX101 & Eu tenho muita experiência com compras pela internet & 883 & 5,74 & 1,173 & $20 \%$ & 6,00 \\
\hline & EX102 & Eu não faço pesquisas na internet com frequência. & 883 & 2,78 & 2,127 & $77 \%$ & 2,00 \\
\hline & EX103 & Eu sou bom em fazer pesquisas na internet. & 883 & 5,80 & 1,236 & $21 \%$ & 6,00 \\
\hline & EX104 & $\begin{array}{l}\text { Eu consigo encontrar informação sobre produtos } \\
\text { rapidamente na internet. }\end{array}$ & 883 & 5,94 & 1,156 & $19 \%$ & 6,00 \\
\hline & EX105 & $\begin{array}{l}\text { Quando o assunto é comprar pela internet, eu me } \\
\text { considero um especialista. }\end{array}$ & 883 & 5,25 & 1,334 & $25 \%$ & 5,00 \\
\hline \multirow{4}{*}{ 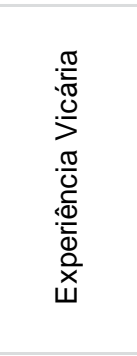 } & EV111 & $\begin{array}{l}\text { Meus amigos têm tido boas experiências com o uso de } \\
\text { canais múltiplos de vendas de lojas de varejo. }\end{array}$ & 883 & 4,65 & 1,263 & $27 \%$ & 4,00 \\
\hline & EV112 & $\begin{array}{l}\text { Meus colegas de trabalho têm tido boas experiências } \\
\text { com o uso de canais múltiplos de vendas de lojas de } \\
\text { varejo. }\end{array}$ & 883 & 4,65 & 1,252 & $27 \%$ & 4,00 \\
\hline & EV113 & $\begin{array}{l}\text { Minha família tem tido boas experiências com o uso de } \\
\text { canais múltiplos de vendas de lojas de varejo. }\end{array}$ & 883 & 4,86 & 1,285 & $26 \%$ & 5,00 \\
\hline & EV114 & $\begin{array}{l}\text { Meus filhos me ajudam na busca de informação e } \\
\text { compra de produtos. }\end{array}$ & 883 & 3,95 & 1,878 & $48 \%$ & 4,00 \\
\hline \multirow{4}{*}{ 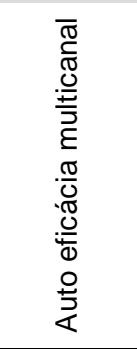 } & $\mathrm{AE} 121$ & $\begin{array}{l}\text { Acho fácil utilizar com sucesso diferentes canais de } \\
\text { lojas do varejo durante o processo de compra. }\end{array}$ & 883 & 5,54 & 1,277 & $23 \%$ & 6,00 \\
\hline & AE122 & $\begin{array}{l}\text { Acredito que sei avaliar as opções oferecidas pelos } \\
\text { múltiplos canais de venda de lojas do varejo. }\end{array}$ & 883 & 5,66 & 1,160 & $20 \%$ & 6,00 \\
\hline & AE123 & $\begin{array}{l}\text { Eu me sinto confiante usando diferentes canais de } \\
\text { vendas de lojas do varejo. }\end{array}$ & 883 & 5,51 & 1,252 & $23 \%$ & 6,00 \\
\hline & AE124 & $\begin{array}{l}\text { Sou capaz de lidar com os serviços de diferentes canais } \\
\text { de vendas de lojas do varejo. }\end{array}$ & 883 & 5,62 & 1,176 & $21 \%$ & 6,00 \\
\hline
\end{tabular}

Legenda: AT - afinidade tecnológica, EX - experiência prévia com internet, EV - experiência vicária, $\mathrm{AE}$ - autoeficácia multicanal. Fonte - elaborado pelo autor.

A seguir (Quadro 9), a satisfação ligada à loja física (SA193 e SA194) apresentou medianas pontuadas em 4,0 em relação aos demais itens do construto. Quanto à confiança o item "baseado em minha experiência passada eu acredito que a transação na loja on-line é confiável" revelou maior pontuação para média $(5,63)$ e 
mediana $(6,0)$ em relação aos demais itens. Em geral os respondentes apresentam mediana pontuada em 5,0 para os demais itens.

Quanto à lealdade ao varejista, observam-se medianas iguais $(4,0)$ para os itens, sinalizando baixa intenção de lealdade com coeficientes de variação acima de $30 \%$.

Quadro 9 - estatística descritiva das variáveis push

\begin{tabular}{|c|c|c|c|c|c|c|c|}
\hline $\begin{array}{l}\text { Variáveis } \\
\text { Push }\end{array}$ & & & $\mathrm{N}$ & Média & $\begin{array}{l}\text { Desvio } \\
\text { padrão }\end{array}$ & $\begin{array}{c}\text { Coef. } \\
\text { Variação }\end{array}$ & Mediana \\
\hline \multirow{5}{*}{ 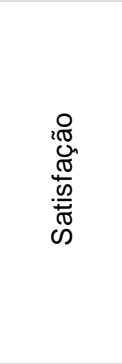 } & SA191 & $\begin{array}{l}\text { As compras através de múltiplos canais de vendas me } \\
\text { satisfazem desde que sejam de uma mesma loja varejista. }\end{array}$ & 883 & 4,04 & 1,549 & $38 \%$ & 4,00 \\
\hline & SA192 & $\begin{array}{l}\text { Eu faço a maior parte das minhas pesquisas na internet e na } \\
\text { hora de comprar é que eu decido onde quero comprar. }\end{array}$ & 883 & 5,76 & 1,305 & $23 \%$ & 6,00 \\
\hline & SA193 & $\begin{array}{l}\text { Eu gosto de fazer a compra na loja física, pois assim eu posso } \\
\text { olhar e conferir o produto. }\end{array}$ & 883 & 4,31 & 1,616 & $37 \%$ & 4,00 \\
\hline & SA194 & $\begin{array}{l}\text { Eu gosto de fazer a compra na loja física, pois assim eu posso } \\
\text { sentir o produto. }\end{array}$ & 883 & 4,27 & 1,650 & $39 \%$ & 4,00 \\
\hline & SA195 & $\begin{array}{l}\text { Gosto muito de comprar por meio de vários canais de vendas e } \\
\text { me sinto livre para mudar de loja online para física ou vice-versa }\end{array}$ & 883 & 5,58 & 1,394 & $25 \%$ & 6,00 \\
\hline \multirow{5}{*}{ 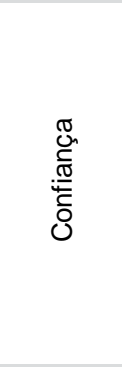 } & CF201 & $\begin{array}{l}\text { Baseado em minhas experiências passadas, eu acredito que a } \\
\text { transação na loja online é confiável. }\end{array}$ & 883 & 5,63 & 1,213 & $22 \%$ & 6,00 \\
\hline & CF202 & $\begin{array}{l}\text { Eu acredito que a transação na loja física é sempre mais } \\
\text { confiável do que na loja online. }\end{array}$ & 883 & 4,65 & 1,725 & $37 \%$ & 5,00 \\
\hline & CF203 & $\begin{array}{l}\text { Eu acredito que a transação na loja física é mais segura do que } \\
\text { na loja online. }\end{array}$ & 883 & 4,68 & 1,714 & $37 \%$ & 5,00 \\
\hline & CF204 & Eu acredito que a transação na loja online é sempre segura. & 883 & 4,59 & 1,454 & $32 \%$ & 5,00 \\
\hline & CF205 & $\begin{array}{l}\text { Eu confio que a loja online irá prontamente me informar se } \\
\text { ocorrer qualquer problema com meu pedido. }\end{array}$ & 883 & 4,69 & 1,565 & $33 \%$ & 5,00 \\
\hline \multirow{4}{*}{$\begin{array}{l}\frac{0}{0} \\
\frac{\pi}{0} \\
\stackrel{\Xi}{\Xi}\end{array}$} & LE211 & $\begin{array}{l}\text { Por enquanto, eu duvido que troque as lojas varejistas online } \\
\text { em que eu estou acostumado a usar e comprar. }\end{array}$ & 883 & 4,37 & 1,590 & $36 \%$ & 4,00 \\
\hline & LE212 & $\begin{array}{l}\text { Por enquanto, eu duvido que eu troque as lojas físicas nas } \\
\text { quais estou acostumado a comprar. }\end{array}$ & 883 & 4,00 & 1,579 & $39 \%$ & 4,00 \\
\hline & LE213 & $\begin{array}{l}\text { Raramente eu pensaria em mudar da loja varejista online em } \\
\text { que atualmente compro. }\end{array}$ & 883 & 3,98 & 1,609 & $40 \%$ & 4,00 \\
\hline & LE214 & $\begin{array}{l}\text { Raramente eu pensaria em mudar de loja física em que } \\
\text { atualmente compro. }\end{array}$ & 883 & 3,78 & 1,607 & $43 \%$ & 4,00 \\
\hline
\end{tabular}

Legenda: SA - satisfação, CF - confiança, LE - lealdade.

Fonte: elaborado pelo autor

Sobre as variáveis mooring, podem-se destacar algumas observações interessantes (Quadro 10). Sobre o custo de mudança $(\mathrm{CM})$ a mediana pontua 6,0 , para a frequência ocasional da experiência com outras lojas, maior do que a mediana de "eu tenho mudado muito de loja ou rede varejista" $(5,0)$, evidenciando que o comportamento multicanal não incluiu muitos varejistas. Os itens da variável integração percebida (IN) apontaram uma mediana 4,0 (neutro). Busca de variedade (BV) apresentou mediana mais elevada $(5,0$ e 6,0$)$ do que Integração 


\section{percebida. A variável RF162 - retenção na firma - apresentou baixa média em relação às demais.}

Quadro 10- Estatística descritiva das variáveis Mooring

\begin{tabular}{|c|c|c|c|c|c|c|c|}
\hline $\begin{array}{l}\text { Variáveis } \\
\text { Mooring } \\
\end{array}$ & & & $\mathrm{N}$ & Média & $\begin{array}{l}\text { Desvio } \\
\text { padrão }\end{array}$ & $\begin{array}{c}\text { Coef. } \\
\text { Variação } \\
\end{array}$ & Mediana \\
\hline \multirow{4}{*}{ 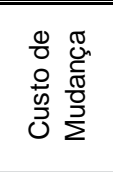 } & CM131 & Às vezes eu experimento outras lojas e redes varejistas. & 883 & 5,31 & 1,361 & $26 \%$ & 6 \\
\hline & CM132 & Custa esforço para eu mudar de loja ou rede varejista. & 883 & 3,67 & 1,727 & $47 \%$ & 4 \\
\hline & CM133 & Eu tenho mudado muito de loja ou rede varejista. & 883 & 4,54 & 1,538 & $34 \%$ & 5 \\
\hline & CM134 & Leva tempo para eu mudar de loja ou rede varejista. & 883 & 3,85 & 1,695 & $44 \%$ & 4 \\
\hline \multirow{4}{*}{ 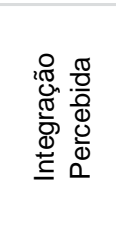 } & IN141 & Eu posso comprar o produto pela internet dentro da loja física. & 883 & 3,99 & 1,840 & $46 \%$ & 4 \\
\hline & IN142 & Eu posso retirar o produto na loja física da rede varejista. & 883 & 4,23 & 1,785 & $42 \%$ & 4 \\
\hline & IN143 & $\begin{array}{l}\text { Eu posso devolver o produto pela loja física, caso ele esteja } \\
\text { com defeito. }\end{array}$ & 883 & 4,04 & 1,916 & $47 \%$ & 4 \\
\hline & IN144 & Eu posso trocar o produto na loja física. & 883 & 4,07 & 1,934 & $47 \%$ & 4 \\
\hline \multirow{6}{*}{ 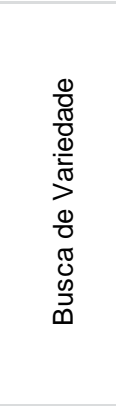 } & BV151 & Eu compro coisas que eu não tinha planejado adquirir. & 883 & 3,31 & 1,978 & $60 \%$ & 3 \\
\hline & BV152 & $\begin{array}{l}\text { Eu gosto um bocado de variedade de alternativas de tipo e } \\
\text { marca de produtos do varejo. }\end{array}$ & 883 & 5,24 & 1,554 & $30 \%$ & 6 \\
\hline & BV153 & $\begin{array}{l}\text { Eu gosto de experimentar diferentes canais de vendas dentro } \\
\text { das alternativas do varejo. }\end{array}$ & 883 & 5,19 & 1,436 & $28 \%$ & 5 \\
\hline & BV154 & $\begin{array}{l}\text { Eu gosto de explorar e alternar entre lojas físicas e loja online } \\
\text { (internet). }\end{array}$ & 883 & 5,19 & 1,486 & $29 \%$ & 5 \\
\hline & BV155 & $\begin{array}{l}\text { Eu gosto de novos estilos e diferentes tipos de produto e } \\
\text { marca. }\end{array}$ & 883 & 5,16 & 1,427 & $28 \%$ & 5 \\
\hline & BV156 & $\begin{array}{l}\text { Pesquisar uma nova loja e um novo site é geralmente uma } \\
\text { perda de tempo. }\end{array}$ & 883 & 2,99 & 1,755 & $59 \%$ & 3 \\
\hline \multirow{4}{*}{ 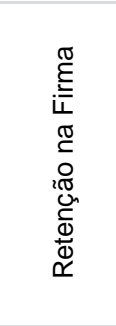 } & RF161 & $\begin{array}{l}\text { Eu não tenho problema em mudar entre os canais de vendas } \\
\text { varejistas. }\end{array}$ & 883 & 5,09 & 1,441 & $28 \%$ & 5 \\
\hline & RF162 & $\begin{array}{l}\text { Eu não gosto de mudar para o canal de venda de outro varejista } \\
\text { depois de eu ter gasto algum tempo com pesquisa online no } \\
\text { site de um varejista. }\end{array}$ & 883 & 3,41 & 1,702 & $50 \%$ & 4 \\
\hline & RF163 & $\begin{array}{l}\text { Eu teria feito troca entre lojas e canais de vendas varejistas, se } \\
\text { eu pudesse fazer isso sem aborrecimento. }\end{array}$ & 883 & 4,61 & 1,490 & $32 \%$ & 5 \\
\hline & RF164 & $\begin{array}{l}\text { Não há dificuldades técnicas associadas com a troca entre } \\
\text { canais de vendas de varejistas. }\end{array}$ & 883 & 4,41 & 1,563 & $35 \%$ & 4 \\
\hline \multirow{6}{*}{ 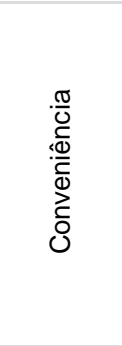 } & CO171 & Comprar na internet é muito prático. & 883 & 6,12 & 1,045 & $17 \%$ & 6 \\
\hline & CO172 & $\begin{array}{l}\text { Eu economizo muito tempo comprando produtos como esse na } \\
\text { internet. }\end{array}$ & 883 & 6,06 & 1,091 & $18 \%$ & 6 \\
\hline & $\mathrm{CO173}$ & É maravilhoso comprar esses produtos em lojas online. & 883 & 5,71 & 1,224 & $21 \%$ & 6 \\
\hline & $\mathrm{CO174}$ & $\begin{array}{l}\text { Passear em lojas físicas e comprar online é muito conveniente } \\
\text { para mim. }\end{array}$ & 883 & 5,19 & 1,497 & $29 \%$ & 5 \\
\hline & CO175 & Pesquisar em lojas físicas é muito prático. & 883 & 4,17 & 1,767 & $42 \%$ & 4 \\
\hline & CO176 & $\begin{array}{l}\text { Pesquisar pela internet e comprar em loja física é muito } \\
\text { conveniente para esse produto. }\end{array}$ & 883 & 4,65 & 1,670 & $36 \%$ & 5 \\
\hline \multirow{5}{*}{$\begin{array}{l}\frac{0}{5} \\
\stackrel{5}{0} \\
0 \\
0 \\
.0 \\
.00 \\
0 \\
0 \\
0\end{array}$} & DS181 & $\begin{array}{l}\text { Eu prefiro comprar em sites que não demoram em carregar e } \\
\text { onde a navegação é rápida. }\end{array}$ & 883 & 5,91 & 1,360 & $23 \%$ & 6 \\
\hline & DS182 & $\begin{array}{l}\text { Eu não gosto do formato de apresentação diferente de alguns } \\
\text { websites de lojas varejistas. }\end{array}$ & 883 & 4,85 & 1,448 & $30 \%$ & 5 \\
\hline & DS183 & $\begin{array}{l}\text { Em muitos sites tenho que navegar muito até achar o que } \\
\text { procuro. }\end{array}$ & 883 & 4,91 & 1,476 & $30 \%$ & 5 \\
\hline & DS184 & É realmente irritante quando os sites demoram a carregar. & 883 & 5,96 & 1,383 & $23 \%$ & 6 \\
\hline & DS185 & $\begin{array}{l}\text { Para falar a verdade, não aguento mais as propagandas no site } \\
\text { de lojas varejistas. }\end{array}$ & 883 & 4,60 & 1,555 & $34 \%$ & 5 \\
\hline
\end{tabular}

Legenda: CM - custo de mudança, In - percepção de integração da firma, BV - busca de variedade, $\mathrm{RF}$ - retenção na firma, CO - conveniência, DS - design do site.

Fonte - elaborado pelo autor. 
A estatística descritiva para as variáveis Pull (Quadro 11), de modo geral evidenciaram baixa adesão ao varejo off-line e coeficientes de variação maiores que $30 \%$. A qualidade percebida pontuou medianas iguais (4,0 - neutro).

Quadro 11- Estatística Descritiva das variáveis Pull

\begin{tabular}{|c|c|c|c|c|c|c|c|}
\hline $\begin{array}{l}\text { Variáveis } \\
\text { Pull }\end{array}$ & & & $\mathrm{N}$ & Média & $\begin{array}{l}\text { Desvio } \\
\text { Padrão }\end{array}$ & $\begin{array}{l}\text { Coef. } \\
\text { Variação }\end{array}$ & Mediana \\
\hline \multirow{6}{*}{$\begin{array}{l}\frac{\pi}{0} \\
\frac{0}{0} \\
0 \\
\frac{0}{0} \\
0 \\
0 \\
\frac{0}{0} \\
\frac{\pi}{0} \\
\frac{0}{0} \\
0\end{array}$} & QP221 & $\begin{array}{l}\text { Eu posso chegar a qualquer momento numa loja } \\
\text { varejista. }\end{array}$ & 883 & 4,04 & 1,771 & $44 \%$ & 4,00 \\
\hline & QP222 & Gosto da atmosfera e decoração das lojas. & 883 & 4,02 & 1,583 & $39 \%$ & 4,00 \\
\hline & QP223 & $\begin{array}{l}\text { Os funcionários da loja varejista atendem } \\
\text { imediatamente quando eu faço uma reclamação. }\end{array}$ & 883 & 3,57 & 1,643 & $46 \%$ & 4,00 \\
\hline & QP224 & $\begin{array}{l}\text { Os funcionários da loja estão sempre dispostos a me } \\
\text { ajudar quando tenho problema com os serviços. }\end{array}$ & 883 & 3,72 & 1,618 & $43 \%$ & 4,00 \\
\hline & QP225 & $\begin{array}{l}\text { Os funcionários da loja me dão atenção } \\
\text { pessoalmente. }\end{array}$ & 883 & 4,05 & 1,602 & $40 \%$ & 4,00 \\
\hline & QP226 & $\begin{array}{l}\text { Os funcionários das lojas entendem minhas } \\
\text { necessidades específicas. }\end{array}$ & 883 & 3,88 & 1,599 & $41 \%$ & 4,00 \\
\hline \multirow{6}{*}{ 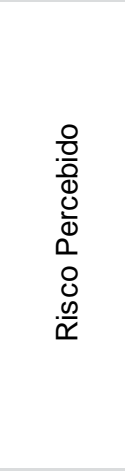 } & RP231 & $\begin{array}{l}\text { A chance de comprar de um site fraudulento é } \\
\text { grande. }\end{array}$ & 883 & 4,01 & 1,747 & $44 \%$ & 4,00 \\
\hline & RP232 & $\begin{array}{l}\text { A chance de ter problemas de remessa e entrega de } \\
\text { produtos é grande. }\end{array}$ & 883 & 4,14 & 1,653 & $40 \%$ & 4,00 \\
\hline & RP233 & $\begin{array}{l}\text { A privacidade de meus dados pessoais não está } \\
\text { garantida quando eu compro em loja online. }\end{array}$ & 883 & 4,06 & 1,660 & $41 \%$ & 4,00 \\
\hline & RP234 & $\begin{array}{l}\text { A probabilidade de erro no pagamento do produto é } \\
\text { maior comprando em loja online. }\end{array}$ & 883 & 3,76 & 1,687 & $45 \%$ & 4,00 \\
\hline & RP235 & $\begin{array}{l}\text { É difícil julgar a qualidade do produto, comprando em } \\
\text { loja online. }\end{array}$ & 883 & 4,15 & 1,733 & $42 \%$ & 4,00 \\
\hline & RP236 & $\begin{array}{l}\text { Existe grande probabilidade de que eu não receba o } \\
\text { produto correto. }\end{array}$ & 883 & 3,79 & 1,662 & $44 \%$ & 4,00 \\
\hline \multirow{5}{*}{ 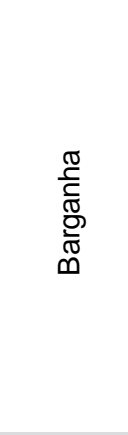 } & BA241 & Eu adoro pechinchar. & 883 & 4,61 & 1,779 & $39 \%$ & 5,00 \\
\hline & BA242 & $\begin{array}{l}\text { Eu tenho muito orgulho de ser um comprador } \\
\text { esperto. }\end{array}$ & 883 & 4,24 & 1,665 & $39 \%$ & 4,00 \\
\hline & BA243 & $\begin{array}{l}\text { Estou pronto a gastar um tempo extra nas compras } \\
\text { para conseguir os melhores preços nos produtos que } \\
\text { estou procurando. }\end{array}$ & 883 & 4,64 & 1,804 & $39 \%$ & 5,00 \\
\hline & BA244 & $\begin{array}{l}\text { É importante eu conhecer todas as alternativas de } \\
\text { transação disponíveis antes de fazer uma compra. }\end{array}$ & 883 & 5,13 & 1,614 & $31 \%$ & 5,00 \\
\hline & BA245 & $\begin{array}{l}\text { Parte do meu divertimento é o prazer que me dá } \\
\text { quando eu consigo um benefício extra da loja física } \\
\text { onde comprei o produto. }\end{array}$ & 883 & 4,57 & 1,779 & $39 \%$ & 5,00 \\
\hline \multirow{5}{*}{ 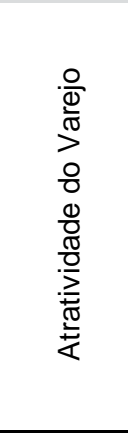 } & AV251 & $\begin{array}{l}\text { Eu estou mais satisfeito com os serviços da loja } \\
\text { física do que das lojas online da internet. }\end{array}$ & 883 & 3,58 & 1,639 & $46 \%$ & 4,00 \\
\hline & AV252 & $\begin{array}{l}\text { Gosto de comprar em loja física porque quero tocar e } \\
\text { sentir o produto. }\end{array}$ & 883 & 4,18 & 1,687 & $40 \%$ & 4,00 \\
\hline & AV253 & $\begin{array}{l}\text { Gosto de comprar em loja física porque quero ver o } \\
\text { produto, seu funcionamento e suas dimensões. }\end{array}$ & 883 & 4,40 & 1,678 & $38 \%$ & 5,00 \\
\hline & AV254 & $\begin{array}{l}\text { No geral, as práticas da loja física em que eu compro } \\
\text { me beneficiam mais do que as práticas das lojas } \\
\text { online. }\end{array}$ & 883 & 3,79 & 1,609 & $42 \%$ & 4,00 \\
\hline & AV255 & $\begin{array}{l}\text { Regra geral, comprar da loja física é melhor do que } \\
\text { comprar de loja online. }\end{array}$ & 883 & 3,58 & 1,662 & $46 \%$ & 4,00 \\
\hline
\end{tabular}

$$
\text { Fonte - elaborado pelo autor. }
$$


As questões de risco percebido também tiveram baixas medianas e iguais $(4,0)$ para fraude, logística e distribuição, privacidade dos dados, erro de pagamento e qualidade do produto recebido. Sobre a barganha, "eu tenho muito orgulho de ser um comprador experto" teve menor mediana $(4,0)$ quando o respondente se autoavalia no seu desempenho. Porém o gosto de barganhar recebeu mediana $(5,0)$ e a compra técnica, com exploração de todas as alternativas foi melhor média $(5,13)$ e mediana $(5,0)$.

Finalmente para o construto atratividade no varejo, destaca-se o item AV253 com mediana 5,0 e média 4,4. O gosto de comprar em loja física foi mais bem pontuado quando se trata de verificar questões técnicas do produto.

Os itens do construto free-riding (Quadro 12), para a pergunta "eu iria pesquisar numa loja on-line, mas comprar em uma loja física ou vice-versa", apresentaram medianas 5,0, exceto a FR 262, uma distribuição quase simétrica da frequência.

Quadro 12- Estatística descritiva - variáveis dependente

\begin{tabular}{|c|c|c|c|c|c|c|c|}
\hline $\begin{array}{c}\text { Variáveis } \\
\text { dependentes }\end{array}$ & & & $\mathrm{N}$ & Média & $\begin{array}{l}\text { Desvio } \\
\text { Padrão }\end{array}$ & $\begin{array}{c}\text { Coef. } \\
\text { Variação }\end{array}$ & Mediana \\
\hline \multirow{4}{*}{ 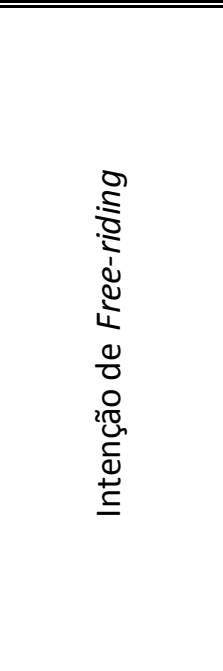 } & FR261 & $\begin{array}{l}\text { Quando eu compro produtos } \\
\text { semelhantes aos desta pesquisa. }\end{array}$ & 883 & 4,60 & 1,440 & $31 \%$ & 5,00 \\
\hline & FR262 & $\begin{array}{l}\text { Quando eu compro produtos diferentes } \\
\text { dos desta pesquisa. }\end{array}$ & 883 & 4,45 & 1,393 & $31 \%$ & 4,00 \\
\hline & FR263 & $\begin{array}{l}\text { Sinto-me confortável em navegar nos } \\
\text { múltiplos canais de vendas de uma } \\
\text { mesma rede varejista, para pesquisa } \\
\text { pela internet e compra na loja física ou } \\
\text { vice-versa, quando se trata de produtos } \\
\text { como o desta pesquisa. }\end{array}$ & 883 & 4,91 & 1,379 & $28 \%$ & 5,00 \\
\hline & FR264 & $\begin{array}{l}\text { Sinto-me confortável em navegar nos } \\
\text { múltiplos canais de vendas de } \\
\text { diferentes lojas varejistas, para } \\
\text { pesquisa pela internet e compra na loja } \\
\text { física ou vice-versa. No caso de produtos } \\
\text { como o desta pesquisa. }\end{array}$ & 883 & 4,96 & 1,375 & $28 \%$ & 5,00 \\
\hline
\end{tabular}

Fonte - elaborado pelo autor. 


\subsubsection{Perfil da amostra}

A amostra evidencia uma participação de $65,2 \%$ de homens (Quadro 13), maior frequência para renda familiar mensal (Quadro 14) entre $R \$ 1.500,00$ a $R \$ 3.000,00$, faixa etária (Quadro 16) bem distribuída e com maior frequência para 31 a 40 anos. E, finalmente o nível de escolaridade (Quadro 18) com maior frequência foi para segundo grau completo. Os respondentes pertencem a 23 estados, sendo $2 \%$ da região norte, $10 \%$ da região nordeste, $5 \%$ da região centro-oeste, $67 \%$ da região sudeste e $16 \%$ da região sul (Quadro 20).

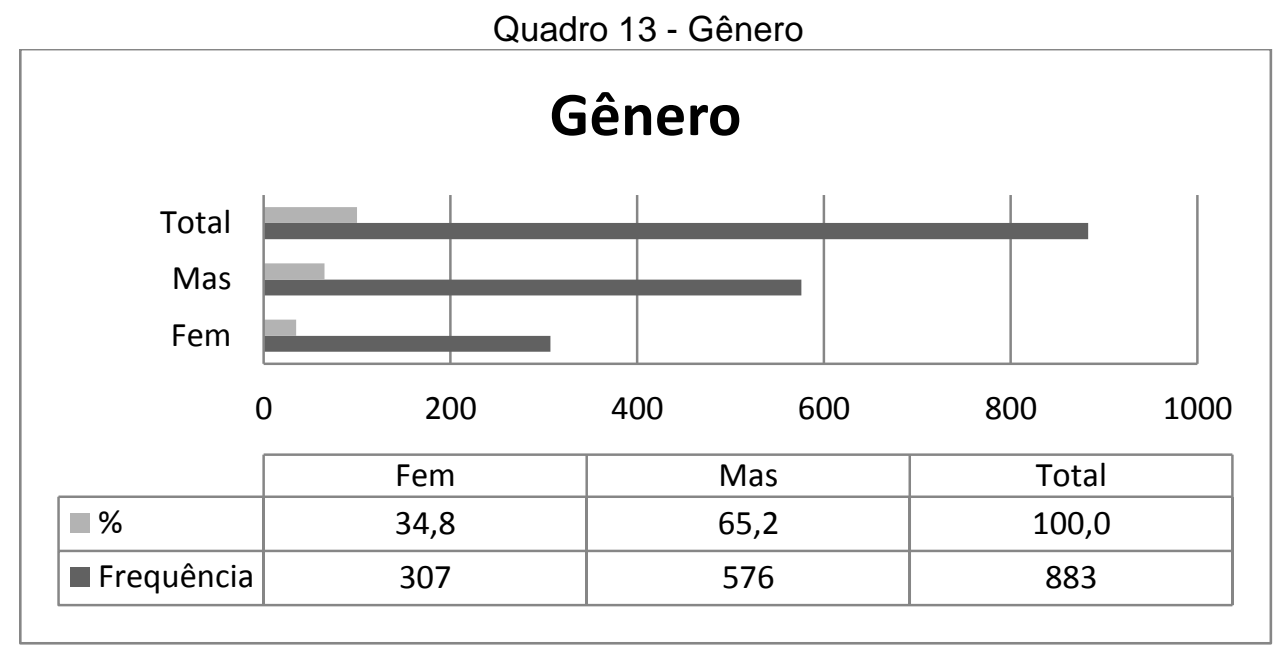

Fonte: elaborado pelo autor

Quadro 14 - Renda Familiar Mensal

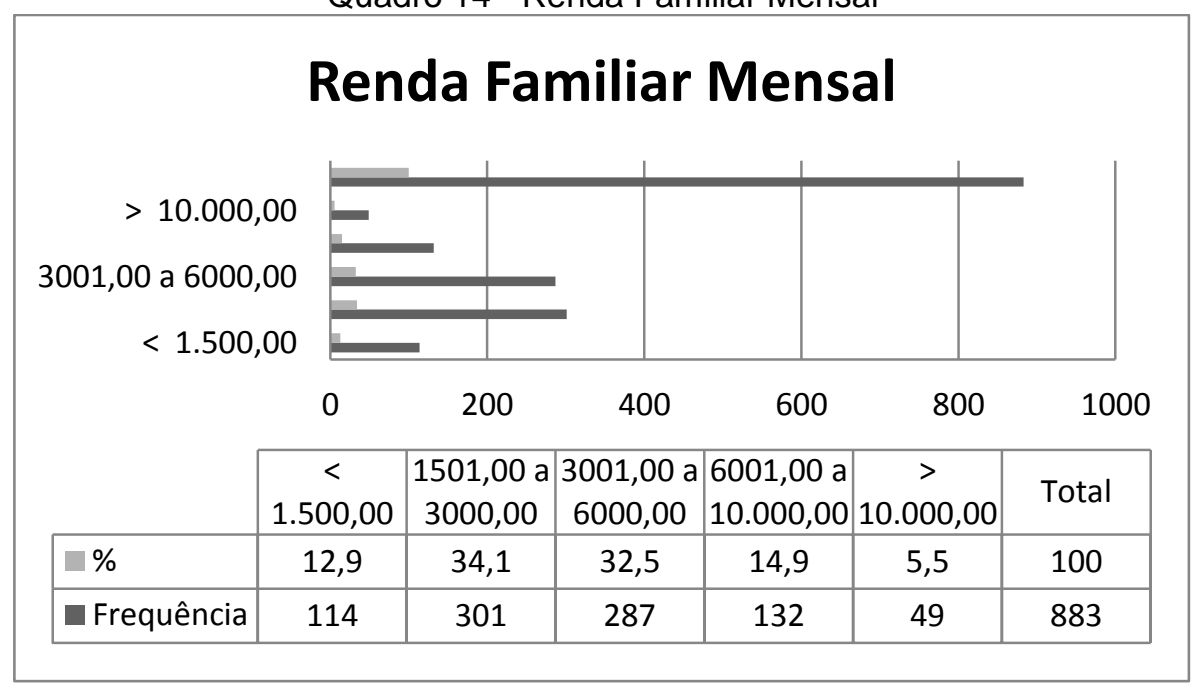

Fonte: elaborado pelo autor. 
Quadro 15 - Gênero x Faixa de renda mensal

\begin{tabular}{|l|c|c|c|c|c|c|}
\cline { 2 - 7 } \multicolumn{1}{c|}{} & \multicolumn{7}{c|}{ Faixa de Renda } \\
\hline Gênero & $<$ & $1501-$ & & & & \\
\hline Feminino & $14 \%$ & 3000 & $3001-6000$ & $6001-10.000$ & $>10.000$ & Total Geral \\
\hline Masculino & $12 \%$ & $32 \%$ & $32 \%$ & $17 \%$ & $7 \%$ & $100 \%$ \\
\hline Total Geral & 114 & 301 & 287 & 132 & 49 & 883 \\
\hline
\end{tabular}

No grupo de mulheres (Quadro 17), há maior proporção de mulheres jovens (24,2\% menor que 30 anos) do que no grupo de homens (19,3\%). Por sua vez, há respondentes homens mais velhos em maior proporção no grupo de homens $(24,7 \%$ com mais de 50 anos) do que no grupo de mulheres (19,7\%). No grupo de mulheres (Quadro 19) há maior proporção de mulheres com nível de escolaridade de pósgraduação completa (16\%) do que no grupo de homens (13\%). E, finalmente, quanto à faixa de renda, no grupo de mulheres há uma proporção de mulheres que ganham faixas mais baixas do que comparativamente no grupo de homens (Quadro 15).

Quadro 16- Faixa etária

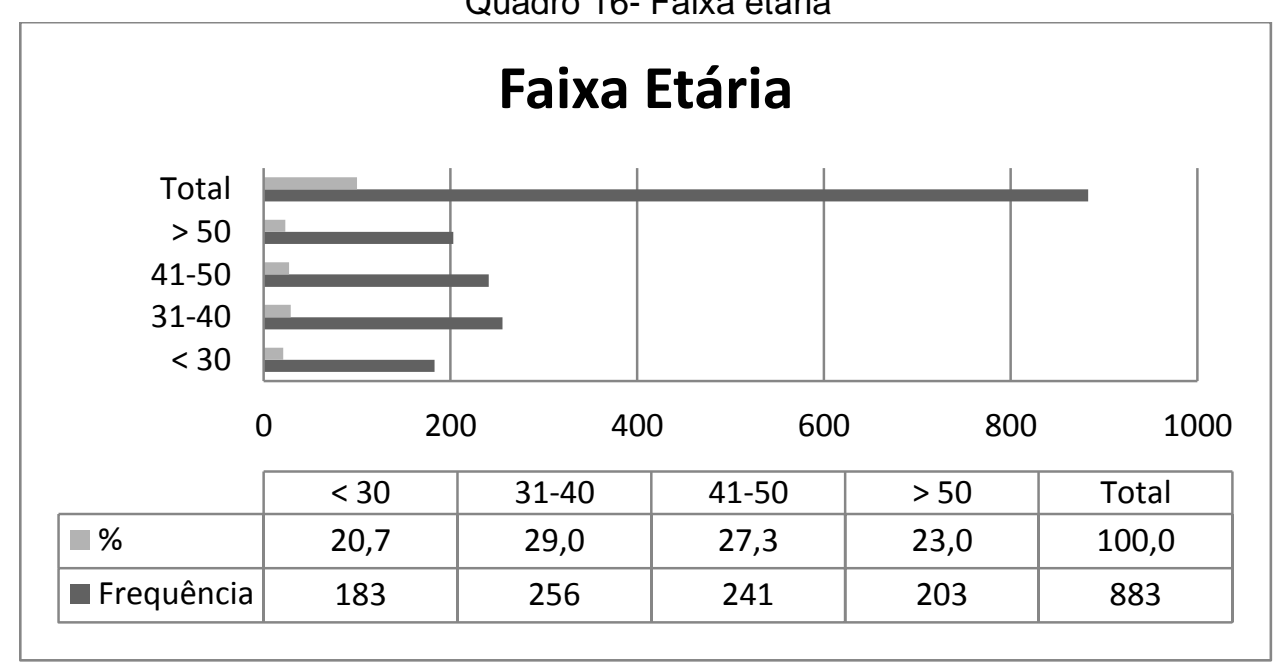

Fonte: elaborado pelo autor.

Quadro 17 - Gênero versus Faixa Etária

\begin{tabular}{|c|c|c|c|c|c|}
\cline { 2 - 6 } \multicolumn{1}{c|}{} & \multicolumn{5}{c|}{ Faixa etária } \\
\hline Gênero & $<30$ & $31-40$ & $41-50$ & $>50$ & Total Geral \\
\hline Feminino & $24,2 \%$ & $31,0 \%$ & $25,2 \%$ & $19,7 \%$ & $100,0 \%$ \\
\hline Masculino & $19,3 \%$ & $27,8 \%$ & $28,3 \%$ & $24,7 \%$ & $100,0 \%$ \\
\hline & Fonte: elaborado pelo autor.
\end{tabular}


Quadro 18 - Nível de escolaridade

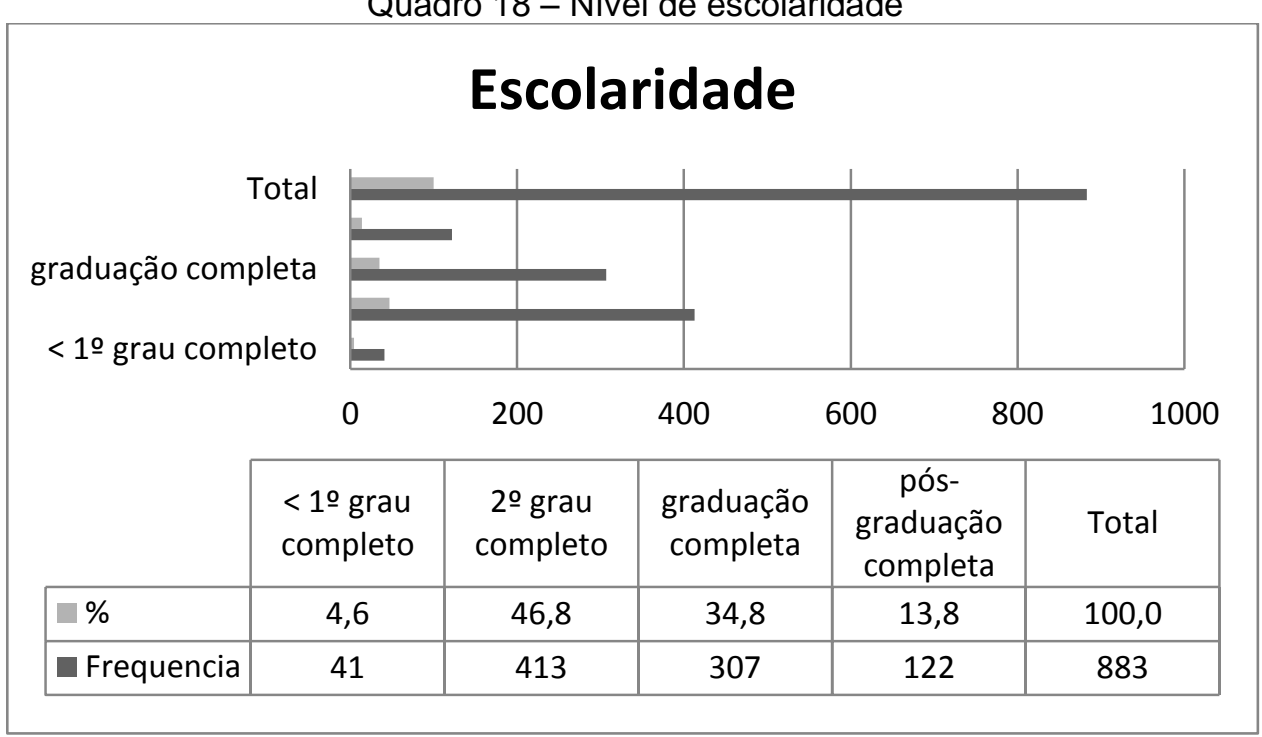

Fonte: elaborado pelo próprio autor.

Quadro 19 - Gênero versus Escolaridade

\begin{tabular}{|l|c|c|c|c|c|}
\hline & Escolaridade & & & & \\
\hline Gênero & $\begin{array}{c}\text { 1ㅇ g } \\
\text { completo }\end{array}$ & $\begin{array}{c}\text { Pós } \\
\text { completo }\end{array}$ & Graduação & $\begin{array}{c}\text { Graduação } \\
\text { completo }\end{array}$ & $\begin{array}{c}\text { Total } \\
\text { Geral }\end{array}$ \\
\hline Feminino & $5 \%$ & $45 \%$ & $35 \%$ & $16 \%$ & $100 \%$ \\
\hline Masculino & $5 \%$ & $48 \%$ & $35 \%$ & $13 \%$ & $100 \%$ \\
\hline
\end{tabular}

Fonte: elaborado pelo próprio autor.

A questão (5) refere-se ao estado onde mora o respondente. Foram 23 estados coletados e o Quadro 20 realiza uma comparação com a estimativa da população residente no Brasil para 2013, segundo as unidades de federação do IBGE. 
Quadro 20 - Distribuição da amostra em relação à população brasileira

\begin{tabular}{|l|l|c|c|c|}
\hline Brasil & $\mathbf{2 0 1 . 0 3 2 . 7 1 4}$ & $100 \%$ & 883 & $100 \%$ \\
\hline Região Norte & 16.983 .484 & $8 \%$ & 18 & $2 \%$ \\
\hline Rondônia & 1.728 .214 & $1 \%$ & & $0 \%$ \\
\hline Acre & 776.463 & $0 \%$ & 1 & $0 \%$ \\
\hline Amazonas & 3.807 .921 & $2 \%$ & 4 & $0 \%$ \\
\hline Roraima & 488.072 & $0 \%$ & 3 & $0 \%$ \\
\hline Pará & 7.969 .654 & $4 \%$ & 10 & $1 \%$ \\
\hline Amapá & 734.996 & $0 \%$ & & $0 \%$ \\
\hline Tocantins & 1.478 .164 & $1 \%$ & & $0 \%$ \\
\hline Região Nordeste & $\mathbf{5 5 . 7 9 4 . 7 0 7}$ & $28 \%$ & 87 & $10 \%$ \\
\hline Maranhão & 6.794 .301 & $3 \%$ & 2 & $0 \%$ \\
\hline Piauí & 3.184 .166 & $2 \%$ & 2 & $0 \%$ \\
\hline Ceará & 8.778 .576 & $4 \%$ & 18 & $2 \%$ \\
\hline Rio Grande do Norte & 3.373 .959 & $2 \%$ & 2 & $0 \%$ \\
\hline Paraiba & 3.914 .421 & $2 \%$ & 1 & $0 \%$ \\
\hline Pernambuco & 9.208 .550 & $5 \%$ & 18 & $2 \%$ \\
\hline Alagoas & 3.300 .935 & $2 \%$ & 3 & $0 \%$ \\
\hline Sergipe & 2.195 .662 & $1 \%$ & & $0 \%$ \\
\hline Bahia & 15.044 .137 & $7 \%$ & 41 & $5 \%$ \\
\hline Região Sudeste & 84.465 .570 & $42 \%$ & 596 & $67 \%$ \\
\hline Minas Gerais & 20.593 .356 & $10 \%$ & 108 & $12 \%$ \\
\hline Espíito Santo & 3.839 .366 & $2 \%$ & 9 & $1 \%$ \\
\hline Rio de Janeiro & 16.369 .179 & $8 \%$ & 133 & $15 \%$ \\
\hline São Paulo & 43.663 .669 & $22 \%$ & 346 & $39 \%$ \\
\hline Região Sul & $\mathbf{2 8 . 7 9 5 . 7 6 2}$ & $14 \%$ & 141 & $16 \%$ \\
\hline Paraná & 10.997 .465 & $5 \%$ & 50 & $6 \%$ \\
\hline Santa Catarina & 6.634 .254 & $3 \%$ & 39 & $4 \%$ \\
\hline Rio Grande do Sul & 11.164 .043 & $6 \%$ & 52 & $6 \%$ \\
\hline Região Centro-Oeste & 14.993 .191 & $7 \%$ & 41 & $5 \%$ \\
\hline Mato Grosso do Sul & 2.587 .269 & $1 \%$ & 8 & $1 \%$ \\
\hline Mato Grosso & 3.182 .113 & $2 \%$ & 8 & $1 \%$ \\
\hline Goiás & 6.434 .048 & $3 \%$ & 9 & $1 \%$ \\
\hline Distrito Federal & 2.789 .761 & $1 \%$ & 16 & $2 \%$ \\
\hline GE: & \multicolumn{1}{|c|}{$5 \%$} \\
\hline
\end{tabular}

Fonte: adaptado de IBGE: estimativas da população residente no Brasil e unidades da federação com data de referência em 1ํ de julho de 2013. Diretoria de Pesquisas - DPE - Coordenação de

População e Indicadores Sociais - COPIS.

\subsubsection{Análise das perguntas de corte e filtro}

O questionário quantitativo apresentou uma pergunta de corte $(\mathrm{P} 1)$ direcionada para produtos de maior complexidade e envolvimento tanto para a busca quanto para a 
compra entre multicanais. A Tabela 2 apresenta o resultado das múltiplas respostas para a amostra de 883 respondentes. Maior parcela de respondentes para smartphones e celulares, em segundo console videogame e em terceiro, eletrodomésticos em geral. Dois respondentes dessa categoria compraram apenas um secador (mulher) e barbeador elétrico (homem).

Tabela 2 - Produtos que comprou nos últimos seis meses

\begin{tabular}{|c|c|c|c|c|c|c|}
\hline & Mulher & $\begin{array}{c}\% \\
\text { casos }\end{array}$ & Homem & $\begin{array}{c}\% \\
\text { casos }\end{array}$ & Total & $\begin{array}{l}\% \text { de } \\
\text { casos }\end{array}$ \\
\hline Smartphone/celular & 132 & $15 \%$ & 256 & $29 \%$ & 388 & $43,9 \%$ \\
\hline Console Videogame & 88 & $10 \%$ & 170 & $19 \%$ & 258 & $29,2 \%$ \\
\hline eletrodomésticos e portáteis & 104 & $12 \%$ & 130 & $15 \%$ & 234 & $26,5 \%$ \\
\hline TV Digital & 63 & $7 \%$ & 111 & $13 \%$ & 174 & $19,7 \%$ \\
\hline Computador/ notebook & 66 & $7 \%$ & 106 & $12 \%$ & 172 & $19,5 \%$ \\
\hline Tablet & 49 & $6 \%$ & 85 & $10 \%$ & 134 & $15,2 \%$ \\
\hline Impressora & 38 & $4 \%$ & 73 & $8 \%$ & 111 & $12,6 \%$ \\
\hline Câmara digital & 31 & $4 \%$ & 78 & $9 \%$ & 109 & $12,3 \%$ \\
\hline Ar condicionado & 19 & $2 \%$ & 60 & $7 \%$ & 79 & $8,9 \%$ \\
\hline DVD/Blue Ray & 28 & $3 \%$ & 51 & $6 \%$ & 79 & $8,9 \%$ \\
\hline Aparelho de som & 26 & $3 \%$ & 51 & $6 \%$ & 77 & $8,7 \%$ \\
\hline Filmadora & 6 & $1 \%$ & 13 & $1 \%$ & 19 & $2,2 \%$ \\
\hline Total & 650 & & 1184 & & 1834 & \\
\hline
\end{tabular}

Sobre a experiência vicária (P2) antes da busca e da compra do produto, a questão permitiu múltiplas respostas dos respondentes (Tabela 3). Destaca-se que $47 \%$ da amostra não buscou informação do produto com ninguém, $25 \%$ com os amigos e $24 \%$ com a família. Houve diferenças de comportamento de experiência vicária entre mulheres e homens. A amostra revela que as mulheres fizeram mais consulta à família do que a amigos.

Tabela 3 - Buscou informação sobre o produto com quem?

\begin{tabular}{lcccccc}
\hline Exp. Vicária & Feminino & $\begin{array}{c}\text { \% de } \\
\text { casos }\end{array}$ & Masculino & $\begin{array}{c}\text { \% de } \\
\text { casos }\end{array}$ & Total & $\begin{array}{c}\text { \% de } \\
\text { casos }\end{array}$ \\
\hline \hline Ninguém & 128 & $14 \%$ & 287 & $33 \%$ & 415 & $47 \%$ \\
Com amigos & 69 & $8 \%$ & 148 & $17 \%$ & 217 & $25 \%$ \\
Família & 98 & $11 \%$ & 114 & $13 \%$ & 212 & $24 \%$ \\
Especialistas & 41 & $5 \%$ & 91 & $10 \%$ & 132 & $15 \%$ \\
Colegas do trabalho & 33 & $4 \%$ & 66 & $7 \%$ & 99 & $11 \%$ \\
\hline \hline Total & 369 & & 706 & & 1075 & \\
\hline
\end{tabular}


Indagados sobre o local onde buscaram a informação do produto (P3,Tabela 4), os respondentes tiveram a opção de múltiplas respostas. Destaca-se que $76 \%$ das respostas foram para busca na internet brasileira e 39,5\% para sites de comparação de preços. Em terceiro ficou o cruzamento entre canais: loja on-line $\rightarrow$ loja física com $31,3 \%$ de casos.

Tabela 4 - Local de busca de informação para o produto.

\begin{tabular}{lcc}
\hline Onde buscou informação? & Frequência \% de casos \\
\hline \hline Internet Brasileira & 671 & $76,0 \%$ \\
Site de comparação de preços & 349 & $39,5 \%$ \\
Loja online e depois loja Física & 276 & $31,3 \%$ \\
Site do fabricante & 275 & $31,1 \%$ \\
Loja Física & 246 & $27,9 \%$ \\
Loja física e depois loja online & 123 & $13,9 \%$ \\
Internet Estrangeira & 122 & $13,8 \%$ \\
Televisão & 74 & $8,4 \%$ \\
Consulta por telefone & 26 & $2,9 \%$ \\
Outros citados: & 7 & $0,8 \%$ \\
$\quad$ Sites de reclamação & 3 & $0,3 \%$ \\
$\quad$ Fórum, blogs, redes sociais & 2 & $0,2 \%$ \\
\hline \hline Total & 2174 \\
\hline
\end{tabular}

Sobre o local efetivo da compra (P5) a pergunta ofereceu uma escolha para um único local de compra, sendo que $60 \%$ responderam que compraram em loja on-line e 38\% compraram em loja física (Tabela 5). Porém o cruzamento entre local de busca (P3, múltiplas respostas) e local de compra efetiva (P5) (Tabela 6) mostra que houve uma diferença nominal de $2 \%$ dos resultados obtidos na tabela anterior, sendo compra em loja física $36 \%$ e em loja on-line $62 \%$. Como são percepções do consumidor a variação de resultados é constatada.

Tabela 5 - Local de compra efetivo.

\begin{tabular}{lcc}
\hline Local de Compra & Respostas & $\%$ \\
\hline \hline Loja online brasileira & 530 & $60 \%$ \\
Loja física & 337 & $38 \%$ \\
Loja online estrangeira & 12 & $1 \%$ \\
outros & 2 & $0 \%$ \\
telefone & 2 & $0 \%$ \\
\hline \hline
\end{tabular}


Tabela 6 - Cruzamento entre local de busca (P3-múltipla resposta) e local de compra efetivo (P5resposta única).

\begin{tabular}{|c|c|c|c|c|c|c|c|c|c|}
\hline \multirow{2}{*}{ Onde buscou? } & & \multicolumn{7}{|c|}{ Onde comprou efetivamente? } & \multirow{2}{*}{$\begin{array}{l}\% \text { de } \\
\text { casos }\end{array}$} \\
\hline & & Lj Física & $\%$ & OL Brasil & $\%$ & OL não Br & telefone & Outros & \\
\hline Internet Brasileira & 671 & 217 & $32 \%$ & 443 & $66 \%$ & 7 & 2 & 2 & $76 \%$ \\
\hline Site de comparação de preços & 348 & 98 & $28 \%$ & 244 & $36 \%$ & 3 & 1 & 2 & $39 \%$ \\
\hline Loja online e depois loja Física & 276 & 126 & $46 \%$ & 147 & $22 \%$ & 3 & & & $31 \%$ \\
\hline Site do fabricante & 274 & 78 & $28 \%$ & 189 & $28 \%$ & 6 & & 1 & $31 \%$ \\
\hline Loja Física & 246 & 139 & $57 \%$ & 106 & $16 \%$ & 1 & & & $28 \%$ \\
\hline Loja física e depois loja online & 123 & 30 & $24 \%$ & 91 & $14 \%$ & 1 & 1 & & $14 \%$ \\
\hline Internet Estrangeira & 122 & 37 & $30 \%$ & 76 & $11 \%$ & 9 & & & $14 \%$ \\
\hline Televisão & 74 & 35 & $47 \%$ & 39 & $6 \%$ & & & & $8 \%$ \\
\hline Consulta por telefone & 26 & 12 & $46 \%$ & 14 & $2 \%$ & & & & $3 \%$ \\
\hline Outros & 14 & 5 & $36 \%$ & 9 & $1 \%$ & & & & $2 \%$ \\
\hline Total geral & 2174 & 777 & $36 \%$ & 1358 & $62 \%$ & 30 & 4 & 5 & \\
\hline
\end{tabular}

E quando indagados sobre o número de lojas em que pesquisou e depois comprou (P4 e P6) (Tabela 7 e Tabela 8), observa-se que as mulheres e os homens tendem a reduzir o volume de lojas para compra após a busca do produto (Tabela 7 e Tabela 8). As mulheres responderam que o número de lojas para compra efetiva aumentou em $73 \%$ para uma loja $(26=>45)$ e as respostas dos homens aumentaram em $33 \%$ para uma única loja $(70=>93)$.

Tabela 7 - Quantas lojas buscou para informação?

\begin{tabular}{lcccccc}
\hline Busca & Mulher & $\mathbf{\%}$ & Homem & $\mathbf{\%}$ & Total & $\%$ \\
\hline \hline Apenas 1 & 26 & $8 \%$ & 70 & $12 \%$ & 96 & $11 \%$ \\
Até 3 lojas & 113 & $37 \%$ & 186 & $32 \%$ & 299 & $34 \%$ \\
$>$ 3 lojas & 168 & $55 \%$ & 320 & $56 \%$ & 488 & $55 \%$ \\
\hline \hline Total Geral & $\mathbf{3 0 7}$ & $100 \%$ & $\mathbf{5 7 6}$ & $100 \%$ & $\mathbf{8 8 3}$ & $100 \%$ \\
\hline
\end{tabular}

Tabela 8 - Quantas Lojas buscou para compra efetiva?

\begin{tabular}{lcccccc}
\hline Compra & Mulher & $\mathbf{\%}$ & Homem & $\mathbf{\%}$ & Total & \% \\
\hline \hline Apenas 1 & 45 & $15 \%$ & 93 & $16 \%$ & 138 & $16 \%$ \\
Até 3 lojas & 103 & $34 \%$ & 168 & $29 \%$ & 271 & $31 \%$ \\
$>$ 3 lojas & 159 & $52 \%$ & 315 & $55 \%$ & 474 & $54 \%$ \\
\hline \hline Total Geral & $\mathbf{3 0 7}$ & $100 \%$ & $\mathbf{5 7 6}$ & $100 \%$ & $\mathbf{8 8 3}$ & $100 \%$ \\
\hline
\end{tabular}


Em seguida, pesquisou-se o hábito de compra (P7) com escolha forçada para quatro opções de busca e compra. Ressalta-se que $41 \%$ respondeu a primeira opção busca on-line e compra loja física, o que não se confirmou na Tabela 5. Há uma variação de compra em loja física entre $38 \%$ a $41 \%$ dos respondentes. O cruzamento (tabela dinâmica) entre os resultados do hábito de compra e o local efetivo da compra (Tabela 10) evidencia alguma depuração sobre os compradores em loja física (279, $32 \%$ ) ao invés de $41 \%$ como na Tabela 9.

Tabela 9 - Hábito de busca e compra

\begin{tabular}{lcc}
\hline \multicolumn{1}{c}{ Hábito de compra } & respostas & $\%$ \\
\hline \hline Busca online e compra loja física & 364 & $41 \%$ \\
Busca off-line e compra online & 83 & $9 \%$ \\
Busca on/off-line e compra online & 248 & $28 \%$ \\
Busca e compra online & 188 & $21 \%$ \\
\hline \hline
\end{tabular}

Tabela 10 - Cruzamento do hábito com o local de compra efetiva

\begin{tabular}{lccccccccc}
\hline & $\mathrm{LF}$ & $\%$ & $\mathrm{OL} \mathrm{Br}$ & $\%$ & $\mathrm{OL}$ não Br Telefone & Outros & Total & $\%$ \\
\hline \hline Busca online e compra loja física & 279 & $32 \%$ & 81 & $9 \%$ & 2 & 1 & 1 & 364 & $41 \%$ \\
Busca off-line e compra online & 18 & $2 \%$ & 64 & $7 \%$ & 1 & & & 83 & $9 \%$ \\
Busca on/off-line e compra online & 28 & $3 \%$ & 215 & $24 \%$ & 4 & 1 & & 248 & $28 \%$ \\
Busca e compra online & 12 & $1 \%$ & 170 & $19 \%$ & 5 & & 1 & 188 & $21 \%$ \\
\hline \hline & 337 & $38 \%$ & 530 & $60 \%$ & 12 & 2 & 2 & 883 & $100 \%$ \\
\hline
\end{tabular}

$E$, finalmente, para mais uma pergunta de corte, sobre busca e compra (P8) em relação ao free-riding entre varejistas ("ainda sobre as suas opções de pesquisa e compra de produtos como os que foram comprados" - marque uma única resposta de cada conjunto), foram realizadas duas perguntas de cruzamentos fixados: 8.1busca on-line e compra loja física, 8.2 - busca em loja física e compra on-line. A Tabela 11 revelou que $48 \%$ dos respondentes informaram que a busca on-line e compra em loja física acabou em retenção no mesmo varejista e $28 \%$ (249) informou que mudou de varejista, ou seja, realizou o free-riding entre varejistas. Tabela 12 revelou que $30 \%$ (266) dos respondentes fez uma busca em loja física antes de comprar on-line, realizando a retenção na mesma loja varejista, porém 39\% (344) mudaram de varejista e realizou o free-riding. 
Tabela 11 - P.8.1- Intenção de free-riding - busca on-line e compra loja física

\begin{tabular}{lcc}
\hline Busca online e compra loja física & Respostas & $\%$ \\
\hline \hline Mesma rede varejista & 424 & $48 \%$ \\
Outro varejista & 249 & $28 \%$ \\
Não se aplica & 210 & $24 \%$ \\
\hline \hline
\end{tabular}

Fonte - elaborado pelo autor.

Tabela 12- P.8.2 - Intenção de free-riding - busca loja física e compra on-line

\begin{tabular}{lcc}
\hline Busca loja física e compra online & Respostas & $\%$ \\
\hline \hline Mesma rede varejista & 266 & $30 \%$ \\
Outro varejista & 344 & $39 \%$ \\
Não se aplica & 273 & $31 \%$ \\
\hline \hline
\end{tabular}

Fonte - elaborado pelo autor.

O cruzamento entre Tabela 11 e Tabela 12 esclareceu mais sobre a retenção no mesmo varejista correspondendo a 179 respondentes nas duas questões (8.1 e 8.2) e $221(80+116+25)$ com intenção de free-riding entre canais (Tabela 13).

Tabela 13 - Cruzamento entre questões 8.1 e 8.2

\begin{tabular}{|c|c|c|c|c|c|c|c|}
\hline 8.1 & Varejista $=$ & $\%$ & Varejista $\neq$ & $\%$ & Não se aplica & Total & $\%$ \\
\hline Mesma rede varejista & 179 & $20 \%$ & 25 & $3 \%$ & 62 & 266 & $30 \%$ \\
\hline Outro varejista & 80 & $9 \%$ & 116 & $13 \%$ & 148 & 344 & $39 \%$ \\
\hline Não se aplica & 165 & $19 \%$ & 108 & $12 \%$ & & 273 & $31 \%$ \\
\hline Total & 424 & $48 \%$ & 249 & $28 \%$ & 210 & 883 & $100 \%$ \\
\hline
\end{tabular}

Fonte - elaborado pelo autor.

Resumindo, os resultados evidenciaram que cerca de $36 \%$ a $41 \%$ dos respondentes realizaram compra em loja física, $48 \%$ retido no mesmo varejista e $28 \%$ comprou em outro varejista. Por sua vez, $60 \%$ a $62 \%$ dos respondentes realizaram compra em loja on-line, sendo 30\% retido na mesma rede varejista e 39\% comprou em outro varejista. Chiu et al. (2011) selecionou apenas os respondentes que realizaram o free-riding entre varejistas. Para esta pesquisa primeiro consideram-se as respostas que confirmaram a intenção de free-riding em relação a outro varejista, constantes nas perguntas 8.2 (344) e em seguida 8.1 (249), retirando-se 116 respondentes que 
eram comuns às duas perguntas (intersecção), resultando num total de 477 casos de respondentes diferentes. Porém foi abandonada a proposta de Chiu et al. (2011) de fixar em apenas um cruzamento (busca on-line e compra off-line) e resolveu-se estudar para a amostra como de 883 casos para o modelo estrutural, dado que o presente estudo não pretendeu fixar apenas um cruzamento entre busca e compra.

\subsubsection{Análise fatorial Exploratória e Confirmatória}

A análise fatorial exploratória, realizada pelo software IBM SPSS versão 19, foi utilizada para remoção ou manutenção de itens em cada construto teórico. Foi utilizado o método de extração de componentes principais, rotação ortogonal pelo método Varimax. A rotação tem o intuito de facilitar a interpretação e ajusta os resultados para que cada variável se associe a um único fator (FÁVERO, BELFIORE e CHAN, 2009, p.235). Foram realizadas três rodadas da análise, sendo a primeira com todos os fatores; todas as rodadas com os 883 casos. As variáveis estudadas foram padronizadas para que as novas variáveis transformadas tivessem média 0 e desvio padrão 1. O pressuposto da normalidade multivariada foi relaxado. Segundo Hair et al. (2005) a normalidade multivariada dos dados seria necessária na avaliação da significância dos fatores, teste que não se aplicou a presente análise.

Foram consideradas as cargas fatoriais acima de 0,3 em relação ao tamanho da amostra. Cabe assinalar que a carga fatorial representa a correlação entre o fator e a variável original (HAIR et al., 2005).

Ao serem definidos os fatores, foi estabelecido o critério da raiz latente (critério de Kaiser) em função dos valores próprios (eigenvalues) acima de 1, de tal forma que cada fator explicasse no mínimo a variância de uma variável do modelo. A adequação da análise fatorial foi verificada pela estatística KMO que avaliou a adequação da amostra com relação ao grau de correlação parcial entre as variáveis e pôde assumir valores entre 0 e 1(FÁVERO, BELFIORE e CHAN, 2009).

As análises fatoriais confirmatórias foram realizadas após refinamento das dimensões obtidas com a análise fatorial exploratória, apenas com os itens 
previamente definidos anteriormente, realizada pelo software IBM SPSS AMOS versão 21. Desta forma, a unidimensionalidade do construto foi aferida durante as duas etapas ${ }^{40}$.

As análises fatoriais exploratórias (AFE) e confirmatórias (AFC) para construtos individuais foram apresentadas juntas de forma a permitir uma visão de todo processo de análise e os construtos foram organizados segundo os grupos de variáveis do modelo teórico PPM - Push-Pull-Mooring.

\subsubsection{Variáveis Push}

Fator 1 (Hipótese1) - autoeficácia multicanal (FA_AE)

\section{Análise Fatorial Exploratória}

O fator (Quadro 21) apresentou as quatro variáveis do construto teórico que refletem a habilidade de compra em diferentes canais de vendas. O fator possui variância total explicada de $83 \%$.

Quadro 21: Fator 1 - Autoeficácia multicanal Matriz Componente

\begin{tabular}{|l|r|}
\hline & Componente \\
\cline { 2 - 2 } & \multicolumn{1}{|c|}{1} \\
\hline $\mathrm{AE} 121$ &, 873 \\
$\mathrm{AE} 122$ &, 930 \\
$\mathrm{AE} 123$ &, 910 \\
$\mathrm{AE} 124$ &, 929 \\
\hline
\end{tabular}

Legenda: (AE121) acho fácil utilizar com sucesso diferentes canais de lojas do varejo durante o processo de compra; (AE122) acredito que sei avaliar as opções oferecidas pelos múltiplos canais de venda de loas do varejo; (AE123) eu me sinto confiante, usando diferentes canais de vendas de loja do varejo; (AE124) Sou capaz de lidar com os serviços de diferentes canais de vendas de lojas do varejo.

Fonte: saída (output) da análise do IBM SPSS

\footnotetext{
${ }^{40}$ As análises fatoriais confirmatórias foram realizadas sob orientação e supervisão do prof.. Dr Leandro Prearo - USCS - Universidade Municipal de São Caetano do Sul.
} 


\section{Análise Fatorial Confirmatória}

A primeira análise de qualidade da dimensão autoeficácia multicanal apresentou problemas de ajustamento conforme Tabela 14. O modelo foi reajustado, segundo Marôco (2010) pela avaliação dos resíduos padronizados e pela recomendação do índice de modificação dado pelo Amos para esta análise. Houve indicação para inserção da covariância entre os erros das variáveis AE121 e 122, melhorando significativamente os índices, sendo esta a última opção de ajuste (Figura 12).

Tabela 14 - Qualidade de ajustamento Autoeficácia

\begin{tabular}{|c|c|c|c|c|c|c|c|c|c|c|}
\hline $\mathrm{AE}$ & $\begin{array}{l}\text { Limite das } \\
\text { cargas }(\beta) \\
\end{array}$ & $x^{2}$ & $g l$ & $x^{2} / g l$ & $\mathrm{p}$ & GFI & AGFI & $\mathrm{CFI}$ & TLI & RMSEA \\
\hline Mod Inicial & {$[0,81 ; 0,92]$} & 59,499 & 2 & 29,749 & $<0,01$ & 0,967 & 0,833 & 0,981 & 0,943 & 0,181 \\
\hline Mod Mod 1 & {$[0,77 ; 0,94]$} & 6,335 & 1 & 6,335 & $>0,01$ & 0,996 & 0,964 & 0,998 & 0,989 & 0,078 \\
\hline
\end{tabular}

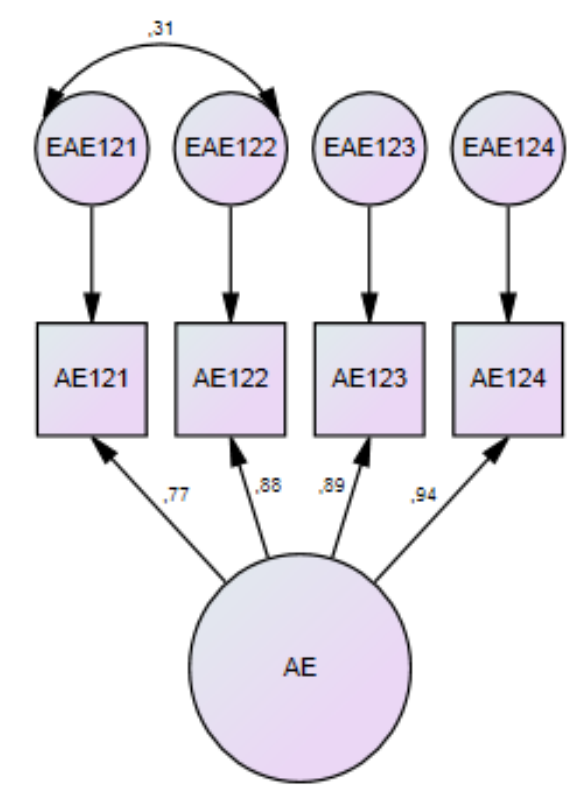

Figura 12 - Diagrama de caminho: Construto Autoeficácia Fonte: saída (output) da análise do Amos (IBM SPSS)

\section{Fator 2 - (Hipótese 2) Experiência prévia com Internet (FA_EX)}

\section{Análise Fatorial Exploratória}

O fator (Quadro 22) foi formado apenas para quatro variáveis, sendo excluída uma variável, a EX102 "eu não faço pesquisas na internet com frequência", por ter obtido baixa comunalidade $(<50 \%)$. A dimensão detecta o grau de experiência prévia com 
compras pela internet o que evidencia o grau de eficácia pessoal. $O$ fator tem variância preservada de $70 \%$.

Quadro 22: Fator 2- Experiência prévia com internet

Matriz Componente

\begin{tabular}{|l|r|}
\hline & Componente \\
\cline { 2 - 2 } & \multicolumn{1}{|c|}{1} \\
\hline EX101 &, 791 \\
EX103 &, 871 \\
EX104 &, 845 \\
EX105 &, 847 \\
\hline
\end{tabular}

Legenda: EX101 eu tenho muita experiência com compras pela internet; EX103 eu sou bom em fazer pesquisas pela internet; EX104 eu consigo encontrar informação sobre produtos rapidamente na internet; EX105 quando o assunto é comprar pela internet, eu me considero um especialista.

Fonte: saída (output) da análise do IBM SPSS

\section{Análise Fatorial Confirmatória}

A primeira análise de qualidade demonstrou mau ajustamento dos índices (Tabela 15). O modelo foi reajustado, segundo Marôco (2010) pela avaliação dos resíduos padronizados e, segundo o índice de modificação sugerido pelo Amos, recomendando a inserção de covariância entre os erros das variáveis EX 101 e 105, melhorando significativamente os índices, sendo esta a última opção de ajuste.

Tabela 15: Qualidade de ajustamento Experiência com Internet

\begin{tabular}{|c|c|c|c|c|c|c|c|c|c|c|}
\hline EX & $\begin{array}{l}\text { Limite das } \\
\text { cargas }(\beta)\end{array}$ & $x^{2}$ & $g l$ & $\mathrm{X}^{2} / g l$ & $\mathrm{p}$ & GFI & AGFI & CFI & TLI & RMSEA \\
\hline Mod Inicial & 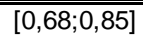 & 42,874 & 2 & 21,437 & $<0,05$ & 0,976 & 0,878 & 0,975 & 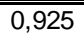 & 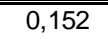 \\
\hline Mod Mod 1 & {$[0,64 ; 0,88]$} & 3,627 & 1 & 3,627 & $>0,05$ & 0,998 & 0,980 & 0,998 & 0,990 & 0,055 \\
\hline
\end{tabular}




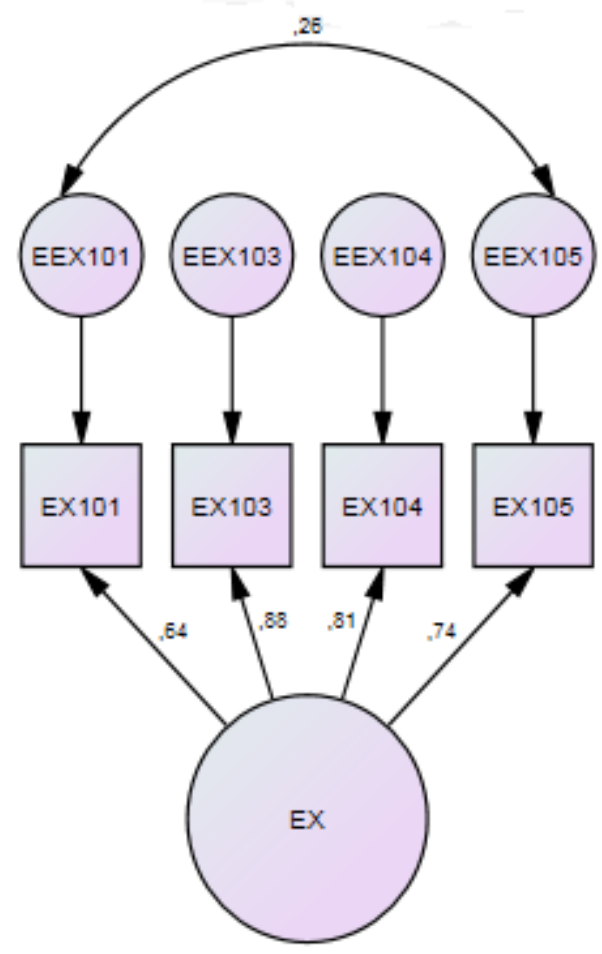

Figura 13 - Diagrama de caminho: Construto Experiência Prévia com Internet Fonte: saída (output) da análise do Amos (IBM SPSS)

\section{Fator 3 - (Hipótese 3) Afinidade tecnológica (FA_AT)}

\section{Análise Fatorial Exploratória}

O fator (Quadro 23) foi formado pelas quatro variáveis originais do construto teórico que captura o grau de conforto em compras de lojas on-line. $O$ fator teve sua variância explicada por $76 \%$.

Quadro 23: Fator 3 - Afinidade Te
Matriz Componente
\begin{tabular}{|l|r|}
\hline & Componente \\
\cline { 2 - 2 } & 1 \\
\hline AT91 &, 714 \\
AT92 &, 873 \\
AT93 &, 915 \\
AT94 &, 889 \\
\hline
\end{tabular}

Legenda: AT91 - com relação à tecnologia, eu me sinto tão atualizado quanto meus colegas; AT92 eu acho fácil fazer compras pela internet; AT93 - para mim é fácil eu usar a internet; AT94 - sinto-me à vontade para aprender novas tecnologias.

Fonte: saída (output) da análise do IBM SPSS 


\section{Análise Fatorial Confirmatória}

A primeira análise de qualidade demonstrou mau ajustamento (Tabela 16) dos índices. O modelo foi reajustado, segundo Marôco (2010) pela avaliação dos resíduos padronizados e, segundo o índice de modificação sugerido pelo Amos, que recomendou a inserção de covariância entre os erros das variáveis AT91 e 93, melhorando significativamente os índices, sendo esta a última opção de ajuste (Figura 14).

Tabela 16 - Qualidade de ajustamento Afinidade Tecnológica

\begin{tabular}{ccccccccccc}
\hline \multirow{2}{*}{ AT } & $\begin{array}{c}\text { Limite das } \\
\text { cargas }(\beta)\end{array}$ & \multirow{2}{*}{$X^{2}$} & gl & $X^{2} / g l$ & $p$ & GFI & AGFI & CFI & TLI & RMSEA \\
\hline \hline Mod Inicial & {$[0,51 ; 0,93]$} & 26,733 & 2 & 13,367 & $<0,01$ & 0,986 & 0,930 & 0,988 & 0,963 & 0,118 \\
Mod Mod 1 & {$[0,62 ; 0,95]$} & 0,595 & 1 & 0,595 & $>0,05$ & 1,000 & 0,997 & 1,000 & 1,001 & 0,000 \\
\hline
\end{tabular}

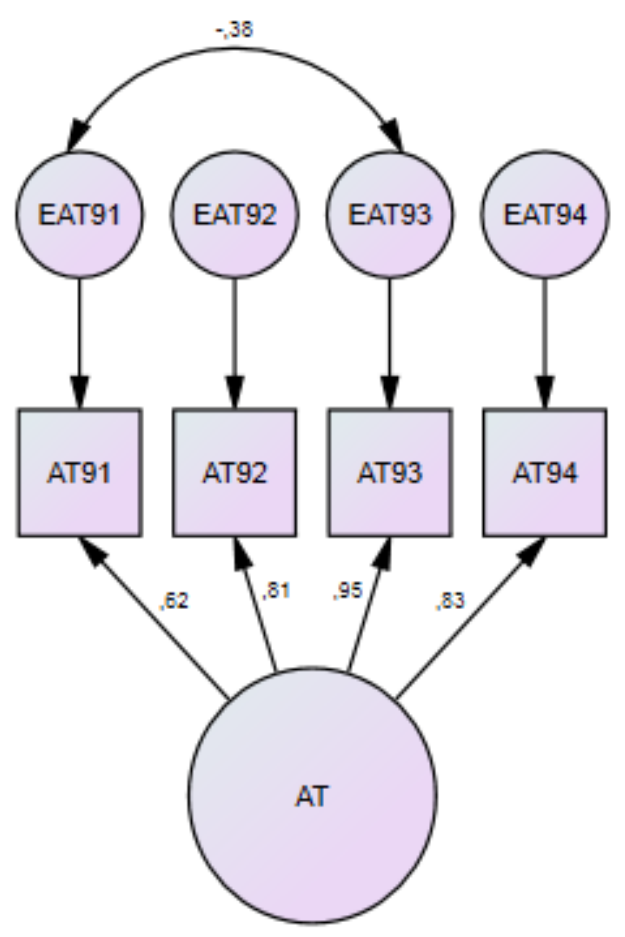

Figura 14 - Diagrama de caminho: Construto Afinidade Tecnológica Fonte: saída (output) da análise do Amos (IBM SPSS)

Fator 4 (Hipótese 4) Experiência Vicária (FA_EV)

\section{Análise Fatorial Exploratória}

O fator (Quadro 24) foi formado com apenas três variáveis, sendo excluída a variável EV114 - "meus filhos me ajudam na busca de informação e compra de produtos", por ter obtido baixa comunalidade. A dimensão descreve o processo de 
aprendizagem por observação, além do esforço, por meio de um processo de comparação nos grupos de referencia. A variância explicada pelo fator foi de $80 \%$.

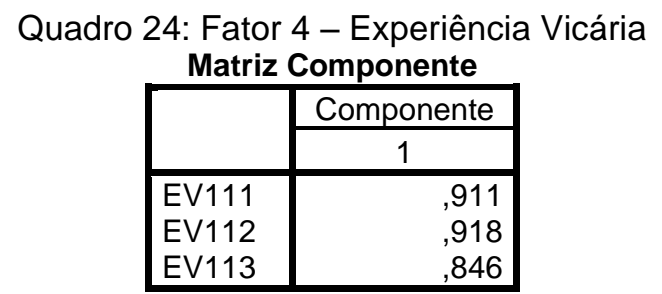

Legenda: EV111 - meus amigos têm tido boas experiências com o uso de canais múltiplos de vendas de lojas de varejo; EV112 - meus colegas de trabalho têm tido boas experiências com o uso de canais múltiplos de vendas de lojas de varejo; EV113 - minha família tem tido boas experiências com o uso de canais múltiplos de vendas de lojas de varejo.

Fonte: saída (output) da análise do IBM SPSS

\section{Análise Fatorial Confirmatória}

A primeira estimativa resultou em super ajustamento do modelo do construto Experiência Vicária (Tabela 17; Figura 15).

Tabela 17 Qualidade de Ajustamento Experiência Vicária

\begin{tabular}{ccccccccccc}
\hline EV & $\begin{array}{c}\text { Limite das } \\
\text { cargas }(\beta)\end{array}$ & $\mathrm{X}^{2}$ & $\mathrm{gl}$ & $\mathrm{X}^{2} / g l$ & $\mathrm{p}$ & GFI & AGFI & CFI & TLI & RMSEA \\
\hline \hline Mod inicial & {$[0,72 ; 0,90]$} & 0,000 & 0 & 0,000 & $<0,05$ & 1,000 & - & 1,000 & - & - \\
\hline
\end{tabular}

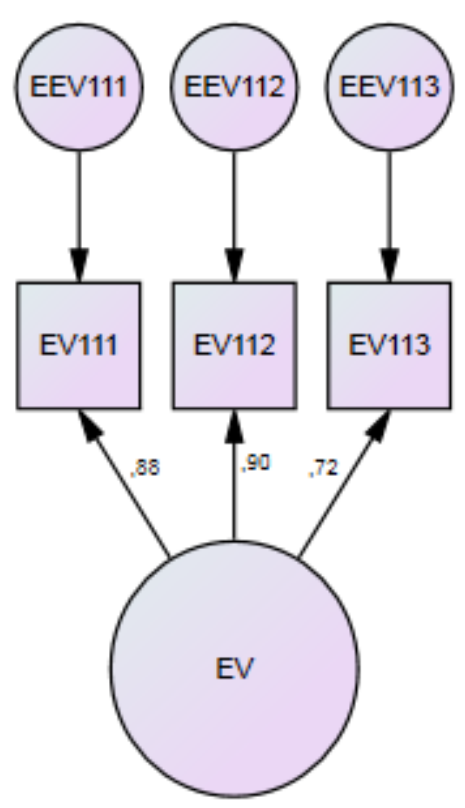

Figura 15 - Diagrama de caminho: Construto Experiência Vicária Fonte: saída (output) da análise do Amos (IBM SPSS) 
Fator 11 (Hipótese 11) Satisfação (FA_SA)

\section{Análise Fatorial Exploratória}

A satisfação na experiência de compra formou dois fatores (Quadro 25), porém uma variável foi excluída (SA191 - as compras através de múltiplos canais de vendas me satisfazem desde que sejam de uma mesma loja varejista). O construto satisfação não foi unidimensional porque apresentava itens com foco em loja física e com foco no multicanal. $O$ fator 1 - satisfação com loja física, expressa a satisfação em pegar e sentir o produto; o fator 2 - satisfação free-riding, expressa a satisfação pelo desejo de liberdade entre canais de vendas. A variância acumulada explicada pelos fatores foi de $82 \%$.

$\begin{gathered}\text { Quadro 25: Fator 11 Satisfação } \\
\text { Matriz Componente } \\
\text { Rotacionada }\end{gathered}$
\begin{tabular}{|r|r|r|}
\hline & \multicolumn{2}{|c|}{ Componente } \\
\cline { 2 - 3 } & 1 (LF) & 2 (FR) \\
\hline SA192 & &, 831 \\
SA193 &, 971 & \\
SA194 &, 974 & \\
SA195 & &, 839 \\
\hline
\end{tabular}

Legenda: Sobre a minha experiência de compra de produtos como esses. SA192 - eu faço a maior parte de minhas pesquisas na internet e na hora de comprar é que eu decido onde quero comprar; SA193 - eu gosto de fazer a compra na loja física, pois assim eu posso olhar e conferir o produto; SA194 - eu gosto de fazer a compra na loja física, pois assim eu posso sentir o produto. SA195 gosto muito de comprar através de vários canais de vendas e me sinto livre para mudar de loja online para física ou vice-versa de quaisquer varejistas.

Fonte: saída (output) da análise do IBM SPSS

\section{Análise Fatorial Confirmatória}

A primeira rodada da análise não apresentou ajuste, prejudicado pelo fato de serem apenas duas variáveis para cada construto SAFR e SALF, abaixo do recomendado pela literatura. Porém, dada a importância dos construtos para o modelo estrutural, eles foram mantidos. O fator SA_FR teve a variância do erro da variável SA195 fixada em 1 (Tabela 18) e assim foi possível calcular as estimativas (Figura 16). A mesma correção foi feita no fator SA_LF, com a variância do erro da variável SA194 ajustada para 0,5 (Tabela 19, Figura 17) e assim foram calculadas as estimativas. Ambas resultaram num ajustamento perfeito. 
Tabela 18 - Qualidade do ajustamento - Satisfação em Free-riding

\begin{tabular}{ccccccccccc}
\hline \multirow{2}{*}{ SAFR } & $\begin{array}{l}\text { Limite das } \\
\text { cargas }(\beta)\end{array}$ & $\mathrm{X}^{2}$ & $\mathrm{gl}$ & $\mathrm{X}^{2} / g l$ & $\mathrm{p}$ & GFI & AGFI & CFI & TLI & RMSEA \\
\hline \hline Mod Inicial & {$[0,57 ; 0,70]$} & 0,000 & 0 & 0,000 & $<0,01$ & 1,000 & - & 1,000 & - & - \\
\hline
\end{tabular}

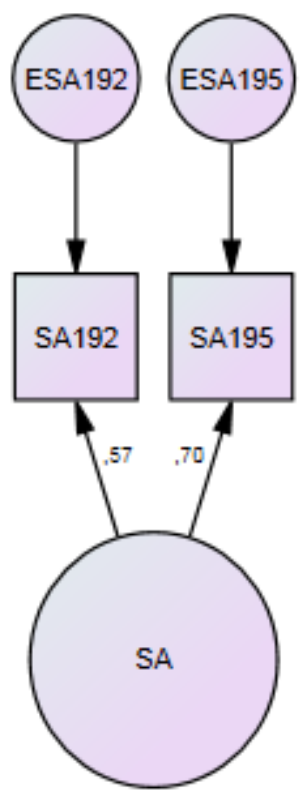

Figura 16 - Diagrama de caminho: Construto Satisfação em Free-riding Fonte: saída (output) da análise do Amos (IBM SPSS)

Tabela 19 - Qualidade do ajustamento - Satisfação em Loja Física

\begin{tabular}{ccccccccccc}
\hline SALF & $\begin{array}{r}\text { Limite das } \\
\text { cargas }(\beta)\end{array}$ & $\mathrm{X}^{2}$ & $\mathrm{gl}$ & $\mathrm{X}^{2} / g l$ & $\mathrm{p}$ & $\mathrm{GFI}$ & AGFI & CFI & TLI & RMSEA \\
\hline \hline Mod Inicial & {$[0,90 ; 1,00]$} & 0,000 & 0 & 0,000 & $<0,01$ & 1,000 & - & 1,000 & - & - \\
\hline
\end{tabular}




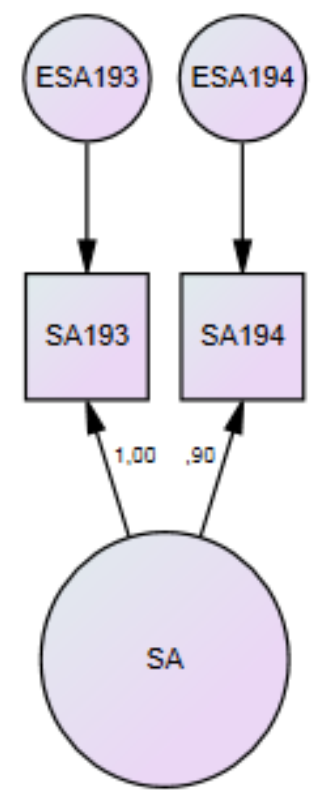

Figura 17 - Diagrama de caminho: Construto Satisfação Loja Física Fonte: saída (output) da análise do Amos (IBM SPSS)

\section{Fator 12 (Hipótese 12) Confiança (FA_CF)}

\section{Análise Fatorial Exploratória}

O construto teórico aborda a transferência da confiança em loja física de um dado varejista para sua loja on-line. Formaram-se dois fatores: Fator 1 - confiança on-line - formado pela percepção de que a transação on-line é confiável de um varejista que já conheço em sua loja física; Fator 2 - confiança loja física, formada pela percepção de que a loja física é sempre mais confiável e segura do que a loja online do mesmo varejista. A variância acumulada explicada pelos fatores foi de $76 \%$ (Quadro 26).

$\begin{gathered}\text { Quadro 26: Fator 12 - Confiança } \\
\text { Matriz Componente } \\
\text { Rotacionada }\end{gathered}$
\begin{tabular}{|l|r|r|}
\hline & \multicolumn{2}{|c|}{ Componente } \\
\cline { 2 - 3 } & $1(\mathrm{OL})$ & \multicolumn{1}{c|}{$2(\mathrm{LF})$} \\
\hline CF201 &, 736 & \\
CF202 & &, 955 \\
CF203 & &, 955 \\
CF204 &, 840 & \\
CF205 &, 830 & \\
\hline
\end{tabular}

Legenda: Compreendendo que uma rede varejista possua tanto loja física quanto loja on-line, como seria sua experiência de compra? CF201 - baseado em minhas experiências passadas eu acredito que a transação na loja on-line é confiável; CF202 - eu acredito que a transação na loja física é sempre mais confiável do que na loja on-line; CF203 - eu acredito que a transação na loja física é mais segura do que na loja on-line; CF204 - eu acredito que a transação na loja on-line é sempre segura; CF205 - eu confio que a loja on-line irá prontamente me informar se ocorrer qualquer problema com meu pedido. 


\section{Análise Fatorial Confirmatória}

A primeira rodada do fator (CF_OL) gerou um super ajustamento (Tabela 20; Figura 18). A primeira rodada da análise para o construto $C F \_L F$ não apresentou ajuste, prejudicado pelo fato de serem apenas duas variáveis, abaixo do recomendado pela literatura. A variância do erro ECF203 foi fixada em 0,5 e assim foi possível calcular as estimativas (Tabela 21; Figura 19).

Tabela 20 - Qualidade de ajustamento Confiança On-line

\begin{tabular}{ccccccccccc}
\hline \multirow{2}{*}{ CFOL } & $\begin{array}{l}\text { Limite das } \\
\text { cargas }(\beta)\end{array}$ & $\mathrm{X}^{2}$ & $\mathrm{gl}$ & $\mathrm{X}^{2} / g l$ & $\mathrm{p}$ & GFI & AGFI & CFI & TLI & RMSEA \\
\hline \hline Mod Inicial & {$[0,56 ; 0,75]$} & 0,000 & 0 & 0,000 & $<0,01$ & 1,000 & - & 1,000 & - & - \\
\hline
\end{tabular}

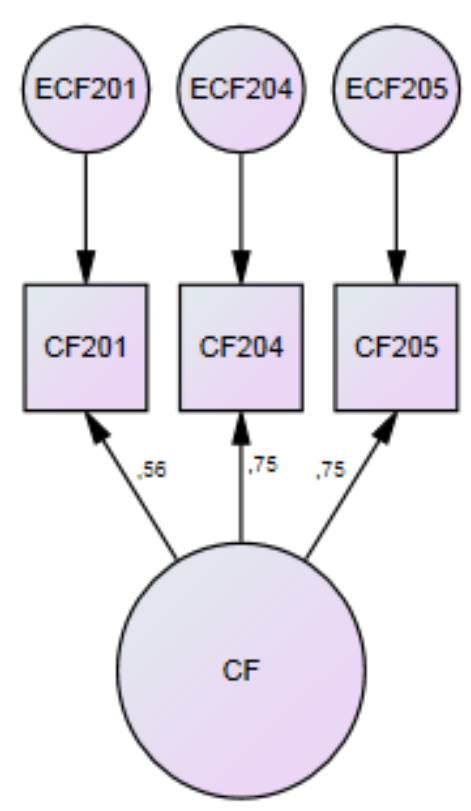

Figura 18 - Diagrama de caminho: Construto Confiança On-line

Fonte: saída (output) da análise do Amos (IBM SPSS)

Tabela 21 - Qualidade de ajustamento Confiança Loja Física

\begin{tabular}{ccccccccccc}
\hline CFLF & $\begin{array}{l}\text { Limite das } \\
\text { cargas }(\beta)\end{array}$ & $\mathrm{X}^{2}$ & $\mathrm{gl}$ & $\mathrm{X}^{2} / g l$ & $\mathrm{p}$ & $\mathrm{GFI}$ & AGFI & CFI & TLI & RMSEA \\
\hline \hline Mod Inicial & {$[0,91 ; 0,92]$} & 0,000 & 0 & 0,000 & $<0,01$ & 1,000 & - & 1,000 & - & - \\
\hline
\end{tabular}




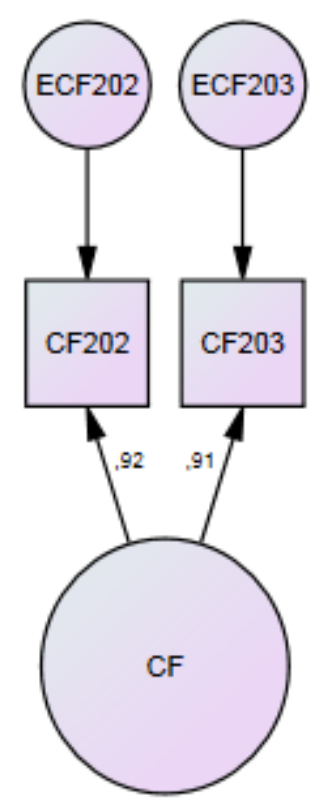

Figura 19 - Diagrama de caminho: Construto Confiança Loja Física Fonte: saída (output) da análise do Amos (IBM SPSS)

\section{Fator 13 (Hipótese 13) Lealdade (FA_LE)}

\section{Análise Fatorial exploratória}

A lealdade pode ser distinta entre os múltiplos canais, impactando na retenção pela firma. Formou-se um único fator que expressa lealdade ao hábito do local de compra, seja loja on-line ou loja física. A variância preservada dos dados originais foi de 72\% (Quadro 27).

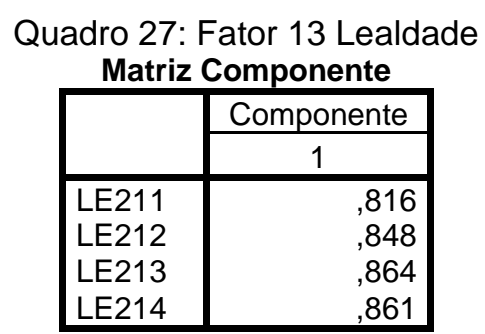

Legenda: Ainda sobre a minha experiência de compra: LE211 - por enquanto, eu duvido que troque as lojas varejistas on-line em que eu estou acostumado a usar e comprar; LE212 - por enquanto, eu duvido que eu troque as lojas físicas nas quais estou acostumado a comprar; LE213 - raramente eu pensaria em mudar da loja varejista on-line em que atualmente compro; LE214 - raramente eu pensaria em mudar de loja física em que atualmente compro.

Fonte: saída (output) da análise do IBM SPSS

\section{Análise Fatorial Confirmatória}

A primeira estimativa do modelo apresentou mau ajustamento. O modelo foi reajustado, segundo Marôco (2010) pela avaliação dos resíduos padronizados e, 
segundo o índice de modificação sugerido pelo Amos, que recomendou a inserção de covariância entre os erros das variáveis LE211 e 214, melhorando significativamente os índices, sendo esta a última opção de ajuste (Tabela 22; Figura 20).

Tabela 22 - Qualidade de ajustamento - Lealdade

\begin{tabular}{ccccccccccc}
\hline \multirow{2}{*}{ LE ou LD } & $\begin{array}{c}\text { Limite das } \\
\text { cargas }(\beta)\end{array}$ & \multirow{2}{*}{$\mathrm{X}^{2}$} & $\mathrm{gl}$ & $\mathrm{X}^{2} / g l$ & $\mathrm{p}$ & $\mathrm{T}$ GFI & AGFI & \multirow{2}{*}{ CFI } & \multirow{2}{*}{ TLI } & RMSEA \\
\hline \hline Mod Inicial & {$[0,72 ; 0,84]$} & 243,513 & 2 & 121,757 & $<0,05$ & 0,906 & 0,53 & 0,874 & 0,622 & 0,370 \\
Mod Mod & {$[0,73 ; 0,95]$} & 1,195 & 1 & 1,195 & $>0,05$ & 0,999 & 0,993 & 1,000 & 0,999 & 0,015 \\
\hline
\end{tabular}

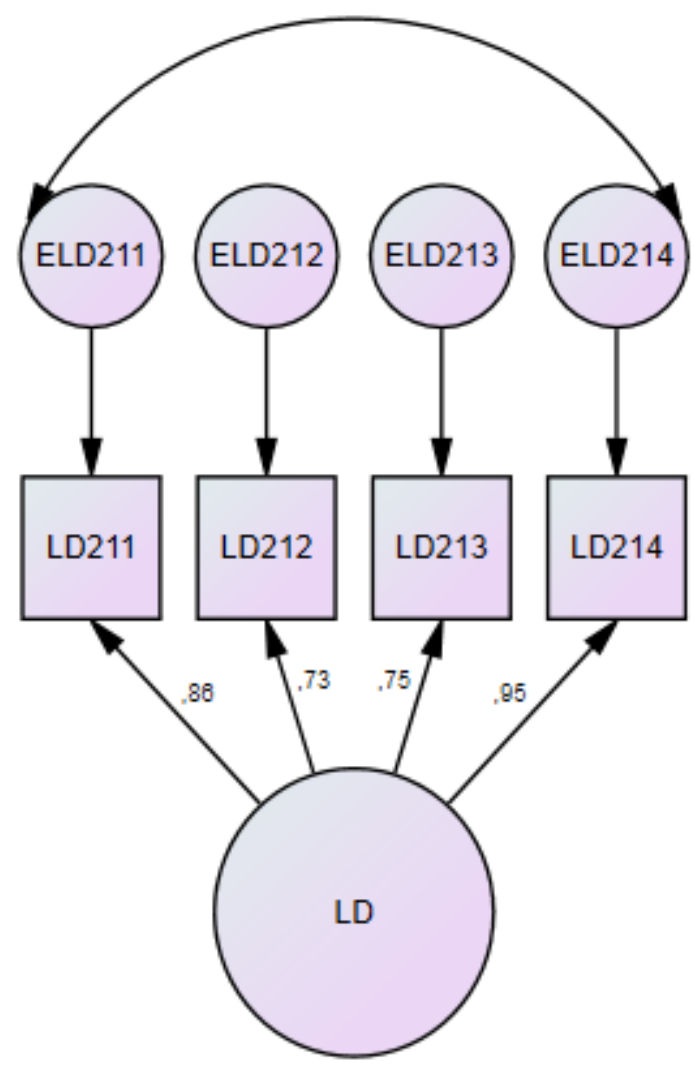

Figura 20 - Diagrama de caminho: Construto Lealdade Fonte: saída (output) da análise do Amos (IBM SPSS)

\subsubsection{Variáveis Mooring}

Fator 5 - (Hipótese 5) Retenção da Firma (FA_RF)

\section{Análise Fatorial Exploratória}

O fator (Tabela 23) foi formado com apenas duas variáveis do construto teórico. A retenção da firma é uma dimensão que mede alguma forma de aprisionamento do 
cliente, de forma que o mesmo fique dependente. O construto teórico se refere ao mudar ou não de canal de vendas de varejistas. As variáveis que foram excluídas: RF162 - eu não gosto de mudar para o canal de venda de outro varejista depois de eu ter gasto algum tempo com pesquisa on-line no site de um varejista; RF163 - eu teria feito troca entre lojas e canais de vendas varejistas se eu pudesse fazer isso sem aborrecimento. Desta forma, o fator representou apenas a disposição à mudança entre canais de vendas varejistas o que não implica retenção na firma. $O$ fator foi explicado por $65 \%$ de variância.

Tabela 23: Fator 5 - Retenção na Firma

Matriz Componente

\begin{tabular}{|l|r|}
\hline & Componente \\
\cline { 2 - 2 } & 1 \\
\hline RF161 &, 809 \\
RF164 &, 809 \\
\hline
\end{tabular}

Legenda: RF161 - eu não tenho problema em mudar entre os canais de vendas varejistas; RF 164 Não há dificuldades técnicas associadas com a troca entre canais de vendas de varejistas.

Fonte: saída (output) da análise do IBM SPSS

\section{Análise Fatorial Confirmatória}

A primeira análise não apresentou ajuste prejudicado pelo fato de serem apenas duas variáveis, abaixo do recomendado pela literatura. Porém, dada a importância do construto para o modelo estrutural, ele foi mantido. A variância do erro ERF164 foi fixada em 1 e assim foi possível calcular as estimativas (Tabela 24; Figura 21).

Tabela 24 - Qualidade de ajustamento Retenção na Firma

\begin{tabular}{ccccccccccc}
\hline \multirow{2}{*}{ RF } & $\begin{array}{l}\text { Limite das } \\
\text { cargas }(\beta)\end{array}$ & $\mathrm{X}^{2}$ & $\mathrm{gl}$ & $\mathrm{X}^{2} / g l$ & $\mathrm{p}$ & GFI & AGFI & CFI & TLI & RMSEA \\
\hline \hline Mod Inicial & {$[0,40 ; 0,77]$} & 0,000 & 0 & 0,000 & $<0,05$ & 1,000 & - & 1,000 & - & - \\
\hline
\end{tabular}




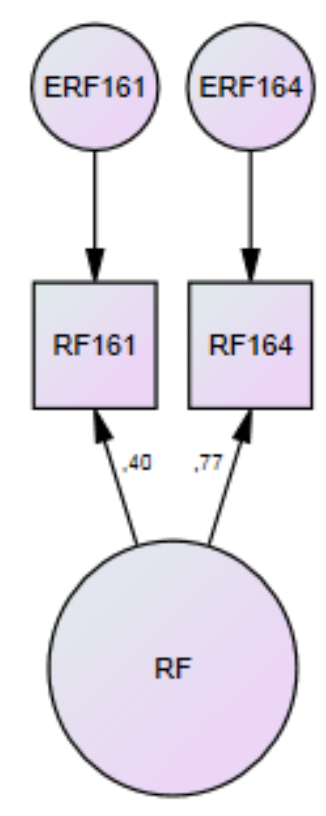

Figura 21 - Diagrama de caminho: Construto Retenção na Firma Fonte: saída (output) da análise do Amos (IBM SPSS)

\section{Fator 6 (Hipótese 6) Busca de Variedade (FA_BV)}

\section{Análise Fatorial Exploratória}

O construto original tinha seis variáveis, porém a dimensão final foi obtida com quatro variáveis. Duas variáveis foram excluídas. A BV156 - "pesquisar uma nova loja em um novo site é geralmente uma perda de tempo" tinha problema na correlação da anti-imagem com erros abaixo de $50 \%$. Ao ser retirada a variância explicada pelo fator ficou em 52\%. A matriz rotacionada evidenciou que BV151 e BV156 formavam um segundo fator (Quadro 28).

Quadro 28: Fator 6 - Busca de variedade com dois componentes Matriz Componente Rotacionada

\begin{tabular}{|l|r|r|}
\hline & \multicolumn{2}{|c|}{ Componentes } \\
\cline { 2 - 3 } & 1 & 2 \\
\hline BV151 & &, 769 \\
BV152 &, 773 & \\
BV153 &, 853 & \\
BV154 &, 727 & \\
BV155 &, 809 & \\
BV156 & &, 821 \\
\hline
\end{tabular}

Fonte: saída (output) da análise do IBM SPSS 
Ao escolher a retirada da segunda variável BV151 - "eu compro coisas que eu não tinha planejado adquirir", a variância explicada pelo fator aumentou para $63 \%$, conforme (Quadro 29).

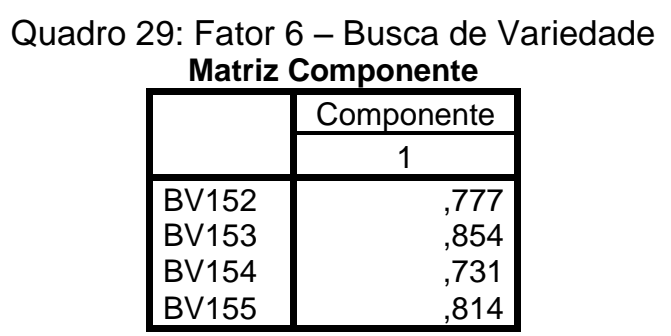

Legenda: BV152- eu gosto um bocado de variedade de alternativas de tipo e marca de produtos do varejo; BV153- eu gosto de experimentar diferentes canais de vendas dentro das alternativas do varejo; BV154- eu gosto de explorar e alternar entre lojas físicas e loja on-line (internet); BV155- eu gosto de novos estilos e diferentes tipos de produto e marca.

Fonte: saída (output) da análise do IBM SPSS

O fator busca de variedade expressou pela variedade de alternativas e de estilos de marcas e produtos e, de experimentar diferentes canais de vendas.

\section{Análise Fatorial Confirmatória}

A primeira análise de qualidade demonstrou mau ajustamento dos índices. O modelo foi reajustado, segundo Marôco (2010) pela avaliação dos resíduos padronizados e, segundo o índice de modificação sugerido pelo Amos, que recomendou a inserção de covariância entre os erros das variáveis BV152 e 154, melhorando significativamente os índices, sendo esta a última opção de ajuste (Tabela 25; Figura 22).

Tabela 25 - Qualidade de ajustamento Busca de Variedade

\begin{tabular}{ccccccccccc}
\hline \multirow{2}{*}{ BV } & $\begin{array}{r}\text { Limite das } \\
\text { cargas }(\beta)\end{array}$ & $\mathrm{X}^{2}$ & $\mathrm{gl}$ & $\mathrm{X}^{2} / g l$ & $\mathrm{p}$ & $\mathrm{GFI}$ & AGFI & CFI & TLI & RMSEA \\
\hline \hline Mod Inicial & {$[0,61 ; 0,83]$} & 26,013 & 2 & 13,006 & $<0,01$ & 0,986 & 0,928 & 0,979 & 0,937 & 0,117 \\
\hline \hline Mod Mod 1 & {$[0,65 ; 0,80]$} & 5,594 & 1 & 5,594 & $>0,01$ & 0,997 & 0,968 & 0,996 & 0,976 & 0,072 \\
\hline
\end{tabular}




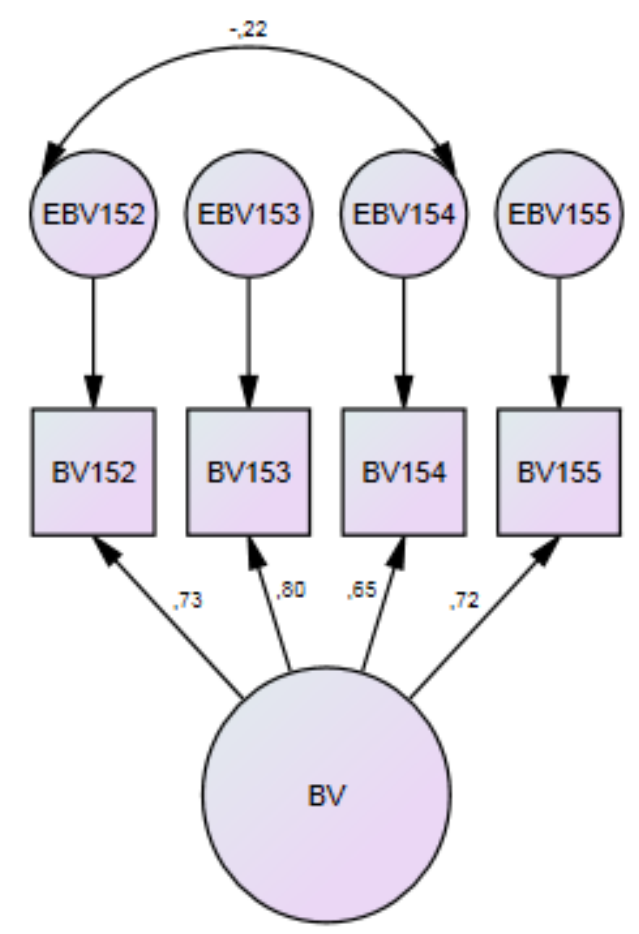

Figura 22 - Diagrama de caminho: Construto Busca de Variedade Fonte: saída (output) da análise do Amos (IBM SPSS)

\section{Fator 7 (Hipótese 7) Custo de Mudança (FA_CMR, FA_CMM)}

\section{Análise Fatorial exploratória}

O construto teórico possui quatro variáveis que se organizaram em dois fatores. A dimensão custo de mudança reflete os custos de ocasião associados ao processo de mudança de um provedor para outro e incluem vários custos. Para esse construto os custos abordados foram de mudança entre canais quanto ao esforço, tempo e volume de mudanças. As duas dimensões se organizaram na seguinte forma: o fator 1 expressa o alto custo para mudança (FA_CMR), ou seja, o respondente se importa em mudar entre canais de vendas, pois o custo de mudança é alto para ele. $O$ fator 2 expressa o baixo custo de mudança para os respondentes (FA_CMM), havendo uma maior possibilidade em mudar de varejista. Os fatores são explicados por $75 \%$ da variância acumulada (Quadro 30). 


\section{Quadro 30: Fator 7 - Custo de Mudança \\ Matrix Componente}

Rotacionada

\begin{tabular}{|l|r|r|}
\hline & \multicolumn{2}{|c|}{ Componente } \\
\cline { 2 - 3 } & 1 (CMR) & 2 (CMM) \\
\hline CM131 &, 895 &, 833 \\
CM132 & &, 830 \\
CM133 &, 895 & \\
CM134 & & \\
\hline
\end{tabular}

Legenda: CM131 - às vezes eu experimento outras lojas e redes varejistas; CM132 - custa esforço para eu mudar de loja ou rede varejista; CM133 - eu tenho mudado muito de loja ou rede varejista; CM134 - leva tempo para eu mudar de loja ou rede varejista.

Fonte: saída (output) da análise do IBM SPSS

\section{Análise Fatorial Confirmatória}

A primeira rodada da análise não apresentou ajuste, prejudicado pelo fato de serem apenas duas variáveis para cada construto CMR e CMM, abaixo do recomendado pela literatura. Porém, dada à importância dos construtos para a o modelo estrutural, eles foram mantidos. A variância do erro ECMR134 foi fixada em 1 (Tabela 26; Figura 23) e assim foi possível calcular as estimativas. A mesma correção foi feita na variância do erro ECMM133 (Tabela 27, Figura 24) e assim foram calculadas as estimativas.

Tabela 26 - Qualidade de ajustamento Custo de Mudança (alto)- CMR

\begin{tabular}{ccccccccccc}
\hline CMR & $\begin{array}{c}\text { Limite das } \\
\text { cargas }(\beta)\end{array}$ & $\mathrm{X}^{2}$ & $\mathrm{gl}$ & $\mathrm{X}^{2} / g l$ & $\mathrm{p}$ & GFI & AGFI & CFI & TLI & RMSEA \\
\hline \hline Mod Inicial & {$[0,75 ; 0,81]$} & 0,000 & 0 & 0,000 & $<0,01$ & 1,000 & - & 1,000 & - & - \\
\hline
\end{tabular}




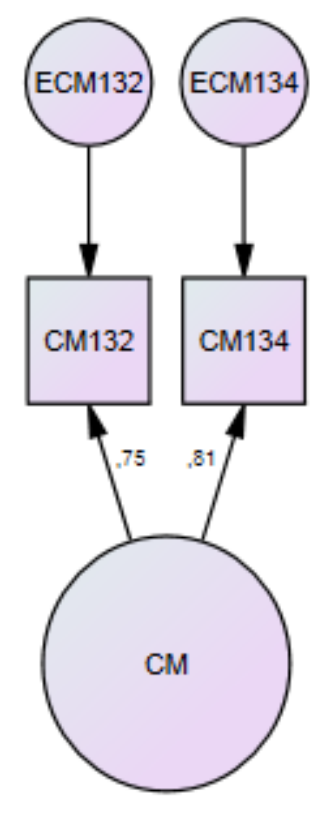

Figura 23 - Diagrama de caminho: Construto Alto Custo de Mudança (CMR) Fonte: saída (output) da análise do Amos (IBM SPSS)

Tabela 27 - Qualidade de ajustamento Custo de Mudança (baixo) - CMM

\begin{tabular}{ccccccccccc}
\hline CMM & $\begin{array}{c}\text { Limite das } \\
\text { cargas }(\beta)\end{array}$ & $\mathrm{X}^{2}$ & $\mathrm{gl}$ & $\mathrm{X}^{2} / g l$ & $\mathrm{p}$ & $\mathrm{GFI}$ & AGFI & CFI & TLI & RMSEA \\
\hline \hline Mod Inicial & {$[0,51 ; 0,76]$} & 0,000 & 0 & 0,000 & $\mathrm{p}<0,01$ & 1,000 & - & 1,000 & - & - \\
\hline
\end{tabular}

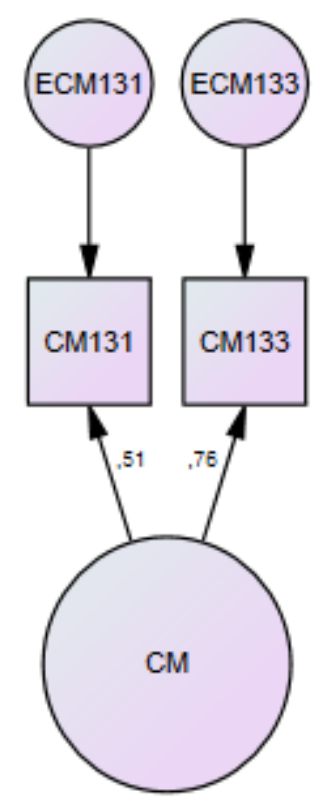

Figura 24 - Diagrama de caminho: Construto Baixo Custo de Mudança (CMM) Fonte: saída (output) da análise do Amos (IBM SPSS) 
Fator 8 (Hipótese 8) Integração Percebida (FA_IN)

\section{Análise Fatorial Exploratória}

O fator foi formado pelas quatro variáveis do construto teórico para integração percebida (Quadro 31). O fator é explicado por $70 \%$ da variância preservada dos dados originais. A dimensão integração percebida contempla a percepção do consumidor sobre os canais de compra.

$$
\begin{aligned}
& \text { Quadro 31: Fator 8 - Integração Percebida } \\
& \text { Matrix Componente } \\
& \qquad \begin{array}{|l|r|}
\hline & \text { Componente } \\
\cline { 2 - 2 } & 1 \\
\hline \text { IN141 } & , 727 \\
\text { IN142 } & , 801 \\
\text { IN143 } & , 906 \\
\text { IN144 } & , 900 \\
\hline
\end{array}
\end{aligned}
$$

Legenda: Quando eu compro um produto na loja on-line da internet: In141 - eu posso comprar o produto pela internet dentro da loja física; IN142 - eu posso retirar o produto na loja física da rede varejista; In143 - eu posso devolver o produto pela loja física, caso ele esteja com defeito; IN144 - eu posso trocar o produto na loja física.

Fonte: saída (output) da análise do IBM SPSS

\section{Análise Fatorial Confirmatória}

A primeira análise de qualidade demonstrou mau ajustamento (Tabela 28) dos índices. O modelo foi reajustado, segundo Marôco (2010) pela avaliação dos resíduos padronizados e, segundo o índice de modificação sugerido pelo Amos, que recomendou a inserção de covariância entre os erros das variáveis IN141 e 142,

\begin{tabular}{|c|c|c|c|c|c|c|c|c|c|c|}
\hline IN & $\begin{array}{l}\text { Limite das } \\
\text { cargas }(\beta)\end{array}$ & $x^{2}$ & $g l$ & $\mathrm{X}^{2} / g l$ & $\mathrm{p}$ & GFI & AGFI & CFI & TLI & RMSEA \\
\hline Mod Inicial & $\overline{[0,52 ; 0,94]}$ & $\overline{119,212}$ & 2 & 59,606 & $<0,05$ & 0,940 & 0,698 & 0,948 & $\bar{~} 0,844$ & (0,258 \\
\hline Mod Mod 1 & {$[0,50 ; 0,96]$} & 0,027 & 1 & 0,027 & $>0,05$ & 1,000 & 1,000 & 1,000 & 1,003 & 0,000 \\
\hline
\end{tabular}
havendo um super ajustamento (Figura 25).

Tabela 28 - Qualidade de ajustamento - Integração Percebida 


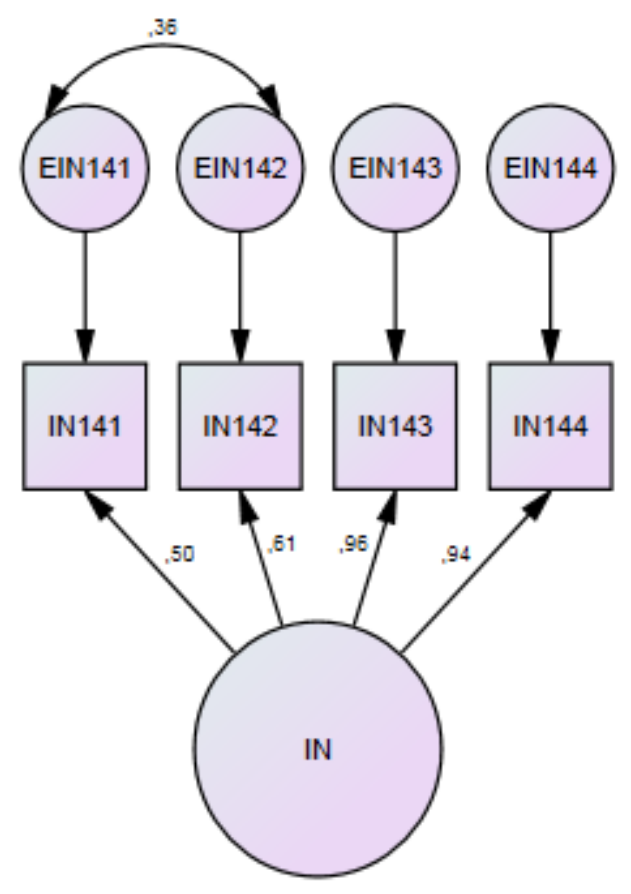

Figura 25 - Diagrama de caminho: Construto Integração Percebida Fonte: saída (output) da análise do Amos (IBM SPSS)

\section{Fator 9 (Hipótese 9) Conveniência (FA_CO)}

\section{Análise Fatorial Exploratória}

O construto teórico para conveniência possui seis variáveis que foram organizadas em dois fatores: Fator 1 - Conveniência on-line e Fator 2 - Conveniência loja física. Ao pensar a satisfação do consumidor num contexto multicanal buscou-se a influencia da conveniência da loja off-line de varejistas para a loja on-line. Os fatores foram explicados por $73 \%$ da variância preservada dos dados originais. (Quadro 32) 
Quadro 32: Fator 9 - Conveniência

Matrix Componente

Rotacionada

\begin{tabular}{|l|r|r|}
\hline \multirow{2}{*}{} & \multicolumn{2}{|c|}{ Componente } \\
\cline { 2 - 3 } C0171 & 1 (OL) & \multicolumn{1}{|c|}{2 (LF) } \\
CO172 &, 911 & \\
C0173 &, 922 & \\
CO174 &, 875 & \\
CO175 &, 436 &, 672 \\
C0176 & &, 836 \\
\hline
\end{tabular}

Legenda: Na compra de produtos como esses: CO171 - Comprar na internet é muito prático; CO172 - eu economizo muito tempo comprando produtos como esse na internet; CO173 - é maravilhoso comprar esses produtos em loja on-line; CO174 - passear em lojas físicas e comprar on-line é muito conveniente para mim; CO175 - pesquisar em lojas físicas é muito prático; CO176 - pesquisar na internet e comprar em loja física é muito conveniente para esse produto.

Fonte: saída (output) da análise do IBM SPSS

\section{Análise Fatorial Confirmatória}

A primeira rodada da análise já apresentou um super ajustamento para os construtos COOL (Tabela 29; Figura 26) e COLF (Tabela 30, Figura 27).

Tabela 29 - Qualidade de ajustamento - Conveniência On-line

\begin{tabular}{ccccccccccc}
\hline cooL & $\begin{array}{c}\text { Limite das } \\
\text { cargas }(\beta)\end{array}$ & $\mathrm{X}^{2}$ & $\mathrm{gl}$ & $\mathrm{X} 2 / g l$ & $\mathrm{p}$ & GFI & AGFI & CFI & TLI & RMSEA \\
\hline \hline Mod Inicial & {$[0,78 ; 0,92]$} & 0,000 & 0 & 0 & $<0,01$ & 1,000 & - & 1,000 & - & - \\
\hline
\end{tabular}

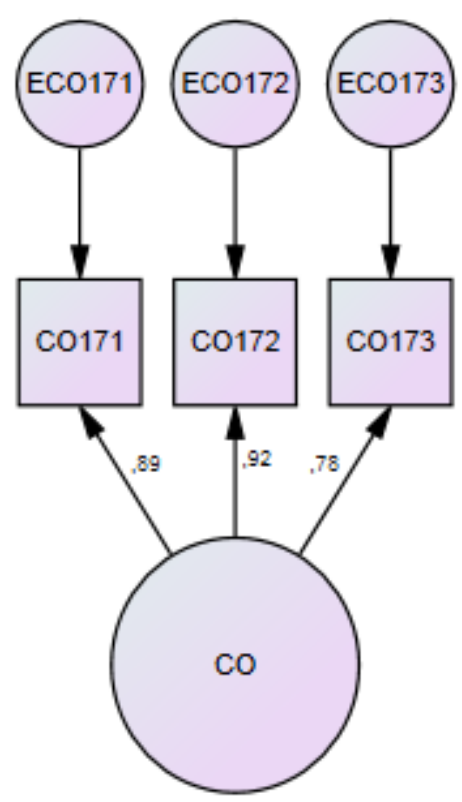

Figura 26 - Diagrama de caminho: Construto Conveniência On-line Fonte: saída (output) da análise do Amos (IBM SPSS) 
Tabela 30 - Qualidade de ajustamento - Conveniência Loja Física

\begin{tabular}{ccccccccccc}
\hline \multirow{2}{*}{ COLF } & $\begin{array}{l}\text { Limite das } \\
\text { cargas }(\beta)\end{array}$ & $\mathrm{X}^{2}$ & gl & $\mathrm{X}^{2} / g l$ & $\mathrm{p}$ & GFI & AGFI & CFI & TLI & RMSEA \\
\hline \hline Mod Inicial & {$[0,56 ; 0,73]$} & 0 & 0 & 0 & $<0,01$ & 1,000 & - & 1,000 & - & - \\
\hline
\end{tabular}

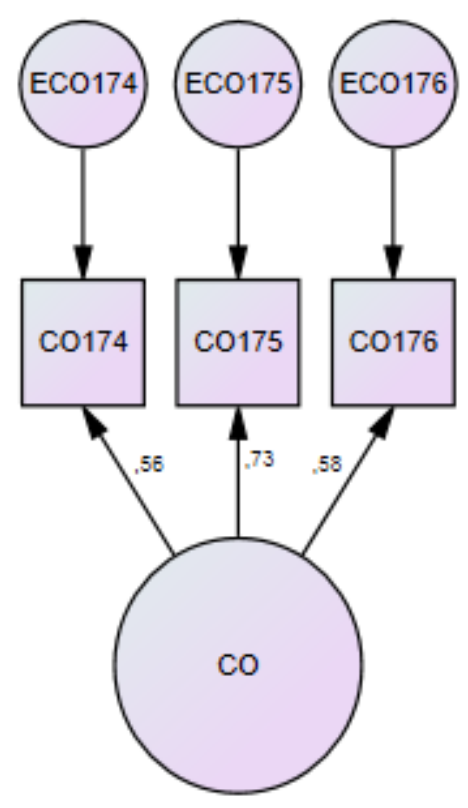

Figura 27 - Diagrama de caminho: Construto Conveniência Loja Física Fonte: saída (output) da análise do Amos (IBM SPSS)

\section{Fator 10 (Hipótese 10) Design do Site (FA_DS)}

\section{Análise Fatorial Exploratória}

O fator (Quadro 33) foi formado com quatro variáveis do construto original, sendo excluída a variável DS185 - "para falar a verdade não aguento mais as propagandas no site de lojas varejistas". O fator expressa a percepção do respondente quanto ao desenho do site, uma forma de o respondente demonstrar sua satisfação por meio do desenho e da funcionalidade do site. A variância explicada pelo fator foi de $58 \%$.

Quadro 33: Fator 10 - Design do Site

Matriz Componente

\begin{tabular}{|l|r|}
\hline & Componente \\
\cline { 2 - 2 } & \multicolumn{2}{|c|}{1} \\
\hline DS181 &, 734 \\
DS182 &, 767 \\
DS183 &, 756 \\
DS184 &, 780 \\
\hline
\end{tabular}

Legenda: DS181 - eu prefiro comprar em sites que não demoram em carregar e onde a navegação é rápida; DS182 - eu não gosto do formato de apresentação diferente de alguns websites de lojas varejistas; DS183 - em muitos sites tenho que navegar muito até achar o que procuro; DS184 - é realmente irritante quando os sites demoram a carregar.

Fonte: saída (output) da análise do IBM SPSS 


\section{Análise Fatorial Confirmatória}

A rodada da análise do modelo inicial apresentou um mau ajustamento (Tabela 31). O modelo foi reajustado, segundo Marôco (2010) pela avaliação dos resíduos padronizados e, segundo o índice de modificação sugerido pelo Amos, que recomendou a inserção de covariância entre os erros das variáveis DS181 e 184, resultando em melhoria. Em seguida, uma segunda covariância entre os erros das variáveis DS181 e 183, resultou em super ajustamento (Tabela 31; Figura 28).

Tabela 31 - Qualidade de ajustamento Design do Site

\begin{tabular}{ccccccccccc}
\hline DS & $\begin{array}{c}\text { Limite das } \\
\text { cargas }(\beta)\end{array}$ & \multirow{2}{*}{$\mathrm{X}^{2}$} & $\mathrm{gl}$ & $\mathrm{X}{ }^{2} / g l$ & $\mathrm{p}$ & $\mathrm{GFI}$ & $\mathrm{AGFI}$ & $\mathrm{CFI}$ & $\mathrm{TLI}$ & $\mathrm{RMSEA}$ \\
\hline \hline Mod Inicial & {$[0,62 ; 0,68]$} & 105,655 & 2 & 52,828 & $<0,01$ & 0,943 & 0,715 & 0,882 & 0,646 & 0,242 \\
Mod Mod 1 & {$[0,55 ; 0,79]$} & 0 & 0 & 0 & $<0,01$ & 1 & - & 1 & - & - \\
\hline
\end{tabular}

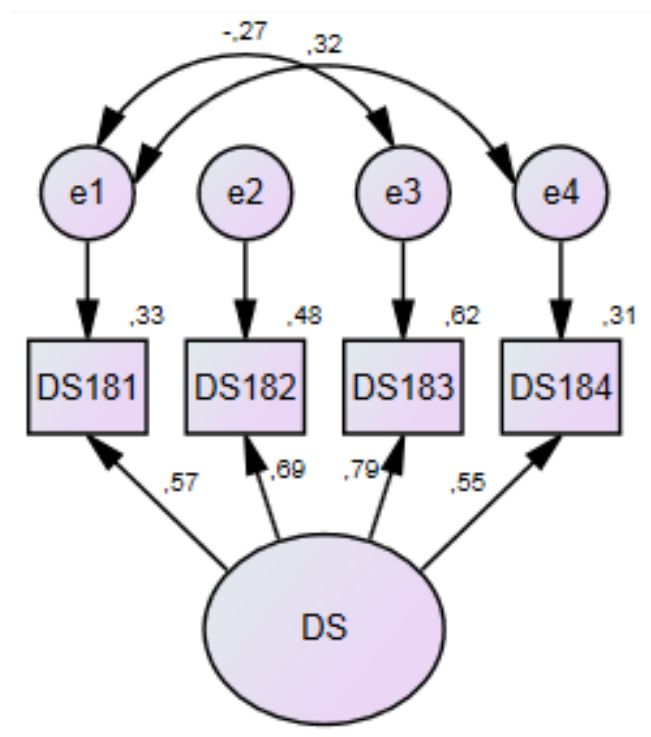

Figura 28 - Diagrama de caminho: Construto Design do Site

Fonte: saída (output) da análise do Amos (IBM SPSS)

\subsubsection{Variáveis Pull}

Fator 14 (Hipótese 14) Grau de atratividade do varejo off-line (FA_AV)

\section{Análise Fatorial Exploratória}

O fator atratividade dos canais físicos (Quadro 34) tem efeito positivo sobre o cruzamento entre canais. A variância preservada dos dados originais foi de $76 \%$. 
Quadro 34: Grau de atratividade

Component Matrix ${ }^{\mathrm{a}}$

\begin{tabular}{|l|r|}
\hline & Component \\
\cline { 2 - 2 } & 1 \\
\hline AV251 &, 839 \\
AV252 &, 881 \\
AV253 &, 860 \\
AV254 &, 896 \\
AV255 &, 879 \\
\hline
\end{tabular}

Legenda: Eu me sinto atraído para as lojas físicas: AV251 - Eu estou mais satisfeito com os serviços da loja física do que das lojas on-line da internet; AV252 - gosto de comprar em loja física porque quero tocar e sentir o produto; AV253 - gosto de comprar em loja física porque quero ver o produto seu funcionando e suas dimensões; AV254 - No geral, as práticas da loja física em que eu compro me beneficiam mais do que as práticas das lojas on-line; AV255 - regra geral, comprar da loja física é melhor do que comprar de loja on-line.

Fonte: saída (output) da análise do IBM SPSS

\section{Análise Fatorial Confirmatória}

A primeira estimativa do modelo apresentou mau ajustamento. O modelo foi reajustado, segundo Marôco (2010) pela avaliação dos resíduos padronizados e, segundo o índice de modificação sugerido pelo Amos, que recomendou a inserção de covariância entre os erros das variáveis AV252 e 253, melhorando significativamente os índices, sendo esta a última opção de ajuste (Tabela 32; Figura 29).

Tabela 32 - Qualidade de Ajustamento - Atratividade do Varejo

\begin{tabular}{ccccccccccc}
\hline AV & $\begin{array}{c}\text { Limite das } \\
\text { cargas }(\beta)\end{array}$ & $\mathrm{X}^{2}$ & $\mathrm{gl}$ & $\mathrm{X}^{2} / \mathrm{gl}$ & $\mathrm{p}$ & $\mathrm{GFI}$ & $\mathrm{AGFI}$ & \multirow{2}{*}{ CFI } & \multirow{2}{*}{ TLI } & RMSEA \\
\hline \hline Mod Inicial & {$[0,80 ; 0,88]$} & 533,494 & 5 & 106,699 & $<0,01$ & 0,406 & 0,267 & 0,854 & 0,707 & 0,346 \\
Mod Mod 1 & {$[0,73 ; 0,90]$} & 32,372 & 4 & 8,093 & $<0,01$ & 0,985 & 0,945 & 0,992 & 0,980 & 0,090
\end{tabular}




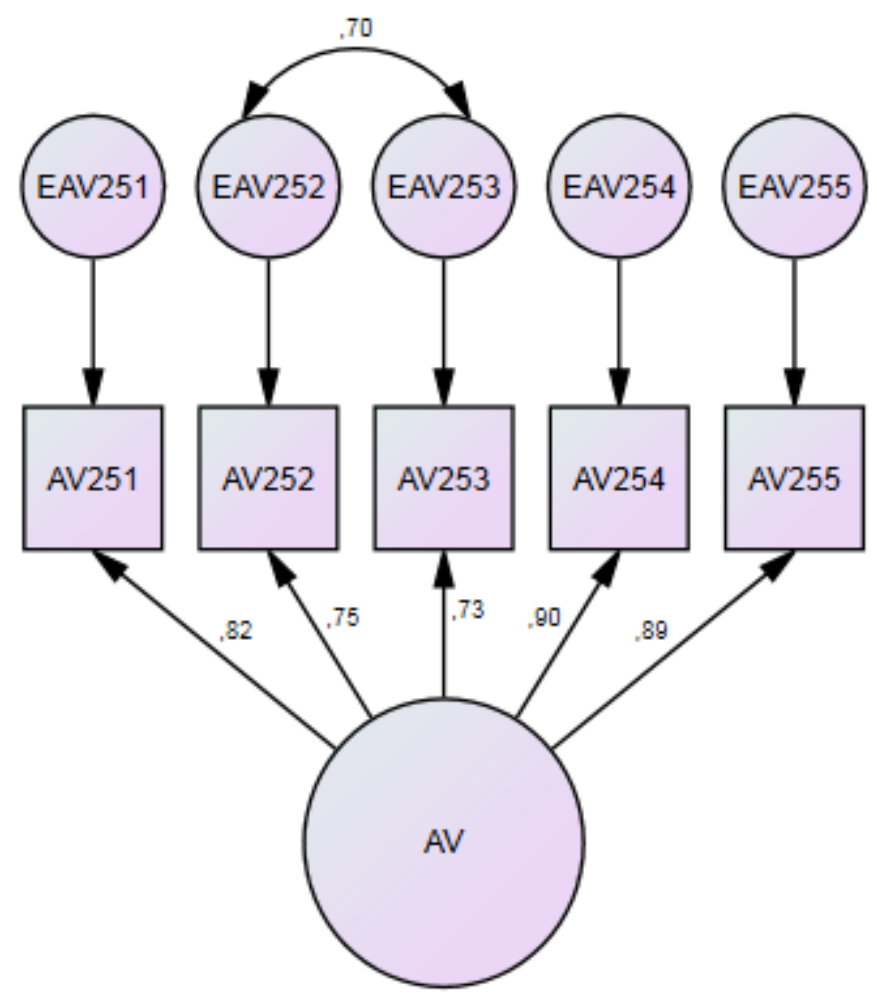

Figura 29 - Diagrama de caminho Construto Atratividade do Varejo Fonte: saída (output) da análise do Amos (IBM SPSS)

\section{Fator 15 (Hipótese 15) Risco percebido (FA_RP)}

\section{Análise Fatorial Exploratória}

Foi identificado um único fator (Quadro 35) para a percepção de risco na compra online com variância explica de $74 \%$.

$\begin{aligned} & \text { Quadro 35: Fator } 15-\text { Risco Percebido } \\
& \text { Matriz Componente }\end{aligned}$
\begin{tabular}{|l|r|}
\hline & Componente \\
\cline { 2 - 2 } & 1 \\
\hline RP231 &, 833 \\
RP232 &, 887 \\
RP233 &, 879 \\
RP234 &, 873 \\
RP235 &, 823 \\
RP236 &, 880 \\
\hline
\end{tabular}

Legenda: Eu prefiro não fazer compras na internet por que: RP231 - a chance de comprar de um site fraudulento é grande; RP232 - a chance de ter problemas de remessas e entrega de produtos é grande; RP233 - a privacidade de meus dados pessoais não está garantida quando eu compro em loja on-line; RP234 - a probabilidade de erro no pagamento do produto é maior comprando em loja on-line; RP235 - é difícil julgar a qualidade do produto, comprando em loja on-line; RP236 - existe grande probabilidade de que eu não receba o produto correto.

Fonte: saída (output) da análise do IBM SPSS 


\section{Análise Fatorial Confirmatória}

A primeira análise de qualidade da dimensão risco percebido apresentou problemas de ajustamento (Tabela 33). O modelo foi reajustado, segundo Marôco (2010) pela avaliação dos resíduos padronizados e, segundo o índice de modificação sugerido pelo Amos, que recomendou a inserção de covariância entre os erros em cada etapa, conforme a seguir: 1- erro entre variáveis RP231 e 232; 2- erro entre variáveis RP235 e 236; 3- erro entre variáveis RP231 e 233 e, 4- erro entre as variáveis RP232 e 234, melhorando significativamente os índices, sendo esta a última opção de ajuste (Figura 30).

Tabela 33 - Qualidade de ajustamento Risco Percebido

\begin{tabular}{ccccccccccc}
\hline RP & $\begin{array}{c}\text { Limite das } \\
\text { cargas }(\beta)\end{array}$ & $\mathrm{X}^{2}$ & $\mathrm{gl}$ & $\mathrm{X}^{2} / \mathrm{gl}$ & $\mathrm{p}$ & $\mathrm{GFI}$ & \multirow{2}{*}{ AGFI } & \multirow{2}{*}{ CFI } & \multirow{2}{*}{ TLI } & \multirow{2}{*}{ RMSEA } \\
\hline \hline Mod Inicial & {$[0,78 ; 0,86]$} & 209,106 & 9 & 23,234 & $<0,01$ & 0,920 & 0,814 & 0,952 & 0,92 & 0,159 \\
Mod Mod 1 & {$[0,75 ; 0,87]$} & 55,949 & 8 & 6,994 & $<0,01$ & 0,978 & 0,943 & 0,988 & 0,978 & 0,082 \\
Mod Mod 2 & {$[0,76 ; 0,86]$} & 33,373 & 7 & 4,768 & $<0,01$ & 0,987 & 0,962 & 0,994 & 0,986 & 0,065 \\
Mod Mod 3 & {$[0,75 ; 0,86]$} & 23,430 & 6 & 3,905 & $<0,01$ & 0,991 & 0,97 & 0,996 & 0,989 & 0,057 \\
Mod Mod 4 & {$[0,74 ; 0,88]$} & 7,518 & 5 & 1,504 & $>0,05$ & 0,997 & 0,988 & 0,999 & 0,998 & 0,024 \\
\hline
\end{tabular}

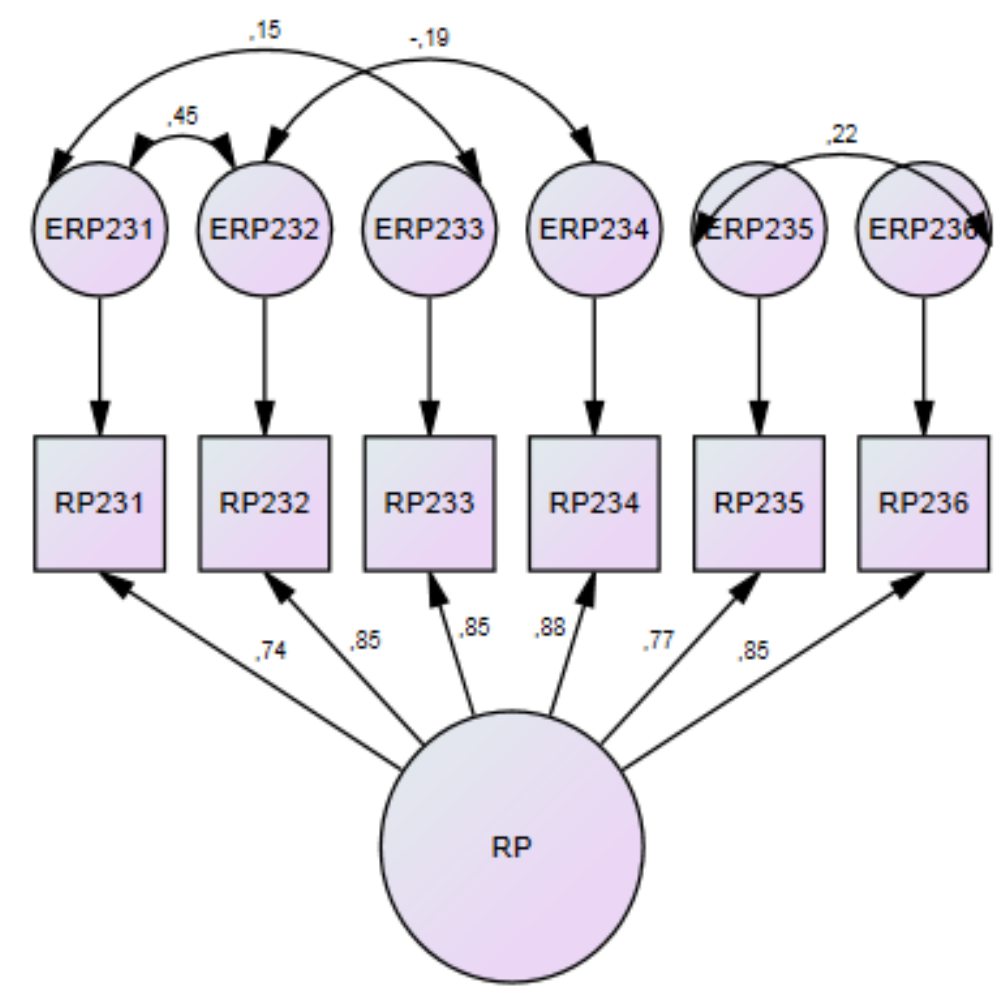

Figura 30 - Diagrama de caminho: Construto Risco Percebido Fonte: saída (output) da análise do Amos (IBM SPSS) 


\section{Fator 16 (Hipótese 16) Qualidade Percebida (FA_QP)}

\section{Análise Fatorial Exploratória}

O fator Qualidade Percebida de serviços da loja física (Quadro 36) tem efeito positivo na atratividade para o varejo off-line. A qualidade foi expressa pela acessibilidade ao varejo tradicional, atmosfera e decoração, atendimento pessoal. Resultou em único fator com variância explicada de $72 \%$.

Quadro 36: Fator 17 - Qualidade Percebida
Matriz Componente
\begin{tabular}{|l|r|}
\hline & Componente \\
\cline { 2 - 2 } & 1 \\
\hline QP221 &, 737 \\
QP222 &, 803 \\
QP223 &, 903 \\
QP224 &, 906 \\
QP225 &, 862 \\
QP226 &, 882 \\
\hline
\end{tabular}

Legenda: Eu prefiro realizar a minha compra na loja física por que: QP221 - eu posso chegar a qualquer momento numa loja varejista; QP222 - gosto da atmosfera e decoração das lojas; QP223 os funcionários da loja varejista atendem imediatamente quando eu faço uma reclamação; QP224 os funcionários da loja estão sempre dispostos a me ajudar quando tenho problema com os serviços; QP225 - os funcionários da loja me dão atenção pessoalmente; QP226 - os funcionários das lojas atendem minhas necessidades específicas.

Fonte: saída (output) da análise do IBM SPSS

\section{Análise Fatorial Confirmatória}

A primeira análise de qualidade da dimensão risco percebido apresentou problemas de ajustamento (Tabela 34). O modelo foi reajustado, segundo Marôco (2010) pela avaliação dos resíduos padronizados e, segundo o índice de modificação sugerido pelo Amos, que recomendou a inserção de covariância entre os erros em cada etapa, conforme a seguir: 1- entre os erros das variáveis QP221 e 222; 2- erros entre as variáveis QP225 e 226; 3- erros entre as variáveis QP224 e 225; 4- erros entre as variáveis QP222 e 224; 5- erros entre as variáveis QP221 e 224, melhorando significativamente os índices, sendo esta a última opção de ajuste (Figura 31). 
Tabela 34 - Qualidade de ajustamento para Qualidade Percebida

\begin{tabular}{ccccccccccc}
\hline QP & $\begin{array}{c}\text { Limite das } \\
\text { cargas }(\beta)\end{array}$ & \multirow{2}{*}{$X^{2}$} & $g l$ & $X^{2} / g l$ & $p$ & GFI & AGFI & CFI & TLI & RMSEA \\
\hline \hline Mod Inicial & {$[0,63 ; 0,92]$} & 442,137 & 9 & 49,126 & $<0,01$ & 0,859 & 0,671 & 0,901 & 0,835 & 0,234 \\
Mod Mod 1 & {$[0,61 ; 0,93]$} & 216,489 & 8 & 27,061 & $<0,01$ & 0,923 & 0,799 & 0,952 & 0,911 & 0,172 \\
Mod Mod 2 & {$[0,61 ; 0,94]$} & 50,531 & 7 & 7,219 & $<0,01$ & 0,982 & 0,945 & 0,990 & 0,979 & 0,084 \\
Mod Mod 3 & {$[0,61 ; 0,93]$} & 29,496 & 6 & 4,916 & $<0,01$ & 0,990 & 0,963 & 0,995 & 0,987 & 0,067 \\
Mod Mod 4 & {$[0,61 ; 0,93]$} & 20,277 & 5 & 4,055 & $<0,01$ & 0,993 & 0,970 & 0,997 & 0,990 & 0,059 \\
Mod Mod 5 & {$[0,64 ; 0,94]$} & 4,785 & 4 & 1,196 & $>0,05$ & 0,998 & 0,991 & 1,000 & 0,999 & 0,015 \\
\hline
\end{tabular}

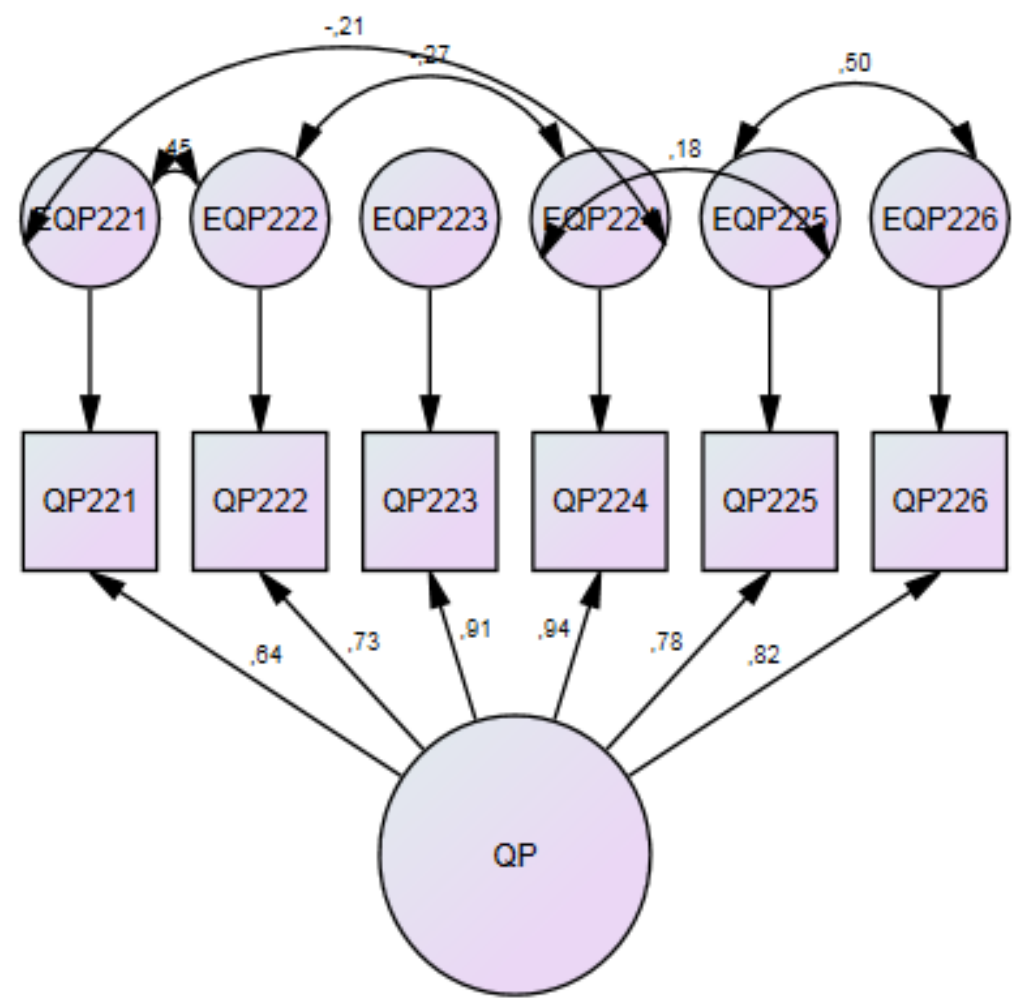

Figura 31 - Diagrama de caminho: Construto Qualidade Percebida

Fonte: saída (output) da análise do Amos (IBM SPSS)

Fator 17 (Hipótese 17) Barganha (FA_BA)

\section{Análise Fatorial Exploratória}

Foi formado um único fator (Quadro 37) com as cinco variáveis do construto teórico, explicado por uma variância de $74 \%$. 


\section{Quadro 37: Fator 17 - Barganha}

Matriz Componente

\begin{tabular}{|l|r|}
\hline & \multicolumn{2}{|c|}{ Componente } \\
\cline { 2 - 2 } & 1 \\
\hline BA241 &, 828 \\
BA242 &, 857 \\
BA243 &, 901 \\
BA244 &, 838 \\
BA245 &, 868 \\
\hline
\end{tabular}

Legenda: Eu gosto de comprar em loja física por que: BA241 - eu adoro pechinchar; BA242 - eu tenho muito orgulho de ser um comprador esperto; BA243 - estou pronto a gastar um tempo extra nas compras para conseguir os melhores preços nos produtos que estou procurando; BA244 - é importante eu conhecer todas as alternativas de transação disponíveis antes de fazer uma compra; BA245 - parte do meu divertimento é o prazer que me dá quando eu consigo um benefício extra da loja física onde comprei o produto.

Fonte: saída (output) da análise do IBM SPSS

\section{Análise Fatorial Confirmatória}

A primeira análise de qualidade da dimensão barganha apresentou problemas de ajustamento (Tabela 35). O modelo foi reajustado, segundo Marôco (2010) pela avaliação dos resíduos padronizados e, segundo o índice de modificação sugerido pelo Amos, que recomendou a inserção de covariância entre os erros em cada etapa, conforme a seguir: 1- entre os erros das variáveis BA241 e 242; 2- entre os erros das variáveis BA242 e 244, melhorando significativamente os índices, sendo esta a última opção de ajuste (Figura 32).

Tabela 35 - Qualidade de ajustamento - Barganha

\begin{tabular}{ccccccccccc}
\hline BA & $\begin{array}{c}\text { Limite das } \\
\text { cargas }(\beta)\end{array}$ & $\mathrm{X}^{2}$ & $\mathrm{gl}$ & $\mathrm{X}^{2} / g l$ & $\mathrm{p}$ & GFI & AGFI & CFI & TLI & RMSEA \\
\hline \hline Mod Inicial & {$[0,77 ; 0,89]$} & 90,211 & 5 & 18,042 & $<0,01$ & 0,960 & 0,880 & 0,971 & 0,942 & 0,139 \\
Mod Mod 1 & {$[0,73 ; 0,90]$} & 29,340 & 4 & 7,335 & $<0,01$ & 0,987 & 0,952 & 0,991 & 0,978 & 0,085 \\
Mod Mod 2 & {$[0,74 ; 0,89]$} & 8,047 & 3 & 2,682 & $>0,01$ & 0,996 & 0,982 & 0,998 & 0,994 & 0,044 \\
\hline
\end{tabular}




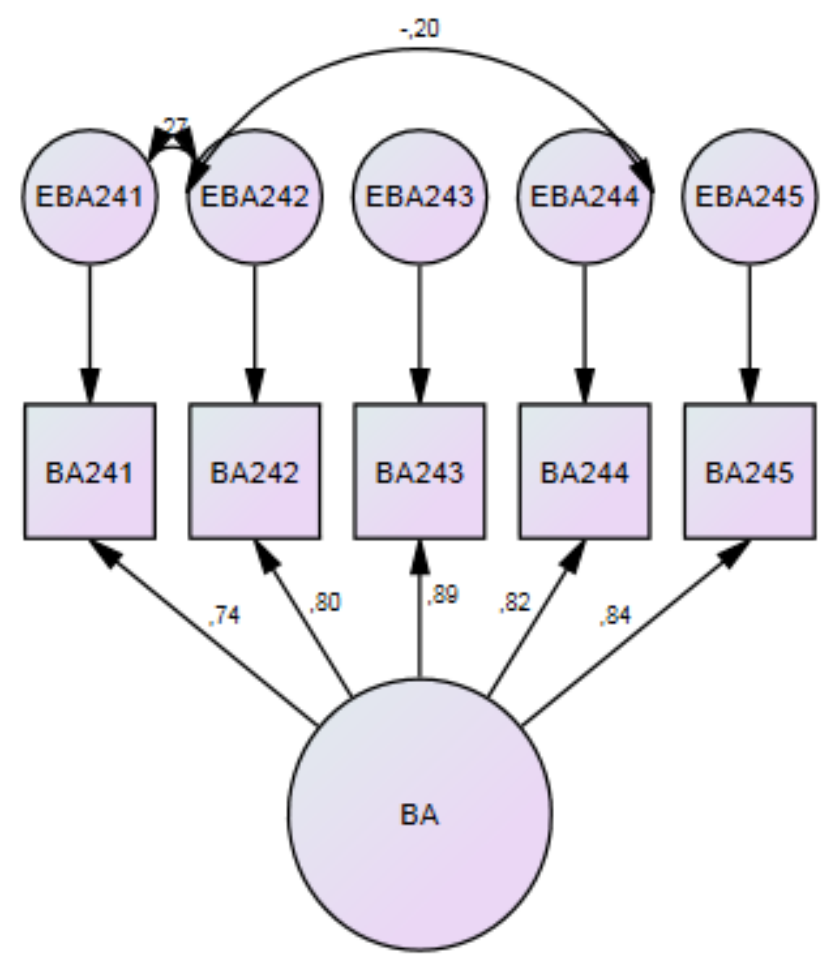

Figura 32 - Diagrama de caminho: Construto Barganha Fonte: saída (output) da análise do Amos (IBM SPSS)

\subsubsection{Fator 18 - Intenção de Free-riding (FA_FR)}

\section{Análise Fatorial Exploratória}

Foi formado um único fator free-riding com variância explicada de 72\% (Quadro 38).

Quadro 38: Fator 18 - Intenção Free-riding
Component Matrix ${ }^{\text {a }}$
\begin{tabular}{|l|r|}
\hline & Component \\
\cline { 2 - 2 } & 1 \\
\hline FR261 &, 849 \\
FR262 &, 799 \\
FR263 &, 882 \\
FR264 &, 863 \\
\hline
\end{tabular}

Legenda: Eu iria pesquisar numa loja on-line, mas comprar em uma loja física ou vice-versa. FR261 quando eu compro produtos semelhantes aos desta pesquisa; FR262 - quando eu compro produtos diferentes ao desta pesquisa; FR263 - Sinto-me confortável em navegar nos múltiplos canais de vendas de uma mesma rede varejista, para pesquisa pela internet e compra na loja física ou viceversa, quando se trata de produtos como o desta pesquisa; FR264 - sinto-me confortável em navegar nos múltiplos canais de vendas de diferentes lojas varejistas para pesquisa pela internet e compra na loja física ou vice-versa, no caso de produtos como desta pesquisa.

Fonte: saída (output) da análise do IBM SPSS 


\section{Análise Fatorial Confirmatória}

A primeira análise de qualidade da dimensão risco percebido apresentou problemas de ajustamento (Tabela 36). O modelo foi reajustado, segundo Marôco (2010) pela avaliação dos resíduos padronizados e, segundo o índice de modificação sugerido pelo Amos, que recomendou a inserção de covariância entre os erros das variáveis FR261 e 222, melhorando significativamente os índices, sendo esta a última opção de ajuste (Figura 33).

Tabela 36 - Qualidade de ajustamento Intenção de Free-riding

\begin{tabular}{ccccccccccc}
\hline FR & $\begin{array}{c}\text { Limite das } \\
\text { cargas }(\beta)\end{array}$ & \multirow{2}{*}{$X^{2}$} & $g l$ & $X^{2} / g l$ & $p$ & GFI & AGFI & CFI & TLI & RMSEA \\
\hline \hline Mod inicial & {$[0,60 ; 0,93]$} & 311,174 & 2 & 155,587 & $<0,01$ & .862 & 0,309 & 0,856 & 0,569 & 0,419 \\
\hline \hline Mod Mod 1 & {$[0,56 ; 0,95]$} & 0,418 & 1 & 0,418 & $>0,05$ & 1,000 & 0,998 & 1,000 & 1,002 & 0,000 \\
\hline
\end{tabular}

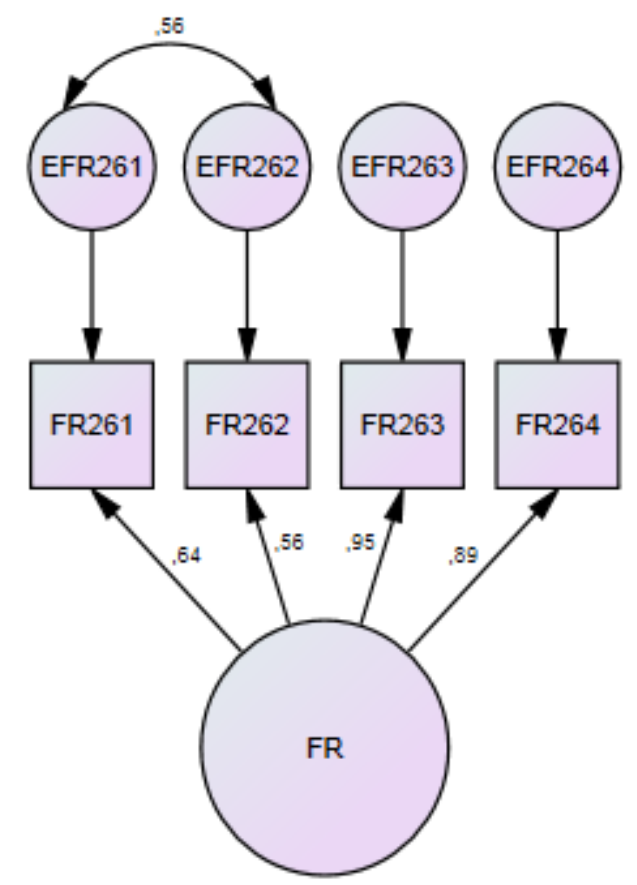

Figura 33 - Diagrama de caminho: Construto Intenção de Free-riding Fonte: saída (output) da análise do Amos (IBM SPSS) 


\subsubsection{Quadro resumo dos fatores}

A análise fatorial exploratória individual definiu novos construtos em relação ao modelo teórico que foram validados pela análise fatorial confirmatória. No modelo teórico proposto eram 17 hipóteses, porém foram confirmados 22 fatores com 78 variáveis. Confirmaram-se dois construtos para satisfação: SA_FR e SA_LF; dois construtos para custo de mudança: CMR - alto custo de mudança e CMM - baixo custo de mudança. Foram formados dois construtos para conveniência: $\mathrm{CO}$ _OL conveniência on-line e CO_LF - conveniência loja física. Lealdade formou apenas um construto. Formaram-se dois construtos para confiança: $\mathrm{CO}$ _OL - confiança online e CF_LF - confiança loja física. Oito variáveis foram excluídas dos fatores (EX102, EV114, BV151, BV156, RF162, RF163, DS185, SA191). Os construtos novos entraram no modelo proposto em locais diferentes conforme literatura empírica, Quadro 39. 
Quadro 39 - Resumo dos fatores após análise fatorial exploratória e confirmatória

\begin{tabular}{|c|c|c|c|c|c|c|}
\hline FATORES & & HIPÓTESES & HIPÓTESE & $\begin{array}{l}\text { NOME } \\
\text { FATOR }\end{array}$ & $\begin{array}{c}\text { No } \\
\text { VARIÁVEIS }\end{array}$ & $\begin{array}{l}\text { VARIÁVEIS } \\
\text { INCLUÍDAS }\end{array}$ \\
\hline AUTO EFICÁCIA MULTICANAL & \multirow{7}{*}{ 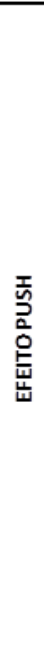 } & $\begin{array}{l}\text { O alto nivel de auto eficácia no varejo } \\
\text { multicanal tem efeito positivo no free } \\
\text { riding entre canais. }\end{array}$ & $\mathrm{H} 1$ & FA_AE & 4 & $\begin{array}{c}\text { AE } 121 \\
122,123,124\end{array}$ \\
\hline AFINIDADE TECNOLÓGICA & & $\begin{array}{l}\text { A afinidade com internet tem efeito } \\
\text { positivo para a auto eficácia no varejo } \\
\text { multicanal. }\end{array}$ & $\mathrm{H} 3$ & FA_AT & 4 & $\begin{array}{c}\text { AT } 91,92,93 \\
94\end{array}$ \\
\hline EXPERIÊNCIA INTERNET & & $\begin{array}{l}\text { A experiência prévia com internet tem } \\
\text { efeito positivo para a auto eficácia no } \\
\text { varejo multicanal. }\end{array}$ & $\mathrm{H} 2$ & FA_EX & 4 & $\begin{array}{c}\text { EX101,103, } \\
104,105\end{array}$ \\
\hline EXPERIÊNCIA VICÁRIA & & $\begin{array}{l}\text { Experiência vicária tem efeito positivo } \\
\text { para a auto eficácia no varejo multicanal. }\end{array}$ & $\mathrm{H} 4$ & FA_EV & 3 & $\begin{array}{c}\text { EV } 111,112, \\
113\end{array}$ \\
\hline $\begin{array}{l}\text { SATISFAÇÃO FREE RIDING } \\
\text { (OL) }\end{array}$ & & $\begin{array}{l}\text { A maior satisfação free-riding de } \\
\text { compras tem efeito positivo sobre a auto } \\
\text { eficácia no varejo multicanal. }\end{array}$ & $\mathrm{H} 11 \mathrm{~A}$ & FA_SA_FR & 2 & SAFR192,195 \\
\hline LEALDADE & & $\begin{array}{l}\text { A maior lealdade ao canal online tem } \\
\text { efeito positivo sobre a auto eficácia no } \\
\text { varejo multicanal. }\end{array}$ & $\mathrm{H} 13$ & FA_LE & 4 & $\begin{array}{l}\text { LE211,212, } \\
213,241\end{array}$ \\
\hline CONFIANÇA ONLINE & & $\begin{array}{l}\text { A maior confiança no canal online tem } \\
\text { efeito positivo sobre a auto eficácia no } \\
\text { varejo multicanal. }\end{array}$ & $\mathrm{H} 12 \mathrm{~A}$ & FA_CF_OL & 3 & $\begin{array}{c}\text { CFOL } 201,204,2 \\
05\end{array}$ \\
\hline RETENÇÃO NA FIRMA & \multirow{7}{*}{ 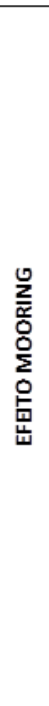 } & $\begin{array}{l}\text { A retenção dentro dos canais da firma de } \\
\text { um varejista tem efeito negativo no free- } \\
\text { riding de canais para outros varejistas. }\end{array}$ & H5 & FA_RF & 2 & RF161, 164 \\
\hline BAIXO CUSTO DE MUDANÇA & & $\begin{array}{l}\text { O baixo custo de mudança tem efeito } \\
\text { negativo sobre a retenção da firma } \\
\text { através de seu multicanal do varejista. }\end{array}$ & $\mathrm{H} 7 \mathrm{~B}$ & FA_CMM & 2 & СMM132,134 \\
\hline ALTO CUSTO DE MUDANÇA & & $\begin{array}{l}\text { O alto custo de mudança possui um efeito } \\
\text { positivo sobre a retenção da firma através } \\
\text { do multicanal do varejista. }\end{array}$ & H7A & FA_CMR & 2 & CMR131,133 \\
\hline INTEGRAÇÃO PERCEBIDA & & $\begin{array}{l}\text { A percepção do consumidor sobre a } \\
\text { integração multicanal tem efeito positivo } \\
\text { na retenção da firma do varejista. }\end{array}$ & H8 & FA_IN & 4 & $\begin{array}{l}\text { IN141,142, } \\
143,144\end{array}$ \\
\hline BUSCA DE VARIEDADE & & $\begin{array}{l}\text { A busca de variedade tem efeito positivo } \\
\text { na retenção pela firma entre os } \\
\text { multicanais do mesmo varejista. }\end{array}$ & H6 & FA_BV & 4 & $\begin{array}{c}\text { BV } \\
152,153,154 \\
155\end{array}$ \\
\hline CONVENIENCIA ON LINE & & $\begin{array}{l}\text { A maior conveniência de compra pelo } \\
\text { canal online tem efeito positivo sobre a } \\
\text { retenção na firma do varejista. }\end{array}$ & H9A & FA_CO_OL & 3 & $\begin{array}{c}\text { COOL171,172, } \\
173\end{array}$ \\
\hline DESIGN SITE & & $\begin{array}{l}\text { O desenho do site e sua funcionalidade } \\
\text { tem efeito positivo na retenção da firma } \\
\text { pelo varejista. }\end{array}$ & $\mathrm{H} 10$ & FA_DS & 4 & $\begin{array}{c}\text { DS } \\
181,182,183 \\
184\end{array}$ \\
\hline ATRATIVIDADE VAREJO & \multirow{7}{*}{ 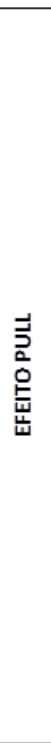 } & $\begin{array}{l}\text { A atratividade do varejo tradicional tem } \\
\text { efeito positivo no cruzamento entre canais } \\
\text { e entre varejistas com a intenção de free } \\
\text { riding. }\end{array}$ & $\mathrm{H} 14$ & FA_AV & 5 & $\begin{array}{c}\text { AV } \\
251,252,253 \\
254,255\end{array}$ \\
\hline CONFIANÇA LOJA FISICA & & $\begin{array}{l}\text { A maior confiança no canal tradicional tem } \\
\text { efeito positivo sobre a atratividade do } \\
\text { varejo tradicional. }\end{array}$ & $\mathrm{H} 12 \mathrm{~B}$ & FA_CF_LF & 2 & CFLF202,203 \\
\hline SATISFAÇÃO LOJA FISICA & & $\begin{array}{l}\text { A maior satisfação de compras pelo canal } \\
\text { tradicional tem efeito positivo sobre a } \\
\text { atratividade do varejo. }\end{array}$ & $\mathrm{H} 11 \mathrm{~B}$ & FA_SA_LF & 2 & SALF193,194 \\
\hline CONVENIENCIA LOJA FISICA & & $\begin{array}{l}\text { A maior conveniência de compra pelo } \\
\text { canal tradicional tem efeito positivo na } \\
\text { atratividade do varejo tradicional. }\end{array}$ & $\mathrm{H} 9 \mathrm{~B}$ & FA_CO_LF & 3 & $\begin{array}{c}\text { COLF174,175,1 } \\
76\end{array}$ \\
\hline QUALIDADE PERCEBIDA & & $\begin{array}{l}\text { A qualidade percebida do serviço no } \\
\text { canal tradicional tem efeito positivo na } \\
\text { atratividade do varejo tradicional. }\end{array}$ & H16 & FA_QP & 6 & $\begin{array}{c}\text { QP } 221,222 \\
223,224,225 \\
226 \\
\end{array}$ \\
\hline RISCO PERCEBIDO & & $\begin{array}{l}\text { O risco percebido pela compra online } \\
\text { tem um efeito positivo na atratividade pelo } \\
\text { varejo tradicional. }\end{array}$ & $\mathrm{H} 15$ & FA_RP & 6 & \begin{tabular}{|c|}
$\mathrm{RP}$ \\
$231,232,233,2$ \\
$34,235,236$ \\
\end{tabular} \\
\hline BARGANHA & & $\begin{array}{l}\text { A necessidade de barganhar tem efeito } \\
\text { positivo na atratividade pelo varejo } \\
\text { tradicional. }\end{array}$ & H17 & FA_BA & 5 & $\begin{array}{c}B A \\
241,242,243 \\
244,245\end{array}$ \\
\hline FREE RIDING & & & DEP & FA_FR & 4 & $\begin{array}{c}\mathrm{FR} \\
261,262,263 \\
264\end{array}$ \\
\hline
\end{tabular}




\subsubsection{Comparação de médias dos fatores}

A análise de comparação de médias dos fatores, por meio de testes estatísticos univariados, para variáveis nominais e ordinais permite observar se o padrão de comportamento medido pelo escore fatorial difere entre grupos (de variáveis nominais ou ordinais). Os grupos estudados foram: idade, gênero, escolaridade, renda, P4- quantas lojas visitou para buscar informação, P5- local de compra, P6quantas lojas visitou para realizar a compra efetiva, P7- hábito de compra, P8.1 e 8.2 - fixado o cruzamento entre busca e compra que determinam free-riding ou a retenção em dada marca varejista. Isso foi medido pela comparação entre as médias dos escores fatoriais de cada grupo.

Pelo SPSS (versão 19) foi realizado o teste de análise de variância (ANOVA), incluindo os testes de Scheffe e Bonferroni. Embora a normalidade das distribuições dos scores fatoriais não tenha sido confirmada para nenhum dos 22 fatores, em se tratando de grandes amostras e pelo teorema do limite central "se a população básica é não normal, a distribuição de médias amostrais será aproximadamente normal para grandes amostras". Stevenson (1981, p. 181). No presente estudo a amostra tem 883 indivíduos e pode ser considerada uma grande amostra (acima de 30 observações). Além disso, foi feito o teste não paramétrico de Mann-Whitney para testar se duas amostras independentes provêm de populações com medianas iguais. E o teste Kruskal-Wallis para testar se três ou mais amostras independentes foram extraídas de populações com médias iguais, conforme Stevenson (1981).

Primeiramente se realizou uma análise por grupo de variáveis do modelo Push-PullMooring e em seguida, uma visão geral do resultado das diferenças significativas de médias. ${ }^{41}$

\footnotetext{
${ }^{41}$ As análises de comparação de média foram realizadas sob orientação e supervisão da doutoranda de Contabilidade - FEA USP, Prof. … Heloisa Bernardo.
} 


\subsubsection{Comparação de médias para Fatores Push}

O Quadro 41 e Quadro 42 resumem os achados encontrados na comparação de médias entre grupos que abrangem as perguntas 4, 5, 6, 7 e 8, para fatores com variáveis Push obtidos da análise fatorial exploratória.

\begin{tabular}{|c|c|c|c|c|c|}
\hline \multirow{3}{*}{ Grupos } & \multirow{3}{*}{$\begin{array}{l}\text { Tamanho } \\
\text { do grupo }\end{array}$} & \multicolumn{4}{|c|}{ Variáveis Push } \\
\hline & & \multicolumn{4}{|c|}{ Média dos fatores por grupo } \\
\hline & & FA_AT & FA_EX & FA_EV & FA_AE \\
\hline \multicolumn{6}{|c|}{ P4- Número de Busca } \\
\hline 1 loja & 96 & $-0,35$ & $-0,175$ & $-0,143$ & $-0,358$ \\
\hline$<3$ lojas & 299 & $-0,13$ & $-0,257$ & $-0,036$ & $-0,107$ \\
\hline$>3$ lojas & 488 & 0,15 & 0,192 & 0,050 & 0,136 \\
\hline \multicolumn{6}{|c|}{ P5- Local de Compra } \\
\hline Loja Física & 337 & $-0,05$ & $-0,136$ & 0,026 & $-0,080$ \\
\hline Online Brasil & 530 & 0,03 & 0,090 & $-0,005$ & 0,054 \\
\hline \multicolumn{6}{|c|}{ P6- Número de compra } \\
\hline 1 loja & 138 & $-0,100$ & $-0,067$ & 0,089 & $-0,156$ \\
\hline$<3$ lojas & 271 & $-0,102$ & $-0,249$ & $-0,032$ & $-0,099$ \\
\hline$>3$ lojas & 474 & 0,088 & 0,162 & $-0,008$ & 0,102 \\
\hline \multicolumn{6}{|c|}{ P7- Hábito de compra } \\
\hline Online $\rightarrow$ L. física & 364 & $-0,063$ & $-0,093$ & $-0,003$ & $-0,073$ \\
\hline L. física $\rightarrow$ Online & 83 & $-0,409$ & $-0,284$ & $-0,108$ & $-0,128$ \\
\hline L.F./OL $\rightarrow$ Online & 248 & 0,086 & 0,117 & 0,132 & 0,149 \\
\hline Online & 188 & 0,190 & 0,151 & $-0,120$ & 0,001 \\
\hline \multicolumn{6}{|c|}{ P8.1- Retenção ou Free- riding Online } \\
\hline Retenção Varejista & 424 & $-0,020$ & $-0,049$ & 0,012 & $-0,015$ \\
\hline Free-ride Varejistas & 249 & $-0,038$ & $-0,028$ & $-0,029$ & $-0,047$ \\
\hline Não se aplica & 210 & 0,086 & 0,133 & 0,009 & 0,086 \\
\hline \multicolumn{6}{|c|}{ P8.2- Retenção ou Free- riding Loja Física } \\
\hline Retenção Varejista & 266 & $-0,083$ & $-0,017$ & 0,104 & 0,007 \\
\hline Free-ride Varejistas & 344 & 0,061 & 0,050 & $-0,008$ & 0,011 \\
\hline Não se aplica & 273 & 0,004 & $-0,046$ & $-0,091$ & $-0,021$ \\
\hline
\end{tabular}

Legenda: Fatores afinidade tecnológica, experiência com internet, experiência vicária e autoeficácia. Os sombreados representam (sem escala) o intervalo de confiança (5\%) da média, para os métodos Scheffe e Bonferroni.

Fonte: resultados da análise pelo autor

A análise permitiu identificar distinção entre as dimensões fatorais push para "quantas lojas visitou para a busca de informação" (P4) que foi categorizada em três grupos: 1- apenas uma loja (96 respondentes), 2- em até três lojas (299 respondentes) e, 3- acima de três lojas (488 respondentes). Os fatores Afinidade tecnológica ( $A T)$, experiência com internet $(E X)$ e autoeficácia multicanal ( $A E$ ) tiveram diferenças significativas de médias (e mais altas) em relação ao grupo que realiza busca em mais de três lojas do que o grupo que pesquisa em até três lojas, evidenciando que respondentes com habilidade e experiência na internet realizam 
buscas em mais lojas para buscar informação sobre o produto. Foram encontradas diferenças de médias significativas, com médias maiores para o grupo 3 (acima de três lojas) em relação aos fatores satisfação em free-riding (SA_FR) e confiança online (CF_OL) (Quadro 41).

Em seguida foi tratada a pergunta sobre o local de compra efetivo (P5): 5.1 - loja física (337 respondentes), 5.2- loja on-line de site brasileiro (530 respondentes), 5.3loja on-line de site estrangeiro (12 respondentes), 5.4- por telefone (2 respondentes), 5.5- outro (especificar) com duas respostas consideradas inadequadas e categorizadas como 1.000 (comprei de um amigo; comprei de profissional). Os grupos 1 e 2 estão representados por 98\% dos respondentes (867). Como o grupo 3 e 4 foram muito pequenos, não foi possível fazer comparação estatística entre as médias. Apenas o fator experiência com internet $(E X)$ apresentou diferença de médias significativa entre o grupo 1- loja física e o grupo 2 - loja on-line em site brasileiro, sendo médias maiores para o grupo 2, evidenciando que os experientes em internet preferem a busca em lojas on-line. Houve diferença significativa de médias e com médias mais altas para as lojas on-line Brasil no fator confiança online (CF_OL) (Quadro 41).

Sobre "quantas lojas físicas/on-line visitou para compra efetiva" (P6) os resultados da comparação de média foram semelhantes aos da questão P4. Os fatores afinidade tecnológica (AT), experiência com internet (EX) e o fator autoeficácia ( $A E)$ apresentam diferenças significativas entre as médias de "até três lojas" e "acima de três lojas", sendo o último grupo com médias maiores em relação ao anterior, confirmando que os respondentes com maior afinidade tecnológica e experiência buscam em vários locais de compra on-line, com maior liberdade para free-riding entre canais. $O$ fator lealdade (LE) apresentou médias maiores e significativas para até três lojas, apresentando evidências de lealdade para alguns varejistas. $O$ fator satisfação em free-riding (SA_FR) apresentou médias mais altas e significativas para "acima de três lojas" em relação a uma e a três lojas, evidenciando maior disposição dos respondentes para free-riding. O fator confiança on-line (CF_OL) apresentou diferença significativa de média e média maior para acima de três lojas, em relação a uma única loja. 
Para a pergunta sobre o "hábito de compra" (P7) quase todas as variáveis push apresentaram diferença de médias significantes pela Anova, mas nem todas foram confirmadas pelos métodos Scheffer e Bonferroni. A variável apresentou quatro categorias para hábito de compra: 7.1 - você buscou informação em loja on-line antes de comprar numa loja física (364 respondentes do grupo 1); 7.2- você buscou informação em loja física antes de comprar em loja on-line (83 respondentes do grupo 2); 7.3- você buscou informação na loja on-line e loja física antes de comprar na loja on-line (248 respondentes do grupo 3); 7.4- você buscou informação e comprou na loja on-line (188 respondentes do grupo 4). O fator afinidade tecnológica (AT) apresentou média mais alta para o grupo 4 (busca e compra on-line) que possui média diferente dos grupos 1 e 2 . Há também diferença significativa de médias do grupo 2 em relação ao grupo 1,3 e 4, que pode ser explicado pelos poucos respondentes do grupo 2 (pesquisa em loja física e compra em loja on-line). O fator experiência com internet (EX) mostra diferenças de médias entre o grupo 2 em relação a 3 e 4, havendo maior média para o grupo 4 - busca e compra on-line. 0 fator satisfação (SA_FR) apresentou maior média para o grupo 3. O fator lealdade (LE) apresentou maior média para o grupo 2 (busca informação na loja física e compra pela internet).

Sobre as opções de pesquisa e compra (P 8.1), "pesquisou on-line e comprou efetivamente em loja física", foram três categorias: 1- da mesma rede varejista pesquisada na loja on-line (424); 2- de outro varejista não pesquisado na loja on-line (249); 3- não se aplica (210). O fator lealdade apresentou diferenças de médias, com média mais alta para o grupo 1 mesma rede varejista em relação ao não se aplica, porém não houve diferença de médias significativa entre o grupo 1 e 2.

Sobre as opções de pesquisa e compra ( $P$ 8.2), "pesquisou loja física e comprou efetivamente na loja on-line", foram três categorias: 1- da mesma rede varejista pesquisada na loja física (266), 2- de outro varejista não pesquisado em loja física (344), 3- não se aplica (273). Houve diferenças de médias significativas entre grupo 1 e 2 para o fator satisfação em free-riding , com média mais alta para o grupo 2 em relação ao 1. Também houve diferenças de médias significativas para o construto lealdade, com média mais alta para o grupo 1 em relação ao 2, havendo evidências 
de que àqueles que preferem a mesma rede varejista estão relacionados a ela por lealdade.

Numa visão geral, os construtos sobre as variáveis Push (afinidade tecnológica, experiência com internet, satisfação FR, confiança OL, autoeficácia) apresentaram uma tendência a maiores médias para busca em mais de três lojas e hábito de compra on-line (Quadro 40 e Quadro 41Quadro 41 - Comparação de médias para os fatores SA_FR, CF_OL, LE), com exceção da lealdade (LE).

\begin{tabular}{|c|c|c|c|c|}
\hline \multirow{3}{*}{ Grupos } & \multirow{3}{*}{$\begin{array}{l}\text { Tamanho } \\
\text { do grupo }\end{array}$} & \multicolumn{3}{|c|}{ Variáveis Push } \\
\hline & & \multicolumn{3}{|c|}{ Média dos fatores por grupo } \\
\hline & & FA_SA_FR & FA_CF_OL & FA_LE \\
\hline \multicolumn{5}{|c|}{ P4 - Número de Busca } \\
\hline 1 loja & 96 & $-0,362$ & $-0,255$ & $-0,059$ \\
\hline$<3$ lojas & 299 & $-0,115$ & $-0,047$ & 0,127 \\
\hline$>3$ lojas & 488 & 0,141 & 0,079 & $-0,066$ \\
\hline \multicolumn{5}{|c|}{ P5 - Local de Compra } \\
\hline Loja Física & 337 & $-0,075$ & $-0,215$ & $-0,009$ \\
\hline Online Brasil & 530 & 0,046 & 0,144 & 0,014 \\
\hline \multicolumn{5}{|c|}{ P6 - Número de compra } \\
\hline 1 loja & 138 & $-0,270$ & $-0,198$ & 0,077 \\
\hline$<3$ lojas & 271 & $-0,132$ & 0,014 & 0,138 \\
\hline$>3$ lojas & 474 & 0,154 & 0,049 & $-0,101$ \\
\hline \multicolumn{5}{|c|}{ P7 - Hábito de compra } \\
\hline Online $\rightarrow$ L. física & 364 & $-0,050$ & $-0,143$ & 0,056 \\
\hline L. física $\rightarrow$ Online & 83 & $-0,139$ & 0,072 & 0,377 \\
\hline L.F./OL $\rightarrow$ Online & 248 & 0,197 & 0,116 & $-0,167$ \\
\hline Online & 188 & $-0,101$ & 0,092 & $-0,056$ \\
\hline \multicolumn{5}{|c|}{ P8.1- Retenção ou Free- riding Online } \\
\hline Retenção Varejista & 424 & $-0,050$ & 0,037 & 0,238 \\
\hline Free-ride Varejistas & 249 & 0,029 & $-0,104$ & $-0,091$ \\
\hline Não se aplica & 210 & 0,066 & 0,049 & $-0,117$ \\
\hline \multicolumn{5}{|c|}{ P8.2- Retenção ou Free- riding Loja Física } \\
\hline Retenção Varejista & 266 & $-0,117$ & 0,064 & 0,238 \\
\hline Free-ride Varejistas & 344 & 0,113 & 0,073 & $-0,091$ \\
\hline Não se aplica & 273 & $-0,029$ & $-0,153$ & $-0,117$ \\
\hline
\end{tabular}

Legenda - Fatores de satisfação em free-riding (SA_FR), confiança on-line (CF_OL) e lealdade (LE). A numeração P4, P5, P6 etc. referem-se a perguntas do questionário.

Fonte: resultados da análise pelo autor 


\subsubsection{Comparação de médias para fatores Mooring}

Os quadros abaixo resumem todos os achados encontrados na comparação de médias entre grupos que abrangem as perguntas 4, 5, 6, 7 e 8, para os 7 fatores das variáveis Mooring, obtidos com a análise fatorial exploratória.

A pergunta 4: "quantas lojas visitou para a busca de informação") foi categorizada em três grupos: 1- apenas uma loja (96), 2- em até três lojas (299) e, 3- acima de três lojas (488).

Encontradas diferenças de médias significativas e médias maiores no grupo 3 (acima de 3 lojas) para os fatores baixo custo de mudança (CMM) e busca de variedade (BV) (Quadro 42) ; retenção na firma (RF), conveniência on-line (CO_OL) e Design do site (DS), (Quadro 43).

\begin{tabular}{|c|c|c|c|c|c|}
\hline \multirow{3}{*}{ Grupos } & \multirow{3}{*}{$\begin{array}{l}\text { Tamanho } \\
\text { do grupo }\end{array}$} & \multicolumn{4}{|c|}{ Variáveis Mooring } \\
\hline & & \multicolumn{4}{|c|}{ Média dos fatores por grupo } \\
\hline & & FA_CMR & FA_CMM & FA_IN & FA_BV \\
\hline \multicolumn{6}{|c|}{ P4 - Número de Busca } \\
\hline 1 loja & 96 & 0,023 & \begin{tabular}{|l|l|}
$-0,377$ \\
\end{tabular} & $-0,049$ & $-0,176$ \\
\hline$<3$ lojas & 299 & 0,091 & $-0,119$ & 0,054 & $-0,111$ \\
\hline$>3$ lojas & 488 & $-0,060$ & 0,147 & $-0,023$ & 0,102 \\
\hline \multicolumn{6}{|c|}{ P5 - Local de Compra } \\
\hline Loja Física & 337 & $-0,032$ & \begin{tabular}{|l|}
$-0,008$ \\
\end{tabular} & 0,075 & $-0,053$ \\
\hline Online Brasil & 530 & 0,033 & 0,005 & $-0,036$ & 0,044 \\
\hline \multicolumn{6}{|c|}{ P6 - Número de compra } \\
\hline 1 loja & 138 & 0,082 & \begin{tabular}{|l|l|}
$-0,277$ \\
\end{tabular} & $-0,033$ & $-0,171$ \\
\hline$<3$ lojas & 271 & 0,207 & $-0,100$ & 0,090 & $-0,103$ \\
\hline$>3$ lojas & 474 & $-0,142$ & 0,138 & $-0,042$ & 0,109 \\
\hline \multicolumn{6}{|c|}{ P7 - Hábito de compra } \\
\hline Online $\rightarrow$ L. física & 364 & 0,035 & $-0,073$ & 0,126 & 0,013 \\
\hline L. física $\rightarrow$ Online & 83 & 0,265 & 0,032 & $-0,026$ & $-0,089$ \\
\hline L.F./OL $\rightarrow$ Online & 248 & $-0,140$ & 0,167 & $-0,056$ & 0,153 \\
\hline Online & 188 & $-0,002$ & $-0,093$ & $-0,158$ & $-0,187$ \\
\hline \multicolumn{6}{|c|}{ P8.1- Retenção ou Free- riding Online } \\
\hline Retenção Varejista & 424 & 0,132 & $-0,088$ & 0,071 & $-0,037$ \\
\hline Free-ride Varejistas & 249 & $-0,072$ & 0,066 & 0,026 & 0,026 \\
\hline Não se aplica & 210 & $-0,180$ & 0,101 & $-0,175$ & 0,044 \\
\hline \multicolumn{6}{|c|}{ P8.2- Retenção ou Free- riding Loja Física } \\
\hline Retenção Varejista & 266 & 0,222 & \begin{tabular}{|l|l|}
$-0,018$ \\
\end{tabular} & 0,122 & $-0,007$ \\
\hline Free-ride Varejistas & 344 & $-0,067$ & 0,061 & $-0,044$ & 0,044 \\
\hline Não se aplica & 273 & $-0,133$ & $-0,060$ & $-0,064$ & $-0,048$ \\
\hline
\end{tabular}

Legenda: Alto custo de mudança (CMR), baixo custo de mudança (CMM), integração percebida (IN), busca de variedade (BV). Os sombreados representam (sem escala) o intervalo de confiança (5\%) da média, para os métodos Scheffe e Bonferroni.

Fonte: resultado da análise pelo autor 
Quanto ao local de compra efetivo com cinco categorias: 5.1- loja física (337 respondentes), 5.2- loja on-line de site brasileiro (530 respondentes), 5.3- loja on-line de site estrangeiro (12 respondentes), 5.4- por telefone (2 respondentes), 5.5- outro (especificar) com duas respostas consideradas inadequadas e categorizadas como 1.000 (comprei de um amigo; comprei de profissional), com duas respostas consideradas inadequadas e categorizadas como 1.000 (comprei de um amigo; comprei de profissional). Os grupos 1 e 2 estão representados por 98\% dos respondentes (867). Como o grupo 3 e 4 foram muito pequenos, não foi possível fazer comparação estatística entre as médias.

Houve diferença significativa de médias e médias mais altas para lojas on-line Brasil no fator conveniência on-line (CO_OL) (Quadro 43).

Sobre o número de lojas em que efetivamente pesquisou para comprar o produto (P6), categorizado em três grupos: grupo 1 - uma loja (138), grupo 2 - até três lojas (271), grupo 3 - acima de três lojas (474), apresentaram diferenças de comportamento em relação ao número de lojas para informação do produto.

O fator alto custo de mudança (CMR) (Quadro 42) apresentou média maior para até três lojas, evidenciando que os respondentes percebem alto custo para visitar mais de três lojas para comprar efetivamente. O resultado confirma os achados no artigo de Chiu et al. (2011). Em contrapartida os fatores baixo custo de mudança (CMM), busca de variedade (BV) e conveniência on-line (CO_OL) apresentaram maiores médias para acima de três lojas, confirmando que há maior disponibilidade para free-riding entre canais on-line (Quadro 42 e Quadro 43).

Sobre o hábito de compra (P7), a variável nominal apresentou quatro categorias: 7.1 - você buscou informação em loja on-line antes de comprar numa loja física (364); 7.2- você buscou informação em loja física antes de comprar em loja on-line (83); 7.3- você buscou informação na loja on-line e loja física antes de comprar na loja online (248); 7.4- você buscou informação e comprou na loja on-line (188). Foram encontradas maiores médias para o grupo 1- "busca on-line e compra loja física" para o fator integração percebida (IN), conforme visualizado no Quadro 42. 
Destacaram-se maiores médias em relação ao grupo 3 - "buscou informação on-line e loja física antes de comprar na loja on-line" para os fatores baixo custo de mudança (CMM) e busca de variedade (BV), evidenciando que visitam a loja física para checar o produto antes de comprar on-line (). E por fim apenas o fator alto custo de mudança (CMR) apresentou médias mais altas para o grupo 2 - "buscou informação na loja física antes de comprar on-line": (Quadro 42).

Quadro 43 - Comparação de médias dos fatores RF, CO_OL e DS

\begin{tabular}{|c|c|c|c|c|}
\hline \multirow{3}{*}{ Grupos } & \multirow{3}{*}{$\begin{array}{l}\text { Tamanho } \\
\text { do grupo }\end{array}$} & \multicolumn{3}{|c|}{ Variáveis Mooring } \\
\hline & & \multicolumn{3}{|c|}{ Média dos fatores por grupo } \\
\hline & & FA_RF & FA_CO_OL & FA_DS \\
\hline \multicolumn{5}{|c|}{ P4 - Número de Busca } \\
\hline 1 loja & 96 & $-0,266$ & $-0,295$ & $-0,295$ \\
\hline$<3$ lojas & 299 & $-0,068$ & $-0,091$ & $-0,008$ \\
\hline > 3 lojas & 488 & 0,094 & 0,114 & 0,063 \\
\hline \multicolumn{5}{|c|}{ P5 - Local de Compra } \\
\hline Loja Física & 337 & $-0,034$ & $-0,233$ & $-0,016$ \\
\hline Online Brasil & 530 & 0,011 & 0,143 & 0,005 \\
\hline \multicolumn{5}{|c|}{ P6 - Número de compra } \\
\hline 1 loja & 138 & $-0,210$ & $-0,218$ & $-0,177$ \\
\hline$<3$ lojas & 271 & 0,000 & $-0,071$ & 0,022 \\
\hline > 3 lojas & 474 & 0,061 & 0,104 & 0,039 \\
\hline \multicolumn{5}{|c|}{ P7 - Hábito de compra } \\
\hline Online $\rightarrow$ L. física & 364 & $-0,003$ & $-0,190$ & $-0,001$ \\
\hline L. física $\rightarrow$ Online & 83 & $-0,196$ & $-0,140$ & $-0,055$ \\
\hline L.F./OL $\rightarrow$ Online & 248 & 0,132 & 0,191 & 0,043 \\
\hline Online & 188 & $-0,082$ & 0,179 & $-0,031$ \\
\hline \multicolumn{5}{|c|}{ P8.1- Retenção ou Free- riding Online } \\
\hline Retenção Varejista & 424 & $-0,049$ & $-0,030$ & $-0,051$ \\
\hline Free-ride Varejistas & 249 & 0,016 & $-0,145$ & 0,055 \\
\hline Não se aplica & 210 & 0,079 & 0,233 & 0,038 \\
\hline \multicolumn{5}{|c|}{ P8.2- Retenção ou Free- riding Loja Física } \\
\hline Retenção Varejista & 266 & 0,014 & $-0,031$ & $-0,054$ \\
\hline Free-ride Varejistas & 344 & 0,034 & 0,136 & 0,009 \\
\hline Não se aplica & 273 & $-0,057$ & $-0,141$ & 0,042 \\
\hline
\end{tabular}

Legenda: RF - retenção na firma, CO_OL - conveniência on-line e DS - design do site. Os sombreados representam (sem escala) 0 intervalo de confiança (5\%) da média, para os métodos Scheffe e Bonferroni.

Fonte: resultado da análise pelo autor

Sobre as opções de pesquisa e compra ( $P$ 8.1), "pesquisou on-line e comprou efetivamente em loja física", foram três categorias: 1- da mesma rede varejista pesquisada na loja on-line (424); 2- de outro varejista não pesquisado na loja on-line (249); 3- não se aplica (210). Encontraram-se médias mais altas para o grupo 1 em 
relação aos fatores: alto custo de mudança (CMR) e integração percebida (IN) (Quadro 42). O fator alto custo de mudança (CMR) evidencia diferença significativa, com média maior para retenção no mesmo varejista grupo 1 - "mesma rede varejista". O fator integração percebida (IN) apresentou diferenças de médias significativas apenas entre os grupos 1 e 3 .

Sobre as opções de pesquisa e compra (8.2), "pesquisou loja física e comprou efetivamente na loja on-line", foram três categorias: 1- da mesma rede varejista pesquisa na loja física (266), 2- de outro varejista não pesquisado em loja física (344), 3- não se aplica (273). Constatou-se que houve diferença significativa de médias entre grupo 1 e 2 e médias maiores para o grupo 1 "mesma rede varejista" em relação ao fator alto custo de mudança (CMR) (Quadro 42).

\subsubsection{Comparação de médias para fatores Pull}

O Quadro 44 e Quadro 45 resumem todos os achados encontrados na comparação de médias entre grupos que abrangem as perguntas 4, 5, 6, 7 e 8, para os fatores das variáveis Pull obtidos com a análise fatorial exploratória e confirmatória.

A pergunta 4: "quantas lojas visitou para a busca de informação" foi categorizada em três grupos: 1- apenas uma loja (96), 2- em até três lojas (299) e, 3- acima de três lojas (488). Não houve diferenças de médias significativas para o número de lojas em que realizou a busca. 
Quadro 44 - Comparação de médias dos fatores QP, RP, BA, AV.

\begin{tabular}{|c|c|c|c|c|c|}
\hline \multirow{3}{*}{ Grupos } & \multirow{3}{*}{$\begin{array}{l}\text { Tamanho } \\
\text { do grupo }\end{array}$} & \multicolumn{4}{|c|}{ Variáveis Pull } \\
\hline & & \multicolumn{4}{|c|}{ Média dos fatores por grupo } \\
\hline & & FA_QP & FA_RP & FA_BA & FA_AV \\
\hline \multicolumn{6}{|c|}{ P4- Número de Busca } \\
\hline 1 loja & 96 & 0,052 & 0,024 & $-0,187$ & 0,031 \\
\hline$<3$ lojas & 299 & 0,097 & 0,019 & 0,009 & 0,088 \\
\hline$>3$ lojas & 488 & $-0,070$ & $-0,017$ & 0,032 & $-0,060$ \\
\hline \multicolumn{6}{|c|}{ P5- Local de Compra } \\
\hline Loja Física & 337 & 0,127 & 0,145 & 0,109 & 0,271 \\
\hline Online Brasil & 530 & $-0,064$ & $-0,095$ & $-0,060$ & $-0,155$ \\
\hline \multicolumn{6}{|c|}{ P6- Número de compra } \\
\hline 1 loja & 138 & 0,098 & 0,058 & $-0,078$ & 0,090 \\
\hline$<3$ lojas & 271 & 0,111 & $-0,033$ & $-0,048$ & 0,029 \\
\hline$>3$ lojas & 474 & $-0,092$ & 0,002 & 0,050 & $-0,043$ \\
\hline \multicolumn{6}{|c|}{ P7- Hábito de compra } \\
\hline Online $\rightarrow$ L. física & 364 & 0,185 & 0,152 & 0,105 & 0,241 \\
\hline L. física $\rightarrow$ Online & 83 & 0,045 & 0,002 & 0,105 & 0,141 \\
\hline L.F./OL $\rightarrow$ Online & 248 & $-0,132$ & $-0,064$ & 0,035 & $-0,135$ \\
\hline Online & 188 & $-0,204$ & $-0,211$ & $-0,296$ & $-0,350$ \\
\hline \multicolumn{6}{|c|}{ 8.1- Retenção ou Free- riding Online } \\
\hline Retenção Varejista & 424 & 0,091 & 0,041 & 0,048 & 0,037 \\
\hline Free-ride Varejistas & 249 & 0,071 & 0,058 & 0,099 & 0,189 \\
\hline Não se aplica & 210 & $-0,269$ & $-0,152$ & $-0,215$ & $-0,299$ \\
\hline \multicolumn{6}{|c|}{ 8.2- Retenção ou Free- riding Loja Física } \\
\hline Retenção Varejista & 266 & 0,164 & 0,046 & 0,004 & 0,021 \\
\hline Free-ride Varejistas & 344 & $-0,119$ & $-0,081$ & $-0,051$ & $-0,110$ \\
\hline Não se aplica & 273 & $-0,009$ & 0,057 & 0,060 & 0,118 \\
\hline
\end{tabular}

Legenda: QP- qualidade percebida, RP - risco percebido, BA - barganha, AV - atratividade do varejo. Os sombreados representam (sem escala) o intervalo de confiança (5\%) da média, para os métodos Scheffe e Bonferroni.

Fonte: resultados da análise pelo autor

Sobre o local da compra (P5), a escolha entre loja física ou on-line teve o fator risco percebido (RP) com média maior para o grupo que comprou na loja física. Portanto, para os respondentes sensíveis a risco em lojas on-line, preferem realizar a compra em loja física para os produtos pesquisados. O mesmo ocorreu com o fator atratividade do varejo (AV) que apresentou média maior para o grupo 1 - loja física (Quadro 44). Há evidências de que os respondentes para loja física apresentaram maior percepção a risco à compra on-line e se sentiram mais atraídos ao varejo tradicional. As lojas físicas, por sua vez, permitem que os consumidores possam tocar e ver produtos, levar para casa na hora da compra, possuem melhor atendimento sobre o produto. Foi encontrada média mais alta para loja física no fator satisfação loja física (SA_LF) (Quadro 45), e talvez a satisfação esteja relacionada aos respondentes que preferem olhar, conferir e sentir o produto. Outros autores 
atribuem à necessidade de interação social como uma das fontes de motivação para compra no varejo tradicional (TAUBER, 1972; ROHM E SWAMINATHAN, 2004).

\begin{tabular}{|c|c|c|c|c|}
\hline \multirow{3}{*}{ Grupos } & \multirow{3}{*}{$\begin{array}{l}\text { Tamanho } \\
\text { do grupo }\end{array}$} & \multicolumn{3}{|c|}{ Variáveis Pull } \\
\hline & & \multicolumn{3}{|c|}{ Média dos fatores por grupo } \\
\hline & & FA_SA_LF & FA_CF_LF & FA_CO_LF \\
\hline \multicolumn{5}{|c|}{ P4 - Número de Busca } \\
\hline 1 loja & 96 & $-0,065$ & $-0,161$ & $-0,064$ \\
\hline$<3$ lojas & 299 & 0,052 & 0,037 & 0,024 \\
\hline$>3$ lojas & 488 & $-0,019$ & 0,009 & $-0,002$ \\
\hline \multicolumn{5}{|c|}{ P5 - Local de Compra } \\
\hline Loja Física & 337 & 0,292 & 0,100 & 0,132 \\
\hline Online Brasil & 530 & $-0,181$ & $-0,061$ & $-0,069$ \\
\hline \multicolumn{5}{|c|}{ P6 - Número de compra } \\
\hline 1 loja & 138 & 0,049 & $-0,079$ & 0,001 \\
\hline$<3$ lojas & 271 & 0,085 & 0,034 & 0,022 \\
\hline$>3$ lojas & 474 & $-0,063$ & 0,003 & $-0,013$ \\
\hline \multicolumn{5}{|c|}{ P7 - Hábito de compra } \\
\hline Online $\rightarrow$ L. física & 364 & 0,288 & 0,139 & 0,166 \\
\hline L. física $\rightarrow$ Online & 83 & 0,000 & 0,133 & 0,244 \\
\hline L.F./OL $\rightarrow$ Online & 248 & $-0,130$ & $-0,107$ & $-0,083$ \\
\hline Online & 188 & $-0,386$ & $-0,186$ & $-0,319$ \\
\hline \multicolumn{5}{|c|}{ P8.1- Retenção ou Free- riding Online } \\
\hline Retenção Varejista & 424 & 0,081 & 0,035 & 0,116 \\
\hline Free-ride Varejistas & 249 & 0,132 & 0,094 & 0,039 \\
\hline Não se aplica & 210 & $-0,319$ & $-0,181$ & $-0,280$ \\
\hline \multicolumn{5}{|c|}{ P8.2- Retenção ou Free- riding Loja Física } \\
\hline Retenção Varejista & 266 & 0,057 & 0,026 & 0,145 \\
\hline Free-ride Varejistas & 344 & $-0,172$ & $-0,056$ & $-0,097$ \\
\hline Não se aplica & 273 & 0,161 & 0,046 & $-0,019$ \\
\hline
\end{tabular}

Legenda: satisfação (SA_LF), confiança (CF_LF), conveniência (CO_LF). Os sombreados representam (sem escala) o intervalo de confiança (5\%) da média, para os métodos Scheffe e Bonferroni.

Fonte: resultados da análise pelo autor

Para a questão sobre o número de lojas que visitou efetivamente para comprar o produto (P6), o fator qualidade percebida (QP) apresentou média significativa maior para menos de três lojas em relação à acima de três lojas (Quadro 44). Há evidências de que os respondentes possuem uma seleção de até três lojas que apresentam maior qualidade percebida. 
Para o hábito de compra (P7), a variável apresenta quatro categorias: 7.1 - você buscou informação em loja on-line antes de comprar numa loja física (364 respondentes do grupo 1); 7.2- você buscou informação em loja física antes de comprar em loja on-line (83 respondentes do grupo 2); 7.3- você buscou informação na loja on-line e loja física antes de comprar na loja on-line (248 respondentes do grupo 3); 7.4- você buscou informação e comprou na loja on-line (188 respondentes do grupo 4). Todas as variáveis pull apresentaram diferenças de médias significativas. Maiores médias em relação ao grupo 1 - "busca on-line e compra loja física" foram encontradas nos sete fatores: qualidade percebida (QP), risco percebido (RP), barganha (BA), satisfação (SA_LF), confiança (CF_LF), conveniência (CO_LF) e atratividade do varejo (AV). O fator barganha e risco percebido apresentaram média maior para busca on-line / compra loja física em relação à busca e compra on-line. Os fatores atratividade do varejo, satisfação, confiança e conveniência com lojas físicas apresentaram médias maiores para o grupo 1 em relação ao grupo 3 e 4 (Quadro 44 e Quadro 45).

Sobre as opções de pesquisa e compra ( $P$ 8.1), "pesquisou on-line e comprou efetivamente em loja física", foram três categorias: 1- da mesma rede varejista pesquisada na loja on-line (424); 2- de outro varejista não pesquisado na loja on-line (249); 3- não se aplica (210). Não se encontrou diferenças significativas de médias para esses fatores.

Sobre as opções de pesquisa e compra (8.2), "pesquisou loja física e comprou efetivamente na loja on-line", foram três categorias: 1- da mesma rede varejista pesquisada em loja física (266), 2- de outro varejista não pesquisado em loja física (344), 3- não se aplica (273). Constatou-se que o fator qualidade percebida (QP), satisfação (SA_LF), confiança (CF_LF) e conveniência (CO_LF) apresentaram médias maiores para retenção na mesma rede varejista (grupo 1), havendo evidências de que o atendimento na loja física talvez faça a diferença para esses respondentes (Quadro 44 e Quadro 45). 


\subsubsection{Comparação de médias do fator intenção de free-riding}

O fator intenção de free-riding não apresentou diferenças significativas de médias para os grupos que abrangem as perguntas 4, 5, 6, 7 e 8, obtidos com a análise fatorial exploratória, exceto para o hábito de compra em que se destacou média maior para o grupo 3 - busca loja física e on-line e compra na loja on-line em relação ao grupo 4 - busca e compra on-line. $\mathrm{O}$ fato evidenciou que a maior média está relacionada com o free-riding entre busca loja física e on-line e compra na loja online para esses produtos. (Quadro 46)

Quadro 46 - Comparação de médias do fator Intenção de free-riding

\begin{tabular}{|c|c|c|}
\hline Grupos & Média d & $\begin{array}{l}\text { los fatores por } \\
\text { grupo } \\
\text { FA_FR }\end{array}$ \\
\hline \multicolumn{3}{|c|}{ P4- Número de Busca } \\
\hline 1 loja & $-0,315$ & \\
\hline$<3$ lojas & 0,000 & \\
\hline$>3$ lojas & 0,062 & \\
\hline \multicolumn{3}{|c|}{ P5- Local de Compra } \\
\hline Loja Física & 0,048 & \\
\hline Online Brasil & $-0,035$ & \\
\hline \multicolumn{3}{|c|}{ P6- Número de compra } \\
\hline 1 loja & $-0,087$ & \\
\hline$<3$ lojas & $-0,057$ & \\
\hline$>3$ lojas & 0,058 & \\
\hline \multicolumn{3}{|c|}{ P7- Hábito de compra } \\
\hline Online $\rightarrow$ L. física & 0,007 & \\
\hline L. física $\rightarrow$ Online & 0,010 & \\
\hline L.F./OL $\rightarrow$ Online & 0,147 & \\
\hline Online & $-0,211$ & \\
\hline \multicolumn{3}{|c|}{ 8.1- Retenção ou Free- riding Online } \\
\hline Retenção Varejista & $-0,009$ & \\
\hline Free-ride Varejistas & 0,003 & \\
\hline Não se aplica & 0,014 & \\
\hline \multicolumn{3}{|c|}{ 8.2- Retenção ou Free- riding Loja Física } \\
\hline Retenção Varejista & $-0,046$ & \\
\hline Free-ride Varejistas & 0,086 & \\
\hline Não se aplica & $-0,063$ & \\
\hline
\end{tabular}

Comentários: os sombreados representam (sem escala) o intervalo de confiança (5\%) da média, para os métodos Scheffe e Bonferroni.

Fonte: resultados da análise pelo autor 


\subsubsection{Variáveis de perfil da amostra em relação aos fatores}

O Quadro 47 mostra as diferenças significativas de médias das variáveis de perfil e os fatores.

O fator integração percebida (IN) apresentou maior escore médio avaliado para o gênero feminino em relação ao masculino.

O fator experiência com internet $(\mathrm{EX})$ apresenta maior escore médio para a faixa etária até 30 anos em relação aos grupos acima de 41 anos.

O fator barganha $(\mathrm{BA})$ apresentou média significativa maior para a faixa de 41 a 50 anos em relação à idade de até 30 anos. $\mathrm{E}$ o mesmo fator apresentou maior média significativa para o gênero feminino em relação ao masculino. Há evidências de que o barganhar está relacionado nesta amostra mais com mulheres de idade mais avançada.

O fator lealdade (LE) apresentou escore médio mais alto para baixa escolaridade (até $1^{\circ}$ grau completo) em relação à graduação completa e à pós-graduação. O fator também está relacionado com renda, cujo escore médio mais elevado está para o grupo 2 - $R \$ 1501$ - 3000 em relação ao grupo 3 - $R \$ 3001-6000$. Há evidências de que a lealdade esteja mais relacionada com baixa educação e baixa renda.

O fator qualidade percebida (QP) teve escore médio mais elevado para a escolaridade grupo 2 - até segundo grau completo, em relação ao grupo 5 - pósgraduação completa.

O fator confiança em loja física (CF_LF) apresentou maior escore em renda familiar dos grupos 2 e 3 em relação ao grupo 5 (> R $\$ 10.000,00$ ). 
Quadro 47 - comparação de médias significativas das variáveis de perfis e fatores

\begin{tabular}{|c|c|c|c|c|c|c|c|c|c|c|c|c|c|c|c|c|c|}
\hline \multirow[t]{2}{*}{ Grupos } & \multirow{2}{*}{$\begin{array}{l}\text { Tamanho } \\
\text { do grupo }\end{array}$} & \multicolumn{16}{|c|}{ Média dos fatores por grupo } \\
\hline & & FA_EX & FA_CMR & & FA_IN & & FA_BV & & FA_RF & & FA_CF_LF & & FA_LE & & FA_QP & & FA_BA \\
\hline \multicolumn{18}{|c|}{ Q1-Idade } \\
\hline até 30 anos & 183 & 0,265 & & & & $-0,017$ & & & & & & $0,0,445$ & & 0,082 & & $-0,202$ & \\
\hline $31-40$ anos & 256 & 0,123 & & & & 0,022 & & & & & & 0,032 & & 0,083 & & 0,019 & \\
\hline $41-50$ anos & 241 & $-0,061$ & & & & 0,126 & & & & & & $-0,025$ & & $-0,034$ & & 0,110 & \\
\hline acima de 50 anos & 203 & $-0,322$ & & & & $-0,162$ & & & & & & \begin{tabular}{|c|}
$-0,196$ \\
\end{tabular} & & $-0,221$ & & 0,029 & \\
\hline \multicolumn{18}{|c|}{ Q2 - Gênero } \\
\hline Feminino & 307 & & & 0,113 & & & & & & & & & & & & 0,099 & \\
\hline Masculino & 576 & & & $\mid-0,060$ & & & & & & & & & & & & $\mid-0,053$ & \\
\hline \multicolumn{18}{|c|}{ Q3 - Escolaridade } \\
\hline $1^{\circ}$ grau completo & 41 & & & & & & & $-0,365$ & & & & 0,445 & & 0,082 & & & \\
\hline $2^{\circ}$ grau completo & 413 & & & & & & & \begin{tabular}{|c|}
$-0,065$ \\
\end{tabular} & & & & 0,032 & & 0,083 & & & \\
\hline \begin{tabular}{|l} 
Graduaçăo Completa \\
\end{tabular} & 307 & & & & & & & \begin{tabular}{|l|}
0,077 \\
0
\end{tabular} & & & & $-0,025$ & & $-0,034$ & & & \\
\hline \begin{tabular}{|l} 
Pós- graduação completa \\
\end{tabular} & 122 & & & & & & & \begin{tabular}{|l|l|}
0,149 \\
\end{tabular} & & & & $-0,196$ & & $-0,221$ & & & \\
\hline \multicolumn{18}{|c|}{ Q4 - Renda familiar } \\
\hline até $\mathrm{R} \$ 1.500,00$ & 114 & & & & & & & & & 0,016 & & 0,177 & & & & & \\
\hline $\mathrm{R} \$ 1501,00$ a $\mathrm{R} \$ 3.000,00$ & 301 & & & & & & & & & 0,083 & & 0,148 & & & & & \\
\hline $\mathrm{R} \$ 3.000,01-\mathrm{R} \$ 6.000,00$ & 287 & & & & & & & & & 0,065 & & $-0,130$ & & & & & \\
\hline$R \$ 6001,00-R \$ 10.000,00$ & 132 & & & & & & & & & $-0,189$ & & $-0,116$ & & & & & \\
\hline Acima de $\mathrm{R} \$ 10.000,00$ & 49 & & & & & & & & & \begin{tabular}{|c|}
$-0,414$ \\
\end{tabular} & & \begin{tabular}{|c|}
$-0,243$ \\
\end{tabular} & & & & & \\
\hline
\end{tabular}

Comentários: os sombreados representam (sem escala) o intervalo de confiança (5\%) da média, para os métodos Scheffe e Bonferroni. 


\subsection{Pressupostos da MEE}

O software AMOS (IBM: SPSS) ofereceu como saída o teste de normalidade das 41 variáveis exógenas e avaliou a normalidade multivariada para o modelo estrutural final. Os resultados estão apresentados abaixo (Tabela 37).

A normalidade foi avaliada pelos coeficientes de assimetria e curtose, tanto univariada quanto multivariada. Os valores de assimetria e curtose são, em valor absoluto, inferiores a 1,5, não indicando, por isso, desvios consideráveis à normalidade. Nenhuma variável apresentou valores de curtose $>10$ e assimetria $>3$, indicadores de violações severas à distribuição e todas foram inferiores ao valor crítico. Porém a curtose multivariada foi 785 , valor muito grande para assumir normalidade multivariada.

A verificação de outliers multivariados foi realizada para todos os itens da base de 883 casos pela distância de Mahalanobis. Encontraram-se apenas dois casos (15211043, 15554094) que apresentaram Zscores >3 (4,79 e 4,00 respectivamente), e caem fora da tendência das observações restantes. Podem ser valores extremos que ocorrem naturalmente, ainda que com frequência muito baixa. Portanto, não impactaram na covariância entre variáveis e não comprometeram a qualidade de ajustamento. 
Tabela 37 - Avaliaç̃o de normalidade e normalidade multivariada

\begin{tabular}{|c|c|c|c|c|c|}
\hline Variável & Assimetria & $\begin{array}{l}\text { Valor } \\
\text { Crítico } \\
\end{array}$ & Curtose & $\begin{array}{r}\text { Valor } \\
\text { crítico } \\
\end{array}$ & Resultado \\
\hline SA193 & $-0,408$ & $-4,949$ & $-0,365$ & $-2,214$ & aceita \\
\hline SA194 & $-0,378$ & $-4,591$ & $-0,454$ & $-2,753$ & aceita \\
\hline CM131 & $-1,077$ & $-13,063$ & 1,348 & 8,174 & aceita \\
\hline CM133 & $-0,474$ & $-5,752$ & $-0,278$ & $-1,685$ & aceita \\
\hline SA192 & $-1,211$ & $-14,690$ & 1,605 & 9,737 & aceita \\
\hline SA195 & $-0,807$ & $-9,795$ & 0,164 & 0,994 & aceita \\
\hline BV155 & $-0,823$ & $-9,990$ & 0,601 & 3,646 & aceita \\
\hline BV154 & $-0,968$ & $-11,739$ & 0,778 & 4,720 & aceita \\
\hline BV153 & $-0,892$ & $-10,820$ & 0,699 & 4,237 & aceita \\
\hline BV152 & $-0,991$ & $-12,027$ & 0,573 & 3,473 & aceita \\
\hline EX101 & $-1,024$ & $-12,422$ & 1,194 & 7,243 & aceita \\
\hline EX103 & $-1,292$ & $-15,669$ & 1,905 & 11,553 & aceita \\
\hline EX104 & $-1,519$ & $-18,430$ & 2,831 & 17,170 & aceita \\
\hline EX105 & $-0,721$ & $-8,751$ & 0,495 & 3,001 & aceita \\
\hline QP226 & $-0,222$ & $-2,693$ & $-0,577$ & $-3,499$ & aceita \\
\hline QP225 & $-0,277$ & $-3,359$ & $-0,571$ & $-3,461$ & aceita \\
\hline QP224 & $-0,013$ & $-0,154$ & $-0,681$ & $-4,130$ & aceita \\
\hline QP223 & 0,069 & 0,842 & $-0,667$ & $-4,046$ & aceita \\
\hline QP222 & $-0,290$ & $-3,522$ & $-0,336$ & $-2,039$ & aceita \\
\hline QP221 & $-0,139$ & $-1,688$ & $-0,796$ & $-4,826$ & aceita \\
\hline RP231 & $-0,195$ & $-2,363$ & $-0,835$ & $-5,064$ & aceita \\
\hline RP232 & $-0,235$ & $-2,854$ & $-0,681$ & $-4,131$ & aceita \\
\hline RP233 & $-0,251$ & $-3,049$ & $-0,679$ & $-4,118$ & aceita \\
\hline RP234 & $-0,045$ & $-0,546$ & $-0,756$ & $-4,585$ & aceita \\
\hline RP235 & $-0,262$ & $-3,179$ & $-0,766$ & $-4,647$ & aceita \\
\hline RP236 & $-0,053$ & $-0,645$ & $-0,734$ & $-4,455$ & aceita \\
\hline AV251 & $-0,038$ & $-0,462$ & $-0,663$ & $-4,024$ & aceita \\
\hline AV252 & $-0,365$ & $-4,429$ & $-0,509$ & $-3,088$ & aceita \\
\hline AV253 & $-0,488$ & $-5,925$ & $-0,343$ & $-2,080$ & aceita \\
\hline AV254 & $-0,203$ & $-2,468$ & $-0,561$ & $-3,401$ & aceita \\
\hline AV255 & 0,009 & 0,108 & $-0,676$ & $-4,100$ & aceita \\
\hline AE124 & $-0,876$ & $-10,624$ & 0,756 & 4,586 & aceita \\
\hline AE123 & $-0,943$ & $-11,445$ & 0,967 & 5,865 & aceita \\
\hline AE122 & $-0,981$ & $-11,900$ & 1,091 & 6,620 & aceita \\
\hline AE121 & $-1,056$ & $-12,810$ & 1,380 & 8,368 & aceita \\
\hline RF164 & $-0,293$ & $-3,559$ & $-0,184$ & $-1,117$ & aceita \\
\hline RF161 & $-0,630$ & $-7,646$ & 0,173 & 1,047 & aceita \\
\hline FR264 & $-0,511$ & $-6,202$ & 0,515 & 3,126 & aceita \\
\hline FR263 & $-0,490$ & $-5,945$ & 0,454 & 2,754 & aceita \\
\hline FR262 & $-0,297$ & $-3,602$ & 0,387 & 2,345 & aceita \\
\hline FR261 & $-0,377$ & $-4,579$ & 0,308 & 1,866 & aceita \\
\hline Multivariada & & & 785,602 & 196,568 & rejeita \\
\hline
\end{tabular}




\subsection{Unidimensionalidade, Confiabilidade e Validade.}

A unidimensionalidade foi apresentada anteriormente nas análises das dimensões individuais, primeiro pela análise fatorial exploratória e depois, pela análise fatorial confirmatória, com a amostra de 883 casos. A confiabilidade foi medida pela confiabilidade composta e a validade convergente foi medida pela análise da variância extraída média (Quadro 48). Também se realizou a análise de resíduos padronizados. A análise de resíduos padronizados obteve-se pela matriz de covariância, segundo o método da distribuição assimptótica livre (ADF) para o software Amos (IBM: SPSS). Os resultados evidenciam que os fatores, que já haviam sofrido algum ajustamento pelo índice de modificação, apresentaram resultados abaixo de 2.0 na análise de resíduos (Quadro 48).

Em geral a confiabilidade composta obteve resultados acima de $\geq 0,70$ exceto para dois construtos: Baixo custo de mudança $(C M M=0,687)$ e Retenção na firma $(\mathrm{RF}=0,623)$. Bagozzi e $\mathrm{Yi}$ (2012) comentam que em modelos complexos cargas baixas para a confiabilidade individual $(\geq 0,50)$ são aceitas desde que os índices de qualidade de ajustamento sejam bons. $O$ construto retenção na firma (RF) foi importante para o modelo proposto e, o mesmo, apresentou bom ajustamento como fator e depois dentro do modelo estrutural.

Quanto à validade convergente, obteve-se para o construto retenção na firma (RF), um resultado de $\mathrm{VEM}_{\mathrm{RF}}=0,476$, ou seja, demonstrando que a variância extraída média dos indicadores encontra-se em nível de saturação abaixo do recomendado (VEM $\leq 0,50$ ). Bollen (1989) flexibiliza para limites $\geq 0,44$.

Em seguida, partiu-se para a validade discriminante que foi analisada pela orientação de Marôco (2010), conforme descrito no capítulo sobre o método. O teste da diferença dos $\mathrm{X}^{2}$ foi realizado entre os modelos estruturais no passo $\mathrm{P} 10 \mathrm{com}$ dez construtos na sua forma saturada e livre. Os resultados obtidos com os $X^{2}$ críticos, mostram evidências de que as diferenças de qui-quadrados rejeitam a hipótese nula, de igualdade entre os qui-quadrados dos modelos P10 saturado e P10 livre, constatando validade discriminante (Tabela 38). 
Tabela 38 - Diferenças de Qui-quadrado entre modelo estrutural P10 saturado e livre

\begin{tabular}{cccc}
\hline Modelo & P10 Saturado & P10 & $\neq$ P10 \\
\hline \hline $\mathbf{X}^{\mathbf{2}}$ & 2453,208 & 2120,721 & 332,487 \\
$\mathbf{g l}$ & 743 & 736 & 7 \\
$\mathbf{X}^{\mathbf{2}}$ crítico & & & rejeita H国, <1\% \\
\hline \multicolumn{2}{c}{ Legenda: Valor do $\mathrm{X}^{2}$ crítico foi calculado para $\alpha=0,01}$.
\end{tabular}

Em seguida tratou-se da verificação de correlações entre variáveis latentes no modelo estrutural final (P10), após obtenção de bom ajustamento, comparando-se com o resultado das variâncias extraídas médias (VEM). O output do software AMOS (IBM: SPSS), diferente do LISREL, não oferece uma saída de correlações entre variáveis exógenas e endógenas, portanto a verificação, segundo o método de Fornell e Larcker (1981), foi feita apenas para a correlação entre as variáveis exógenas, as que realmente interessam para esta análise (MARÔCO, 2010) (Tabela $39)$. 
Quadro 48 - Confiabilidade composta, Variância Extraída, análise de resíduos padronizados.

\begin{tabular}{|c|c|c|c|c|c|c|}
\hline CONSTRUTO & & HIPÓTESE & FATOR & $\begin{array}{c}\text { Confiabilidade } \\
\text { Composta }\end{array}$ & $\begin{array}{c}\text { Variância } \\
\text { extraída }\end{array}$ & $\begin{array}{l}\text { Análise dos } \\
\text { resíduos } \\
\text { padronizados }\end{array}$ \\
\hline AFINIDADE TECNOLÓGICA & \multirow{7}{*}{ EFEITO PUSH } & H3 & FA_AT & 0,930 & 0,772 & 0,256 \\
\hline EXPERIÊNCIA INTERNET & & $\mathrm{H} 2$ & FA_EX & 0,908 & 0,716 & 0,377 \\
\hline EXPERIÊNCIA VICÁRIA & & $\mathrm{H} 4$ & FA_EV & 0,927 & 0,809 & 0,000 \\
\hline SATISFAÇÃO FREE-RIDING & & H11a & FA_SA_FR & 0,820 & 0,607 & 0,000 \\
\hline CONFIANÇA ON-LINE & & $\mathrm{H} 12 \mathrm{a}$ & FA_CF_OL & 0,820 & 0,607 & 0,000 \\
\hline LEALDADE & & $\mathrm{H} 13$ & FA_LE/LD & 0,939 & 0,796 & 0,232 \\
\hline AUTOEFICÁCIA MULTICANAL & & $\mathrm{H} 1$ & FA_AE & 0,959 & 0,855 & 0,364 \\
\hline Baixo CUSTO DE MUDANÇA - FAVORÁVEL MUDANÇA & \multirow{7}{*}{ 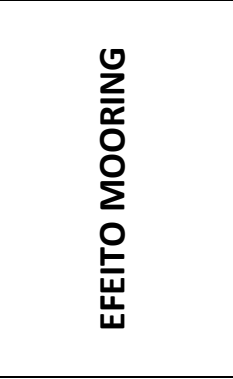 } & $\mathrm{H} 7 \mathrm{~b}$ & FA_CMM & 0,687 & 0,533 & 0,000 \\
\hline Alto CUSTO DE MUDANÇA - RESISTENTE & & $\mathrm{H7a}$ & FA_CMR & 0,846 & 0,734 & 0,000 \\
\hline INTEGRAÇÃO PERCEBIDA & & $\mathrm{H} 8$ & FA_IN & 0,902 & 0,711 & 0,023 \\
\hline BUSCA DE VARIEDADE & & $\mathrm{H} 6$ & FA_BV & 0,885 & 0,660 & 0,568 \\
\hline RETENÇÃO NA FIRMA & & $\mathrm{H} 5$ & FA_RF & 0,623 & 0,476 & 0,000 \\
\hline CONVENIENCIA ON LINE & & $\mathrm{H9a}$ & FA_CO_OL & 0,942 & 0,844 & 0,000 \\
\hline DESIGN SITE & & $\mathrm{H} 10$ & FA_DS & 0,829 & 0,554 & 0,000 \\
\hline SATISFAÇÃO LOJA FISICA & \multirow{7}{*}{ EFEITO PULL } & $\mathrm{H} 11 \mathrm{~b}$ & FA_SA_LF & 0,972 & 0,947 & 0,000 \\
\hline CONFIANÇA LOJA FISICA & & $\mathrm{H} 12 \mathrm{~b}$ & FA_CF_LF & 0,952 & 0,908 & 0,000 \\
\hline CONVENIENCIA LOJA FISICA & & $\mathrm{H} 9 \mathrm{~b}$ & FA_CO_LF & 0,758 & 0,514 & 0,000 \\
\hline QUALIDADE PERCEBIDA & & $\mathrm{H} 16$ & FA_QP & 0,952 & 0,770 & 0,383 \\
\hline RISCO PERCEBIDO & & $\mathrm{H} 15$ & FA_RP & 0,958 & 0,794 & 0,397 \\
\hline BARGANHA & & $\mathrm{H} 17$ & FA_BA & 0,948 & 0,786 & 0,396 \\
\hline ATRATIVIDADE VAREJO & & $\mathrm{H} 14$ & FA_AV & 0,948 & 0,786 & 0,766 \\
\hline FREE-RIDING & & & FA_FR & 0,905 & 0,713 & 0,084 \\
\hline
\end{tabular}

Fonte: calculados pelo próprio autor 
Os resultados para o modelo estrutural final (Tabela 39) evidenciam que os fatores latentes apresentaram validade discriminante quando a variância extraída média (VEM) de cada fator latente é maior ao ser comparada com o quadrado da correlação entre fatores.

\begin{tabular}{|c|c|c|c|c|c|c|c|c|c|c|}
\hline & $\mathrm{AE}$ & EX & SA_FR & $\mathbf{R F}$ & BV & CMR & AV & $\mathbf{R P}$ & QP & SA_LF \\
\hline $\mathrm{AE}$ & 0,772 & & & & & & & & & \\
\hline EX & 0 & 0,716 & & & & & & & & \\
\hline SA_FR & 0 & 0,2228 & 0,607 & & & & & & & \\
\hline RF & 0 & 0 & 0 & 0,476 & & & & & & \\
\hline BV & 0 & 0,1772 & 0,461 & 0 & 0,660 & & & & & \\
\hline CMR & 0 & 0,1296 & 0,3329 & 0 & 0,2107 & 0,734 & & & & \\
\hline AV & 0 & 0 & 0 & 0 & 0 & 0 & 0,786 & & & \\
\hline $\mathbf{R P}$ & 0 & 0,0835 & 0,0144 & 0 & 0,0009 & 0,0003 & 0 & 0,794 & & \\
\hline QP & 0 & 0,005 & 0,0002 & 0 & 0,0164 & 0,0026 & 0 & 0,126 & 0,770 & \\
\hline SA_LF & 0 & 0,2601 & 0,0262 & 0 & 0,0059 & 0,0137 & 0 & 0,149 & 0,156 & 0,947 \\
\hline
\end{tabular}

O software AMOS (IBM: SPSS) não disponibiliza matriz de correlação entre variáveis exógenas e endógenas, portanto a análise adicional sugerida pela revisão de Grewal, Cote e Baumgartner (2004) foi realizada apenas para variáveis exógenas. Cabe ressaltar que ao se analisar as correlações entre variáveis exógenas do modelo estrutural final P10 (Tabela 40), verifica-se uma forte correlação entre as variáveis BV e SA_FR com valor igual a 0,679 e entre SA_FR e CMR, com valor de correlação 0,577 . Porém, a confiabilidade composta para o fator BV é 0,885 , para SA_FR é 0,820 e CMR é 0,846 , indicando que há boa consistência interna nos fatores e que a presença de erros tipo II não é substancial. 
Tabela 40 - Correlações entre variáveis exógenas do modelo P10

\begin{tabular}{|c|c|c|c|c|c|c|c|c|c|c|}
\hline & $\mathrm{AE}$ & EX & SA_FR & $\mathbf{R F}$ & BV & CMR & AV & $\mathbf{R P}$ & QP & SA_LF \\
\hline $\mathrm{AE}$ & 1 & & & & & & & & & \\
\hline EX & & 1 & & & & & & & & \\
\hline SA_FR & & 0,472 & 1 & & & & & & & \\
\hline RF & & & & 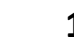 & & & & & & \\
\hline BV & & 0,421 & 0,679 & & 1 & & & & & \\
\hline CMR & & 0,360 & 0,577 & & 0,459 & 1 & & & & \\
\hline AV & & & & & & & 1 & & & \\
\hline RP & & $-0,289$ & $-0,120$ & & $-0,030$ & 0,017 & & 1 & & \\
\hline QP & & $-0,071$ & 0,013 & & 0,128 & 0,051 & & 0,355 & 1 & \\
\hline SA_LF & & $-0,510$ & 0,162 & & 0,077 & 0,117 & & 0,386 & 0,395 & 1 \\
\hline
\end{tabular}

\subsection{Validação do modelo proposto}

Após a análise confirmatória dos construtos individuais seguiu-se com 0 procedimento para validação do modelo teórico, pois inicialmente eram 17 hipóteses com 18 construtos e após a identificação dos fatores, foram gerados novos fatores, sendo o total de 22 construtos. O novo modelo foi desenhado a partir dos resultados dos construtos da análise confirmatória seguido de MEE pelo método da máxima verossimilhança no software Amos (versão 21, IBM:SPSS). Aplicou-se 0 procedimento de índices de qualidade de ajustamento ${ }^{42}$.

Para facilitar o entendimento do procedimento de ajuste conforme recomendação pelos índices de modificação (IM) do Amos foram criados passos (P) durante o ajustamento do modelo (Tabela 41). Seguindo o procedimento indicado por Marôco (2010), no Passo 1 (P1) foram retirados os construtos lealdade (LE ou LD) do efeito push - autoeficácia (AE) e design do site (DS) do efeito mooring retenção da firma (RF) que apresentaram insignificância do valor $p$, com $p>0,05 \%$. Em seguida, foram inseridas covariâncias pela ordem decrescente de valores pelos índices de modificação (IM), avaliando-se a inserção das covariâncias, segundo a revisão de literatura. Este procedimento foi realizado em cinco rodadas até não se obter melhor

\footnotetext{
${ }^{42}$ Realizado conjuntamente com o Prof. Dr. Leandro Prearo (USCS) em 19/03/2014.
} 
resultado nos índices de qualidade. Ao final, observou-se que GFI e AGFI ainda encontraram-se muito baixos ( $G F I=0,795$ e $A G F I=0,777)$. Em seguida partiu-se para o P2, com a retirada do construto afinidade tecnológica $(A E \leftarrow A T)$, devido a sua estimativa apresentar o menor beta $(b=0,044)$. Subiram os valores de GFI $(0,800)$ e AGFI $(0,781)$. Não houve necessidade de inserção de novas covariâncias e na ausência de possibilidades de ajustes, partiu-se para $\mathrm{P} 3 \mathrm{com}$ a retirada de mais um construto, confiança on-line $\left(\mathrm{AE} \leftarrow \mathrm{CF} \_\mathrm{OL}\right)$ que apresentou carga padronizada mais frágil (no output do AMOS está como o beta padronizado) $(C P=-0,16)$. 
Tabela 41 - Resultados do procedimento de ajustamento do modelo

\begin{tabular}{|c|c|c|c|c|c|c|c|c|c|}
\hline Validação do modelo & $\mathrm{X}^{2}$ & $g l$ & $X^{2} / g l$ & $\mathrm{p}$ & GFI & AGFI & $\mathrm{CFI}$ & $\mathrm{TLI}$ & RMSEA \\
\hline Geral com 22 fatores & 11248,387 & 2888 & 3,895 & $<0,01$ & 0,671 & 0 & (0,824 & 0,817 & 0,057 \\
\hline P1 sem DS e LD & 9243,355 & 2311 & 4,000 & $<0,01$ & 0,701 & 0,679 & 0,840 & 0,833 & 0,058 \\
\hline ajustes covariância & 7934,391 & 2304 & 3,444 & $<0,01$ & 0,755 & 0,736 & 0,870 & 0,864 & 0,053 \\
\hline ajustes covariância & 7464,841 & 2298 & 3,248 & $<0,01$ & 0,774 & 0,756 & 0,881 & 0,875 & 0,050 \\
\hline ajustes covariância & 7189,392 & 2291 & 3,138 & $<0,01$ & 0,786 & 0,767 & 0,887 & 0,881 & 0,049 \\
\hline ajustes covariância & 7087,081 & 2288 & 3,098 & $<0,01$ & 0,790 & 0,772 & 0,889 & 0,883 & 0,049 \\
\hline ajustes covariância & 6939,035 & 2285 & 3,037 & $<0,01$ & 0,795 & 0,777 & 0,893 & 0,886 & 0,048 \\
\hline P2 sem AT & 6392,521 & 2024 & 3,158 & $<0,01$ & 0,800 & 0,781 & 0,893 & 0,886 & 0,049 \\
\hline P3 sem CF_OL & 5632,124 & 1840 & 3,061 & $<0,01$ & 0,818 & 0,801 & 0,903 & 0,897 & 0,048 \\
\hline ajustes covariância & 5548,422 & 1838 & 3,019 & $<0,01$ & 0,822 & 0,804 & 0,905 & 0,900 & 0,048 \\
\hline P4 sem IN e com CMM & 5139,281 & 1603 & 3,206 & $<0,01$ & 0,825 & 0,807 & 0,904 & 0,897 & 0,050 \\
\hline P4 sem CMM e com IN & 5189,643 & 1718 & 3,021 & $<0,01$ & 0,828 & 0,811 & 0,910 & 0,904 & 0,048 \\
\hline P5 sem IN e sem CMM & 4766,723 & 1490 & 3,199 & $<0,01$ & 0,832 & 0,814 & 0,909 & 0,903 & 0,050 \\
\hline P6 sem CF_LF & 4514,812 & 1384 & 3,266 & $<0,01$ & 0,834 & 0,815 & 0,910 & 0,903 & 0,051 \\
\hline ajustes covariância & 4455,896 & 1382 & 3,224 & $<0,01$ & 0,836 & 0,817 & 0,911 & 0,905 & 0,050 \\
\hline ajustes covariância & 4229,279 & 1378 & 3,069 & $<0,01$ & 0,843 & 0,824 & 0,918 & 0,911 & 0,048 \\
\hline ajustes covariância & 4047,230 & 1352 & 2,950 & $<0,01$ & 0,848 & 0,830 & 0,923 & 0,916 & 0,047 \\
\hline P7 sem BA & 3280,732 & 1126 & 2,914 & $<0,01$ & 0,866 & 0,848 & 0,930 & 0,924 & 0,047 \\
\hline ajustes covariância & 3149,540 & 1118 & 2,817 & $<0,01$ & 0,872 & 0,854 & 0,934 & 0,928 & 0,045 \\
\hline P8 S/ EV & 2832,221 & 977 & 2,899 & $<0,01$ & 0,878 & 0,859 & 0,936 & 0,929 & 0,046 \\
\hline P9 S/CO_LF & 2305,916 & 853 & 2,703 & $<0,01$ & 0,892 & 0,874 & 0,948 & 0,942 & 0,044 \\
\hline P10 S/ CO_OL & 2120,721 & 736 & 2,881 & $<0,01$ & 0,894 & 0,876 & 0,946 & 0,940 & 0,046 \\
\hline P11 S/ QP E COM SA_LF & 1610,394 & 529 & 3,044 & $<0,01$ & 0,904 & 0,885 & 0,948 & 0,941 & 0,048 \\
\hline P12 S/ SA_LF E COM QP & 1837,048 & 665 & 2,762 & $<0,01$ & 0,901 & 0,884 & 0,951 & 0,945 & 0,045 \\
\hline P11 S/ QP E COM SA_LF ajustes covariância & 1610,394 & 529 & 3,044 & $<0,01$ & 0,904 & 0,885 & 0,948 & 0,941 & 0,048 \\
\hline
\end{tabular}

Legenda: P1, P2, P3 etc. representam os passos (P) do procedimento durante a análise e seus resultados nos índices de qualidade de ajustamento. 
Em seguida houve ajustes de covariância que elevaram mais um pouco o GFI (0,822, aceitável) e o AGFI (0,804, muito bom), sendo os demais índices com ajustamento muito bom. O P4 foi realizado em duas sequências de retiradas. O construto integração percebida (RF < - - IN) apresentou beta mais frágil $(b=0,69)$ e o construto baixo custo de mudança (RF < - - - CMM) apresentou em seguida a segunda opção de beta mais frágil $(b=-0,0103)$. Primeiro retirou-se IN e manteve-se CMM. Na sequência, retirou-se primeiro CMM e manteve-se IN. Os resultados de ajustamento melhoraram pouco os índices de qualidade, principalmente GFI e AGFI, então se partiu para o P5, retirando-se os dois construtos, obtendo-se GFI $(0,831$, aceitável) e AGFI (0,813, muito bom) e demais índices já estavam com ajustamento muito bom.

Em seguida, no P6 retirou-se o construto confiança loja física ( $\left.A V \leftarrow C F \_L F\right)$ que apresentou o beta mais frágil $(b=0,106)$ e foram feitas três rodadas de ajustes de covariância, resultando no GFI (0,848, aceitável) e AGFI (0,830, muito bom). Não havendo melhor qualidade, partiu-se para o $\mathrm{P} 7 \mathrm{com}$ a retirada do construto efeito barganha $(A V \leftarrow B A)$ que apresentou o beta mais frágil $(b=0,144)$. Em seguida foram feitos ajustes de covariância, obtendo-se ainda um GFI baixo (0,872, aceitável). Partiu-se para o P8, sem o construto experiência vicária $(A E \leftarrow E V)$, que apresentou o beta mais frágil $(b=0,211)$. Em seguida, partiu-se para o $P 9$, com a retirada do construto conveniência loja física $\left(A V \leftarrow C O \_L F\right)$, que apresentou o beta mais frágil $(b=0,215)$, resultando ainda num $\operatorname{GFI}$ baixo $(0,892$, aceitável). $\mathrm{O}$ próximo passo, $\mathrm{P} 10$ retirou o construto conveniência on-line $\left(\mathrm{RF} \leftarrow \mathrm{CO} \_\mathrm{OL}\right)$ que apresentou o beta mais frágil ( $b=0,299)$, porém ainda numa qualidade de ajustamento aceitável para o GFI $(0,894$, aceitável). O P11 foi realizado em dois estágios. Primeiramente se retirou 0 construto qualidade percebida ( $A V \leftarrow Q P$, com $b=0,374)$ e manteve-se a satisfação loja física ( $A V \leftarrow S A \_L F$; com $b=0,368$ ) e em seguida se inverteu a ordem de retirada dos construtos com o P12, mantendo-se QP e retirando SA_LF, conforme a Tabela 41. Optou-se ${ }^{43}$ pelo modelo estrutural resultante do passo P10 (Figura 34, Tabela 42).

\footnotetext{
${ }^{43}$ Reunião com Prof. Mazzon dia 7/04/14.
} 


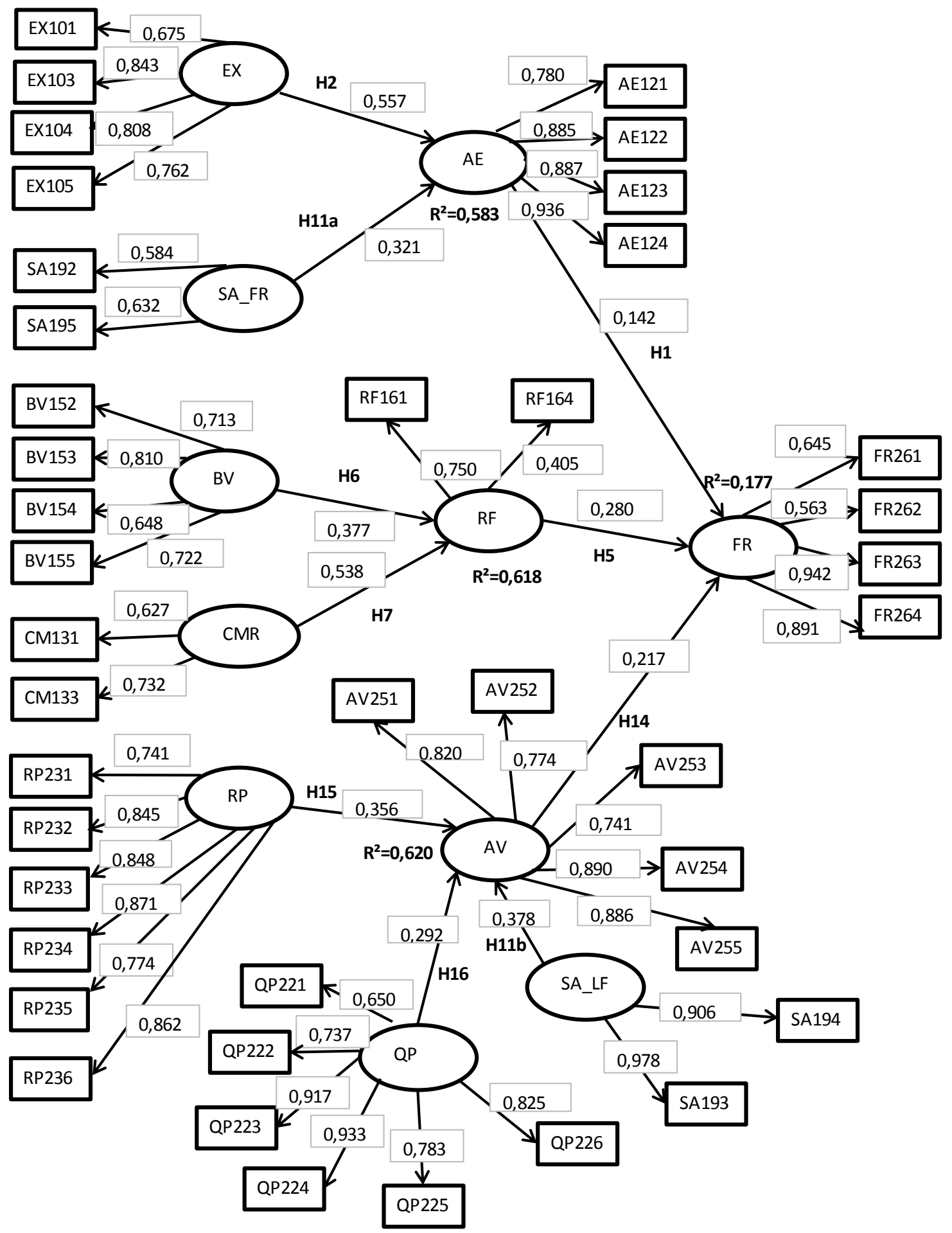

Figura 34 - Modelo Estrutural final (P10)

Fonte - o próprio autor

Tabela 42 - Qualidade de ajustamento do modelo estrutural P10

\begin{tabular}{lccccccccc}
\hline Validação do modelo & $X^{2}$ & $g l$ & $X^{2} / g l$ & $p$ & GFI & AGFI & CFI & TLI & RMSEA \\
\hline \hline P10 & 2120,721 & 736 & 2,881 & $<0,01$ & 0,894 & 0,876 & 0,946 & 0,940 & 0,046 \\
\hline
\end{tabular}

O modelo estrutural P10 é apresentado com suas cargas padronizadas. Observouse que o efeito mooring retenção na firma, diferente dos resultados de Chiu et al. 
(2010) apresentou sinal positivo, ou seja, o efeito mooring contribuiu para a intenção de free-riding. $O$ construto foi composto por quatro afirmações e apenas duas dela formaram fator: "eu não tenho problema em mudar entre os canais de vendas varejistas", "não há dificuldades técnicas associadas com a troca entre canais de vendas de varejistas". Por sua vez, foram rejeitas: "eu não gosto de mudar para o canal de venda de outro varejista depois de eu ter gasto algum tempo com a pesquisa on-line no site do varejista"; "eu teria feito a troca entre lojas e canais de vendas varejistas, se eu pudesse fazer isso sem aborrecimento". Sugere que apesar de o consumidor aderir ao free-riding entre canais e entre varejistas, ele pode estar retido em varejistas de sua preferência, fenômeno a ser capturado por outras variáveis latentes.

As variáveis endógenas apresentaram o seguinte poder de explicação da variância pelos seus antecedentes $\left(R^{2}\right)$ : autoeficácia $(0,583)$, retenção na firma $(0,618)$, atratividade do varejo tradicional $(0,620)$ e free-riding $(0,177)$. Em seguida obtiveramse os parâmetros estimados para cada relação do modelo estrutural final P10 com suas cargas fatoriais padronizadas, seus respectivos valores $t$ crítico e erros estimados padrão, bem como a verificação de aceitação/rejeição das hipóteses do estudo (Tabela 43). 
Tabela 43 - Teste de hipóteses para o modelo estrutural final P10

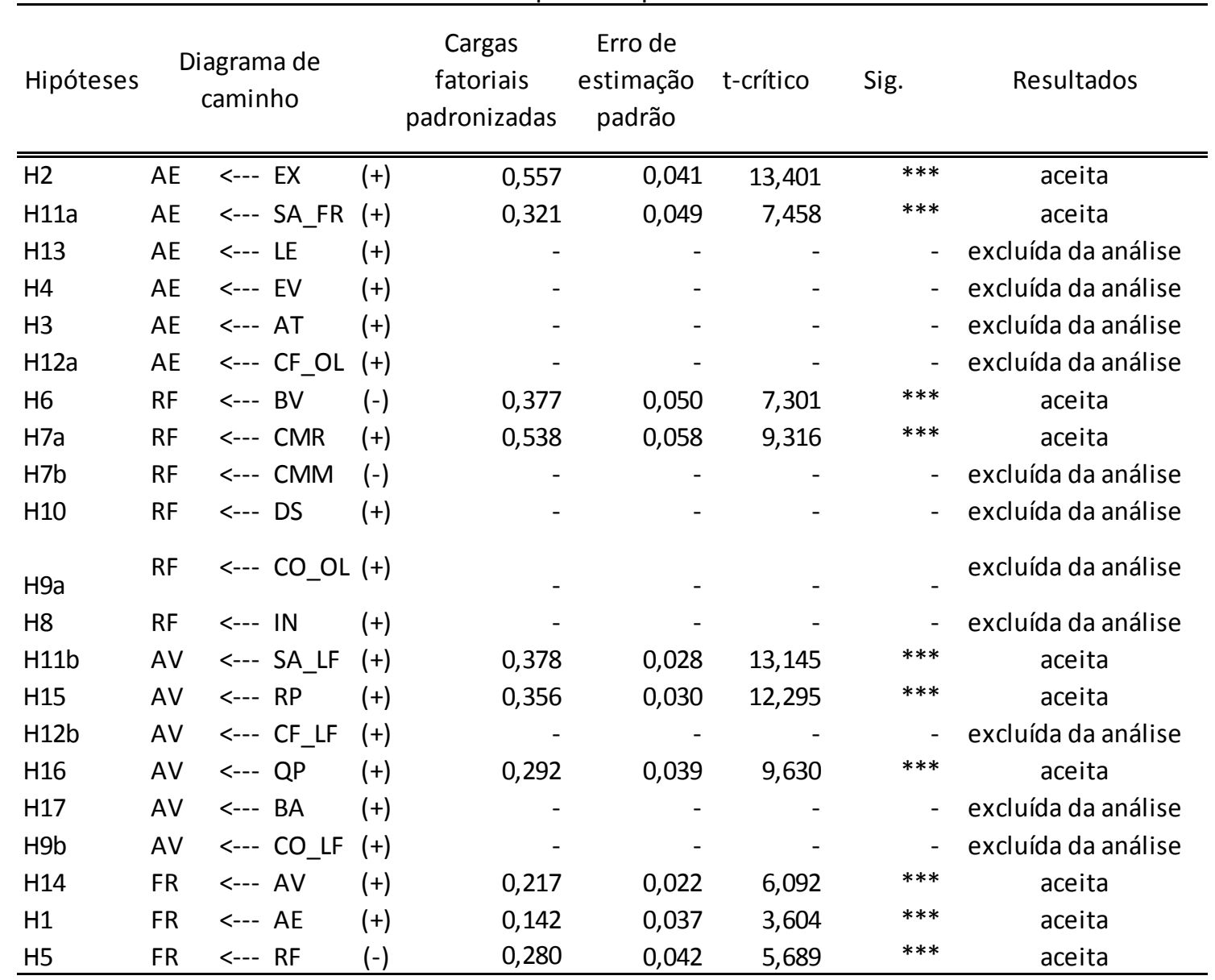

Legenda: níveis de significância: ${ }^{* * *}: 1 \%$.

\subsection{Mediação}

Foram realizadas as análises para investigar o efeito de mediação segundo Baron e Kenny (1986) e Hair et al. (2009). A qualidade de ajustamento do modelo estrutural, pela mediação completa (full) não ofereceu um melhor ajustamento do que o modelo hipotetizado (Tabela 44). Se os dois modelos produzem ajustes semelhantes, então há suporte para mediação, segundo Hair et al. (2009). 
Tabela 44 - Qualidade de ajustamento para efeitos de mediação

\begin{tabular}{lccccccccc}
\hline Qualidade de ajustamento & $\mathrm{X}^{2}$ & $\mathrm{gl}$ & $\mathrm{X}^{2} / g l$ & $\mathrm{p}$ & $\mathrm{GFI}$ & AGFI & CFI & TLI & RMSEA \\
\hline \hline P10 & 2120,721 & 736 & 2,881 & $<0,01$ & 0,894 & 0,876 & 0,946 & 0,940 & 0,046 \\
P10 FULL & 2048,223 & 729 & 2,810 & $<0,01$ & 0,899 & 0,880 & 0,949 & 0,942 & 0,045 \\
P10 direto & 3594,781 & 737 & 4,878 & $<0,01$ & 0,840 & 0,813 & 0,889 & 0,877 & 0,066
\end{tabular}

São quatro condições necessárias para atender à exigência de mediação, conforme Baron e Kenny (1986) e Hair at al (2009): (1) - as variáveis independentes afetam as variáveis mediadoras; (2) - os mediadores afetam as variáveis dependentes. 0 modelo proposto (p10) atende a essas duas condições. No modelo proposto P10 todos os caminhos são significantes e os resultados confirmam as duas condições (Tabela 45). Em seguida, (3) - as variáveis independentes afetam diretamente a variável dependente, pelo modelo direto. No modelo direto encontramos três diagramas de caminho que não atendem a esta condição: experiência previa com internet $(E X)$, alto custo de mudança $(C M R)$ e qualidade percebida (QP) (Tabela $45)^{44}$. Portanto, como exceção, apenas estas variáveis independentes não afetam diretamente a variável dependente e não são significativas. As demais são significativas $(p<0,05)$ e satisfazem ao efeito de mediação.

Finalmente, como condição (4), a mediação existe se os diagramas de caminho diretos das variáveis independentes se tornam insignificantes ou reduzidos (mediação parcial) no modelo full. Nota-se que houve insignificância para o diagrama FR <- AE no modelo full, não confirmando o efeito mediador de $A E$ (autoeficácia). A carga padronizada para este diagrama de caminho, já se apresentava baixa (há mais variância do erro do que variância explicada). $A$ análise da tabela evidencia que houve redução, suportando a mediação parcial para apenas FR $\leftarrow R P(0,113)$, quando se compara os dados em módulo e sendo significativo.

\footnotetext{
${ }^{44}$ Elaboração de dados conjunta com Prof. Leandro Prearo em 18/04/2014
} 
Tabela 45 - Análise de mediação para o modelo estrutural P10

\begin{tabular}{|c|c|c|c|c|c|c|c|c|c|}
\hline \multirow{2}{*}{$\begin{array}{c}\text { Hipóteses } \\
\text { H2 }\end{array}$} & \multicolumn{3}{|c|}{$\begin{array}{l}\text { Diagrama de } \\
\text { caminho }\end{array}$} & \multirow{2}{*}{$\begin{array}{c}\text { Modelo } \\
\text { P10 }\end{array}$} & \multirow{2}{*}{ 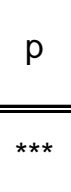 } & \multirow[t]{2}{*}{$\begin{array}{c}\text { Modelo } \\
\text { Direto }\end{array}$} & \multirow[t]{2}{*}{$p$} & \multirow{2}{*}{$\begin{array}{c}\text { Modelo } \\
\text { Full } \\
0,560\end{array}$} & \multirow{2}{*}{ p } \\
\hline & $A E$ & $<---$ & EX & & & & & & \\
\hline $\mathrm{H} 11 \mathrm{a}$ & $\mathrm{AE}$ & $<---$ & SA_FR & 0,321 & $* * *$ & & & 0,317 & $\star \star \star *$ \\
\hline $\mathrm{H} 6$ & RF & $<---$ & BV & 0,377 & $\star * \star *$ & & & 0,366 & $* * *$ \\
\hline $\mathrm{H} 7 \mathrm{a}$ & $\mathrm{RF}$ & $<---$ & CMR & 0,538 & 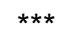 & & & 0,528 & $* \star *$ \\
\hline $\mathrm{H} 11 \mathrm{~b}$ & AV & $<---$ & SA_LF & 0,378 & $\star * *$ & & & 0,377 & $* \star *$ \\
\hline $\mathrm{H} 15$ & AV & $<---$ & $\mathrm{RP}$ & 0,356 & $* * *$ & & & 0,356 & $\star \star \star *$ \\
\hline $\mathrm{H} 16$ & AV & $<---$ & QP & 0,292 & $\star \star * \star$ & & & 0,293 & $* * *$ \\
\hline $\mathrm{H} 14$ & FR & $<---$ & AV & 0,217 & $* \star *$ & 0,170 & $* * *$ & 0,184 & $* \star *$ \\
\hline $\mathrm{H} 1$ & $\mathrm{FR}$ & $<---$ & $\mathrm{AE}$ & 0,142 & $* * *$ & 0,107 & $* * *$ & $-0,037$ & - \\
\hline \multirow[t]{8}{*}{$\mathrm{H} 5$} & FR & $<---$ & $\mathrm{RF}$ & 0,280 & $* \star *$ & 0,210 & $* * *$ & 0,232 & ** \\
\hline & FR & $<---$ & EX & & & $-0,096$ & - & $-0,019$ & - \\
\hline & $\mathrm{FR}$ & $<---$ & SA_FR & & & 0,651 & $* * *$ & 0,783 & $\star \star \star *$ \\
\hline & $\mathrm{FR}$ & $<---$ & BV & & & $-0,18$ & $* * *$ & $-0,300$ & $* * *$ \\
\hline & $\mathrm{FR}$ & $<---$ & CMR & & & $-0,072$ & - & $-0,205$ & $\star \star *$ \\
\hline & FR & $<---$ & $\mathrm{RP}$ & & & 0,121 & $* * *$ & 0,113 & ** \\
\hline & FR & $<---$ & $\mathrm{QP}$ & & & 0,074 & - & 0,072 & - \\
\hline & $\mathrm{FR}$ & $<---$ & SA_LF & & & $-0,092$ & ** & $-0,115$ & ** \\
\hline
\end{tabular}

Legenda: $A E$ - autoeficácia multicanal, AV - atratividade do varejo, BV - busca de variedade, CMR alto custo de mudança, EX - experiência previa com internet, QP- qualidade percebida, RF- retenção na firma, RP - risco percebido, SA_LF - satisfação loja física, SA_FR- satisfação em free-riding, níveis de significância: ${ }^{* \star}: 5 \% ;{ }^{* * *}: 1 \%$

Finalmente, pelo procedimento de Hair et al. (2009) e Baron e Kenny (1986) o efeito mediador não está confirmado para: 1- autoeficácia ( $A E)$, sendo a hipótese H1 não confirmada; 2- retenção na firma (RF), sendo a H5 também não confirmada. O efeito mediador está confirmado apenas para atratividade do varejo (AV) em relação a risco percebido, H15 (Figura 35).

O conceito de efeito direto é claro estatisticamente e não é claro teoricamente. Às vezes existem razões teóricas para se esperar efeito direto (ZHAO; LYNCH JR.; CHEN, 2010). Os resultados da mediação no modelo direto para as variáveis: experiência previa com internet (EX), qualidade percebida (QP) e alto custo de mudança (CMR), podem ser explicados estatisticamente, porém talvez não possam ser explicados teoricamente. 


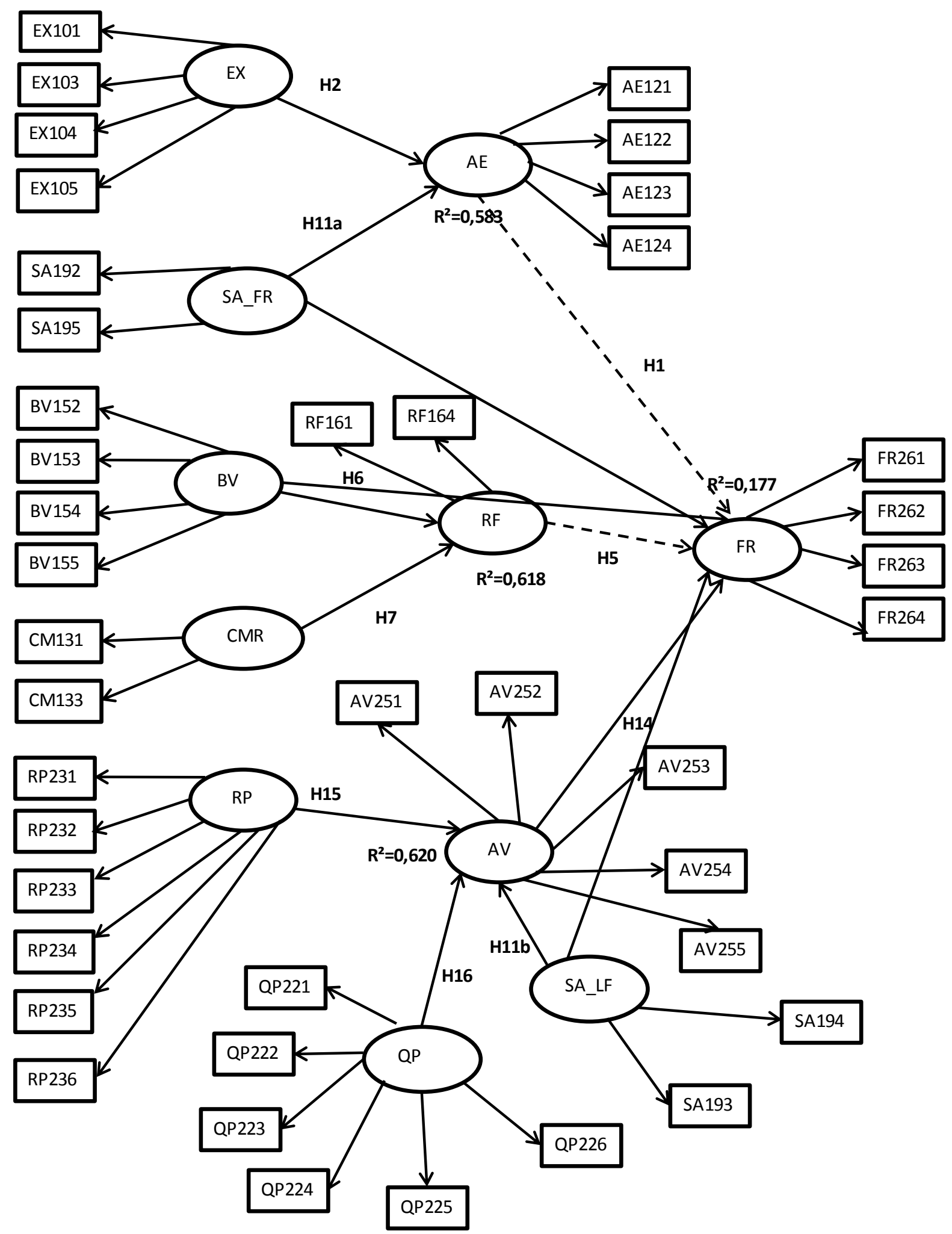

Figura 35 - Desenho do modelo final P10 após mediação Fonte: elaborado pelo autor

O alto custo de mudança (CMR) não teria relação direta com intenção de free-riding, bem como a qualidade percebida (QP - atendimento dentro da loja) também não 
teria relação com intenção de free-riding. Ambas expressam percepções de consumidores que não estão abertos ao free-riding entre varejistas o que reforça ainda ser muito forte o vínculo do consumidor ao atendimento dentro da loja. O custo de esforço e tempo para mudança de varejista (CMR) está provavelmente relacionado com preferências do consumidor por varejistas. As variáveis SA_FR, SA_LF e BV possuem mais força diretamente com intenção de free-riding.

\subsection{Moderação}

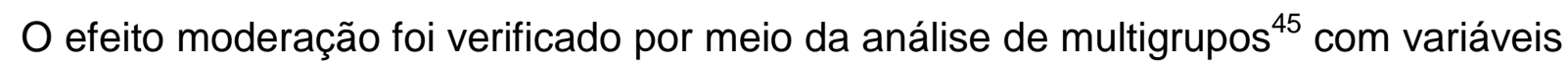
de perfil e outras variáveis categóricas, as mesmas utilizadas para comparação de médias dos fatores pela ANOVA: Q1-idade, Q2-gênero, Q3-escolaridade, Q4-renda. Além das variáveis de perfil, foram utilizadas as questões: P4- "ao buscar informação, quantas lojas físicas elou on-line visitou?"; P6- "ao comprar efetivamente o produto, quantas lojas on-line e/ou física visitou?"; P7- "o que melhor representa o seu hábito de compra?"; P8.1 - "hábito de compra busca on-line e compra efetiva em loja física"; P8.2 - "hábito de compra busca em loja física e compra efetiva em loja on-line".

Para facilitar à visualização do modelo Push-Pull-Mooring, as análises foram discriminadas por efeito push (habilidade de autoeficácia multicanal para sair do destino on-line), efeito mooring (contexto que ancora o consumidor no mesmo varejista) e efeito pull (fatores que atraem o consumidor para o varejo tradicional).

\subsubsection{Moderação por Idade (Q1)}

Idade apresentou poder de moderação, conforme resultados demonstrados na Tabela 46. Há diferenças significativas entre o modelo restrito e livre, com $\mathrm{X}_{\mathrm{c}}$ $=143,246$ e para os diagramas de caminho com $g l=4$, o $X^{2}{ }_{c}=9,487$, o que traz

${ }^{45}$ Orientação dada pelo prof. Leandro Prearo nas datas de 18/04/14 e 23/04/14 
evidências de que a idade apresenta efeito moderador para o modelo estrutural final. Os diagramas de caminhos com diferenças significativas de $X^{2}$ estão relacionados: ao efeito push - autoeficácia $(F R \leftarrow A E)$ e para apenas experiência com internet $(A E$ $\leftarrow E X)$; ao efeito mooring - retenção na firma $(F R \leftarrow R F)$ e apenas para o alto custo de mudança $(R F \leftarrow C M R)$; ao efeito pull - atratividade do varejo (FR $\leftarrow A V)$.

Tabela 46- Moderação pela idade

\begin{tabular}{lcccccc}
\hline Relação Fixada & $\mathbf{X}^{\mathbf{2}}$ & $\boldsymbol{g l}$ & $\mathbf{\Delta \mathbf { X } ^ { \mathbf { 2 } }}$ & $\boldsymbol{\Delta} \boldsymbol{g l}$ & $\mathbf{p}$-value & Moderação \\
\hline \hline Modelo livre & 5378,342 & 2947 & & & & \\
Modelo restrito & 5544,227 & 3064 & 165,885 & 117 & $* * *$ & efeito moderador \\
\hline FR <- - - AE & 5400,372 & 2951 & 22,030 & 4 & $* * *$ & apresenta $\neq$ \\
FR <- - RF & 5396,290 & 2951 & 17,948 & 4 & $* * *$ & apresenta $\neq$ \\
FR <- - - AV & 5434,352 & 2951 & 56,010 & 4 & $* * *$ & apresenta $\neq$ \\
AE <- - - EX & 5401,092 & 2951 & 22,750 & 4 & $* * *$ & apresenta $\neq$ \\
AE<- - - SA_FR & 5379,782 & 2951 & 1,440 & 4 & & não apresenta $\neq$ \\
RF <- - - BV & 5383,716 & 2951 & 5,374 & 4 & & não apresenta $\neq$ \\
RF <- - - CMR & 5396,336 & 2951 & 17,994 & 4 & $* * *$ & apresenta $\neq$ \\
AV <- - - QP & 5381,975 & 2951 & 3,633 & 4 & & não apresenta $\neq$ \\
AV <- - - RP & 5380,549 & 2951 & 2,207 & 4 & & não apresenta $\neq$ \\
AV <- - - SA_LF & 5384,508 & 2951 & 6,166 & 4 & & não apresenta $\neq$ \\
\hline & \multicolumn{7}{c}{ Legenda: níveis de significância: $: 10 \% ; ~ * *: 5 \% ; ~ * * *: 1 \%$} &
\end{tabular}

Em seguida, foram analisadas as forças das cargas padronizadas nas relações dos diagramas de caminho e suas significâncias. A Tabela 47 mostra que dentro do efeito push (autoeficácia), a relação $A E \leftarrow E X$ apresenta maior intensidade de força para as faixas etárias: entre 31-40 anos (0,638), $\leq 30$ anos $(0,617), 41-50$ anos $(0,564)$ em relação à faixa de $>50$ anos $(0,396)$. Algo que seria esperado dado que a internet foi criada dentro das gerações mais recentes ( $Y$ e $Z$ ). A relação $A E$ $\leftarrow$ SA_FR com satisfação em free-riding teve maior intensidade com a faixa de 41-50 anos (0,370). Dentro do efeito mooring (retenção na firma), a relação $F R \leftarrow R F$ foi a que apontou maior força para a faixa etária 31-40 anos. O alto custo de mudança $(R F \leftarrow C M R)$ mostrou relação muito intensa para a faixa etária $\leq 30$ anos $(0,821)$, sinalizando a questão do custo do tempo e do esforço para mudar de loja ou rede varejista. Seguido da faixa etária de 41-50 anos $(0,548)$ e da faixa $>50$ anos $(0,491)$. Com busca de variedade (BV), houve maior intensidade na relação na faixa de 41-50 anos $(0,474)$. 
Tabela 47 - Estatísticas da análise de multigrupo idade

\begin{tabular}{|c|c|c|c|c|c|c|c|c|c|c|c|c|c|c|c|c|}
\hline \multirow[b]{2}{*}{ Relação Fixada } & \multicolumn{3}{|c|}{$\leq 30$ anos } & \multicolumn{4}{|c|}{$31-40$ anos } & \multicolumn{4}{|c|}{41 a 50 anos } & \multicolumn{5}{|c|}{$>50$ anos } \\
\hline & CFP & EP & valor-t & $p$ & CFP & EP & valor-t & $p$ & CFP & EP & valor-t & $p$ & CFP & EP & valor-t & $p$ \\
\hline FR <- - $A E$ & 0,160 & 0,087 & 1,627 & - & 0,143 & 0,068 & 2,126 & ** & 0,171 & 0,071 & 1,969 & $* *$ & 0,160 & 0,067 & 2,240 & ** \\
\hline$F R<---$ RF & $-0,028$ & 0,078 & $-0,271$ & - & 0,399 & 0,098 & 4,070 & $* * *$ & 0,283 & 0,074 & 2,772 & $* * *$ & 0,239 & 0,078 & 2,612 & $* * *$ \\
\hline$F R<---A V$ & 0,198 & 0,051 & 2,392 & $* *$ & 0,227 & 0,044 & 3,768 & $* * *$ & 0,071 & 0,032 & 1,047 & - & 0,392 & 0,054 & 5,114 & $* * *$ \\
\hline$A E<---E X$ & 0,617 & 0,124 & 6,083 & $* * *$ & 0,638 & 0,079 & 8,747 & $* * *$ & 0,564 & 0,064 & 7,328 & $* * *$ & 0,396 & 0,096 & 4,388 & $* * *$ \\
\hline$A E<--$ SA_FR & 0,326 & 0,111 & 3,691 & $* * *$ & 0,273 & 0,073 & 3,982 & $* * *$ & 0,370 & 0,083 & 4,513 & $* \star *$ & 0,327 & 0,151 & 3,100 & $* * *$ \\
\hline RF <- - - BV & 0,097 & 0,128 & 0,829 & - & 0,387 & 0,098 & 3,807 & $* * *$ & 0,474 & 0,107 & 4,630 & $* * *$ & 0,387 & 0,089 & 3,998 & $* * *$ \\
\hline RF <- - - CMR & 0,821 & 0,178 & 5,774 & $* * *$ & 0,439 & 0,108 & 4,008 & $* * *$ & 0,548 & 0,091 & 5,049 & $* * \star$ & 0,491 & 0,133 & 4,328 & $* * *$ \\
\hline$A V<---Q P$ & 0,261 & 0,080 & 4,022 & $* * *$ & 0,406 & 0,086 & 6,226 & $* * *$ & 0,189 & 0,073 & 3,658 & $* * *$ & 0,311 & 0,069 & 5,109 & $* * *$ \\
\hline$A V<---R P$ & 0,384 & 0,070 & 5,859 & $* * *$ & 0,314 & 0,059 & 5,594 & $* * *$ & 0,339 & 0,056 & 6,360 & $* \star *$ & 0,372 & 0,054 & 6,508 & $* * *$ \\
\hline AV <- - - SA_LF & 0,381 & 0,058 & 6,492 & $* * *$ & 0,231 & 0,057 & 4,245 & $* * *$ & 0,509 & 0,051 & 9,218 & $\star * *$ & 0,408 & 0,057 & 6,742 & *** \\
\hline
\end{tabular}

Dentro do efeito pull (atratividade pelo varejo tradicional), houve maior intensidade na relação $(F R \leftarrow A V)$ para a faixa etária $>50$ anos $(0,392)$, seguido de $31-40$ anos $(0,227)$. Algo esperado por ser uma geração (> 50 anos) que comprou tradicionalmente em loja física. Olhando-se as relações com AV, destaca-se a relação mais intensa da faixa etária 31-40 com qualidade percebida $(0,406)$ e também para a faixa etária $>50$ anos $(0,311)$. A qualidade é expressa em função do atendimento, da atmosfera e do acesso. $O$ risco percebido ( $\mathrm{V} V \leftarrow \mathrm{RP})$ apresentou relação mais intensa com a geração mais nova, $\leq 30$ anos $(0,384)$, seguido pela faixa $>50$ anos $(0,372)$. O risco foi medido pelas questões: segurança, logística de entrega, erro de transação. As compras on-line possibilitaram a transação com novos consumidores no mercado brasileiro, de locais distantes em que não existem lojas físicas de um determinado varejista. Porém entre a compra e a entrega do produto, a percepção de risco está presente e idade exerce moderação. E, finalmente, a satisfação loja física ( $A V \leftarrow S A$ LF) foi mais intensa para a faixa etária de 41-50 anos $(0,509)$, sendo em segundo lugar para $>50$ anos $(0,408)$, mas em terceiro, surpreendeu a geração mais nova $\leq 30$ anos $(0,381)$. Olhar e conferir 0 produto, bem como sentir o produto tiveram relações mais fortes para as faixas acima de 41 anos. Sinaliza que a satisfação de ir à loja física ainda é representativa quando o moderador é idade. 
Resumindo, a faixa etária $\leq 30$ anos tem mais intensidade de força nas relações com as variáveis: alto custo de mudança $(\mathrm{CMR})$ e percepção de risco (RP). A faixa etária 31-40 anos tem maior força nas relações com as variáveis: retenção na firma (RF) experiência com internet (EX), qualidade percebida (QP). A faixa etária 41-50 anos apresenta maior força nas relações com as variáveis: satisfação em free-riding (SA_FR), busca de variedade (BV) e satisfação loja física (SA_LF). E a faixa > 50 anos, apresentou maior força nas relações com atratividade do varejo tradicional $(\mathrm{AV})$.

Para análise de comparação de médias das variáveis latentes e suas significâncias, houve o ajustamento do banco de dados idade para apenas quatro respostas: 1 - $\leq$ 30 anos (183), 2- 31-40 anos (256), 3- 41-50 anos (241), 4- > 50 anos (203).

Não houve diferenças de médias entre as faixas etárias $\leq 30$ anos e 31-40 para as variáveis latentes. A variável latente experiência prévia com internet (EX) apresentou maiores médias para a faixa $\leq 30$ anos (Tabela 48), em seguida a faixa 41-50 (Tabela 49) e >50 anos (Tabela 50). O fator EX, da análise fatorial exploratória, apresentou diferenças de médias significativas (ANOVA) para idade, de forma similar.

A variável satisfação em free-riding (SA_FR) apresentou maior média para a faixa 41-50 anos em relação à faixa $\leq 30$ anos (Tabela 48). A satisfação está relacionada com a liberdade de movimento entre canais.

Tabela 48 - Teste de diferenças de médias para idade

\begin{tabular}{lcccc}
\hline \multicolumn{1}{c}{ Variáveis latentes } & $\mathbf{3} 30$ anos & $\mathbf{4 1 - 5 0}$ & valor-t & $\mathrm{p}$ \\
\hline \hline Experiência previa com internet (EX) & 0 & $-\mathbf{0 , 3 0 2}$ & $-\mathbf{3 , 0 5 5}$ & ${ }^{* * *}$ \\
Satisfação free-riding (SA_FR) & 0 & $\mathbf{0 , 2 4 7}$ & $\mathbf{2 , 2 8 9}$ & $* *$ \\
Alto custo de mudança (CMR) & 0 & $-0,134$ & $-1,047$ & - \\
Busca de Variedade (BV) & 0 & $\mathbf{0 , 2 1 8}$ & $\mathbf{2 , 0 6 0}$ & $*$ \\
Qualidade percebida (QP) & 0 & 0,084 & 0,810 & - \\
Risco percebido (RP) & 0 & 0,084 & 0,810 & - \\
Satisfação loja física (SA_LF) & 0 & 0,118 & 0,767 & - \\
\hline \multicolumn{4}{c}{ Legenda: níveis de significância: ${ }^{*}: 10 \% ;{ }^{* *}: 5 \% ;{ }^{* *}: 1 \%$} &
\end{tabular}

A variável latente alto custo de mudança (CMR) avalia o tempo e o esforço para mudança de varejista. Apresentou média mais alta para a faixa etária $\leq 30$ anos em 
relação à faixa > 50 anos (Tabela 49). Há evidências de que a variável latente "alto custo de mudança" é importante para esta faixa etária.

Tabela 49 - Teste de diferenças de médias para idade

\begin{tabular}{|c|c|c|c|c|}
\hline Variáveis latentes & $\leq 30$ anos & $>50$ anos & valor-t & $p$ \\
\hline Experiência previa com internet (EX) & 0 & $-0,592$ & $-5,533$ & $* * *$ \\
\hline Satisfação free-riding (SA_FR) & 0 & 0,028 & 0,265 & - \\
\hline Alto custo de mudança (CMR) & 0 & $-0,257$ & $-2,063$ & ** \\
\hline Busca de Variedade (BV) & 0 & $-0,162$ & $-1,270$ & - \\
\hline Qualidade percebida (QP) & 0 & 0,048 & 0,381 & - \\
\hline Risco percebido (RP) & 0 & 0,437 & 2,886 & $* * *$ \\
\hline Satisfação loja física (SA_LF) & 0 & 0,112 & 0,740 & - \\
\hline
\end{tabular}

Tabela 50 - Teste de diferenças de médias para idade

\begin{tabular}{lcccc}
\hline \multicolumn{1}{c}{ Variáveis latentes } & $\mathbf{3 1 - 4 0}$ & $\mathbf{4 1 - 5 0}$ & valor-t & $\mathbf{p}$ \\
\hline \hline Experiência previa com internet(EX) & 0 & $\mathbf{- 0 , 2 2}$ & $\mathbf{- 2 , 2 2 2}$ & ${ }^{* *}$ \\
Satisfação free-riding (SA_FR) & 0 & 0,09 & 0,870 & - \\
Alto custo de mudança (CMR) & 0 & $-0,013$ & $-0,106$ & - \\
Busca de Variedade (BV) & 0 & 0,137 & 1,349 & - \\
Qualidade percebida (QP) & 0 & 0,108 & 1,064 & - \\
Risco percebido (RP) & 0 & 0,122 & 0,916 & - \\
Satisfação loja fisica (SA_LF) & 0 & 0,121 & 0,855 & - \\
\hline \multicolumn{4}{c}{ Legenda: níveis de significância: ${ }^{*}: 10 \% ;{ }^{* *}: 5 \% ;{ }^{* * *: 1 \%}$} &
\end{tabular}

A variável busca de variedade (BV) mediu o desejo pela variedade de produtos, marcas e canais de compra. Apresentou média maior para a faixa 41-50 anos (Tabela 48) em relação à faixa de $\leq 30$ anos e à faixa $>50$ anos (Tabela 52). O fator individual BV da análise fatorial exploratória apresentou resultado similar. 
Tabela 51 - Teste de diferenças de médias para idade

\begin{tabular}{lcccc}
\hline \multicolumn{1}{c}{ Variáveis latentes } & $\mathbf{3 1 - 4 0}$ & $\mathbf{7 0}$ anos & valor-t & $\mathbf{p}$ \\
\hline \hline Experiência previa com internet(EX) & 0 & $-\mathbf{0 , 4 7 4}$ & $-\mathbf{4 , 4 8 9}$ & $* * *$ \\
Satisfação free-riding (SA_FR) & 0 & $-0,039$ & $-0,362$ & - \\
Alto custo de mudança (CMR) & 0 & $-0,061$ & $-0,533$ & - \\
Busca de Variedade (BV) & 0 & $-\mathbf{0 , 2 1 8}$ & $-1,790$ & $*$ \\
Qualidade percebida (QP) & 0 & 0,166 & 1,440 & - \\
Risco percebido (RP) & 0 & $\mathbf{0 , 2 3 3}$ & $\mathbf{1 , 6 5 1}$ & $*$ \\
Satisfação loja fisica (SA_LF) & 0 & 0,07 & 0,503 & - \\
\hline
\end{tabular}

Legenda: níveis de significância: *:10\%; **: 5\%; ${ }^{* * *}: 1 \%$

A variável latente risco percebido (RP) apresentou média maior para a faixa $>50$ anos em relação às faixas $\leq 30$ anos (Tabela 49) e 31-40 anos (Tabela 51).

Tabela 52 - Teste de diferenças de médias para idade

\begin{tabular}{lcrrc}
\hline \multicolumn{1}{c}{ Variáveis latentes } & $\mathbf{4 1 - 5 0}$ & $\mathbf{> 5 0}$ anos & valor-t & $\mathbf{p}$ \\
\hline \hline Experiência previa com internet(EX) & 0 & $\mathbf{- 0 , 2 8 4}$ & $\mathbf{- 2 , 5 7 6}$ & ${ }^{* * *}$ \\
Satisfação free-riding (SA_FR) & 0 & $-0,163$ & $-1,415$ & - \\
Alto custo de mudança (CMR) & 0 & $-0,095$ & $-0,755$ & - \\
Busca de Variedade (BV) & 0 & $-\mathbf{0 , 3 6 9}$ & $\mathbf{- 3 , 2 0 1}$ & ${ }^{* * *}$ \\
Qualidade percebida (QP) & 0 & 0,038 & 0,336 & - \\
Risco percebido (RP) & 0 & 0,086 & 0,597 & - \\
Satisfação loja fisica (SA_LF) & 0 & $-0,091$ & $-0,593$ & - \\
\hline \multicolumn{1}{c}{ Legenda: níveis de significância: ${ }^{*}: 10 \% ;{ }^{* *}: 5 \% ;{ }^{* * *}: 1 \%$} &
\end{tabular}

\subsubsection{Moderação por gênero (Q2)}

A verificação de moderação pelo gênero (Tabela 53) apresentou diferença significativa entre o modelo restrito e o modelo livre com $X^{2}{ }_{c}=103,01$. Há evidências de que o gênero tem efeito moderador sobre o modelo estrutural e sobre os diagramas de caminhos com $g l=1, \circ \quad X^{2}{ }_{c}=3,841$ que apresentaram diferenças significativas de $X^{2}$. Estão relacionados: ao efeito mooring - retenção na firma (FR $\leftarrow R F)$ e ao efeito pull - atratividade do varejo ( $F R \leftarrow A V)$. 
Tabela 53 - Moderação pelo gênero

\begin{tabular}{|c|c|c|c|c|c|c|}
\hline Relação Fixada & $\mathrm{x}^{2}$ & $g l$ & $\Delta \mathrm{X}^{2}$ & $\Delta g l$ & p-value & Moderação \\
\hline Modelo livre & 3299,333 & 1472 & & & & \\
\hline Modelo restrito & 3466,610 & 1553 & 167,277 & 81 & $* * *$ & genero modera \\
\hline$F R<---A E$ & 3299,504 & 1473 & 0,171 & 1 & & não apresenta $\neq$ \\
\hline$F R<---R F$ & 3303,358 & 1473 & 4,025 & 1 & $* * *$ & \\
\hline$F R<---A V$ & 3307,998 & 1473 & 8,665 & 1 & $* * *$ & apresenta $\neq$ \\
\hline$R F<---B V$ & 3300,485 & 1473 & 1,152 & 1 & & não apresenta $\neq$ \\
\hline RF <- - - CMR & 3299,942 & 1473 & 0,609 & 1 & & esenta $\neq$ \\
\hline$A V<---Q P$ & 3299,334 & 1473 & 0,001 & 1 & & não apresenta $\neq$ \\
\hline$R F<---R P$ & 3299,395 & 1473 & 0,062 & 1 & & não apresenta $\neq$ \\
\hline RF <- - - SA_LF & 3299,740 & 1473 & 0,407 & 1 & & não apresenta $\neq$ \\
\hline
\end{tabular}

Além disso, foram analisadas as forças das cargas padronizadas nas relações. A Tabela 54 apresenta a dinâmica de forças pelas cargas fatoriais padronizadas entre homens e mulheres e suas significâncias.

As mulheres apresentaram maior força $(0,470)$ na relação com os efeitos mooring (FR $\leftarrow R F)$ e os homens maior força $(0,279)$ na relação com os efeitos push (FR $\leftarrow A V$ ). Dentro dos efeitos push (autoeficácia) a relação $A E \leftarrow E X$ mostrou-se muito forte para ambos, maior para mulheres $(0,607)$ e menor intensidade para homens $(0,532)$. Os homens apresentaram maior intensidade na relação $A E \leftarrow S A \_F R(0,354)$ do que mulheres. Dentro dos efeitos mooring os achados mostraram mais força na busca de variedade para homens $(0,417)$, relação $R F \leftarrow B$. Para a relação $\mathrm{RF} \leftarrow \mathrm{CMR}$ ambos apresentaram intensidade de força na relação, porém mulheres com $(0,615)$ e homens $(0,513)$, na questão de esforço e tempo para mudança de varejista. Dentro dos efeitos pull $(\mathrm{FR} \leftarrow \mathrm{AV})$ houve maior força significante para homens e não houve para mulheres. Homens apresentaram mais força para a relação com qualidade percebida $(A \bigvee \leftarrow Q P)$, sendo homens $(0,310)$ e mulheres $(0,256)$. O mesmo para a relação com satisfação loja física ( $\left.A V \leftarrow S A \_L F\right)$, sendo que homens $(0,391)$ mostram maior intensidade na relação do que as mulheres $(0,343)$.

Resumindo, mulheres apresentaram mais força nas relações com experiência de internet (EX) e alto custo de mudança de varejista (CMR). Os achados para homens 
indicam relação mais intensa com as variáveis: satisfação em free-riding (SA_FR), busca de variedade (BV), qualidade percebida (QP) e satisfação loja física (SA_LF).

Tabela 54- Estatísticas da análise de multigrupo para gênero

\begin{tabular}{|c|c|c|c|c|c|c|c|c|}
\hline \multirow[b]{2}{*}{ Relação Fixada } & \multicolumn{3}{|c|}{ Homens } & \multicolumn{5}{|c|}{ Mulheres } \\
\hline & CFP & EP & valor-t & $p$ & CFP & EP & valor-t & $p$ \\
\hline$F R<---A E$ & 0,159 & 0,047 & 3,215 & $* * *$ & 0,137 & 0,054 & 2,206 & ** \\
\hline$F R<---R F$ & 0,191 & 0,052 & 3,278 & $* * *$ & 0,470 & 0,070 & 5,165 & $* * *$ \\
\hline$F R<---A V$ & 0,279 & 0,029 & 6,182 & $* * *$ & 0,078 & 0,033 & 1,404 & - \\
\hline$A E<---E X$ & 0,532 & 0,054 & 10,352 & $* * *$ & 0,607 & 0,059 & 8,799 & $* * *$ \\
\hline$A E<-.-S A \_F R$ & 0,354 & 0,061 & 6,563 & $* * *$ & 0,260 & 0,080 & 3,805 & $* * *$ \\
\hline RF $<---$ BV & 0,417 & 0,059 & 6,666 & $* * *$ & 0,251 & 0,098 & 2,690 & $* * *$ \\
\hline RF <- - - CMR & 0,513 & 0,071 & 7,372 & $* * *$ & 0,615 & 0,106 & 5,891 & $* * *$ \\
\hline$A V<---Q P$ & 0,310 & 0,044 & 8,577 & $* * *$ & 0,256 & 0,081 & 4,592 & $* * \star$ \\
\hline$A V<---R P$ & 0,356 & 0,035 & 10,403 & $* * *$ & 0,360 & 0,057 & 6,643 & $* * *$ \\
\hline AV <- - - SA_LF & 0,391 & 0,034 & 11,156 & $* * *$ & 0,343 & 0,049 & 6,874 & $* * *$ \\
\hline
\end{tabular}
Legenda: CFP- cargas fatoriais padronizadas, EP- erro padrão. Níveis de significância: *:10\%; **: $5 \%$;
${ }_{\star * *}: 1 \%$.

No teste de comparação de médias para gênero, os resultados não foram significativos, portanto não existem diferenças de médias para as variáveis latentes exógenas entre homens e mulheres, embora exista o efeito de moderação pelo gênero. Os achados confirmam a análise fatorial exploratória (ANOVA). Encontraram-se diferenças de médias para apenas dois fatores que não foram incluídos no modelo estrutural final (integração na firma e barganha, ambos com médias maiores para mulheres).

\subsubsection{Moderação por escolaridade (Q3)}

Para a análise de moderação por escolaridade, o banco de dados foi ajustado de cinco respostas para duas respostas: 1 - até segundo grau completo (453) e 2graduação completa (430). Apesar da diferença de $\mathrm{X}^{2}$ ter sido significativa, $\mathrm{H} \square$ não foi rejeitada, pois $X^{2}{ }_{c}=43,773$ é maior do que o qui-quadrado da diferença $(42,935)$, portanto não houve evidência de efeito de moderação pela escolaridade (Tabela 55). 
Tabela 55 - Moderação pela escolaridade

\begin{tabular}{lcccccc}
\hline Relação Fixada & $\mathbf{X}^{\mathbf{2}}$ & $\boldsymbol{g l}$ & $\mathbf{\Delta \mathbf { X } ^ { 2 }}$ & $\boldsymbol{\Delta} \boldsymbol{g l}$ & $\mathbf{p}$-value & Moderação \\
\hline \hline Modelo livre & 3168,227 & 1473 & & & & \\
Modelo restrito & 3211,162 & 1503 & 42,935 & 30 & $* *$ & $\begin{array}{c}\text { não há efeito } \\
\text { moderador }\end{array}$ \\
\hline
\end{tabular}

Legenda: níveis de significância: *:10\%; ${ }^{* *}: 5 \% ;{ }^{* * *}: 1 \%$

\subsubsection{Moderação por renda (Q4)}

Para a análise de moderação por renda, houve um reajuste do banco de dados para três faixas: 1- < $R \$ 3.000$, 2- $R \$ 3.001-R \$ 6000$ e 3- > $R \$ 6.001$. Os resultados foram apresentados na Tabela 56. Há diferenças significativas entre o modelo restrito e livre, com $X^{2}{ }_{c}=79,0819$ e para os diagramas de caminho com $g l=3$, o $X^{2}{ }_{c}=7,815$. Há evidências de que a renda apresenta efeito moderador sobre o modelo estrutural $e$ os diagramas de caminhos com diferenças significativas de $X^{2}$. Estão relacionados ao efeito push - autoeficácia ( $F R \leftarrow A E)$, para experiência com internet $(A E \leftarrow E X)$ e satisfação em free-riding ( $\mathrm{AE} \leftarrow \mathrm{SA}$ _FR); ao efeito mooring - para o alto custo de mudança $(R F \leftarrow C M R)$ e busca de variedade $(R F \leftarrow B V)$; ao efeito pull - atratividade do varejo $(F R \leftarrow A V)$ e apenas para a relação com qualidade percebida $(A \bigvee \leftarrow Q P)$.

Tabela 56 - Moderação pela renda

\begin{tabular}{lcccccc}
\hline Relação Fixada & $\mathbf{X}^{\mathbf{2}}$ & $\boldsymbol{g l}$ & $\mathbf{\Delta \mathbf { X } ^ { \mathbf { 2 } }}$ & $\boldsymbol{\Delta} \boldsymbol{g l}$ & $\mathbf{p}$-value & Moderação \\
\hline \hline Modelo livre & 4260,566 & 2210 & & & & \\
Modelo restrito & 4359,222 & 2270 & 98,656 & 60 & $* * *$ & efeito moderador \\
\hline FR <- - - AE & 4271,000 & 2213 & 10,434 & 3 & $* * *$ & apresenta $\neq$ \\
FR <- - - RF & 4266,890 & 2213 & 6,324 & 3 & & não apresenta $\neq$ \\
FR <- - - AV & 4265,456 & 2213 & 4,890 & 3 & $* * *$ & apresenta $\neq$ \\
AE <- - - EX & 4282,475 & 2213 & 21,909 & 3 & $* * *$ & apresenta $\neq$ \\
AE<- - - SA_FR & 4271,313 & 2213 & 10,747 & 3 & $* * *$ & apresenta $\neq$ \\
RF <- - - BV & 4271,878 & 2213 & 11,312 & 3 & $* * *$ & apresenta $\neq$ \\
RF <- - - CMR & 4276,115 & 2213 & 15,549 & 3 & $* * *$ & apresenta $\neq$ \\
AV <- - - QP & 4269,266 & 2213 & 8,700 & 3 & $* * *$ & apresenta $\neq$ \\
AV <- - - RP & 4264,673 & 2213 & 4,107 & 3 & & não apresenta $\neq$ \\
AV <- - - SA_LF & 4267,479 & 2213 & 6,913 & 3 & & não apresenta $\neq$ \\
\hline
\end{tabular}


A Tabela 57 mostra a estatística da moderação pela renda. Os achados mostram maior força para a relação $F R \leftarrow R F$ na faixa de renda $>R \$ 6.001(0,511)$, maior força para a relação $F R \leftarrow A E$ na faixa $R \$ 3.001-6.000 \quad(0,272)$. A relação $F R \leftarrow A V$ apresentou força distribuída entre as faixas $<R \$ 3.000(0,247)$ e $>R \$ 6.001(0,256)$. Alguns padrões se destacam nas relações de força com as variáveis exógenas. Entre as variáveis do efeito push, a experiência com internet $(A E \leftarrow E X)$ apresentou forte intensidade com a faixa de menor renda $(<R \$ 3.000)(0,657)$ em relação às demais faixas de renda. Destaca-se que a relação com a variável satisfação em free-riding (AE $\left.\leftarrow S A \_F R\right)$ apresentou maior força para a faixa $R \$ 3.001-6.000(0,479)$. Para as variáveis de efeito mooring, os achados indicam que a variável alto custo de mudança $(\mathrm{RF} \leftarrow \mathrm{CMR})$ apresenta maior intensidade de relação com a faixa $<R \$ 3.000(0,624)$ e > R \$6.001 (0,529). A variável busca de variedade possui relação mais intensa com a faixa $>R \$ 6.001(0,592)$. E entre as variáveis de efeito pull, a relação $F R \leftarrow A V$ apresentou maior força para a renda familiar $>R \$ 6.001(0,256)$, seguido de $<R \$ 3.000(0,247)$, o que sugere o quanto o varejo tradicional é atrativo para estas faixas etárias. A qualidade percebida (QP) possui maior intensidade de relação com a faixa $<\mathrm{R} \$ 3.000$ e a satisfação com loja física (SA_LF) tem maior força na faixa $>R \$ 6.001$.

Tabela 57 - Estatística da análise de multigrupo para renda

\begin{tabular}{|c|c|c|c|c|c|c|c|c|c|c|c|c|}
\hline \multirow[b]{2}{*}{ Relação Fixada } & \multicolumn{4}{|c|}{$<\mathrm{R} \$ 3.000$} & \multicolumn{3}{|c|}{$R \$ 3.001-6.000$} & \multicolumn{5}{|c|}{$>\mathrm{R} \$ 6.001$} \\
\hline & CFP & EP & valor-t & $\mathrm{p}$ & CFP & EP & valor-t & $\mathrm{p}$ & CFP & EP & valor-t & $\mathrm{p}$ \\
\hline$F R<---A E$ & 0,159 & 0,057 & 2,738 & $* * *$ & 0,272 & 0,067 & 3,820 & $* * *$ & $-0,042$ & 0,066 & $-0,528$ & - \\
\hline$F R<---$ RF & 0,202 & 0,059 & 2,999 & $* * *$ & 0,226 & 0,070 & 2,571 & $* * *$ & 0,511 & 0,100 & 4,533 & $* * *$ \\
\hline FR $<--$ - AV & 0,247 & 0,033 & 4,739 & $* * *$ & 0,127 & 0,039 & 2,109 & $* *$ & 0,256 & 0,049 & 3,326 & $* * *$ \\
\hline$A E<--~-~ E X$ & 0,657 & 0,059 & 10,663 & $* * *$ & 0,489 & 0,067 & 6,640 & $* * *$ & 0,429 & 0,096 & 5,006 & $* * *$ \\
\hline AE<- - - SA_FR & 0,224 & 0,057 & 3,958 & $* * *$ & 0,479 & 0,099 & 5,656 & $* * *$ & 0,302 & 0,125 & 3,444 & $* * *$ \\
\hline RF $<---$ BV & 0,312 & 0,069 & 4,113 & $* * *$ & 0,403 & 0,113 & 4,076 & $* * *$ & 0,592 & 0,118 & 5,272 & $* * *$ \\
\hline RF <- - - CMR & 0,624 & 0,095 & 7,039 & $* * *$ & 0,319 & 0,106 & 3,029 & $* * *$ & 0,529 & 0,094 & 5,051 & $* \star *$ \\
\hline$A V<---Q P$ & 0,350 & 0,060 & 7,652 & $* * *$ & 0,252 & 0,078 & 4,529 & $* * *$ & 0,221 & 0,067 & 3,632 & $* * *$ \\
\hline$A V<---R P$ & 0,362 & 0,043 & 9,078 & $* * *$ & 0,360 & 0,057 & 6,248 & $* * *$ & 0,331 & 0,060 & 5,470 & $* \star \star$ \\
\hline AV <- - - SA_LF & 0,328 & 0,041 & 8,226 & $* * *$ & 0,350 & 0,052 & 6,284 & $* * *$ & 0,498 & 0,058 & 7,925 & $* * *$ \\
\hline
\end{tabular}

Resumindo, a faixa > $\$$ \$6.001 apresentou uma força de relação maior com as variáveis busca de variedade (BV), satisfação loja física (SA_LF) e retenção na firma $(R F)$. A faixa $R \$ 3.000-6.000$ mostrou maior força nas relações com satisfação free- 
riding (SA_FR) e autoeficácia ( $\mathrm{AE}$ ). $\mathrm{A}$ faixa $<\mathrm{R} \$ 3.000$ tem relação mais intensa com a experiência prévia com internet (EX), alto custo de mudança (CMR) e qualidade percebida (QP).

A comparação de médias de variáveis exógenas mostrou que satisfação em freeriding teve diferença de média significativa e maior para a faixa $>\mathrm{R} \$ 6.001 \mathrm{em}$ relação à $R \$ 3.000-6.000$ e <R $\$ 3.000$ (Tabela 58 e Tabela 59). Indica que satisfação em free-riding está atrelada com a maior disponibilidade de renda. Também revelou que o risco percebido é menor para faixa $>R \$ 6.001$ em relação à faixa $R \$ 3.000$ 6.000. Interessante notar que o alto custo de mudança possui diferença de média significativa e maior para a faixa $>R \$ 6.001$ em relação à faixa $<R \$ 3.000$. O tempo $e$ o esforço de mudança de varejista mostrou ser mais custoso para a faixa mais abastarda.

Tabela 58 - Teste de diferenças de médias - renda

\begin{tabular}{lcccc}
\hline \multicolumn{1}{c}{ Variáveis latentes } & $<\mathbf{R} \$ \mathbf{3 . 0 0 0}$ & $>\mathbf{R} \$ 6001$ & valor-t & $\mathbf{p}$ \\
\hline \hline Experiência previa com internet (EX) & 0 & 0,115 & 1,200 & - \\
Satisfação free-riding (SA_FR) & 0 & $\mathbf{0 , 2 9 1}$ & $\mathbf{2 , 8 0 1}$ & $* * *$ \\
Alto custo de mudança (CMR) & 0 & $\mathbf{0 , 2 3 1}$ & $\mathbf{1 , 9 8 8}$ & $* *$ \\
Busca de Variedade (BV) & 0 & 0,012 & 0,107 & - \\
Qualidade percebida (QP) & 0 & $-0,176$ & $-1,479$ & - \\
Risco percebido (RP) & 0 & $-0,223$ & $-1,604$ & - \\
Satisfação loja física (SA_LF) & 0 & $\mathbf{- 0 , 2 5 9}$ & $\mathbf{- 1 , 8 0 2}$ & $*$ \\
\hline \multicolumn{4}{c}{ Legenda: níveis de significância: ${ }^{*}: 10 \% ;{ }^{* *}: 5 \% ;{ }^{* * *}: 1 \%}$. \\
\end{tabular}

Tabela 59 - Teste de diferenças de média para renda

\begin{tabular}{lcccc}
\hline \multicolumn{1}{c}{ Variáveis latentes } & $\mathbf{R} \$ \mathbf{3 0 0 1 - 6 0 0 0}$ & $\mathbf{> R} \mathbf{6 0 0 1}$ & valor-t & $\mathbf{p}$ \\
\hline \hline Experiência previa com internet (EX) & 0 & 0,025 & 0,233 & - \\
Satisfação free-riding (SA_FR) & 0 & $\mathbf{0 , 1 8 5}$ & $\mathbf{1 , 7 3 5}$ & $*$ \\
Alto custo de mudança (CMR) & 0 & 0,100 & 0,772 & - \\
Busca de Variedade (BV) & 0 & $-0,086$ & $-0,805$ & - \\
Qualidade percebida (QP) & 0 & $-0,055$ & $-0,478$ & - \\
Risco percebido (RP) & 0 & $\mathbf{- 0 , 2 6 2}$ & $\mathbf{- 1 , 7 9 4}$ & $*$ \\
Satisfação loja física (SA_LF) & 0 & $-0,147$ & $-0,983$ & - \\
\hline \multicolumn{4}{c}{ Legenda: níveis de significância: ${ }^{*}: 10 \% ;{ }^{* *}: 5 \% ;{ }^{* * *}: 1 \%}$.
\end{tabular}

Os resultados foram diferentes da diferença de médias calculada para os fatores individuais. Pela ANOVA, apenas os fatores confiança e lealdade apresentaram diferenças entre médias das faixas de renda. 


\subsubsection{Moderação por busca de informação (P4)}

A questão P4- "ao buscar informação, quantas lojas visitou on-line e/ou loja física?" tiveram três possibilidades de respostas: 1 loja (site de comparação de preços ou a visita a apenas uma loja), até 3 lojas e acima de 3 lojas. Os resultados foram apresentados na Tabela 60. Há diferenças significativas entre o modelo restrito e livre, com $X^{2}{ }_{c}=101,897$ e para os diagramas de caminho com $g l=3$, o $X^{2}{ }_{c}=7,815$. Há evidências de que a renda apresenta efeito moderador sobre o modelo estrutural $e$ os diagramas de caminhos com diferenças significativas de $\mathrm{X}^{2}$ estão relacionados: ao efeito push - para apenas experiência com internet ( $A E \leftarrow E X)$; ao efeito mooring - para o alto custo de mudança $(R F \leftarrow C M R)$ e busca de variedade $(R F \leftarrow B V)$; ao efeito pull - para os três construtos qualidade percebida $(A V \leftarrow Q P)$, risco percebido $(A V \leftarrow R P)$ e satisfação loja física $\left(A V \leftarrow S A \_L F\right)$.

Tabela 60 - Moderação pela busca de informação

\begin{tabular}{lcccccc}
\hline Relação Fixada & $\mathbf{X}^{\mathbf{2}}$ & $\boldsymbol{g l}$ & $\boldsymbol{\Delta} \mathbf{X}^{\mathbf{2}}$ & $\boldsymbol{\Delta} \boldsymbol{g l}$ & $\mathbf{p}$-value & Moderação \\
\hline \hline Modelo livre & 4482,178 & 2210 & & & & \\
Modelo restrito & 4594,985 & 2290 & 112,807 & 80 & $* * *$ & efeito moderador \\
\hline FR <- - - AE & 4483,456 & 2213 & 1,278 & 3 & $* * *$ & não apresenta $\neq$ \\
FR <- - - RF & 4482,737 & 2213 & 0,559 & 3 & $* * *$ & não apresenta $\neq$ \\
FR <- - - AV & 4483,263 & 2213 & 1,085 & 3 & $* * *$ & não apresenta $\neq$ \\
AE <- - - EX & 4503,294 & 2213 & 21,116 & 3 & $* * *$ & apresenta $\neq$ \\
AE<- - - SA_FR & 4486,784 & 2213 & 4,606 & 3 & $* * *$ & não apresenta $\neq$ \\
RF <- - - BV & 4490,760 & 2213 & 8,582 & 3 & $* * *$ & apresenta $\neq$ \\
RF <- - - CMR & 4495,139 & 2213 & 12,961 & 3 & $* * *$ & apresenta $\neq$ \\
AV <- - - QP & 4490,321 & 2213 & 8,143 & 3 & $* * *$ & apresenta $\neq$ \\
AV <- - - RP & 4490,365 & 2213 & 8,187 & 3 & $* * *$ & apresenta $\neq$ \\
AV <- - - SA_LF & 4492,536 & 2213 & 10,358 & 3 & $* * *$ & apresenta $\neq$ \\
\hline & \multicolumn{7}{c}{ Legenda: níveis de significância: ${ }^{*}: 10 \% ;{ }^{* *}: 5 \% ;{ }^{* * *}: 1 \%$} &
\end{tabular}

Analisando-se a dinâmica de forças nas relações e suas significâncias, a Tabela 61 mostra que para os efeitos push, a relação $F R \leftarrow A E$ possui maior força para a categoria "uma loja" $(0,228)$, o que sinaliza a possibilidade do uso de site de comparação de preços para a busca de informação sobre o produto comprado, como expressão da autoeficácia multicanal. A relação com experiência prévia na internet (EX) mostrou maior força com a categoria "até três lojas" $(0,618)$ e a satisfação em free-riding obteve maior força com a categoria (uma loja), reforçando a 
hipótese da habilidade de consulta em sites de comparação de preços. Dentro dos efeitos mooring, a relação $F R \leftarrow R F$ foi mais forte para a categoria "até três lojas" $(0,357)$, sinalizando que existe uma preferencia por alguns varejistas. Surpreendente que o resultado da dinâmica de forças com busca de variedade ( $R F \leftarrow B V)$ teve mais intensidade com uma loja $(0,586)$, sinalizando que os sites de comparação de preço possuem a variedade esperada para produtos e marcas. $O$ alto custo de mudança (CMR) apresentou maior intensidade de força na relação com a categoria > de três lojas $(0,603)$. Sinaliza que para busca, o que importa é quantidade de lojas, apesar de efetivar a compra nas minhas lojas preferidas.

Tabela 61 - Estatística da análise de multigrupo sobre a busca de informação

\begin{tabular}{|c|c|c|c|c|c|c|c|c|c|c|c|c|}
\hline \multirow[b]{2}{*}{ Relação Fixada } & \multicolumn{4}{|c|}{1 LOJA } & \multicolumn{3}{|c|}{ ATÉ 3 LOJAS } & \multicolumn{5}{|c|}{$>3$ LOJAS } \\
\hline & CFP & EP & valor-t & $p$ & CFP & EP & valor-t & $p$ & CFP & EP & valor-t & $p$ \\
\hline$F R<---A E$ & 0,228 & 0,078 & 1,969 & ** & 0,137 & 0,055 & 2,108 & ** & 0,122 & 0,056 & 2,323 & ** \\
\hline$F R<---R F$ & 0,201 & 0,103 & 1,534 & - & 0,357 & 0,060 & 4,239 & $* * *$ & 0,240 & 0,065 & 3,621 & $* * *$ \\
\hline$F R<---A V$ & 0,250 & 0,063 & 2,349 & ** & 0,245 & 0,035 & 3,993 & $* * *$ & 0,207 & 0,032 & 4,343 & $* * *$ \\
\hline$A E<--~-E X$ & 0,509 & 0,135 & 4,644 & $* * *$ & 0,618 & 0,061 & 8,359 & $* * *$ & 0,532 & 0,057 & 9,523 & $* \star *$ \\
\hline AE $<-$ - - SA_FR & 0,388 & 0,194 & 3,199 & $* \star *$ & 0,268 & 0,078 & 3,705 & $* * *$ & 0,325 & 0,059 & 5,767 & $* * *$ \\
\hline RF <- - - BV & 0,586 & 0,117 & 4,737 & $* \star *$ & 0,402 & 0,099 & 4,454 & $* * *$ & 0,340 & 0,066 & 4,669 & $* * *$ \\
\hline RF <- - - CMR & 0,419 & 0,171 & 2,938 & $* * *$ & 0,432 & 0,106 & 4,403 & $* * *$ & 0,603 & 0,075 & 7,283 & $* * *$ \\
\hline$A V<---Q P$ & 0,261 & 0,099 & 2,998 & $* * *$ & 0,373 & 0,062 & 7,258 & $* * *$ & 0,263 & 0,055 & 6,366 & *** \\
\hline$A V<---R P$ & 0,404 & 0,095 & 4,334 & $* \star *$ & 0,422 & 0,050 & 8,550 & $* * *$ & 0,319 & 0,040 & 8,148 & $* * *$ \\
\hline$A V<-.-S A \_L F$ & 0,358 & 0,109 & 3,439 & $* * *$ & 0,264 & 0,046 & 5,557 & $* * *$ & 0,426 & 0,037 & 11,024 & $* * *$ \\
\hline
\end{tabular}

$E$, dentro dos efeitos pull, houve maior intensidade de força nas relações com qualidade percebida (QP) e risco percebido (RP) para a categoria de "até três lojas" $(0,373$ e 0,422 respectivamente), sinalizando que o número três indica a preferência de compra para alguns varejistas do mercado seja pela qualidade de atendimento, seja pela percepção de risco. Porém a relação $A V \leftarrow S A \_L F$ apresentou maior força para busca em mais de três de lojas $(0,426)$, estando em segundo para uma loja $(0,358)$. Sinaliza que a satisfação de compra em loja física está relacionada com busca em muitas lojas e em seguida, com a busca em uma loja (provável site de comparação de preços).

Em resumo, a categoria "uma loja" apresentou força maior na relação com as variáveis latentes: satisfação em free-riding (SA_FR) e busca de variedade (BV). A 
categoria "até três lojas" demonstrou maior força na relação com as variáveis latentes: experiência previa com internet (EX), qualidade percebida (QP) e risco percebido (RP). A categoria de busca "acima de três lojas" mostrou maior intensidade de relação com as variáveis: alto custo de mudança (CMR) e satisfação loja física (SA_LF).

A comparação de médias das variáveis latentes e suas significâncias apresentaram resultados interessantes. Comparando-se as médias para a variável latente satisfação em free-riding, confirmou-se a diferença entre médias para as três categorias e com médias maiores para a categoria "acima de três lojas", o que aponta para a satisfação na liberdade de busca, uma habilidade em multicanais (Tabela 62, Tabela 63 e Tabela 64).

Tabela 62 - Diferença de médias para busca de informação

\begin{tabular}{lcccc}
\hline \multicolumn{1}{c}{ Variáveis latentes } & 1 LOJA & ATÉ 3 LOJAS & valor-t & $\mathbf{p}$ \\
\hline \hline Experiência previa com internet (EX) & 0 & $-0,059$ & $-0,399$ & - \\
Satisfação free-riding (SA_FR) & 0 & $\mathbf{0 , 3 0 2}$ & $\mathbf{2 , 3 4 5}$ & ${ }^{* *}$ \\
Alto custo de mudança (CMR) & 0 & $\mathbf{0 , 3 0 2}$ & $\mathbf{2 , 0 9 9}$ & ${ }^{* *}$ \\
Busca de Variedade (BV) & 0 & 0,060 & 0,431 & - \\
Qualidade percebida (QP) & 0 & 0,018 & 0,129 & - \\
Risco percebido (RP) & 0 & $-0,053$ & $-0,303$ & - \\
Satisfação loja fisica (SA_LF) & 0 & 0,181 & 1,094 & - \\
\hline \multicolumn{4}{c}{ Legenda: níveis de significância: ${ }^{*}: 10 \%{ }^{* *}: 5 \% ;{ }^{* * *}: 1 \%}$.
\end{tabular}

A variável experiência prévia com internet (EX) também apresentou diferenças de médias significativas, com média maior para a categoria > três lojas e que confirma a hipótese H2 com maior autoeficácia multicanal (Tabela 63 e Tabela 64). A variável alto custo de mudança (CMR) apresentou diferenças de médias significativas para todas as categorias, sendo média maior para a categoria > três lojas. Sugere que apesar da habilidade de busca de informação existe um alto custo de mudança para aceitar a compra em varejistas que não estejam nas preferencias do consumidor (Tabela 62, Tabela 63 e Tabela 64). 
Tabela 63 - Diferença de médias para busca de informação

\begin{tabular}{lcccc}
\hline \multicolumn{1}{c}{ Variáveis latentes } & 1 LOJA & > 3 LOJAS & valor-t & p \\
\hline \hline Experiência previa com internet (EX) & 0 & $\mathbf{0 , 4 3 1}$ & $\mathbf{3 , 4 0 2}$ & ${ }^{* * *}$ \\
Satisfação free-riding (SA_FR) & 0 & $\mathbf{0 , 5 8 1}$ & $\mathbf{4 , 4 5 2}$ & ${ }^{* * *}$ \\
Alto custo de mudança (CMR) & 0 & $\mathbf{0 , 6 5 4}$ & $\mathbf{4 , 7 1 4}$ & ${ }^{* * *}$ \\
Busca de Variedade (BV) & 0 & $\mathbf{0 , 3 1 7}$ & $\mathbf{2 , 3 1 7}$ & ${ }^{* *}$ \\
Qualidade percebida (QP) & 0 & $-0,193$ & $-1,562$ & - \\
Risco percebido (RP) & 0 & $-0,076$ & $-0,465$ & - \\
Satisfação loja fisica (SA_LF) & 0 & 0,089 & 0,556 & - \\
\hline \multicolumn{4}{c}{ Legenda: níveis de significância: ${ }^{*}: 10 \% ;{ }^{* *}: 5 \% ;{ }^{* * *}: 1 \%}$. &
\end{tabular}

A variável busca de variedade (BV) apresentou diferença de média significativa e média maior para a categoria > três lojas, sinalizando que há uma preferência de busca mais ampla de informação sobre marca e produtos antes de realizar a compra dos produtos deste estudo (Tabela 63 e Tabela 64).

Houve diferenças de média significativas para a variável qualidade percebida (QP) com médias maiores para busca em até três lojas em relação à busca acima de três lojas, o que sinaliza a preferencia do consumidor para lojas que já conhece e tem relacionamento de compra (Tabela 64).

Tabela 64 - Diferença de médias para busca de informação

\begin{tabular}{lcccc}
\hline \multicolumn{1}{c}{ Variáveis latentes } & ATÉ 3 LOJAS & > 3 LOJAS & valor-t & $\mathrm{p}$ \\
\hline \hline Experiência previa com internet (EX) & 0 & $\mathbf{0 , 4 8 6}$ & $\mathbf{5 , 9 6 4}$ & ${ }^{* * *}$ \\
Satisfação free-riding (SA_FR) & 0 & $\mathbf{0 , 2 5 4}$ & $\mathbf{2 , 9 1 6}$ & ${ }^{* * *}$ \\
Alto custo de mudança (CMR) & 0 & $\mathbf{0 , 3 6 2}$ & $\mathbf{3 , 7 3 8}$ & ${ }^{* * *}$ \\
Busca de Variedade (BV) & 0 & $\mathbf{0 , 2 5 6}$ & $\mathbf{2 , 9 1 8}$ & ${ }^{* * *}$ \\
Qualidade percebida (QP) & 0 & $-\mathbf{0 , 1 7 7}$ & $\mathbf{- 2 , 0 6 0}$ & ${ }^{* *}$ \\
Risco percebido (RP) & 0 & $-0,063$ & $-0,586$ & - \\
Satisfação loja física (SA_LF) & 0 & $-0,064$ & $-0,574$ & - \\
\hline \multicolumn{2}{c}{ Legenda: níveis de significância: ${ }^{*}: 10 \%{ }^{* *}: 5 \% ;{ }^{* * *}: 1 \%}$. &
\end{tabular}

Resumindo, os achados indicam médias maiores e significativas, conforme o Quadro 49.

Quadro 49- Resumo das médias maiores e significativas para busca (P4)

\begin{tabular}{|c|c|c|}
\hline Uma loja & Até três lojas & Acima de três lojas \\
\hline & QP & SA_FR \\
& EX \\
& CMR \\
& BV \\
\hline
\end{tabular}


As análises dos fatores individuais com ANOVA não encontraram diferenças de médias significativas para CMR e para QP em comparação com as diferenças de médias encontradas no modelo estrutural final.

\subsubsection{Moderação por local de compra efetiva (P6)}

Para a questão "P6 - sobre a compra efetiva, quantas lojas on-line e/ou loja física visitou?" não foi encontrado efeito de moderação com diferença de $X^{2}$ significativa, conforme Tabela 65 , abaixo.

Tabela 65- P6: Sobre a compra efetiva: quantas lojas visitou?

\begin{tabular}{lcccccc}
\hline Relação Fixada & $\mathbf{X}^{\mathbf{2}}$ & $\boldsymbol{g l}$ & $\boldsymbol{\Delta \mathbf { X } ^ { 2 }}$ & $\boldsymbol{\Delta} \boldsymbol{g l}$ & $\mathbf{p}$-value & Moderação \\
\hline \hline Modelo livre & 4342,281 & 2210 & & & & \\
Modelo restrito & 4440,896 & 2290 & 98,615 & 80 & - & não modera \\
\hline
\end{tabular}

\subsubsection{Moderação por hábito de compra (P7)}

A questão P7 - "o que melhor representa o seu hábito de compra?" teve quatro opções de resposta: 1 - busca on-line e compra loja física; 2- busca em loja física e compra on-line; busca em loja on-line e física para compra on-line e, 4- busca e compra on-line. Foi encontrado efeito de moderação, conforme a Tabela 66.

Há diferenças significativas entre o modelo restrito e livre de, com $X^{2}{ }_{c}=146,567$, portanto rejeitou Ho. Quase todas as relações apresentaram efeito moderador, exceto para a relação $\mathrm{FR} \leftarrow \mathrm{AE}, \mathrm{FR} \leftarrow \mathrm{AV}$ e $\mathrm{AV} \leftarrow \mathrm{RP}$ cujas diferenças de $\mathrm{X}^{2}$ foram menores do que o $X^{2}=9,488$ e não rejeitaram Ho ou não foram significativas. 
Tabela 66 - Moderação para P7: hábito de compra

\begin{tabular}{lcccccc}
\hline Relação Fixada & $\mathbf{X}^{\mathbf{2}}$ & $\boldsymbol{g l}$ & $\mathbf{\Delta \mathbf { X } ^ { \mathbf { 2 } }}$ & $\mathbf{\Delta} \boldsymbol{g l}$ & $\mathbf{p}$-value & Moderação \\
\hline \hline Modelo livre & 5539,008 & 2947 & & & & \\
Modelo restrito & 5729,900 & 3067 & 190,892 & 120 & $* * *$ & efeito moderador \\
\hline FR <- - - AE & 5543,339 & 2951 & 4,331 & 4 & & não apresenta $\neq$ \\
FR <- - RF & 5549,880 & 2951 & 10,872 & 4 & $* * *$ & apresenta $\neq$ \\
FR <- - - AV & 5544,529 & 2951 & 5,521 & 4 & & não apresenta $\neq$ \\
AE <- - - EX & 5574,551 & 2951 & 35,543 & 4 & $* * *$ & apresenta $\neq$ \\
AE<- - - SA_FR & 5563,980 & 2951 & 24,972 & 4 & $* * *$ & apresenta $\neq$ \\
RF <- - - BV & 5550,029 & 2951 & 11,021 & 4 & $* * *$ & apresenta $\neq$ \\
RF <- - - CMR & 5558,065 & 2951 & 19,057 & 4 & $* * *$ & apresenta $\neq$ \\
AV <- - - QP & 5555,903 & 2951 & 16,895 & 4 & $* * *$ & apresenta $\neq$ \\
AV <- - - RP & 5548,679 & 2951 & 9,671 & 4 & & não apresenta $\neq$ \\
AV <- - - SA_LF & 5557,054 & 2951 & 18,046 & 4 & $* * *$ & apresenta $\neq$ \\
\hline \hline
\end{tabular}

Em seguida se analisou a dinâmica de forças nas relações e suas significâncias. A Tabela 67 mostra que dentro dos efeitos push a maior força na relação $F R \leftarrow A E$ está para a categoria busca $L F / O L \rightarrow$ compra $O L(0,239)$. A relação $A E \leftarrow E X$ apresenta maior intensidade para a categoria "busca e compra OL" $(0,749)$, seguido de busca $L F / O L \rightarrow$ compra OL $(0,564)$, o que reforça a hipótese $\mathrm{H} 2$ sobre o efeito positivo na autoeficácia para o varejo multicanal. A relação com satisfação freeriding ( $\mathrm{AE} \leftarrow \mathrm{SA}$ _FR) evidencia maior hábito de compra com busca $\mathrm{LF} \rightarrow$ compra $\mathrm{OL}$ $(0,645)$ e em seguida Busca OL $\rightarrow$ compra LF $(0,456)$. Dentro dos efeitos mooring a relação $F R \leftarrow R F$ teve muita força para a categoria busca $L F \rightarrow$ compra $\operatorname{OL}(0,648)$. A relação $R F \leftarrow C M R$ se confirma com maior intensidade de força para alto custo de mudança na mesma categoria $(0,570)$, sinalizando que há consumidores que foram primeiro na loja tradicional para buscar informação mais detalhada sobre o produto e depois realizar a compra on-line. Porém há também força nas relações para a categoria busca OL e compra LF $(0,514)$ e busca $L F / O L \rightarrow$ compra OL $(0,512)$. O custo de esforço e tempo para mudança de varejista está representado nas três relações e com menor força para a categoria busca e compra $\mathrm{OL}(0,390)$. Pode significar um relacionamento de longo prazo com varejistas de suas preferências. A variável busca de variedade (BV) apresentou maior força com a categoria busca e compra OL, sinalizando que a internet detém muita informação sobre produtos e de forma variada. 
Tabela 67 - Estatística da análise de multigrupo sobre o hábito

\begin{tabular}{|c|c|c|c|c|c|c|c|c|c|c|c|c|c|c|c|c|}
\hline \multirow[b]{2}{*}{ Relação Fixada } & \multicolumn{3}{|c|}{ BUSCA OL->>COMPRA LF } & \multicolumn{5}{|c|}{ BUSCA LF.->COMPRA OL } & \multicolumn{3}{|c|}{ BUSCA LF/OL-->COMPRA OL } & \multicolumn{5}{|c|}{ BUSCA OL-->COMPRA OL } \\
\hline & CFP & EP & valor-t & $\mathrm{p}$ & CFP & EP & valor-t & $p$ & CFP & EP & valor-t & $p$ & CFP & EP & valor-t & $p$ \\
\hline$R<-\cdots A E$ & 0,198 & 0,059 & 3,114 & *** & $-0,003$ & 0,084 & $-0,023$ & & 0,239 & 0,073 & 3,127 & *** & 0,101 & 0,079 & 1,275 & - \\
\hline$R<--$ RF & 49 & 0,064 & 694 & - & 648 & 138 & 3,084 & *** & 0,320 & 072 & ,139 & *** & 0,369 & ,098 & 3,592 & *** \\
\hline$R<-A$ AV & 38 & 0,039 & 310 & *** & 180 & 050 & 1,740 & * & 0,125 & 036 & 846 & * & 0,265 & 0,057 & 3,415 & *** \\
\hline E<- - - EX & 0,434 & 0,077 & 6,443 & *** & 0,372 & 0,122 & 2,564 & *** & 0,564 & 0,065 & 6,842 & *** & 0,749 & 0,089 & 8,233 & *** \\
\hline E<- . - SA_FI & 0,456 & 0,087 & 6,290 & *** & 0,645 & 0,389 & 2,989 & *** & 0,154 & 0,059 & 2,097 & ** & 0,188 & 0,097 & 2,382 & ** \\
\hline$F<-.-B V$ & 0,383 & 0,075 & 5,071 & *** & 0,253 & 0,217 & 1,463 & - & 0,345 & 0,093 & 3,566 & *** & 0,550 & 0,128 & 4,400 & *** \\
\hline$F<---C M R$ & 0,514 & 0,096 & 6,008 & *** & 0,570 & 0,228 & 2,938 & *** & 0,512 & 0,122 & 4,433 & *** & 0,390 & 0,095 & 3,277 & *** \\
\hline |<- - - QP & 0,252 & 0,063 & 5,361 & *** & 0,216 & 0,110 & 2,338 & ** & 0,230 & 0,077 & 3,907 & *** & 0,473 & 0,082 & 6,639 & *** \\
\hline $\mathrm{AV}<-$ - - RP & 0,378 & 0,047 & 7,999 & *** & 0,290 & 0,089 & 3,355 & *** & 0,338 & 0,057 & 5,915 & $* * *$ & 0,365 & 0,065 & 5,994 & *** \\
\hline$V<--$ SA_LF & 371 & 051 & 7,692 & *** & 519 & 0,084 &, 095 & 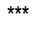 & 0,424 &, 050 & 635 & 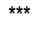 & ,243 & ,053 & 4,289 & \\
\hline
\end{tabular}

Legenda: CFP- cargas fatoriais padronizadas, EP- erro padrão. Níveis de significância: *:10\%; **:5\%; $* * *: 1 \%$

Dentro dos efeitos pull, destaca-se a relação $F R \leftarrow A V$ com maior força para busca $e$ compra OL $(0,265)$, seguido de busca on-line e compra em loja física $(0,238)$. A relação $A V \leftarrow Q P$ apresentou maior intensidade de força com a categoria busca e compra OL, uma resposta surpreendente. Os consumidores com habito de busca e compra OL pontuaram alto nas preferências de compra em loja física. Provavelmente preferem, mas não podem. E por quais razões não podem? Sobre a relação com o risco percebido $(A V \leftarrow R P)$ a categoria busca $O L$ e compra $L F$ teve maior força $(0,378)$, seguido de busca e compra OL $(0,365)$, o que também surpreendeu. Será que o consumidor não tem opção de compra em LF na cidade onde mora? A relação $A V \leftarrow S A \_L F$ mostrou maior força para a categoria busca $L F \rightarrow$ compra OL $(0,519)$, seguido da categoria busca LF e OL $\rightarrow$ compra OL $(0,424)$ e, em terceiro a categoria busca OL e compra $\operatorname{LF}(0,371)$. A necessidade de olhar, conferir e sentir o produto antes de realizar a compra on-line.

No teste de comparação de médias das variáveis latentes e suas significâncias, a variável satisfação loja física (SA_LF) apresentou maiores médias para busca OL e compra LF (Tabela 68, Tabela 69, Tabela 70, Tabela 72 e Tabela 73).

Tabela 68 - Teste de diferenças de médias para hábito

\begin{tabular}{lcccc}
\hline \multicolumn{1}{c}{ Variáveis latentes } & BUSCA OL->COMPRA LF & BUSCA LF-->COMPRA OL & valor-t & p \\
\hline \hline Experiência previa com internet (EX) & 0 & $-0,209$ & $-1,441$ & - \\
Satisfação free-riding (SA_FR) & 0 & $-0,021$ & $-0,216-$ & - \\
Alto custo de mudança (CMR) & 0 & 0,095 & $0,639-$ \\
Busca de Variedade (BV) & 0 & $-0,127$ & $-0,863-$ \\
Qualidade percebida (QP) & 0 & $-0,144$ & $-0,962-$ & - \\
Risco percebido (RP) & 0 & $-0,176$ & $-0,947$ & - \\
Satisfação loja física (SA_LF) & 0 & $-\mathbf{0 , 4 8 7}$ & $\mathbf{- 2 , 5 9 9}$ & *** \\
\hline
\end{tabular}


A variável experiência com internet (EX) apresentou maior diferença de média significativa para a categoria busca OL/LF e compra OL (Tabela 69, Tabela 70, Tabela 71 e Tabela 72).

Tabela 69 - Teste de diferenças de médias para hábito

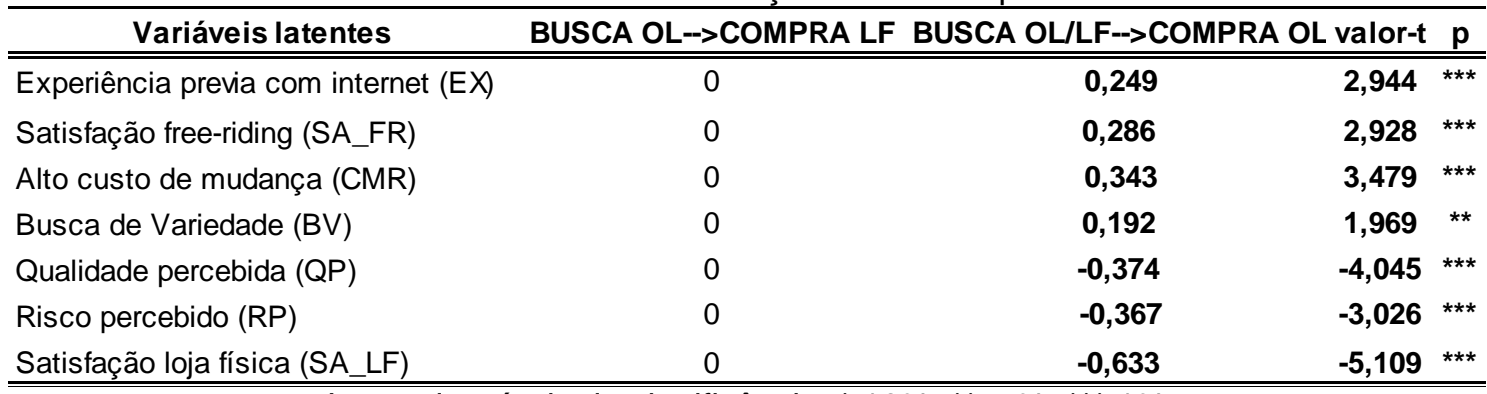

Legenda: níveis de significância: ${ }^{*}: 10 \% ;{ }^{* *}: 5 \% ;{ }^{* \star *}: 1 \%$

A variável satisfação em free-riding teve maior média para a categoria busca OL e $L F \rightarrow$ compra OL o que evidencia a satisfação em transitar no multicanal (Tabela 69, Tabela 71 e Tabela 73).

Tabela 70 - Teste de diferenças de médias para hábito

\begin{tabular}{|c|c|c|c|c|}
\hline Variáveis latentes & BUSCA OL-->COMPRA LF & BUSCA OL-->COMPRA OL & valor-t & $\mathbf{p}$ \\
\hline Experiência previa com internet (EX) & 0 & 0,233 & 2,643 & 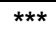 \\
\hline Satisfação free-riding (SA_FR) & 0 & $-0,161$ & $-1,377$ & - \\
\hline Alto custo de mudança (CMR) & 0 & 0,046 & 0,345 & - \\
\hline Busca de Variedade (BV) & 0 & $-0,240$ & $-2,194$ & ** \\
\hline Qualidade percebida (QP) & 0 & $-0,450$ & $-4,106$ & *** \\
\hline Risco percebido (RP) & 0 & $-0,559$ & $-4,228$ & $* \star *$ \\
\hline Satisfação loja física (SA_LF) & 0 & $-1,067$ & $-7,733$ & $\star \star \star *$ \\
\hline
\end{tabular}

A variável alto custo de mudança $(\mathrm{CMR})$ apresentou maior média significativa para a categoria busca OL e LF $\rightarrow$ compra OL (Tabela 69, Tabela 71 e Tabela 73).

A variável busca de variedade (BV) apresentou diferença de médias significativas, com maior média para a categoria busca OL e LF $\rightarrow$ compra OL. 
Tabela 71 - Teste de diferenças de médias para hábito

\begin{tabular}{lcccc}
\hline \multicolumn{1}{c}{ Variáveis latentes } & BUSCA LF-->COMPRA OL BUSCA OL/LF-->COMPRA OL valor-t & $\mathbf{p}$ \\
\hline \hline Experiência previa com internet (EX) & 0 & $\mathbf{0 , 4 8 0}$ & $\mathbf{3 , 0 8 6}$ & *** \\
Satisfação free-riding (SA_FR) & 0 & $\mathbf{0 , 4 1 1}$ & $\mathbf{2 , 9 7 8}$ & $* \star$ \\
Alto custo de mudança (CMR) & 0 & $\mathbf{0 , 2 8 3}$ & $\mathbf{1 , 8 0 8}$ \\
Busca de Variedade (BV) & 0 & $\mathbf{0 , 3 4 3}$ & $\mathbf{2 , 3 3 5}$ & $* *$ \\
Qualidade percebida (QP) & 0 & $\mathbf{- 0 , 2 5 9}$ & $\mathbf{- 1 , 6 8 4}$ \\
Risco percebido (RP) & 0 & $-0,235$ & $-1,228-$ \\
Satisfação loja física (SA_LF) & 0 & $-0,083$ & $-0,452$ & - \\
\hline
\end{tabular}

Legenda: níveis de significância: $: 10 \% ;{ }^{* *}: 5 \% ;{ }^{* * *}: 1 \%$

A variável qualidade percebida (QP) apresentou diferenças de médias significativas, com média maior para a categoria busca OL $\rightarrow$ compra LF (Tabela 69, Tabela 70, Tabela 71 e Tabela 72).

Tabela 72 - Teste de diferenças de médias para hábito

\begin{tabular}{|c|c|c|c|c|}
\hline Variáveis latentes & BUSCA LF-->COMPRA OL & BUSCA OL-->COMPRA OL & valor-t & $p$ \\
\hline Experiência previa com internet (EX) & 0 & 0,362 & 2,313 & ** \\
\hline Satisfação free-riding (SA_FR) & 0 & 0,018 & 0,135 & - \\
\hline Alto custo de mudança (CMR) & 0 & $-0,036$ & $-0,194$ & - \\
\hline Busca de Variedade (BV) & 0 & $-0,014$ & $-0,094$ & - \\
\hline Qualidade percebida (QP) & 0 & $-0,409$ & $-2,383$ & 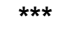 \\
\hline Risco percebido (RP) & 0 & $-0,479$ & $-2,546$ & $* * *$ \\
\hline Satisfação loja física (SA_LF) & 0 & $-0,494$ & $-2,532$ & 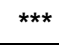 \\
\hline
\end{tabular}

Legenda: níveis de significância: ${ }^{*}: 10 \% ;{ }^{* *}: 5 \% ;{ }^{* * *}: 1 \%$

A variável risco percebido (RP) apresentou diferenças de médias significativas e com média maior para busca OL e compra LF e menor média para busca e compra OL, sinalizando que esta categoria ainda representa maior risco percebido, quanto a transação, segurança e logística de entrega (Tabela 69, Tabela 70, Tabela 72 e Tabela 73).

Tabela 73 - Teste de diferenças de médias para hábito

\begin{tabular}{|c|c|c|c|c|}
\hline Variáveis latentes & BUSCA OL/LF-->COMPRA OL & BUSCA OL-->COMPRA OL & valor-t & $p$ \\
\hline Experiência previa com internet (EX) & 0 & $-0,007$ & $-0,073$ & - \\
\hline Satisfação free-riding (SA_FR) & 0 & $-0,406$ & $-3,418$ & 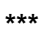 \\
\hline Alto custo de mudança (CMR) & 0 & $-0,312$ & $-2,213$ & ** \\
\hline Busca de Variedade (BV) & 0 & $-0,430$ & $-3,659$ & *** \\
\hline Qualidade percebida (QP) & 0 & $-0,049$ & $-0,437$ & - \\
\hline Risco percebido (RP) & 0 & $-0,231$ & $-1,696$ & * \\
\hline Satisfação loja física (SA_LF) & 0 & $-0,466$ & $-3,185$ & *** \\
\hline
\end{tabular}

Abaixo foi realizado o Quadro 50 - resumo sobre os achados de médias maiores e significativas. A análise individual dos fatores com ANOVA obteve resultados semelhantes para hábito de compra. 
Quadro 50 - Resumo sobre médias maiores e significativas para hábito

\begin{tabular}{|c|c|c|c|}
\hline Busca OL $\rightarrow$ compra & Busca LF $\rightarrow$ compra & Busca OL e LF $\rightarrow$ & Busca e compra OL \\
LF & OL & compra OL & \\
\hline SA_LF & & EX & \\
QP & & SA_FR & \\
RP & & CMR & \\
\hline
\end{tabular}

Fonte: elaborado pelo autor

\subsubsection{Moderação por opções de pesquisa e compra P8}

A questão P8 foi realizada em duas etapas (8.1 e 8.2) com escolha forçada para opção de pesquisa e compra que representasse o melhor hábito de compra. A P8.1 fixou a busca on-line e compra efetiva na loja física com três possibilidades de resposta: 1- na mesma rede varejista pesquisada na loja on-line, 2- de outro varejista não pesquisado na loja on-line e 3- não se aplica. Os achados indicam efeito moderador conforme Tabela 74. Há diferenças significativas entre o modelo restrito e o livre, com $X^{2}{ }_{c}=101,879$. Apenas quatro diagramas de caminho confirmaram o efeito moderador com significância: efeito push para $A E \leftarrow E X$; efeito mooring para $\mathrm{RF} \leftarrow \mathrm{BV}$ e $\mathrm{RF} \leftarrow \mathrm{CMR}$; efeito pull para a relação $\mathrm{FR} \leftarrow \mathrm{AV}$. Todos com resultados maiores do que $\circ \mathrm{X}_{\mathrm{C}}{ }_{\mathrm{C}}=7,815$.

Tabela 74 - Moderação por busca em loja on-line e compra efetiva em loja física

\begin{tabular}{lcccccc}
\hline \multicolumn{1}{c}{ Relação Fixada } & $\mathbf{X}^{2}$ & $\boldsymbol{g l}$ & $\Delta \mathbf{X}^{2}$ & $\Delta \boldsymbol{g l}$ & $\mathrm{p}$-value & Moderação \\
\hline \hline Modelo livre & 4333,603 & 2210 & & & & \\
Modelo restrito & 4449,414 & 2290 & 115,811 & 80 & $* * *$ & efeito moderador \\
\hline FR <- - - AE & 4335,031 & 2213 & 1,428 & 3 & $<0.05$ & não apresenta $\neq$ \\
FR <- - - RF & 4339,468 & 2213 & 5,865 & 3 & $<0.05$ & não apresenta $\neq$ \\
FR <- - - AV & 4346,259 & 2213 & 12,656 & 3 & $<0.05$ & apresenta $\neq$ \\
AE <- - - EX & 4354,906 & 2213 & 21,303 & 3 & $<0.05$ & apresenta $\neq$ \\
AE<- - - SA_FR & 4339,228 & 2213 & 5,625 & 3 & $<0.05$ & não apresenta $\neq$ \\
RF <- - - BV & 4342,490 & 2213 & 8,887 & 3 & $<0.05$ & apresenta $\neq$ \\
RF <- - - CMR & 4346,537 & 2213 & 12,934 & 3 & $<0.05$ & apresenta $\neq$ \\
AV <- - - QP & 4339,052 & 2213 & 5,449 & 3 & $<0.05$ & não apresenta $\neq$ \\
AV <- - - RP & 4341,138 & 2213 & 7,535 & 3 & $<0.05$ & não apresenta $\neq$ \\
AV <- - - SA_LF & 4340,851 & 2213 & 7,248 & 3 & $<0.05$ & não apresenta $\neq$ \\
\hline$\quad$ Legenda: níveis de significância: *:10\%; **: $5 \% ;{ }^{* * *}: 1 \%$
\end{tabular}

A análise da dinâmica de forças das cargas padronizadas nas relações e de suas significâncias mostraram resultados interessantes (Tabela 75). Dentro dos efeitos 
push (autoeficácia), a relação $(\mathrm{FR} \leftarrow \mathrm{AE})$ teve mais força para a categoria "outro varejista" $(0,224)$ o que confirma a hipótese $\mathrm{H} 1$ de free-riding em relação à autoeficácia multicanal. A relação $(A E \leftarrow E X)$ apresentou força para as duas categorias, porém maior para outro varejista $(0,573)$, seguido de mesmo varejista $(0,557)$ em se tratando do cruzamento entre canais. A relação com satisfação em free-riding (AE $\left.\leftarrow S A \_F R\right)$ mostrou maior força com a categoria "outro varejista", 0 que confirma a hipótese $\mathrm{H} 11$ a de free-riding no multicanal.

Tabela 75 - Estatísticas da análise de multigrupo para local de busca e compra efetiva (P8.1)

\begin{tabular}{|c|c|c|c|c|c|c|c|c|c|c|c|c|}
\hline \multirow[b]{2}{*}{ Relação Fixada } & \multicolumn{4}{|c|}{ Mesmo Varejista } & \multicolumn{3}{|c|}{ Outro Varejista } & \multicolumn{5}{|c|}{ Não se aplica } \\
\hline & CFP & EP & valor-t & $p$ & CFP & EP & valor-t & $\mathrm{p}$ & CFP & EP & valor-t & $\mathrm{p}$ \\
\hline$F R<---A E$ & 0,121 & 0,051 & 2,294 & ** & 0,224 & 0,064 & 2,695 & 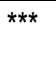 & 0,141 & 0,084 & 1,861 & * \\
\hline$F R<---R F$ & 0,250 & 0,061 & 3,844 & *** & 0,087 & 0,067 & 0,927 & - & 0,437 & 0,091 & 4,100 & *** \\
\hline FR $<---$ AV & 0,309 & 0,034 & 6,048 & *** & 0,070 & 0,037 & 1,075 & - & 0,102 & 0,049 & 1,459 & - \\
\hline$A E<---E X$ & 0,557 & 0,065 & 8,809 & , & 0,573 & 0,070 & 7,868 & $* * *$ & 0,518 & 0,074 & 6,383 & *** \\
\hline$A E<--$ SA_FR & 0,283 & 0,085 & 4,391 & **** & 0,419 & 0,079 & 5,657 & *** & 0,355 & 0,068 & 4,132 & *** \\
\hline RF <- - - BV & 0,365 & 0,068 & 4,932 & *** & 0,331 & 0,111 & 2,999 & $\star * *$ & 0,470 & 0,118 & 4,975 & *** \\
\hline RF <- - - CMR & 0,539 & 0,083 & 6,527 & 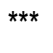 & 0,509 & 0,136 & 4,033 & *** & 0,507 & 0,094 & 5,151 & *** \\
\hline$A V<---Q P$ & 0,302 & 0,055 & 7,141 & 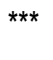 & 0,265 & 0,064 & 4,860 & $* * *$ & 0,307 & 0,098 & 4,070 & *** \\
\hline$A V<--$ - RP & 0,396 & 0,045 & 9,131 & *** & 0,344 & 0,048 & 6,735 & $* * \star$ & 0,307 & 0,061 & 4,816 & *** \\
\hline AV $<-.$. SA_LF & 0,314 & 0,044 & 7,482 & $* * *$ & 0,466 & 0,047 & 8,898 & $* * *$ & 0,373 & 0,054 & 5,838 & *** \\
\hline
\end{tabular}

Legenda: CFP- cargas fatoriais padronizadas, EP- erro padrão. Níveis de significância: *:10\%; ${ }^{* *}: 5 \%$; $* * *: 1 \%$.

Dentro dos efeitos mooring destaca-se a maior força para a relação (FR $\leftarrow$ RF) na categoria "mesmo varejista" $(0,250)$, confirmando a hipótese $\mathrm{H} 5$, apesar de o efeito ser positivo sobre o free-riding. A maior força na relação $\mathrm{RF} \leftarrow \mathrm{CMR}$ com o alto custo de mudança $(0,539)$ para a categoria "mesmo varejista" confirma a hipótese $\mathrm{H} 7 \mathrm{a}$, embora a força seja ligeiramente inferior para "outro varejista" $(0,509)$, o que sinaliza a evidência de preferência por um varejista, independente do pesquisado on-line. A relação $\mathrm{RF} \leftarrow \mathrm{BV}$ mostrou mais força para mesmo varejista $(0,365)$ em relação a outro varejista $(0,331)$ quando a busca é on-line e a compra na loja física.

Dentro dos efeitos pull existe maior força na relação (FR $\leftarrow$ VV) para mesmo varejista $(0,309)$ o que sinaliza a intenção de free-riding para um varejista tradicional, confirmando a hipótese $\mathrm{H} 14$. A relação $(\mathrm{AV} \leftarrow \mathrm{QP})$ e a relação $(\mathrm{AV} \leftarrow \mathrm{RP})$ apresentaram mais força para a categoria "mesmo varejista" (0,302 e 0,396 respectivamente) o que sinaliza a confirmação da hipótese $\mathrm{H} 16$ e H15. A relação 
(AV $\leftarrow$ SA_LF) apresentou mais força na categoria "outro varejista" o que indica a preferência por um varejista tradicional, diferente do pesquisado na loja on-line, reforçando a hipótese $\mathrm{H} 11 \mathrm{~b}$.

Resumindo, a categoria "mesmo varejista" mostrou maior força nas relações com busca de variedade $(0,365)$, o alto custo de mudança de varejista $(C M R)(0,539)$ e à maior percepção de risco na compra on-line $(0,396)$. As relações $\operatorname{FR} \leftarrow R F(0,250)$ e $\mathrm{FR} \leftarrow \mathrm{AV}(0,309)$ apresentaram-se mais intensas com a categoria "mesmo varejista". A categoria "outro varejista" obteve maior intensidade de força para as variáveis: experiência prévia com internet $(0,573)$, satisfação em free-riding $(0,419)$, satisfação loja física $(0,466)$ e a relação $F R \leftarrow A E$ possui mais força $(0,224)$ o que suporta 0 free-riding entre varejistas.

A análise de comparação de médias demonstrou diferenças de médias significativas, com média maior para a categoria "outro varejista" na relação com a variável alto custo de mudança (CMR), conforme Tabela 76. Isto sinaliza que apesar da busca ser livre nas lojas on-line, há uma preferencia de compra em varejistas já conhecidos do consumidor devido ao custo do tempo e do esforço para mudar de varejista.

Tabela 76 - Teste de diferenças de médias para busca on-line e compra loja física

\begin{tabular}{|c|c|c|c|c|}
\hline Variáveis latentes & Mesmo varejista & Outro varejista & valor-t & $\mathbf{p}$ \\
\hline Experiência previa com internet (EX) & 0 & 0,018 & 0,202 & - \\
\hline Satisfação free-riding (SA_FR) & 0 & 0,042 & 0,478 & - \\
\hline Alto custo de mudança (CMR) & 0 & 0,252 & 2,433 & $* *$ \\
\hline Busca de Variedade (BV) & 0 & 0,077 & 0,794 & - \\
\hline Qualidade percebida (QP) & 0 & $-0,047$ & $-0,494$ & - \\
\hline Risco percebido (RP) & 0 & 0,051 & 0,435 & - \\
\hline Satisfação loja física (SA_LF) & 0 & 0,080 & 0,653 & - \\
\hline
\end{tabular}

A análise dos fatores individuais pela ANOVA obteve resultados diferentes.

A questão 8.2 não obteve significância nas diferenças de $X^{2}$ entre o modelo restrito e livre (Tabela 77) e desta forma o efeito moderador não pode ser comprovado. 
Tabela 77 - Moderação pela busca loja física e compra efetiva on-line

\begin{tabular}{lcccccc}
\hline Relação Fixada & $\mathbf{X}^{2}$ & $\boldsymbol{g l}$ & $\Delta \mathbf{X}^{2}$ & $\Delta \boldsymbol{g l}$ & p-value & Moderação \\
\hline \hline Modelo livre & 4342,659 & 2210 & & & & \\
Modelo restrito & 4440,482 & 2290 & 97,823 & 80 & - & não modera \\
\hline
\end{tabular}




\section{Conclusões}

A literatura de comportamento sobre alternância entre firmas, bem como a literatura de alternância entre canais é muito recente. Os achados empíricos basearam-se nos estudos sobre retenção do consumidor e lealdade, conforme Bolton, Kannan e Bramlett (2000) e Zauberman (2003); seguiram pela abordagem do custo de mudança e barreiras de mudança (JONES; MOTHERSBAUGH; BEATTY, 2000; BURNHAM; FRELS; MAHAJAN, 2003; DHOLAKIA; ZHAO; DHOLAKIA, 2005); depois pela abordagem do valor percebido por cada canal e modificação da teoria ação racional (VERHOEF; DONKERS, 2005); e para retenção e free-riding (VAN BAAL; DACH, 2005). A contribuição da teoria de migração de Bansal, Taylor e James (2005) sugeriu um modelo com uma estrutura teórica única e integrada na área de comportamento de alternância. Tsai et al. (2006) desenvolveram um modelo integrativo, contemplando a intenção de recompra, satisfação geral e barreiras de mudança com e-varejistas. Chiu et al. (2011) reformulou o modelo de migração com variáveis mediadoras auto eficácia multicanal, retenção na firma e atratividade do varejista tradicional. O artigo de Swaid e Wigand (2012) traz a percepção entre canais on-line e off-line para valor e lealdade no ambiente multicanal varejista. E Badrinarayanan et al. (2012) estudaram os efeitos da transferência e congruência da imagem do varejista multicanal na intenção de compra pelas lojas on-line.

Quando o consumidor utiliza multicanais para uma transação, ele pode obter serviços com um dado varejista e colocar o pedido com outro e desta forma se engaja em free-riding. No varejo, os consumidores realizam free-riding quando uma empresa não pode cobrar separadamente pelos serviços. Embora disponibilize informação de produto ela não consegue distinguir os consumidores free-riders dos demais consumidores. Os serviços oferecidos pelos varejistas são considerados públicos. Outra consideração para free-riding no varejo é a concorrência de lojas tradicionais, quando os serviços oferecidos e o preço não são similares entre elas. $\mathrm{A}$ empresa varejista que não se engaja em multicanais acabará perdendo os consumidores que cruzam canais e desta forma a concorrência irá receber a compensação (VAN BAAL, DACH, 2005). Os múltiplos canais se expandem cada vez mais com novas experiências de compra por smartphones, dispositivos móveis, 
comunidades virtuais, sites de reclamações etc. O comportamento de compra do consumidor se torna cada vez mais complexo. Por sua vez, a aquisição de novos canais pelo varejista impacta na lealdade de consumidores. A retenção por lealdade ao varejista parece ser diferente para os distintos canais de marketing, segundo Verhoef e Donkers (2005).

Por outro lado, há uma preferência dos consumidores por variedade de opções de canais nos processos de decisão de compra de produtos e serviços e muitos consumidores se tornaram usuários multicanais. Verhoef, Neslin e Vroomen (2007) modificaram o modelo ação racional (TRA), incluindo a atratividade do canal para busca e/ou para compra, sem relacionar diretamente atributos com compra, pois a teoria ação racional relata que a escolha é mediada por atitudes em direção ao canal.

O presente estudo focou em produtos da categoria de experiência que requerem além do preço, investigar sobre a marca, a qualidade e entender sobre os atributos do produto para estimar a utilidade da compra, segundo Nelson (1970).

Chiu et al. (2011) experimentaram o modelo de migração e argumentaram que num ambiente multicanal a discussão deve considerar retenção e free-riding no cruzamento entre canais. No modelo proposto por Chiu et al. (2011), os fatores PPM foram transformados em variáveis latentes: autoeficácia, retenção na firma e atratividade do varejo tradicional. O modelo dos autores contemplou apenas um tipo de cruzamento: busca on-line e compra off-line. Retenção na firma significou busca e compra em um mesmo varejista, tanto num único canal como em cruzamento entre o canal on-line e off-line.

Para este estudo, diferente do modelo de Chiu et al. (2011), deu-se a opção de o respondente indicar a sua preferencia de busca e compra, segundo a atratividade de cada canal, permitindo outros cruzamentos possíveis. Foram incluídas variáveis latentes como satisfação, lealdade, confiança tanto para autoeficácia multicanal quanto para atratividade do varejo tradicional, pois ambos apresentam "atratividades" na percepção do consumidor. A literatura de alternância em serviços 
relata as variáveis satisfação e confiança como efeito push (aquilo que faz sair da origem), segundo Bansal, Taylor e James (2005), pensando na insatisfação para sair da origem. Porém no desenho proposto para este estudo, a satisfação, a confiança e a lealdade foram inseridas como efeitos push e pull, ambas com efeitos positivos sobre a autoeficácia e sobre a atratividade do varejo tradicional, pensando na proposta de Verhoef, Neslin e Vroomen (2007) com a inclusão da ideia de atratividade de cada canal.

Os efeitos mooring (ancoragem) compõem variáveis relacionadas a contexto como: normas subjetivas, busca de variedade, custo de mudança, comportamento anterior de alternância e atitudes em relação à mudança. Conveniência e design do site, por serem conceitos focados no contexto de cada canal foram inseridos aqui. A conveniência foi também incluída como efeito pull, com a opção para canal tradicional, assim como o construto barganha que surgiu a partir da pesquisa exploratória.

$\mathrm{Na}$ proposta de Chiu et al. (2010) o efeito push consistiu da percepção do consumidor quanto à sua autoeficácia multicanal com a influência positiva no cruzamento entre canais e intenção de free-riding. O efeito pull consistiu da atratividade relativa dos concorrentes do varejo tradicional com a influência positiva na intenção de free-riding. Entretanto, o efeito mooring consistiu da variável retenção na firma com carga negativa na relação com intenção de free-riding.

Uma vez alocado os construtos no modelo, caminhou-se para a etapa de validação do modelo estrutural. Neste processo com os 22 construtos, apenas permaneceram dez que proporcionaram qualidade de ajustamento e validação.

\subsection{Conclusões e implicações acadêmicas}

A primeira constatação relevante de diferenças entre o modelo de Chiu et al. (2011) e o proposto neste estudo foi o efeito mooring (retenção na firma), influenciando positivamente a intenção de free-riding (Figura 34), ao invés de negativamente, 
como indicado nos achados pelos autores (Figura 6). E esta relação teve mais força do que a autoeficácia ( $\mathrm{AE}$ ) e a atratividade do varejo tradicional (AV). No modelo de Chiu et al. (2011) também foi a relação com maior força, porém negativa. Sugere que ao suportar o free-riding, o alto custo de mudança e o atendimento na variedade de produtos e marcas pelo varejista dão suporte para retenção na firma, existindo preferências do consumidor por um ou poucos varejistas não capturados pelo modelo proposto.

A variável latente Integração percebida (IN) não teve aderência ao modelo estrutural final e foi retirada durante o processo de validação. Os achados de Chiu et al. (2010) também constataram a não significância da relação entre retenção da firma e integração percebida no modelo hipotetizado. Durante treinamento dado à Viavarejo que integra Casas Bahia e Ponto Frio ${ }^{46}$, foi constatado com os gestores que a gestão operacional dos canais on-line e loja física ainda permanecem independentes quanto aos estoques. Os gestores de loja são comissionados pela receita de vendas e não pela eficiência de vendas que contempla todo o processo da operação desde o pedido até a entrega ao consumidor, incluindo o canal telefônico para reclamações e devoluções. O atendimento telefônico de pós-vendas já aparece de forma mais integrada, porém operações existentes nos EUA e Inglaterra não foram encontradas ainda no Brasil, por exemplo, "click and collect" (comprar on-line e retirar na loja mais próxima). E para este estudo a percepção de integração do consumidor é bem subjetiva. No teste de comparação de médias (ANOVA) há diferenças significativas e médias maiores para mulheres quanto à percepção de integração.

O modelo final foi composto com dez construtos. O efeito push, representado pela autoeficácia multicanal $(\mathrm{AE})$ consistiu das variáveis: experiência prévia com internet (EX) e satisfação em free-riding (SA_FR). O efeito mooring representado pela retenção na firma $(R F)$ consistiu das variáveis já confirmadas em estudos anteriores: alto custo de mudança (CMR) e busca de variedade (BV). O efeito pull representado pela atratividade do varejo tradicional (AV) consistiu das seguintes variáveis: satisfação loja física (SA_LF), qualidade percebida (QP) e risco percebido (RP). 0

\footnotetext{
${ }^{46}$ Treinamento dado como uma das professoras em 18/09/2013.
} 
modelo teve aderência para a satisfação tanto em relação à eficácia multicanal quanto em relação à atratividade do varejo tradicional, destacando o que é atrativo em cada canal, segundo a ideia dos autores Verhoef, Neslin e Vroomen (2007). Sugere que a satisfação (free-riding e loja física) capturou o sentido de atratividade na percepção do consumidor para escolha num ambiente multicanal.

Os resultados encontrados sobre o efeito de mediação das variáveis autoeficácia multicanal $(A E)$, retenção da firma $(R F)$ e atratividade do varejo tradicional ( $A V$ ) redesenharam o modelo final. $O$ efeito mediador não foi confirmado para autoeficácia e retenção na firma (Figura 35). Portanto o paradigma push-pullmooring do modelo de migração não se configurou para este estudo, pois a H1 e H5 não foram confirmadas como variáveis mediadoras. O efeito mediador se confirmou para atratividade do varejo tradicional $(A V)$ apenas para risco percebido (RP). A qualidade percebida (QP) e satisfação loja física (SA_LF) não considera AV como mediador. Porém, há uma discussão de Zhao, Lynch Jr. e Chen (2010) em torno do modelo direto proposto pelo teste de Baron e Kenny (1986) em relação às razões teóricas que se espera do modelo direto.

Diferente dos achados de Chiu et al. (2010), a variável latente experiência vicária (EV) também não teve aderência ao modelo final na composição da autoeficácia multicanal, proveniente da teoria da aprendizagem social (BANDURA, 1977). E talvez isto explique a ausência de suporte para o efeito de mediação do construto autoeficácia multicanal.

A análise de moderação por multigrupos ofereceu uma tipologia rica com as variáveis categóricas. A análise da dinâmica de forças nas relações entre construtos (diagramas de caminho) contribuiu para riqueza de informação das forças nas relações e as diferenças de médias significativas contribuíram para o maior entendimento da importância do construto dentro do modelo estrutural. A moderação ocorreu para seis variáveis categóricas: idade, gênero, renda, P4- na busca de informação sobre o produto - quantas lojas visitou? (com três respostas: uma loja, até três lojas e acima de três lojas), P7 - O que representa o seu hábito de compra? (quatro categorias: busca on-line e compra off-line, busca off-line e compra on-line, 
busca on-line e off-line e compra on-line, busca e compra on-line) e, finalmente, $\mathrm{P}$ 8.1 - Sobre o hábito de busca on-line e compra efetiva em loja física (com três opções de escolha para resposta: da mesma rede/loja varejista, outra rede/loja varejista, não se aplica).

Os achados foram organizados segundo o paradigma do modelo de migração pushpull-mooring, destacando-se a relação (diagrama de caminho) e a dinâmica de forças (cargas padronizadas) entre grupos.

\section{Efeitos push}

A relação $\mathrm{FR} \leftarrow \mathrm{AE}$ (autoeficácia multicanal com free-riding) apresentou moderação para idade e renda familiar. Não houve moderação para gênero o que sugere que a relação não teve distinção entre homens e mulheres. Porém a maior intensidade de força foi para a faixa etária de 31-40 anos e em segundo lugar para $\leq 30$ anos, algo esperado dado que a internet foi criada e desenvolvida nas gerações mais recentes (Y e Z). A renda de $\mathrm{R} \$ 3.000-6.000$ apresentou maior relação de força. Quanto ao hábito, os resultados mostraram maior relação de força com busca on-line e loja física para compra efetiva on-line. E quando fixado o cruzamento busca on-line e compra loja física, maior força foi encontrada para outros varejistas, se configurando

o free-riding. Denota uma geração jovem, com renda familiar mediana, que faz busca on-line e na loja física, comprando efetivamente na loja virtual. Quando fixa o cruzamento compra em outros varejistas. Denotam intenção de free-riding no multicanal varejo.

A relação $A E \leftarrow E X$ (experiência prévia com internet e autoeficácia) demonstrou efeito de moderação para idade, renda, P4 (busca), P7 (hábito) e P 8.1 (varejista). Na análise da dinâmica de forças, idade apresentou forte intensidade na seguinte ordem: 31-40 anos, $\leq 30$ anos, 41-50 anos e por último, > 50 anos. Algo esperado dado que a internet foi criada e desenvolvida nas gerações mais recentes ( $\mathrm{Y}$ e Z ). Mulheres apresentaram uma intensidade de força superior a homens; também maior intensidade para a faixa de renda familiar < $R \$ 3.000$. Maior força para pesquisa em uma loja, o que sugere o site de comparação de preços. O hábito de compra 
apresentou forte relação para busca e compra on-line, seguido de busca on-line/loja física e compra efetiva on-line. Apesar dos resultados para relação de força, médias maiores e significativas foram encontradas para busca on-line/loja física $\rightarrow$ compra on-line, não havendo diferenças de médias para busca e compra on-line. Para opção busca on-line e compra loja física, a relação de forças foi muito próxima, sendo em primeiro outro varejista $(0,573)$, seguido de mesmo varejista $(0,557)$. Sugere que a orientação dada pelo site de comparação de preços determina a escolha de varejistas com melhor preço. Reforça a hipótese $\mathrm{H} 2$ e a intenção de free-riding.

Em resumo, experiência prévia com internet revela uma geração mais experiente e jovem com internet, público mais feminino, renda mais baixa, se utilizam de site de comparação de preços, acostumados a buscar e comprar on-line e se visitam a loja física vão para checar o produto, não possuem aderência ao varejista durante o cruzamento entre canais. E quando fixado o cruzamento busca on-line $\rightarrow$ compra loja física praticamente não houve diferença entre mesmo e outro varejista, constituindo-se em free-riders.

A relação $A E \leftarrow S A \_F R$ (satisfação free-riding com autoeficácia) apresentou moderação para renda, P7 - hábito e p 8.1 (busca OL $\rightarrow$ compra LF e relação a varejistas). Ao se analisar a dinâmica de forças, os achados indicam que a relação apresentou maior força para a faixa 41-50 anos. A sensação de liberdade no ambiente multicanal para as pessoas desta faixa etária foi surpreendente. A intensidade foi maior para homens do que mulheres, maior na faixa de renda $R \$ 3.001-6.000$, seguido de acima de $R \$ 6.001$. A relação com hábito de compra apresentou maior intensidade para busca na loja física e compra on-line, seguido de busca on-line e compra loja física. Porém, médias maiores e significativas foram encontradas para o hábito busca on-line e loja física $\rightarrow$ compra on-line. Quando fixado o cruzamento busca on-line $\rightarrow$ compra loja física, houve maior intensidade para outro varejista, confirmando a hipótese H11a e confirmando o comportamento de free-riding. Resumindo, a satisfação em free-riding expressa a satisfação pela liberdade no multicanal. Revela um segmento de consumidores mais velhos, principalmente homens, com mais dinheiro, acostumados ao cruzamento entre canais com busca e compra em canais diferentes para os produtos deste estudo. 
Quando fixado o cruzamento busca on-line $\rightarrow$ compra loja física preferem outro varejista e sugere que fazem negociação de preço com a loja/rede varejista. Constituem-se em verdadeiros free-riders.

\section{Efeitos mooring}

A relação $F R \leftarrow R F$ (retenção na firma com intenção de free-riding) apresentou efeito de moderação para idade, gênero e P7 - hábito. Analisando-se a dinâmica de forças pelas cargas fatoriais em relação aos três construtos mediadores ( $A E, R F, A V)$, a relação $\mathrm{FR} \leftarrow \mathrm{RF}$ apresentou maior intensidade de força para a faixa de idade 31-40 anos. As mulheres apresentaram maior força nesta relação. Há maior força para renda familiar acima de $\mathrm{R} \$ 6001$. Maior força para busca até três lojas. A relação apresentou maior força para o hábito de busca na loja física e compra on-line e, quando fixado o cruzamento busca on-line $\rightarrow$ compra loja física, a opção é para o mesmo varejista. Em resumo, a retenção na firma se mostra para faixa etária não tão jovem, principalmente de mulheres, com mais disponibilidade de dinheiro e que realizam a busca em até três lojas, sugerindo alguma preferência por varejistas, acostumadas ao cruzamento entre canais com maior força para busca em loja física e compra on-line. Quando fixado o cruzamento em busca on-line $\rightarrow$ compra loja física, maior força para o mesmo varejista. Os achados confirmam a $\mathrm{H} 5$, apesar de a retenção na firma (RF) ter apresentado efeito positivo sobre o free-riding. Um freeriding entre canais com retenção.

A relação $\mathrm{RF} \leftarrow \mathrm{CMR}$ (alto custo de mudança e retenção na firma) apresentou moderação para idade, renda, P4- busca de informação, P7- hábito e P 8.1 varejista. $\mathrm{Na}$ análise da dinâmica de forças entre os grupos, apresentou maior força para a idade $\leq 30$ anos, sugerindo que o custo de mudança em relação ao tempo e o esforço para mudar de loja/varejista importa. Mulheres apresentaram mais força na relação do que homens. Há maior intensidade de força para a renda familiar < $R \$ 3.000$, seguido de > $R \$ 6.001$. A busca de informação apresentou maior força para acima de três lojas. O hábito de compra apresentou maior força com a busca loja física para compra on-line, seguido de mesma força para busca on-line e compra em loja física e, busca on-line e loja física para compra on-line. Análise de comparação 
de médias mostrou maiores médias para busca on-line e loja física $\rightarrow$ compra online. E, quando fixado o cruzamento busca on-line $\rightarrow$ compra loja física, houve maior força para o mesmo varejista, ligeiramente superior em relação a outro varejista. Resumindo, a variável custo de mudança foi expressa em relação ao custo do esforço e de tempo para mudança de varejista, detalhado pela tipologia de Burnham, Frels e Mahajan (2003). O custo de mudança mostrou-se mais forte para mulheres jovens, com renda familiar mais baixa, seguida de maior renda (os extremos). Buscam em mais de três lojas, realizam busca e compra em canais diferentes. Quando o cruzamento é fixado na busca on-line $\rightarrow$ compra loja física, mesmo varejista tem ligeiramente mais força, o que denota retenção no varejista ou sugere preferencia por varejista.

A relação $F R \leftarrow B V$ (busca de variedade e retenção na firma) apresentou moderação para renda, P4- busca de informação, P7- hábito e P8.1 varejista. A análise da dinâmica de forças entre grupos apresentou maior intensidade para a faixa etária 41 50 anos. Maior força para homens do que mulheres e renda familiar acima de $\mathrm{R} \$ 6.001$. Na busca de informação apresentou maior força para 1 loja, sugerindo o site de comparação de preços como referência para busca. E para o hábito de compra, a maior força ficou para busca e compra on-line, porém médias significativas maiores foram encontradas para busca on-line e loja física $\rightarrow$ compra on-line. Quando o cruzamento é fixado para busca on-line e compra loja física, a força é ligeiramente superior para o mesmo varejista, em relação a outro varejista. Sugere uma relação entre o resultado do site de comparação de preços e a escolha do varejista. A busca de variedade reflete o fenômeno em que os consumidores estão dispostos a negociar o prazer pela variedade. Rohm e Swaminathan (2004) construíram uma tipologia dos compradores pela internet e destacaram a busca de variedade. Mostrou-se mais forte para homens de idade mais avançada e com mais dinheiro. Sugere que realizam a busca em site de comparação de preços e possuem como hábito a busca e compra on-line para os produtos em estudo. Quando avaliado o cruzamento fixado em busca on-line $\rightarrow$ compra loja física, permanecem no mesmo varejista o que sugere o uso do site de comparação de preços como balizador da compra. Não confirmou a hipótese H6 e foi exatamente ao contrário, porém houve mais força para retenção no varejista. 


\section{Efeitos pull}

A relação $\mathrm{FR} \leftarrow \mathrm{AV}$ (atratividade do varejo com intenção de free-riding) apresentou moderação para idade, gênero, renda e P.8.1 - varejista. Ao se analisar a dinâmica de forças, foi encontrada maior força para a faixa etária > 50 anos, sugerindo ser esta uma geração que tradicionalmente comprou em lojas físicas. Houve significância e maior força para homens. Não houve significância para mulheres. Houve maior relação de força com a faixa de renda familiar $>R \$ 6.001$ e $<R \$ 3.000$. Maior intensidade de forças para busca de informação em uma e até três lojas. $O$ hábito de compra mostrou maior relação para busca e compra on-line, seguido de busca on-line e compra loja física. Quando fixado o cruzamento entre canais para busca on-line $\rightarrow$ compra loja física, apresentou maior força para mesmo varejista, sugerindo a ausência de free-riding entre varejistas, apesar do cruzamento entre canais. Atratividade do varejo tradicional tem relação de mais força com homens da geração mais velha, de maior renda familiar, seguido de menor, mais força como usuários do site de comparação de preços. Surpreendeu o fato de que a maior força seja para hábito de busca e compra on-line, seguido de busca on-line e compra loja física. E quando o cruzamento é fixado busca on-line $\rightarrow$ compra loja física, evidencia maior força para mesmo varejista, indicando retenção no varejista.

A relação $A V \leftarrow Q P$ (qualidade percebida e atratividade do varejo tradicional) apresentou moderação para renda, busca de informação e hábito de compra. Ao se analisar a dinâmica de forças, foi encontrada maior força para a faixa etária de 31-40 anos, seguido de > 50 anos. Maior força da relação: para homens, para a faixa de renda familiar < $R \$ 3.000$, com busca de informação em até três lojas, hábito de busca e compra on-line. Porém a análise de comparação de médias apresentou maiores médias significativas para busca on-line $\rightarrow$ compra loja física. Na categoria com cruzamento fixado em busca on-line $\rightarrow$ compra loja física a maior força foi para mesmo varejista. $O$ construto qualidade percebida está relacionado com facilidade de acesso, atmosfera e atendimento em loja. Maior força para homens de faixa etária mediana seguida de mais velhos, renda familiar baixa, que realizam busca em até três lojas, porém estão acostumados a buscar e comprar on-line. Quando respondem o cruzamento fixado em busca on-line $\rightarrow$ compra loja física escolhem 0 
mesmo varejista. A percepção de qualidade confirma a hipótese $\mathrm{H} 16$ e a maior retenção no varejista.

A relação $A V \leftarrow R P$ (risco percebido e atratividade do varejo tradicional) moderação apenas para busca de informação (P4) e P 8.1 - busca on-line e compra loja física (mesmo ou outro varejista). Ao se analisar a dinâmica de forças da relação, foi encontrada maior força para a faixa $\leq 30$ anos, seguida de $>50$ anos. Não houve praticamente diferença entre forças para homens e mulheres. Maior força para as rendas familiares < $R \$ 3.000$ e $R \$ 3.001-6.000$. Maior força para busca de informação até três lojas. A maior força para o hábito de compra busca on-line e compra efetiva loja física (confirmado pelas maiores médias significativas) está atrelada à percepção de maior risco (conforme a hipótese H15), seguido de maior força para busca e compra on-line (porém representa a menor média significativa em relação às outras categorias). A percepção de risco permanece para estes consumidores da internet. Quando fixado o cruzamento entre canais para busca on-line $\rightarrow$ compra loja física, a maior força foi para mesmo varejista, o que sugere a não intenção de freeriding entre varejistas quando se considera a percepção de risco. Consumidores avaliaram o risco percebido pelo desempenho, financeiro, total e de tempo. Maior ênfase de risco nas faixas jovens e mais velhas, em conjunto com renda mais baixa e mediana, respectivamente. Busca em até três varejistas, o que sugere preferência por varejistas e talvez até pela experiência repetida de compra. Sinaliza que a experiência repetida de compras com o mesmo varejista ameniza o risco percebido.

A relação $A V \leftarrow S A \_L F$ (satisfação com loja física e atratividade do varejo) apresentou efeito de moderação para busca e informação, hábito de compra e P 8.1 - opção de varejista quando há busca on-line e compra loja física. A dinâmica das relações de forças para as variáveis categóricas apresentou maior força para a faixa de idade 41-50 anos, seguido de > 50 anos. Força maior para: homens em relação a mulheres, com a maior renda $>\mathrm{R} \$ 6.001$. Maior força para busca de informação em mais de três lojas, seguido de uma loja. O hábito de compra revelou maior força para busca em loja física e compra on-line (confirmado pelas maiores médias significativas), seguido da busca on-line e loja física para compra on-line e depois busca on-line e compra loja física. E no cruzamento entre busca on-line e compra 
loja física, a maior força encontrada foi para outro varejista, evidenciando a intenção de free-riding quando há o cruzamento entre canais. Resumindo, satisfação pela loja física reflete a necessidade de olhar, conferir, sentir o produto. Assim como a satisfação em free-riding, a satisfação loja física apresentou maior força para homens mais velhos, o que sugere a relação desta geração com a tradição do varejo físico. Maior renda, com busca de informação em várias lojas e uma loja (site de comparação de preços). Realizam busca e compra em canais diferentes, portanto cruzam canais e sinalizam que realizam o free-riding para outros varejistas, não confirmando a hipótese $\mathrm{H} 11 \mathrm{~b}$, pois não sinalizam que compram na loja física, apesar de visitarem a loja física.

Em seguida, os resultados da análise de multigrupos sob o enfoque das variáveis categóricas possibilitaram ampliar a percepção das diferenças de forças e diferenças de médias.

A moderação por faixa etária destaca a faixa etária $\leq 30$ anos com maior intensidade de força para a variável alto custo de mudança (CMR) e percepção de risco (RP). A faixa etária 31-40 anos apresentou maior força nas relações com retenção na firma $(R F)$, experiência prévia com internet $(E X)$ e qualidade percebida (QP). A faixa etária 41-50 anos mostrou maior relação de força com satisfação em free-riding (SA_FR), busca de variedade (BV) e satisfação loja física (SA_LF). A faixa > 50 anos mostrou maior relação de força com atratividade do varejo tradicional (AV), um resultado esperado. Maior média significativa para a faixa $\leq 30$ anos com experiência prévia em internet (EX), confirmando a habilidade natural da geração; também para alto custo de mudança (CMR) quando comparado com > 50 anos. Sugere que o custo do esforço e tempo é importante para esta faixa etária mais jovem em relação à mudança de varejista. Maior média significativa para a idade 41 50 anos na satisfação em free-riding (SA_FR), exprimindo a sensação de liberdade num ambiente multicanal. Busca de variedade (BV) apresentou maior média significativa para a faixa de 41-50 anos. O risco percebido (RP) apresentou média maior e significativa para a faixa $>50$ anos. 
A moderação pelo gênero evidenciou que as mulheres apresentaram maior relação de força nas relações com experiência prévia em internet (EX) e alto custo de mudança (CMR). Para homens as relações mais intensas foram com satisfação em free-riding (SA_FR), busca de variedade (BV), qualidade percebida (QP) e satisfação loja física (SA_LF).

A moderação pela renda familiar evidenciou que a faixa $>R \$ 6.001$ apresentou maior relação de força com busca de variedade (BV), satisfação loja física (SA_LF) e retenção na firma $(R F)$. A faixa $R \$ 3.000-6.000$ mostrou maior força nas relações com satisfação em free-riding (SA_FR) e autoeficácia (AE). A faixa $<R \$ 3.000$ teve relação mais intensa com a experiência prévia em internet $(E X)$, alto custo de mudança $(C M R)$ e qualidade percebida $(Q P)$. A comparação de médias revelou que a satisfação em free-riding apresentou médias maiores significativas para a faixa > $\mathrm{R} \$ 6.001$ e sugere que com maior renda maior satisfação em free-riding. Também revelou que o risco percebido $(\mathrm{RP})$ é menor para esta faixa de renda e o alto custo de mudança (CMR) possui média maior, o que sugere que o custo de tempo e esforço importa.

A moderação pela busca de informação (P4) evidenciou que a categoria uma loja apresentou maior força para a relação com satisfação em free-riding (SA_FR) e busca de variedade (BV). Sugere que o site de comparação de preços satisfaz em variedade e satisfação na liberdade multicanal. Porém média maior e significativa foi encontrada para a satisfação em free-riding na categoria acima de três lojas. A categórica até três lojas apresentou maior força na relação com experiência prévia em internet $(E X)$, qualidade percebida (QP) e risco percebido (RP). Sugere preferências dos consumidores por varejistas da sua experiência histórica de busca e compra de produtos. A categoria acima de três lojas mostrou maior força nas relações com alto custo de mudança (CMR) e satisfação loja física (SA_LF).

A moderação pelo hábito de compra (P7) para a categoria busca on-line $\rightarrow$ compra loja física apresentou maior força para a relação com risco percebido (RP). Sugere que a percepção de risco na compra on-line conduza consumidores à compra efetiva na loja física e a utilização do canal on-line apenas para busca. A categoria busca 
loja física $\rightarrow$ compra on-line apresentou maior força na relação com retenção na firma (RF), satisfação em free-riding (SA_FR), alto custo de mudança (CMR) e satisfação loja física (SA_LF). Sinaliza a presença do esforço e tempo para mudança de varejista, denotando alguma preferência por varejistas. A satisfação na liberdade multicanal pela compra efetiva on-line e a satisfação na busca feita em loja física que reflete o olhar, conferir e sentir o produto antes de realizar a compra.

A categoria busca on-line e loja física $\rightarrow$ compra on-line apresentou maior força na relação com autoeficácia (AE). A categoria busca e compra on-line mostrou maior força para atratividade do varejo (AV), experiência prévia com internet $(E X)$, busca de variedade (BV), qualidade percebida (QP). O que não faz sentido para esta categoria foi a relação com qualidade percebida e atratividade do varejo. Sugere que embora exista o desejo do atendimento no varejo tradicional a busca e a compra efetiva é realizada on-line. Pode sinalizar ausência de sortimento do varejo tradicional em suas cidades. Pode sinalizar melhores preços obtidos pelas lojas online, apesar do desejo de atendimento em loja física.

$\mathrm{Na}$ análise de comparação de médias, médias maiores foram obtidas na categoria busca on-line $\rightarrow$ compra loja física para: satisfação em loja física (SA_LF), qualidade percebida (QP) e risco percebido (RP). Os resultados sugerem claramente o desejo de olhar, conferir, sentir o produto na loja física, além do risco percebido pela compra on-line. A atratividade que envolve a compra pelo canal loja física está na atmosfera e no atendimento pessoal, como qualidade percebida. As maiores médias significativas foram encontradas na categoria busca on-line e loja física $\rightarrow$ compra online para as variáveis: experiência previa com internet, satisfação em free-riding e alto custo de mudança. Sugere que apesar da experiência previa com internet e a satisfação em free-riding também existe um alto custo de mudança de varejista. Sinaliza que a compra é realizada dentro das preferencias de varejistas, levando em consideração o histórico de experiência de compra.

\section{A moderação ao se fixar o cruzamento busca on-line $\rightarrow$ compra loja física ( $P$}

8.1) mostrou que a categoria mesmo varejista apresentou maior força nas relações com busca de variedade (BV), alto custo de mudança (CMR), risco percebido (RP), 
retenção na firma (RF) e atratividade do varejo tradicional (AV) o que faz sentido a preferência por varejistas com histórico de compra. Apesar de haver o cruzamento entre canais não fica confirmada a intenção de free-riding entre varejistas. Os achados para a categoria outro varejista mostraram maior relação de força com as variáveis: experiência prévia em internet (EX), satisfação em free-riding (SA_FR), satisfação loja física (SA_LF) e a autoeficácia (AE). Média maior e significativa para a categoria outro varejista para as variáveis: alto custo de mudança $(\mathrm{CMR})$ o que também sugere a preferência de compra com varejistas já conhecidos do consumidor. Apesar de haver a intenção de free-riding, sugere que o consumidor optou para realizar o free-ride para um varejista de sua preferência histórica de compras.

\section{Contribuições Acadêmicas}

Os estudos do comportamento de alternância multicanal receberam contribuição, ao ser testado o modelo de migração dentro de um fenômeno real no mercado brasileiro. Houve um avanço quanto ao modelo proposto por Chiu et al. (2011) a partir da proposta de Bansal, Taylor e James (2005) e da proposta de Verhoef, Neslin e Vroomen (2005). A pesquisa de campo proporcionada pela empresa E-bit ofereceu diversidade e variedade de consumidores para o entendimento do fenômeno multicanal.

A análise de moderação permitiu descrever uma tipologia para entender a dinâmica de forças entre relações de variáveis em canais múltiplos e traz um novo olhar sobre as motivações da atratividade de cada canal.

O estudo sobre o free-riding evidencia que ele existe, tanto para gerações mais jovens quanto para faixa mais madura que se sente satisfeito com o free-riding. Entretanto, o consumidor sinaliza que possui preferências por varejistas, motivado pelo seu relacionamento de longo prazo ou fatores não capturados pelo modelo. $O$ que se destaca no free-riding para os construtos manifestos para autoeficácia e retenção na firma é a inversão dos papéis dos canais de busca e compra. A tradicional busca on-line não se confirma para os produtos pesquisados (de 
experiência). A busca inclui a loja física para ver, conferir e sentir o produto. A compra tradicional em loja física se reverte para uma compra on-line o que causa impacto nos negócios do varejo. Há uma maior preferência para compra on-line, mesmo para os construtos relacionados à retenção na firma. Por sua vez, os construtos relacionados ao efeito pull - atratividade do varejo mostram o tradicional cruzamento entre busca on-line e compra loja física e, se confirma com maior propensão à retenção na firma, exceto para a variável satisfação loja física, um segmento de pessoas de idade mais avançada, renda mais baixa, mais acostumadas com compra no varejo tradicional que ao cruzarem o canal sinalizam o free-riding para suas preferências e escolhas de varejistas.

\subsection{Implicações gerenciais}

Retenção do consumidor pelo varejista e free-riding são abordagens que devem ser consideradas em contexto mais amplo do varejo multicanal. O free-riding ocorre para consumidores com experiência previa de internet, jovens confiantes. Entretanto, a satisfação em free-riding mostrou faixas mais maduras e com renda familiar mais elevada. Isto pode se tornar um problema para operações de varejistas ainda lentas na adoção de integração multicanal ou gestão de canais independentes. Também foi constatado que existe um segmento de consumidores que preferem realizar a compra na loja física pelo fato de perceberem mais qualidade e baixo risco, sugerindo a transação de produtos mais caros para dentro das lojas físicas.

Os resultados revelam maior força para as operações de busca em loja física ao invés de compra em loja física, e isso impacta na operação do varejo. As lojas físicas precisam ser repensadas tanto para o relacionamento com o cliente, como posicionamento do negócio (loja showroom). Os resultados indicam uma inversão da tradicional busca on-line, quando se trata de produtos como os pesquisados. Parece que olhar, conferir, sentir o produto antes de decidir a compra on-line é importante. Dados reportados pela Forrester Research (2012) indicam crescimento do cruzamento entre canais de busca on-line para compra em loja física da ordem de 44\% até 2016 nos EUA. O volume de vendas acontece nas lojas físicas como resultado da busca on-line. As vendas devem ser estimuladas por dispositivos 
móveis, investimentos de grandes lojas de departamento com campanhas on-line "know before you go". Em contrapartida, as lojas físicas possuem entrega imediata associada a níveis de serviços. Estratégias de discriminação de preços clara, gestão de sortimento diferenciada para os canais, e programas de marketing específicos para cruzamento entre canais e desenvolvimento de aplicativos para consulta em dispositivos móveis.

Por sua vez, a retenção na firma apresentou mais força com mulheres com renda alta, buscam em até três lojas, porém o hábito de busca em loja física e compra online, mostra uma inversão de cruzamento entre canais, o que sugere uma preferência por varejistas, não capturada pelo modelo. O alto custo de mudança importa e sugere cruzamento entre canais de busca e compra, porém as forças entre "mesmo ou outro varejista" estão praticamente equivalentes, confirmando um free-riding entre canais de busca e compra. A busca de variedade mostrou maior força para homens com faixas de idade mais avançadas e mais renda familiar.

Os achados contribuem para a gestão multicanal e colocam luz nas motivações para a experiência de compra num ambiente multicanal. Percebe-se que há um enorme potencial a ser explorado em canais de vendas quando se pensa o multicanal além das opções de busca e compra, integrando os consumidores engajados em comunidades sociais, sites de reclamação, sites de revisão de produtos em tempo real, sites de comparação de marcas, reclamações no serviço de atendimento ao consumidor, todos conectados por interesses e todos os canais utilizados simultaneamente, conforme aponta Thoma (2010).

Uma abordagem de canais unificados e convergentes que suportam processos integrados para entregar informação e comunicação de marketing consistente em todos os canais de vendas. Winter (2012) acredita na convergência entre os canais on-line e off-line, havendo cada vez mais superposição, se transformando na oportunidade de repensar a experiência de compra, juntando os benefícios de ambos os canais e agregando valor. 
A experiência de compra está atrelada à entrega eficiente e eficaz do varejista. $A$ boa execução dos processos de operação pelas vendas on-line garante maior retenção do consumidor no varejo multicanal aliada à tecnologia e ações de comunicação de marketing em tempo real. Prazos de entrega encurtados para compras on-line aproximarão as opções de compra entre lojas físicas e on-line. No Brasil, o tempo de entrega on-line tem sido maior do que em relação à loja física, exceto como o caso de parcerias bem sucedidas de co-branding como Lenovo e Walmart, por exemplo, em que um computador foi entregue em praticamente 48 horas na porta de casa pelo fabricante.

A tipologia de consumidores disponibilizou caminhos para o desenho das ações de marketing, em ambiente multicanal integrado de varejistas, oferecendo uma visão holística de experiência de compra ao consumidor.

Os achados nos levam a pensar em retenção (lealdade) pelo lado do consumidor, pela satisfação geral com a repetição da experiência de compra por meio de múltiplos canais. Muitos passos precisam ainda ser dados pelos grandes varejistas no Brasil quando comparados com a Amazon, por exemplo, ou quando comparados com a Best Buy. E ao ofertar níveis de conveniência como o clickandcollect.

\subsection{Limitações do estudo e direcionamentos futuros}

Os achados devem ser interpretados à luz de sua limitação para uma pesquisa survey, as quais oferecem direcionamentos futuros.

O estudo possibilitou o aprofundamento do entendimento da dinâmica do fenômeno em ambiente multicanal, olhando para cruzamento entre dois canais com produtos de categoria de experiência, segundo Nelson (1970).

Embora a base de respondentes tenha sido grande, com 883 casos, não foi suficiente para obter validação do pressuposto de normalidade multivariada, dado que o modelo mostrou ser muito complexo para o método da máxima 
verossimilhança de MEE. O número de casos foi insuficiente para rodar o método de distribuição assimptótica livre. Se ampliar a base de dados para 2.000 casos, o pressuposto de normalidade multivariada cai. A base necessita ser ampliada para a publicação nacional e internacional de artigos ou, outra possibilidade é mudar o método de análise para partial least square (PLS).

O modelo estrutural final apresentou algumas variáveis latentes com dois itens apenas, como a satisfação free-riding, satisfação loja física, retenção da firma e o alto custo de mudança, dificultando o processo de qualidade de ajustamento e a perda de variáveis latentes. Dada a importância destas variáveis optou-se por não retirá-las.

O estudo avança no entendimento da atratividade de cada canal para busca e compra no ambiente multicanal, segundo Verhoef, Neslin e Vroomen (2007)

As percepções dos consumidores não foram relacionadas ao serviço específico de um varejista $A$ ou $B$, o que denota um aumento da subjetividade do respondente $e$ tornaria a pesquisa muito pesada e mais complexa.

O questionário on-line apresentou considerável perda de controle sobre as respostas. Não foi realizado pré-teste do questionário. Além disso, o questionário on-line não sofreu o rodízio dos blocos e itens, o que pôde causar o efeito halo ressaltado pela ciência comportamental, um tipo de viés ${ }^{47}$ cognitivo do respondente. Porém a base de casos revelou uma riqueza de diversidade e variedade pelo perfil do respondente, permitindo uma rica análise de moderação, de forças e de diferenças de médias significativas para o modelo estrutural.

Direcionamentos futuros para a pesquisa de comportamento de alternância implicaria o desenvolvimento de novos itens de mensuração e testadas as variáveis latentes. Além disso, uma nova composição de itens para satisfação, retenção na firma e custo de mudança, corrigindo a deficiência de itens.

${ }^{47}$ Common method biases 
A experiência vicária proposta por Bandura (1999) pode ser atualizada com a inclusão da aprendizagem com comunidades virtuais, sites de revisão, sites de reclamação, ou seja, tudo aquilo que inclua uma aprendizagem social.

O construto retenção na firma poderá ser ampliado conforme o artigo de Dholakia, Zhao e Dholakia (2005) que inclui devolução ou retorno de mercadorias por canal. Alguns novos construtos a serem testados: comportamento de recompra, ampliação da percepção de qualidade de serviços via website (garantia, prontidão de resposta, processo de acompanhamento, prazo de entrega, pós-venda, retornos etc.). Para barreiras de mudança, Tsai et al. (2006) sugerem a construção de comunidade virtual e a expectativa futura de compartilhamento de valor. A comunidade virtual representa uma forma de associação dentro de um contexto para compartilhar a experiência de consumo com um dado e-varejista, encorajando a comunicação entre todos os atores envolvidos na compra de produtos. A expectativa de compartilhamento de valor é definida pela extensão em que os consumidores percebem que os valores tangíveis dos benefícios econômicos serão compartilhados pelo serviço do varejista no futuro, uma forma de retenção psicológica pelo relacionamento com o varejista. 


\section{Referências}

AAGJA, J.P.; MAMMEN, T.; SARASWAT, A. Validating service convenience scale and profiling customers: a study in the indicant context. Vikalpa, Ahmedabad, v.36, n.4, October-December, 2011.

AAKER, David A.; KUMAR, V.; DAY, George S. Pesquisa de marketing. 2. ed. São Paulo: Atlas, 2004.

ANDERSON JR, W. T. Convenience orientation and consumption behavior. Journal of Retailing, New York, v.48, n.3, p. 49-127, Fall, 1972.

ANDERSON, T. L. Relationships among internet attitudes, internet use, romantic beliefs, and perceptions of on-line romantic relationships. CyberPsychology \& Behavior, Cambridge (MA), v.8, n.6, p. 521-531, 2005.

ANDERSON, J.C.; GERBING, D.W. Structural equation modeling in practice: a review and recommended two-step approach. Psychological Bulletin, Washington, v. 103, n.3, p.411-423, 1988.

BAKOS, Y. The emerging landscape for retail e-commerce. Journal of Economic Perspectives, Pittsburgh, v. 15, n.1, p. 69-80, 2001.

BADRINARAYANAN, V.; BECERRA, E. P.; KIM, C-H; MADHAVARAM, S. Transference and congruence effects on purchase intentions in on-line stores of multi-channel retailers: initial evidence from the U.S. and South Korea. Journal of the Academy of Marketing Science, New York, v.40, p. 539-557, 2012.

BAGOZZI, R.P. Structural equation models in experimental research. Journal of Marketing Research, Chicago, v.14, p. 209-226, May, 1977.

BAGOZZI, R. P. ; YI, Y. Specification, evaluation, and interpretation of structural equation models. Journal of the Academy of Marketing Science, New York, v. 401, n.8, p.8-34, 2012.

BALASUBRAMANIAN, S.; RAGHUNATHAN, R.; MAHAJAN, V. Consumers in a multichannel environment product utility, process utility, and channel choice. Journal of Interactive Marketing, Philadelphia, v.19, n.2, p. 12-30, 2005.

BANCO DE TESES CAPES. Disponível em:

http://www.capes.gov.br/servicos/banco-de-teses. Acesso em: 16/05/2012.

BANDURA, A. Social Learning Theory. New Jersey: Prentice-Hall, 1977.

Press, 1999.

Self-efficacy in Changing Societies. New Jersey: Cambridge University

BANDURA, A.; JOURDEN, F.J. Self-regulatory mechanism governing the impact of social comparison on complex decision making. Journal of Personality and Social Psychology, Washington, v. 60, n.6, p. 941-951, 1991. 
BARON, R.M.; KENNY, D.A. The moderator-mediator variable distinction in social psychological research: conceptual, strategic, and statistical considerations. Journal of Personality and Social Psychology, Washington, v.51, n. 6, p. 1173-1172, 1986.

BANSAL, H.S.; TAYLOR, S.F.; JAMES, Y.St. Migrating to new service providers: toward a unifying framework of consumers' switching behaviors. Journal of Academy of Marketing Science, New York, v. 33, n.1, p. 96-115, 2005.

BAPTISTA, P.P. Lealdade do consumidor e os seus antecedentes: um estudo aplicado ao setor varejista na internet. 184 p. Tese - marketing. Universidade de São Paulo - Programa de Pós-Graduação em Administração), São Paulo, 2005.

BARRET, P. Structural equation modeling: adjudging model fit. Personality and Individual Differences, Toronto, v. 42, n. 5, p. 815-824, 2007.

BENDOLY, E.; BLOCHER, J.D.; BRETTHAUER, K.M.; KRISHNAN, S.; VENKATARAMAN, M.A. On-line/in-store integration and customer retention. Journal of Service Research, Arizona, v.7, n.4, p.313-327, 2005.

BENTLER, P.M. On tests and indices for evaluating structural models. Personality and Individual Differences, Toronto, v.42, p. 825-829, 2007.

BERRY, L. L.; SEIDERS, K.; GREWAL, D. Understanding service convenience. Journal of Marketing, Chicago, v. 66, p. 1-17, July 2002.

BETTMAN, J.R. Perceived risk and its components: a model and empirical test. Journal of Marketing Research, Chicago, v. X, p. 184-190, May, 1973.

BLACKWELL, R.D.; MINIARD, P. W.; ENGEL, J. F. Comportamento do consumidor. 9. ed. Tradução de Eduardo Teixeira Ayrosa (coord.). São Paulo: Cengage Learning, 2011.

BOBBITT, L.M.; DABHOLKAR, P.A. Journal of Service Management, Bingley, v. 12, n. 5, p. 423-450, 2001.

BOLLEN, K. A. Structural equations with latent variables. New York: John Wiley \& Sons, 1989.

BOLTON, R.N.; KANNAN, P.K.; BRAMLETT, M.D. Implications of loyalty program membership and service experiences for customer retention and value. Journal of the Academy of Marketing Science. New York, v. 28, n. 1, p. 95-108, 2000.

BRASHEAR, Thomas G.; KASHYAP, Vishal; MUSANTE, Michael D.; DONTHU, Naveen. A profile of the internet shopper: Evidence from six countries. Journal of Marketing Theory and Practice, Winter Park, v. 17, n. 3, p. 267-281, summer 2009. 
BRYNJOLFSSON, E.; HU, U. J.; RAHMAN, M.S. Competing in the age of omnichannel retailing. Sloan Management Review. Boston, v. 54, n.4, p.23-29, Summer, 2013.

BURKE, R.R. Technology and customer interface: what consumers want in the physical and virtual store. Journal of the Academy of Marketing Science, New York, v.30, n.4, p. 411-432, 2002.

BURNHAM, T.A.; FRELS, J.K.; MAHAJAN, V. Consumer Switching Costs: a Typology, Antecedents, and Consequences. Journal of the Academy of Marketing Science, New York, v.31, n.2, p.109-126, 2003.

CARLTON, D.W.; CHEVALIER, J. A. Free-riding and sales strategies for the internet. The Journal of Industrial Economics, Malden, v. XLIX, n. 4, p. 441-461, December, 2001.

CHANG, M-L; WU, W-Y. Revisiting Perceived Risk in the Context of On-line Shopping: An Alternative Perspective of Decision-Making Styles. Psychology \& Marketing, Malden, v. 29, n. 5, p. 378-400, May 2012.

CHAUDHURI, A.; HOLBROOK, M.B. The chain of effects from brand trust and brand affect to brand performance: the role of brand loyalty. Journal of Marketing, Chicago, v.65, p. 81-93, April 2001.

CHELLAPPA, R.K.; PAVLOU, P.A. Perceived informational security, financial liability and consumer trust in electronic commerce transactions. Logistics Information Management, Bingley, v.15, n. 5/6, p. 358-368, 2002.

CHIU, Hung-Chang; HSIEH, Yi-Ching; ROAN, Jinshyang; TSENG, Kuan-Jen; HSIEH, Jung-Kuei. The challenge for multichannel services: cross-channel free-riding behavior. Electronic Commerce Research and Applications; Amsterdam, v.10, issue 2, p. 268-277, March-April, 2011.

CHRISTODOULIDES, G.; MICHAELIDOU, N. Shopping motives as antecedents of e-satisfaction and e-loyalty. Journal of Marketing Management, Scotland, v. 27, n. 1-2, p. 181-197, February, 2011.

COMPEAU, D.R.; HIGGINS, C.A.; Computer self-efficacy: development of a measure and initial test. MIS Quarterly, Arizona, v. 19, n. 2, p. 189-211,1995.

COPELAND, M. T. Relation of consumers' buying habits to marketing methods. Havard Business Review, Boston, v.1, n.3, p. 282-289, April 1923.

CORTINA, J.M. What is coefficient alpha? An examination of theory and applications. Journal of applied Psychology, Washington, v. 78, n. 1, p. 98-104, 1993.

COUGHLAN, A.T.; ANDERSON, E.; STERN, L.W.; EL-ANSARI, A.I. Canais de Marketing e Distribuição. Tradução de Lucia Simonini. 6. ed. Porto Alegre: Bookman, 2002. 
DABHOLKAR, P. A. Incorporating choice into an attitudinal framework: analyzing models of mental comparison process. Journal of consumer research, Chicago, v. 21, June, p. 100-118, $1994 . \quad$ Disponível em: http://www.acrwebsite.org/volumes/display.asp?id=7357\&print=1. Acesso em: 28/12/12.

DASH, S.; SAJI, K.B. The role of consumer self-efficacy and website social-presence in customers' adoption of B2C on-line shopping: an empirical study in the Indian context. Journal of International Consumer Marketing, New York, v.20, n.2, p.3348, 2007.

DELOITTE: Reinventing retail: a multi-channel transformation, 2011. Disponível em: http://www.deloitte.com/view/en_GX/global/search/index.htm?searchKeywordsField= reinventing+retailing\&searchKeywordsFieldDefault=Search\&searchBtn. $x=7$ \&searchB tn. $y=3$. Acesso em: 26/12/2011.

DICK, A. S.; BASU, K. Customer loyalty: toward an integrated conceptual framework. Journal of Academic of Marketing Science, New York, v.22, n. 2, p. 99-113, 1994.

DIRETRIZES PARA APRESENTAÇÃO DE DISSERTAÇÕES E TESE DA USP: PARTE I (ABNT). Disponível em:

http://www.usp.br/sibi/produtos/imgs/Caderno_Estudos_9_PT_1.pdf. Acesso em 18/10/2012.

DHOLAKIA, R. R.; ZHAO, M.; DHOLAKIA, Multichannel retailing: a case study of early experience. Journal of Interactive Marketing, New York, v. 19, n.2, p. 63-74, 2005.

DOM STRATEGY PARTNERS. Disponível em:

http://www.domsp.com.br/boutique/linhas/GEM. Acesso em: 26/12/2011.

DOWLING, G.R.; STAELIN, R. A model of perceived risk and intended risk-handling activity. Journal of Consumer Research, Chicago, v.21, p. 119-134, June, 1994.

DOWLING, G.; UNCLES, M. Do customer loyalty programs really work? Sloan Management Review, Boston, v.38, p. 71-82, Summer, 1997.

DUTTA, S.; SEGEV, A. Business transformation on the internet. European Management Journal, Amsterdam, v.17, n.5, p. 466-476, 1999.

EASTIN, M. S. Teen internet use: Relating Social Perceptions and Cognitive Models to Behavior. Cyberpsychology \& Behavior, New Rochelle, v.8, n.1, p.62-75, 2005.

E-bit Relatório Webshoppers 25a edição, 2011. Disponível em: http://ebiz.01 mix.net/Arquivos/Pesquisas/WebShoppers25.pdf. Acesso em: 17/08/2012.

EDISON, S.W.; GEISSLER, G.L. Measuring attitudes towards general technology: antecedents, hypotheses and scale development. Journal of Targeting, Measurement and Analysis for Marketing, Hampshire, v.12, n.2, p. 137-156, 2003. 
EVANSCHITZKY, H; IYER, G. R.; HESSE, J.; AHLERT, D. E-satisfaction: a reexamination. Journal of Retailing, New York, v.80, p. 239-247, 2004.

FISHBEIN, M.; AJZEN, I. Belief, Attitude, Intention and Behavior: an introduction to Theory and Research. Massachusetts: Addison Wesley Publishing Company, 1975. Disponível em:

http://people.umass.edu/aizen/f\&a1975.html. Acesso em 27/04/2012.

FISHBEIN, M; MIDDLESTADT, S. Noncognitive effects on attitude formation and change: fact 0 artifact? Journal of Consumer Psychology, Philadelphia, v. 4, n.2, p. 181-202, 1995.

FÁVERO, L.P.L.; BELFIORE, P. P. e CHAN, B. Análise de dados: modelagem multivariada para tomada de decisões. São Paulo: Campus, 2009.

FORD, N.; MILLER, D.; MOSS, N. The role of individual differences in internet searching: an empirical study. Journal of the American Society for Information Science and Technology, Hoboken, v. 52, n.12, p. 1049-1066, 2001.

FORNELL, C. A national customer satisfaction barometer: the Swedish experience. Journal of Marketing, Chicago, v. 56, n. 1, p. 6-21, 1992.

FORNELL, C.; LARCKER, D. F. Evaluating structural equation models with unobservable variables and measurement error. Journal of Marketing Research, Chicago, v.18, n.1, p. 39-50, Feb., 1981.

FORRESTER RESEARCH: US Cross-Channel Retail Forecast, 2011 to 2016.FORRESTER, Cambridge, USA, July, 2012. Disponível em: http://gallery.mailchimp.com/1c9638b4183ef253c2212becf/files/US_Cross_Channel_ Retail_F.pdf. Acesso em 5/05/2014

GANESH, J; REYNOLDS, K.E.; LUCKETT, M.G. Retail patronage behavior and shopper typologies: a replications and extension using a multi-format, multi-method approach. Journal of the Academy Marketing Science, New York, v.35, p. 369381, 2007.

GARBARINO, E.; STRAHILEVITZ, M. Gender differences in the perceived risk of buying on-line and the effects of receiving a site recommendation. Journal of Business Research, Philadelphia, v.57, n.7, p. 768-775, 2004.

GARVER, M. S.; MENTZER, J. T. Logistics research methods: employing structural equation modeling to test construct validity. Journal of Business Logistics, Arkansas, v.20, n.1, 1999.

GOOGLE NGRAM VIEWER. Disponível em:

http://books.google.com/ngrams/graph?content=multichannel\%2C+multichannel+sal es $\% 2 \mathrm{C}+$ multichannel+marketing\&year_start $=1800 \&$ year_end $=2013 \&$ corpus $=15 \& \mathrm{sm}$ oothing=3\&share $=$. Acesso em: 22/03/2013. 
GREWAL, R.; COTE, J. A.; BAUMGARTNER, H. Multicollinearity and measurement error in structural equation models: implications for theory testing. Marketing Science, Catonsville, v. 23, n.4, p. 519-529, Fall, 2004.

GIESE, J.L.; COTE, J. A. Defining consumer satisfaction. Academy of Marketing Science Review, Ruston, v.1, p. 1-24, $2000 . \quad$ Disponível em: http://www.amsreview.org/articles/giese01-2000.pdf, acesso em 22/11/2012.

GIGLIO, E. M. O comportamento do consumidor. 3. ed. São Paulo: Cengage Learning, 2008.

GIL, A. C. Como elaborar projetos de pesquisa. 4. ed. São Paulo: Atlas, 2007.

GILLETT, P.L. In-home shoppers. An overview. Journal of Marketing, Chicago, v.40, n.4, p. 81-88, 1976.

GIRARD,T.; KORGAONKAR, P.; SILVERBLATT, R. Relationship of type of product, shopping orientations, and demographics with preference for shopping on the internet. Journal of Business and Psychology, New York, v.18, n. 1, fall, 2003.

GISE, J.L.; COTE, J.A. Defining consumer satisfaction. Academy of Marketing Science Review, Ruston, v.1, p. 1-24, 2000. Disponível em: http://www.amsreview.org/articles/giese01-2000.pdf, acesso em 2/05/2013.

GRAHAM, G.H. The world of business. EUA: Addison-Wesley, 1985.

GREMAUD, A. P. Manual de Economia. Organizadores: Diva Benevides Pinho e Marcos Antônio Sandoval de Vasconcellos. 4. ed. São Paulo: Saraiva, 2003.

HAGEN, K.M.; TERRY, B. G; WILSON, C.P.; OATS, R.G. Using vicarious Experience and Verbal Persuasion to Enhance Self-Efficacy in Pre-service Teachers: "Priming the pump" for Consultation. School Psychology Quarterly, Washington, v.13, nr. 2, p. 169-178, 1998.

HAHN, K.H.; KIM, J. The effect of offline brand trust and perceived internet confidence on on-line shopping intention in the integrated multi-channel context. International Journal of Retail \& Distribution Management, Bingley, v. 37, n.2, p. 126-141, 2009.

HAIR JR, J. F.; ANDERSON, R.E.; TATHAM, R. L.; BLACK, W. C. Multivariate data Analysis. 4. ed. New Jersey: Prentice Hall, 1995.

HAIR JR, J. F.; ANDERSON, R.E.; TATHAM, R. L.; BLACK, W. C. Análise multivariada de dados. Traduzido por Adonai Schlup Sant'Anna e Anselmo Chaves neto. 5. ed. Porto Alegre: Bookman, 2005.

HAIR JR, J.F.; BLACK, W.C.; BABIN, B.J.; ANDERSON, R.E.; TATHAN, R.L. Análise multivariada de dados. Traduzido por Adonai Schlup Sant'Anna. 6.ed. Porto Alegre: Bookman, 2009. 
HARDGRAVE, B. Omnichannel retailing. RFID Journal. [S.I.], v. 9, n.6, p. 38-38, Nov/Dec 2012.

HARRIS INTERACTIVE. Disponível em:

http://www.harrisinteractive.com/Products.aspx. Acesso em 26/12/2011.

HAWKINS, D.L.; MOTHERSBAUGH, D.L.; BEST, R.J. Comportamento do Consumidor. Traduzido por Claudia Mello Belhassof. 10. ed. Rio de Janeiro: Elsevier, 2007.

HEIDE, J. B. Interorganizational governance in marketing channels. The Journal of Marketing, Chicago, v.58, p. 71-85, 1994.

IBGE: disponível em:

http://www.ibge.gov.br/home/estatistica/populacao/estimativa2013/estimativa_tcu.sht m. Acesso em: 27/04/2014.

IBM: Institute for Business Value. Chu, J.; Pike, T. Integrated multi-channel retailing (IMCR): a roadmap to the future. Disponível em: http://ftp.boulder.ibm.com:21/software/websphere/pdf/ibv_imcr.pdf. Acesso em 26/12/2011.

INTERNET RETAILER: Disponível em: http://www.internetretailer.com/top500/. Acesso em: 11/04/2014.

IPEA ao vivo: Instituto de pesquisa econômica aplicada. Venda on-line cresce no Brasil, mas receita é de só $1 \%$ de todo o varejo. G1.COM.BR, São Paulo, 20/06/2011, 11:26. Disponível em:

http://www.ipea.gov.br/portal/images/stories/PDFs/comunicado/110602_comunicadoi pea95.pdf. Acesso em 4/05/2012.

JONES, M.A.; MOTHERSBAUGH, D.L.; BEATTY, S.E. Switching barriers and repurchase intentions in services. Journal of Retailing, New York, v. 76, n.2, p. 259$274,2000$.

JONES, M.A.; TROCCHIA, P.J.; MOTHERSBAUGH, D.L. Noneconomic motivations for price haggling: an exploratory study. Advances in Consumer Research, Duluth, v. 24, p. 388-391,1997.

JOHNSON, E, J.; BELLMAN, S.; LOHSE, G.L. Cognitive Lock-In and the Power Law of Practice. Journal of Marketing, Chicago, v. 67, p. 62-75, April 2003.

JOHNSON, C.J.; WICHERN, D.W. Applied multivariate statistical analysis. 4.ed., New Jersey: Prentice Hall, 1998.

JÖRESKOG, K; SÖRBOM, D. Recent developments in structural equation modeling. Journal of Marketing Research, Chicago, v. XIX, November, p. 404-416,1982.

JÖRESKOG, K; SÖRBOM, D LISREL 8: user's reference guide, 2. ed. Lincolnwood: Scientific Software International, 1996. Disponível em: 
http://books.google.co.in/books?id=9AC-s50RjacC\&printsec=frontcover\&hl=pt$B R \&$ source $=g b s \_g e \_s u m m a r y \_r \& c a d=0 \# v=s n i p p e t \& q=p .28 \& f=f a l s e$. Acesso em 23/03/2014.

KAUFMAN-SCARBOROUGH, C.; LINDQUIST, J. D. E-shopping in a multiple channel environment. Journal of Consumer Marketing, Bingley, v. 19, n. 4/5, p. 333-350, 2002.Disponível em:

http://www.crab.rutgers.edu/ ckaufman/JCMEshopping.pdf. Acesso em 25/02/14.

KELLEY, E. J. The importance of convenience in consumer purchasing. The Journal of Marketing, Chicago, v.23, n. 1, p. 32-38, Jul 1958.

KLEIN, L.R.; FORD, G.T. Consumer search for information in the digital age: an empirical study of repurchase search for automobiles. Journal of Interactive Marketing, v.17, n.3, p. 29-49, 2003.

KLINE, R. B. Principles and Practice of Structural Equation Modeling. 3. ed. New York: The Guilford Press, 2011.

KONUS, U.; VOERHEUF,P. C.; NESLIN, S. A. Multichannel shopper segments and their covariates. Journal of Retailing, New York, v. 84, n.4, p. 398-413, 2008.

KOTLER, P. Marketing in Australia. 2. ed. Australia: Prentice Hall, 1989.

KOTLER, P. Administração de Marketing. São Paulo: Prentice Hall, 2000.

KOTLER, P.; ARMSTRONG, G. M. Principles of marketing. 12. ed. New Jersey: Prentice Hall, 1989.

KOTLER, P; ARMSTRONG, G. Princípios de Marketing. 9. ed. São Paulo: Prentice Hall, 2003.

KOTLER, P.; KELLER, K.L. Administração de Marketing. Tradução de Monica Rosenberg, Claudia Freire e Brasil Ramos Fernandes. 12. ed. São Paulo: Pearson, 2006.

KOTLER, P.; KELLER, K.L. Marketing Management. 14. ed. New Jersey: Pearson, 2012.

KUMAR, V.; VENKATESAN, R.; Who are the multichannel shoppers and do they perform? Correlates of multichannel shopping behavior. Journal of Interactive Marketing, New York, v.19, n. 2, p. 44-62, 2005.

LAZONDER, A. W.; BIEMANS, H. J. A.; WOPEREIS, I. Differences between novice and experienced users in searching information on the World Wide Web, Journal of the American Society for Information Science, New York, v.51, n.6, p. 576-581, 2000. 
LEE, E.S. A theory of migration. Demography, New York, vol. 3, n.1, p. 47-57, 1966. Disponível em: http://www.students.uni-mainz.de/jkissel/Skripte/Lee.pdf. Acesso em: 11/02/2014.

LEGATT, H. Have you met the omni-channel shoppers? BizReport: E-commerce [S.I.], October 23, 2009. Disponível em: http://www.bizreport.com/2009/10/have_you_met_the_omnichannel_shoppers.html\#. Acesso em: 03/03/2014.

LIEBOWITZ, S. Rethinking The Network Economy: The True Forces That Drive The Digital Marketplace. New York: Amacom, 2002. Disponível em: http://wwwpub.utdallas.edu/ liebowit/knowledge_goods/book.pdf. Acesso em: 20/06/2012.

MADDUX, J.E.; NORTON, L.W.; STOLTENBERG, C.D. Self-efficacy expectancy, and outcome value: relative effects on behavioral intentions. Journal of Personality and Social psychology, v.51, n.4,p. 783-789, 1986.

MAHMOOD, M. A.; BAGCHI, L.; FORD, T.C. On-line shopping behavior: crosscountry empirical research. International Journal of Electronic Commerce, Armonk, v.9, nr.1, p. 9-30, Fall, 2004.

MAITY, M.; HSU, M.K.; PELTON, L. E. Consumer's on-line information search: gen yers' finding needles in the internet haystack. Journal of Marketing Channel, New York, v.19, n.1, p. 49-76, 2012.

MALHOTRA, N. K. Pesquisa de Marketing: uma orientação aplicada. Traduzido por Laura Bocco. Reimpressão, 4. Ed. Porto Alegre: Bookman, 2006.

MANKIW, N. G. Introdução à economia. Tradução de Allan Vidigal Hastings. 3. ed. São Paulo: Thomson Learning, 2006.

MARCHETTI, R.; PRADO, P.H.M. Um tour pelas medidas de satisfação do consumidor. RAE - Revista de Administração de Empresas, v. 41, n.4, p. 56-67, out/dez 2001.

MARCONI, M. de A.; LAKATOS, E. M. Fundamentos de metodologia científica. 6. ed. São Paulo: Atlas, 2007.

MARÔCO, J. Análise de equações estruturais: fundamentos teóricos, software e aplicações. Portugal: Rolo \& Filhos II, 2010.

MARÔCO, J. e GARCIA-MARQUES, T. Qual a fiabilidade do alfa de Cronbach? Questões antigas e soluções modernas? Laboratório de Psicologia, Lisboa, v.4, n.1, p.65-90, 2006.

MATTAR, F.N. Administração de Varejo. Rio de Janeiro: Elsevier, 2011. 
MAYER, R.C.; DAVIS, J.H.; SCHOORMAN, F.D. An integrative model of organizational trust. Academy of Management Review, New York, v. 20, n. 3, p. 709-734, 1995.

MAZZON, J. A. Análise do programa de alimentação do trabalhador sob o conceito de marketing social, 1981, número de páginas. Tese - em administração - Faculdade de Economia, Administração e Contabilidade da Universidade de São Paulo, São Paulo, 1981.

MCKEE, D.; SIMMERS, C.S.; LICATA, J. Customer self-efficacy and response to service. Journal of Service Research, Arizona, v.7, n.3, p. 207-220,Feb, 2006.

MENARD, C. The economics of Hybrid Organizations. Journal of Institutional and Theoretical Economics, Tübingen, v.160, p. 345-376, 2004.

MEUTER, M. L.; BITNER, M. J.; OSTROM, A. L.; BROWN, S. W. Choosing among alternative service delivery modes: an investigation of customer trial of self-service technologies. Journal of Marketing, Chicago, v. 69, n. 2, p. 61-83, 2005.

McKINSEY: Multi-Channel Marketing: Making "bricks and clicks" stick, August, 2000. Disponível em:

http://notebookmanuals.bestmanualguide.com/pdfs/multi-channel-marketing-makingbricks-and-clicks-stick.html, acesso em 26/12/2011.

MICK, D.G.; FOURNIER, S. Paradoxes of technology: consumer cognizance, emotions, and coping strategies. Journal of Consumer Research, Chicago, v.25, n.2, p. 123-143, 1998.

MOLINA, M.E.R Perceived value, customer attitude and loyalty in retailing. Journal of Retailing \& Leisure Property, Hampshire, v.7, n.4, p. 305-314, 2008.

MONTOYA-WEISS, M. M.; VOSS, G.B.; GREWAL, D; Determinants of On-line Channel Use and Overall Satisfaction with a Relational Multichannel Service Provider. Journal of the Academy of Marketing Science, New York, v.31, nr.4, p. 448-458, 2003.

MOREIRA, A. da S. Dinheiro no Brasil: um estudo comparativo do significado do dinheiro entre as regiões geográficas brasileiras. Estudos de Psicologia, Natal, v.7, n.2, p. 379-387, 2002.

MORGAN, R.M.; HUNT, S.D. The commitment-trust theory of relationship marketing. Journal of Marketing, Chicago, v.58, p. 20-38, July, 1994.

NELSON, P. Information and consumer behavior. Journal of Political Economy, Chicago, v.78, n.2, p. 311-329, 1970.

NESLIN, S.A.; GREWAL, D.; LEGHORN, R.; SHANKAR, V.; TEERLING, M.L.; THOMAS, J.S.; VERHOEF, P.C. Challenges and opportunities in multichannel customer management. Journal of Service Research, Arizona, v.9, n.2, p.95-112, 2006. 
NIELSEN NETRATING. On-line retail report card: highest conversion rates amongst non-brick-and-mortar retailers, Nielsen NetRatings Megaview on-line retail, 2005. Disponível em: http://www.nielsen-on-line.com/pr/pr_050407.pdf. Acesso em: 22/05/2012.

NIRMALYA, B.; JAYASHREE, D; HARSH, P. Paradigms of satisfaction research: a conceptual foundation. Advances in Management, [S.I.], v.5. N.3, p. 17-20, Mar, 2012.

OLIVER, R.L. Measurement and evaluation of satisfaction process in retail settings. Journal of Retailing, New York, v. 57, n. 3, Fall, p. 25-48, 1981.

. Whence consumer Loyalty? Journal of Marketing, Chicago, v.63 (edição especial), p. 33-44, 1999.

OLIVEIRA, F. A. Risco percebido e Orientação para Compras: um estudo empírico em Varejo Multicanal. 2009, 97p. Dissertação - administração. Pontifícia Universidade Católica do Rio de Janeiro, Rio de Janeiro, 2009. Disponível em: http://www2.dbd.puc-

rio.br/pergamum/biblioteca/php/mostrateses.php?open=1\&arqtese=0712880_09_Indi ce.html. Acesso em 16/05/2012.

OTNES, C; MCGRATH, M.A. Perceptions and realities of male shopping behavior. Journal of Retailing, New York, v. 77, p. 111-137, 2001.

PARASURAMAN, A.; ZEITHAML, V.A.; BERRY, L.L. SERVQUAL: a multiple-item scale for measuring consumer perceptions of service quality. Journal of Retailing, New York, v.64, n.1, p. 12-40, Spring, 1988.

PARENTE, J. Varejo no Brasil. São Paulo: Atlas, 2010.

PORTER, M. E. What is strategy? Harvard Business Review, Boston, NovemberDecember, 1996.

PORTO, R. M. Varejo multicanal: grau de integração e o varejo de livros no Brasil. 2006, 267p. Tese (Doutorado) na Fundação Getúlio Vargas de São Paulo Administração de Empresas, SP, 2006.

PREARO, L. C. O uso de técnicas estatísticas multivariadas em dissertações e teses sobre o comportamento do consumidor: um estudo exploratório. 2008, 100p. Dissertação - administração - Faculdade de Economia, Administração e Contabilidade da USP, São Paulo, 2008.

RANAWEERA, C.; PRABHU, J. The influence of satisfaction, trust and switching barriers on customer retention in a continuous purchasing setting. International Journal of Service Industry Management, Bingley, v.14, n.4, p. 374-395, 2003.

RANKING IBEVAR: 120 maiores empresas do varejo brasileiro. PROVAR (Programa de Varejo - FIA), São Paulo, 2013. 
REICHHELD, F.F.; SCHEFTER, P. E-loyalty: your secret weapon on the web. Harvard Business Review, v.78, n.4, p. 105-113, July-August, 2000.

REINARTZ, W.; KRAFFT, M.; HOYER, W. D. The customer relationship management process: its measurement and impact on performance. Journal of Marketing Research, Chicago, v. XLL, p. 293-305, Aug, 2004.

RIGBI, D. The future of shopping. Harvard Business Review, Massachusetts, p.6576, December, 2011.

ROHM, A.J.; SWAMINATHAN, V. A typology of on-line shoppers based on shopping motivations. Journal of Business Research, Miamisburg, v.57, n. 7, p. 748-757, Jul, 2004.

ROSENBLOOM, B. Marketing Channels. 7. ed. Mason: Thomson Learning, 2004.

SAUER, P. L.; DICK, A. Using moderator variables in structural equation models. Advances in Consumer Research, Duluth, v.20, 1993.

SAWHNEY, M. Don't homogenize, synchronize. Harvard Business Review, Boston, v.79, p. 101-108, 2001.

SCHIFFMAN, L. G; KANUK, L.L. Comportamento do Consumidor. Traduzido por Dalton Conde de Alencar. 9. ed. Rio de Janeiro: LTC, 2009.

SCHINDLER, R.M. The excitement of getting a bargain: some hypotheses concerning the origins and effects of smart-shopper feelings. Advances in Consumer Research, Duluth, v. 16, p. 447-453, 1989.

SCHRAMM-KLEIN, H.; WAGNER, G.; STEINMANN, S.; MORSCHETT, D. Crosschannel integration - is it valued by customers? The International Review of Retail, Distribution and Consumer Research, London, v.21, n.5, p. 501-511, December, 2011.

SELTZER, L. F. Influencing the "shape" of resistance: an experimental exploration of paradoxical directives and psychological reactance. Basic and Applied Social Psychology, New York, v. 4(1), p. 47-71, 1983.

SHANKAR, V.; SMITH, A.K.; RANGSWAMY, A. Customer satisfaction and loyalty in on-line and offline environments. International Journal of Research in Marketing, Amsterdam, v. 20, ed. 2, p. 153-176, Jun 2003.

SHARMA, S.; DURAND, R.M.;GUR-ARIE,0. Identification and analysis of moderator variables. Journal of Marketing Research, Chicago, v.18, n.3, p. 291-300, Aug. 1981.

SHINYASHIKI, R. T. A influencia da autoeficácia dos gestores na administração de crises. Tese (Doutorado) da Universidade de São Paulo, na Faculdade de 
Economia, Administração e Contabilidade USP - departamento de administração, SP, 2006.

SOLOMON, M.R. O comportamento do consumidor: comprando, possuindo e sendo. Traduzido por Luiz Claudio de Queiroz Faria. 9a edição. Porto Alegre: Bookman, 2011.

SOUZA, M. G.; SERRENTINO, A. Multivarejo: na próxima economia. São Paulo: Makron books, 2002, 211p.

STELZER, J. Looking beyond multichannel. CRM Magazine. [S.I.], v.17, n.9, p. 6-6, Sep 1, 2013.

STEVENSON, W.J. Estatística aplicada à administração. Traduzido por Alfredo Alves de Farias. São Paulo: Harbra, 1981

SWAID, S. I.; WIGAND, R. T. The effect of perceived site-to-store service quality on perceived value and loyalty intentions in multichannel retailing. International Journal of Management, Chicago, v. 29, n. 3, part 2, p. 301-313, Sep 2012.

SWAMINATHAN, V.; LEPKOWSKA-WHITE, E.; RAO, B.P. Browsers or buyers in cyberspace? An investigation of factors influencing electronic exchange. Journal of Computer-Mediated Communication, Pennsylvania, v. 5, n. 2, p. 1-23, 1999.

SZIMANSKI, D.M.; HISE, R.T. E-satisfaction: an initial examination. Journal of Retailing, New York, v. 76, n.3, p. 309-322, 2000.

TAUBER, E.M. Why do people shop? Journal of Marketing, Chicago, v.36, p. 4659, Oct, 1972.

TELLES, R. A efetividade da "matriz de amarração" de Mazzon nas pesquisas em administração. Revista de Administração, v.36, n. 4, p.64-72, out/dez, 2001.

THOMA, C. The Omnichannel shopper: anytime, anyplace, anywhere. Retail online Integration. [S.I.], December 23, 2010. Disponível em: http://www.retailonlineintegration.com/article/the-omnichannel-shopper-anytime-anyplace-anywhere/1. Acesso em: 3/03/2014.

TSAI, H.T.; HUANG, H.C.; JAW, Y.L.; CHEN, W.K. Why on-line customers remain with a particular e-retailer: an integrative model and empirical evidence. Psychology and Marketing, Auburn, v. 23, n. 5, p. 447-464, 2006.

TSE, D.K.; NICOSIA, F.M.; WILTON, P. C. Consumer satisfaction as a process. Psychology \& Marketing, Auburn, v. 7, n. 3, p. 177-193, Fall, 1990.

TSE, D.K.; WILTON, P. C. Models of consumer satisfaction formation: an extension. Journal of Marketing Research, Chicago, v. XXV, p. 204-212, May, 1988. 
TOP OF MIND internet (2007), Datafolha, São Paulo, 30 de maio de 2007. Disponível em http://datafolha.folha.uol.com.br/po/ver_po.php?session=455\#,. Acesso em: 5/05/2012.

UNIVERSIDADE DE SÃO PAULO. Sistema Integrado de Bibliotecas. Diretrizes para apresentação de dissertações e teses da USP: documento eletrônico e impresso; parte I (ABNT). 2. ed. São Paulo: SIBi/USP, 2009.

URBANY, J.E. An Experimental Examination of the Economics of Information. Journal of Consumer Research, Chicago, v.13, September, 1986.

VAN BAAL, S.; DACH, C. Free-riding and customer retention across retailers' channels. Journal of Interactive Marketing, New York, p. 75-85, Spring, 2005.

VERGARA, S. C. Projetos e Relatórios de Pesquisa em Administração. 9. ed. São Paulo: Atlas, 2007.

VERHOEF, P. C.; DONKERS, B. The Effect of Acquisition Channels on Customer Loyalty and Cross-Buying. Journal of Interactive Marketing, New York, v. 19, $\mathrm{nr} 2$, Spring, p. 31-44, 2005.

VERHOEF, P. C.; NESLIN, S.A., VROOMEN, B.. Multichannel customer management: understanding the research-shopper phenomenon. International Journal of Research in Marketing, Amsterdam, v.24, n. 2, p.129-148, 2007.

WANG, G.; NETEMYER, R.G. The effects of job autonomy, customer demandingness, and trait competitiveness on salesperson learning, self-efficacy, and performance. Journal of the Academy of Marketing Science, New York, v. 30, n. 3, p. 217-228, 2002.

WEBSHOOPERS 23a edição, E-bit, 2010. Disponível em: http://www.slideshare.net/GersonR/relatrio-webshoppers-23-balano-geral-de-2010. Acesso em: 16/05/2012.

WEBSHOOPERS 29a edição, E-bit, 2014. Disponível em: http://img.ebit.com.br/webshoppers/pdf/WebShoppers2014.pdf. Acesso em: 20/06/2014.

WEINBERG, B.D.; PARISE, S.; GUINAN, P.J. Multichannel Marketing: mindset and program development. Business Horizons, Indiana, v. 50, n. 5, p. 385-394, 2007.

WILDING, R. Multichannel or omnichannel? Logistics \& Transport Focus. [S.I.], v.15, n.10, p. 44-44, Dec, 2013.

WILLIAMSON, O. E. Comparative Economic Organization: The analysis of discrete structural alternatives. Administrative Science Quarterly, Michigan, v.36, p. 269296, 1991.

WIND, J.; MAHAJAN, V.; GUNTHER, R. Convergence Marketing: strategies for reaching the new hybrid consumer. EUA: Prentice Hall, 2002. 
WINTER, R. The omnichannel shopper. Display \& Design Ideas. [S.I.], v. 24, n. 3, p. 16-16, April/May, 2012.

WOOD, R.; BANDURA, A. Social Cognitive Theory of Organizational Management. Academy of Management Review, New York, v. 14, n. 3, p. 361-384, 1989.

YALE, L.; VENKATESH, A. Toward the construct of convenience in consumer research. Advances in Consumer Research, Duluth, v.13, n.1, p. 403-408, 1986.

YU, U.; NIEHM, L.; RUSSEL, D. W. Exploring perceived channel price, quality, and value as antecedents of channel choice and usage in multichannel shopping. Journal of Marketing Channel, New York, v. 18, p. 79-102, 2011.

ZAUBERMAN, G. The inter-temporal dynamics of consumer lock-in. Journal of Consumer Research, Chicago, v. 30, n. 3, p.405-419, 2003.

ZHAO, X.; LYNCH JR, J.G.; CHEN, Q. Reconsidering Baron and Kenny: myths and truths about mediation analysis. Journal of Consumer Research, Chicago, v.37, p. 197-206, August, 2010.

ZEITHAML, V. A. Consumer perception of price, quality, and value: a means-end model and synthesis of evidence. Journal of Marketing, Chicago, v.52, p.2-22, July, 1988.

ZEITHAML, V.A.; PARASURAMAN, A.; MALHOTRA, A. Service quality delivery through web sites: a critical review of extant knowledge. Journal of the Academy of Marketing Science, New York, v.30, n.4, p. 362-375, 2002. 
APÊNDICE 1 - ROTEIRO DE ENTREVISTA

APÊNDICE 2 - QUESTIONÁRIO DA PESQUISA

ANEXO 1 - QUESTIONÁRIO ORIGINAL COM FONTES BIBLIOGRÁFICAS. 


\section{ANPÊNDICE 1 - ROTEIRO DE ENTREVISTA DA PESQUISA EXPLORATÓRIA}

\section{Roteiro de entrevista em profundidade}

1. Você fez alguma compra de produtos da linha branca, eletroeletrônico, notebook, tablets ou smartphones nos últimos 6 meses?

2. Como você realizou a compra?

3. O que você pesquisou sobre o produto?

4. Como você obteve informação sobre o produto?

5. Em que momento você decidiu pela compra do produto?

6. Como você decidiu pela compra do produto?

7. Você buscou informação sobre o produto em uma loja on-line antes de comprar numa loja física?

8. Você buscou informação numa loja física antes de comprar on-line?

9. Você buscou informação numa loja on-line da empresa A e comprou na loja online da empresa $\mathrm{B}$ ?

10. Você buscou informação numa loja física da empresa $A$ e comprou na loja on-line da empresa B?

11. Você buscou informação numa loja on-line da mesma loja física que você decidiu comprar?

12. Quais motivações ou necessidades o fizeram realizar a decisão de compra dessa forma?

13. Quais cuidados ou preocupações você teve para realizar a busca e a compra?

14. No que você acredita como melhor busca e transação para compra de produtos como estes?

15. Você se sente confortável em utilizar vários canais de varejo para realizar a sua busca e compra?

16. O que você preza como valor ao realizar compras em múltiplos canais?

17. Na próxima compra você faria diferente?

18. Como você se considera no uso de internet em relação a seus colegas?

19. Como você se considera no uso de tecnologia em relação a seus colegas?

20. Como você qualifica a sua experiência de compra por múltiplos canais? 
APÊNDICE 2 - QUESTIONARIO DA PESQUISA QUANTITATIVA 


\section{Questionário da Pesquisa Quantitativa}

\section{PERGUNTAS DE CORTE:}

1-Nos últimos 6 meses você comprou algum desses produtos? (aceita múltiplas respostas)

Aparelho de som ( )

Aparelho de ar condicionado ( )

Aparelho DVD/ Blue Ray player ( )

Câmera Digital ( )

Computador/ notebook ( )

Console de Videogame ( )

Eletrodomésticos ( )

Qual? Especificar no campo:

Filmadora ( )

Impressora ( )

Smartphone/ celular ( )

Tablet ( )

TV Digital ( )

Caso o respondente não marque um desses produtos: agradecer e dispensá-lo.

2-Antes de fazer a compra você buscou informação sobre o produto com alguém?

Com quem? (aceita múltiplas respostas)

( ) com amigos que compraram

( ) com colegas de trabalho

( ) com sua família (filhos e/ou cônjuge)

( ) com especialistas

( ) com ninguém

3-Onde você buscou informação para esse(s) produto(s)? (aceita múltiplas respostas)

( ) consulta por telefone

( ) na internet em sites brasileiros

( ) na internet em sites estrangeiros

( ) na televisão

( ) na loja física

( ) na loja da internet e depois na loja física

( ) na loja física e depois na loja da internet

( ) site do fabricante

( ) site de comparação de preços

( ) outro.

Especificar no campo abaixo: 
4- Ao buscar informação sobre o produto, quantas lojas on-line e/ou física você visitou aproximadamente? (aceita uma única resposta)

loja ( ) até 3 lojas ( ) acima de 3 lojas ( )

5-Após buscar as informações necessárias, onde você efetivamente comprou? (aceita uma única resposta).

( ) na loja física

( ) na loja on-line da internet de site brasileiro

( ) na loja on-line da internet de site estrangeiro

( ) por telefone

( ) outro.

Especificar no campo abaixo:

6-Para comprar efetivamente o produto quantas lojas on-line e/ou físicas aproximadamente você visitou? (aceita uma única resposta)

loja ( ) até 3 lojas ( ) acima de 3 lojas ( )

7-Para a pesquisa e compra final do produto, marque o que melhor representa seu hábito de compra: (aceita uma única resposta).

Você buscou informação em loja on-line (internet) antes de comprar numa loja física. ( )

Você buscou informação em loja física antes de comprar em loja on-line. ( ）

Você buscou informação na loja on-line e loja física antes de comprar na loja on-line ( )

Você buscou informação e comprou na loja on-line ( )

8-Ainda sobre as suas opções de pesquisa e compra de produtos como os que foram comprados, marque o que melhor representa seu hábito de compra: (marque apenas 1 resposta de cada conjunto)

8.1-Pesquisou o produto em loja on-line (internet) e comprou efetivamente em loja física.

Da mesma rede varejista pesquisada na loja on-line. ( )

De outro varejista não pesquisado na loja on-line. ( )

Não se aplica ( )

8.2-Pesquisou o produto em loja física e comprou efetivamente na loja on-line (internet).

De mesma rede varejista pesquisada na loja física. ( )

De outro varejista não pesquisado em loja física. ( )

Não se aplica ( )

Caso o consumidor não assinale nenhuma resposta 8.1 ou 8.2: agradecer e dispensá-lo da pesquisa.

\begin{tabular}{|l|l|l|l|l|l|l|}
\hline \multicolumn{2}{|l|}{ DISCORDO } & \multicolumn{4}{l|}{ CONCORDO } \\
\hline totalmente & muito & pouco & neutro & pouco & muito & totalmente \\
\hline 1 & 2 & 3 & 4 & 5 & 6 & 7 \\
\hline
\end{tabular}


9-Sobre a minha afinidade com ambientes virtuais (lojas on-line) de compra.

Com relação à tecnologia, eu me sinto tão atualizado quanto meus colegas.

Eu acho fácil fazer compras pela internet.

Para mim, é fácil eu usar a internet.

Sinto-me à vontade para aprender novas tecnologias.

10-Sobre a minha experiência anterior de compra pela internet.

Eu tenho muita experiência com compras pela internet

Eu não faço pesquisas na internet com frequência.

Eu sou bom em fazer pesquisas na internet.

Eu consigo encontrar informação sobre produtos rapidamente na internet.

Quando o assunto é comprar pela internet, eu me considero um especialista.

11-Sobre a pesquisa do produto que comprei:

(entendam-se canais múltiplos de vendas como: loja virtual, loja física, venda por telemarketing, venda direta da fábrica etc.)

Meus amigos têm tido boas experiências com o uso de canais múltiplos de vendas de lojas de varejo.

Meus colegas de trabalho têm tido boas experiências com o uso de canais múltiplos de vendas de lojas de varejo.

Minha família tem tido boas experiências com o uso de canais múltiplos de vendas de lojas de varejo.

Meus filhos me ajudam na busca de informação e compra de produtos.

12-Sobre minha habilidade de compra em diferentes canais de vendas

Acho fácil utilizar com sucesso diferentes canais de lojas do varejo durante o processo de compra.

Acredito que sei avaliar as opções oferecidas pelos múltiplos canais de venda de lojas do varejo.

Eu me sinto confiante usando diferentes canais de vendas de lojas do varejo. Sou capaz de lidar com os serviços de diferentes canais de vendas de lojas do varejo.

13-Quando eu compro um produto como este:

Às vezes eu experimento outras lojas e redes varejistas.

Custa esforço para eu mudar de loja ou rede varejista.

Eu tenho mudado muito de loja ou rede varejista.

Leva tempo para eu mudar de loja ou rede varejista. 
14-Quando eu compro um produto na loja on-line da internet:

Eu posso comprar o produto pela internet dentro da loja física.

Eu posso retirar o produto na loja física da rede varejista.

Eu posso devolver o produto pela loja física, caso ele esteja com defeito.

Eu posso trocar o produto na loja física.

15-Na compra de produtos como esses...

Eu compro coisas que eu não tinha planejado adquirir.

Eu gosto um bocado de variedade de alternativas de tipo e marca de produtos do varejo.

Eu gosto de experimentar diferentes canais de vendas dentro das alternativas do varejo.

Eu gosto de explorar e alternar entre lojas físicas e loja on-line (internet).

Eu gosto de novos estilos e diferentes tipos de produto e marca.

Pesquisar uma nova loja e um novo site é geralmente uma perda de tempo.

16-Quando eu compro pelos canais de vendas de lojas varejistas:

Eu não tenho problema em mudar entre os canais de vendas varejistas.

Eu não gosto de mudar para o canal de venda de outro varejista depois de eu ter gasto algum tempo com pesquisa on-line no site de um varejista.

Eu teria feito troca entre lojas e canais de vendas varejistas, se eu pudesse fazer isso sem aborrecimento.

Não há dificuldades técnicas associadas com a troca entre canais de vendas de varejistas.

17-Na compra de produtos como esses...

Comprar na internet é muito prático.

Eu economizo muito tempo comprando produtos como esse na internet.

É maravilhoso comprar esses produtos em lojas on-line.

Passear em lojas físicas e comprar on-line é muito conveniente para mim.

Pesquisar em lojas físicas é muito prático.

Pesquisar pela internet e comprar em loja física é muito conveniente para esse produto.

18-Sobre a minha experiência de compra nos sites de varejistas on-line:

Eu prefiro comprar em sites que não demoram em carregar e onde a navegação é rápida.

Eu não gosto do formato de apresentação diferente de alguns websites de lojas varejistas.

Em muitos sites tenho que navegar muito até achar o que procuro.

É realmente irritante quando os sites demoram a carregar.

Para falar a verdade, não aguento mais as propagandas no site de lojas varejistas. 
19-Sobre a minha experiência de compra de produtos como esses.

As compras através de múltiplos canais de vendas me satisfazem desde que sejam de uma mesma loja varejista.

Eu faço a maior parte das minhas pesquisas na internet e na hora de comprar é que eu decido onde quero comprar.

Eu gosto de fazer a compra na loja física, pois assim eu posso olhar e conferir o produto.

Eu gosto de fazer a compra na loja física, pois assim eu posso sentir o produto. Gosto muito de comprar através de vários canais de vendas e me sinto livre para mudar de loja on-line para física ou vice-versa de quaisquer varejistas.

20-Compreendendo que uma rede varejista possua tanto loja física quanto loja online (na internet), como seria sua experiência de compra:

Baseado em minhas experiências passadas, eu acredito que a transação na loja online é confiável.

Eu acredito que a transação na loja física é sempre mais confiável do que na loja online.

Eu acredito que a transação na loja física é mais segura do que na loja on-line.

Eu acredito que a transação na loja on-line é sempre segura.

Eu confio que a loja on-line irá prontamente me informar se ocorrer qualquer problema com meu pedido.

21-Ainda sobre a minha experiência de compra para esse produto:

Por enquanto, eu duvido que troque as lojas varejistas on-line em que eu estou acostumado a usar e comprar.

Por enquanto, eu duvido que eu troque as lojas físicas nas quais estou acostumado a comprar.

Raramente eu pensaria em mudar da loja varejista on-line em que atualmente compro.

Raramente eu pensaria em mudar de loja física em que atualmente compro.

22-Eu prefiro realizar minhas compras na loja física por que:

Eu posso chegar a qualquer momento numa loja varejista.

Gosto da atmosfera e decoração das lojas.

Os funcionários da loja varejista atendem imediatamente quando eu faço uma reclamação.

Os funcionários da loja estão sempre dispostos a me ajudar quando tenho problema com os serviços.

Os funcionários da loja me dão atenção pessoalmente.

Os funcionários das lojas entendem minhas necessidades específicas.

23-Eu prefiro não fazer compras pela internet por que: 
A chance de comprar de um site fraudulento é grande.

A chance de ter problemas de remessa e entrega de produtos é grande.

A privacidade de meus dados pessoais não está garantida quando eu compro em loja on-line.

A probabilidade de erro no pagamento do produto é maior comprando em loja online.

É difícil julgar a qualidade do produto, comprando em loja on-line.

Existe grande probabilidade de que eu não receba o produto correto.

\section{4-Eu gosto de comprar em loja física por que:}

Eu adoro pechinchar.

Eu tenho muito orgulho de ser um comprador esperto.

Estou pronto a gastar um tempo extra nas compras para conseguir os melhores preços nos produtos que estou procurando.

É importante eu conhecer todas as alternativas de transação disponíveis antes de fazer uma compra.

Parte do meu divertimento é o prazer que me dá quando eu consigo um benefício extra da loja física onde comprei o produto.

25-Eu me sinto atraído para as lojas físicas por que:

Eu estou mais satisfeito com os serviços da loja física do que das lojas on-line da internet.

Gosto de comprar em loja física porque quero tocar e sentir o produto.

Gosto de comprar em loja física porque quero ver o produto, seu funcionamento e suas dimensões.

No geral, as práticas da loja física em que eu compro me beneficiam mais do que as práticas das lojas on-line.

Regra geral, comprar da loja física é melhor do que comprar de loja on-line.

26-Eu iria pesquisar numa loja on-line, mas comprar em uma loja física ou viceversa:

Quando eu compro produtos semelhantes aos desta pesquisa.

Quando eu compro produtos diferentes dos desta pesquisa.

Sinto-me confortável em navegar nos múltiplos canais de vendas de uma mesma rede varejista, para pesquisa pela internet e compra na loja física ou vice-versa, quando se trata de produtos como o desta pesquisa.

Sinto-me confortável em navegar nos múltiplos canais de vendas de diferentes lojas varejistas, para pesquisa pela internet e compra na loja física ou vice-versa. No caso de produtos como o desta pesquisa. 
27-Para finalizar, me fale um pouco de você.

Qual a sua idade?

\begin{tabular}{|l|l|l|l|l|}
\hline Até 20 anos & $21-30$ & $31-40$ & $41-50$ & Acima de 50 \\
\hline & & & & \\
\hline
\end{tabular}

Gênero: feminino ( ) masculino ( )

Qual o nível de escolaridade mais alto que você concluiu?

\begin{tabular}{|l|l|l|l|l|}
\hline $\begin{array}{l}\text { 10 grau } \\
\text { incompleto }\end{array}$ & $\begin{array}{l}\text { 19 grau } \\
\text { completo }\end{array}$ & $\begin{array}{l}2^{\circ} \text { grau } \\
\text { completo }\end{array}$ & $\begin{array}{l}\text { Graduação } \\
\text { completa }\end{array}$ & $\begin{array}{l}\text { Pós-graduação } \\
\text { completa }\end{array}$ \\
\hline & & & & \\
\hline
\end{tabular}

Qual a faixa de renda familiar mensal?

\begin{tabular}{|l|l|l|l|l|}
\hline Até $R \$ 1.500$ & $R \$ 1501-R \$ 3.000$ & $\begin{array}{l}R \$ 3.001- \\
R \$ 6.000\end{array}$ & $\begin{array}{l}R \$ 6001- \\
R \$ 10.000\end{array}$ & $\begin{array}{l}\text { Acima de } \\
R \$ 10.000\end{array}$ \\
\hline & & & & \\
\hline
\end{tabular}

Estado:

(UF)

Obrigado por responder este questionário! Sua opinião foi muito importante para nós. 
ANEXO 1 - QUESTIONÁRIO ORIGINAL COM FONTES BIBLIOGRÁFICAS. 


\begin{tabular}{|c|c|c|}
\hline & PERGUNTAS DE CORTE & FUNDAMENTAÇÃO TEÓRICA \\
\hline Pergunta de corte: & $\begin{array}{l}\text { 1. Nos últimos } 6 \text { meses você comprou algum desses produtos? } \\
\text { eletrodomésticos, aparelho DVD, aparelho de som, filmadoras, } \\
\text { câmeras digitais, gravadores; computadores, notebooks, impressoras, } \\
\text { tablets ou produtos de alta tecnologia? (aceita múltiplas respostas) } \\
\text { Eletrodomésticos( ) Qual? } \\
\text { Aparelho de som( ) } \\
\text { Aparelho de ar condicionado ( ) } \\
\text { Filmadora( ) } \\
\text { Câmera Digital( ) } \\
\text { Gravador( ) } \\
\text { Computador/ notebook( ) } \\
\text { Impressora( ) } \\
\text { Tablet( ) } \\
\text { Produto de alta tecnologia( ) } \\
\text { Qual? }\end{array}$ & $\begin{array}{l}\text { Feito pelo autor, segundo } \\
\text { Nelson (1970). }\end{array}$ \\
\hline $\begin{array}{l}\text { Pergunta de corte: } \\
\text { Cross-channelfree- } \\
\text { riding }\end{array}$ & $\begin{array}{l}\text { 2. Antes de fazer a compra você conversou com alguém sobre o produto? } \\
\text { Com quem? (aceita múltiplas respostas) } \\
\text { ( ) com sua família (filhos e/ou cônjuge) } \\
\text { ( ) com amigos que compraram } \\
\text { ( ) com colegas de trabalho }\end{array}$ & $\begin{array}{l}\text { Autor da tese, se orientando } \\
\text { por Bandura (1977). Oliveira } \\
\text { (2009) } \\
\text { Chiu et al. (2011), adaptado } \\
\text { pelo autor da tese. }\end{array}$ \\
\hline
\end{tabular}




\begin{tabular}{|c|c|}
\hline & $\begin{array}{l}\text { ( ) com especialistas } \\
\text { ( ) com ninguém } \\
\text { 3. Onde você costuma buscar informação sobre esses produtos? (marque } \\
\text { o mais frequente) } \\
\text { ( ) na internet em sites brasileiros } \\
\text { ( ) na internet em sites estrangeiros } \\
\text { ( ) na televisão } \\
\text { ( ) consulta por telefone } \\
\text { ( ) na loja física } \\
\text { ( ) na internet e depois na loja } \\
\text { ( ) na loja e depois na internet } \\
\text { 4. Quantas lojas aproximadamente visitou na busca de informação? } \\
\text { 5. Após buscar as informações necessárias, onde você efetivamente } \\
\text { comprou? (marque a mais frequente). } \\
\text { ( ) na loja física } \\
\text { ( ) na loja da internet de site brasileiro } \\
\text { ( ) na loja da internet de site estrangeiro } \\
\text { ( ) por telefone } \\
\text { ( ) outro. Qual? }\end{array}$ \\
\hline
\end{tabular}




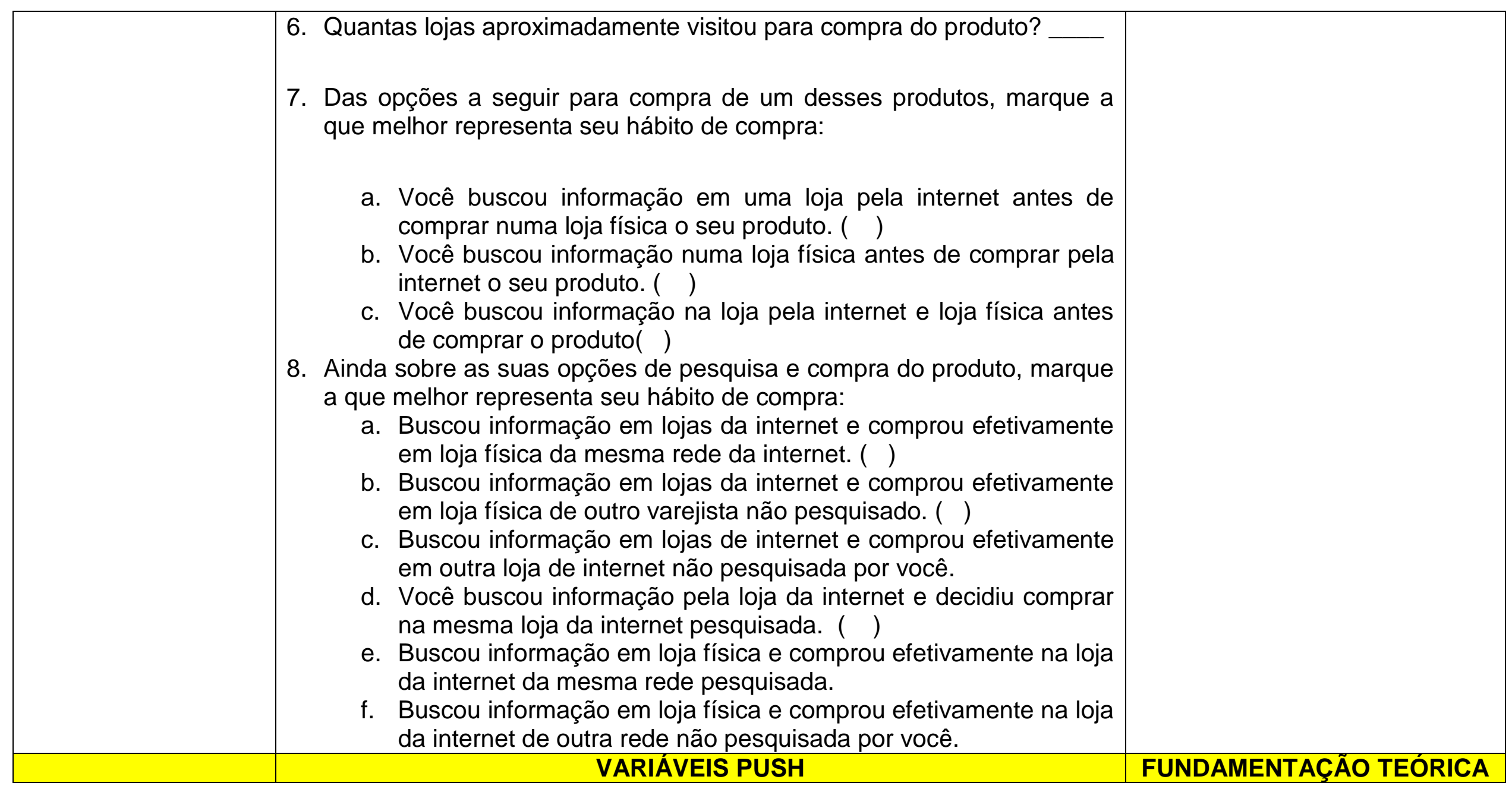




\begin{tabular}{|c|c|c|}
\hline Technology affinity & $\begin{array}{l}\text { Sobre a minha afinidade com ambientes virtuais de compra. } \\
\text { 1. I am comfortable learning new technology. } \\
\text { 2. I feel up-to-date on technology as my peers. } \\
\text { 3. I find the on-line shopping easy do use. } \\
\text { 4. It is easy for me to use internet. }\end{array}$ & $\begin{array}{l}\text { As questões foram ajustadas } \\
\text { para compras on-line. } \\
\text { Maity, Hsu e Pelton (2012) (Q } 2 \\
\text { e 3) } \\
\text { Edison e Geissler (2003) } \\
\text { (adaptaram de Parasuraman, } \\
\text { 2000; Rosen, Sears and Weil, } \\
\text { 1993) }\end{array}$ \\
\hline $\begin{array}{l}\text { Experiência anterior } \\
\text { com Internet }\end{array}$ & $\begin{array}{l}\text { Sobre a minha experiência de compra pela internet. } \\
\text { 6. With respect to on-line shopping, I consider myself and expert. } \\
\text { 7. I have a lot of experience with on-line shopping. } \\
\text { 8. I don't often search on the internet. } \\
\text { 9. I am good at searching on the internet. } \\
\text { 10. I can find product information in a short time on the internet. }\end{array}$ & $\begin{array}{l}\text { Ford, Miller e Moss (2001) } \\
\text { Chiu et al. (2011) } \\
\text { Maity, Hsu e Pelton (2012) } \\
\text { (questão } 8 \text { e 9) }\end{array}$ \\
\hline Vicarious experience & $\begin{array}{l}\text { Sobre como eu busquei informação sobre o produto que foi comprado } \\
\text { 11. My colleagues have had successful experiences using multiple } \\
\text { channels. } \\
\text { 12. My friends have had successful experiences using multiple channels. } \\
\text { 13. My family has had successful experiences using multiple channels. } \\
\text { 14. Tanto meus amigos como colegas de trabalho tiveram experiências de } \\
\text { sucesso em múltiplos canais de venda. } \\
\text { 15. Meus filhos me ajudam, facilitam a busca de informação e compra de } \\
\text { produtos. }\end{array}$ & $\begin{array}{l}\text { Compeau and Higgins (1995) } \\
\text { Chiu et al. (2011) } \\
\text { Inclusão da questão } 3 \text { a } 5 \text { pelo } \\
\text { autor da tese, como extensão } \\
\text { do meio social, baseado na } \\
\text { pesquisa exploratória. }\end{array}$ \\
\hline $\begin{array}{l}\text { Autoeficácia } \\
\text { multicanal }\end{array}$ & $\begin{array}{l}\text { Sobre a minha habilidade de compra em diferentes canais de vendas } \\
\text { 14. I feel confident using different retailing channels. } \\
\text { 15. I have the capability to deal with the services at different channels. } \\
\text { 16. It is easy for me to successfully use different retailing channels in the }\end{array}$ & $\begin{array}{l}\text { Maity, Hsu e Pelton (2012) para } \\
\text { Q14. } \\
\text { Wang e Netemyer (2002); } \\
\text { Mckee Simmers, Licata (2006) }\end{array}$ \\
\hline
\end{tabular}




\begin{tabular}{|c|c|c|}
\hline & $\begin{array}{l}\text { process of purchase. } \\
\text { 17. I believe I am good at evaluating the choices of multiple retailing } \\
\text { channels. }\end{array}$ & $\begin{array}{l}\text { Chiu et al. (2011) } \\
\text { As questões foram ajustadas } \\
\text { para o contexto da pesquisa. }\end{array}$ \\
\hline Satisfaction & $\begin{array}{l}\text { Sobre a minha experiência de compra de produtos como esses. } \\
\text { 18. I do most of my research on the internet and then when it comes time to } \\
\text { buying I can make a decision on where I want to purchase. } \\
\text { 19. Eu gosto de fazer a pesquisa na internet e a compra final na loja, pois } \\
\text { assim eu posso olhar e conferir o produto. } \\
\text { 20. Eu gosto de fazer a pesquisa na internet e a compra final na loja, pois } \\
\text { assim eu posso sentir o produto. } \\
\text { 21. As compras através de múltiplos canais de vendas me satisfazem } \\
\text { desde que seja de um mesmo varejista. } \\
\text { 22. Gosto muito de comprar através de vários canais de vendas e me sinto } \\
\text { livre para mudar de loja quando mudo de um canal on-line para o off- } \\
\text { line ou vice-versa. }\end{array}$ & $\begin{array}{l}\text { Adaptado de Szymanski; Hise } \\
(2000) ; \\
\text { Contribuição da pesquisa } \\
\text { exploratória. (Q.19 e 20) } \\
\\
\text { Tese Baptista, (2005) ajustada } \\
\text { para multicanal (Q21 a 22). }\end{array}$ \\
\hline Trust & $\begin{array}{l}\text { Ainda sobre a minha experiência de compra nesses produtos... } \\
\text { 23. I do believe that the transaction through my offline store is always } \\
\text { reliable than comparing to on-line store. } \\
\text { 24. I do believe that the transaction through my offline store is always safe } \\
\text { than comparing to my on-line store. } \\
\text { 25. I do believe that the transaction through my on-line store is always safe. } \\
\text { 26. I do believe that the transaction through my on-line store is always } \\
\text { reliable. } \\
\text { 27. I am confident that my on-line store will promptly inform me if at all any } \\
\text { problem occur with any of my transactions. } \\
\text { 28. I am confident that my transaction through my on-line store will always } \\
\text { be transparent. } \\
\text { 29. I do believe that my on-line store always keeps my best interest. } \\
\text { Based on my past experience, I can say that my on-line store is }\end{array}$ & $\begin{array}{l}\text { Ajustado para multicanal pelo } \\
\text { autor. } \\
\text { Dash; Saji (2007) } \\
\text { Chellappa (2002) } \\
\text { Hahn; Kim (2009) }\end{array}$ \\
\hline
\end{tabular}




\begin{tabular}{|c|c|c|}
\hline & $\begin{array}{l}\text { trustworthy. } \\
\text { 30. I still only trust the transaction through offline store. }\end{array}$ & \\
\hline \multirow[t]{2}{*}{ Loyalty } & $\begin{array}{l}\text { E ainda sobre a minha experiência de compra nesses produtos: } \\
\text { 31. I seldom consider switching to another retailing on-line store. } \\
\text { 32. I seldom consider switching to another retailing offline store. } \\
\text { 33. As long as the present service continues, I doubt that I would switch on- } \\
\text { line retailing stores that I am used too. } \\
\text { 34. As long as the present service continues, I doubt that I would switch } \\
\text { offiline retailing stores that I am used too. } \\
\text { 35. I try to use the on-line retailing store whenever I need to make a search } \\
\text { and an offline store whenever I need to make a purchase, but both of } \\
\text { the same retail store. } \\
\text { 36. I try to use the on-line retailing store whenever I need to make a search } \\
\text { and purchase at any other offline retail store. } \\
\text { 37. I try to use the offline retailing store whenever I need to make a search } \\
\text { and purchase at on-line store of the same retail store. } \\
\text { 38. I try to use the offline retailing store whenever I need to make a search } \\
\text { and purchase at other on-line store. } \\
\text { 39. When I need to make a purchase of these products, on-line retail stores } \\
\text { are my first choice. }\end{array}$ & $\begin{array}{l}\text { Christodoulides e Michaelidou } \\
\text { (2011) ajustado para a } \\
\text { pesquisa. }\end{array}$ \\
\hline & VARIÁVEIS MOORING & FUNDAMENTAÇÃO TEÓRICA \\
\hline Switching costs & $\begin{array}{l}\text { Quando eu compro um produto como este: } \\
\text { 40. It takes time to switch between retailers. } \\
\text { 41. It takes effort to switch between retailers. } \\
\text { 42. I have switched between retailers a lot. } \\
\text { 43. I occasionally try other retailers. }\end{array}$ & $\begin{array}{l}\text { Jones, Mothersbaugh, Beatty } \\
\text { (2000) } \\
\text { Chiu et al. (2011) } \\
\text { Incluídas questões } 42 \text { e } 43 \text { pelo } \\
\text { autor do artigo de Burnham, } \\
\text { Frels, Mahajan (2003), } \\
\text { adaptada para o varejo. }\end{array}$ \\
\hline
\end{tabular}




\begin{tabular}{|c|c|c|}
\hline $\begin{array}{l}\text { Multichannel } \\
\text { integration }\end{array}$ & $\begin{array}{l}\text { When I purchase from the on-line store: } \\
\text { 44. I can pick up the product from its offline channel. } \\
45 . \text { I can return the product in its offline channel, caso esteja com defeito. } \\
\text { 46. I can change the product in its offline channel. } \\
\text { 47. I can buy on-line inside the offline store. } \\
\text { 48. Eu posso telefonar para o serviço de pós-venda e resolver o problema } \\
\text { diretamente com a loja em que comprei o produto. }\end{array}$ & $\begin{array}{l}\text { Chiu et al. (2011) build } 3 \text { items } \\
\text { based on Burke (2002). O autor } \\
\text { da tese incluiu mais dois } \\
\text { serviços (questão } 47 \text { e } 48 \text { ) e } \\
\text { adequou a Q.45. }\end{array}$ \\
\hline Variety seeking & $\begin{array}{l}\text { Na compra de produtos como esses... } \\
\text { 49. I like to try different channels across retail alternatives. } \\
50 . \text { I like a great deal of variety of retail alternatives for product types and } \\
\text { brands. } \\
51 . \text { I like new and different styles of product types and brands } \\
52 . \text { I carefully plan my purchases. (reverse coding) } \\
\text { 53. I buy things I have not planned to purchase. } \\
\text { 54. I enjoy exploring alternatively offline and on-line stores. } \\
\text { 55. Investigating a new store and site is generally a waste of time (reverse } \\
\text { coding) }\end{array}$ & $\begin{array}{l}\text { Brashear et al. (2009) } \\
\text { Ajustadas pelo autor para o } \\
\text { objeto da pesquisa. } \\
\text { Christodoulides; Michaelidou } \\
\text { (2011). (Q. 53,54,55) }\end{array}$ \\
\hline Within-firm lock-in & $\begin{array}{l}\text { Quando eu compro pelos canais de vendas dos varejistas: } \\
\text { 56. I have no trouble switching between retailers channels. (reverse item) } \\
57 . \text { I don't like to switch to another retailer channel after I have invested } \\
\text { some time to search the on-line retailer's site. } \\
\text { 58. There are no technical difficulties associated with switching between } \\
\text { retailers; } \\
\text { 59. I might have switched between retailers if I could do so without hassle. }\end{array}$ & $\begin{array}{l}\text { Neslin et al. (2006); Ranaweera } \\
\text { e Prabhu (2003); } \\
\text { Tsai et al. (2006); Chiu et al. } \\
\text { (2011). Questão } 58 \text { e } 59 \\
\text { incluídas pelo autor da tese (de } \\
\text { RANAWEERA, PRABBHU, } \\
\text { 2003), adaptada para o varejo } \\
\text { multicanal. }\end{array}$ \\
\hline Convenience & $\begin{array}{l}\text { Na compra de produtos como esses... } \\
\text { 60. Internet shopping is very convenient for this kind of product. } \\
\text { 61. Internet is often frustrating (reverse coding) }\end{array}$ & $\begin{array}{l}\text { Adaptado de Szymanski; Hise } \\
\text { (2000), Evanschitzky et al. } \\
\text { (2004) e }\end{array}$ \\
\hline
\end{tabular}




\begin{tabular}{|c|c|c|}
\hline & $\begin{array}{l}\text { 62. Shopping at traditional stores is very convenient for searching products } \\
\text { like these one. } \\
\text { 63. Searching on-line and buying at traditional stores is very convenient for } \\
\text { these kinds of products. } \\
64 . \text { I save a lot of time by shopping products like these on the Internet. } \\
\text { 65. Browsing at traditional stores and shopping on-line is very convenient } \\
\text { for me. } \\
\text { 66. I can just pull things up on the net and find what I need, go ahead and } \\
\text { order it, and have it shipped without traveling a mile. } \\
\text { It's wonderful buying these products on-line. } \\
67 . \text { I only use internet to get information about these products and I buy at } \\
\text { traditional stores. } \\
\text { 68. I use internet to get information about these products and I also use to } \\
\text { buy the same products. }\end{array}$ & $\begin{array}{l}\text { Christodoulides, Michaelidou } \\
\text { (2011). }\end{array}$ \\
\hline \multirow[t]{2}{*}{ Site design } & $\begin{array}{l}\text { Sobre a minha experiência de compra nos sites de varejistas on-line: } \\
\text { 69. I find sites that I can navigate quickly and don't take forever to load up } \\
\text { to be more satisfying sites to shop. } \\
\text { 70. A lot of web sites are not well designed. It seems to take forever to } \\
\text { navigate down far enough into the site to find what I am looking for. } \\
\text { 71. Speeking frankly, I've gotten really tired of the advertising. } \\
\text { 72. It takes a lot of time for some of these Web pages to load. It's really } \\
\text { annoying. } \\
\text { 73. I don't like the different presentation format of some retail websites }\end{array}$ & $\begin{array}{l}\text { Adaptado de Szymanski; Hise, } \\
(2000)\end{array}$ \\
\hline & VARIÁVEIS PULL & FUNDAMENTACCÃO TEÓRICA \\
\hline $\begin{array}{l}\text { Perceived service } \\
\text { quality of competitors } \\
\text { offline }\end{array}$ & $\begin{array}{l}\text { Eu prefiro realizar minhas compras na loja física por que: } \\
\text { Tangibility: } \\
\text { 74. Retail atmosphere and décor appearance are appealing to me. }\end{array}$ & $\begin{array}{l}\text { SERVQUAL scale from } \\
\text { Parasuranam, Zeithhaml e } \\
\text { Berry (1988); }\end{array}$ \\
\hline
\end{tabular}




\begin{tabular}{|c|c|c|}
\hline & $\begin{array}{l}\text { Reliability: } \\
\text { 75. I can always reach retail store anytime I want to. } \\
\text { Responsiveness: } \\
\text { 76. Employees of retail store take actions immediately when I make } \\
\quad \text { complain. } \\
\text { 77. Employees of retail store are always willing to help me if I have problem } \\
\quad \text { with services. } \\
\text { Empathy: } \\
\text { 78. Retail store has employees who give me personal attention. } \\
\text { 79. Employees of retail store understand my specific needs }\end{array}$ & $\begin{array}{l}\text { Zeitlhaml; Parasuraman e } \\
\text { Malhotra (2002); Dutta and } \\
\text { Segev (1999); } \\
\text { Zeitlhalm (1988); } \\
\text { Chiu et al. (2011). } \\
\text { Ajustado pelo autor da tese } \\
\text { para varejo físico. }\end{array}$ \\
\hline $\begin{array}{l}\text { Perceived risk of } \\
\text { purchasing on line }\end{array}$ & $\begin{array}{l}\text { Eu prefiro não fazer compras pela internet por que: } \\
\text { The possibility of getting the wrong product (total risk) } \\
\text { 80. There is a large probability that I do not get the right product X when } \\
\text { buying in an on-line store. } \\
\text { Difficulty in judging product quality (performance risk) } \\
\text { 81. It is difficult to judge the quality of product } X \text { in on-line shopping. } \\
\text { Incorrect payments (finance risk) } \\
\text { 82. The probability on wrong payments for product X is large in on-line } \\
\text { shopping. } \\
\text { Insecure personal data (finance risk) } \\
\text { 83. Privacy of my personal data is not secured when buying product X in } \\
\text { on-line shopping.(reversed) } \\
\text { Purchasing from a fraudulent site. (finance risk) } \\
\text { 84. The probability of purchasing from a fraudulent site is large. } \\
\text { Encountering problems of shipping and delivering (timing risk) } \\
\text { 85. The probability of encountering problems of shipping and delivering in } \\
\text { on-line shopping is large. }\end{array}$ & $\begin{array}{l}\text { Verhoef, Neslin, Vroomen } \\
\text { (2007); Garbarino e Strahilevitz, } \\
\text { (2004) (Q.84); } \\
\text { Chiu et al. (2011). } \\
\text { Ajustes nas frases pelo autor. }\end{array}$ \\
\hline $\begin{array}{l}\text { Bargaining } \\
\text { Smart-shopper } \\
\text { feelings }\end{array}$ & $\begin{array}{l}\text { Eu gosto de comprar em loja física por que: } \\
\text { 86. I love to bargain. } \\
\text { 87. Part of the enjoyment is the pleasure it gives when I get extra benefit at } \\
\text { the store where I bought the product. }\end{array}$ & $\begin{array}{l}\text { Otnes, McGrath (2000) (Q86); } \\
\text { Jones, Trocchia, Mothersbaugh } \\
\text { (1997) (Q86 e 87) ajustados } \\
\text { pelo autor. }\end{array}$ \\
\hline
\end{tabular}




\begin{tabular}{|c|c|c|}
\hline & $\begin{array}{l}\text { 88. The satisfaction of winning extra discount on the price product is my } \\
\text { pleasure. } \\
\text { 89. I take great pride in being a smart-shopper } \\
\text { 90. I am willing to expend extra time shopping to get best possible prices on } \\
\text { the goods I am looking for. } \\
\text { 91. It is important to me be aware of all available alternatives before making } \\
\text { a purchase. } \\
\text { 92. I always compare price. }\end{array}$ & $\begin{array}{l}\text { Ganesh, Reynolds, Luckett } \\
\text { (2007) (Q89 a 91) } \\
\text { Christodoulides, Michaelidou } \\
\text { (2011). }\end{array}$ \\
\hline $\begin{array}{l}\text { The attractiveness of } \\
\text { competitors' offline } \\
\text { retail store }\end{array}$ & $\begin{array}{l}\text { Eu me sinto atraído para as lojas físicas por que: } \\
\text { 93. I would be more satisfied with the services from this offline store where I } \\
\text { purchase the product than from on-line stores. } \\
\text { 94. I would be probably happier with the services from this offline store than } \\
\text { from on-line stores. } \\
\text { 95. All in all, the policies of this offline store that I purchase from would } \\
\text { benefit me more than on-line stores. } \\
\text { 96. Overall, purchasing from this offline store would be better than } \\
\text { purchasing from on-line stores. } \\
\text { 97. Eu obtive melhor negociação de preço quando fiz a transação na loja } \\
\text { física. } \\
\text { 98. Eu obtive benefício adicional quando fiz a compra na loja física. } \\
\text { 99. Gosto de comprar em loja física porque quero tocar e sentir o produto. } \\
\text { 100. Gosto de comprar em loja física porque quero ver o produto, seu } \\
\text { funcionamento e suas dimensões. }\end{array}$ & $\begin{array}{l}\text { Bansal, Taylor e James (2005); } \\
\text { and Jones, Mothersbaugh, } \\
\text { Beatty (2000); } \\
\text { Chiu et al. (2011). } \\
\text { Contribuição da pesquisa } \\
\text { exploratória feita pelo autor (Q. } \\
97 \text { a 100). }\end{array}$ \\
\hline & VARIÁVEL DEPENDENTE & FUNDAMENTAÇÃO TEÓRICA \\
\hline $\begin{array}{l}\text { Cross channel free- } \\
\text { riding intentions }\end{array}$ & $\begin{array}{l}\text { I would search in an on-line store but purchase in another brick-and- } \\
\text { mortar store when: } \\
\text { 101. I bought similar products like the ones in this research } \\
\text { 102. I bought other products different from the ones in this research. } \\
\text { 103. Sinto-me confortável em navegar em vários canais de vendas de } \\
\text { uma mesma rede varejista, tanto pela internet quanto em sua loja } \\
\text { física. }\end{array}$ & $\begin{array}{l}\text { Van Baal e Dach (2005); } \\
\text { Chiu et al. (2011). } \\
\text { Contribuição do autor (Q103 e } \\
\text { 104). }\end{array}$ \\
\hline
\end{tabular}


104. Sinto-me confortável em navegar entre vários canais de vendas de vários varejistas do mercado, tanto pela internet quanto pela loja física. 